\title{
Resurstillväxt via innovationskapital
}

\section{Per Staffan Boström}

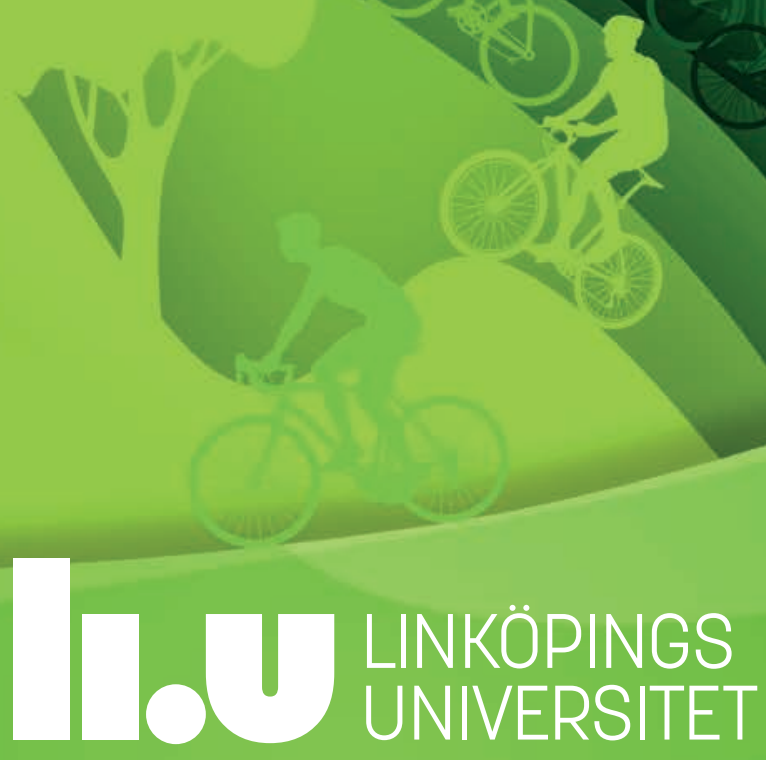





\title{
Resurstillväxt via innovationskapital
}

\section{Resource Growth Through Corporate Innovation Capital.}

\author{
Per Staffan Boström
}

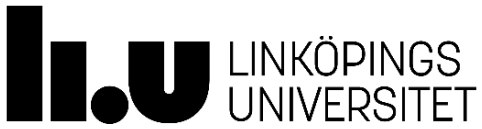

Institutionen för ekonomisk och industriell utveckling, Industriell ekonomi

Tekniska fakulteten

Linköpings universitet, SE-581 83 Linköping, Sweden

Linköping 2021 

Internationell Licens $\underline{\text { https://creativecommons.org/licenses/by/4.0/deed.sv }}$

(C) Per Staffan Boström, 2021

Printed in Sweden by LiU-tryck, 2021

ISBN 978-91-7929-111-2 (tryckt)

ISBN 978-91-7929-112-9 (PDF) (print)

https://doi.org/10.3384/9789179291129

ISSN 0345-7524 nr. 2189 


\section{Abstract}

In recent decades, it has been found that an increasing proportion of companies' resource base consist of so-called intangible assets, immaterial resources, such as in partnerships in development companies. Large corporations invest in companies with expected future spin-offs and in the development of ideas in incubators, while at the same time the resources available under the legal control of an undertaking, as in R\&D collaboration projects, relatively also have decreased.

A specific phenomenon has also been observed internationally over the last two decades and it is a company-specific phenomenon that cannot be directly explained by cyclical changes. The phenomenon appears as an 'imbalance' in the relationship between identified (tangible/intangible) and unidentified (intangible) immaterial resources and in their development over time. This dissertation is based on this change and how it affects companies' ability to strategically act in specific around the development of their innovation capital and how economic governance is then affected.

The purpose of the thesis is to analyse changes in the company's strategic governance when the assets in the company's resource base are shifted from tangibles to intangibles and especially the unidentified resources, and partly to provide the basis for an applicable governance model based on management's expectations of the company's internal resource growth, primarily from its innovation activities. Literature on the company's resource base and growth (RBT), strategic financial management and management control are the theoretical perspectives that form the starting point for the study. Gradually, the literature has been supplemented by for example, decision- and system theory.

The method chosen is nomologist deduction (Popper-Hempel, 1952), which in short means trying to explain and understand a defined part of the practice using understanding and relevant theory, in order to understand a broader context with new assumptions. Empirically, the research has been set up so that data is collected and analysed in different case studies, one feasibility study and four 'cases' studied over a long period of time. This has made it possible to analyse and discuss each case individually in the thesis, but also to be able to follow a development that the respective 'case' itself has difficulty in capturing.

The results of the total systemic analysis of all 'cases' in the thesis indicate that the internal resource growth generated and accounted for in various forms is driven by conditions caused by external change but has been made possible by management's strategic priorities regarding the company's resource base.

Based on the thesis's empirical evidence, models are developed to support management's decisions and actions regarding the resource base, models that can contribute to companies' innovation capital and not only supporting the company's short-term development but also contributing to long-term, sustainable value growth. Companies can choose a number of resource-based company-specific strategies, both for their material and immaterial, intangible resources to support company-specific innovation collaboration objectives and taking into account the company's time aspect, long-term sustainable competitiveness and competitive advantage. 
To address this, the thesis points to the need to weigh opportunities and risks in strategic decisions, to apply a multidisciplinary approach and to use available and new financial and technical tools adapted to the many questions about how to strengthen the company's innovation capital. The research suggests that companies should focus on resources and capabilities that, in an expected and communicated situation, have the potential to streamline the company's long-term competitive positioning, while developing organizational processes to address shortand long-term challenges and uncertainties.

Keywords: Resource based view; sustainable growth; resource growth; value growth; management control; economic governance; financial control; immaterial; intangibles; resource; resource base; dynamic capability; factor market; innovation capital; added value; structure capital; resilience; knowledge integration 


\section{Sammanfattning}

Under senaste decennierna har konstaterats att en allt större andel av företags resurser utgörs av s k osynliga tillgångar, immateriella tillgångar, såsom ägarandelar i utvecklingsbolag, investering i avknoppningsbolag och utveckling av idéer i inkubatorer, samtidigt som de resurser som finns under ett företags juridiska kontroll i bland annat samarbetsprojekt inom FoU, relativt sett har minskat. Under de två senare tioårsperioderna har ett fenomen observerats internationellt som inte direkt kan förklaras med cykliska förändringar. ${ }^{1}$ Fenomenet som är företagsspecifikt visas som en 'obalans' i relationen mellan identifierade materiella/immateriella resurser och oidentifierade immateriella resurser och i dessas utveckling över tid. Denna avhandling tar sin utgångspunkt specifikt i denna förändring och hur det påverkar ett företags möjlighet att strategiskt agera kring utveckling av sitt innovationskapital och hur den ekonomiska styrningen då påverkas.

Syftet med avhandlingen är att dels analysera förändringar i företags strategiska styrning när tillgångarna i företagets resursbas skiftas från materiella till immateriella, dels att ge underlag för en tillämpbar styrmodell som utgår ifrån ledningens förväntningar på företagets interna resurstillväxt, primärt från dess innovationsverksamhet. Litteratur om företagets resursbas och tillväxt (RBT), strategisk finansiell styrning och ekonomistyrning är de teoretiska perspektiven som utgör studiens utgångspunkter. Efterhand har litteratur kompletterats inom angränsande områden som exempelvis besluts- och systemeori.

Den metod som valts är nomolog deduktion (Popper-Hempel, 1952) som i korthet innebär att med hjälp av förförståelse och relevant teori försöka förklara och förstå en avgränsad del av praxis, detta för att med nya antaganden förstå en bredare kontext. Empiriskt har forskningen lagts upp så att data över en längre tid samlats in och analyserats i olika fall (case) efter en genomförd förstudie. Detta har möjliggjort att i avhandlingen både kunna analysera och diskutera varje separat fall för sig, men också att över tid kunna följa den utveckling som respektive fall har genomgått.

Resultatet av den sammanlagda, systemiska analysen av samtliga fall i avhandlingen indikerar att den interna resurstillväxt som genereras och redovisas i olika former, drivs av förhållanden orsakade av externa förändringar men har också möjliggjorts av ledningens strategiska prioriteringar avseende företagets resursbas. Även om litteraturen argumenterar i överensstämmelse med vad analysen visar, indikerar fallen på behovet av nya riktlinjer för hur innovations- och affärsledning vid verksamhet på en konkurrensutsatt utvecklingsmarknad kan förnya och modifiera ett företags resursbas med påverkan på huvudföretagens samlade resursbas.

För att komma till rätta med detta pekar avhandlingen på behovet av att väga möjligheter och risker i strategiska beslut, att tillämpa ett multidisciplinärt synsätt och att använda finansiella och tekniska verktyg som är anpassade till de många frågeställningar om hur man kan stärka företagets innovationskapital.

${ }^{1}$ Studier som genomförts av SP 500 (IP Close Up: Intangible Asset Market Value Study, 2019; uppdaterad 2020) 
Forskningen tyder på att företag bör fokusera på resurser och förmågor som, i en förväntad och kommunicerad situation har potential att effektivisera företagets långsiktiga konkurrenspositionering, och samtidigt utveckla organisatoriska processer för att hantera kortoch långsiktiga utmaningar och osäkerheter.

Baserat på avhandlingens empiri utvecklas modeller för att stödja ledningens hantering av resursbasen, modeller som kan bidra till att företagens innovationskapital och inte endast stödjer företagets kortsiktiga utveckling utan också bidrar till en långsiktig, hållbar värdetillväxt. Företag kan välja ett antal resursbaserade företagsspecifika strategier för sina materiella och immateriella resurser för att stödja företagsspecifika mål avseende innovationssamarbeten och med hänsyn till företagets tidsaspekt, för långsiktigt hållbar konkurrensförmåga och konkurrensfördel.

Nyckelord: Resursbaserat synsätt; hållbar tillväxt; resurstillväxt; ekonomisk styrning; immateriell; resurs; resursbas; förmåga; faktormarknad; innovationskapital; förädlingsvärde; värdetillväxt; strukturkapital; resiliens; kunskapsintegration 


\section{Förord}

Forskningsfrågorna i denna avhandling är formulerade för att fånga det unika från den longitudinella studien som ligger till grund för avhandlingen med de omfattande och djupa åsikter och förståelser om strategisk ekonomistyrning som jag erhållit via aktivt arbete med utformning och utveckling av strategier och ekonomistyrning i företag. De teorier som används skall ses som ett ramverk som skall underlätta och ge förståelse för att flera perspektiv snarare än ett enda behövs för att analysera företags värdetillväxt.

Syftet med min forskning är att beskriva, utforska och analysera hur observerad förändring i företags kapitalstrukturer från materiella till immateriella tillgångar skapar utmaningar men också innebär möjligheter. En fördjupad förståelse av hur företag ser på sina egna resurser och de man får tillgång till genom avtal med andra företag skapar en grund för att kunna ta sig an kommande utmaningar så att möjligheter och risker som dyker upp längs vägen hanteras strategisk.

Empiriskt har forskningen lagts upp så att data samlats in och analyserats i olika fall över en längre tid. Detta för att både kunna analysera och diskutera varje fall för sig men också att över tid kunna följa en utveckling som respektive fall i sig har svårt att fånga. I varje fall finns delar som uppfattas och förstås som mycket framgångsrika i ekonomiska resultat och värdetillväxt. Kontexten är intressant eftersom världen omkring oss utvecklas från ett fokus på att företag kontrollerar huvuddelen av sina tillgångar själv och dessa finns investerade i maskiner, byggnader, produkter och personal. Men de senaste decenniernas skifte mot en mer kunskapsintensiv ekonomi har inneburit att företagen utvecklar nya former för samarbeten med innovativa tjänsteleverantörer, de immateriella resurserna ökar i betydelse och avtalen med andra företag berör även det egna företagets kärnområde, 'core competence'. Företagen möter en utmaning i hur affärseffektivitet skapas över längre tid.

I denna avhandling börjar forskningsprocessen med förståelse av företags prioriteringar, strategier och värderingar samt hur detta reflekteras i den strategiska ekonomistyrningen. Denna avhandling ska återspegla erfarenheter av att hantera strategiska beslut för att skapa värdetillväxt vilket omfattar omvandling av resurser och andra tillgångar. Det finns resultat $\mathrm{i}$ teoretiska och empiriska studier i denna avhandling och det finns en kontinuerlig dialog mellan teorin och empirin som är sammanflätad under reflektionens gång där de kontinuerligt bidrar till att besvara forskningsfrågorna och uppfylla syftet.

Denna avhandling utforskar fenomenet snarare än att dra någon slutsats ur hypoteser eller generera en ny teori eller experimentera med en teori. De studerade objekten (fallen) är alla beskrivningar av en process där resurser och tillgångar hanteras, styrning sker för att uppnå strategiska och ekonomiska mål där det sker inom en given ram. Det skall inte ses som att forskning bara hanterar det framgångsrika utan de öppnar snarare fler frågor som illustrerar och beskriver mer den förändring från materiella till immateriella tillgångar i form av berättande. Berättandet avslöjar reflektioner och genom reflektioner utforskar läsarna idéer och tankar som de studerande företagen lyfte såväl som jag som forskare i denna avhandling fångade och upplevde. De olika fallen genomfördes mellan 2005 och 2019 och dokumenterade i samband med dessas genomförande. Texterna som återfinns i avhandlingen är skrivna 2019 till 2021. Denna avhandling är snarare mer beskrivande än normativ och en studie för att med 
utgångspunkt från företags värden och risker, med fokus på företags kapitalstruktur och mål för värdetillväxt, förstå inverkan på och från ekonomisk styrning över en längre tidshorisont.

\section{VARFÖR}

\section{Why focus on Resource Management?}

"Assets, or economic resources, are the lifeblood of both business enterprises and not-for-profit organizations"

"Since resources or assets confer their benefits on an enterprise by being exchanged, used, or otherwise invested, changes in resources or assets are the purpose, the means, and the result of an enterprise's operations, and a business enterprise exists primarily to acquire, use, produce, and distribute resources".

SOURCE: Financial Accounting Standard Board,_FASB. Concepts Statement 6, paragraphs 11 and 15

\section{VAD}

Tillgångar (Assets) är resurser och kapacitet i det ekonomiska systemet Djur- och Naturenergi (Animals and Natures) är resurser i det ekologiska systemet.

\section{VEM, för VEM och med VEM}

Människors (Humans) information och kommunikation är resurser respektive förmågor i det sociala systemet

\section{NÄR}

Dåtid. Nutid. Framtid.

\section{HUR}

Data.

Verklighet. Teori och modeller. Verklighet.

\section{RESULTAT}

Integration och sammanvägning av förmågor, kapacitet, energi och data kan med förenklade modeller förklara positiv eller negativ tillväxt av resurser, från en verklighet till en annan 


\section{Tack}

Slutligen manifesteras denna kunskaps- och läranderesa i ett tvåhundrasidors dokument. En resa med många tusental av allt; studenter, lästa sidor, skrivna ord, intelligenta inlägg från andras perspektiv, starka känslointryck och nya insikter. Till alla Er som har bidragit till att jag kunnat göra denna resa, doktorander och forskare vid Göteborgs, Örebros, Stockholms och Linköpings Universitet, riktar jag ett hjärtligt tack. Och ett stort tack till lärarkollegorna de senaste sex åren vid Mälardalens Högskola. Ett särskilt stort tack till Norberto Levin, CEO vid Levin Global i Buenos Aires och professor Jean - Pascal Foucault vid Sorbonne i Paris för deras internationella engagemang och att de delat kunskap och praktiska erfarenheter från värdering av immateriella värden.

I forskning är det resultat som räknas. Denna tvåhundrasidiga avhandling är bara början, ett delresultat. Starten på en ny resa mot nya resultat. Men ett delresultat som bara gjorts möjligt med en fantastisk handledarinsats under hela resan. Särskilt vill jag tacka min handledare professor Per-Olof Brehmer som outtröttligt stöttat mig de två sista åren av avhandlingsarbetet.

Denna avhandling baseras på de erfarenheter och förväntningar som framkommit vid alla de samtal jag haft vid möten med så många intressanta personer i och omkring målföretaget $\mathrm{i}$ studien. Personer som delat med sig av sina tankar. Utan dessa samtal hade inte denna avhandling och dess slutsatser varit möjlig. Ett mycket stort tack.

Ett mycket stort tack också till de parter som möjliggjort genomförande av de empiriska studierna och då särskilt riktat till målföretaget i studien och till Vinnova.

Jag riktar ett stort tack till min barndomsvän och advokaten Tommie Bäck som på ett förutsättningslöst sätt granskat trehundra sidor svensk manustext.

Och så till sist; ett tack till min familj, min älskade Karin under tio år, mina älskade barn Frida, Oskar och Niklas och deras familjer, mina syskon och kusiner. Ett stort tack till min bror Håkan som gjort den grafiska layouten. 


\section{Innehållsförteckning}

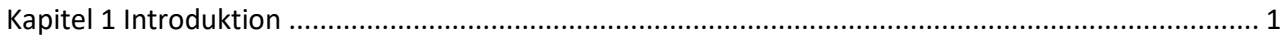

1.1 Omvärldsförändringar över tid och dess påverkan på strategiska ledningsbeslut ........................ 2

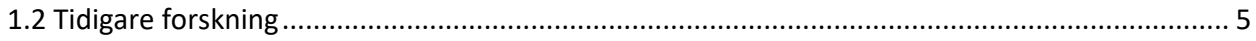

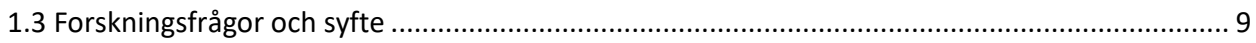

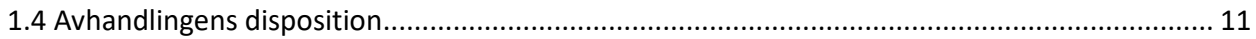

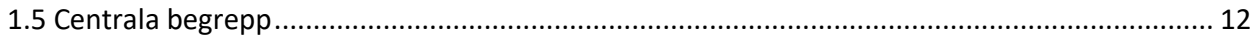

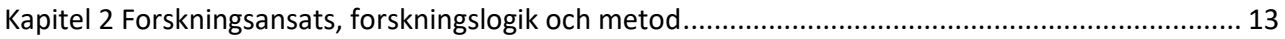

2.1 Vetenskapsteoretisk utgångspunkt för metodval ..................................................................... 13

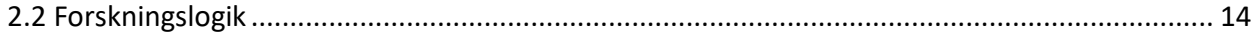

2.2.1 Begränsning vid valet av forskningsansats och forskningslogik ........................................ 17

2.3 Forskarrollen. Praktikern. En forskares förförståelse................................................................. 18

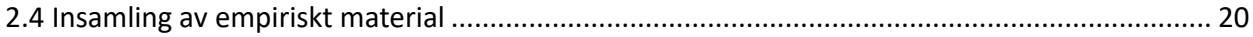

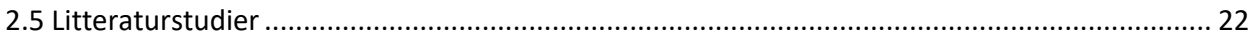

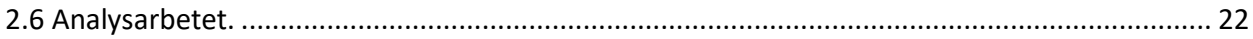

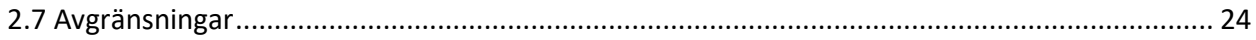

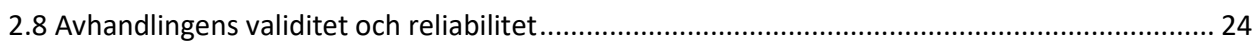

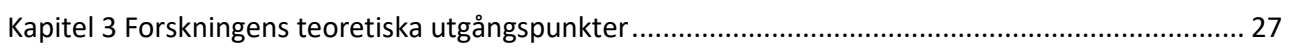

3.1 Strategiforskning och resursbaserad teori och ekonomisk styrning .......................................... 28

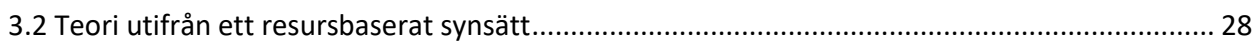

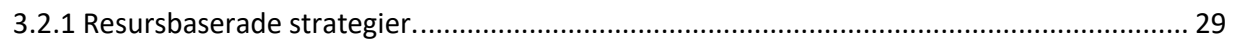

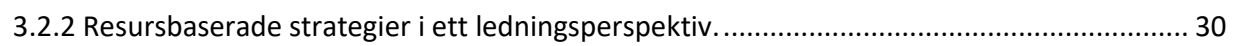

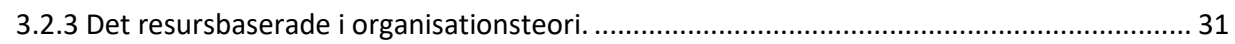

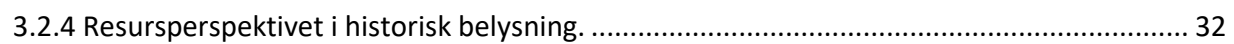

3.3 Resursbaserade teorier avseende företagsstrategiska analyser................................................. 33

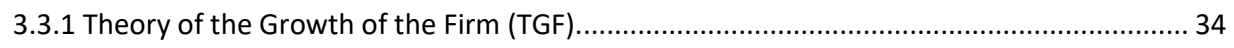

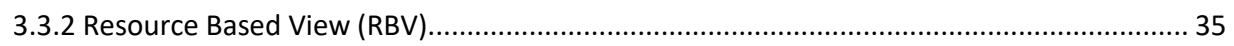

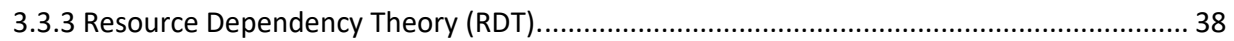

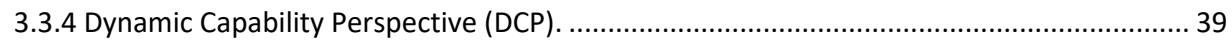

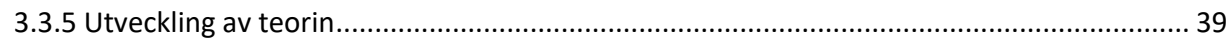

3.4 Det resursbaserade synsättet för studier av strategi och styrning ............................................. 39

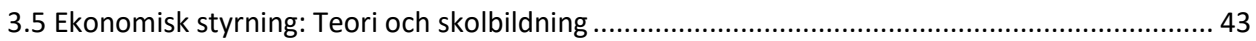

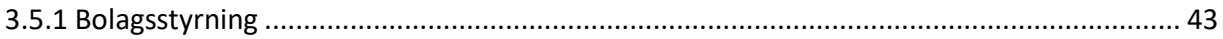

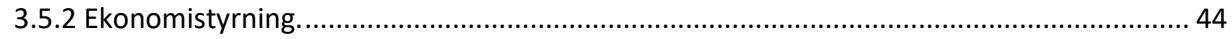

3.5.3 Teori och forskning om ekonomistyrningens roll och tillämpning ..................................... 45 
3.5.5 En genealogisk aspekt på ekonomistyrning: Redovisning med ett tidsperspektiv. .............. 48

3.5.6 Strategisk ekonomistyrning; en utveckling från finansiell redovisning................................. 50

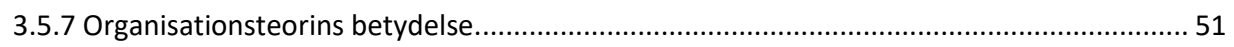

3.5.8 Forskning om företags ekonomistyrning med contingencyansats..................................... 52

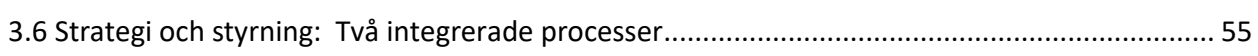

Kapitel 4 Tentativ modell för integrerad resursstrategi och ekonomisk styrning ................................ 57

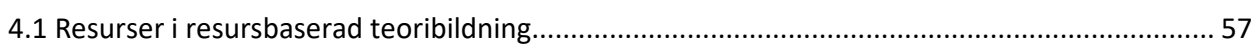

4.1.1 Övriga systemiskt påverkande faktorer i resursbaserad teoribildning. .................................. 59

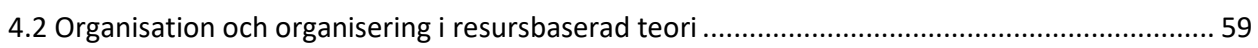

4.3 Beslutsprocesser och värdeskapande processer vid resursbaserat strategiarbete..................... 60

4.4 Mätning och värdeskapande. Begreppen effektivitet och resultat .......................................... 61

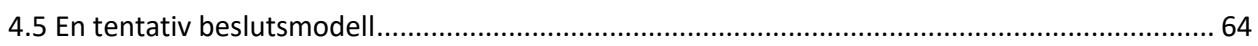

4.7 Implikationer vid val av beslutsmodell för genomförandet av strategi ...................................... 67

Kapitel 5 Initialt arbete 2003 - 2005. Empiri och partiell analys från förstudie och Case ROBO och Case

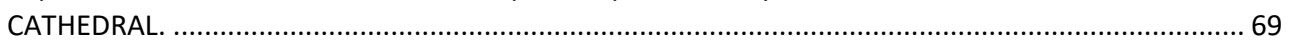

5.1 Inledande seminarier och workshops under perioden 2003 - 2005 ............................................. 70

5.2 Fallstudie 1: Case ROBO: studier vid affärsområde 1 Marketing/Sales (BU 1). ............................ 72

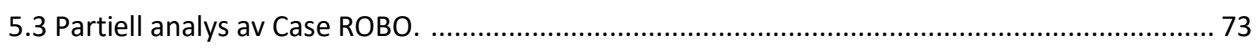

5.4 Fallstudie 2 Case CATHEDRAL: studie vid affärsområde FoU/CR (BU 2)................................... 75

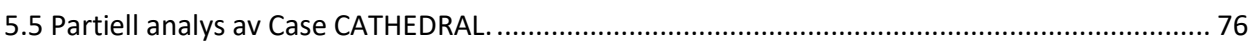

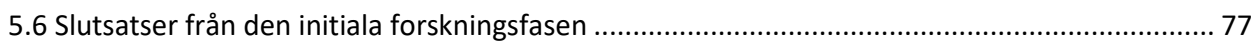

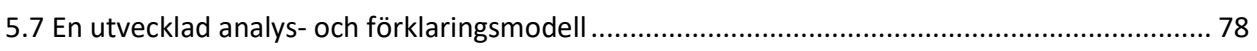

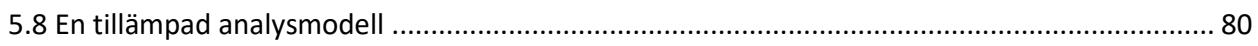

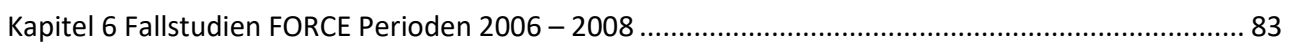

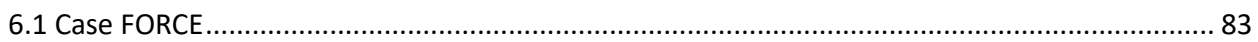

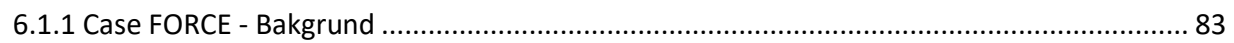

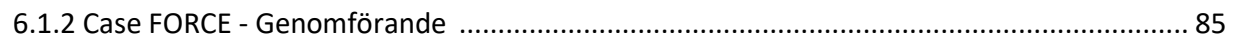

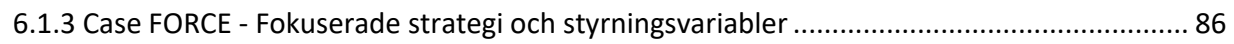

6.1.4 Case FORCE - Informationsinsamling och tidplan. ............................................................ 87

6.2 Sammanfattning av intervjuresultat från ledningsgruppen inom BU 3 redovisade enligt

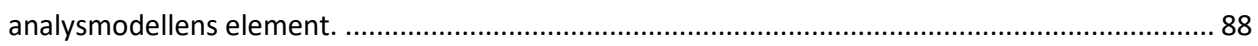

6.2.1 Resultat och kommentarer från samtliga intervjuer med ledningsgruppen......................... 90

6.2.2 Sammanfattning av ledningens uppfattning om begrepp och av ledningens syn på

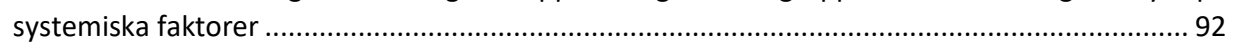

6.2.3 Kompletterande intervjuer med projektledare (PL) och business controller (BC).............. 93 


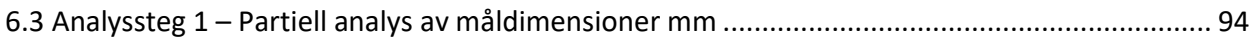

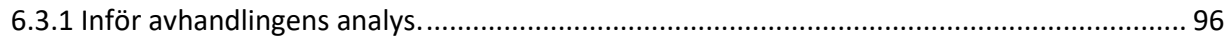

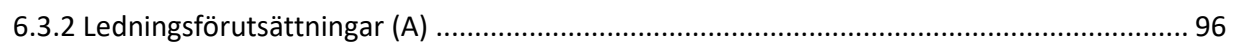

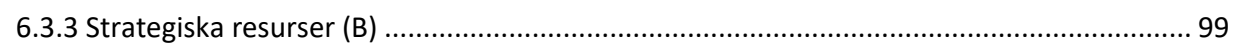

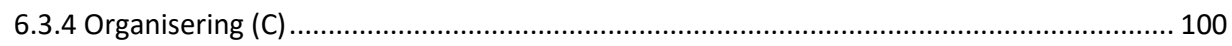

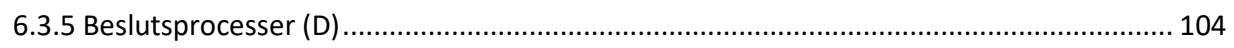

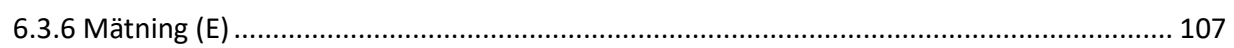

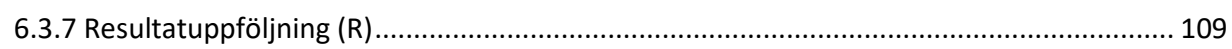

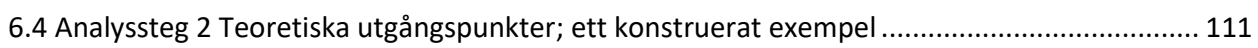

6.4.1 Positionskarta. En modell för positionering av resurser i ett dynamiskt förlopp. .............. 113

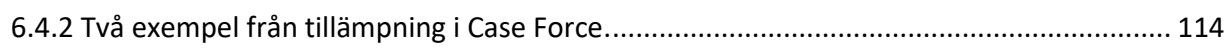

6.4.3 Exempel 1: Expansionsstrategiers implikation på typ av styrning och dess effekter på

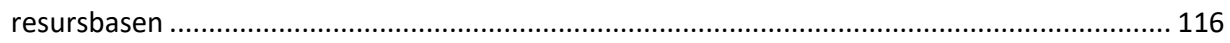

6.4.4 Exempel 2 Konsolideringsstrategiers implikation på typ av styrning och dess effekter på

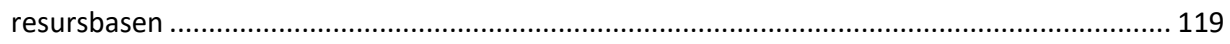

Kapitel 7 Case INNOHUB.01 - .04 (.05) Aktionsforskning vid "öppen innovation" - i ny kontext. ....... 121

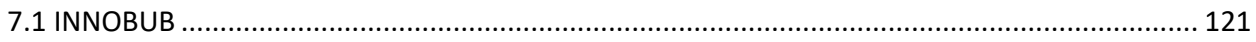

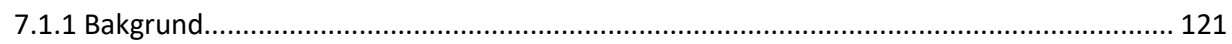

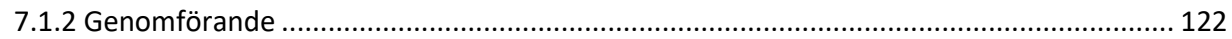

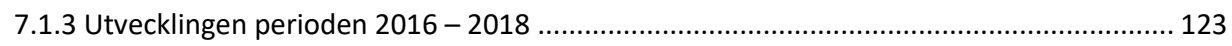

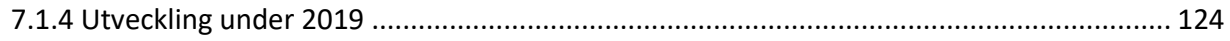

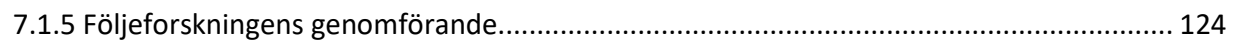

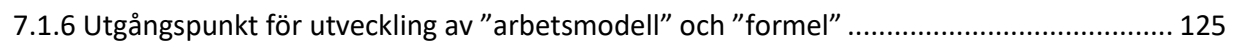

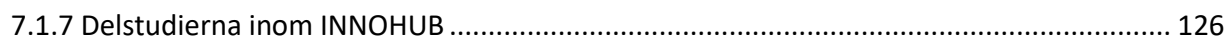

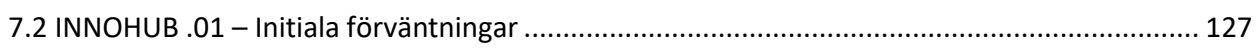

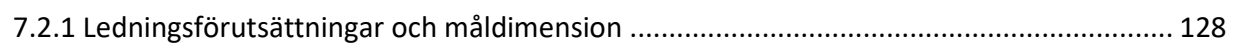

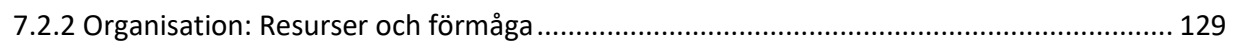

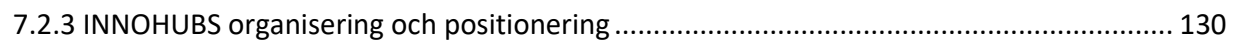

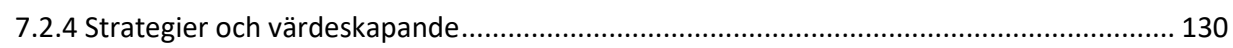

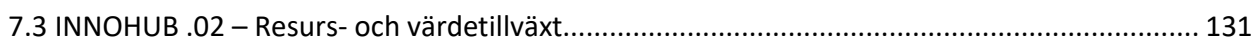

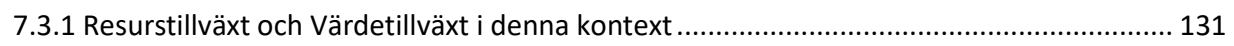

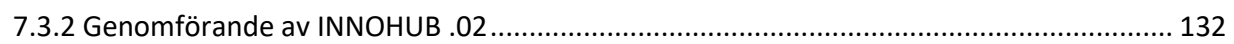

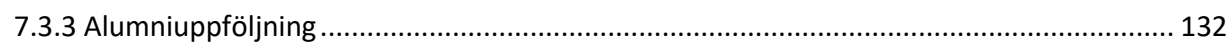

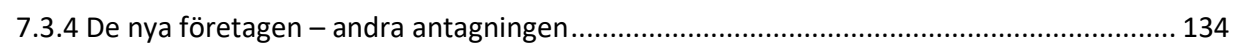

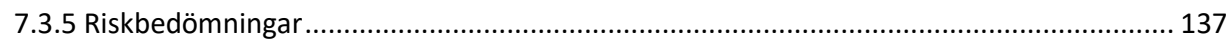

7.3.6 Hinder och möjligheter för uppgradering och uppskalning ......................................... 138 


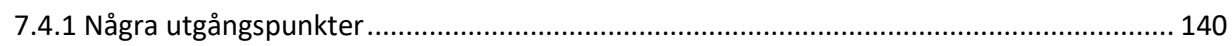

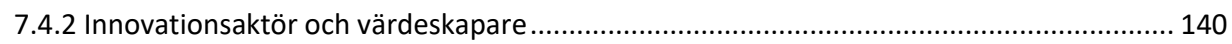

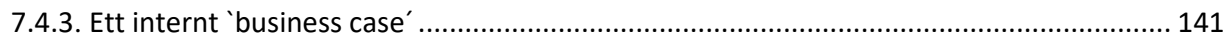

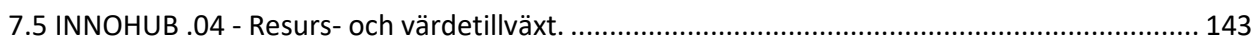

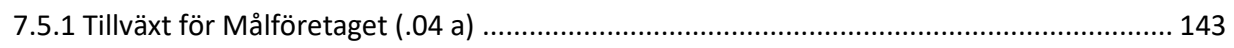

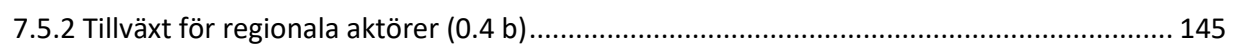

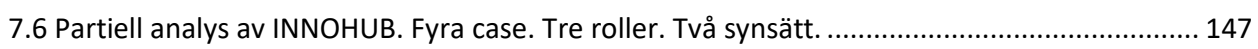

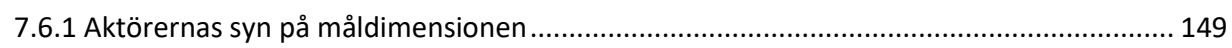

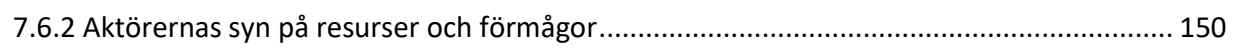

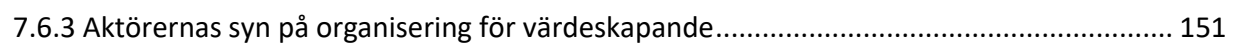

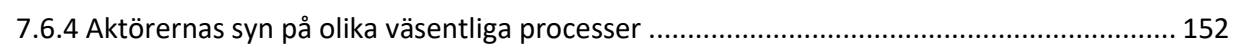

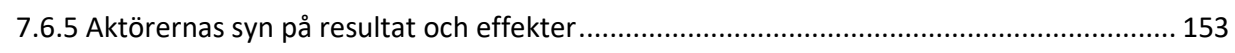

Kapitel 8 Systemisk analys av nutid pekar på strategiska utmaningar............................................... 155

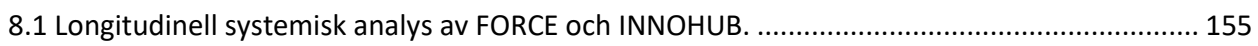

8.2 Strategiska utmaningar identifierar underlag till utvecklad förklaringsmodell ......................... 160

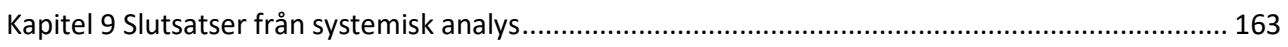

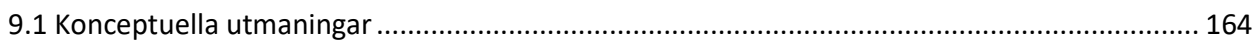

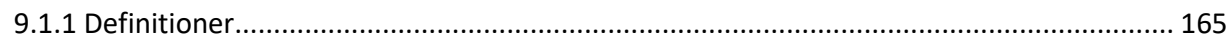

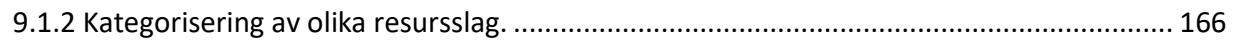

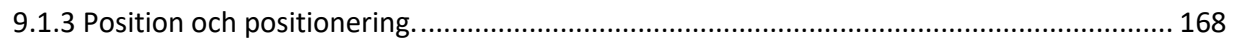

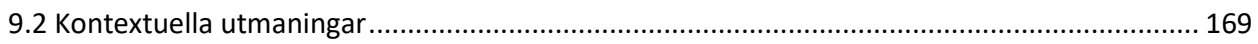

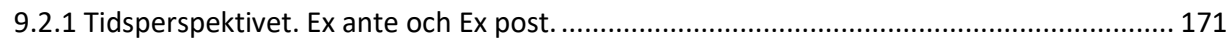

9.3 Mål, resultatplanering och mätning vid inför valet av strategi ................................................. 173

9.4 En reflektion om det resursbaserade synsättet, dess utmaningar och möjligheter ................. 174

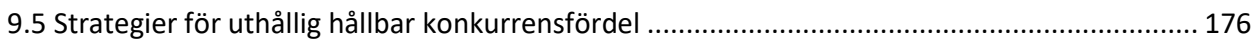

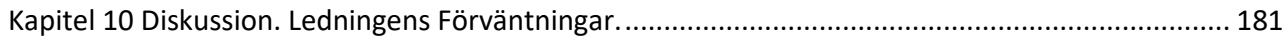

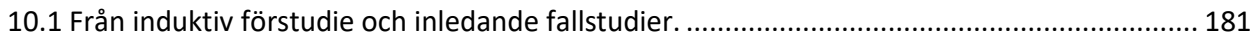

10.2 Alternativ för ekonomisk styrning med betoning på beslutsfattande. ................................... 183

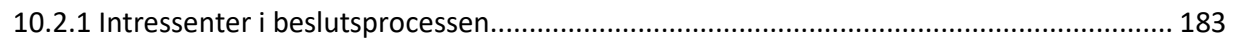

10.2.2 Förväntningsteori bidrar till förståelse av agerandet...................................................... 184

10.2.3 Ledningens förväntningar och argument för ny integrerad styrmodell. .......................... 185

10.3 Utvecklat ramverk för integrerad, dynamisk strategisk ekonomisk styrning .......................... 186

10.3.1 Måldimensionen: Ledningens förväntningar vid framtida ekonomisk styrning. .............. 187

10.3.2 Resurser: Ledningens förväntningar vid en framtida "ny" ekonomistyrning.................... 188 
10.3.3 Organiseringen: Ledningens förväntningar vid en framtida "ny" ekonomistyrning

10.3.4 Beslutsprocesserna: Ledningens förväntningar vid en framtida "ny" ekonomistyrning . 190

10.3.5 Mätningen: Ledningens förväntningar vid en framtida "ny" ekonomistyrning 190

Kapitel 11 Slutsatser.

11.1 Avhandlingens bidrag.

11.1.1 Avhandlingens kunskapsbidrag genom applicering från angränsande kunskapsområden 193

11.1.2 Nya utmaningar, möjligheter och begränsningar 194

11.1.3 Alternativa val 195

11.1.4 Förslaget till ny förklaringsmodell (se kapitel 10.3) 197

11.2 Teoretiska implikationer 197

11.3 Praktiska implikationer. 200

11.4 Förslag till fortsatt forskning 204

Referenser 207

Bilagor

Fallstudier: 
Figur 1. Avhandlingens disposition

Figur 2. Avhandlingens logik; en tankestruktur

Figur 3. Schematisk beskrivning av avhandlingens arbete med att utifrån etablerad analysmodell/er för strategi och styrning med hjälp av de fyra stegen utveckla analysmodell

Figur 4. Ett identifierat 'nytt' fokus inför denna forskning

Figur 5. Förenklad illustration av strategins olika nivåer i organisationens hela beslutsstruktur (förf. egen figur)

Figur 6. Hierarchy of Business Strategy (här tolkad och bearbetad) Simons, 2000.

Figur 7. PDCA-modellen (W. Edwards Deming, 1990-1993)

Figur 8. Från förarbetet i förstudien (2004); förutsättningar för strategisk styrning. Senare sammanställd av målföretagets ledningsgrupp för BU 1(M\&S) och BU 2 (CR).

Figur 9. En tentativ förklaringsmodell med ett strategiskt styrningsperspektiv på organisationens villkor för att kunna skapa resultat (egen och förenklad modell av den s.k. EEM-modellen (EFQM-modellen)

Figur 10. Ledningens målkriterier samt identifierade strategiska resurser och förmågor (författarens sammanfattning och översättning)

Figur 11. Gatemodellen. Processen för PUTV (övre) resp TUTV (nedre)

Figur 12. Organisationens organisering utifrån organisationens processmodell, här bearbetad/förenklad (jfr Porters "Value Chain") b) PUTV omfattar primärt produktutveckling eller produktförnyelse c) TUTV omfattar både 'spaning' och laborativ teknologiutveckling.

Figur 13. En integrerad beslutsmodell för resursbaserad strategi och styrning. Styrningen har delats upp i två delar; a) ex ante och b) ex post. Denna modell har efter genomförd analys av Case FORCE utvecklats utifrån "Hierarchy of Business strategy (Simons, 1995) samt PDCA -modellen (Deming, 1990-1993)

Figur 14. En formaliserad arbetsmodell för strategisk planering och uppföljning utifrån mätbarhetsvillkor vid investering i utvecklingsprojekt.

Figur 15. "Positionskartan" En modell över resurspositionering i miljö och social/relations kontext, organisering och effekter på organisationens resursbas vid olika positionering (härledd och bearbetad från G S (Buzz) Holling (1985).

Figur 16 a Case FORCE kännetecken vid applicering av expansionsstrategi

Figur 16 b Case FORCE kännetecken vid applicering av konsolideringsstrategi

Figur 17 a Konstruerat exempel på strategiskt styrningsperspektiv för Case FORCE vid expansionsstrategi baserat på tentativ förklaringsmodell presenterad i Figur 9.

Figur 17 b. Konstruerat exempel på strategiskt styrningsperspektiv för Case FORCE vid konsolideringsstrategi baserat på tentativ förklaringsmodell presenterad i Figur 9

Figur 18. Arbetsgång i Case INNOHUB

Figur 19. INNOHUB-matrisen. Matris över redovisning av empiri enligt analysmodellen. Redovisningen görs vertikalt d v s i varje delprojekt redovisas samtliga element. Analysen görs horisontellt d v s varje element i modellen analysera parallellt över samtliga delprojekt och ingår i avhandlingens systemiska analys.

Figur 20. Målvariabler för INNOHUBS medlemsföretag enligt textanalys av ursprungligt projektdokument 20160923.

Figur 21. INNOHUB .01 Initiala förväntningar hos 9 av de först antagna 17 företagen (enkätsvar) 
Figur 22. INNOHUB .02 Erfarenheter från samarbete hos 9 av de $15 / 20$ nya företag som intervjuats under perioden (enkätsvar).

Figur 23. INNOHUB .02 förväntningar och tilltro på fortsatt samarbete hos 9 av de $15 / 20$ nya företag som intervjuats under perioden (enkätsvar).

Figur 24. Risker med anknytning till INNOHUB

Figur 25. Upplevda behov för uppgradering och uppskalning

Figur 26. Målföretagets utvecklingsområden, mål och medel (författarens sammanställning)

Figur 27. Regionala och samhälleliga utvecklingsområden, mål och medel

Figur 28. Två synsätt som antas påverka INNOHUBs roll i innovationssystemet

Figur 29. Två behov som innebär strategiska utmaningar för fortsatt forskning och modellutveckling

Figur 30. Definition av begreppet resurs

Figur 31. Kategorisering av resursslag (avhandlingens förslag, illustrerat med hur ett breddat perspektiv på resurser och dess avkastning kan bidra till en större helhetsförståelse runt företagets kapitalisering)

Figur 32. Potentiella beslutsalternativ för organisering av organisationens resurser för utveckling av organisationens/ projektets resursbas (egen figur)

Figur 33. Strategi 1-4: Resursutveckling med positiva förtecken $(+)$ vid expansion (jfr "exploration" versus "exploitation" (March, 1991). Strategi 5-9: Resursutveckling med negativa förtecken (-) (jfr "creative desruction"; frigörande) (Shumpeter, 1994, Holling,1973 ) och "conservation"; konsolidering (Holling, 1973

Figur 34.Strategi 1 - 9, nyckelaktiviteter samt resultat

Figur 35. Strategimodellen: en strategikarta utifrån ett resursperspektiv m a p optimering av kvalitet och kvantitet vid konsolidering respektive exploatering (Matrisen är egenutvecklad)

Figur 36. En ny "robust" totalmodell (baserad på EEM-modellen) och som kan ge en bild av hur ett företags resultat möjliggörs i ett system för resursbaserad ledning och ekonomisk styrning, oberoende av tidsperspektiv resursslag och andra specifika villkor d v s modellen är kontextneutral. Modellens motsvarighet (och argument för den) finns i kvalitetsdiskursen, den s.k. EFQM-modellen

Figur 37. Skifte av strategiskt fokus. Val av fokus vid på en utvecklingsmarknad illustrerad med variablerna Mängd (Qty) och Form (Qal) De blå pilarna indikerar bästa "fit" relativt organisationens strategival.

Figur 38. En "ny" arbetsmodell. Samband mellan strategivariabler och element i ekonomisk styrning $(\mathrm{C}=$ Organiseringen/positionering, $\mathrm{D}=$ Beslutsprocessen /strategival och E = Mätprocessen) och relaterat till de tre förklaringsmodellerna som utvecklats i avhandlingens analys av empiri

Tabell 1 Sammanställning av datainsamling

Tabell 2 Kontextuella och konceptuella utmaningar för fördjupad analys. Siffrorna 1 - 28 refererar till textanalys 
Globalisering, bred spridning och tillämpning av teknologier, nyttjande av expertkunskap och kunskapsbaserade företag är de huvudsakliga faktorerna som ligger bakom dagens komplexa och konkurrensutsatta företagande. I denna dynamiska omgivning konkurrerar företag för att vara framgångsrika och hantera den föränderliga situationen. Men alla företag är inte lika framgångsrika även om de verkar under samma grundläggande marknadsförutsättningar. Vissa företag är marknadsledare, innovativa och förnyare, och andra följer efter dessa men många tappar i konkurrenskraft och lämnar marknaden. När ett företag är avsevärt bättre än konkurrenterna har man lyckats skapa en konkurrensfördel. Porter (1985) menar att denna typ av positionering på en marknad eller inom ett segment sker genom antingen kostnadsledarskap eller en högre grad av differentiering. Men dessa perspektiv på hur konkurrenskraft skapas har ifrågasatts inom främst det resursbaserade teoriområdet (Resource based view - RBV) som poängterar att det är variablerna/elementen resurser (resources) och dynamiska förmågor (dynamic capabilities) som är betydelsefulla och avgörande. RBV tar sin utgångspunkt i det individuella företaget vilket är ett annat än Porters perspektiv.

De två variablerna/elementen resurser och förmågor påverkar strategiska beslut vilket i sin tur definierar ett företags strategi. Men företag kan trots att de äger mer resurser än andra ändå inte lyckas att omsätta detta till att skapa konkurrenskraft. Studier har visat att det endast är när resurserna har ett högt värde, unika, svåra att kopiera eller skapa alternativa designer av som det finns möjlighet att skapa unika positioner (Barney, 1991; Amit och Shoemaker, 1993). Det resursbaserade perspektivet sätter fokus på det unika, de unika resurserna i företaget. Och den konkurrenskraft som skapas och kan vidmakthållas över en längre tid leder till högre effektivitet och prestationer (Peteraf, 1993).

Men den resursbaserade teorin hanterar generellt kunskap, medarbetare och personal som en faktor av samma vikt som andra faktorer. Därmed behandlar man inte den handlingskraft som medarbetare har och förmågan att smälta samman lämpliga faktorer och kompetenser för att ta sig an de mål som definieras vid olika tillfällen. Flexibilitet och dynamik är också aspekter som tar utgångspunkt $\mathrm{i}$ att kunskap är en av de väsentliga aspekterna för att uppnå långsiktig konkurrenskraft. Kunskap är även det mest komplexa och svåra att kopiera vilket gör att fler och fler företag sätter organisationens samlade kunskap som den högst prioriterade frågan i strategiska beslut. Anthony (2012) pekar på att den tidigare fördelen med stora forsknings- och utvecklingsavdelningar med en omfattande och långsiktig finansiell backning och en omfattande och detaljrik marknadskunskap, som bara stora företag kan upprätthålla, har mindre fördelar än tidigare. Delar ligger i att innovationsformerna har förändrats och förändringen har gått fort.

I företags publika redovisning har effekter av dessa fenomen observerats. En effekt är ett fenomen som antas vara ett samtidsfenomen och ett resultat av ökad kunskapsintegration och förändrade prioriteringar som har accentuerats under senare år. Fenomenet har en sådan dignitet att den motiverar en diskussion om förändringar i hur det ökade fokuset på kunskap speglas i företags strategiska ekonomistyrning. Fenomenet har inte observerats i den nationella 
redovisningen på grund av att viss statistik bortprioriteras. ${ }^{2}$ För ett samhälle som Sverige är förmåga att stötta det kunskapsintensiva företagandet av största vikt vilket speglas i tex olika propositioner och utredningar (Prop 2020/21:60; SOU 2018:3). Strategisk ekonomistyrning stödjer både framtagande av strategi och dess implementering, beaktar även icke-finansiella aspekter och balanserar korta och långsiktiga perspektiv. Området tar sin grund i Anthony (1965) och har utvecklats av Otley (1994), Nilsson et al (2011) till att anpassas för den ökade betydelsen av kunskap, fristående företag och en ökad komplexitet på såväl kort som långsiktig konkurrenssituation som berörs av Nilsson och Olve (2001).

Resursbaserad teori och strategisk ekonomistyrning är teorier som är vitt spridda och flera studier har visat på dess potential för att stödja företags strategiska utveckling (Johanson et al 2003; Teece, 2007). Den här avhandlingen fokuserar primärt att utifrån empiriska studier över lång tid och sammanställning av relevant teori kunna ge ett bidrag till denna diskussion. Avhandlingens bidrag till diskussionen blir att visa en eventuell nödvändighet av att, i en samtid med nya omvärldsvillkor för ekonomisk styrning, tillämpa ett vidgat perspektiv i skolbildningen om konkurrensstödjande strategiska fundament.

\subsection{Omvärldsförändringar över tid och dess påverkan på strategiska ledningsbeslut}

Den forskning och de forskningsresultat som denna avhandling tar sin utgångspunkt i omfattar empiriskt perioden 2005 till 2019. Perioden speglar en del av svensk industriell näringslivsutveckling under en, sett i ett europeiskt eller globalt perspektiv, under senare delar av en period av femtio år, 1970 - 2019, en period som uppvisar stora volatila förändringar med finansiella konsekvenser och med effekter på företagens kapitalstruktur. I bilaga görs en sammanställning av observerade makrotrender i syfte att illustrera hur omvärldsförändringar kan bedömas påverka inre och yttre prioriteringar i näringslivets organisationer under olika perioder. Sammanställningen baseras på författarens egna observerade ${ }^{3}$ förändringar och en bedömning av dessas effekter på och av interna beslut och strategier, strategier som potentiellt kan analyseras vidare i fortsatt forskning utifrån kunskapsteoretiska förutsättningar.

Långsiktiga cykliska förändringar kan tydliggöras matematiskt på olika aggregerade nivåer. En roll för den longitudinella forskningen är att visa orsak bakom och verkan vid dessa cykliska mönster. Inom kunskapsområdet nationalekonomi avhandlas bland annat makroekonomiska effekter på och av företagsledningars långsiktiga beslutsfattande och prioriteringar avseende företagens finansiella resurser och nyttan av dessa. Ett exempel är Oxelheim och Wihlborg (2005) som utvecklar en multivariat teoretisk modell för analys av hur omvärldsförändringar och faktorer som inflation, växelkurser och marknadsräntor påverkar företagsledningars interna prioriteringar avseende primärt organisationens finansiella resurser. För en företagsledning är

\footnotetext{
${ }^{2}$ Detta avser Sveriges nationella redovisning. SCB sammanställer sedan ett antal år en nationell balansräkning enligt EU 's regelverk ENS 2010 (EU nr 549/2013), se vidare under www.scb.se/nr0103/. Denna balansräkning inkluderar företagens balansräkning och ett av dess syften är att mäta någon form av nationell avkastning på landets samlade tillgångar.

${ }^{3}$ Se bilaga 8 . Denna sammanställning är ett ovetenskapligt försök att belysa makrotrender under som kan antas påverka och potentiellt kan påverka interorganisatoriska prioriteringar. Syftet med sammanställningen är att utifrån ett längre genealogiskt perspektiv försöka bedöma trender som påverkar företags kapitalstrukturer.
} 
denna kunskap en förutsättning i kommunikationen med 'externa' intressenter på finans- och kapitalmarknad.

Rumelt, Schendel och Teece (1991) diskuterar, med referens till Birger Wernerfelts resursbaserade strategiforskning (Wernerfelt, 1984, 1994), att teorier när det gäller kvalitetsaspekter, immateriella resurser och kunskapstillgångsportföljer utifrån riskaspekter på olika nivåer, explicit vid långsiktigt orienterade 'interna' beslut om FoU och innovation, ifrågasätter nationalekonomiska antaganden och framgent måste hämta sin förståelse utifrån förklaringar från andra kunskapsområden. Skolbildning inom samhällsvetenskaplig forskning, i ständig interaktion med den högre utbildningen, baseras på resultat från en mer eller mindre longitudinell forskning. Longitudinell forskning genomförs antingen med kvantitativa analyser av många års statistik eller med observationer under många år. Den omfattar såväl offentligt liv som näringsliv och innefattar bland annat områden som organisationsteori, ekonomisk och finansiell teori.

Förekomsten av förändringar i kortare eller längre tidsperspektiv, avvikelser och fenomen som observeras i den longitudinella forskningen indikerar ett behov av ökad eller 'ny' kunskap. Inom den företagsekonomiska forskningen kan 'ny' kunskap handla om att försöka förstå och förklara samtida fenomen, fenomen som är direkta konsekvenser av företagens ekonomiska ledning och styrning av hela företagets verksamhet över längre perioder, perioder som uppvisar dynamiska skeenden. Det observerade företagsekonomiska fenomenet ${ }^{4}$ har accentuerats under en period av tjugo år. Fenomenet berör näringslivets andel av en samhällskontext och implicit berörs därmed också ett nationalekonomiskt forskningsområde.

Konkurrenskraft (competitive advantage) kan ses som målbegrepp för företagsledningars strategibeslut. För att beskriva en uthållig konkurrensfördel används omväxlande begreppen hållbar (sustainable) konkurrensfördel respektive bestående (sustained) konkurrensfördel, det senare begreppet definierat inom ramen för strategiteori (Barney, 1991). Begreppen 'hållbar' utveckling (sustainable development) i betydelse av ekologisk, social eller finansiell hållbarhet 5 återfinns inte i nämnda teorier.

I företagens lednings - och utvecklingsperspektiv diskuteras utveckling primärt i termer av tillväxt. Begreppet tillväxt återfinns inte i de modeller som inledningsvis nämnts. Tillväxtteorier avhandlas primärt inom nationalekonomisk diskurs. I företagsekonomisk diskurs inom ramen för förändringsteori förekommer teori om `organisationers framväxt` ur evolutionärt respektive revolutionsperspektiv. (Greiner, 1972)

Redan 1953 avhandlar Kenneth E. Boulding (1953, 1956) inom ramen för systemteori begreppet tillväxt där han argumenterar för att detta är ett 'fenomen' av universell karaktär.

\footnotetext{
4 Det specifika fenomen som har observerats internationellt under de två senare tioårsperioderna är ett företagsspecifikt fenomen och som inte direkt kan förklaras med cykliska förändringar. Det visas som en 'obalans' i relationen mellan identifierade och oidentifierade kapitalvärden och i dessas utveckling över tid. Motsvarande observationer har gjorts i Sverige, vid såväl företagens publika rapportering som vid empirisk forskning. Skillnader mellan olika industrisegment och typ av 'resursbaser’' (tillgångsslag) har observerats. (IP Close Up: Intangible Asset Market Value Study, 2019; uppdaterad 2020)

5 Begreppen "sustainable" och "sustainability" refererar till en nationalekonomisk diskurs "sustainable development "d v s hållbar utveckling. Upprinnelsen är Brundtlandkommissionen; en av FN tillsatt kommission (WCHD) ledd av Norges $\mathrm{f} d$ statsminister Gro Harlem Brundtland. Kommissionens rapport från den $\mathrm{s} k$ Stockholmskonferensen "Our common Future" (1986) har varit dominerande vägledare i den globala agendan för en hållbar ekonomisk och ekologisk och social utveckling.
} 
Tillväxtteori är en "sub division" till teorier inom kunskapsområden om individers beteende; tillväxt är en viktig aspekt av beteende (Boulding, 1956). Boulding (1956) diskuterar möjligheter att förstå ekonomiska mönster och fenomen genom alternativt systematisera kunskap från olika kunskapsområden och beskrivningsnivåer.

"At the more complex levels structural problems become dominant and the complex interrelationships between growth and form are the focus of interest. All growth phenomena are sufficiently alike..." (Boulding, 1956, s.201)

Joseph Schumpeter (1934) var en av de första nationalekonomerna som först tillskrev innovation en central roll för företagens tillväxt. Han menade att det ständiga skapandet av nya produktionsprocesser och produkter är det som driver ekonomisk tillväxt och välstånd. Schumpeters teori om ekonomisk utveckling och tillväxt utgår ifrån 'entreprenören’, en individ som ägnar resurser åt innovationer som i sig driver den ekonomiska utvecklingen. Edith Penrose (1959) fullföljde utvecklingen av Shumpeters teorier i "the theory of the Growth of the Firm, TGF" (Penrose 1959) vilket kan ses som upprinnelsen till det resursbaserade synsättet. Senare forskning om ett resursbaserat synsätt före millennieskiftet (Barney, 1990) poängterade vikten av att tydliggöra generella resursbaserade kriterier och också generella kriterier för tillit vid partnerbaserade strategival, explicit vid strategier för s k vertikal integration. Senare forskning (Johnsson, 2007) tillför en dimension där en unik affärstransaktion värderas utifrån det kvalitativa mervärde som uppstår vid "skarp" konkurrens och kan identifieras utifrån nyttan av en viss resurs eller resursportfölj som möjliggörare vid ett tillväxtscenario.

En möjlighet av att utifrån alternativt teoretiskt kunskapsfält och på organisationsnivå förstå detta fenomen som är en konsekvens i företagets strategiska ekonomistyrning, är att tillämpa ett resursbaserat systemsynsätt. Det innebär ett delvis nytt sätt att spegla företagets struktur genom att i företagets beslutsprocesser fokusera på organisationens resurser utifrån ett internt och externt perspektiv och där företagets målstruktur tydliggörs.

En omvänd relation mellan 'materiella' och 'immateriella' värden har observerats sedan millennieskiftet. Som identifierade immateriella värden redovisas kunskapsintensiva tillgångar som exempelvis kapitaliserat intellektuellt kapital (intellectiual properties, IP). Andra tillgångar är inte lika tydligt identifierade. Detta ses här därför som ett relativt nytt fenomen och ett fenomen som är ett uttryck för en alltmer utvecklad kunskapsintegration och komplexitet vid långsiktigt beslutsfattande. Ägare och företagsledning har en utmaning att balansera valda strategier med en ekonomisk styrning som maximerar effekterna av beslutsfattande relativt organisationens tillväxtmål och påverkan på dess kapitalstrukturer.

Flera forskare har använt "dynamic capabilities" för att studera nya krav på organisation som argumenterar för att det är ett...

"... promising theoretical framework that could be used to motivate theories about organizations, environmental management and subsequent performance" (Russo, 2009, p. 318)

För att ett företag skall kunna förändras och transformeras, krävs att de förmågor man har utvecklas till effektiva dynamiska "capabilities" och förändrar företagen och deras organisatoriska struktur samt design (Helfat och Winter, 2011) för att kunna utveckla nya sätt att formera deras aktiviteter, partnerskap och rutiner för att möta en föränderlig omvärld (Da Giau, et al, 2020). 
Förändringar, positiva och negativa, av dessa värden har observerats i det forskningsarbete som ligger till grund för denna avhandling under perioden 2005 till 2019/20. I en kontext där den publika informationen enligt regelverken avser att belysa en långsiktig utveckling av ett företags verkliga värden /och risker/ så är detta fenomen potentiellt mer omfattande än vad forskning hittills visat och betydelsen av dess påverkan, positivt eller negativt, på samhällsutveckling, företagens tillväxt och kapitalstrukturer kan antas vara betydande. Internationella regelverk har under perioden genomgått omfattande revideringar ${ }^{6}$.

\subsection{Tidigare forskning}

Med vilka glasögon ska detta i verkligheten observerade fenomen belysas? Företagen har under perioden verkat $\mathrm{i}$ en marknad och affärsdynamik som inneburit stora förändringar. En förklaringsmodell fordras som gör det möjligt att förstå denna dynamik och dess konsekvenser, detta för att förstå hur företags lednings- och beslutssystem optimalt anpassas till företagets målstruktur.

Redan i början av 1970-talet togs ett initiativ till en explorativ studie om företagsutveckling vid företagsekonomiska institutionen i Uppsala (Nyström, 1974). Detta i syfte att försöka identifiera mönster som kunde förklara balanserad respektive obalanserad resursutveckling och dess påverkan på innovationsbenägenheten och tillväxten i olika typer av företag.

Den industriella utveckling som företag sedan 1970-talet genomgått kan översiktligt beskrivas som en transformation innebärande i dess betydelse för tillväxt, en förskjutning av materiella resurser till immateriella resurser, d v s en kunskapsdriven produktion. En gradvis övergång från kunskapsdriven produktion, nu med ökad fokusering på miljö- och hållbarhetsmål vid ingången till 2000-talet, inledde på 2010-talet med hjälp av "digitaliseringsrevolutionen" under kommande decennium en omfattande kunskapsintegration och därmed behovet av en multidisciplinär forskning.

Den företagsekonomiska forskningen inom industriell ekonomi har under senare tid avhandlat teman som kunskapsutveckling och kunskapsintegration. Frågeställningar inom kunskapsområden utveckling och innovation (Berggren $\mathrm{m}$ fl, 2011) samt frågor om företagens roll i ett lite vidare sammanhang ${ }^{7}$ har varit föremål för forskning med dessa teman. Sedan millennieskiftet har också ledningsintresset för hållbarhetsarbete och hållbarhetsrapportering påverkat kunskapsutvecklingen inom områden som investerings- och finansieringsteori, extern och intern redovisning men också teori om organisation, strategi och ekonomisk styrning.

Vid kunskapsintegration sker en kontinuerlig kunskapsuppbyggnad i en organisation (Berggren $\mathrm{m} \mathrm{fl}, 2011$ ). Utgångspunkten för denna uppbyggnad av ett 'kunskapskapskapital' är att det behövs delad information, bland annat kunskap i form av incitament för att individer ska reagera samt kunskap om möjliga strategiska mönster (och mål) för hur vi människor agerar (empiri). Denna kunskap kan bara observeras i verkligheten. En fortsatt kontinuerlig longitudinell empirisk forskning om företagets resursutveckling, strategiska mönster som analyseras med

\footnotetext{
${ }^{6}$ Revidering av normerande regelverk för redovisning (GAAP, IFRS m fl.), för ledningssystem (ISO, SOX m fl.), för juridik och intern kontroll/revision (COSO m fl.) samt för rättspraxis inom innovationsområdet (avtals- och patenträtt $\mathrm{mm})$.

7 "Corporate Citizenship" är ett begrepp som redan under 1980-talet ville fokusera företaget som institution och dess roll inom CSR (Corporate Social Responsibility). En här citerad forskare är Ronald Jeurissen (2004).
} 
relevant teori kan bidra till en diskussion om dess validitet, $\mathrm{d}$ v s om generella slutsatser kan dras.

Exempel från empirisk forskning inom områden som medicin, exempelvis vid upptäckten av penicillin, visar att den fortsatta, samlade empiriska forskningen innebar strategier för att såväl minska dess osäkerhet och risk, som för att öka dess kapacitet för värdeskapande $\mathrm{d} v \mathrm{v}$ förmågan att uppnå ytterligare / förväntad/ nytta och värde av innovationen (Mansfield, 1969). En slutsats är att det är en utmaning att finna en förklaringsmodell, utgående från kunskapsintegration och innovation, för att förstå hur 'balans' uppnås i företagens strategiska beslutsprocesser där strategifrågor och styrningsfrågor varvas. Empiriska studier av verkligheten omprövas kontinuerligt med denna modell.

Specifika fenomen som uppmärksammas i den longitudinella forskningen kan tolkas som tecken på 'obalans' d v s avvikelser från "det allmänt vedertagna" vad gäller innehåll, form eller utveckling. Med utgångspunkt i föreställningen om att en 'hållbar' utveckling grundas i någon form av balanskonst över tid så tjänar dessa signaler om 'obalans' som incitament för att, utifrån gällande kunskapsteoretisk förståelse och företagsekonomiska fundament, kunna förklara eller bidra till breddad kunskap och förståelse från åtminstone de tre områdena; finansiell, ekologisk och social hållbarhet. Aspekter på ny teknologi berör samtliga områden.

Ett relativt nytt forskningstema som denna avhandling vill tydliggöra är därför hur 'hållbarhet', relaterat till det mer eller mindre explicita målet tillväxt ${ }^{8}$, avhandlas i teoretisk kontext ${ }^{9}$ och i dess applikation i företags långsiktiga strategier och ekonomiska styrning.

Forskningen inom ekonomistyrningsområdet belyser särskilt betydelsen av samvariation mellan företagsledningars strategiarbete och företagets ekonomiska styrning (Nilsson och Rapp, 2005), allt i syfte att styrningen ska bli optimalt effektiv över tid. Stora omvärldsförändringar gör att forskningen sedan millennieskiftet lyfter fram ett stort behov av ett exceptionellt framåtriktat och aktivt ledarskap (MacIntosh, 1996; Otley, 1995, 1999; Simons, 1995, 2000). Som en konsekvens poängteras behovet av mer långsiktigt inriktad strategisk planering och, i och med det, också en långsiktig och strategiskt orienterad ekonomistyrning.

"We now want to ...argue that organizations enact their environment by way of strategic planning..." "A strategy is a master plan for how organizations intend to compete in its environment and what sort of structure, including coordination and control devices, is required to implement the plan" (MacIntosh, Management Accounting and Control Systems, 1996, s 88)

I företag varvas strategifrågor och styrningsfrågor av individer i organisationens många strategiska beslutsprocesser, i syfte att uppnå s k strategisk kongruens (Nilsson och Rapp, 2005). I företag med strategiskt viktig forskning, d v s FoU och innovation, kan ett mer grundläggande synsätt antas vara viktigt för organisationens långsiktiga konkurrensförmåga,

\footnotetext{
8 "Målet tillväxt” får här representera ett allmänt vedertaget begrepp för företagens förädlingsvärden, d v s en årlig, positiv eller negativ tillväxt av näringslivets andel av BNP.

${ }^{9}$ Denna avhandling baseras primärt på forskningsresultat från empiriska studier i några svenska industriföretag. Samtliga företag har uppvisat en god transparens när det gäller möjligheter att få tillgång till information. Seminarier, workshops med företagen men också studenters uppsatsarbeten, har möjliggjort en forskning om samtida villkor och tendenser för näringslivet.
} 
utveckling och tillväxt. Vad är då ett grundläggande synsätt, vilka mål och förutsättningar påverkar ledningsstrategier mot kloka och långsiktigt effektiva beslut - och vilken typ av ekonomisk styrning påverkar resultat och ger förväntade effekter?

Forskningen inom industriell ekonomi ansluter sedan 1960-talet till ett paradigm som utöver att uppmärksamma heterogenitet på marknader också belyser omvärldens påverkan på näringslivets organisationer. Joe S. Bain utvecklade ett 'paradigm' som kom att benämnas "the structure conduct perfomance paradigm" (SCP) (Bain, 1956, 1959). SCP är en modell som belyser hur externa "chocker" påverkar organisationens struktur och beteende. Modellen är den modell ur vilken Michael Porter senare identifierade strategier för konkurrens (Porter, 1985, 1991). Bains samt speciellt Porters modeller för hur företaget effektivast ska utveckla organisation, produkter och marknader, genom antingen diversifiering eller intern anpassning av organisationens utbud, har i företagsekonomisk skolbildning tillämpats som fundamental kunskap. Konkurrens, med utgångspunkt från ett företags struktur och förutsättningar uppstår, i denna skolbildning, implicit på dess (heterogena) utbudsmarknad, och omfattar utbud av såväl materiella produkter och immateriella tjänster som finansiella produkter och tjänster. Men de två begreppen, hållbar respektive tillväxt, som belysts har fått en större betydelse för företag och är etablerade begrepp inom dessa och andra forskningsfält. Begreppet 'hållbar tillväxt' är föremål för forskning inom främst nationalekonomi och organisationer i en samhällskontext. Begreppet "hållbar" ("sustainable") refererar till FN's agenda för hållbar utveckling i termer av ekologisk, social och finansiell hållbarhet ${ }^{10}$.

James March $(1991,1994)$ beskrev två typer av processer i en organisations utveckling, detta i termer av utveckling respektive exploatering. Crawford S. (Buzz) Holling utvecklade utifrån liknande processer en teori för att förklara hur ekologiska system inkluderande fyra processer kan förstås i ett kretsloppssystem för ekologisk hållbarhet. Hollings modell implicerar förändringar i systemets resursbas utifrån ett 'externt' respektive 'internt' perspektiv. En tillämpning av systemteori (Boulding, 1953; Senge, 1990) samt resiliensteori (Holling, 1973, 1986) kan potentiell också förklara de processer som i en företagsekonomisk kontext bidrar till ett mål för hållbar tillväxt.

Företagsekonomisk skolbildning inom strategiområdet med koppling till ekonomistyrning har "traditionellt" haft och har ett marknadsperspektiv d v s där säljare och köpare identifieras utifrån människors tillfredsställande av mer eller mindre omedelbara och uppenbara behov. En beslutsprocess här speglar detta "utifrån- och in" - perspektiv när det gäller beslut om att utveckla företags konkurrensfördel och också ledningens uppfattning om organisationens förmåga att växa, underförstått volymmässigt d v s med målet en "ökade marknadsandel" på en utbudsmarknad. I såväl SCP-teori som i Porters teori om "the five forces" (Porter, 1979) diskuteras inte företagets målstruktur explicit.

De två senaste tioårsperioderna har inneburit nya villkor för näringslivets företag utifrån samhällsmålen för hållbar utveckling och tillväxt. Denna nya diskurs omfattar såväl teori om resursberoende som hur människan antas påverka en 'resursbas' i olika kontexter. Företagets resursbas relaterar explicit till en faktormarknad för resurser.

${ }^{10} \mathrm{~F}$ n refererar den empiriska forskningen till de 17 utvecklingsmålen i Parisavtalet från 2015 
Ett av företagandets och därmed företagsekonomins grundelement är resurser ${ }^{11}$. Begreppet resurs har inte alltid haft samma innebörd. Under 1900-talet introducerades metoder som självkostnads- och bidragskalkylering, två metoder för primärt kvantitativa beräkningar inom ekonomistyrning. Detta medförde att ingen skillnad gjordes mellan begreppen 'kostnad' och ‘resurs`. 2000-talets redovisningsbegrepp `resurs' definierar begreppet resurs som en `tillgång'.

I ett företags kontext och konkurrensposition, där kvalitativa villkor för företagens legitimitet påverkar strategier och agerande, indikerar dessa nya hållbarhetsmål och villkor ett behov av bredare perspektiv på såväl resurser som marknader i företagsledningars strategiska beslutsfattande. Målen implicerar därmed nya villkor för företags långsiktiga resurstillväxt och värdetillväxt. Och de implicerar behovet av en mer strategisk och övergripande ekonomisk styrning. Denna forskning avhandlar därför hållbarhetstemat genom att implicera alla förekommande resursslag (per definition) i företagets strategiska styrning.

I ledningens utmaning att balansera strategi och ekonomisk styrning är valet av utgångspunkt för styrningen inte självklart. Strategiforskningen har under de senaste decennierna utvecklats med detta 'marknadsperspektiv' och representeras i huvudsak av Michael E. Porter (Porter, 1985, 1990). Denna forskning har tydligt präglat företagens utåtriktade strategiarbete och kommunikation. Det resursbaserade synsättet ("the resource based view", RBV) som idag har stort empiriskt stöd vid ledningars strategival representeras bland annat av Birger Wernerfelt och dennes empiriska studier (Wernerfelt, 1985). Om denna 'nya' teoribildning skriver Richard P. Rumelt m fl;

"Whereas Porter's approach to strategy built on the structure-conductperformance...there was another tradition ... which saw industry structure as reflecting efficiency outcomes rather than market power... and the importance of unique ... resources in sustaining performance” (Rumelt $\mathrm{m} \mathrm{fl}, 1991 \mathrm{s.}$. 8).

En beskrivning av olikheter mellan dessa två synsätt, 'marknadsbaserat' respektive 'resursbaserat' synsätt, illustrerar en pågående perspektivförskjutning i synen på ekonomistyrning som sådan; olikheter som kan förtydligas med exempel från empiri och som nu fordrar en fördjupad problematisering av ekonomistyrning relativt dessa två synsätt, för att kunna helt förstås. Vid jämförelse mellan synsätten måste en diskussion föras om vad en kvalitetsdimension innebär och vilken betydelse den har $\mathrm{i}$ ekonomistyrningen. Det resursbaserade perspektivet exemplifierar kvalitetsaspekter i den empiri som Edith Penrose redovisar. ${ }^{12}$

Utvecklingen av det resursbaserade synsättet, med Edith Penroses' exemplifiering från omfattande empiriska studier av bland annat Herculus Powder Comp., innebar en tydlig fokusering på organisationens "egna" resurser i syfte att försöka skapa en position för organisationens strategiska resurser som underlag för beslut om

\footnotetext{
${ }^{11}$ Assets, or economic resources, are the lifeblood of both business enterprises and not-for-profit organizations". "Since resources or assets confer their benefits on an enterprise by being exchanged, used, or otherwise invested, changes in resources or assets are the purpose, the means, and the result of an enterprise's operations, and a business enterprise exists primarily to acquire, use, produce, and distribute resources". SOURCE: Financial Accounting Standard Board,_FASB. Concepts Statement 6, paragraphs 11 and 15

${ }^{12}$ Edith Penrose's "case" Hercules Powder: (in Edith T. Penrose, The Theory of the Growth of the Firm, New York and Oxford, 1959)
} 
organisationens strategival. I Hercules Powder's fall tydliggjordes detta $i$ samband med och i utvecklingen efter en "de-merger". Organisationens utveckling var nära nog helt "självgenererande". Penrose ville också belysa organisationens förmåga, inklusive ledningens förmåga, att effektivt hantera/utveckla organisationens alla, (strategiska) för företaget unika resurser. Hon poängterar speciellt den potentiella fördel som finns i organisationens "resursbas" $d v s$ resurser som inte utnyttjas men som är utvecklingsbara. I denna hennes empiri handlade det om organisationens specifika kunskap om kemiskt/tekniska ämnen och processer och implicit om organisationens mål att uppnå långsiktigt unika och varaktiga konkurrensfördelar, och en utifrån specifika förutsättningar och villkor genererad hög avkastning, $i$ vissa fall utöver "normal" avkastning ("above normal rents/returns") och tillväxt."

En slutsats av dessa inledande beskrivningar av observation och forskning om två synsätt på strategisk ekonomistyrning i jämförelsen mellan ett mer "traditionellt" synsätt (Porter med flera) och ett resursbaserat synsätt blir att konsekvenserna är olika beroende på vilket strategiskt synsätt som ledningen i sin beslutsprocess väljer för sin styrning (Johnsson, 2006). ${ }^{13} \mathrm{Om}$ ledningen väljer att tillämpa ett resursbaserat synsätt, $\mathrm{d}$ v s väljer beslutskriterier enligt resursbaserad teori så avgörs dels vilken kunskap som ledningen måste ha om potentiell nytta och värde av företagets samtliga resurser, dels hur denna kunskap ska kommuniceras utifrån de förändringsmål som ska åstadkommas (Johnsson, 2006).

I såväl samhälls- som näringslivsperspektiv betonas i företagsekonomisk forskning betydelsen av att näringslivets aktörer, ledning och ägare, beslutar och agerar för att uppnå legitimitet på kortare och längre sikt (Czarniawska $m$ fl. 2007). En utmaning är därför att genom studier av och från forskning om företags ledningssystem om möjligt förstå dels vad som orsakat det observerade fenomenet men primärt utifrån en uttalad målstruktur kunna diskutera en kunskapsteoretisk modell för strategisk ekonomisk styrning som implicerar effekter på företagens kapitalstrukturer.

\subsection{Forskningsfrågor och syfte}

Avhandlingens syfte är utifrån en analys av förändringar i företags strategiska styrning när tillgångarna i företagets resursbas skiftas från materiella till immateriella, föreslå principer för en tillämpbar styrmodell. Den teoretiska utgångspunkten i avhandlingen är resursbaserade teorier och strategisk ekonomistyrning genom vilka företags strategiska styrning för att uppnå långsiktig värdetillväxt studeras.

Den valda forskningslogiken omfattar fyra steg; en induktiv ansats i två steg för att genomföra analys samt två steg för att förklara och utveckla en resursbaserad styrmodell utifrån analysens resultat. Den induktiva ansatsen används för att analysera strategisk styrning utifrån resurs och ekonomistyrningsperspektiven. Därmed är dessa steg mer empirinära än de två följande stegen som stödjer arbetet med att föreslå principer för en tillämpbar styrmodell.

\footnotetext{
${ }^{13}$ I sin bok "Astute competition" diskuterar Peter Johnsson (2006) hur dessa två synsätt påverkar företagets långsiktiga konkurrensfördel. Beskrivningen är intressant då Johnsson argumenterar för hur styrning av enskilda affärsprojekt medverkar till verksamhetens totala styrning.
} 
För att besvara syftet och strukturera arbetet inom de olika stegen av den valda forskningslogiken (Se kapitel 2.2) har tre forskningsfrågor formulerats

För steg 1 och 2 av forskningslogiken har följande forskningsfråga formulerats som avhandlas i kapitel 9:

Forskningsfråga 1: Vilka utmaningar och möjligheter skapas för företags strategiska styrning $i$ samband med av den identifierade förändring av balansen mellan immateriella resurser och tillgångar?

Frågan delas upp med två underrubriker:

(1) Vilka nya utmaningar utifrån resursbaserad analys uppstår i företags strategiska styrning som specifikt kan kopplas till ökningen av de immateriella resurs/tillgångsslagen? Detta avhandlas i kapitel 9.1 och 9.2.

(2) Vilka nya möjligheter och alternativa strategier skapas i företags ekonomiska styrning i samband med det observerade fenomenet? Detta avhandlas i kapitel 9.3 -9.5 .

För steg 3 och 4 av forskningslogiken har följande två forskningsfrågor formulerats och avhandlas i kapitel 10:

Forskningsfråga 2: Vilka alternativa val gör ledningen potentiellt utifrån redovisade förväntningar $i$ en beslutsprocess som möjliggör långsiktigt, vs ett 'betamål’, legitima och effektiva beslut?

Forskningsfråga 3: Hur ser den totala "förklaringsmodell" ut som, utifrån det observerade fenomenet, explicit förklarar olika 'element', delar av förklaringen (orsak, strategi, beslut, styrning och resultat) och dess konsekvenser?

Dessa frågor är formulerade för att både fånga bredden och detaljerna kring det fenomen som studeras här, d v s förändringen i företagen resursbas från materiella till immateriella tillgångar. Frågorna kommer analyseras utifrån den teoretiska lins som resursbaserad och strategisk ekonomistyrningsteori ger vilka tillsammans skapar multipla perspektiv, snarare än enkla och ensidiga, vilket behövs för studier av det komplexa syfte som studeras här.

Syftet med denna min forskning innebär att utforska och beskriva om och i så fall hur förändringen av balansen mellan materiella och immateriella tillgångar skapar nya förutsättningar för konkurrenskraft och nya villkor för strategisk ekonomistyrning. Denna nya situation kräver nytänkande där olika utmaningar och möjligheter utvecklas under förändringen. För att fånga detta är det empiriska materialet formerat kring fyra olika fallbeskrivningar vilka tidigare har redovisats i andra sammanhang och därför är omväxlande skrivna på svenska och engelska. De två första empiriska studierna har ett högt förklaringsvärde för två specifika områden, organisationens beslutsprocesser och dess legitimitet. Fördjupade analyser föreligger som bilagor till avhandlingen. De två tillkommande studierna avhandlar bredare kontext och analyseras som helhet i kapitel 9. 
De sammanlagt fyra fallbeskrivningarna analyseras i denna avhandling utifrån perspektivet av ett fokalt företag, här benämnt målföretaget, en internationellt verksam koncern. Under den långa period som målföretaget har fokuserats har omfattande förändringar skett som medfört kontextuella implikationer såväl teoretiskt som praktiskt. Även om det kan finnas möjlighet att ta andra perspektiv utifrån hur fallstudierna är skrivna så berörs dessa ej i denna avhandling.

Denna avhandling har sin utgångspunkt i den mångåriga erfarenhet jag har från styrning på operativ och strategisk nivå, ekonomiplanering, strategi- och utvecklingsarbete samt innovationsarbete inom internationella koncerner. Fallstudierna är framtagna under faser där forskningsarbetet har varit i fokus och behandlar inte fall där jag under den tid när fallstudierna genomfördes haft en ledande roll i de behandlade företagen. Erfarenheten har dock möjliggjort att jag kunnat möta personerna med både kunskap om deras vardag och den teoretiska lins som forskarutbildningen gett.

\subsection{Avhandlingens disposition}

Avhandlingens disposition visas i figur 1. Avhandlingen startar med en introduktion som beskriver behovet som adresseras genom avhandlingen (kapitel 1). Därefter följer en genomgång av den forskningsansats, med begränsningar, som valts för studien som helhet (kapitel 2: Forskningsansats), sedan redogörs för kunskapsteoretiska utgångspunkter d v s hur och varför en avgränsning gjorts av fokus för avhandlingen (kapitel 3: Forskningsområde).

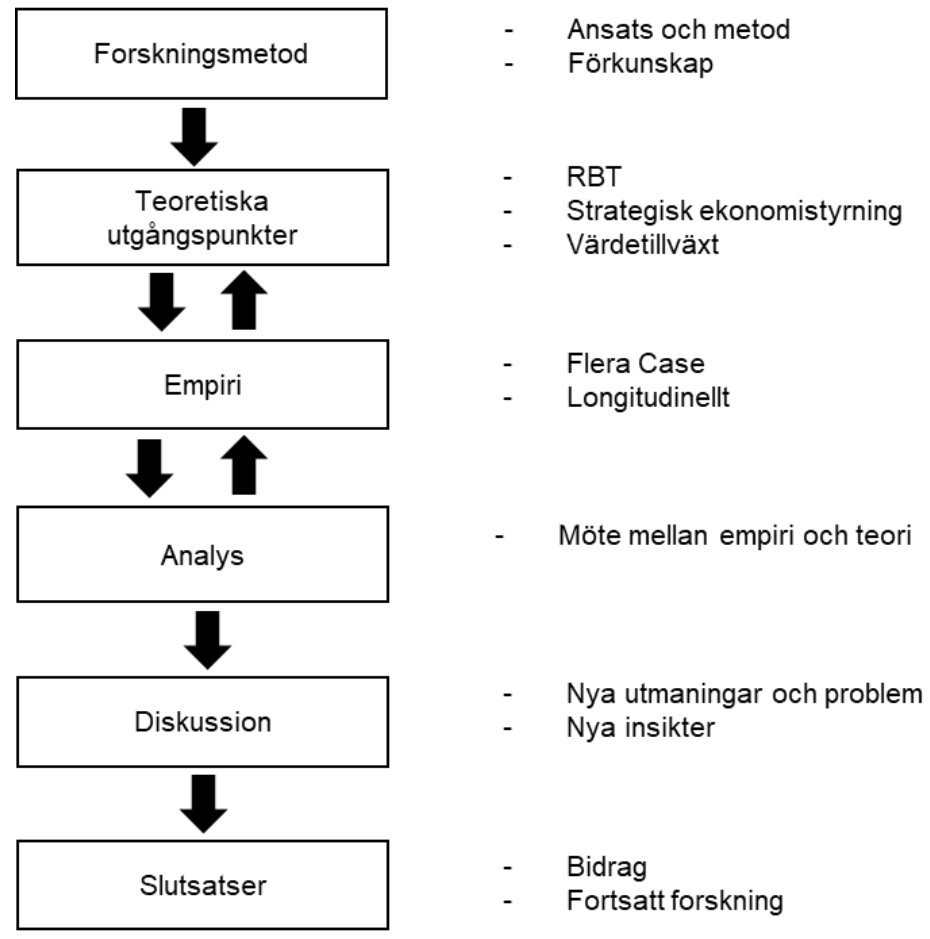

Figur 1. Avhandlingens disposition 
En tentativ modell för analys av kommande empiri utvecklas i kapitel 4. I tre empiriska kapitel redogörs för förstudier samt fyra fallstudier som genomförts under perioderna 2005 - 2009 samt 2015 - 2019. Från en inledande förstudie görs en fördjupad problematisering. Partiell analys görs av resultat från respektive fallstudie (kapitel 5, 6 och 7: Empiri). I ett analyskapitel görs en sammanfattande systemisk analys av samtliga fallstudier (kapitel 8: Analys). I två avslutande kapitel och utifrån de förväntningar som framkommit i empiri och med återkoppling till avhandlingens forskningsfrågor, diskuteras implikationer för fortsatt forskning.

\subsection{Centrala begrepp}

Centrala begrepp i avhandlingens forskningsfokus på resursbaserad ekonomisk styrning.

- Ekonomisk styrning Ett samlingsbegrepp för ledning och samordning av företag utifrån preciserat syfte och mål inkluderande ekonomistyrning på enhetsnivå (på engelska Management Control eller Strategic Management Control).

- Resursbaserad ledning eller ibland resursbaserad ledning och styrning; inkluderar tillgångsstyrning för de resurser (materiella och immateriella) som kontrolleras (på engelska Resource Management; inkluderar även begreppet Asset Management).

- Oidentifierade resurser/tillgångar Dessa kan finnas `internt’ via tex egenupparbetade resurser vilka inte kan aktiveras, utan absorberas löpande i resultatredovisningen, eller 'externt' såsom externt genererad goodwill vilka uppkommer vid förvärv och aktiveras "non-current".

- Identifierade resurser. Dessa bör kunna identifieras och aktiveras som både "current" och "non-current".. Internt identifierade resurser kan tex avse projektrelaterat upparbetat kunskapskapital = innovationskapital (vilket stannar i organisationen och löpande utvecklas).

- Identifierade, immateriella tillgångar (IP och andra "non-current").

- Materiella/Fysiska tillgångar ("current"/"non-current").

- Finansiella tillgångar. Här samtliga monetära tillgångar, inklusive derivat.

- Betamål = ett här konstruerat begrepp med innebörden ett framtida mål som innefattar en förändring. I avhandlingen antas målet vara en optimalt hållbar, intern resurstillväxt och en balanserad /hållbar/ värdetillväxt för ägare över tid. 


\section{Kapitel 2 Forskningsansats, forskningslogik och metod}

I detta kapitel, beskriver jag de forskningsmetoder som använts och den approach som använts i genomförandet av studierna och i skrivandet av avhandlingen. Som beskrivs i samband med syftet är avhandlingen strukturerad kring två ansatser vilka också beskrivs; en induktiv ansats i två steg för att genomföra analys samt därefter två steg för att förklara och utveckla en resursbaserad styrmodell utifrån analysens resultat. Forskningen och de fallstudier som genomförts innehåller många dimensioner och för avhandlingen har en fokusering skett.

\subsection{Vetenskapsteoretisk utgångspunkt för metodval}

Det kunskapsområde som valts för avhandlingen omfattar finansiella och icke-finansiella respektive kvantitativa och kvalitativa värdebegrepp. Empiri omfattar villkor för en `hållbar värdetillväxt', d v s inte endast finansiella villkor. Icke-finansiella villkor avser förutsättningar för ekonomisk styrning och implicerar faktorer på faktormarknader för naturresurser och humankapital.

Inför metodvalet har en forskningsansats valts som avser att möjliggöra en tvärvetenskaplig analys. Ursprunget till den ansats som tillämpas är nomolog deduktion (Popper - Hempel 1952). Nomolog deduktion (ND) är en logik som kan liknas vid den s k abduktionen. Charles Sander Peirce (1839 - 1914), en fysiker från USA, utvecklade en logik som han benämnde abduktion. Denna logik skulle kunna uppfattas som vetenskaplig procedur som innefattar både deduktiva och induktiva steg i en forskningsprocess. Genom att observera fenomen i en verklighet kan en hypotetisk modell skapas och som genom en deduktiv analys, stödd av teori, härleder fakta från den hypotetiska modellen. Insamlad och redovisad data är såväl kvantitativ som kvalitativ. I ett tredje steg prövas 'hypotesen’ genom empirisk studie. Empiriska resultat jämförs med tidigare erfarenhetsbaserade utsagor från empiriska studier av mer induktiv art. Med viss sannolikhet (se även Taleb, 2008) förväntas andra fenomen kunna förklaras och därmed förstås. Detta har varit en utgångspunkt för hur studierna lagts upp, hur analyserna genomförts och hur syftet med avhandlingen besvaras.

Nomolog deduktion ställer vissa krav på logik och lagbundenhet i orsak-verkansamband för att ett forskningsresultat ska anses ha validitet. Den abduktiva logiken tillämpas här med en beprövad modell för kvalitetsstyrning, EEM-modellen, ${ }^{14}$ som valts för såväl redovisning som deduktiv analys av empiriskt material. Modellen är prövad i en systemkontext (Dahlgaard-Park, 2008). Författaren ser att EEM-modellen är lämplig och enkelt kan anpassas för att fånga olika former av ekonomistyrningsmål. EEM-modellen har även föreslagits som en modell för att identifiera framgångsfaktorer för innovation och produktutveckling (Dahlgaard och DahlgaardPark 2006). Analysen här benämns `systemisk analys` och bygger på att forskaren måste ha förståelse, erfarenhet och kompetens kring existerande förutsättningar för att kunna revidera modellen för att bättre passa den givna kontexten.

\footnotetext{
${ }^{14}$ EEM-modellen (EFQM-modellen) är en modell för att beskriva ett företags hela verksamhet. Den används i syfte att mäta kvalitetsaspekter och är utvecklad av 'the European Foundation for Quality Management'. Den har utvecklats i olika tillämpningar vid implementering av långsiktiga strategiförändringar. Två exempel är omdaningen av det statsägda danska järnvägssystemet och för att utveckla bilföretaget Nissan inför etablering i Sydafrika (Witcher et al, 2008).
} 


\subsection{Forskningslogik}

Här nedan görs en redogörelse av en logik som i fyra steg lett fram till avhandlingens slutsatser och fullgörande av dess överställda syfte. Dessa steg illustrerar den forskningsansats, nomolog deduktion (Hempel, 1952) som valts för avhandlingen.

Avhandlingsarbetets logik presenteras i punktform. Syftet med denna logik är att illustrera hur en systematiserad analys av styrning och strategi dels kan vara underlag för att utforma en modell för att dels förstå och förklara en företagslednings strategi och ekonomistyrning mot ett uttalat mål, dels kan förklara beskrivna fenomen som en konsekvens av styrningen - eller potentiellt en förutsättning för en strategisk styrning.

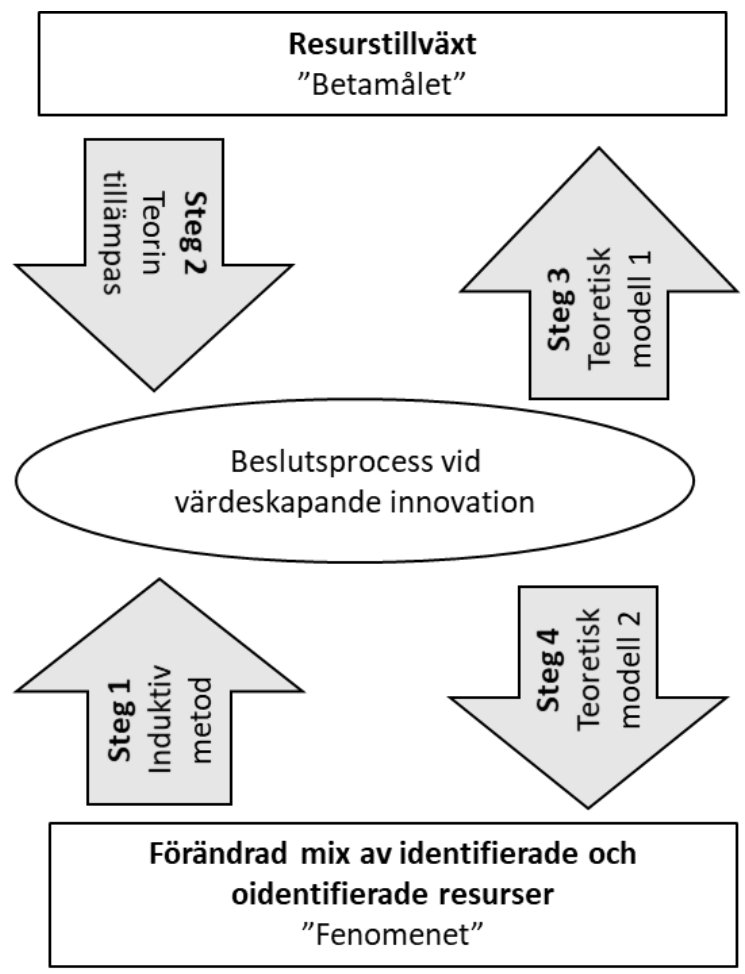

Figur 2. Avhandlingens logik; en tankestruktur

Här redogörs för de fyra stegen i korthet:

Steg 1 - Analys via induktiv metod. Med denna logik har konstaterats ett fenomen med eskalerande obalanser som potentiellt inte är strategiskt hållbart/alternativt är potentiellt strategiskt hållbart; d v s ett observerat mönster under en längre period som potentiellt påverkar såväl företagens kapitalstrukturer som ledning och styrning av/med både identifierat och oidentifierat, immateriellt kapital. Vidare görs ett urval från ett antal empiriska studier för att analysera behov eller nya mönster i företagens beslutsprocesser och prioriteringar. Här 
konstateras i två fallstudier (Case ROBO och Case CATHEDRAL) att kunskapen inom/om den valda kontexten, R\&D, är låg, att det framställs oklarheter i målstruktur och målformuleringar, att begrepp tolkas olika samt förväntningar på hur organiseringen av resurser för R\&D ska göras.

I detta steg görs ett försök att med en problematisering av resursbaserad, strategisk ekonomisk styrning (bolagsstyrning och ekonomistyrning per definition) teoretiskt belysa hur observerat fenomen kan förklaras Det konstateras att resursbaserade synsätt (TGF/RBV/RBT) endast delvis ger en kunskap, exempelvis kunskap om förvärvsstrategi, för att analysera och förstå fenomenet med denna 'obalans'. Det konstateras att även om resursbaserad teori (Barney, 2007) primärt utgår från förutsättningar på en 'strategisk faktormarknad' så exemplifieras resultatet av styrning utifrån 'marknadsinriktade strategier'. Dessa strategier avser primärt att uppnå 'kvantitativa' konkurrensfördelar på en heterogen utbudsmarknad. En strategi med en 'resursbaserad inriktning', utifrån 'kvalitativa' (kunskaps) /aspekter på strategier på en dynamisk faktormarknad (förändring av ledarskap, systemkapacitet, innovation etc), kunde potentiellt bidra till en bättre förklaring av det observerade fenomenet.

Steg 2 - Analys utifrån valda teorier. Här avhandlas hur dessa olika synsätt potentiellt påverkar företagsledningars beslut. Här föreslås en analysmodell för att analysera empiri utifrån en fokusering på faktormarknaden, en "systemmodell".

Vidare formuleras utifrån denna empiri, förslag till hur detta "problemkomplex" dels kan förstås teoretiskt genom att öka kunskap om begrepp, definitioner och processer, dels genom operationalisering av begrepp och tillväxtformler och en tydlig målstruktur och med ett övergripande mål, här det s k 'betamålet', kan möjliggöra för en ledning att tillämpa en resursbaserad styrning.

Här görs en definition av begreppet resurs för mätbarhet samt en formel för 'resurstillväxt' för att få en teoretisk förståelse av "fenomenet" tillväxt i empiri (och potentiellt för praktisk tillämpning).

I denna fas görs en redovisning och en partiell analys av en ytterligare fallstudie; Case FORCE. Här konstateras svagheter/brister i teorin för att förklara fenomenet och här exemplifieras därför med "ny" teori, utvecklad från resiliensteori (Holling, 1973, 2006) hur strategialternativ i fallstudien potentiellt påverkar företagets kapitalstruktur d v s dess resursbas RB (+/-) samt relaterade sättet att styra.

Fyra modeller exemplifierar A) mål, B) resurser, C) villkor för organisering (tid mm) och D) företagets processer, d v s beslutsprocesser och värdeskapande processer. Här görs en redovisning och en partiell analys av en fjärde, omfattande fallstudie; Case INNOHUB. Syftet med den partiella analysen är primärt att klargöra förväntningar, olika strategier och agerande från olika aktörer i ett nytt koncept; "öppen innovation".

Steg 3 - Utvecklar modellversion 1. I detta steg föreslås komponenter, element i "ny integrerad modell”, i syfte att få en teoretisk helhetsförståelse (EEM + PDCA) av ett potentiellt ledningssystem med utgångspunkt från någon form av given mål- och beslutsstruktur

I denna fas diskuteras (utifrån Case INNOHUB) "öppen innovation" d v s förekomsten av ett "internt" och ett "externt" perspektiv i samarbetsprojekt och detta som en potentiell hot/möjlighet eller ett villkor för/förutsättning för en ledningspolicy som möjliggörs med ett 
"sammantaget" ledningssystem, en möjlig tillämpbar arbetsmodell för resursbaserad ledning och styrning.

Vidare diskuteras modellerna ovan, detta som möjligt underlag för kommande hypoteser, genom att analysera förväntningar samt om dessa styrker tanken att ett uttalat "resource management" en tillämpning av alla fyra steg i arbetsmodellen (B, C, D, E/R) är en lösning, en "metod" för att nå företagets "betamål".

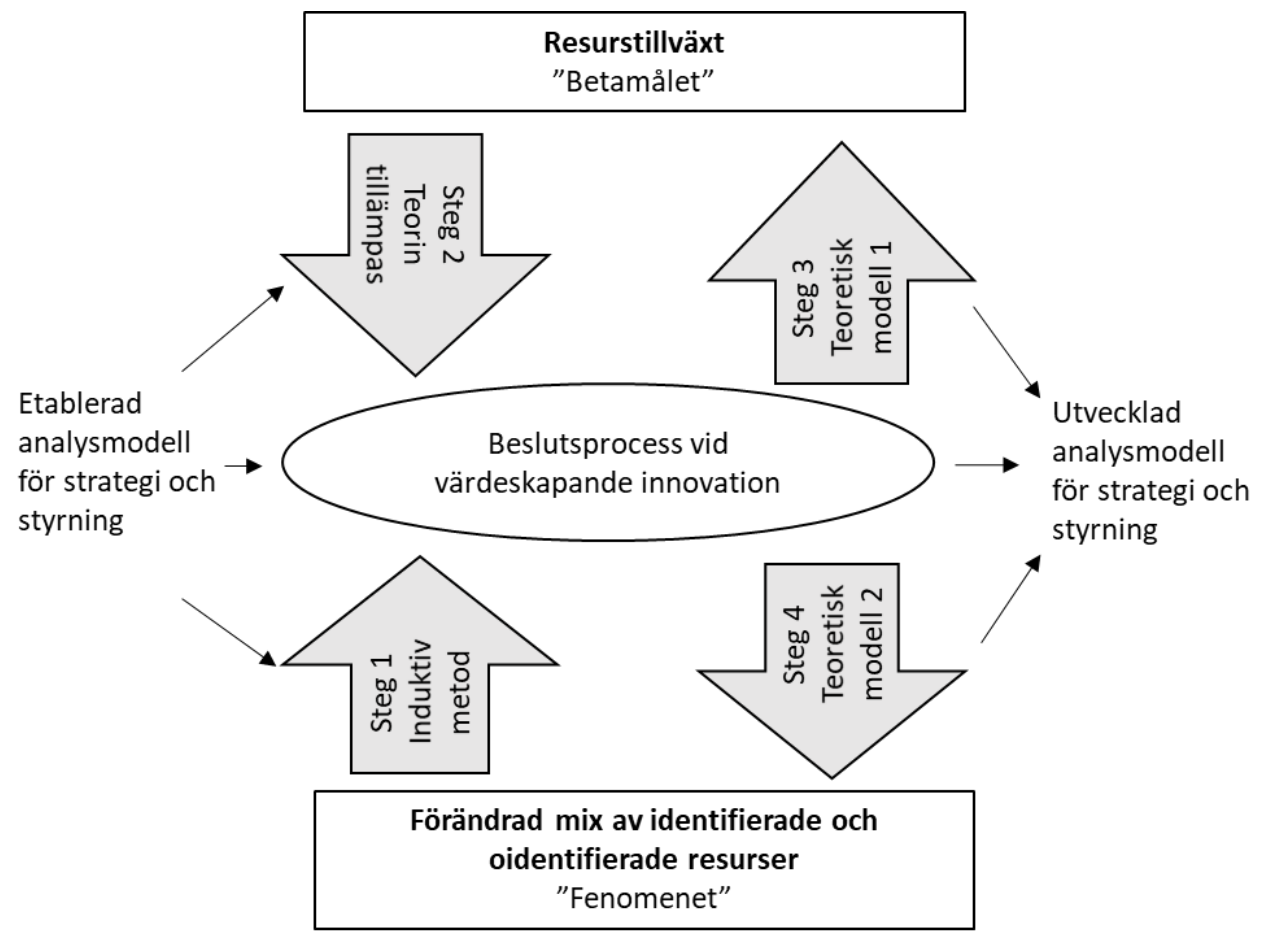

Figur 3. Schematisk beskrivning av avhandlingen arbete med att utifrån etablerad analysmodell/er för strategi och styrning med hjälp av de fyra stegen utveckla analysmodellen

Steg 4 - Vidareutveckling av modellversion 2. Slutligen diskuteras möjligheten att, om generellt tillämpligt, åtgärda ett fenomen med 'obalans' genom ökad kunskap och kunskapsintegration och explicit genom att, med en utvecklad referensram, identifiera ett innovationskapital som en avgörande post i företagets kapitalstruktur.

För att i någon mån verifiera att en potentiell tillämpning av ett "resource management" följs ett ISO-projekt (som en referensgrupp). I ISO-sammanhang benämns "resursbaserad" strategi 
= SAM(P) ("strategic asset management planning"), vilket i nuläget omfattar organisationens samlade resursbas, d v s även organisationens strukturkapital/(intangibles). ${ }^{15}$

Vidare diskuteras om det kan konstateras (bland annat genom att ISO arbetet bekräftar) att ett tydligt trendbrott med nya mönster, kan identifieras i synen på företags långsiktiga framgång eller om det handlar om en "tillfällig" och naturlig men långsiktig "cyklisk" förändring i anpassning till mer tillfälliga attitydförändringar och politiska bedömningar i omvärlden.

Avhandlingen tar sin utgångspunkt i etablerade teorier och dessa används vid analys i de två första stegen. Utifrån detta utvecklas analysmodellen utifrån arbetet inom de avslutande stegen, steg 3 och steg 4 , se figur 3 .

\subsubsection{Begränsning vid valet av forskningsansats och forskningslogik}

Den forskningsansats som valts, nomolog deduktion eller abduktion, innefattar en induktiv metod för insamling av empiriska data, $\mathrm{d} v \mathrm{~s}$ en metod som i denna studie innebär aktionsforskning eller deltagande forskning. Denna kvalitativa insamlingsmetodik implicerar en aktiv och tolkande logik och i denna empiri en inte helt värderingsfri studie av en avgränsad del av verkligheten. Kvalitativ metod implicerar frågeställningar om resultatens validitet och om snedvridningar uppstår utifrån såväl forskningsansats som forskarens förförståelse vid genomförande och vid tolkning av resultat.

Denna logik med "nomolog deduktion" som valts har i sig begränsningar. I försök att identifiera dessa begränsningar har ett försök gjorts som förberedelse inför metodvalet (Boström, 2015). ${ }^{16}$ Logiken vid genomförande är generellt tillämplig, Den primära begränsningen vid analys av ett forskningsresultat ligger i att detta är helt kontextberoende.

En ytterligare begränsning vid metodvalet aktionsforskning är forskarens förförståelse. Daniel Kahneman, pristagare av Alfred Nobels ekonomipris, redogör i sin bok "Thinking, fast and slow" (Kahneman, 2011) för bland annat hur snedvridningar, d v s systematiska fel i individuella tolkningar av verkligheten uppkommer under vissa omständigheter. Peter Senge redogör i sin bok "the Fifth discipline" (Senge, 2006) bland annat för hur individens föreställningar, våra s $\mathrm{k}$ mentala modeller, kan begränsa vårt tänkande - och handlande. David D. Resnik (Resnik, 1998) framhåller i sin bok "the ethics of science" att ingen forskning är helt värderingsfri.

Genom att välja denna forskningsansats, med sina begränsningar, inför en serie studier som primärt genomförs som aktionsforskning, prövas gränserna för avhandlingens vetenskaplighet. Genom detta val av en logik, med implicita krav på lagbundenhet, är förhoppningen att influens av den förförståelse som här redogörs för ska kunna minimeras och att tolkningen inte ska

\footnotetext{
${ }^{15}$ ISO arbetet syftar till en helhetsstyrning för att minska "siloeffekter" i en organisations strategiska arbete. Se SAMP-modellen/ISO TS 55010 (Alignment to Finance ). Övriga ISO-regelverk som berörs är ISO 56000 (Innovation), ISO 55000/1/2 (Asset Management), ISO 30401 (Knowledge Management), ISO 37000 (Government of Organizations), ISO 9000 (kvalitetstyrning) samt ISO 144001 (miljöledning).

${ }^{16}$ I samband med forskarutbildning i aktionsforskning under 2015 diskuterades tillämpning av metodvalet "nomolog deduktion" och i vilken utsträckning metoden var tillämplig samt vilka begränsningar (kontextuellt och konceptuellt) metoden medförde. Ett försök att finna dessa avgränsningar i denna kontext gjordes därför en PM. Mode 0 eller Mode Zero (Boström, 2015).
} 
påverkas alltför mycket av personliga "mentala modeller" eller på grund av snedvridning av fakta.

\subsection{Forskarrollen. Praktikern. En forskares förförståelse.}

Detta avhandlingsarbete har efter en initial fas bedrivits i en global industrikoncerns svenska verksamhet där avhandlingens författare varit verksam och bland annat ansvarat för ett större utbildningsprogram för hela organisationen. Miljön där aktionsforskningen bedrivs är till stor del en forskningsmiljö där personer som medverkar i de fyra fallstudierna är forskare och forskningsledare. Även affärsutvecklande enheter har studerats.

Den roll som en aktionsforskare får är upp till betraktaren att avgöra och tilldela. Uppfattning om lojalitet, akademisk hemvist och forskarens förtrogenhet med forskningsområdet ger denne legitimitet och tillgång till information. För att tydliggöra akademisk hemvist och lojalitet har beskrivningen av rollen, i den empiri som genomförts under den senare period, extra tydliggjorts som aktionsforskare, en roll där dialog har prioriterats. Förtrogenhet från tidigare praxis har potentiellt påverkat att möjligheterna till dialog underlättats. Efterhand har en formalisering av forskarrollen utifrån akademisk hemvist blivit allt viktigare.

För att läsaren av denna avhandling ska bedöma metodval, objektivitet och graden av sanningssökande ges här i jag-form en beskrivning av förförståelse inom företagsekonomiområdet - en förförståelse som efter ekonomexamen utvecklats under fem decennier inom svenskt näringsliv inom både handel och industri.

Min yrkesbana startade, parallellt med ekonomistudierna, i bokbranschen som är en utpräglat kunskapsbaserad tjänsteverksamhet, men samtidigt med stort inslag av materiella värden och global konkurrens. Böcker, såväl svensk som utländsk litteratur, ansågs dyra av såväl studenter som människor i vardagen då kunskapen som förmedlades sällan kopplades till själva produkten (boken som media) i distributionskedjan.

Under utbildningen till ekonom och som underlag till en kandidatuppsats på 1970-talet deltog jag i utformningen och implementeringen av ett för branschen då unikt försörjningssystem för böcker. Mitt intresse för de mycket stora värden som bands i lagerhållning och i distribution, medförde att jag funderade mycket på hur dessa värden skulle kunna göras mer rörliga d v s böckerna skulle nå sina kunder direkt utan att "onödiga" kostnader skulle behöva drabba dem.

Kandidatuppsatsen baserades på en ny teori som kallas positionsanalysen (Söderbaum, 1975). På 1990-talet kom detta intresse för logistik att manifesteras i ett stort utvecklingsprojekt med en fysisk etablering, ett s k "lagerlöst system" för Norden och för Fords reservdelsdistribution i Örebro.

Parallellt med utbildningen på högre nivå har jag bland annat samlat erfarenheter från bolagssfärerna Investor och Beijer. Som divisionscontroller och i ledningsposition i ett tillverkande bilindustriföretag (SAAB-SCANIA) på 1980-talet, fick jag bland annat kunskap om och ansvar för genomförande av 'kapitalrationalisering' och ekonomisk styrning. KAPRAT var en modell för effektivisering som kom att tillämpas i industrin under många år och var en modell som i dagsläget skulle kunna betraktas som ett verktyg i det vi idag i många företag ser som resurseffektivisering; ett centralt tema $i$ organisationens mer eller mindre 
kunskapsbaserade och "agila", ekonomiska styrning. En känd tillämpning av denna styrning var i slutet av 1990-talet styrmodellen T50 vid ABB.

Att det fanns en annan sida av detta med kapitalrationalisering, $\mathrm{d} v \mathrm{~s}$ något som inte bara handlade om kostnader och flöden av materiella värden, förstod jag först senare när jag som rektor och vd ansvarade för ett antal privata utbildningsföretag; d v s kunskapsutvecklande miljöer och program. Detta initiala intresse för värdering av kunskap och kunskapsspridning fick mig senare att söka svar på frågor om mer osynliga, immateriella värden, och så småningom också om de processer som kunde observeras vid mer långsiktiga och strategiskt viktiga beslut $\mathrm{i}$ industrin.

Efter många år som anställd och konsult inom svensk industri (SAAB- Scania och ABB) har jag, utöver förståelsen för kortsiktiga lönsamhetsfrågor utvecklat en förståelse för den ofta svåra situation som man som människa dagligen ställs inför om man har någon form av beslutande roll i en organisation. Särskilt påtagligt svåra var de beslut som handlade om utveckling av ny teknologi, nya produkter mm. Hur jag tänker som processledare, projektledare, produktchef, utvecklingschef, personalchef eller i en VD- eller annan ledarroll - om jag ska tänka och agera - men ändå lite mer långsiktigt, var en ständigt återkommande och aktuell reflektion. Vilka erfarenheter ligger bakom mitt sätt att värdera olika beslutskriterier och förhoppningsvis komma fram till beslut som är bra? Vad är bra, vilka kriterier och värden är viktigast $i$ ett längre perspektiv och för vem? Detta framstod som ett intressant område att forska om i samband med att jag år 2005 påbörjade min forskarutbildning. Parallellt med forskarutbildningen har jag genomfört undervisning och handledning på kandidat- och magisternivå vid tre universitet.

I början av 2000-talet initierade ledningen i ett av Sveriges då största verkstadsbolag ett arbete för att utveckla ledningsstandards ISO 14001 utifrån ett s k 'Triple Bottom Line'-perspektiv (Anthony m fl, 2014). Detta arbete blev en inkörsport till mitt intresse för hur immateriellt kapital och värdering av detta kapital skulle göras i en global koncern med stora materiella värden. F n (2019) pågår en utveckling som inom ramen för en ny standard: "asset management" (inom ISO 55000-serien). Jag medverkar nu som expert i tre internationella arbetsgrupper inom ISO/TC 251, WG5/WG6/WG9 där min medverkan dels är att potentiellt kunna bidrag till standardutveckling med praxis för interna beslutssystem, men framförallt att lära av global expertis om värdering vid tillgångar och då primärt immateriella tillgångar.

Mina reflektioner och frågor om detta immateriella kapital och hur det ska avhandlas har dels handlat om nyfikenhet och att försöka skapa en egen insikt i ämnet, dels också för att utveckla ett forskningstema; d v s ett tema där teorier ska kunna utvecklas och verifieras på ett vetenskapligt sätt. För att möjliggöra för läsaren av avhandlingen att bedöma min förförståelse har jag sammanfattat denna i bokkonceptet "Resurstillväxt" (Boström, 2015). 


\subsection{Insamling av empiriskt material}

Logiken nomolog deduktion innebär primärt studier av fenomen i verkligheten, fenomen som måste beskrivas utifrån ett tolkande, hermeneutiskt förhållningssätt. Allt viktigare initialt för utformning av syftet med avhandlingsarbetet och inför metodvalet har varit betydelsen av ett uttalat mål att relatera till för att analysera och förstå den 'interna' styrningen i de kontexter som studeras.

Det initialt observerade fenomenet avseende företagens kapitalstrukturer uppmärksammades först i samband med uppsatshandledning vid magisterstudenters analys och tolkning av företags balansräkningar över längre perioder d v s en utveckling som pågått under många år. Fenomenet har senare bekräftas som ett 'verkligt' fenomen genom andra källor dels i samband med ISO arbete under 2019 och forskningsrapporter (IP Close Up, 2019). Att kunna relatera forskningen och informationsinsamling om företagens strategiska styrning till detta fenomen öppnade möjlighet till ytterligare djupare förståelse för långsiktiga effekter på företagens kapitalstrukturer och ledningars förhållningssätt till detta fenomen.

Redan vid inledande informationsinsamling d v s vid seminarier och "förtroliga" samtal med företagsledare och affärsansvariga om att skapa långsiktig värdetillväxt framkom att en drivkraft för att skapa värde var förmågan att skapa en 'resurstillväxt' för att kunna växa med 'egna' resurser d v s utvecklingsbara resurser som skulle stanna kvar och "arbeta" i företaget. Detta för att långsiktigt medverka till en `extern’ värdetillväxt. För att kunna relatera empiriska forskningsresultat till de teoretiska utgångspunkterna för avhandlingen definierades därför tidigt ett mål; ett $\mathrm{s} \mathrm{k}$ `betamål'17. Betamålet identifierades på en hög beskrivningsnivå som `en optimalt hållbar, intern resurstillväxt och en balanserad/hållbar/värdetillväxt för ägare över tid'. Prefixet 'beta' avser en förändringsfaktor, detta för att indikera att en resursbaserad, strategisk ekonomisk styrning kännetecknas av dynamik och dynamisk förmåga (Eisenhart $\mathrm{m}$ fl,, 2000; Teece, 2009).

Den vidare insamlingen av information från avhandlingens 'verklighet' har genomförts med en förstudie samt fyra fallstudier, "case studies" (Yin, 1994). Insamling av information vid inledande seminarier och workshops i förstudien har primärt genomförts med informella samtal med deltagare från ledande positioner i större företag men också med benchmark- respektive brainstormingtekniker. De två inledande fallstudierna (under perioden 2005 - 2009) genomfördes med enkäter och djupintervjuer med utvalda "nyckelpersoner"; personer som representerar de olika kontexter som studeras. Omfattning av intervjuer och övrig informationsinsamling redovisas för respektive fall i kapitel 5 - 7 samt i separata dokument. Personerna har anonymiserats men kan identifieras med kodbeteckningar. I tabell 1 redovisas omfattningen av de mer strukturerade informationsinsamlingen.

\footnotetext{
${ }^{17}$ Se begrepplista. Betamål = ett här konstruerat begrepp med innebörden ett framtida mål som innefattar en förändring. Begreppet har konstruerats för att tydliggöra ledningens ambition att utreda och anpassa mål till styrkan i de amplituder som marknaden förväntas visa exempelvis konjunkturella förändringar. Beta = en tillväxtfaktor som tillämpas i bla a Johnssons tillväxtmodell där den benämns TGf.
} 


\begin{tabular}{|c|c|c|c|}
\hline Empiri & Aktivitet & Medverkande & År \\
\hline Förstudier & $\begin{array}{l}\text { Inledande brainstorming med } \\
\text { målföretaget behov av mätning av } \\
\text { FoU }\end{array}$ & 6 p (Ansvarig FoU, 5 Controllers) & 2003 \\
\hline Förstudie (WS, benchmarks) & $\begin{array}{l}\text { Inledande seminarium med } 10 \\
\text { företag }+4 \mathrm{WS}\end{array}$ & $\begin{array}{l}10 \text { p Företagens personalchef, } \\
\text { miljöchef och finanschefer }\end{array}$ & 2004 \\
\hline Förstudie; enskilda intervjuer & Projektinitiativ med målföretaget & $\begin{array}{l}\text { Ledningsgrupp BU 1(M\&S) samt } \\
\text { BU } 2 \text { (FoU) }(4 \mathrm{p})\end{array}$ & 2005 \\
\hline Case ROBO (organisering) & Kalkyler, gateprocess & $\begin{array}{l}2 \text { p Styrgrupp FoU (chefscontroller } \\
\text { BU 1, BU2) }\end{array}$ & 2005 \\
\hline \multirow[t]{2}{*}{ Case ROBO } & Business Case 1 & $\begin{array}{l}1 \text { p Produktportföljansvarig } \\
1 \text { p FoU/projektansvarig } \\
2 \text { p Teknikansvariga }\end{array}$ & $\begin{array}{l}2005 \\
2005 \\
2005 \\
\end{array}$ \\
\hline & Business Case 2 & $\begin{array}{l}1 \text { p Produktportföljansvarig } \\
1 \text { p FoU/projektansvarig }\end{array}$ & $\begin{array}{l}2005 \\
2005\end{array}$ \\
\hline \multirow[t]{4}{*}{ Case CATHEDRAL } & Intervju global (koncernledning) & Programansvarig & 2005 \\
\hline & Intervju ledning BU FOU/CR & $1+1$ p Ansvarig BU & 2005 \\
\hline & Intervjuer ledning & $2 \mathrm{p}$ produktlinjeansvariga & 2005 \\
\hline & Intervjuer lokala "teamleaders/ & $2 \mathrm{p}$ (specialister) & 2005 \\
\hline \multirow[t]{3}{*}{ Case FORCE } & Projektinitiering & 6 p Ledningsgrupp BU 3 & 2006 \\
\hline & Intervjuer & $\begin{array}{l}2 \text { p Projektledare BU3 } \\
\text { /BU FOU/CR }\end{array}$ & 2007 \\
\hline & Intervjuer & $\begin{array}{l}2 \text { p Controller BU } 3 \\
\text { /BU FOU/CR }\end{array}$ & 2007 \\
\hline Case INNOHUB, förstudie & Intervju + enkät & 3 företagare & 2017 \\
\hline \multirow[t]{2}{*}{ Case INNOHUB .01 } & Intervjuer ledning & $17 / 20$ förtagare & 2018 \\
\hline & Enkät & 9/17 företag & 2018 \\
\hline .02 & Intervjuer ledning & 20 företag varav 15 nya & 2019 \\
\hline .02 & Enkät & 9/15 nya företag & 2019 \\
\hline .03 & $\begin{array}{l}\text { Intervjuer ledning } \\
\text { Intervjuer medarbetare inkl. } \\
\text { CASE } \\
\text { Advisory Board }\end{array}$ & $\begin{array}{l}\text { VD (8 tillf.) samt } \\
\text { CO (2 tillf. }) \\
6 \text { p ( } 3 \text { tillf. }) \\
\text { (4 tillf.) }\end{array}$ & $\begin{array}{l}2018 \\
2018 \\
2018 \\
2018\end{array}$ \\
\hline .03 & Intervjuer ledning & VD (2 tillf.) & 2019 \\
\hline $.04 a$ & $\begin{array}{l}\text { Intervjuer BC BU FoU/CR } \\
\text { Intervjuer BC Finans }\end{array}$ & $\begin{array}{l}\text { (2 tillf.) } \\
(2 \text { tillf. })\end{array}$ & $\begin{array}{l}2018 / 2019 \\
2019\end{array}$ \\
\hline $.04 \mathrm{~b}$ & $\begin{array}{l}\text { Intervju näringslivschef Region } \\
\text { Intervju experter Region } \\
\text { Intervju näringslivschef Stad }\end{array}$ & $\begin{array}{l}(2 \text { tillf. }) \\
2 \mathrm{p}(2 \text { tillf. }) \\
(2 \text { tillf. })\end{array}$ & $\begin{array}{l}2017 / 2018 \\
2018 \\
2018\end{array}$ \\
\hline
\end{tabular}

Tabell 1 Sammanställning av datainsamling 
I de två mer omfattande fallstudierna (Case FORCE och Case INNOHUB) som avsett omfattande specifika projekt (under perioden 2015 - 2019) genomfördes informationsinsamlingen genom enkäter, djupintervjuer samt med aktionsforskning. Kriterier och omfattning av informationsinsamling redogörs för respektive fall i kapitel 5. Såväl företag som personer har anonymiserats men kan identifieras med företagsnummer och personkoder.

Inför formulering av syftet med denna avhandling var, med hänvisning till "beta-målet," utgångspunkten inför de mer informella samtalen den initiala frågeställningen för dessa samtal huruvida en förväntad tillväxt (positiv eller negativ) av den aktuella resursbasen, eller del därav, kan gälla som mål för organisationens strategier.

Varje fallstudie består av delstudier där resultaten jämförs vid kommande analys. Partiell analys har gjorts vid varje fallstudie. Som underlag för slutsatser har textanalyser gjorts vid såväl partiella analyser som vid den sammanlagda systemiska analysen. Respondenterna vid de första två fallstudierna (Se bilaga Case ROBO och Case CATHEDRAL) förväntades kunna besvara följande två explicita frågeställningar som, utifrån de fenomen och brister som observerats i de beslutsprocesser som granskats, bedömdes leda till effektiva beslut:

- hur ser den beslutsprocess ut som medför minimerad påverkan av risker ${ }^{18}$ och samtidigt möjliggör långsiktigt, versus betamålet, legitima och effektiva beslut?

- hur ser den totala "förklaringsmodell" ut som, utifrån behovet av en ny styrmodell, explicit förklarar olika 'element' styrningen (orsak, strategi, beslut, styrning och resultat) och dess konsekvenser?

\subsection{Litteraturstudier}

Under hela forskarutbildningen och tiden för avhandlingsarbetet har omfattande litteraturstudier genomförts. En del av dessa redovisas som referenser till avhandlingstexten. Merparten av referenser är citerade artiklar från välrenommerad forskning. Utöver de böcker som refererats har kunskap från litteratur inom närliggande områden som exempelvis termodynamik, finansteori och ekonomisk historia inhämtats. Databaser, SCB-statistik m. m. har använts för källkritisk granskning. I sammanlagt tjugotalet forskarkurser har omfattande kritisk analys av artiklar gjorts tillsammans med andra kursdeltagare, inom respektive område.

\subsection{Analysarbetet.}

En utgångspunkt inför analysarbetet var att den information som insamlats för analys inte endast var historisk utan också framtidsorienterad d v s den var påverkad av de intervjuades förväntningar inför framtiden av den pågående transformeringen och organiseringen i det aktuella företaget. Ett försök att illustrera denna fokusförskjutning inför analysarbetet görs i figur 4.

\footnotetext{
${ }^{18}$ I denna avhandling är behandlas 'risk' som en identifierad, avgränsad `osäkerhetsfaktor' vid beslutsfattande. En exakt definition av riskbegreppet saknas $\mathrm{f} n$. Osäkerhetsfaktorn varierar beroende på kontext och beskrivningsnivå.
} 


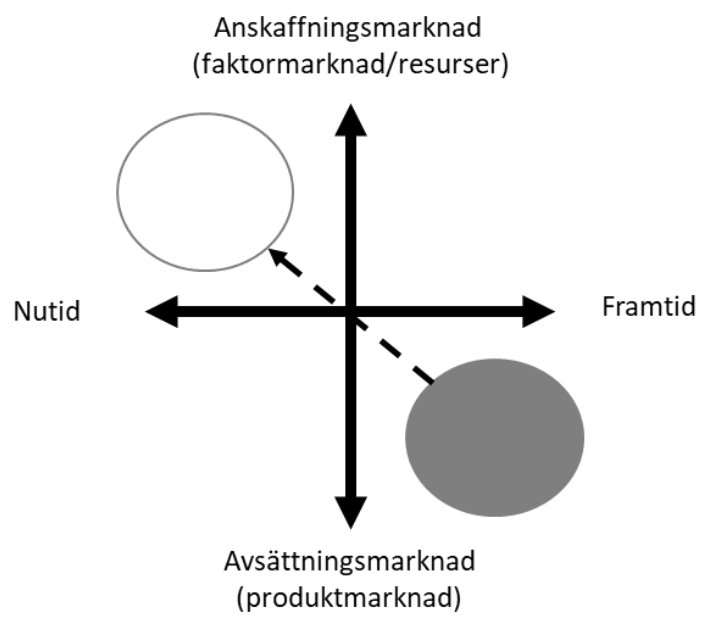

Figur 4 Ett identifierat "nytt" fokus inför denna forskning

När fokus skiftar från en nutid som är historiskt betingad, till en nutid som är en diskonterad framtid och samtidigt fokus skiftar från ett perspektiv med utbud och efterfrågan från en avsättningsmarknad/produktmarknad till en anskaffningsmarknad/faktormarknad så uppstår behov av ny kunskap; ett kunskapsgap. Tidsperspektivet förändrar beslutskriterier. Nya marknadsvillkor innebär förändringar i beslutsmodeller.

Dessa två behov indikerar ett område där det finns behov av ny kunskap; ett kunskapsgap. Detta "gap" illustreras med ovanstående figur. Den streckade linjen markerar behovet av en ny förklaringsmodell i ett pågående fokusskifte för forskning och kunskapsgenerering och samtidigt explicit ny kunskap om beslutsmodeller och kriterier för resursbaserade beslut.

I samband med förstudien och diskussionen om lämplig forskningsansats för denna avhandling gjordes en kontextuell avgränsning. Den avgränsas till att avhandla 'organisationsnivån' och tre resursområden. ${ }^{19}$ Med organisation avses ett företag eller delar av detta. Då ett individperspektiv avhandlas inom ramen för kontexten framgår detta.

Med utgångspunkt från det "forskningsgap" som identifierats ovan samt behovet att förklara det fenomen som observerats om förändringar i företagens resursbaser, så konstateras ett behov av en förklaringsmodell som dels omfattar kontexten organisationen och organisering av dess resursbaser, samt ett behov av en modell för att beskriva hur strategi och ekonomistyrning samverkar konceptuellt; d v s en modell för vad vi menar med integrerad strategi och ekonomistyrning, utifrån resursbaserad teori.

\footnotetext{
${ }^{19}$ Se kontextbeskrivning i dokumentet "Mode Zero" (Boström 2015)
} 


\subsection{Avgränsningar}

Studien är avgränsad till en specifik samhällskontext, en s.k. samhällsformation dvs målföretaget (som juridisk enhet) och dess partners samt delar av företaget. Företaget analyseras med avseende på dess tidiga FoU-processer, dvs organisationens processer för teknologiutveckling, produkt- och tjänsteutveckling. Informationsinsamlingen i dessa fyra case genomförs i huvudsak på affärsenhetsnivå som minsta organisatoriska analysenhet. Analyser och beräkningar har genomförts i enskilda projekt, specifika processer och på lägre nivåer av system.

Studierna på organisatorisk nivå omfattar målföretagets svenska verksamhet men kan omfatta ett globalt åtagande, här bland annat ett av koncernens sju globala forskningsprogram. Respektive case avser en specifik organisatorisk kontext. Initiala intervjuer på divisions/koncernnivå, i de två första fallstudierna (Case ROBO och Case CATHEDRAL) intervjuer om utveckling inom två affärsområden i en befintlig division, i den tredje fallstudien (Case FORCE) i samband med uppbyggnad av ett helt 'nytt' affärsområde vid målföretaget samt $\mathrm{i}$ den fjärde fallstudien (Case INNOHUB) vid uppbyggnad av en helt ny struktur som samlar olika intressenter, utöver målföretaget. Detta har medfört kontextuella implikationer vid tolkning av de olika 'verkligheterna’. I Case INNOHUB är således analysen utförd avseende även målföretagets externa intressenter och därmed uppkomna divergerande förutsättningar. I sökande efter kontextneutrala villkor för en strategisk styrning har därför den övergripande målformuleringen det $\mathrm{s} \mathrm{k}$ 'betamålet' introducerats med syfte att tydliggöra teoretiska och praktiska implikationer inför fortsatt forskning.

\subsection{Avhandlingens validitet och reliabilitet}

Denna avhandling har använt nomolog deduktion som ansats och därför har arbetet strukturerats för att kunna identifiera och verifiera de faktorer som har betydelse samt hur de länkar till teorier. Ett arbetssätt inom kvalitativ forskning för att öka forskningens validitet och reliabilitet är att använda triangulering genom att kombinera mer än en approach/perspektiv i studien av fenomenet för att korsvalidera slutsatserna (Given, 2008; Kowalkowski, Kindström och Witell, 2011). Denzin (1978) identifierar fyra sätt där triangulering kan användas: data, metod, forskare och teori.

Triangulering av data innebär till att samla in data från olika respondenter vid olika tidpunkter och platser (Denzin, 1978). Metodmässig triangulering kräver att datainsamling och analys sker via olika tekniker och procedurer (Denzin, 1978). I denna studie har ett stort antal intervjuer genomförts vid olika enheter och organisationer under en period från 2003/2004 till 2019/2020 med informanter både på olika ledningsnivåer och inom olika organisationer. Alla organisationer har koppling till det fokala företaget genom att vara ett av dess affärsområden, ett nyutvecklat kunskapsområde som är möjligt att knoppa av eller som partners i det kunskapsnätverk som etableras för att inkubera och utveckla idéer. Utöver de genomförda intervjuerna har ytterligare data samlats in genom medverkan i workshops och mindre ledningsmöten, minnesanteckningar och presentationsmaterial samt publikt tillgängliga rapporter används för att kunna triangulera intervjuerna och därefter presentera det inom ramen för avhandlingens fyra case. 
Att använda flera forskare bygger på att mer än en forskare medverkar i forskningsprocessen för att undvika bias. I delar av studierna har denna form av triangulering använts såsom i förstudien och i Case FORCE. I dessa har andra forskare medverkat vid vissa intervjuer och andra har genomförts individuellt.

Teoretisk triangulering omfattar användning av olika teoretiska perspektiv i studien. Denna studie bygger i huvudsak på teorier som fokuserar på strategier för att långsiktigt utveckla resurser som ökar konkurrenskraften genom att fokusera på två kompletterande områden: resursbaserad teori och strategisk ekonomistyrning. Utöver detta har perspektiv som bygger vidare från dessa områden använts, såsom modeller för ledningssystem för kvalitetsstyrning, för att förklara de empiriska resultaten. 


\section{Kapitel 3 Forskningens teoretiska utgångspunkter}

Analys av avhandlingens fallstudier har utgått ifrån teorier som potentiellt förväntats förklara uppkomsten och betydelsen av observerade förändringar i företagens kapitalstrukturer. Ytterligare teori har tillkommit under avhandlingsarbetets gång. Avhandlingen fokuserar de värdeförändringar som delvis är effekter av en förskjutning från materiella till immateriella resurser och som observerade i publika redovisningar av företags balansräkningar. Dessa immateriella värdeförändringar är antingen externt genererade från investeringar (goodwill) eller från internt genererat intellektuellt kapital (intellectual properties).

Parallellt följs det normeringsarbete pågår inom ramen för ISO regelverken ${ }^{20}$ och avser förändringar som kan förväntas ha eller haft implikation på dessa värdeförändringar. Ett teoriområde med förväntad implikation på framtida beslutsprocesser och kapitalstrukturer är riskteori. Definition av RISK-begreppet pågår ${ }^{21}$ och riskteori avhandlas därför inte i denna analys. 'Risk' avhandlas här därför endast med referens till den s k resursberoende teoribildningen, RDT (Pfeffer \& Salancik, 1978).) och med innebörden 'osäkerhet' vid beslut om systemavgränsningar (system boundaries). (Simons, 1995)

Inledningsvis nämns med referens till systemteori (Boulding, 1953) samt resiliensteori (Holling, 1986) att dessa modeller implicerar organisationers resursbas på olika systemnivåer och i Hollings modell utifrån ett 'externt' respektive 'internt' systemsynsätt. Dessa två skolbildningar kan potentiell förklara de processer som i en företagsekonomisk kontext bidrar till det interna mål som 'betamålet’ här representerar d v s hållbar resurstillväxt. En tillämpning av ett systemsynsätt implicerar analys av företagets processer bland annat med teori om processanalys (Pettigrew, 1997; Hinings, 1997). Peter Senge (2008) redogör för exempel på implikationer på ett företags strategiska ledningssystem och processer vid tillämpning av ett systemsynsätt.

I denna avhandling representerar begreppet värdetillväxt en faktisk förändring av värde, $\mathrm{d} v \mathrm{~s}$ inte en värdering av ett hypotetiskt värde. En faktisk mätning av värde kan göras först när den aktuella resursen i dess förädlade form förvärvas, $\mathrm{d}$ v s när den "växlas ut" från en intern miljö till en extern miljö eller omvänt. I detta sammanhang betraktas internpriser som resultat från en hypotetisk värdering av värde. Mätningen av värdeförändring kan göras av såväl säljare som köpare som grund för beräkning av avkastning från respektive parts resursbas. Värdetillväxt avser enskilda objekt och avhandlas här primärt som bidrag till en infrastruktur eller som strukturkapital om det exempelvis handlar om avyttring/förvärv av patent etc.

\footnotetext{
${ }^{20}$ I skrivande stund (2020) diskuteras normgivande teoribildning inom ramen för standardiseringsarbete avseende ledningssystem för materiella och immateriella tillgångar, ekonomiska resurser av olika slag. Tre mätbara komponenter diskuteras som utgångspunkt för företags organiska värdeförändring, $\mathrm{d} v \mathrm{~s}$ värdeskapande resurstillväxt, med påverkan på företagets kapitalstruktur; utgifter (capex, opex), risker och prestation (performance). Såväl balansräkning som resultaträkning berörs.

${ }^{21}$ Riskteori för analys av intern kontroll har utvecklats primärt inom finansiell sektor; forskning pågår vi Harvard (Kaplan, Mikes et al, 2009). Utveckling av ramverk för riskhantering pågår som utvecklingsprojekt i ISO 31000 samt inför revidering av ISO 55000.
} 
Då begreppet värdetillväxt endast kan mätas i en 'extern' miljö tillämpas i en 'intern' miljö begreppet resurstillväxt vid värdering av tillväxt; på projektnivå, affärsenhetsnivå etc. En resurs värderas utifrån den nytta (benefit/disbenefit) som resurser bidrar till i en viss miljö.

Begreppet resurs implicerar i denna avhandling även den förmåga som enlig teori förutsätter en värdeförändring av resursen (Penrose, 1959, Teece et al, 1994). I begreppet ekonomisk resurs impliceras också begreppet tillgång (IASB Conceptual framework 2020, in Marton et al, 2018).

Teknologisk forskning inom det FoU-område där avhandlingen fallstudier genomförs beskrivs som "mega-trend"- utveckling, d v s flera utvecklingslinjer pågår under samma tid och utvecklingen förväntas fortsätta. Teoretisk utgångspunkt vid studier av samtliga observerade utvecklingsprojekt är följande; genom att implicera ett hållbarhetsperspektiv vid resursutveckling av en organisations samtliga resurser kan strategier för att uppnå långsiktig värdetillväxt och effekter av dessa strategier förklaras, bland annat effekter på företagets kapitalstruktur (resursbasen).

\subsection{Strategiforskning och resursbaserad teori och ekonomisk styrning}

Avhandlingens kontext är omfattande. För en totalanalys av avhandlingens empiri antas att 'nya' förklaringsmodeller fordras, detta för att täcka hela kontexten och dels förklara tillämpningen av strategisk ekonomisk styrning och dess konsekvenser.

Strategiforskning i en företagskontext har sedan 1950-talet utvecklats dels från militär tillämpning, dels från spelteori. En av föregångarna är Igor Ansoff som 1968 utvecklade en teori för företaget utifrån sin artikel om strategiskt tänkande i framtidens företag (Ansoff, 1965). Strategiforskningen har sedan dess utvecklats i olika skolbildningar. Richard Whittington (Wittington, 2002) sammanfattar fyra skolbildningar: Klassisk strategiteori, evolutionistisk strategiteori, systemteoretisk strategiteori och processuell strategiteori. Som utgångspunkt för analys av avhandlingens empiri tillämpas delvis evolutionistisk strategiteori (Mintzberg, 1978). En systemteoretisk strategimodell med inslag av processanalys tillämpas vid kommande analys.

En utgångspunkt för denna studie är ett också antagande att ekonomistyrningsteori med resursbaserad teoribildning som utgångspunkt (Penrose $\mathrm{m} \mathrm{fl}$ ), relativt ett mer marknadsorienterat synsätt potentiellt bättre kan förklara vad som möjliggör en långsiktigt ekonomiskt hållbar resurstillväxt. Detta bland annat genom att enskilda resurser i resursbasen (per definition) och resursbaserade strategier, med hjälp av systemteori och systemisk analys, kan identifieras på en faktormarknad ${ }^{22}$ och hur dessa resursers tillväxt kan värderas och därmed förändra resursbasens värde och bidra till företagets värdetillväxt.

\subsection{Teori utifrån ett resursbaserat synsätt}

I strategisammanhang har som nämnt inledningsvis det resursbaserade synsättet beskrivits som en strategi sedd inifrån- och ut (the inside- out - perspective) i en organisation. Detta har ställts emot en strategi som omvänt innebär ett utifrån- och in perspektiv (the outside - in -

${ }^{22}$ Se bilaga 7; en jämförelse mellan två synsätt: presenterad vid Qmod conference 2009 Se referens Boström, 2009. 
perspective). De olika synsätten handlar om hur ledningen i en organisation genom sitt strategival kan påverka organisationens förändring (DeWitt and Meyer, 2010).

Ursprunget till det resursbaserade synsättet (the resource based theory) är Edith Peenrose tidiga teori om hur företag växer (Penrose, 1959) där Penrose i sin bok "The Theory of the Growth of the Firm" (TGF) gör ett första försök från en ekonom att betrakta ett företag som en organisation bestående av "flesh and blood" med resurser (resources) och interna förmågor (capabilities).

En tolkning av `inifrån- och ut synsättet' är att Penrose menar att en ledning som tillämpar ett resursbaserat synsätt anser att strategi primärt inte ska bygga på externt identifierade möjligheter utan på organisationens egna styrkefaktorer $\mathrm{d} v \mathrm{~s}$ ett `internt' synsätt, dock att resurserna även kan vara lokaliserade externt, men att företaget har kontrollen över dem. Framgångsrika organisationer bygger medvetet och under en längre period upp en stark resursbas, vilket gör att de kan tillvarata tillfällen på marknader som annars inte är möjligt. I en framgångsrik organisation är det dess resurser och organisationens egen förmåga som är styrande för utvecklingen på kort och lång sikt (Penrose 1959).

\subsubsection{Resursbaserade strategier.}

Vad innebär då en resursbaserad strategi? Förenklat innebär ett resurssynsätt, i företagsekonomisk forskning och praktik runt strategier, att en strategi primärt utgår ifrån hur organisationens egna eller "lånade" resurser, d v s de resurser som företaget har tillgång till ("in possession of') ska förvaltas och utvecklas internt för att företaget ska kunna uppvisa uthålliga konkurrensfördelar (sustainable/sustained competitive advantages). I organisationens strategiska arbete ställer organisationens ledning implicit strategiska 'frågor' där organisationens resurser och förmågor är centrala.

Olika typer av företag förfogar över olika typer av resurser och uppvisar därmed olika villkor för hur dess specifika, givna resurser påverkar organisationens inre, strategiska arbete (Peteraf, 1993). En utveckling av resursperspektivet i organisationens strategiska arbete innebär också valet mellan att utveckla befintliga resurser eller utveckla/förvärva potentiella eller helt nya resurser.

Ett resursbaserat synsätt beskriver en dimension av strategier för företag och företagande med olika fokus. Med ett 'externt' fokus kan, med ett resursperspektiv, strategier långsiktigt karaktäriseras som positionering på en anskaffningsmarknad/faktormarknad med potentiella, heterogent fördelade resurser. Ett 'internt' fokus förklarar då hur organisationens processer och kapacitet påverkas av och med olika resurser och hur dessa förädlas.

Edith Penrose anses vara den person som lade grunden till detta forskningsfält. Hennes uppmärksammade forskning om företags liv och växande finns beskrivet i boken "the Theory of the Growth of the Firm" (Penrose, T., 1959)". Här ges några citat av andra forskare som illustrerar hur Penrose tänkte:

"The Firm, for Penrose, is a pool of resources organized in an administrative framework" (Best and Garnsey, 1999 s. F188) 
"From the Penrosian perspective, the firm strategically shapes the market, rather than reacting passively to it, but within a moving, historically contingent environment"(Best and Garnsey, op sit, s. F189)

"Penrose focused on the insides of such /"of flesh and blood"/ organisations to explain endogenus knowledge-creation, innovation and firm growth, saw the external environment, as an image in the minds of management and posited a dynamic interaction between internal and external environment, which defined what she called firms productive opportunities". (Pitelis, 2005 s. 67)

"..if one examines... firms... with a long history of successful growth...their strength lies in the fact that they have... a position with respect to the use of certain resources and technology and the exploitation of certain types of markets..." (Pitelis, op sit, s. 69)

\subsubsection{Resursbaserade strategier i ett ledningsperspektiv.}

Vad innebär egentligen detta med resurser och förmågor i sådana sammanhang där ledningen formulerar strategier för att uppnå mål för sin organisation? Hur kan strategiska beslut förstås utifrån hur ledningen betraktar resurser och organisatoriska förmågor som gör det möjligt att utveckla och använda resurserna? Vad är resurs respektive vad är förmåga? I vilket eller vilka sammanhang och på vilken eller vilka nivå/er i företaget ska innebörden av dessa begrepp analyseras för att förklara ett företags utveckling och framgång eller motgång?

Ett exempel från idrotten kan illustrera dessa frågeställningar. Några frågor utifrån en idrottsmetafor och exempel från olika nivåer inom idrottslig verksamhet kan tydliggöra beslutssituationen inför ledningens strategival: Företags verklighet innebär inga spelsystem, inga självklara förutsättningar och ingen spelfördel finns som är bestående över tid. Verkligheten, speciellt för ett globalt företag, är mer komplicerad. Genom dessa fria associationer till idrotten är det potentiellt möjligt att förstå resursbaserade strategier som förklarar ett företags långsiktiga framgång. En idrottsmetafor:

Hur kan vi förklara framgången för ett elitlag eller utvecklingen för ett ishockeylandslag? Vad ligger bakom framgången för golfspelare som år efter år toppar på "touren"? Hur förklaras att den smartaste tempo- eller etappcyklisten vinner i längden? Vad är själva "kärnan" i det som ger oss en generell förklaring till framgång? Finns det någon specifik strategi som är mer effektiv än någon annan?

Vad ska vi studera hos enskilda idrottsmän och kvinnor för att förstå? Ska vi fokusera på deras energiintag, kosthållning och ämnesomsättning, på hur mycket de tränar eller på hur mycket tävlingsrutin de har? Eller vad de har för synliga, fysiska förutsättningar i muskler eller benstomme? Eller är det kanske deras unika, mer osynliga genetiska förutsättningar som är förklaringen till deras återkommande idrottsliga framgångar och deras uthållighet?

Vad betyder tränarens kunskap för den enskilde spelarens eller hela lagets "växande"? Hur mycket betyder det vilken information som spelledaren har tillgång till om den enskilde spelaren eller om laget? Vad betyder spelplanen när det gäller vilken strategi som väljs inför en match? Hur mycket förklaras av 
coachens beslutsförmåga under en match? Eller vad betyder "materialarens" insatser för lagets extrema och återkommande framgångar?

Hur mycket förklaras av lagets organisation på olika nivåer från speluppställningar vid matcherna till hela spel- och spelarorganisationens förmåga att ta vara på, förvalta och använda inkomsterna från matchsystemet för att strategiskt utveckla laget men också enskilda spelare?

Om strategierna bakom en organisationsutveckling och framgång kan förstås, hur ska resultat och effekter mätas och värderas på olika nivåer? Många förutsättningar är kända och utvärderingsmetoderna är likartade för alla system, oberoende om systemet representerar ett företag, en idrottsorganisation eller en enskild idrottsman. Om det är möjligt att förklara en "medveten destruktivitet" (jfr Schumpeter, 1942) hos en enskild idrottsutövare eller konstatera ett negativ resultat $\mathrm{i}$ vissa idrotter över tid så är det potentiellt möjligt att förstå vad som kan orsaka en sådan situation i ett företag.

En reflektion utifrån dessa idrottsexempel och som utgångspunkt för analys av denna avhandlings empiri är att det är ledningens val av långsiktig strategi, utifrån kunskap om olika förutsättningar samt förmågan att tolka, värdera och tillämpa information om organisationens tillgång till resurser, förmågor och kapacitet för dess tillväxt, som skapar långsiktig framgång. En utgångspunkt är att det inte är en strategi som leder till framgång. Ett antal olika strategier kan antas om analysen utgår ifrån förändringar som sker över tid.

\subsubsection{Det resursbaserade i organisationsteori.}

Ett grundläggande problem vid analys med ett resursbaserat synsätt handlar om på vilken sikt, med hänsyn till tidsperspektivet, som strategin ska visa resultat och effekter. Ett annat grundläggande problem, utöver en bestämning av ett tidsperspektiv, är på vilken preciserad nivå som resurser och förmågor ska studeras när det gäller hur systemet, människan och organisationen utvecklas utifrån dessa strategier. Det resursbaserade synsättet innebär en nödvändig avgränsning för en organisation till en systemnivå där kunskap är tillgänglig för ledningspersoner i deras beslutsfattande (Boulding, 1956) och där beräkningar av resultat och effekter kan utföras.

Inom organisationsteorin diskuteras strategi - och ledarskap - på såväl operationella som strategiska nivåer och samtidigt utifrån två andra perspektiv på själva organisationen. Organisationen betraktas utifrån antingen ett tydligt "top down"-ledarskapsperspektiv ("the organizational leadership perspective") eller med ett "bottom-up" -perspektiv ("the organizational dynamic perspective") (DeWitt and Meyer, 2010).

På affärsstrategisk nivå ses en skillnad också när det gäller ledarskapet och dess möjlighet att påverka organisationen utifrån dessa två olika perspektiv Denna möjlighet och också ledarskapets roll, är där olika. Det senare framhåller det dynamiska perspektivet och den dynamiska organisationen mer eller mindre som en självreglerande kultur (Weick, 1979, Schein 1993).

Inom ramen för det dynamiska perspektivet framhålls också det resursbaserade synsättet som, i jämförelse med andra synsätt, innebär att ledarskapets möjlighet att påverka organisationen är mer begränsad (Barney, 1991). Det gäller i synnerhet om det resursbaserade synsättet innebär 
en organisatorisk inlärning av något nytt och som samtidigt förutsätter en "avlärning" av något annat, tidigare känt och tillämpat (Schumpeter, 1942; Barney, 1991).

\subsubsection{Resursperspektivet i historisk belysning.}

Resurser i företagsekonomisk teori är inte explicitgjort förrän under 1900-talet. Ekonomisk resursteori kan härledas till nationalekonomin och till 1700-talets teoretiker som Adam Smith (1723 - 1790). Han diskuterade grunderna för prissättning av resurser i slutet av 1700-talet. En annan nationalekonom, italienaren Piero Sraffa ${ }^{23}$ försökte i början av 1900-talet lansera en egen, med inspiration från Karl Marx, mer "företagsekonomisk" resursteori utifrån David Ricardos teorier och med rötter i neoklassisk ekonomisk teori. Hans teorier fick inget större genomslag.

Ordet resurs brukar härledas till Frankrike och franska språket ${ }^{24}$ även om dess egentliga ursprung är latinets ord "resurgere". Den tidiga användningen av resursbegreppet i Skandinavien kan härledas till sociologin där begreppet är ett uttryck för olika resurser i samhället. Begreppet beskriver t ex hemmets resurser, familjens resurser etc.

Det resursbaserade perspektiv som utvecklats i företagsekonomisk kontext i Penrose' teori (i "the Theory of the Growth of the Firm) ansluter i huvudsak också till David Ricardos syn på begrepp som vinst och värde och på de grunder som forskningen då skulle bedrivas på, d v s på nationalekonomisk grund. Penrose har i sin teoribildning dock ett tydligt företagsperspektiv. Hennes forskning är empirisk och hon tillämpar också en omväxlande deduktiv och induktiv ansats i sin bok. Som tolkare av organisationens, snarare än nationens förutsättningar, måste Penrose anses vara banbrytare och upphovsmakare till resursbaserad strategiteori och till resursbegreppets tillämpning i företagsekonomiska sammanhang.

Trots avsaknad av en tidig företagsekonomisk resursteori har resursbegreppet ändå använts i anslutning till ekonomiska begrepp som effektivitet och produktivitet, i naturekonomiska tillämpningar. ${ }^{25}$ Sedan ett antal år domineras resursteori av det som inom akademin benämns fysisk resursteori. Denna teori förekommer också i företagsekonomisk kontext och har under 2000-talet kommit att känneteckna företags ekologiska frågeställningar. Metoder för applikation av fysisk resursteori inom företagsekonomin har utvecklats med bäring på t ex LCA (Life Cycle Analysis) och används idag som kalkylmodell vid beslut om företags infrastruktur, produkteffektivisering och produktförnyelse. ${ }^{26}$

Som nämnts inledningsvis fick Penrose' teori snart efterföljare. Det resursbaserade perspektivet omfattar ett antal olika teoribildningar. För att kunna analysera respektive teori kan vi ta hjälp av frågeställningarna $\mathrm{i}$ idrottsmetaforen ovan. I exemplen framgår implicit ett flertal frågeställningar som, vad har ledarskapet för förutsättningar (lagkaptenen, lagledare, klubbledare, förbundsledare $\mathrm{m}$ fl.) att utveckla organisationens resurser och förmågor? Vad har förbundet för ambitioner, visioner eller mer konkreta mål? Vad ska man fokusera på respektive nivå om förbundsledning har ett långsiktigt perspektiv? Förvärv eller utveckla egna spelare?

\footnotetext{
${ }^{23}$ Pierro Sraffa $(1898-1983)$

${ }^{24}$ Resurs; vårt ords ursprung är "resourdre" (FR); jfr sv. översättning (från lat. "resurgere”) "att resa sig".

${ }^{25}$ I naturekonomi och dess tillämpning; äv. inom fysisk resursteori (Se; "backcasting" etc.)

${ }^{26} \mathrm{LCA} / \mathrm{LCC}$, primärt i nationalekonomisk tillämpning bland annat vid investeringar i infrastruktur
} 
Hur ska man organisera för ansvarstagande och för att spelarnas åtagande ska vara genomförbart? Hur ska planeringen genomföras med sikte på vad man vill genomföra och uppnå? Och kanske det viktigaste; vad ska man, utifrån hur man tolkat sin uppgift, värdera som ett långsiktigt resultat och långsiktig effekt av sitt engagemang? Ska man värdera ett kvantitativt eller kvalitativt resultat? När och av vem ska utvärderingen göras och hur ska resultatet användas för att utveckla organisationen vidare? Eller möjligen avveckla? Och hur ska inkomster från spelsystemets framgångar förvaltas och återinvesteras i nya resurser av olika slag?

Några av dessa många frågeställningar är relevanta också vid en analys av resursbaserad teori om teorin ska användas för att förklara hur företag utformar sina strategier $i$ ett mer långsiktigt perspektiv. Den resursbaserade teoribildningen kan analyseras med avseende på:

Fokus för företaget;

- organisationens måldimension i primärt kvalitativa men också kvantitativa termer,

- förutsättningar och villkor för det egna företaget

och vad ledningen fokuserar på vid formulering av strategin (ex ante) ${ }^{27} \mathrm{samt}$

- olika antaganden vad gäller organisationens resurser, produkter, tjänster och förmågor, hur de identifieras och de olika kriterier som gäller för utveckling av dem.

Fokus vid empiri; hur organiseringen går till i samband med strategins implementering:

- Hur och av vem som resultat och effekter ska värderas (ex ante/ex post).

- Organisationens olika utvecklingsstadier över lång tid.

Dessa frågor har varit vägledande i utformningen av frågorna till empiriinsamlingen för de olika fallstudierna.

\subsection{Resursbaserade teorier avseende företagsstrategiska analyser.}

Som utgångspunkt i detta avhandlingsarbete används Penrose' bok "Theory of the Growth of the Firm (Penrose, 1959) samt en artikel av Birger Wernerfelt: "A Resource Based View" (Wernerfelt, 1990). Här refereras också ett antal parallella och efterföljande teoribildningar och forskare som haft avgörande påverkan på såväl resursbegreppets tillämpning som utveckling (Teece, 1982, Barney, 1986, Rumelt 1987, Teece, Pisano och Shuen, 1990, Grant 1991 och Conner och Prahalad, 1996, Eisenhart \& Martin, 2000, m fl.). För att ge ett underlag inför avhandlingens potentiella diskussion om ägarstyrning/bolagsstyrning och om bland annat omgivningens påverkan på företagskontexten om man tillämpar ett resursperspektiv, beskrivs

\footnotetext{
${ }^{27}$ Definition of Ex Ante: Latin for "beforehand". In models where there is uncertainty that is resolved during the course of events, the ex antes values (e.g. of expected gain) are those that are calculated in advance of the resolution of uncertainty. Definition of Ex Post: Latin for "after the fact". In models where there is uncertainty that is resolved during the course of events, the ex post values (e.g. of expected gain) are those that are calculated after the uncertainty has been resolved. (Econterms)
} 
här också kortfattat en ytterligare central teoribildning med ett resursbaserat fokus; "A Resource Dependency Theory" (Pfeffer and Salancik, 1978).

Penrose' teori (TGF) och dess efterföljande teoribildningar har dock från forskarhåll ifrågasatts om de uppfyller de kriterier som gäller för vad en "teori" egentligen är respektive dess relevans för fortsatt forskning. Edith Penrose' bidrag till det resursbaserade perspektivet på företagande har lovordats både utifrån hennes perspektiv på organisationen som en "individ", men också utifrån ett ekonomiskt (läs: vinst) perspektiv. Hennes diskussion är analytisk snarare än normativ och Penrose går utanför gängse teoribildningar. Trots en del invändningar betraktas TGF som en egen teori (Pitelis, 2005).

Den efterföljande skolbildningen (RBV), (Wernerfelt, Barney m fl.) har också mött en del kritik som teoribildning. En analys av RBV som en "strategiteori" ger dock en fördjupad förståelse för betydelsen av begrepp som "heterogenitet", "avkastning av resurser" etc.

Om Wernerfelt startade diskussionen om RBV på allvar så fick teorin snart efterföljare. I mitten av nittiotalet utvecklades bland annat en diskussion om RBV utifrån ett uppenbart behov av ny skolbildning om företags strategiarbete och för förståelsen av framförallt varför företag finns (Eliasson, 1985; Kogut \& Zander, 1992; Conner \& Prahalad, 1993; Barney, 1994, 1996), relativt en transaktionskostnadsteori (Coase, 1937; Williamsson, 1975 med flera) och i viss mån agentteorin (Eisenhart, 1989, $\mathrm{m} \mathrm{fl}$.). Dessa olika teoribildningar har som det framstår mer gemensamt än det som skiljer dem, dock att implikationerna för fortsatt forskning inte är helt uppenbara (Combs och Ketchen, 1999).

Under 2004 publicerades, i ett specialnummer av Management Review, ett antal artiklar under titelns "Beyond Resource Based View", (mrev 15 (1) ed. Moldaschl, M. 2004, samt Moldaschl, M. and Fischer, D., 2004). Här har det resursbaserade perspektivet fått ytterligare utrymme och breddats avsevärt. Artiklarna speglar i viss mån forskningens nuvarande inriktning. Författarna breddar dock perspektivet till att kunna appliceras på annat än företagsekonomi. Begreppet "resource-oriented socio-economic perspective (RSP) uppfattas vara grunden för ny teoribildning.

Ett "resursbaserat" perspektiv på styrning av företag utvecklas dock på flera håll. Som exempel på titlar i litteraturfloran där "resursperspektivet" är centralt, nämns: "Behavioural Accounting Research"; "Business Performance Measurement" och "Knowledge and Social Capital" m.fl. Ett antal ${ }^{28}$ artiklar avhandlar resurser med implikation på forskning explicit inom redovisningsområdet men kan antas implicit avse forskning inom området strategi och styrning av organisationer. De kan i vissa avseenden vara relevant teori inför fortsatt forskning om ett resursbaserat perspektiv på affärsstrategier och dessas implikationer på ekonomistyrningen.

\subsubsection{Theory of the Growth of the Firm (TGF).}

Penrose' teori, TGF, har fokus på det unika företaget. Centralt, till skillnad från neoklassisk jämviktsteori, utgår hennes teori ifrån ett 'kognitivt' synsätt för att förstå organisationen och det unika företaget i ständig förändring. En central fråga i TGF är beskrivningen av företaget och hur dess resurser utvecklas till "productive services" och "productive opportunities". Detta

\footnotetext{
${ }^{28}$ Här avhandlas resurser och ekonomistyrning explicit
} 
kan liknas vid de tjänster ${ }^{29}$ som företaget utvecklar och erbjuder. En utveckling av detta forskningsspår har medfört att en viss distinktion idag görs mellan /kombinationer av/ organisationens resurser, dess egenskaper (characteristics) och förmågor (capabilities) och att dessa samtidigt varierar mellan varje unikt företag. Ytterligare distinktion görs i strategilitteraturen där man diskuterar dynamisk förmåga (dynamic capability) och asymmetrier (asymmetries) som värdefulla för det unika företaget (DeWitt and Meyer, 2010).

Penrose' teorispår är intressant då det i generella termer diskuterar organisationens resursbas. Penrose har i TGF också ett processuellt synsätt för att beskriva organisationens verksamhet. Hon gör en klar distinktion mellan företags /potentiella/ resurser (som tillgångar) och deras respektive förmåga (capability) och implicit dennas begränsning (capacity). Hon diskuterar inte vad som produceras av företaget, för vem eller i jämförelse med andra i konkurrenstermer annat än i termer av "productive services". Detta är en begränsning inför diskussionen om organisationens primära uppgift ${ }^{30}$ så som den definierats i föreliggande studie $\mathrm{d} v \mathrm{~s}$ att förädla potentiella och befintliga immateriella resurser. Hennes teoribildning omfattar dock olika tidsperspektiv, vilket denna avhandling särskilt vill belysa.

Penrose perspektiv omfattar ingen struktur över den s.k. resursbasen. Den skiljer inte på olika resursslag i denna kontext och den innehåller inget som kan kasta ljus över innehållet i en resurs eller hur en resurs kan identifieras (än mindre definieras).

Huvuddragen i Penrose teori är att teorin har organisationens tillväxt som utgångspunkt. Men tillväxten handlar framförallt om kunskapstillväxten som en resurstillväxt d v s en åtskillnad görs mellan kvantitet och kvalitet. I första hand belyser hon en kvalitativ dimension. Företag består av mänskliga och icke-mänskliga resurser. Människorna är de viktigaste resurserna. Resurser skapar ett antal kombinationer av tjänster som avsätts på en marknad för att skapa vinst. Organisationens "gräns" mot marknaden är viktig. Entreprenöriellt tänkande är det som identifierar och skapar en marknad, samtidigt är ledarskapet det som också kan begränsa organisationens tillväxt. TGF har också en kvantitativ dimension i form av att utökning av resursbasen kan göra att marginalavkastningen från den blir låg och därmed stimulerar entreprenörer att allokera organisationens resurser till nya områden för innovation och tillväxt (Pitelis, 2005).

\subsubsection{Resource Based View (RBV).}

En utveckling av ett resursperspektiv redovisades av Birger Wernerfelt 1984. Han publicerade då ett, för nutida skolbildning, avgörande teoretiskt bidrag i en artikel med titeln "RBV. A Resource Based View of the Firm". Artikeln redovisar bland annat erfarenheter från amerikanskt ägda företag som BIC, Boston Consulting Group $\mathrm{m}$ fl. Artikeln omfattar ekonomiska beräkningar som visar konsekvenserna av en diversifiering av organisationens

\footnotetext{
${ }^{29}$ Begreppet 'service' och 'tjänst' har under åren sedan femtiotalet utvecklats i företagsterminologin och har nu en annan innebörd jämfört med Penrose' definition. I föreliggande avhandling kan Penrose begrepp "productive service" närmast jämställas med /vidare-förädlad resurs. Begreppen/vidare-/förädling och förädlingsvärde ersätter här därmed Penrose terminologi, avseende begrepp här som resursförädling, resurseffektivisering, resurstillväxt mm. ; jfr Richardsons begrepp "Activties and Capabilities" (Richardson, 1972)

${ }^{30}$ Källa: Lewin, Carmen, Weigelt and Emery in: "Handbook of organizational change" (Poole, M.S. and Van de Ven, A.H., 2004
} 
resursbas. Den fick stort genomslag och valdes till bästa artikel i Strategic Management Journal (Zajak, 1994, SMJ 5: 171 - 180, 1995, SMJ 16).

Wernerfelt (1994) koncentrerar sig på att utveckla RBV mer eller mindre som verktyg för att analysera /det unika/ organisationens strategi utifrån dess konkurrenssituation, i såväl anskaffnings- som utbudssammanhang. Organisationens strategi analyseras här utifrån ett marknadsperspektiv (Porters produkt/marknadsmatris som fokuserar utbudsmarknaden). Organisationens resursbas, omfattande resurser i mycket vid mening (som exempelvis arbete, kapital, land, teknisk kompetens) ${ }^{31}$ men ändå unika för företaget och i termer av styrka och svagheter. Wernerfelt använder detta för att beräkna förändringar över tid. Han analyserar effekter på lönsamheten utifrån olika "barriärer" för köp/försäljning (inklusive förvärv/avyttring) av produkter respektive resurser. Han gör dock, till skillnad från Penrose, ingen egentlig analys av hur utvecklingen av egna/nya resurser, sker och bidrar till organisationens lönsamhet. En aspekt av tillväxt som Wernerfelt dock nämner är att det ger ett kanske rikare och annorlunda perspektiv att titta på hur man förvaltar portföljer av resurser, $\mathrm{i}$ stället för att titta på portföljer av produkter. Wernerfelt ses i RBV-sammanhang närmast som en företrädare för den s.k. "Structural School" d v s i viss mån orienterad mot neoklassisk teori.

RBV kan sammanfattas enligt följande: ${ }^{32}$

Huvudsaklig fokus för företaget;

- uthållig, långsiktig konkurrensfördel (sustainable competitive advantage),

- unika resurser som inte kan direkt kopieras,

- olikheter i hur effektiva företagen är,

- ofta stora, komplexa och diversifierade organisationer och

- begränsningar "ex ante" och "ex post".

Faktorer som intresserar ledningen vid formulering av strategi; (ex ante),

- att skydda sina resurser från kopiering, stöld och rekrytering av unika resurser,

- att skapa former för bundenhet/isoleringsmekanismer för unika resurser (patentsökning, utbildningssystem $\mathrm{mm}$ ),

- att "nischa" verksamheten och

- att förmå leverera kärnkompetens.

Huvudsakliga antaganden vad gäller resurser;

- olikheter mellan företags resursbaser,

- företaget omfattar flera kluster eller portföljer av resurser,

- unik konkurrensfördel genom att resurserna är unika,

- intern bundenhet/specifik anpassning och

- jämviktsorienterat, lönsamhet `maximerad’ vid utbud= efterfrågan ("Ricardian rent”).

Olika fokus vid empiri: (ex ante/ex post);

- diversifiering,

- fördelar vid "världsklass" (eg. "first mover advantages"),

31 "By a resource is meant anything which could be thought of as a strength or weakness of a given firm" (Wernerfelt, 1984 s. 172-173)

32 Källa: Lewin, Carmen, Weigelt and Emery in: "Handbook of organizational change" (Poole, M.S. and Van de Ven, A.H., 2004) 
- "cross-sectional" -analyser,

- problemet med att operationalisera resurser och

- FoU intensiv verksamhet (där resurserna i sig legitimerar verksamheten).

RBV (= det resursbaserade synsättet) har sedan 1990, då Wernerfelt presenterade detta synsätt, utvecklats runt resursbegreppet med implikationer inom ett antal närliggande forskningsområden med företagskontext. ${ }^{33} \mathrm{RBV}$ används också som samlingsbegrepp för efterföljande teoribildning inom resursområdet.

Huvuddragen i teoribildningen efter RBV och Wernerfelt sammanfattas i Jay Barneys utveckling av teorin (Barney, 1991). Barney menar att för uthållig konkurrensfördel (competitive advantage vs sustained competitive advantage) identifieras resurser i termerna av "value", "rareness", "imitability" och "substitutability" och kan då förstås som organisationens strategiska, "heterogenous" och "immobile" resurser. Vilka dessa kritiska resurser är och hur de bidrar till dessa olika uttryck för konkurrenskraft diskuteras utifrån empiri. Barney identifierar i "vida" termer organisationens resurser som alla tillgångar, förmågor, organisatoriska processer, organisationens olika karaktäristika, information och kunskap och resurser som möjliggör implementering av strategier för att förbättra effektivitet (efficiency and effectiveness). Resurser betraktas som möjliggörare (enablers) för att via effektivitet (per definition) nå och upprätthålla en /uthållig/ konkurrensfördel.

En sammanfattande studie av villkor för och implikationer av det resursbaserade perspektivet på affärsstrategi (i olika konkurrenssituationer) beskrivs av Margret Peteraf (Peteraf, 1993). För att ett företag ska uppnå konkurrensfördel måste resurserna betraktas som strategiska och för detta måste ett antal kriterier vara uppfyllda. Grundkriteriet är att de olika företagen ska ha olika uppsättning av resurser (resource heterogenity) och deras respektive interna förmågor måste vara olika. Om det finns en homogenitet mellan olika företags resursbaser och deras respektive förmågor kan inget av företagen ha en unik konkurrensfördel. Det andra, kanske viktigaste grundvillkoret i praktiken, är att resurser (och förmågor) har begränsad rörlighet eller inte har någon rörlighet alls (imperfect mobility or immobility).

Peteraf (1993) utvecklar ytterligare två villkor, "ex ante"-villkor respektive "ex post" -villkor för konkurrens. Med ex ante villkor avser Peteraf att det egentligen inte kan förekomma någon konkurrens (eller med hennes beskrivning att ingen information egentligen finns om förutsättningarna för konkurrens) inom ett område och vid tidpunkten innan ett företag vill etablera sig med sin produkt etc. I likhet med Barney (Barney 1986) pekar hon på att kostnaden

\footnotetext{
${ }^{33}$ Andra artiklar om RBV med implikation på strategiforskningen och företag är exempel på grundläggande forskning, i fri översättning; RBV och "theories of the FIRM" (Barney, Cease, Foss, Conner \& Prahalad, Penrose, Rumelt, Wernerfelt,); om jämvikt vs evolution (Foss, Nelson \& Winter, Montgomery); om organisationens strategi, strategiforskning (Barney, Bromiley et al, Grant, Mahoney, Peteraf, Rumelt, Chandler); om produktutveckling (Verona); om innovation genom rekombination (Galunic och Rudan); om kompetens (Freiling, Wilkens et al, Grant); om kunskap, kombinerade "capabilities" och teknologi/plagiat (Kogut et al) ; om kompetens som konkurrensmedel (Hamel et al, Priem \& Butler, Prahalad); om resurser, tillgångar och uthållig konkurrensfördel (Dierickx, Foss et al, Black, Rouse, Cockburn) ; om resurser och konkurrens (Barney, Black \& Boal, Wernerfeldt, Grant, Peteraf) : om resurser, teknologi och strategi (Foss et al, Teece\& Pisano \& Shuen) ; om resurser mellan företag - och konkurrensfördel (Duschek, Eisenhart); om resurser och samarbete mellan företag (Combs \& Ketchen) ; om resurser och entreprenörskap (Mousakowski) ; om resurser och effektivitet (Collis); om diversifieringens påverkan på resultatet (Robins, Teece) ; om management Control (Henri) ; om integration med transaktionskostnadsekonomi (Foss, Silverman).
} 
för att implementera strategin inte får överstiga de förväntade intäkterna och att den egentliga "vinsten" genereras av den "osäkerhet" som företaget upplever före implementeringen d v s ju större osäkerhet desto bättre avkastning (profit comes from ex ante uncertainty).

Med ex postvillkor, d v s efter implementering av en strategi, avser hon att det måste finnas krafter som gör att heterogeniteten behålls. Det ena är att begränsa möjlighet för konkurrenter att imitera resurserna, det andra att inte resurserna kan ersättas med andra. Detta är också ett av Porters argument där han i någon mån ansluter till resursbaserad teoribildning (Porter, 1980).

I termer av "kraft" eller "möjliggörare" för detta nämner Peteraf patent, "informationshinder" etc. Karaktären på dessa "möjliggörare" och hur de skapas beskrivs ytterligare av Dierickx m fl. (Dierickx och Cool, 1989) och i termer av mer "osynliga" krafter eller förmågor. Peteraf ser dessa krafter som tillgång för företaget och identifieras inte direkt i termer av resurser, men att det sätter fokus på de resurser som är strategiska och avser resurser som genereras inom företaget (Peteraf, 1993).

Peteraf beskriver vidare hur avkastning, "rents" och "quasi-rents", generas utifrån olika prioriteringar i strategin; "monopoly rents" beskrivs utifrån ett begränsat marknads/ utbudsperspektiv (högre pris) medan "ricardian rents" beskrivs utifrån att företaget har begränsad tillgång på vissa resurser eller begränsade möjligheter att expandera resurserna (implicit en begränsad möjlighet för konkurrenter att imitera dem) så att resurserna värderas och därmed prissätts högre relativt organisationens marginalkostnader för att expandera eller utveckla dem (ibid.)

\subsubsection{Resource Dependency Theory (RDT).}

Några år före Wernerfelt presenterades en teoribildning som kallas "a Resource Dependency Theory" (RDT) (Pfeffer, J. \& Salancik, G.R., 1978). Teorins huvudtema är "extern kontroll, d v s företaget är beroende av omvärlden /s resurser/ för att överleva. Implikationerna i teorin innebär ett kontinuerligt förändrat beteende i företaget, primärt utåtriktade, för att undvika risk och osäkerhet (Se Símons begrepp "Boundary systems", Simons, 1995). Teorin ger bland annat en god förståelse för hur "ledningen" generellt hanterar osäkerhet i vardagen och hur beroendet av omvärlden hanteras.

RDT kan sammanfattas enligt följande: ${ }^{34}$

Huvudsaklig fokus för företaget vid formulering av strategi:

- Begränsning av osäkerhet i omgivningen,

- relationen till andra företag och

- maktkonstellationer inom och mellan företag.

Vad intresserar ledningen:

- Engagerar omgivningen,

- förhandlar utbyte med omgivningen och

- kontrollerar och skapar resurser genom relationer med omgivningen.

${ }^{34}$ Källa: Lewin, Carmen, Weigelt and Emery in: "Handbook of organizational change" (Poole, M.S. and Van de Ven, A.H., 2004) 
Huvudsakliga antaganden vad gäller resurser:

- Företaget förhandlar om resurser för att reducera osäkerhet,

- företaget kan påverka omgivningen inom vissa ramar,

- företaget har handlingsfrihet, med diskretion,

- företaget drivs av/med "egenintresse" och

- asymmetri i ett ömsesidigt beroende till andra.

Fokus vid empiri:

- Studerar interaktivitet/utbytet med omgivningen

- "inkorporation" av ledningen,

- styrelsesammansättning och

- primärt "cross-sectional" analyser.

\subsubsection{Dynamic Capability Perspective (DCP).}

Ett perspektiv som framförallt kompletterar RBV är det "dynamiska perspektivet". Här diskuteras organisationens förmåga i termer av processer, hur resurser ackumuleras, ex postvillkor mm. Ursprunget till teorin är J A Schumpeters "tillväxtteorier" (1934) som sedan utvecklats av (evolutionsteoretikerna) Nelson \& Winter (1989), Dierickx \& Cool (1989) samt D.J. Teece $\mathrm{m}$ fl. (1997, 2000). Här ses organisationens dynamiska förmåga (i termer av organisationens organisatoriska och strategiska processer) som potential att utveckla/"manipulera" organisationens resurser att ingå i organisationens värdeskapande strategier. Konkurrensförmågan ligger dock i hur resurserna i sig organiseras och struktureras ("the configuration of resources", Eisenhart \& Martin, 2000, s. 1118) snarare än i organisationens processer. Detta "dynamiska perspektiv" avhandlas i analysen av "ny" teoretisk referensram (Se kapitel 6)

\subsubsection{Utveckling av teorin}

Om det går att utläsa någon trend ovan är den i så fall att nuvarande (och framtida?) "forskningsfåra" omkring $R B V$ och det resursbaserade perspektivet, med eventuella implikationer på forskning om företags /resursbaserade/ styrning, kommer att "plöjas" i gränslandet mellan två huvudsakliga skolbildningar d v s mellan ett utpräglat kognitivt (processorienterat) synsätt representerat av Penrose' efterföljare och ett mer transaktionellt (strukturorienterat) synsätt, representerat av Wernerfelt. Ett antal artiklar redovisar empiri från forskning i detta "gränsland" (Silverman, 1999) dock i första hand avseende förändring, diversifiering eller kontraktion av organisationens resursbas (Lindell, 1992).

\subsection{Det resursbaserade synsättet för studier av strategi och styrning}

Det resursbaserade synsättet har sedan 1980 snabbt utvecklats med implikationer för ett antal olika skolbildningar, bland annat för teoribildning om kompetensutveckling och organisationsutveckling. Synsättet kan tillämpas med implikation på beslutsmodeller och tillämpningar i organisationens ekonomistyrning (Henri m fl.). En kritik är att definitioner av begrepp och typologier brister avseende operationalitet i där resurser avhandlas. Behovet av operationalitet är dock ett villkor för formalisering av begreppet inom "styrningsdiskursen" utifrån kravet på "mätning. 
Teoriutvecklingen utifrån resursperspektivet i en organisatorisk kontext följer två huvudlinjer. Forskningen utgår i det ena fallet från den s.k. "process school" (Penrose $\mathrm{m}$ fl.) och i det andra av den s.k. "structural school", för närvarande representerat av RBV (the resource based view) (Wernerfelt $\mathrm{m}$ fl.). I den förstnämnda diskuteras resurser i termer av resurser (som tillgångar), men framförallt organisationens förmåga (capability) att generera resultat i olika processer. Fokus är organisationens tillväxt, men utifrån input/produktionsperspektiv snarare än produkt/konsumtionsperspektiv, $\mathrm{d} \mathrm{v} \mathrm{s}$ resultatet av organisationens verksamhet är dess produkter eller tjänster (productive services) som genereras utifrån att dess /unika/ resurser processas och hur företaget betraktar olika möjligheter/förutsättningar (productive opportunities). Som enskilda begrepp innebär såväl resurser och förmågor som resultat och tillväxt (i termer av produkters och tjänsters kvalitet snarare än kvantitet) i denna teoribildning svårigheter att operationalisera.

Inom ramen för den andra tolkningen av det resursbaserade synsättet (RBV) där fokus ligger på resurserna (snarare än på produkterna som genereras), identifieras organisationens resurser som alla de styrkor (eller svagheter), inklusive strukturer och processer, som finns hos ett givet företag och som med 'verktyget' RBV kan analyseras inför beslut om organisationens strategiska utveckling. Detta vidgade perspektiv på resurser (exempelvis patent, teknisk kunskap, maskiner, affärskontakter, effektiva produktionstekniker mm) används som utgångspunkt för att på ett nytt sätt identifiera organisationens mest strategiska resurser, inträdesbarriärer till marknader, imperfektioner på marknader mm (Wernerfelt $\mathrm{m} \mathrm{fl}$.). Det används också för vissa matrisberäkningar men inte heller här med någon egentlig mätning eller operationalisering av resursen i sig, vare sig som input, i själva resursutvecklingen eller som ett resultat. Det sätt som resurser identifieras inom ramen för RBV medför ytterligare svårighet att operationalisera och därmed mäta dem inför organisationens strategiska beslut (ex ante) och vid värdering av det resultat som de förväntas åstadkomma/har åstadkommits d v s i samband med strategins implementering.

Synsättet har också utsatts för prövning av huruvida dess kriterier (för empirisk prövning) (Whetten, 1989) är tillräckliga och om det överhuvudtaget ska betraktas som en relevant "teori". En synpunkt i detta avseende är att det i sitt ursprung (Barney $\mathrm{m}$ fl.) saknar ett dynamiskt resonemang i de modeller som används samt att det i alltför mycket generella termer talar om "resources" och "capabilities" som avgörande för företags konkurrensförmåga (Priem och Butler, 2001). Utvecklingen av "the Dynamic Capability Perspective" (Schumpeter, 1994; Teece et al., 1994) får ses som en möjlighet att på ett mer nyanserat sätt diskutera olika grader av betydelse av organisationens förmåga respektive resurser. Och kanske en möjlighet att operationalisera en viss typ av resurser (respektive förmågor) genom att en ytterligare distinktion av begreppen införs.

En kritisk analys av RBV (Akio, 2005) vill i likhet med Penrose sätta fokus på ledarskapet, m a o ledarens roll och dennes tillgång till information, som avgörande för organisationens konkurrensförmåga och Akio anser att denna interna fokus på ledaren är underskattat i RBV. Utifrån ett ledar-/entreprenörsperspektiv måste själva "resursen" därmed vara mer bestämd utifrån ett internt perspektiv och ledaren/entreprenören är då den som, utifrån unik information (superior information) påverkar en viss resurs i dess "förädling" $\mathrm{d} v \mathrm{~s}$ "the asset accumulation process" (jfr: dynamic capability). Liknande grundläggande slutsatser dras av Dierickx och Karen Cool. 
"The managerial implication drawn is that firm should focus their analysis mainly on the "unique" skills and resources rather than on the competitive environment" (Dierickx \& Cool, 1989)

En utgångspunkt är att, i distinktionen mellan "resurs" och "förmåga", det har utvecklats en slutsats att organisationens/systemets, alternativt ledningens/entreprenörens, förmåga snarare än resursens egenskap är huvudsakliga faktorn bakom konkurrenskraft (Grant, 1991), men att det som ändå ska värderas är resurserna - om de finns eller ej - och dess inneboende egenskaper och resultatet av vad de potentiellt 'avkastar’ utifrån deras värde över tid. Detta implicerar också att det är genom det speciella sätt att samarbeta och koordinera resurserna utifrån deras inneboende egenskaper /och begränsningar/ som företaget utmärker sin "heterogenitet" /vs andra företag i en viss bransch/. Med en uttolkning av idrottsmetaforen utifrån TGF (Penrose, 1959) kan ett liknande resonemang föras;

på en viss nivå är lagkaptenen eller coachens eller lagledarens förmåga leller begränsning i/ att koordinera och organisera spelarnas inbördes förhållande, ofta avgörande för matchens (varje situations) utgång. Eller på individnivå är den "smarte" cyklistens förmåga att använda rätt utväxling av sina krafter vid rätt tillfälle, (i varje lopp) avgörande för långsiktig framgång. Men, utan kunskap eller information om individens energi och speciella styrka eller om formläget, är denna organisationsförmåga inte viktig.

Med referens till Penrose menar Akio därför att det är en ökad kunskap om den potentiella resursen och dess inneboende specifika egenskaper, d v s vad de potentiellt kan förväntas generera kvantitativt och kvalitativt, som hjälper till att skapa möjligheter och att det är därför som Penrose ändå lägger fokus på just resurserna! Men, för att koordineringen ska fungera krävs dock inte bara kunskap om resurserna utan också en beslutsprocess och en förmåga hos företaget att fatta strategiska beslut. En förmåga som kräver insikter om visioner (Vad?) och strategi (Hur?) (Casson 1997 i Akio, 2005)

Penrose menar också, enligt Akio, att resursen är den `service` d v s en egenskap/funktion hos resursen som är input och denna service kan också definieras och identifieras i olika tillstånd eller genom att den har en viss funktion.

"Resources consists of a bundle of "services" and can,....., be defined independently of their use" >>..>> " the very word "service" implies a function, .." (Penrose, 1959).

Akio drar slutsatsen att förmågan egentligen är organisationens möjlighet eller /begränsade/ kapacitet (capacity) att omvandla dessa resursers egenskaper till denna `service som resursen ger utifrån dess funktion, $\mathrm{d}$ v s funktionen kan definieras inom ramen för och synonymt med den "service" som resursen representerar (Akio, 2005). (jfr; lagrad energi som genom påverkan omvandlas till rörelseenergi och vidare till elektricitet eller värme).

Akio menar också att förmågan då kan mätas utifrån "poäng" på denna "service" och implicit således dess funktion. Bra företag har höga poäng. Skillnaden mellan olika företag är då mått på dess unikitet (heterogenicy). 
Vid ytterligare belysning av kriterierna enligt RBV som Barney framför (Barney 1991) menar Akio att beträffande två kriterier, utöver att resurser ska vara heterogena och ha begränsad rörlighet, så har perspektivet några begränsningar eller "brister".

- Att resurser måste vara värdefulla kommenterar Akio med att värdet i så fall måste speglas i ekonomiska termer och beroende på om de är 'synliga' eller 'osynliga' och de måste kunna diskonteras som förväntade framtida värden. Kostnaden för att anskaffa och utveckla resurserna måste dessutom vara med ( $\mathrm{v} v \mathrm{~s}$ en långsiktig investeringsbedömning är implicit i detta kriterium)

- Akio menar vidare utifrån ekonomisk terminologi att frågorna Varför? och Hur? måste ställas när värdet av resurserna diskuteras. Likaså måste hänsyn tas till det pris som marknaden vill betala för organisationens output, $d \mathrm{v}$ s resurser i nästa förädlingssteg.

- Att de måste vara sällsynta kommenterar Akio med att även om resurserna genererar en hög avkastning (rent) så behöver det inte betyda att det innebär en konkurrensfördel bara för att de är sällsynta. Avkastningen måste mer betraktas utifrån ett "hyrpris" för den funktion, en del av kvalitetsdimensionen, som en resurs har; detta oberoende om den är sällsynt eller ej

- Akio menar också att det snarare är antingen eller; land betalas dyrt antingen det är jord som är särskilt fruktsam (fertile) eller om det är sällsynt. Båda villkoren behöver inte vara uppfyllda när ägarna, med ett resursbaserat perspektiv, bedömer den relativa avkastningen/värdet av en resurs på en faktormarknad eftersom man inte kan bedöma vad deras slutliga output kommer att generera utan istället den relativa fördelen/nyttan av olika strategier om vi tillämpar ett resurssynsätt. Med detta menar Akio att RBV uppfyller kriterier för uthållighet, men inte villkor för en konkurrensfördel genererad av en hög avkastning. (Jämför idrottens olika tidsperspektiv; förväntningar av ett förvärv av en "sällsynt” spelartalang jämfört med den smarte cyklistens uthållighetsstrategi).

Diskussionen om en faktormarknad för resurser förs enligt Barney m fl. (Barney 1986). Faktormarknaden är inte perfekt, eftersom förväntningarna hos de som tillämpar strategin är olika beträffande vilken avkastning resurserna ska generera.

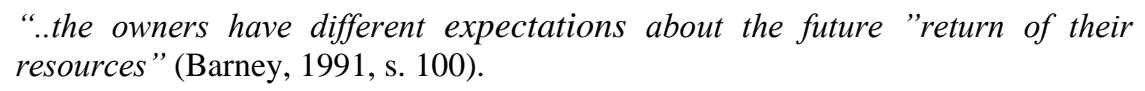

En ytterligare aspekt på RBV utifrån detta perspektiv på konkurrens på faktormarknaden är Margret Peterafs ex ante villkor för konkurrens; organisationens tillgång till information. De företag som har intentionen att uppnå konkurrensfördel måste vara konstant välinformerade om det förväntade framtida värdet av sina resurser (Peteraf, 1993). Vidare måste ex ante värdet vid anskaffning av resurserna vara mindre än ex post värdet annars har ingen avkastning uppstått (Rumelt, 1987, Peteraf, 1993) d v s ingen resurstillväxt har genererats. Utifrån informationsaspekten och företags förväntningar kan denna tillväxt kallas "entrepreneurial rents" (Peteraf, 1993) och den genereras av "informationseffektivitet" d v s egenskapen hos (resursen) informationen utifrån dess kvalitet/funktion relativt uppoffringen vid anskaffningen av densamma, är avgörande för hur resurseffektiv dess "service" är. 
En slutlig aspekt på entreprenören som är underskattad i RBV, i själva "förädlingsprocessen" är dennes roll i samband med innovationer. Att finna nya kombinationer (i syfte att generera avkastning) handlar också om att "förstöra" olika jämviktsförhållanden antingen genom att utveckla nya kvaliteter, nya produktionsprocesser (adjusting) eller att i kombinationer av resurser kreativt skilja på olika resursers inneboende värden (creating) (Schumpeter, 1934 och Kirzner, 1985 i Akio, 2005) (jfr strategi för 'produktförnyelse’ respektive ‘processutveckling').

\subsection{Ekonomisk styrning: Teori och skolbildning}

Detta avsnitt avhandlar primärt teoriområden och begrepp inom diskursen "ekonomisk styrning”. Begreppen tillämpas i en organisatorisk (läs: företags) kontext. Som utgångspunkt inför fortsatt problematisering av 'strategisk styrning' avhandlas här ekonomistyrning och bolagsstyrning. ${ }^{35}$

Skolbildning inom ekonomistyrning fokuserar system för ekonomistyrning (MAS, MCS) och handlar primärt om "ettårs-styrning" (operativ ledning, budget, periodiserade utgifter, avkastningsmått $\mathrm{mm}$ ). Den har ett internt perspektiv där organisationens ledning och primärt "controllern" är aktör. Ett vidare perspektiv på ekonomisk styrning implicerar bolagsstyrning; en reglering av "interna" aktiviteter mellan andra styrfunktioner och funktionärer på nivån över företagsledningens styrning $\mathrm{d}$ v s såväl med organisationens styrelse, via ägardirektiv eller direkt medverkan av ägare. I detta vidare perspektiv omfattar den ekonomiska styrningen i allt större utsträckning frågor om investeringskultur, finansieringsstrategier $\mathrm{mm}$.

\subsubsection{Bolagsstyrning}

Blom, Kärreman och Svensson (2012) redogör för begreppet bolagsstyrning (corporate governance). Författarna använder en bred definition av begreppet där fokus är relationen till organisationens olika intressentgrupper. Primär intressent är organisationens ägare och deras relation till företagets styrelse. Ägarnas påverkan på organisationens styrning har olika karaktär." Hirshman (1970) beskriver ett antal olika "ägarbeteenden" utifrån graden av möjlighet till påverkan på styrningen.

Bolagsstyrning avhandlas primärt inom ett organisationsteoretiskt forskningsfält. I populärtermer kan detta illustreras med en beslutsorganisation som antingen beskrivs utifrån ett "top-down" perspektiv" (ibland som "affärsperspektivet" eller "utifrån och in-perspektivet") eller ett "bottom-up"-perspektiv.

Blom m fl. ger exempel på olika teoretiska utgångspunkter för att förklara och förstå bolagsstyrningens konsekvenser i olika kontexter. Bolagsstyrningen har primärt ett "externt" syfte d v s dess uppkomst som företeelse var en brist på "uppförandekod" för ägare och styrelse i publika företag. De teorier som författarna redovisar kan bidra till förklaring av dessa "uppförandeproblem" bland annat vid problematisering av relationen mellan ägare och styrelse

\footnotetext{
${ }^{35}$ Kommande problematisering av strategisk styrning görs också med referenser till närliggande diskurser och teoriområden; kvalitet, strategi och organisation. Systemteori, institutionell teori och redovisningsteori berörs implicit inför kommande analyser. En tillämpning av "contingency"-ansats avhandlas explicit. Den fortsatta teorigenomgången är avgränsad till forskning och tillämpning i den kontext som kommande analys avser.
} 
avseende implementering av hållbarhetspolicy, organisationens legitimitet och långsiktighet, vid finansiering mm. (Blom, Kärreman och Svensson, 2012).

Ett ökat intresse för implementering av strategier för FoU och innovationer, kompetensförsörjning, karriärplanering, digitalisering, investeringsverksamhet har medfört ett behov att förstå relationen mellan styrelse och ledning i organisationen. De teorier som Blom $\mathrm{m}$ fl redogör för är bland annat agentteori. Ett citat:

”Många studier av och kring bolagsstyrelser vilar på agentteoretisk grund. Utifrån detta perspektiv utgör styrelsen den högsta hierarkiska nivån $i$ beslutsprocessen $i$ företaget. Styrelsen utövar "decision control" över de beslut som initieras på närmast lägre nivå, företagsledningen” Blom, Kärreman och Svensson (2012) s.27

Författarna refererar också till den resursberoendeteorin (RBT), den organisationsteori som utgår ifrån organisationens beroende av externa resurser. Som förklaring till hur en "intern" mer operativt orienterad ekonomisk styrning påverkas av ett resursperspektiv har denna teori ett begränsat värde då dess primära fokus är gränserna mellan organisationen och dess omgivning (Blom, Kärreman och Svensson,2012).

I ett mer långsiktigt styrningsperspektiv, exempelvis vid utveckling av företagets framtida innovationsvillkor, implementering av hållbarhetskriterier för den ekonomiska styrningen eller vid andra legitimitetsfrämjande villkor kan resursberoende teori (RBT) antas ha ett högre förklaringsvärde.

Styrelsens rapportering av bolagsstyrning i publika koncerner avser bland annat tillämpning av regelsystemen IFRS och GAAP. Dessa regelsystem har företagens ägare som primär intressent d v s de avser styrelsens information till ägare och syftar till att skapa goda förutsättningar för handel med aktier och derivat mellan olika ägarkonstellationer. Här accentueras bolagsstyrningens betydelse också för den ekonomiska styrningen då företagens styrelse och enskilda ägare eller ägarkollektiv enligt teori antas kunna ha divergerande intressen. Det är i denna kontext d v s i den externa rapporteringen som förändringar i företagens kapitalstruktur som en konsekvens av organisationens ledning och dess ekonomiska styrning, har observerats

\subsubsection{Ekonomistyrning.}

Ekonomistyrning ("Management Control") och System för ekonomistyrning ("Management Control Systems") definieras i ett stort antal källor. I Nationalencyklopedin definieras begreppet ekonomistyrning som:

Ekonomistyrning avser avsiktlig påverkan på en verksamhet och dess befattningshavare mot vissa mål.

Denna definition används som utgångspunkt i svensk skolbildning på grundläggande nivå inom ämnet företagsekonomi (Ax, Johansson och Kullvén, 2009). Inom företagsekonomiforskningen har två andra företrädare för ekonomistyrningsområdet definierat de två begreppen, ekonomistyrning respektive system för ekonomistyrning, som: 
Ekonomistyrning ("Management Control") är den process genom vilken ledningen motiverar andra medlemmar av en organisation att implementera organisationsstrategier (i översättning av Anthony, 1965).

System för ekonomistyrning ("Management Control Systems") är formella, informationsbaserade rutiner och procedurer som ledningen använder för att underhålla eller förändra olika mönster i organisationens olika aktiviteter (i översättning av Simons, 2000)

Detta är två förhållandevis likartade definitioner men ändå med två delvis olika fokus. Ekonomistyrning beskrivs av Anthony som en process och syftet är att implementera strategier, $\mathrm{d}$ v s fokus ligger på implementeringen av strategin. System för ekonomistyrning beskrivs av Simons i termer av rutiner och procedurer. Dessa är verktyg som används i syftet att underhålla eller förändra aktiviteter. Här ligger fokus på pågående aktiviteter och på förändringsprocessen. De två definitionerna tar utgångspunkt i ledningens syfte med ekonomistyrningen. Beskrivningen av syftet är likartat och beskrivningarna ovan ger uttryck för samma ambition.

De två definitionerna är om än generella så ändå begränsade när det gäller en utökad kontext, om de ska antas avse hela ledningsområdet, $\mathrm{d}$ v s ledning och styrning av organisationer i helt nya former som exempelvis nätverksorganisationer, samarbetsavtal (joint ventures), ideella och andra typer av organisationer som ett modernt och integrerat samhälle består av (Chenhall, 2003).

\subsubsection{Teori och forskning om ekonomistyrningens roll och tillämpning}

Hur och med vilka aspekter på ekonomistyrning har teorin utvecklats under senare år och hur uppfattas ekonomistyrningsteori i sin tillämpning utifrån befintlig kunskap hos företagens ledning? Forskning och skolbildning inom ekonomistyrning leder till en ökad förståelse för företags generella besluts- och strategiarbete. För ett enskilt företag gäller specifika förhållanden. Teoritillämpningarna varierar beroende på vilken kunskap ledningen har om dessa förhållanden och om det sammanhang, den kontext som gäller, exempelvis vilket tidsperspektiv som avses, vilka omvärldsvillkor som gäller, målet och syftet med styrningen $\mathrm{mm}$.

Ett antal översikter av ekonomistyrningens roll har gjorts sedan 1970-talet. (Hofstede, 1978; Merchant och Simons, 1986; Otley, 1995). Två senare genomgångar är författade av Chenhall (2003) samt Berry (2009).

Berrys rapport (Berry m fl, 2009) beskriver ekonomistyrningsteori inom de tre aspekterna beslutsfattandel beslutsprocesser vid strategisk ekonomistyrning med referens till (Anthony, 1965; Miller and Leary, 1997; Connor, $2004 \mathrm{~m} \mathrm{fl.),} \mathrm{om} \mathrm{organisering} \mathrm{och} \mathrm{nya} \mathrm{former} \mathrm{för}$ organisationer (Drucker, 1992; Van der Meer-Kooistra and Scapens, 2004; Håkansson and Lind, $2004 \mathrm{~m}$ fl.) samt system för mätning av resultat ("performance management systems") (PMS/SPMS) (Simons, 1995; Chenhall, 2003, Langfield-Smidt, 2003, Otley, 2005). 
Chenhalls rapport (2003) är en analys av forskning om ekonomistyrning åren 1980 till 2000. Chenhall diskuterar här syftet med ekonomistyrningen och de kontextuella faktorer som påverkar ekonomistyrningen och han redogör för olika författares typologier samt ställer upp ett antal påståenden (propositions) $\mathrm{i}$ anslutning till vad han funnit mest relevant $\mathrm{i}$ de olika teorierna. De kontextuella faktorerna är omgivningen (typ av omgivande miljö), allmän processteknologi (the way tasks transform inputs to outputs) och syftet med mer specifika, teknologier som TQM etc.. Vidare diskuterar han själva organisationens struktur samt dess storlek, som två kontextuella faktorer. Strategi diskuteras ingående, inte explicit som en kontextuell faktor, utan som en förutsättning för att ledningen ska kunna påverka de kontextuella faktorerna.

Två aspekter som uppmärksammats i båda dessa litteraturöversyner, men som inte explicit berörs i denna avhandling, är kulturaspekten (Hofstede, 1980, 1991, 1993; Ouchi, 1980; Peters and Waterman, 1982; Schein, 1985; Simons, 1995 och Scott, 1998) samt aspekter utifrån hur informationsteknologin utvecklats (Hopper, 2005; Chapman, 2005 samt Dechow and Mouritzen, 2005).

Två ekonomistyrningsforskare som inte direkt refereras i dessa två senare litteratursammanställningar är Norman B. MacIntosh (1994) och Robert Anthony (1995). Anthony har en mycket generell tolkning. Hans klassiska beskrivning av MCS m a p organisationens beslutsprocesser (och resurser) anses idag fortfarande giltig:

"..the process by which managers assure that resources are obtained and used effectively and efficiently in the accomplishment of the organization's objectives". (Anthony, 1965)

Anthony pekar på ekonomistyrning som något som sammanbinder planering och genomförande. Han betonar kontrollaspekten och speciellt "output control" vid implementeringen, i MCS. Anthony har tillsammans med Vijay Govindarajan konceptualiserat hur ekonomistyrning tillämpas för att implementera olika strategier och vilka konsekvenser detta har på styrningen på olika nivåer d v s för såväl "corporate strategies" som för "business units strategies". Anthony skiljer därmed på kontrollsystemen på olika nivåer; "strategic" respektive "managerial" eller "operational/task control", där strategisk kontroll har ett mer långsiktigt perspektiv. Han pekar också speciellt på skillnader när det gäller varför företag väljer strategier för att antingen utveckla ("build") eller skörda frukterna av organisationens investeringar ("harvest"). Anthony och Govindarajan har, med exempel från omfattande empiri, beskrivit hur dessa strategier påverkar tre olika instrumentella delar av styrningen; budgetanvändning, prissättning och på incitamentsprogram (Anthony and Govindarajan, 2007).

Norman B. MacIntosh har delvis en mer sociologisk ansats när han beskriver ekonomistyrning i sin "vidaste" kontext. Han refererar till en mycket bred beskrivning av MCS som här utvecklats av författarna Horngren and Sundem:

"...the process of identification, accumulation, analysis, preparation, intepretation and communication of information that assist executives in fullfilling organizational objectives..." (Horngren and Sundem, 1990 s. 4) 
MacIntosh teori utgår ifrån att, beroende på vilken "organisationstyp" som organisationens ledning representerar ("defender", "prospector", analyzer" och "reactor"), så tillämpas styrsystemet i dess olika delar, på olika sätt. Han gör också en analys av empiri och redogör för hur ledningen agerar på olika nivåer och hur detta påverkar användningen av styrsystemet. Även MacIntosh använder sig av olika strategier för att utveckla verksamheten. Han gör en analys av hur dessa strategier kan sammanfalla med olika faser i en produkts livscykel och vad ledningen fokuserar i dessa olika faser; "prospects" under introduktionsfasen, "sales" och "profits" under tillväxtfasen, "efficiency" under mognadsfasen och slutligen "cash flow" under avvecklingsfasen. (MacIntosh, 1994)

\subsubsection{En långsiktigt syftande styrning.}

En organisation, människor, rutiner, system och processer påverkas mer eller mindre av hur strategier formuleras och sedan införs. Ekonomistyrningen utformas och systemet utformas mer eller mindre utifrån hur organisationen på en viss nivå kan förväntas respondera på vad implementeringen långsiktigt kan förväntas leda till, vilket syfte som strategin har, hur den genomförs och vilken grad av förändring av organisationens form och aktivitet som den förväntas innebära. Styrning kan antas mer eller mindre vara utformad utifrån ett specifikt 'strategiskt' syfte, d v s syftet med implementeringen av en viss vald strategi ska uppfattas vara att den leder styrningen mot ett visst mål $i$ ett längre tidsperspektiv.

Det syfte som kan antas för högsta ledningens beslut att implementera en viss strategi är att uppnå ett visst långsiktigt mål; ett resultat som kan mätas och där detta mätresultat också kan användas för att ändra strategin - i syfte att uppnå större förväntad måluppfyllelse. Om styrningen utgår ifrån i långsiktigt ägardirektiv involveras såväl operationell ledning som företagets exekutiva styrelse.

Ett antal olika studier har genomförts såväl teoretiskt som empiriskt vid implementering av strategi och system för en mer 'strategiskt' orienterad styrning. Pia Lindell har bland annat avhandlat två dimensioner i samband med empiri om styrningens roll vid förändring av företagsstrategier - och vid organisering generellt (Lindell, 1992). Hennes slutsatser är bland andra att 'strategisk' styrning är beroende av a) tidsperspektiv och b) preciseringsnivå. Två andra slutsatser är att 'strategisk' styrning kan användas som beteckning på det medvetna agerandet i strategiprocessen och att den mer 'strategiska' styrningen kan variera i olika skeenden i organisationens utveckling.

Fredrik Nilsson har empiriskt avhandlat effekter på ekonomistyrning efter genomförande av ett strategiskt motiverat företagsförvärv (Nilsson, 1997). En slutsats i Nilssons avhandling är att styrningens effektivitet varierar beroende på om det avser verksamhetsintegration eller affärsutveckling. Effektiviteten i styrningen är också beroende på hur långtgående kraven är på koncerngemensam formalisering av strukturer och processer versus kraven på situationsanpassning. En implementering kan förutsätta långtgående och tidskrävande förtroendeskapande åtgärder för att den inte ska misslyckas i sitt syfte.

En annan forskare, Robert Burns (Burns, 1999) har såväl teoretiskt som empiriskt avhandlat effekterna vid införande ett incitamentsprogram som en del av en långsiktig styrning för 
forskningspersoner i en /laborativ/ FoU-miljö; det s.k. "Becks-caset". Resultatet av detta försök sammanfattas här:

"The case highlights the power over resources, decision making and meaning as key facilitators...It also demonstrates barriers to change and conflicts that emerges as new accounting routines fail to impinge on existing laboratory ways of thinking."

(Burns, 1999 s. 566)

Dessa två empiriska studier indikerar dels att det fordras en balans mellan organisationens strukturer och processer som gör att förändring är möjlig, dels att det finns incitament till mer långsiktig förändring som kan kommuniceras. Det visar också betydelsen av hur implementeringen genomförs. I de två fallen (Nilsson, 1997 respektive Burns, 1999) har man konstaterat att effektiviteten i den möjliga användningen av systemen för ekonomistyrning, $\mathrm{d}$ v $\mathrm{s}$ i hur systemen är utformade $\mathrm{m}$ a $\mathrm{p}$ förväntad nytta/relevans respektive om det är enkelt eller komplext, är beroende av hur organisationen responderar på införandet av dem men också utifrån hur den mottagande organisationen bedömer vilken ekonomisk tanke som ligger bakom föreslagen utformning av systemet $\mathrm{d} \mathrm{v} \mathrm{s}$ dess relevans $i$ respektive sammanhang/situation. I fallet "Becks" var den mottagande organisationen FoU (PDD) inte mottaglig utifrån de mönster som fanns i laboratoriemiljön och själva strategin var inte kommunicerad med hänsyn till den situation som medarbetare uppfattade gällde. Syftet med implementeringen som den uppfattades av medarbetarna, bidrog till den konflikt som uppstod. Exemplet visar också betydelsen av att organisationen uppfattar den gällande ekonomiska situationen på samma sätt.

En reflektion om ovanstående empiri är att de handlar om till synes motstridiga ekonomiska målbilder i organisationens verksamhet och det krävs en mycket tydlig kommunikation om målet ska kunna uppfattas på ett entydigt sätt.

\subsubsection{En genealogisk aspekt på ekonomistyrning: Redovisning med ett tidsperspektiv.}

Redovisning i dess mer moderna betydelse, d v s skriftlig redovisning, bokföring eller bokhållning, uppstod redan på 1400-talet. En genealogisk kartläggning ${ }^{36}$ av ekonomisk styrning i svenska företag under första hälften av förra seklet handlar om standardisering av företagens internredovisning och den andra hälften om resultatredovisning där begrepp som täckningsbidrag utvecklades utifrån ett utpräglat marknadsbaserat synsätt. Någon genealogisk sammanställning av företagens tillgångar under 1900-talet kan inte dokumenteras.

Redovisningen eller bokhållningen under detta sekel och tidigare har främst haft betydelsen av att dokumentera inträffade händelser. Ett sätt att se genealogiskt på redovisning är att blicka tillbaka i tiden, d v s när människor, i olika syften, började kommunicera med varandra om inträffade händelser, men också förväntade händelser. Med detta sätt att se på redovisning (och kommunikation) genom att beskriva förväntade respektive inträffade, $\mathrm{d} v \mathrm{~s}$ tidsberoende händelser och aktiviteter, utläser man ett syfte med själva redovisningen vid olika perioder. Analysen visar hur dessa förväntningar, d v s mål och planerade strategier, förändras över tid. Implicit förklarar detta hur förändringar sker i ekonomistyrningen och i de beslutsprocesser

\footnotetext{
${ }^{36}$ Se referenser: Carlsson, L., (2001) Framväxten av intern redovisning i Sverige
} 
som i modernt ledarskap omfattar långa tidsperioder med varierande utvecklingscykler och perioder med inslag av "revolutionerande" omvärldsförändringar.

I grundläggande skolbildning (Ax m fl., 2009) och i praktisk tillämpning handlar ekonomistyrning fortfarande om budget, kalkylering och prissättning och redovisning på såväl strategisk nivå som på verksamhetsnivå, såväl vid förkalkyl som vid efterkalkyl och återkoppling. I någon utsträckning berörs "modern" ekonomistyrning här i form av balanserade styrkort och liknande system. Dessa system kan uppfattas som lösning på problem vid såväl planering som genomförande av styrning i kontexter där det finns behov av nya, framförallt mer långsiktigt orienterade strategier och där ekonomistyrningen har ett mer långtgående syfte relativt organisationens mål. Ett uttryck för denna typ av tidsrelaterade problem i ekonomistyrning som idag diskuteras är att denna generellt anses "börja för sent och sluta för tidigt” (Lindvall- Nilsson, 2008).

Modern ekonomistyrningsteori beskriver system för ekonomistyrning i översättning från engelskans "Management Control Systems" (MCS). I någon utsträckning har detta begrepp utvecklats ifrån ett mer redovisningsorienterat begrepp "Management Accounting and Control" (MAC) och före det "Management Accounting Systems" (MAS). Redovisningens historia och system för redovisning beskrivs oftast som teorins ursprung.

Miller och Napier beskriver ett motsvarande tidsberoende i sin genealogi i termer av redovisning, "ex ante calculation", av förväntad risk respektive vinstmöjlighet respektive redovisningen, "ex post calculation", som verifikation av resultatet d v s den aktuella vinsten/förlusten. (Miller and Napier, 1993).

Margret Peteraf (1993) avhandlar (inom ramen för resursbaserad teori) ekonomiska aspekter, och med hänvisning till nationalekonomins David Ricardo, behovet att analysera ett "före" respektive ett "efter" perspektiv i ekonomistyrningen för att förklara ett dynamiskt förlopp. Hon tillför en förändringskomponent i strategi-/styrningsprocessen. Samtida ekonomistyrningsteori uttrycker detta tidsberoende i termer av svårighet att utveckla en kongruens mellan organisationen i sig och de människor som den representerar och med en återkoppling av information, d v s med ett processuellt synsätt.

Robert Simons, en av ekonomistyrningens nytänkare under 1980-90-talet, skriver:

"MCS provide managers with information to signal the domain in which they should search for opportunities, to communicate plans and goals, (ex ante), to monitor and communicate the achievement of plans and goals, (ex post), and to keep themselves and others informed of emerging developments" (Simons, 1995)

Sedan mitten av åttiotalet pågår en utveckling av skolbildningen runt ekonomistyrning i företag som omfattar organisationens hela verksamhetsstyrning (Lindvall $\mathrm{m}$ fl.) på såväl operativ som strategisk nivå (Teece $\mathrm{m}$ fl.). Forskningen omkring organisationens olika system för ekonomistyrning (Systems for Management Control, MCS) har samtidigt utvecklats till att omfatta inte bara finansiella styrsystem och affärssystem, utan omfattar nu hela organisationens uppsättning av verktyg som beslutsprocesser och beslutsstöd, system och processer för organisering av hela verksamheten. En integration av ekonomistyrningssystem och processer för utformning och implementering av företags olika strategier är en naturlig följd av denna 
utveckling. Den moderna ekonomistyrningslitteraturen är därför i stor utsträckning influerad av hur företagskontexten beskrivs och på vilken nivå av organisationen som beskrivningen görs. I nuvarande ekonomistyrningslitteratur behandlas strategi och styrning primärt på affärsenhetsnivå (Business Unit level, BU).

\subsubsection{Strategisk ekonomistyrning; en utveckling från finansiell redovisning}

Strategiforskningen anses under åttiotalet ha påverkat och påverkats av nationalekonomernas språk och logik, medan utvecklingen av forskningen inom företagsekonomi kontinuerligt utvecklat nya verktyg och teorier som är centrala för företagsstrategiforskningen. Det förekommer dock ett starkt beroende på olika nivåer (Rumelt m fl., 1991).

"The infusion of economic thinking has been driven by five forces or events, all connected with the research program of strategic management". "Each of the forces or events has shaped the connection between economics and strategic management and each continues to pose practical and intellectual challenges that will shape future development”. (Rumelt m fl., 1991 s. 9)

Nationalekonomer som Piero Sraffa (1898 - 1983) med flera utvecklade under 1800-talet olika former av modeller för redovisning av kapitalflöden och andra resurser mellan länder, något som senare utvecklades och genererade Sveriges Riksbanks ekonomipris till Alfred Nobels minne 1972 till Kennet Arrow and John Hicks. Denna redovisningstradition brukar ibland betecknas som "capital accounting" och baseras på jämviktsmodeller som Paretomodellen.

De "forskningsproblem" som beskrivits och inledningsvis har identifierats med koppling till redovisningspraxis, avser företag. De nationalekonomiska teoribildningar som här nämns handlar om också om företag (mikroekonomi), men de ekonomiska utgångspunkterna och diskussionerna är framförallt baserade på nationalekonomisk teori om endogen tillväxt inom ett större system utifrån antaganden om teknologins betydelse för tillväxt (Arrow $\mathrm{m} \mathrm{fl}$ ). Frågor om vad som ska mätas och värderas och hur det ska det göras, hur centrala begrepp som kapital och resurser definieras $\mathrm{m}$ m bygger på dessa nationalekonomiska teorier.

Det är dock osäkert om denna redovisningstradition "capital accouning" har gett upphov till den redovisningstradition som utvecklats i en organisatorisk (läs företags) kontext. De begrepp som vi idag använder inom redovisningsområdet är begreppen "financial accounting" (externredovisning), "management accounting" (MA) (internredovisning) (Chenhall, 2003). Från detta senare begrepp (och "Management Accounting and Control") hämtar vi idag ekonomistyrningens begrepp "Management Control" (MC) och Management Control Systems (MCS). Det är en begreppsutveckling som utifrån en redovisningstradition har utvecklats till teori om ledningssystem för organisationer.

Redovisningsteori ("accounting theory"), redovisningens roll och betydelse för ekonomistyrningens framväxt som teoriområde är dock odiskutabel. Framförallt har redovisning av information för det internt orienterade arbetet i ett företag en lång tradition som underlag för beslut inom den moderna ekonomistyrningen i företag. Idag handlar den externa redovisningen om företaget i dess omvärld och där begreppet bolagsstyrning ("corporate governance”) aktualiserats under senare år. I ett mer långsiktigt perspektiv på ekonomistyrning 
är det därför motiverat att också belysa redovisningens roll och teorins betydelse i både internt och externt avseende. I synnerhet gäller det forskning omkring kommunikationsaspekten på ekonomistyrning och dess potentiella betydelse för beslutsfattande i samband med strategiimplementering. En analys av kommunikationsaspekten måste då belysa betydelsen av informationsteknologins utveckling, ett forskningsområde som implicerar information som bärande resursslag. Det görs dock inte i denna del av avhandlingen.

Begreppet "strategisk styrning" (Lindell, 1992), förekommer i litteraturen sedan några år tillbaka, primärt utifrån ett marknadsorienterat synsätt. Pia Lindell har i en longitudinell studie av Swedish Match (1960 - 1987) genomfört en begreppsutredning utifrån koncernens förändringsstrategier. Konsekvenserna från den av ledningen valda marknadsstrategin hade implikation på hela organisationen. Hennes forskning med implikation på ekonomistyrning innefattar inte bara organisationens operativa/taktiska styrning utan speciellt organisationens och ledningens mer långsiktigt och strategiskt inriktade ekonomiska styrning. Detta begrepp, strategisk styrning, tolkas som organisationens interna ledningssystem och processer för långsiktig ekonomistyrning och att 'strategisk ekonomistyrning' då implicerar 'ekonomiska' incitament. I analogi med beskrivningen av det långsiktigt syftande begreppet nedan kan strategisk, ekonomisk styrning handla om att ifrågasätta själva grunden för organisationens verksamhet (Lindell, 1992). Strategisk ekonomistyrning skulle då handla om företags mer långsiktiga, strategiska beslut; strategier som genom att ledningen bland annat omprövar den verkliga grunden för organisationens verksamhet, dess uppgift/åtagande och vad som ger dess legitimitet, överställt, d v s på koncernnivå handlar om förändring av koncernens totala och långsiktiga kapital eller resursbas.

"Strategisk styrning handlar om att inte bara korrigera ett utfall utan också att ifrågasätta och ompröva själva grunden för den intention som medfört agerandet", (Lindell, 1992 s. 3)

En annan tolkning utifrån ett "marknads-/kundperspektiv" har i senare litteratur samtidigt en koppling till de inre processer som ingår i en strategisk ekonomistyrning (Lindvall med flera, 2001. s 46)

\begin{abstract}
"När forskare använder begreppet strategisk ekonomistyrning är det vanligtvis den typen av utåtriktad ekonomistyrning som avses. I den här uppsatsen har vi valt att även inkludera de rutiner som avser strategisk planering (nedbrytning av vald strategi $i$ budgetar och program) samt uppföljning (rapporter och nyckeltal samt hur de används). Vi menar att en strategisk ekonomistyrning inte bara handlar om strategiformulering, utan också om hur dessa ofta ganska vaga och övergripande strategier omsätts $i$ konkreta planer. Vidare måste målen och planerna komma till uttryck i hur uppöljningen utformas och används".
\end{abstract}

(Lindvall- Nilsson (2008)

\title{
3.5.7 Organisationsteorins betydelse.
}

Ekonomistyrning som eget forskningsområde har utvecklats utifrån två teoriområden inom ekonomiområdet; redovisningsteori ("accounting theory") respektive organisationsteori. Ur 
dessa teorier har något som kan liknas vid ett nytt paradigm vuxit fram under slutet av 1900talet (Brown, 1978).

Organisationsteorin fick under seklet ett allt större inflytande på ekonomistyrningsteorin. Forskare, med huvudsaklig inriktning på organisationens organiseringsproblematik, studerade ekonomistyrning utifrån ett stort antal tänkbara vetenskapliga influenser och perspektiv; bland andra skolbildningar som agentteori (Eisenhart m fl., 2000), institutionell teori (OIE) (Burns \& Scapens m fl., 2000), systemteori och cybernetik (Berry m fl. 2005). Även senare forskning utifrån mer grundläggande utgångspunkter och perspektiv som evolutionsteori försöker förklara ekonomiska livscykler - och förändringsmönster i /och styrning av/ organisationer (Nelson \& Winter, Scott $\mathrm{m}$ fl.). Forskningen om ekonomistyrning diskuterar även kaosteori (Stacey, 1993, Kiel, 1994) för att förklara och förstå stora strukturella förändringar av organisationer.

En forskningsfåra inom contingencyforskningen har tagit fasta på organisationens struktur som en variabel som påverkar och påverkas av ekonomistyrningen. I den forskningen skiljer man bland annat på vad som kommer ut av strukturen (outcomes of structure) och själva mekanismerna i strukturen (the structural mechanism). Organisationen ses som ett resultat av hur strukturer utvecklas (Chenhall, 2003). Mekanismerna handlar om regler, procedurer, kommunikation och om själva beslutsprocesserna (Burns \& Stalker in Chenhall, 2003).

Viss organisationsteori beskriver organisatorisk kontroll och styrning som överställd den strategiska respektive finansiella styrningen (Ireland m fl., 2007). Förändringar i styrsystemen, eller snarare i kontrollaspekten av styrningen, beskrivs här i termer av kulturella skillnader i hur ledningen agerar - snarare än vilken strategi som ligger bakom. Olika typer av företags ekonomistyrning nämns också i ekonomistyrningslitteraturen; styrning med direkt agerande från ledningen, en mer stödjande form av styrning som inkluderar individers självutvärdering samt en tredje form, kulturell företagsstyrning som primärt emanerar ur olika former av kollektivt beteende (Merchant och Van der Stede, 2007). Andra typer diskuteras i olika författares typologier runt ekonomistyrning; om kontextuella faktorer för ekonomistyrning (Merchant, 1985, Simons 1995 m fl.; Malmi \& Brown, 2008) och om användbarhet, nytta och värde av ekonomistyrning (Chenhall \& Morris, 1986; Shields, 1995; Chenhall \& LangfieldSmith, 1998). En typ av ekonomistyrning och dess konsekvenser för FoU beskrivs av Davila (Davila, 2000).

\subsubsection{Forskning om företags ekonomistyrning med contingencyansats}

Den sammanställning över contingencyforskningen om MCS som gjorts av Robert H Chenhall (Chenhall, 2003) handlar specifikt om ekonomistyrning i olika delar av en företagskontext och utifrån att olika strategitypologier som påverkar denna företagskontext, i dessa olika delar. Contingencyansatsen innebär enligt Chenhall vissa begränsningar vid en utvidgad studie d v s en studie $\mathrm{i}$ en vidare företagskontext (extern miljö etc.) och utifrån ett mer nutida/modernt (contemporary) förhållande (Chenhall, 2003). Contingencyforskningen har vuxit fram som ett sätt att analysera, eller en ansats till analys av organisatoriska frågeställningar. 
Contingencyansatsen tillämpas vid forskning på en organisatorisk kontext utifrån en rad olika teorier. ${ }^{37}$.

Contingencyforskningen har närmat sig ekonomistyrningen (MCS). Vid tillämpning av contingencyansats antar man att ledare agerar i syfte att anpassa sin organisation till kontextuella förändringar i syfte att få en bättre "fit" och implicit antar man att detta förklarar en bättre "performance" för företaget. Detta skulle då kunna antas gälla som ett överställt syfte med en contingencyansats vid analys av strategisk ekonomistyrning.

Robert Chenhall diskuterar i sin översyn av contingencyforskning omkring MCS vilken typ av ekonomistyrning som har bidragit till olika "outcomes" efter implementering av olika strategier och därmed innefattande styrningens effekter (Chenhall, 2003). Han lägger tonvikt på ekonomistyrningens form. Han skiljer på systemens användbarhet, vilket beteende som är resultatet respektive vilka effekter det får på organiseringen $\mathrm{d} v \mathrm{~s}$ vilken typ av styrning som uppstår som resultat av ett visst strategival. Syftet med denna fokusering är att förklara att en viss typ av styrning får en bättre "fit" relativt organisationens mål. Han poängterar svårigheterna vid contingencystudier att analysera resultat utifrån olika styrning (och strategival) och vilka konsekvenser styrningen har för organisationens måluppfyllelse.

"..there are broad leaps in logic from useful MCS ...to enhanced organizational performance".. "..there is no compelling evidence to suggest that such links exist" (Chenhall, 2003 p. 132)

Han avslutar sin sammanfattning med en rekommendation att i den fortsatta forskningen om MCS använda både contingencyansats och "case-studies" (och även anomalier). Han ser en utmaning i att skapa ett integrerat teoretiskt ramverk som kombinerar struktur och processer; allt för att stimulera till fortsatt forskning.

Chenhall redovisar också hur ekonomistyrningen har utvecklats utifrån a) syftet med styrningen b) de olika elementen av MCS samt c) meningen med och mätningen av specifika kontextuella variabler. Han har också studerat hur dessa olika teorier har utvecklats. Han pekar på att MCS ("management control") har, jämfört med "accounting", en annan och betydligt mer utvecklad roll i företaget.

"MCS is a broader term that encompasses MAS and also includes other controls such as personal and clan controls" (Chenhall, 2003 s. 134)

Chenhalls översyn visar också att ekonomistyrningen kan betraktas som mer eller mindre organisk/t eller mer eller mindre mekanistisk/t:

- exempel på en organisk form av MCS är "clan control" (Ouchi m fl), "personell control" (Merchant m fl), "prospect control" (Macintosh), "product development control" (Davila), alternativt "strategic, interactive control" (Simons $\mathrm{m} \mathrm{fl}$ ). Den organiska formen

\footnotetext{
${ }^{37}$ En kritik mot contingencybaserad forskning är att den bygger på traditionell (funktionalistisk) teoribildning och inte tillämpats på mer uttolkande eller kritiska perspektiv
} 
karaktäriseras därför här som en processuell form $\mathrm{d} v \mathrm{~s}$ en form för att analysera hur organisationens förädling sker och vilka som bidrar till denna förädling.

- exempel på en mer mekanistisk MCS är "high budget use" (Merchant m fl.), "output and result control" (MacIntosh, Merchant $\mathrm{m}$ fl.), "action control" (Merchant) och "diagnostic control" (Simons). Den mekanistiska formen karaktäriseras här som en instrumentell form av styrning $\mathrm{d} v \mathrm{~s}$ en form för att analysera $\mathrm{vad}$ som förädlas i företaget.

Simons (2000) perspektiv på MCS beskrivs, utifrån syftet och mål-/tidsdimensionerna, alltså av Chenhall som:

- "Strategic Interactive Control" - organiskt ursprung och som "the use of performance evaluation for strategic planning"

respektive

- "Diagnostic control" - mekanistiskt ursprung och som "the use of control to provide feedback on operations".

Såväl Merchant som Simons diskuterar användningen av MCS i contingencytermer vid beskrivningar av de olika typer av ekonomistyrning som avhandlas i deras respektive teoribildning. Chenhall beskriver tre aspekter på vad /en effektiv/ MCS ger och hur effekterna av MCS ska belysas. Han förespråkar en analys av användningen och användbarheten av MCS, vilka beteenden som MCS genererar samt hur organiseringen sker utifrån MCS $\mathrm{m}$ a $\mathrm{p}$ styrningens olika syften.

Chenhall efterlyser en "robust" modell för MCS. Med "robust" avser han bland annat att modellen ska kunna tillämpas som "best practice" eller "State of the Art". Han redogör för de områden där utveckling måste ske för att åstadkomma detta: 1) vad det är som konstituerar ett företags "performance", 2) hur måldimensionen ska beskrivas i termer av "värdeutveckling", 3) hur mer mjuka värden som intangibles ska redovisas som intellektuellt kapital och värderas, 4) hur standardmått ska anges för att vara tillräckligt meningsfulla bland annat för att motivera ständig förändring, 5) hur MCS ska hantera ett utvidgat perspektiv på företags uppgift samt 6) hur strukturen i MCS ska se ut för att få en god transparens i organisationen; bland annat för "feed-back" och för att inlärning/ innovation ska åstadkommas (Chenhall, 2003).

Chenhall pekar på hur forskningen om utformning av MCS speglas utifrån olika aspekter på hur systemet passar in, allt utifrån aspekter i den omgivande "naturen" som teknologiska aspekter, storleken och strukturen i den nationella kulturen - till framförallt strategiaspekter (ibid.)

Chenhall redovisar fyra strategiska typologier, representerade av Miller \& Friesen, Miles \& Snow, Govindarajan \& Gupta och Porter. Chenhall noterar också speciellt kopplingen mellan strategier och typer av system för ekonomistyrning så som de beskrivs av Simons i termer av "beliefs \& boundary systems, diagnostic and interactive control systems" (Simons 1994 in Chenhall 2003). Chenhall diskuterar också den fortsatta forskningen i termer av såväl selektiv ("selection"), interaktiv ("interaction") och systemisk ("systemic") ansats där systemansatsen kan användas om antalet variabler är stort och man vill studera hur dessa (i kombination) påverkar ett företags verksamhet. 
Chenhall redovisar också ett antal olika skolbildningar som också speglar forskningens inriktning inom ekonomistyrningsområdet utifrån olika teoriområden, från ett "transaktionskostnadssynsätt" (Williamsson $\mathrm{m}$ fl.) att, med referens till "ny" institutionell teori (NIE), med nationalekonomiska ambitioner på makronivå beskriva marknader och konkurrens, till ett bredare, "äldre" institutionellt perspektiv (OIE) (Burns m fl.) på organisationens verksamhetsstyrning. Äldre institutionell teori (OIE) omfattar idag i allt större utsträckning, enligt Chenhall, också företags övergripande och långsiktiga strategiarbete, ett arbete där den externa redovisningen är allt viktigare som utgångspunkt för hur den långsiktiga (interna) styrningen ska utformas med avseende på organisationens långsiktiga målsättning.

Två typer, två olika syften och fokus vid användande av extern redovisningsinformation utifrån organisationens måldimension har beskrivits (Simons, Henri, Ulrich, Chenhall m fl.) som; (a) den diagnostiska ("diagnostic control") användningen samt (b) den interaktiva ("strategic, interactive control") användningen. Fokus i den diagnostiska användningen ligger framförallt på hur ledningen analyserar en på något sätt mätbar extern information och jämför /förväntat/ utfall (ex ante/ex post) med organisationens mätbara mål inför den strategiska planeringen. Fokus för den senare, interaktiva tillämpningen avgörs av hur högsta ledningen (ägare, styrelse) kommunicerar informationen och själva är involverade i styrningen av företaget i hög grad. Här är det ledningskulturen; d v s sättet att styra, men också den tidshorisont som ledningen arbetar med i strategiprocessen, som är avgörande för det perspektiv och strategisynsätt som ledningen har.

\subsection{Strategi och styrning: Två integrerade processer.}

Historiskt tillämpas ett antal olika lösningar för att tillfredsställa olika behov av styrning. Den moderna ekonomistyrningslitteraturen beskriver (Merchant, Simons, MacIntosh $\mathrm{m}$ fl.) en flora av metoder och modeller för styrning. Ett sätt att kategorisera dessa metoder är efter vilket specifikt behov som de fyller; d v s vilken nytta de har för användare; respektive vilken grad av komplexitet (alternativt graden av "enkelhet") som de representerar, $\mathrm{d} v \mathrm{~s}$ att respektive personer på viss nivå i organisationen upplever dess relevans i termer av att de förstår och därmed kan tillämpa modellen i strategiarbetet. Utifrån hur man bedömer modellens "nytta" respektive "komplexitet" ur ett långsiktigt perspektiv kan man dra slutsatsen i vilken utsträckning styrningsmodellen kommer att passa $i$ en viss kontext och därmed bidra till en lyckad strategiimplementering. En aspekt av detta när man bedömer implikationer på styrningen är, tidsaspekten eller tidsperspektivet; att vid en viss "tidpunkt", historiskt eller med tanke på var företaget är eller bedöms komma att vara i sin livscykel $i$ förhållande till omgivande konjunkturcykler, är ett visst slags styrning relevant.

Graden av förväntad nytta för användaren (vid beslut vid en viss tidpunkt) är en avgörande kommunikationsaspekt och i och med det kommer en eventuell utveckling av styrningen bara att ske gradvis; implikationerna av ett "nytt" perspektiv kommer att slå igenom gradvis. Detta "problem" måste uppmärksammas i samband med implementering men speciellt när ledningen utformar styrningen; för VEM ska denna nya styrning vara viktig? Och VARFÖR just denna slags styrning vid detta tillfälle? Också här är de två aspekterna giltiga; mätrelevans och kommunikation!

I den nya ekonomistyrningen (Ax m fl, 2009) skriver författarna: 
"Det övergripande syftet med ekonomistyrning är att hjälpa till $i$ arbetet med att uppnå organisationens strategiska målsättningar" (Ax, Johansson och Kulvén, 2007 s. 18).

Hur ett företag implementerar och genomför sitt strategival är påverkat av beslut inom ekonomistyrningen. Omvänt påverkas ekonomistyrningen av beslut vid organisationens inledande strategiarbete (Henri, 2006). Valet av strategiperspektiv påverkar ledningens frågeställningar.

En beskrivning av denna koppling mellan företagsbeslut vid strategiutformning respektive implementering och dess ekonomistyrning kan exemplifieras med ett antal frågor i samband med ekonomistyrning om vi betraktar denna som en integrerad beslutsprocess Vissa frågor relateras då till beslutsprocessens "input", andra till "frågor och svar" i själva processen och några till processens "output". Vi kan då se att beslutsprocessen påverkas av både styrningsfrågor och strategifrågor. En integrerad strategi/styrningsmodell där frågeställningar systematiseras i en processanalys d v s strategi- respektive styrningsfrågor ordnas logiskt utifrån kontext, tillämpning och kommunikationsaspekt möjliggörs potentiellt med en $\mathrm{s} k$ processanalys.

En processanalys ${ }^{38}$ visar att strategiprocessen primärt fokuserar frågorna VAD och HUR (Pettigrew 1997, Hinnings 1997, Simons, 2000, Drucker 2007) och implicit VILKA och VEM. Det är rimligt att (hypotetiskt) anta att kompletterande frågeställningar som VARFÖR, FÖR VEM, MED VEM och VILKET RESULTAT också kan förväntas diskuteras inom ramen för organisationens beslutsprocess på affärsenhetsnivå.

Ekonomistyrningsprocessen, eller systemet för ekonomistyrning, har då en strukturell karaktär med "formella, informationsbaserade rutiner och procedurer" (Simons, 2000) som omfattar ett ifrågasättande av motiv, målgrupp, organisation och förväntat men också upplevt resultat. Denna 'struktur' kan tillämpas vid organisationens strategiarbete och inför förändring av strategierna. Dessa frågor kan härledas till och generaliseras i en strategisk beslutsprocess som omfattar såväl strategi- som ekonomistyrningsbeslut. En beslutsmodell som beskrivs i litteraturen är den s k Deming-modellen eller PDCA-modellen. (Figur 7)

\footnotetext{
${ }^{38}$ En modell för processanalys som bygger på ett antal standardiserade frågor har utvecklats av Pettigrew 1997 och Hinnings 1997 (Se referenslista). En fråga som dock inte avhandlas i denna processanalys är frågan "För Vem?". Se Boström, P. S., A Critical Assessment in Process Analysis (working paper) 2005/2013/2021
} 


\section{Kapitel 4 Tentativ modell för integrerad resursstrategi och ekonomisk styrning}

I denna avhandling handlar dess ontologi om en verklighet som kan beskrivas i systemtermer. Inledningsvis nämns med referens till systemteori (Boulding, 1953) samt resiliensteori (Holling, 1986) att dessa modeller implicerar organisationens resursbas på olika systemnivåer, i Hollings modell också utifrån ett 'externt' respektive 'internt' systemsynsätt. Dessa två skolbildningar kan potentiell förklara de processer som i en företagsekonomisk kontext bidrar till det interna mål som `betamålet’ här representerar d v s hållbar resurstillväxt betraktad utifrån ett ledningsperspektiv i en verklig organisation. En tillämpning av ett systemsynsätt vid analys av företagets processer utifrån en systemmodell implicerar 'inputvariabler' och 'outputvariabler'. I sin bok "The fifth discipline" redogör Peter Senge (2006) för exempel på implikationer på ett företags strategiska ledningssystem vid tillämpning av ett systemsynsätt.

\subsection{Resurser i resursbaserad teoribildning}

I avhandlingen handlar 'episteme' primärt om kunskap om resurser. Inledningsvis har i avhandlingen nämnts begreppet resurs utifrån bland annat språkligt ursprung. Begreppet, utifrån dess språkliga innebörd kan relateras till vardaglig användning, men också till teoretisk eller praktisk definition inom en mängd olika kontexter; bland annat i företagskontext. Inom organisationsteorin har begreppet RESURS tillämpats i en företagskontext sedan mitten av 1900-talet. I nutida ekonomiska sammanhang betyder begreppet 'tillgångar' av olika slag och form, dessa satta i ett sammanhang om vad som skapar/genererar värde i ett företag. Begreppet RESURS gjordes explicit i en företagskontext av Edith Penrose i mitten av 1900-talet och det är relevant att härleda den moderna betydelsen till hennes tolkning.

Trots att ingen egentlig och enhetlig definition av begreppet kan härledas inom strategi-området förekommer olika typologier där begreppet resurs beskrivs. Penrose menar exempelvis att det inte är resursen i sig som är input i en förädlingsprocess, utan att det är den service (productive service) som resursen kan generera, som är input i en process.

Begreppet resurs i resursbaserad teori kopplas till begreppet förmåga (capability) (Teece, 1994). Företaget har reserver av resurser som potentiellt kan utvecklas genom att förmågan att utveckla dem finns. Penrose diskuterar inte explicit förmåga. Medan Penrose beskriver vad begreppet resurs inte är så finner vi ett antal exempel, här även från Penrose, på mer eller mindre omfattande respektive konsistenta tolkningar av vad begreppet resurs, och implicit organisationens förmåga, betyder. Begreppet förmåga inom denna teoribildning beskrivs närmare av bland annat J F Henri ${ }^{39}$ (Henri, 2006).

Några exempel på vad som avses med resurs i en företagskontext:

"By resource is meant anything which could be thought of as a strength or weakness of a given firm...", "...examples are brand-name, in-house knowledge of

\footnotetext{
${ }^{39}$ J-F Henri (Henri, 2006) beskriver fyra specifika (resursbaserade) förmågor som kan förväntas leda till fyra olika strategier och till företags utveckling; innovationsförmåga, organisationens förmåga att lära, organisationens förmåga att orientera sig mot marknaden och entreprenörsförmåga.
} 
technology, employment of skilled personnel, trade contacts, machinery, efficient procedures, capital etc." (Wernerfelt, 1984 s. 175)

"The term resource, however, is rather crude and so it useful to distinguish more fully appropriable assets, such as physical capital or brand names, from less tangible resources such as competence/capabilities" (Lockett , 2005, s. 85)

"The most obvious resources are physical assets such as plant and equipment, factories, $R \& D$ laboratories, office buildings, natural resources, raw material, work in progress and so on ...Financial capital is another obvious form of resource. Less tangible but by no means less important are resources such as brand names, reputation, customer or consumer trust and dealer loyalty, as well as intellectual property rights such as copyrights and patents. " (Foss, 1997)

"However, to make the best use of available resources, organization require capabilities... be the command of a particular material technology, high level marketing skills, effective product development processes...But capabilities are more than this. They are themselves unique resources (!) available to managers, to be deployed in different ways". (Penrose, 1959)

Även om en precis definition av resursbegreppet inte utan vidare låter sig göras i en företagskontext så är några kriterier, såväl från den vardagliga tolkningen som från olika tolkningar inom ramen för strategiforskningen, viktiga att ställa upp inför en vidare tolkning och definition av begreppet.

Några kriterier inför en sådan tolkning kan vara;

- att begreppet kan definieras mer precist i en företagskontext,

- att begreppet resurs ingår i ordklassen substantiv. Det innebär bl a att begreppet kan identifieras i ett ontologiskt sammanhang och för att sedan kunna klassificeras,

• att en resurs är en tillgång som kan användas/återanvändas för att tillfredsställa /mänskliga/ behov,

- att en resurs består av någon komponent exempelvis datainformation,

- att en resurs har en viss inneboende kapacitet (en potentiell verkningsgrad),

- att en resurs kan omfatta någon form av förmåga (capability) eller motsvarande,

- att en resurs kan förändras /genom någon form av medveten ledning / d v s få en ny form,

- att en resurs är mer eller mindre "tangible" d v s en mer eller mindre synlig form och 
- att en resurs består av både ett kvantitativt begrepp (en mängd) och ett kvalitativt begrepp (en form).

En intressant koppling till resursbaserad teoribildning där begreppet förekommer miljöekonomisk kontext kan uppmärksammas m a p resursbegreppet $\mathrm{i}$ betydelsen återhämtning (resilience) (jfr "resourde" = att resa sig). En fri tolkning av resursbegreppet innebär då ett kriterium som betyder en förmåga hos resursen att återhämta sig eller mer allmänt en förmåga hos organisationens resurser att skapas, förändras eller återskapas.

Analogt med denna uppställning kan kriterier för ordet förmåga (capability) ställas upp i syfte att särskilja dessa två begrepp. Med förmåga avses i denna avhandling också ett begrepp som kan relateras till begreppet kapacitet (capacity). I ett systemiskt perspektiv är kapacitet inte bara en kvantitativ term utan också en förmåga/kapacitet, en inneboende kvalitativ egenskap i systemet att förändra förhållanden, inneboende relationer och kombinationer av aktiviteter, så att såväl systemet som dess förmåga (såväl som dess olika resurser) får förändrade egenskaper/funktioner. Förmågan påverkas genom systemets möjlighet/kapacitet att assimilera (alternativt utestänga) information eller inverkan från andra system (Teece, 2008).

\subsection{1 Övriga systemiskt påverkande faktorer i resursbaserad teoribildning.}

I såväl TGF och RBV som övrig resursbaserad teori, kännetecknas de mer systemiskt påverkande faktorerna främst av organisationens synliga (materiella/fysiska) tillgångar. Dessutom ses organisationens policies, dess strategier, dess tillgång till (egna eller partners) övriga, osynliga (immateriella eller inbäddade) resurser och dess organisation och ledningsförmåga, också som systemiska faktorer. Samtidigt betraktas också den (de) förmåga(or) som företaget har att utveckla sina resurser och strategier, som systemiska faktorer Ett exempel på en sådan faktor är den specifikt strategiska ledningsförmågan att ta beslut (rätt beslut och i rätt tid).

Förmågan kan ses som en 'egenskap' eller som en 'funktion' hos resursen i sig. Wernerfelts beskrivning av resurser omfattar exempelvis "brands", tekniskt "know-how", kapital och maskiner, men också olika procedurer i företaget d v s 'resurser' med inneboende egenskaper och kapaciteter som kan tillämpas i olika sammanhang.

Teoribildningen om organisationens dynamiska förmåga (Eisenhart, Teece $\mathrm{m} \mathrm{fl}$.) beskriver organisationens möjliggörare som primärt organisationens olika rutiner, strukturer och system som möjliggör utveckling av organisationens resurser. En intressant förmåga som nämnts ovan, men som i denna forskning hittills inte särskilt poängterats, är systemets elastiska förmåga (resilience) d v s förmågan att återhämta sig (recover) $i$ kvalitativa termer. Inte heller poängteras förmågan att reproducera sig (reproduce) $i$ kvantitativa termer.

\subsection{Organisation och organisering i resursbaserad teori}

I senare strategilitteratur om RBV nämns hur ett ledarskap med en ledning som tillämpar ett resursbaserat synsätt, i vissa situationer, kan medföra en mer disciplinerad organisering och till att striktare former för ansvarstagande och redovisning (DeWitt\& Meyer, 2010) införs. Implicit 
diskuterar författarna här också ansvar med hänvisning till ledarskapets betydelse och hur styrningen påverkar mänskliga faktorer. Organisationens ansvar d v s "responsibility" diskuteras i termer av socialt ansvar och identifieras som en paradox relaterat till organisationens vinstintresse (ibid).

Ingenstans inom resursbaserad teoribildning nämns speciellt hur organisationens organisering bör göras med hänsyn till hur ansvarsfördelningen bör se ut. En organisation betraktas i ett resursbaserat perspektiv snarast som en indirekt konsekvens av organisationens sociala kontext (Penrose, 1952). Kategoriseringen av organisationens resurser är exempel på hur resurserna är organiserade internt och hur organiseringen sker i organisationens processer.

\subsection{Beslutsprocesser och värdeskapande processer vid resursbaserat strategiarbete.}

I litteraturen om RBV och resursbaserad teori, liksom i annan strategilitteratur, beskrivs ledningens strategiarbete som en enda lång och medveten beslutsprocess och som en process som omfattar såväl kontexten som själva faserna i processen (Chenhall, 2003). Medan kontexten beskriver mål för verksamheten och vad företaget och ledningen fokuserar, d v s vad man vill att processerna ska ge för resultat, så beskriver faserna hur det ska ske, vem som ska göra arbetet och när det ska göras (DeWitt \& Meyer, 2010).

Forskningen och dialogen omkring det resursbaserade synsättet har sedan sekelskiftet (2000) argumenterat för och förespråkat en fokusering på kreativa och entreprenöriella processer (Eisenhart $\mathrm{m} \mathrm{fl}$.), men framförallt processer som kräver rationella, förnuftsmässiga argument och beslut och, inte sällan, ren "visdom". Beslutsprocesserna i denna avhandlings kontext handlar om medvetna beslut.

Ett sätt att beskriva strategiprocessen med en förenklad modell visar strategiarbetets plats i ett företags hela beslutsstruktur. (Figur 5) Övergripande strategier och beslut som genereras inom denna, bryts ner i delstrategier i en organisation på dess olika nivåer. Beslutskriterier blir mer operationella ju närmare verksamhetens operativa kärna som besluten tas.

I strategilitteraturen beskrivs också själva strategiarbetet som processer (Mintzberg, 1958). En fördjupning av studier av ledningens, $\mathrm{d} v \mathrm{~s}$ individers beslutsprocesser, leder lätt in forskningen på ett kognitivt arbetsfält. Detta, liksom också hur dessa processer kan göras explicita i ett resursbaserat perspektiv, ligger dock utanför ramen för detta avhandlingsarbete.

En organisations beslutsprocess kan, utan fördjupning inom den kognitiva forskningen, ändå beskrivas i termer av ett antal frågor som (i princip) måste tydliggöras och kan besvaras genom en processanalys (Pettigrew, 1997; Hinings, 1997). Frågorna VAD? , VILKA?/VEM? och HUR? kanaliseras ofta till strategidiskursen (Simons, 2000, Drucker, 2003, DeWitt \& Meyer, 2010). Ett förtydligande av dessa frågor medför en formulering av de resurser och förmågor som måste aktualiseras i en viss beslutsordning. Dessa frågor kan i någon mån också relateras till respektive nivå enligt ovan. I flertalet modeller (Grant, $1991 \mathrm{~m} \mathrm{fl}$.) illustreras också en återkoppling i den vertikala ordningen. 


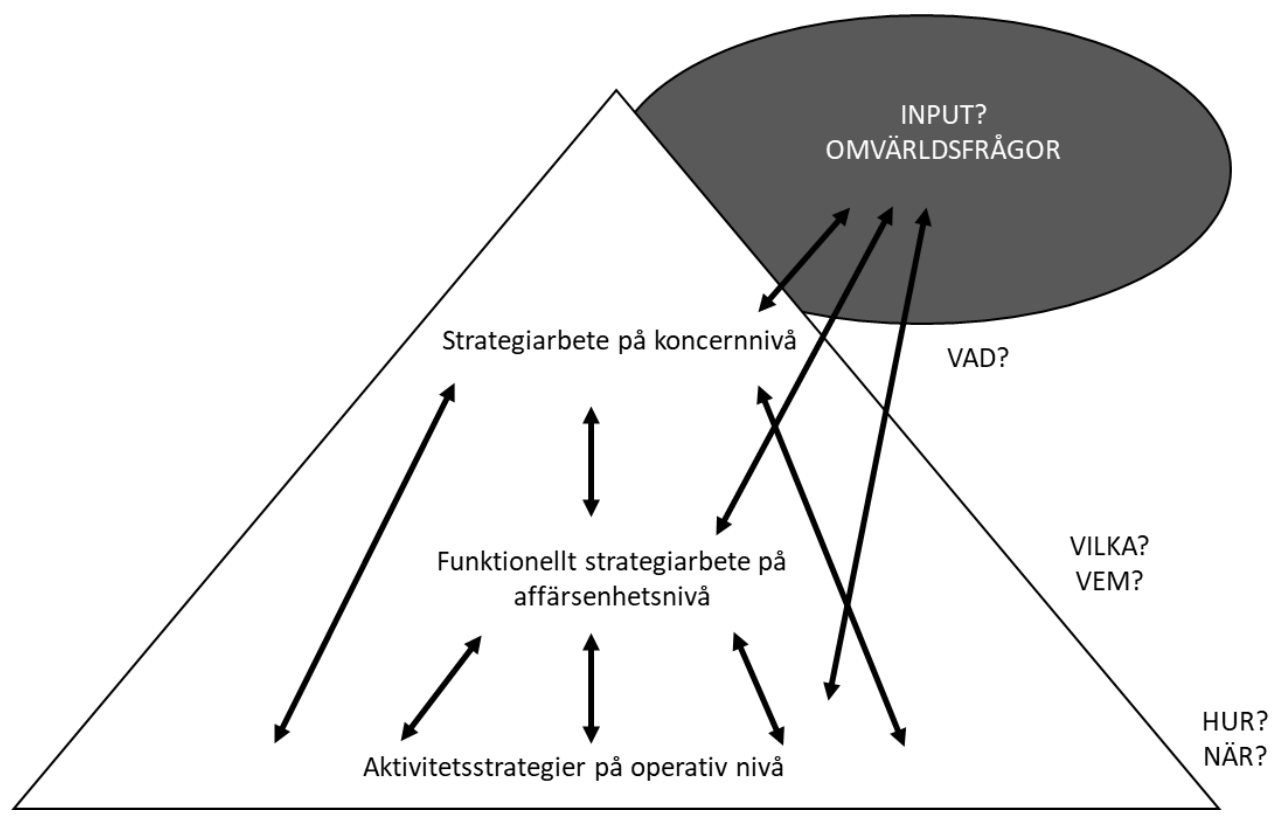

Figur 5. Förenklad illustration av strategins olika nivåer i organisationens hela beslutsstruktur (förf. egen figur)

Enligt Chandler (Chandler, 1962), kan strategifrågorna närmast karaktäriseras av svaren på VAD? (basic long-term goal) och HUR? (courses of action) och VILKA?/VEM? (allocation of /organizational/ resources necessary).

På samma sätt gäller detta "ex post”. Frågorna är principiellt desamma i de beslut som tas efter införandet som före, d v s vid uppföljningen och vid utvärderingen av ett strategiskt projekt.

\subsection{Mätning och värdeskapande. Begreppen effektivitet och resultat}

Inom ramen för resursbaserad teori, med referens primärt till RBV, diskuteras begreppet "efficiency" i termer av både produktivitet (efficiency) och effektivitet (effectiveness). I en sammanställning av RBV litteratur (Priem \& Butler, 2001) om villkor och kriterier för resursbaserad teori (Barney $\mathrm{m}$ fl.), betraktas resurser som bidragande till organisationens värdeskapande (implicit till målet konkurrensfördel) genom effektivitet om de är värdefulla ("valuable") sett ur konkurrenssynpunkt. Med effektivitet avses dock enligt RBV både "efficiency" och "effectiveness".

En annan beskrivning av begreppet "efficiency" som används inom RBV är "the ratio of outputs to inputs". Denna definition leder dock till en teoretisk lagbundenhet och av detta följer då att ett företag som förbättrar sin effektivitet kan bevisa en större "output" än "input" (Priem \& Butler, 2001). Av detta följer också att /positiv/ effektivitet (i termer av antingen produktivitet eller effektivitet) innebär ett större värde på "output" än "input". Barney har dock ett 
kompletterande villkor för när en resurs är värdefull. Det är när den utvecklar möjligheter /eller neutraliserar hot/ i ett företags omgivning (Barney, 1991).

Resursens värde betraktas alltså enligt RBV som centralt vid mätning av "input" respektive "output". Kvoten är därmed central för att beskriva ett resultat från en verksamhet. Resursens effektivitet är enligt RBV ett nödvändigt men inte tillräckligt villkor för organisationens konkurrensförmåga.

RBV säger dock ingenting om nyttan av detta värdeförhållande d v s om effekten av organisationens resultat i förhållande till den resursbas som företaget förfogar över. Detta säger följaktligen ingenting om $i$ vilken utsträckning effektivitet är ett nödvändigt (men inte tillräckligt) villkor för att en viss avkastning kan förväntas leda till konkurrensfördel. En "unik" konkurrensfördel som är primär fokus för RBV, t ex "above normal returns" (Peteraf, 1993) eller "/systematically/ above average returns" (Shoemaker, 1990) och som bedöms leda till uthållig konkurrensfördel (Peteraf $\mathrm{m}$ fl.) måste således beskrivas i en ytterligare måldimension där övriga kriterier bedöms för måluppfyllelse. Denna dimension kan teoretiskt vara avkastning på resurser (return on resources) (Johnsson, 2007)

Enligt Barney kan det vidare vara så att ett antal olika kombinationer av resurser /med inbördes olika värden/ kan leda till olika avkastningsnivåer eller till en speciell nivå på avkastning, totalt sett (Barney, 1991).

RBV och efterföljande skolbildning utifrån resursperspektivet tar sin utgångspunkt framförallt i frågan HUR? d v s det som i strategidiskursen är primärt fokus på en mer operativ nivå eller aktivitetsnivå. En frågeställning för Penrose är att organisationens strategi för tillväxt utgår ifrån organisationens förmåga att utveckla "services" d v s en form av diversifiering (expansion) av verksamheten (utifrån "unika", heterogena resurser). Motsvarande strategi för konsolidering på aktivitetsnivå berörs dock inte! En viktig aspekt av effektivitet i Penrose strategidiskussion är därför i vilken utsträckning som denna diversifiering matchar utvecklingen av organisationens resursbas på en strategisk nivå, m a o att en sorts hypotetisk "contingency"-aspekt läggs på effektivitet. Ju bättre möjlig matchning desto bättre effektivitet.

En invändning mot RBV /och här uttolkade resursteorier/ är att värderingen av resurserna, ska ske i en omgivande kontext d v s i organisationens "opportunities and threats"; exempelvis utifrån hot eller möjligheter på en "produktmarknad" (Priem \& Butler, 2001). Det innebär att värderingen implicit sker 'utifrån och in’ d v s utifrån ett marknadsperspektiv. Om Margret Peterafs' ex ante villkor gäller, d v s att ingen information finns om den potentiella marknaden, så kan följaktligen en värdering utifrån hot eller möjligheter inte heller göras. Inget annat kriterium för värdering ex ante förekommer utom möjligen en värdering av organisationens styrkor/svagheter. Men denna värdering måste ställas i relation till det eller de som legitimerar organisationens verksamhet. ${ }^{40}$

En omvandling av resurser kan, om dessa ex ante villkor gäller som förutsättning för teorin, endast legitimeras av den egna organisationen; d v s systemet legitimerar sig själv ("critical self assessment”) (Garnsey, 1993)

\footnotetext{
${ }^{40}$ David Whetten diskuterar kriterier vid empirisk analys. Han diskuterar "the black box" d v s om osynliga kriterier ger företaget legitimitet (Whetten, 1989).
} 
En slutsats från resursdiskussionen ovan är alltså att effektivitet mäts utifrån den enskilda resursens värde; som "input" respektive "output" i en beslutsprocess. Värdet kan vara såväl förväntat värdet/ex ante /utifrån det/den som 'internt' legitimerar resursens omvandling/ eller ett upplevt värde/ex post på en 'extern’ marknad. Att utgå från konstaterade men potentiella hot och möjligheter på en marknad räcker dock inte för att bestämma resursens effektivitet ("ratio input/output")

David Whetten poängterar att övriga frågor som Var? Vem? och När? negligeras i denna strategidiskussion inför empirisk analys av organisationens "performance" (Whetten, 1989).

Effektivitet beräknas utifrån RBV (tillämpning av input/output) och liknande skolbildning men också utifrån ovanstående diskussion och med ett bredare perspektiv på organisationens uppgift och dess förädling. Ett bredare perspektiv kan då innefatta kompletterande frågor utifrån ledarskapets antaganden om Varför? och frågor som relaterar till vad eller vem som legitimerar en viss strategi $d \mathrm{v}$ s för vem planeras eller genomförs strategin?

Några kriterier som diskuteras i empirisammanhang enligt Cameron \& Whetten, 1981; Wernerfelt, $1984 \mathrm{~m}$ fl. är:

- De kvantitets resp. kvalitetsvariabler utifrån definitionen av "värde" och värdefull.

(d v s vilka specifika kvantitet/kvalitetsmått) ska gälla relativt organisationens mål (Vad?),

- vilken specifik nivå av organisationen som effektiviteten /och legitimitet/ ska mätas på (Var?) (Cameron \& Whetten, 1981),

- ett specifikt tids- eller förändringsperspektiv som ska gälla; antingen livscykel- eller konjunkturperspektiv? (När?) (Cameron \& Whetten, 1981),

- en särskild hänsyn till vilka kombinationer (portfölj) av resurser som kan bidra till ett visst värde (Vilka?) (Wernerfelt, 1984),

- en särskild hänsyn till vilken "funktion" (och nytta) som resursen har i en viss kombination (Varför?) och

- en specifik bedömning av vilket värde som nyttan antas/upplevs representera (för Vem?).

En möjlig slutsats efter ovanstående diskussionen, kriterier för effektivitet är att en "effektiv" produktion /med heterogena resurser enligt $\mathrm{RBV} /$ inte är att ha bättre resurser utan att ha "bättre" kunskap om dessa resursers relativa produktiva utfall (relative productive performance) (Priem \& Butler, 2001 samt Peteraf, 1991).

Inför kommande analys görs följande bedömning: Om kvantitet och kvalitet kan bestämmas utifrån en definition av begreppet resurs som "the basic unit", ex ante/ex post, så kan ett mått på effektivitet bestämmas för respektive resursslag. En kombination av resursslag (= portfölj) på en viss specifik organisatorisk nivå kan hypotetiskt utgöra underlag för beräkning av effektivitet på kombinationen. Detta bildar underlag för en frågeställning om VAD som ska mätas. 
En analys av konceptets begrepp "resultat" som sista beroendevariabel görs $\mathrm{m}$ a $\mathrm{p}$ vad begreppet betyder i denna kontext, d v s för vem dessa organisationens mål gäller och är viktiga och hur de uppnås. Måldimensionen i studien implicerar då i denna kontext att viss resurseffektivitet (per definition) är en förutsättning för att avkastning ska nås och att avkastning är implicit förutsättning för organisationens konkurrensförmåga och hur denna definieras och ska utläsas i resursbaserad teori. Per definition kan avkastning generellt uttryckas både positivt och negativt; en förutsättning för organisationens överlevnad är positiv avkastning över tid.

\subsection{En tentativ beslutsmodell}

En teoretisk analys av styrningsprocessen medför också ett behov att exemplifiera nyttan av en mer 'dynamisk' modell för en integrerad strategisk, ekonomisk styrning utifrån koncernstrategiskt perspektiv.

En modell som redovisas är den s.k. "Hierarchy of Business Strategy" (Simons, 2000). (Figur 6) Robert Simons integrerade modell för strategi/ekonomistyrning implicerar ett tidsperspektiv, ett historiskt perspektiv och ett framtidsinriktat perspektiv. Ekonomistyrningsprocessen, $\mathrm{d} v \mathrm{~s}$ själva styrningen, skulle då kunna beskrivas, i ett ex ante perspektiv inför och i strategiutveckling, respektive inför implementering och genomförande av beslut och aktiviteter, och handlar då primärt om planering respektive genomförande varvat med olika typer av styrning d v s olika grad av deltagande från olika ledningsnivåer i implementeringsprocessen i termer av Simons olika typer av styrning.

Simons modell visar bland annat att planering (ex ante), inklusive identifiering av olika kriterier och mål utifrån koncern- respektive affärsstrategin, utöver kommunikation före och i samband med implementering av strategin, är viktiga moment. Detta kopplat till PMS, i modellen redovisad som en del av strategiutvecklingen, visar också tydligt behovet av en måldimension tidigt i ekonomistyrningsprocessen. Samtidigt visar modellen att ett viktigt inslag i styrningen är återkoppling av de resultat som uppmätts i samband med användningen (ex post) vid organisering och implementeringen av strategin.

Litteraturen beskriver beslutsmodeller på olika nivåer av förståelse och från olika kunskapsfält. Modeller för förståelse av såväl individuellt som organisatoriskt lärande avhandlas inte explicit i denna avhandling. Analysen av kommande empiri syftar primärt till att förstå en kvalitetsmässig dimension av de olika faser som i en beslutsprocess, i ett företag, kräver olika typer av information och där varje fas ska bedömas utifrån ett eller flera kriterier som långsiktighet, effektivitet, mätbarhet mm.

Ett antal beslutsmodeller med olika syften och med olika förklaringsvärde på olika nivåer av ett företag förekommer. Den integrerade beslutsmodell för strategi/styrning som har utformats av Simons är en konceptuell modell där olika steg i en strategisk beslutsprocess beskrivs. Simons modell beskriver behovet av återkoppling. Simons modell är dock statisk i sitt ursprung. ${ }^{41}$

\footnotetext{
${ }^{41}$ I denna studie diskuteras implicit modellen utifrån dess tillämpning att också kunna förklara utveckling, d v s ett dynamiskt perspektiv. För att pröva om modellen är tillämpbar i en utvecklingskontext används begreppen utforskning (exploration) respektive exploatering (exploitation) (March, 1991) som utgångspunkt för koncernstrategin och valet av synsätt (perspective)
} 


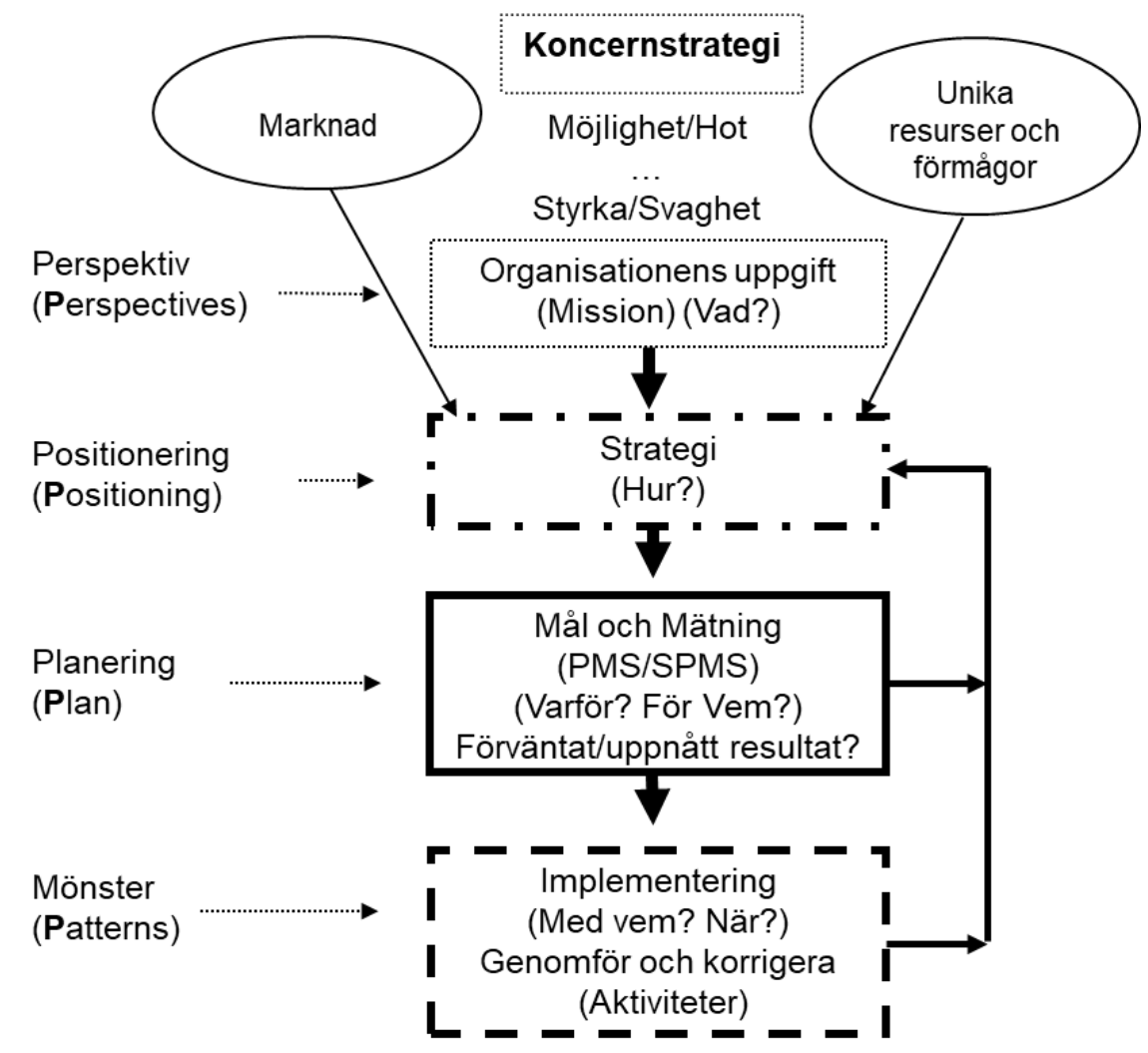

Figur 6. Hierarchy of Business Strategy (här tolkad och bearbetad) Simons, 2000.

I och med att Robert Simons modell implicit visar behovet av ett tidsperspektiv inför konstruktion av empiriska studier, bland annat för att tydligt belysa styrningens "ex ante" respektive "ex post" illustrerar modellen detta "före/efter" också, implicit uttryckt, en "dynamik"; detta genom återkopplingsaspekten (ex post) från ledningens observerade förändringar av mönstren (patterns) i organisationens utveckling.

Simons modell beskriver något mer konkret betydelsen av kopplingen mellan strategi och styrning, allt enligt figuren och SWOT-analysen intar här en plats i styrningsdiskursen. I Simons modell startar strategiarbetet med identifiering av organisationens unika styrkor (bl. a resurser och förmåga) samt dess marknadsförutsättningar. Här beskrivs dels vilka resurser (enligt tillgångssidan på balansräkningen) som är tillgängliga för konkurrens, dels definieras resurser som tillgångar (assets). ${ }^{42}$ Med referens till resursbaserad teori (RBV) (Wernerfelt, 1984) gör Simons en vidare definition av resursbegreppet i och för strategidiskussionen i

\footnotetext{
${ }^{42}$ Med "asset" avses här en resurs, ägd eller kontrollerad av en organisatorisk enhet, och som kan generera framtida fördelar. Snarlika definitioner återfinns i dokumentation från FASB respektive IASC.
} 
ekonomistyrningskontexten ${ }^{43}$. Modellen har därmed också likheter med en modell som tillämpas i kvalitetsdiskusen den s k PDCA-modellen (Deming, 1900 - 1993). (Figur 7)

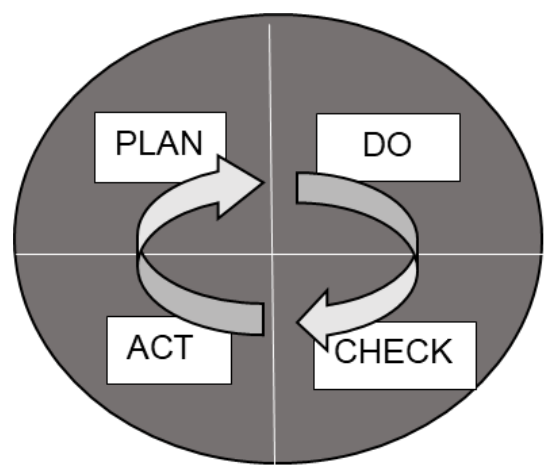

Figur 7. PDCA-modellen (W. Edwards Deming, 1990-1993)

En modell som visar återkopplingsaspekten är den ofta i beslutssammanhang tillämpade 'lärandemodell' som utvecklats av W Edvards Deming (1990 - 1993). Modell som nära ansluter till Simons modell genom en systematisk frågemetodik där "ex ante" frågor vid "Plan", "Do" och "ex post" frågor vid "Check" and "Act" vägleder beslutsfattare i kvalitetsfrämjande förbättringsarbete. Modellen benämns Deming-modellen eller mer populärt PDCA-modellen. Återkopplingsaspekten i modellen implicerar också här ett tidsperspektiv.

Utöver detta tidsperspektiv ("före/efter") kan styrning illustreras i olika faser i ett företags utveckling (Greiner, 1972: MacIntosh, 1994) där tidpunkten för beslutet är viktigt och där en mer långsiktig styrning påverkas tidigt i organisationens utvecklingsprocesser. ${ }^{44}$

Forskarna Andrew Pettigrew (1997) respektive C.R. Hinings (1997) har utvecklat modeller för processanalys utifrån ett antal enkla frågor. I denna avhandling analyseras beslutsprocessen utifrån Simons modell där frågorna från processanalys (Pettigrew, 1997) ställs och detta i en viss ordning. ${ }^{45}$ och relaterat till ordningen i PDCA-modellen. Simons modell väljs primärt för att förklara integrerade processer i ett företag.

\footnotetext{
${ }^{43}$ Med resurs avser Simons (med referens till RBV) tillgångar på balansräkningen ("current assets"). produktiva tillgångar ("productive assets") samt osynliga tillgångar av olika slag ("intangible assets"). I senare strategilitteratur är dessa ytterligare definierade i två kategorier med underkategorier "synliga": (organisationens finansiella, organisatoriska, fysiska, teknologiska resurser) respektive "osynliga" (organisationens mänskliga resurser, dess innovativa resurser och dess och "rykte) (Ireland m fl., 2007).

${ }^{44}$ De modeller som diskuteras i denna avhandling fokuserar bland annat organisationens beslutsprocesser runt FoU (Krishnan \& Ulrich, 2001) - men också, som nämnts ovan i ledningens användning av mätsystemen (PMS) $\mathrm{d} v \mathrm{~s}$ hur de använder systemen generellt och i anslutning till organisationens strategiarbete, ex ante och ex post (Henri, 2006).

${ }^{45}$ En modell för processanalys som bygger på ett antal standardiserade frågor har utvecklats av Pettigrew 1997 och Hinings 1997 (Se referenslista). En fråga som dock inte avhandlas i deras modell för processanalys är frågan "För Vem?".
} 


\subsection{Implikationer vid val av beslutsmodell för genomförandet av strategi.}

En beslutsmodells utformning påverkas av den kontext där modellen ska appliceras d v s i vilket sammanhang den tillämpas. Kontexten beskriver vilken typ av företag som avses, hur organisationens "struktur" eller organisation ser ut eller vilka utgångspunkter ledningen har samt vilka perspektiv som ledningen tillämpar vid strategisk planering.

En viktig utgångspunkt vid analys av beslutsprocessen är att även om processen $i$ sig är oförändrad så påverkas besluten dels utifrån den strategi som man vill tillämpa (jfr Porter, Govindarajan, Miles \& Snow $\mathrm{m}$ fl.) men också beroende på den effekt som ledningen specifikt förväntar sig av sitt beslut, d v s organisationens förväntade gensvar som en konsekvens av hur företaget styrs, d v s implementerar och dito tillämpar en viss beslutsordning. Effekter som uppmärksammats i samband med ovan nämnda försök till implementering av strategier (Nilsson, 1999, Burns, 1999) kan sammanfattas på följande sätt; hur organisationen responderar på beslutet beror på ledningens bedömning av a) beslutsmodellens tillämplighet b) beslutsgångens och beslutets relevans för den egna verksamheten och c) hur beslutet kommuniceras. Dess förväntade effekter kan påverka var prioriteringarna görs i beslutsprocessen (ibid).

Inför kommande empiri och analys görs som utgångspunkt ett antagande att den beslutsmodell som valts är relevant utifrån dess syfte $\mathrm{d} v \mathrm{~s}$ att den motsvara den aktuella organisationens mål, att den motsvarar ledningens förväntningar samt att ledningens beslut kommuniceras utifrån modellen. 


\section{Kapitel 5 Initialt arbete 2003 - 2005. Empiri och partiell analys från förstudie och Case ROBO och Case CATHEDRAL.}

Fem empiriska studier har genomförts, en förstudie och fyra fallstudier med ett s k 'målföretag'. Förstudien genomfördes under perioden 2003 - 2004 med ett inledande seminarium och parallella workshops. Vid det inledande seminariet med rubriken `Resurstillväxt, målet för hållbar tillväxt' i Stockholm medverkade forskare från akademin och ledare från ett tiotal företag. Urvalet företag gjordes som ett bekvämlighetsurval, d v s en tidigare kontakt fanns vid respektive företag. Företagens ledare inbjöds att medverka vid seminariet med för att diskutera ett hållbarhetstema om resurstillväxt och värdetillväxt. Som ett led i denna 'förstudie' genomfördes workshops med deltagande företag varav ett med 'målföretaget' för denna avhandling.

Perioden 2005 - 2009 genomfördes fallstudier vid ett av, då fem affärsområden (business areas, BA) i ett av de medverkande företagen, 'målföretaget' och med specifika tema; vid en affärsenhet (BU) inom affärsområdet med tema 'beslutsprocessen' (Case ROBO) samt vid företagets affärsenhet för FoU (BU FOU/CR) med tema 'legitimitet' (Case CATHEDRAL). Dessa inledande seminarier och fallstudier avsåg att ta reda på vilka utmaningar, med avgränsning till ledning av verksamheter med forskning och innovation, som intervjupersonerna upplevde vid tillfället, vilka verktyg som användes vid beslutsprocesser vid projekt som implicit handlade om hållbarhet. Avhandlingen redogör i detta kapitel sammanfattande för resultat från dessa fallstudier. I bilagt material redogörs dels för förstudiernas förutsättningar dels för genomförande. Fördjupning av fallen, Case ROBO och Case CATHEDRAL, görs i separata dokument (engelsk text). Se Fallstudier.

Perioden 2009 - 2019 genomfördes två längre fallstudier vid samma företag vilka kommer redovisas i kapitel 6 och kapitel 7. Den första av dessa två studier avsåg ett "högrisk-projekt" inom energiområdet (Case FORCE) och inom ett affärsområde Marketing \& Sales. Den sista fallstudien (Case INNOHUB) avsåg ett initiativ med s k “öppen innovation’; ett Vinnovafinansierat initiativ vid ett 'målföretag' med en bred ansats och ett stort antal medverkande. Studierna under perioden 2015 - 2019, genomfördes i 'målföretaget ' som vid tiden för de båda studierna implementerade en rad omfattande strategiska beslut. Valet av detta 'målföretag' för den första studien (FORCE) var en naturlig följd av de två inledande fallstudierna med syfte att utforska ytterligare förståelse. I den andra studien (INNOHUB) gjordes valet av följeforskare av Vinnova och 'målföretaget'.

Då dessa fyra fallstudier avsåg att besvara forskningsfrågorna utifrån olika perspektiv så görs i respektive kapitel en kortare partiell analys efter respektive redovisning ${ }^{46}$. Partiell analys avser att undersöka om och i vilken utsträckning de olika elementen i den strategiska styrningen i respektive empiri kan förklaras av teorin eller om ytterligare ‘förklaringsmodell’ måste sökas, något som diskuteras som strategiska utmaningar för den fortsatta forskningen.

\footnotetext{
${ }^{46}$ I kommande systemisk analys (i kapitel 8 och 9) undersöks och diskuteras styrningen potentiella effekter på det observerade fenomenet d v s effekter av styrningen på företagets resultat- och kapitalstruktur.
} 
Nedan redovisas kort resultatet från initialt genomförda studier. Partiell analys görs av respektive fallstudiestudie $\mathrm{m} \mathrm{h}$ a frågor som bedöms relevanta för syftet med avhandlingen.

\subsection{Inledande seminarier och workshops under perioden 2003 - 2005}

Under 2003 togs kontakt med flera företag om hur företagsstyrning skulle utvecklas i relation till den förändring som företagen genomgick. De initiala kontakterna ledde till att ett gemensamt seminarium för benchmarking planerades med att antal börsnoterade bolag. Seminariet i Stockholm 2004 samlade tio personer, samtliga ledningspersoner från ett flertal svenska företag; Vattenfall AB, Ericsson AB, ABB AB, Sandvik AB, Stora Enso AB m fl. Personerna representerade dessa företags personal-, finans- och miljöenheter och alla var uttalat engagerade i hållbarhetsfrågor. Vid detta seminarium redovisades Miljödepartementets och SCB's rapport "Sustainable development: Indicators for Sweden ${ }^{47}$ och skillnader respektive beroenden mellan samhällsperspektiv och företagsperspektiv diskuterades. För att tydliggöra det resursorienterade synsättet som en utgångspunkt för dessa dialoger om ekonomiskt hållbar, strategisk styrning beskrevs också andra synsätt företagsnivån inom teori - och skolbildning 48 Grundläggande skillnader mellan synsätten diskuterades. ${ }^{49}$ I bilagor ${ }^{50}$ återfinns exempel på rapporter från dessa inledande dialoger.

De många frågor som diskuterades vid det inledande seminariet, vid parallella workshops/brainstorming kan sammanfattas på följande sätt: hur ska (företags) strategisk styrning ske på ett hållbart/uthålligt sätt? Två centrala teman som kom att fokuseras efter dessa förberedande dialoger var: resurseffektivitet och ekonomistyrning, båda utifrån ett ledningsperspektiv.

För att avhandla forskningstemat 'ett resursbaserat perspektiv på ekonomisk styrning' genomfördes under perioden också ett antal enskilda intervjuer med personer från dessa medverkande företag. Vid en workshop i ett av företagen, 'målföretaget' önskade de medverkande vidare att forskningen kunde utveckla en enkel tumregel eller en modell för att illustrera ledningens olika beslutsproblem i samband med en mer strategisk ekonomistyrning.

Figuren nedan (Figur 8) illustrerar de olika faktorer som de intervjuade i denna förberedande studie ansåg sig måste ta hänsyn till i samband med beslut med att förändra organisationens position för att genom högre resurseffektivitet uppnå en ökad tillväxt. Målet 'tillväxt genom optimal avkastning' diskuterades som fortsatt tema för några 'business case' som föreslogs för genomförande inom målföretagets forsknings- och utvecklingsverksamhet (BU FoU/CR samt BU 1)). Bland annat önskade man kartlägga behovet av mer specifik kompetens för ledningen av verksamheten. Några krav på en 'ny' enkel styrmodell skulle dels kunna beskriva mer 'sociala aspekter' (relationen mellan olika organisationsenheter, beslutsprocesser $\mathrm{mm}$ ) men

\footnotetext{
${ }^{47}$ I dokumentet "Sustainable development - Indicators for Sweden" (2001) beskrivs ett antal indikatorer för hållbar utveckling: "the indicators here give some idea of what we hand over to coming generations, their manoeuvrability, when it comes to economic resources, ecological ressources and human resources" "..how qualitative increases in the components of efficiency...., strenghten the values and increases the resources for coming generations..."

${ }^{48}$ Professor Peter Söderbaum redovisade den senaste utvecklingen inom ekologisk ekonomi. Se referenser: Söderbaum: Ecolocical economics

${ }^{49}$ Se bilagorna 7.8

${ }^{50}$ Se bilagorna $1(\mathrm{a}, \mathrm{b}, \mathrm{c})$
} 
framförallt lyftes vilka överställda egenskaper som var viktiga för styrningen och vilka mål som man såg viktiga framgent, avseende både konkurrens och företagets interna styrningsmål. Mätbarheten poängterades, i synnerhet mätbarhet och effektivitet i projekten

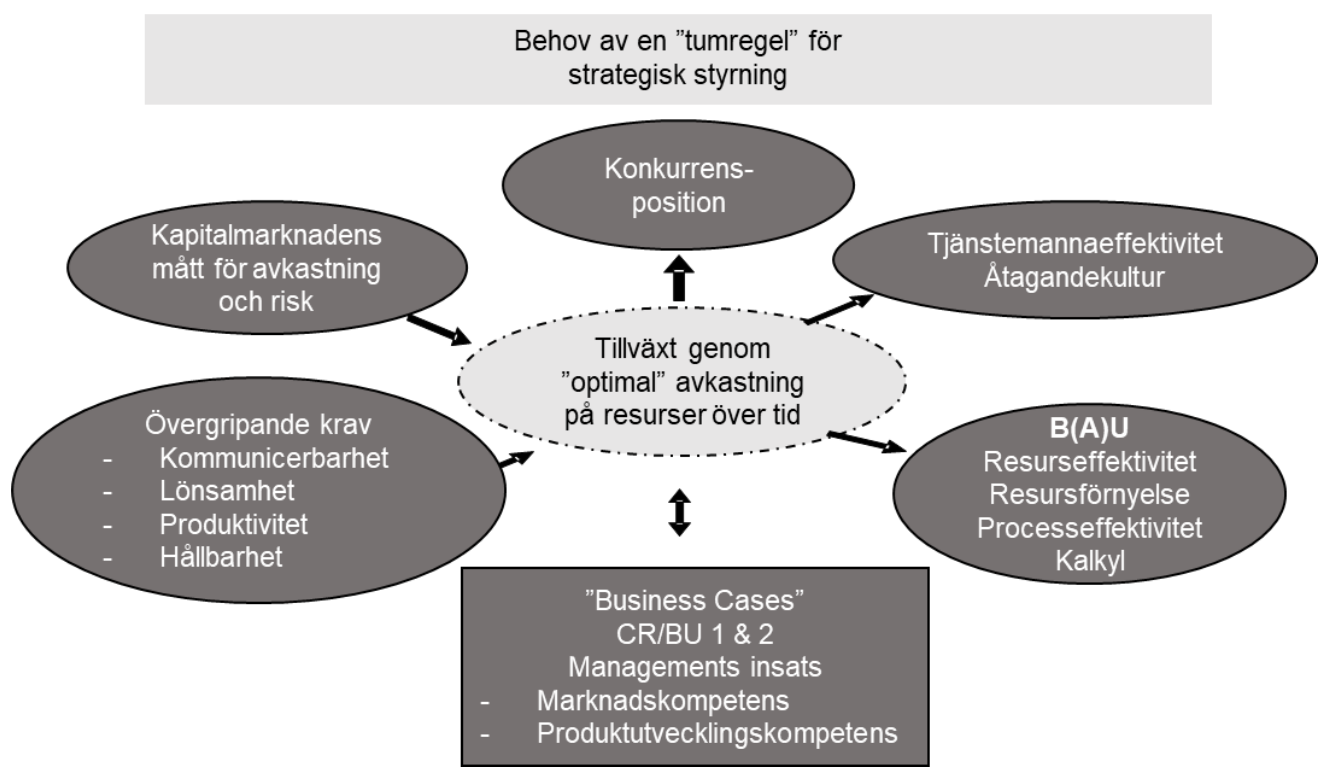

Figur 8. Från förarbetet i förstudien (2004); förutsättningar för strategisk styrning. Senare sammanställd av målföretagets ledningsgrupp för BU 1(M\&S) och BU 2 (CR).

Ett centralt begrepp i denna bild är ordet "resurseffektivitet". Utifrån den måldimension som explicit beskrivs, "optimal avkastning på resurser över tid" användes begreppet "resurseffektivitet" synonymt med begreppet effektivitet ibland lite tveeggat med begreppet produktivitet, $\mathrm{m}$ a o begreppsfloran var inte helt tydlig och begreppen inte väldefinierade. En intressant aspekt var ledningens behov att förstå kapitalmarknaden och dess begrepp.

Efter dessa inledande brainstorming och workshops påbörjades 2004 och genomfördes succesivt planeringen av ett antal mer fördjupade studier, med avgränsning till två "tidiga processer" inom målföretaget; i affärsenheten (BU 1) Marknadsföring och Försäljning, tre delstudier, och i affärsenheten (BU 2) FoU/CR, en studie. Resultaten från dessa fyra studier och fördjupad analys beskrivs i sin helhet i två "working-papers" ${ }^{51}$ vilka återfinns som bilagor till denna avhandling. Här nedan presenteras fallstudierna sammanfattande med avslutande partiell analys.

\footnotetext{
${ }^{51}$ Boström, P S: A Critical Assessment in Process Analysis (working paper) 2005/2013/2021 (Bilaga A) Boström, P S: Legitimacy as analyzing concept (working paper) 2005/2014/2021 (Bilaga B)
} 


\subsection{Fallstudie 1: Case ROBO: studier vid affärsområde 1 Marketing/Sales (BU 1). ${ }^{52}$}

Case ROBO omfattar två av tre studier som genomförts vid affärsenhet BU 1 i företaget under 2005. Verksamheten hade en relativt jämn orderingång. Hotet från konkurrenter i framförallt Japan stegrades. Produktutvecklingen av organisationens produkter inriktades på två fronter; utveckling av en "ny" plattform för kommunikation (sladdlöst etc.) samt utveckling av nya användarapplikationer.

Under perioden 2003 - 2005 hade ett antal förmöten samt intervjuer med personer inom en affärsenhet, BU 1, genomförts. Cirka tjugo kortare möten utöver intervjuer med nyckelpersoner hade genomförts. I dessa lednings-/referensgrupper medverkade ett 15-tal personer.

Vid brainstorming om ekonomistyrningen inför dessa tre projekt på affärsenheten, genomförda med ett antal ledningspersoner, chefscontroller från organisationens gemensamma forskningscenter (FoU/CR) respektive affärsenheten (BU 1) samt produktutvecklingsansvarig och projektledare på ett produktsegment, indikerades ett antal specifika behov.

Studierna av kommande projekt (Case ROBO) avsågs genomföras under ledning av en styrgrupp. ${ }^{53}$ Utifrån referensgruppens önskemål formulerade styrgruppen tidigt krav på ett nytt system för ekonomistyrning utifrån nya /"resursbaserade"/ kriterier; man ville kunna mäta den "unika" kompetens som ledningen hade samt också ha avsevärt bättre beslutsunderlag i den interna styrningen, gärna i form av dessa "tumregler", bland annat för mer "hållbara" beslut med referens till "uthållighetskriteriet".

Reflektionerna från följande fråga från referensgruppen exemplifierade väl detta:

Vad är värdet av det man "sätter in" (som resurser) och vad är viktigt i beslutssammanhang?

"...om mjukvaruutvecklingen ... försening kan bero på att rätt resurser inte finns.. det fordrar därför ännu hårdare fokus på PROJEKTEN $i$ verksamhetsstyrningen! Om detta sker ökar förståelsen för resursbilden också om man håller TIDEN. Samtidigt indikeras om man gör rätt grejor".

(Chefscontroller inom BU 1 och BU 2 (FoU/CR))

"Högre kvalitet i beslutsunderlaget - Vad är det? Vi måste veta mer om mänskliga behov - förståelse för mänsklighet och marknad. Svårt att bedöma tid $i$ annat avseende - $i$ vilket perspektiv arbetar man / balansen mellan det som bolaget måste sälja inom närmaste tiden versus vad som ska utvecklas för marknaden i längre perspektiv".

(Chefscontroller inom BU 1 och BU 2 (FoU/CR))

"Det fordrar framförallt en strategisk syn på utveckling av kompetens: Marknaden är en förståelse för människor - det räcker inte med att prata med kunden. En sådan strategi måste bygga på att vi vet att det är $i$ linje med organisationens affärsstrategi och en förståelse för hela FÖRETAGET. Den enskilda forskaren styr inte, men måste ha denna kännedom..."

\footnotetext{
${ }^{52}$ Projektet i sin helhet Se: Boström, P S: A Critical Assessment in Process Analysis (working paper) 2005/2013/2021

${ }^{53}$ Perioden 2005 - 2009 har tre (3) stycken "case studies" genomförts med styrgruppen inom affärsområde 1 (BU1) Analyser har samtidigt genomförts av koncernens (och konkurrenters) bokslut, på olika nivåer, med tillämplig metodik.
} 
(Controller inom BU)

"Affärsområdet har den övergripande strategin på 3 - 5 år. Detta måste kommuniceras bättre till våra forskare och produktutvecklare".

(Chefscontroller inom BU 1 och BU 2 (FoU/CR))

En ytterligare fråga exemplifierade hur beslutsprocessen ser ut och vad som mäts/värderas och hur.

Vad är till exempel värdet på det man gör när man tar beslut och det man får ut?

"Man beräknar så att det känns rätt i maggropen; man anpassar" ... "valet är ju svårt - om volymen minskar så har man ju gjort fel val - kanske upptäcks det för sent...- svårt men viktigt att se tillbaka, att se utfallet utifrån det val man gjort. Viktigt att få med alla variabler som gjorde att man gjorde valet. För att se förädlingen - det är viktigt att se hela kedjan.

Utgångspunkten är: Vi har rätt beslut - vad ligger till grund för detta --- det gick fel --- förbättra! Ju större vetskap om vad som påverkar beslutet - desto lättare att förbättra".

(Produktchefen ("gate-assessor") för projekt A)

Samtidigt indikerar intervjuerna några problem i det att beslutsgången i projekten, som följde en viss mall för organisering av projekten, den s.k., 'Gate-modellen', inte alltid var önskvärd att koordinera mellan enheterna.

'...viktigt att kunna mäta med olika organisatoriska avgränsningar, exempelvis vill vi kunna mäta effektivitet i produktutvecklingsorganisationen (avgränsat bl. a mot Marknad och Sälj)”.

(Projektledare för projekt/FoU)

Följande antal personer har intervjuats/ingått i studien ${ }^{54}$. I styrgrupp ingick två personer utöver de intervjuade sex nyckelpersonerna.

Ytterligare material om studiens genomförande finns i de rapporter som återfinns som bilaga ${ }^{55}$ till avhandlingen.

\subsection{Partiell analys av Case ROBO. ${ }^{56}$}

Förarbetets frågeställningar och diskussionerna med styrgruppen medförde att kommande studier beslutades fokusera endast två processer inom ramen för ekonomistyrningen:

\footnotetext{
${ }^{54}$ I styrgrupper och referensgrupper har följande personer intervjuats:

Case ROBO Styrgrupp: (2 p) (Controller CR), (Segmentschef BU FoU/CR/BU)

Case ROBO Intervjuade nyckelpersoner (6 p)

${ }^{55}$ Se bilaga A ("A Critical Assessment in Process Analysis", working paper)

56 Analysen av Case ROBO inriktades på utveckling av två "nya" applikationer vilket innebar att dessa utvärderingar inta avsåg en genomförd produktstrategi utan endast planeringsfasen. Generellt uppfattades uppföljning av kalkyler (ex post) ha lägre prioritet
} 
beslutsprocesserna och organiseringsprocessen. Denna fallstudie kunde därför primärt analyseras utifrån en processanalys (Pettigrew, 1997; Hinings, 1997).

Ett resultat av diskussionerna om beslutskriterierna innebar följande slutsats som kommunicerades med styrgruppen:

Vid beslut om strategiskt viktiga projekt följer själva beslutprocessen en viss tänkt struktur eller form (den s.k. Gate modellen) och samtidigt kom frågeställningarna alltid i en viss ordning i någon form av beslutsprocess: Först ställdes och besvaras frågorna om VAD? och HUR? $\mathrm{d} v \mathrm{~s}$ affärsstrategiska frågor, dock mer eller mindre otydligt. I nästa fas ställdes frågan Varför? inför ("ex ante") /ekonomiska / beräkningar av projektens potentiella resultat. Dessa frågor var tydligare. Som beslutsunderlag användes här en traditionell kalkylmodell vid beräkningarna.

Någon egentlig ekonomisk utvärdering av dessa två utvecklingsprojekt gjordes inte löpande. Styrningsfrågorna framstod som relativt underordnade. Någon bedömning utöver finansiella konsekvenser från projekten gjordes inte. FoU investeringar togs direkt mot projektets beräknade täckningsbidrag, vilket innebar att ingen investeringsbedömning/budget/kalkyl gjordes för den interna verksamheten och följaktligen inte heller någon utvärdering av det finansiella flödet. Däremot genomfördes en investeringskalkyl (pay-off) för en kunds räkning utifrån en beräkning av projektets energieffektivitet $\mathrm{d} v \mathrm{~s}$ där energiförädlingen $(\mathrm{d}$ v s förmågan att förädla resursen energi i olika former) var den förmåga som, baserat på ett givet resursslag, var unikt och gav legitimitet till verksamheten.

I samband med denna studie testades ett antal olika teoretiska modeller i syfte att förstå beslutsprocesserna vid ekonomistyrning mm. Simons strukturmodell (Figur 6) användes vid analys av ett antal beslut vid olika "gates". Genom att diskutera vilka frågeställningar som togs upp och när, och vilken betydelse de hade för projektet, så resulterade studien bland annat i en klar åtskillnad mellan olika faser d v s ex ante , d v s mål, kalkyler, balanced scorecard-mått, LCA-mått och ex post, d v s i och för uppföljning av resultatet och vilka effekter som uppstått, i de fall detta förekom på denna nivå.

Som ett resultat av analysen av dessa "case studies" diskuterades också tillämpning en 'ny beslutsmodell' för denna kontext; ett förtydligande av Simons modell för integrerad strategi/styrning med PDCA-modellen (Deming, 1990 - 1993) (Figur 7) som har karaktären av en processmodell med krav på återkoppling på alla frågeställningar.

Studien visade vidare också att en fråga som kunde avgöra ett projekts 'vara eller inte vara', var frågan FÖR VEM? Detta konstaterande ledde till att denna fråga bedömdes viktig att ha med $i$ analyser av ekonomistyrningens effekter $\mathrm{d} \mathrm{v} \mathrm{s}$ där såväl mätproblem som den interna organiseringen beträffande personligt åtagande, ansvar för de olika momenten i "gatemodellen" var frågor som prioriterades vid analys av beslutsprocessen.

Sammanfattningsvis indikerades (2005) ett behov av hårdare fokus på projekten, bättre kvalité på resursslaget 'information', nya "tumregler" för den strategiska styrningen där man också kunde värdera ledningskompetens, där man fick bättre kunskap om människor och marknad, bättre kunskap om nödvändig prioritering ur finansiell synpunkt, bättre kunskap om hela företaget, men också striktare avgränsning till den egna enheten när det gällde mätning/värdering av resurserna. Samtidigt som det var viktigt med tillbakablickande ("backcasting" och "ex ante"-fokus) så var det viktigt att få med alla variabler i styrningen. Det senare indikerade behovet av en mer mekanistiskt/diagnostisk styrning (Se Chenhall, 2003). 


\subsection{Fallstudie 2 Case CATHEDRAL: studie vid affärsområde FoU/CR (BU 2). ${ }^{57}$}

Case CATHEDRAL omfattar en serie om sex intervjuer med personer på olika nivåer inom $\mathrm{BU}$ 2. ${ }^{58} \mathrm{BU} 2$ (FoU/CR) är koncernens gemensamma forskningscenter och är en global affärsenhet. Detta forskningscenter har (2005) huvudansvar (projektsansvar och funktionellt ansvar) för två av koncernens sju globala forskningsprogram. Denna studie avsåg endast att diskutera organisatorisk 'legitimitet', kriterier för ansvar, organisatoriskt åtagande och enhetens befogenheter ("accountability" versus "responsibility") i och för den koncerngemensamma forskningsstrategin och för att kunna utvärdera organisationens beslutsprocess avseende FoU, dess ekonomiska styrning och resultat och effekter av denna.

Frågorna handlade om: Vad är "legitim" forskning? Vem ger legitimitet till viss forskning etc.? Vad legitimerar enhetens totala verksamhet och hur organiseras forskningens resurser utifrån dessa kriterier?

De personer som intervjuats kom från olika delar av FoU- organisationen, d v s även utanför respektive forskningsgrupp/projekt. Det är en organisation som är komplex, den är organiserad som en global matris och speglar därmed hela företaget. Ansvaret är globalt respektive regionalt; dels för ett visst strategiskt viktigt teknikområde eller produktområde med lönsamhetsansvar; dels med ett funktionellt område med kostnadsansvar för en affärsenhet (BU). Man reglerar och redovisar explicit formerna för ansvar gällande åtagandet gentemot affärsenheterna.

"Legitimitet inom FoU innebär att kunna visa upp sig frikopplade från den kommersiella verksamheten; syftet är att skapa en "kritisk massa av resurser och kompetens, vi ska vara en central resurs, föra samman flera kompetenser på olika nivåer... legitimitet har vi så länge vi levererar".

Gruppchef affärsenhet FoU/CR (BU 2):

Samtidigt visar studien att "history and experience matters".

"Legitimitet kommer från någon som har affärsanknytning genom utvecklingen av gamla produkter och genom underhåll av nya produkter och på de frågor $d v s$ de motiv som denna utveckling kan baseras på”.

Avdelningschef 1

... och att ledarskap, mål och resultat är viktiga:

"...det handlar om att ledningen ger legitimitet $d v s$ en andra ordningens legitimitet (utöver den första ordningens mer formella) vilket visar sig genom ledningens sätt satt agera.

Avdelningschef 2

\footnotetext{
${ }^{57}$ Projektet i sin helhet Se Boström, P S: Legitimacy as analyzing concept (working paper) 2005/2014/2021

58 Under 2005 genomfördes ett antal möten samt intervjuer med personer inom affärsområde 2 (BU FoU/CR)

Case CATHEDRAL Styrgrupp: 2 p (Controller, CR), (Segmentschef BU FoU/CR/ BU 2)

Case CATHEDRAL Intervjuade $6 \mathrm{p}$ (Se"working paper,'Legitimacy as Analysing Concept)
} 
"...legitimitet hänger samman med förtroende $d v s$ man skapar förtroende hos någon genom att visa resultat... detta sker genom kompetens; dels genom att bygga relationen och detta tillsammans ger förståelse. Man börjar med att bygga relationen - det tar tid men om man kan hitta gemensamma mål går det fortare... vi låter resultaten tala...!"

Avdelningschef

\subsection{Partiell analys av Case CATHEDRAL.}

Denna fallstudie analyseras primärt utifrån begreppet 'legitimitet' (Pfeffer, 1975; Berry, 2005; Charniawska \& Wolf, 2007) och implicit utifrån hållbarhetskriterier och ett potentiellt samhällsåtagande (Jeurissen, 2004). En utgångspunkt för studien är att företagslednings strategiska ledning, dess beslutsfattande och långsiktiga styrning och agerande kan prövas utifrån krav på legitimitet, utifrån såväl 'internt' som 'externt' perspektiv.

Analysen av fallstudien CATHEDRAL prövar om "legitimitet" kan användas som ett analysverktyg för att analysera såväl organisationens långsiktiga strategi och ekonomistyrning avseende organiseringen runt FoU's resurser och åtagande gentemot affärsenheterna och i ledningen av olika strategiskt viktiga utvecklingsprojekt.

Studien visade att avseende 'legitimitet', beroende på vilken nivå i organisationen personen tillhörde och vilken typ av organisation denne representerade (projekt respektive funktionell organisation), så varierade uppfattningen om vad som primärt avsågs med begreppet "legitimt". Däremot var samstämmigheten stor bland de intervjuade beträffande vad som ansågs vara legitimt i olika avseenden.

Inför utformningen av en framtida strategisk ekonomistyrning $\mathrm{m}$ a $\mathrm{p}$ organiseringen, indikerades här att det dels handlade om att se tillbaka på vad som varit viktigt $\mathrm{i}$ utvecklingen av produkterna och bygga vidare på detta, $\mathrm{d}$ v s även här en tillbakablickande typ av styrning ("backspegeln") dels en centralisering av viktiga "resurser", här i form av kompetens (läs: förmåga) och mer eller mindre frikopplad från kommersiella villkor. I studien indikerades också en stark centralisering och en styrning med inslag av isolering/bundenhet. Detta indikerade en mer mekanistiskt orienterad organisation. Vidare poängterades att man värderade (möjligheten till) att leverera och visa resultat; detta var enskilt den variabel som gav högsta legitimitet till organisationens verksamhet.

Studien har i och med detta bidragit till en förståelse av hur legitimitet ("legitimacy") kan tolkas och också användas som `analysverktyg' i olika kontexter. Synen på vad som är legitimt kan potentiellt förklara skillnader i strategi- respektive styrningsdiskursen. Dessutom kan denna studie, inom ramen för strategisk styrning också med ett resursperspektiv ge förutsättningar för en gemensam, "generell" syn på vad som är legitim utveckling och vilka resurser och förmågor som därmed prioriteras och på det sättet bidra till tydlighet inom respektive diskurs. Ett referat av R Jeurissen i anslutning till empiriorganisationens initiativ för "corporate responsibility" diskuterades: (Jeurissen, 2004).

"A further study including strategic discussions and a shared view in resource efficiency - in finance, human and natural resources - and emerging values, the meaning of legitimacy, of business strategy may give a body of knowledge for future research of company performance and its legitimacy" (Jeurissen, 2004, pp 87-96) 
En analys av ledningens gemensamma syn på organisationens/koncernens samlade förädling, i termer av legitimitet, ansågs kunna ge den fortsatta forskningen en grund för utvecklingen av /en modell för/ system för strategisk mer resursbaserad ekonomistyrning på lägre nivå ("BAU"). En consensus omkring legitimitetsbegreppet och ett förtydligande av resursrelaterade begrepp, ansågs potentiellt kunna underlätta såväl organisering som införande av nya mätprocesser.

\subsection{Slutsatser från den initiala forskningsfasen}

De inledande studierna inför detta avhandlingsarbete, i dess initiala fas, genomfördes i samråd med en ledningsgrupp för att förstå och tydliggöra insikten om behovet av en modell för ekonomisk styrning för att uppnå hållbarhetsmål. Samtidigt hade fenomenet med en allt eskalerande 'obalans' i företagens kapitalstruktur observerats redan vid millennieskiftet.

För att förstå den verklighet som företag hanterar användes initialt, vid genomförande och analys av dessa studier, en induktiv ansats $\mathrm{d} v \mathrm{~s}$ för att, genom att analysera skeenden i några verkliga fall dra slutsatser från dessa med hjälp av relevant teori, uppnå en bredare förståelse. Studierna av företags beslutsprocesser och legitimitetsaspekter har genomförts utifrån ett potentiellt övergripande mål; här ett s k "betamål" som kommunicerats med deltagarna.

Inför sammanställning av respektive analys uppstod dock ett behov av en analysmodell som stöd för analysarbetet. Valet att tillämpa ett resursbaserat synsätt och att sätta fokus på företagets tidiga processer, $\mathrm{d}$ v s dess innovationsprocesser har därför bidragit till utveckling av en form för det fortsatta analysarbetet; en tentativ modell som dels utgår ifrån ett resursbaserat synsätt, dels omfattar de huvudsakliga moment som kan antas ingå i en utvecklad ekonomisk styrning av innovationsverksamhet mot detta "betamål".

Utifrån avhandlingens forskningsfrågor fokuserades två delar i analysen: en konceptuell och en kontextuell del. Forskningsfrågorna medförde ett behov att förstå i vilka avseenden ett teoretiskt resursbaserat synsätt potentiellt påverkar såväl konceptet $\mathrm{d} v \mathrm{~s}$ innehållet som kontexten $d v s$ tillämpningen av ett företags system för ekonomisk styrning. Ett antal delfrågor inför analysen ställdes därför avseende

- innehållet $\mathrm{d} \mathrm{v} \mathrm{s}$

a) modeller eller metoder för identifikation och operationalisering av verksamhetens mål,

b) definitioner av och innebörden i ett eller flera resursrelaterade begrepp,

c) ekonomistyrningens förändrade villkor generellt samt

- tillämpningen $\mathrm{d} \mathrm{v} \mathrm{s}$

d) identifikation av organisationen och dess strategiska resurser och förmåga och möjliga strategier för att uppnå målen,

e) specifikt för tre utvalda element av styrningen i en modell som speciellt omfattar organisationens beslutsprocesser, dess organisering av resurser och mätning av organisationens "performance" och 
f) hur den långsiktiga och strategiska styrningen kunde antas påverkas i dessa tre olika element.

Sammantaget indikerade dessa behov inför analys en mer utvecklad förklaringsmodell där analysmomenten tydliggjordes.

\subsection{En utvecklad analys- och förklaringsmodell}

En analysmodell omfattar hela eller delar av en förklaringsmodell. Då en analysmodell för induktiv analys ska relatera till känd teori och skolbildning har den s k EEM-modellen ${ }^{59}$ bedömts vara relevant som förklaringsmodell och utgöra basen för en analysmodell. Modellen relaterar till de behov, avseende såväl innehåll som tillämpning, som framkommit i analysen av de inledande studierna.

En förklaringsmodell omfattar de huvudsakliga områden där /olika/ aspekter vid styrning avhandlas; exempelvis beslutsprocesser eller agerande. (Czarniawska $\mathrm{m} \mathrm{fl}$.) Var och en av dessa aspekter och processer omfattar en eller flera variabler som i den fortsatta studien utgör i sig oberoende respektive beroende variabler i ett sammanhang som analyseras. Totalt omfattar den förklaringsmodell som utformats utifrån EEM-modellen sex olika element av ekonomisk styrning:

Möjliggörare ("input control") omfattar tre 'element': organisationens ledning, dess mål och policies samt dess resurser. Dessa tre element utgör primärt oberoende variabler i den fortsatta analysen.

Processer ("process control") omfattar två element: beslutsprocessen och organiseringen

Resultat ("output control") omfattar ett element: mätsystemet

Inputvariabler; möjliggörare (enablers)

- Måldimension (ledningsförutsättningar)

- Resurser/Mätbarhet ("Vad?")

Processvariabler; processer (processes)

- Organisering ("Vem, vilka?"'För vem, varför?") (C)

- Beslut (Hur? med Vem?)

Outputvariabler; resultat och effekter (results)

- Mätning (Vad?)

- Resultatplanering

Den modell som initialt valts för analysen av empiri är EEM-modellen ${ }^{60}$ (eller EFQMmodellen). EEM-modellen har utvärderats $\mathrm{m}$ a p tillämpning i ekonomistyrningssammanhang

\footnotetext{
59 EEM-modellen (eller EFQM-modellen) är en modell för ledningssystem för kvalitetsstyrning. Modellen beskrivs i teorikapitlet och som underlag för empirisk analys i analyskapitlet (Kapitel 5).

${ }^{60}$ EEM-modellen har bland annat tillämpats i omfattande empiri i bilföretaget Nissan (SA) (Witcher, B. J. et al, 2008). Med denna "tillväxtmodell” kunde man där visualisera ett antal "möjliggörare ("enablers”) eller systemiska faktorer" som villkor för en strategisk ekonomistyrning och dess "output". Modellen visualiserar organisationens resursbas (resursernas tillstånd), $\mathrm{d}$ v s organisationens positionering av resurser och förmågor. Med ett antal indikatorer kan modellen också spegla såväl finansiella resultat som ekonomiska värden för olika intressenter.
} 
och prövats empiriskt med ett "contingency" respektive "cybernetiskt" perspektiv (DahlgaardPark, 2008). En avsikt är att tillämpa EEM-modellen för en sammanfattande longitudinell, systemisk analys av de två case om genomfördes under den senare perioden samt inför avhandlingens slutsatser av samtliga empiriska studier. Med tillämpning av modellen utvecklas förståelse samt med förutsättningar för att forskningsfrågorna kan besvaras. Den tentativa förklaringsmodellen har här följande förenklade utseende:

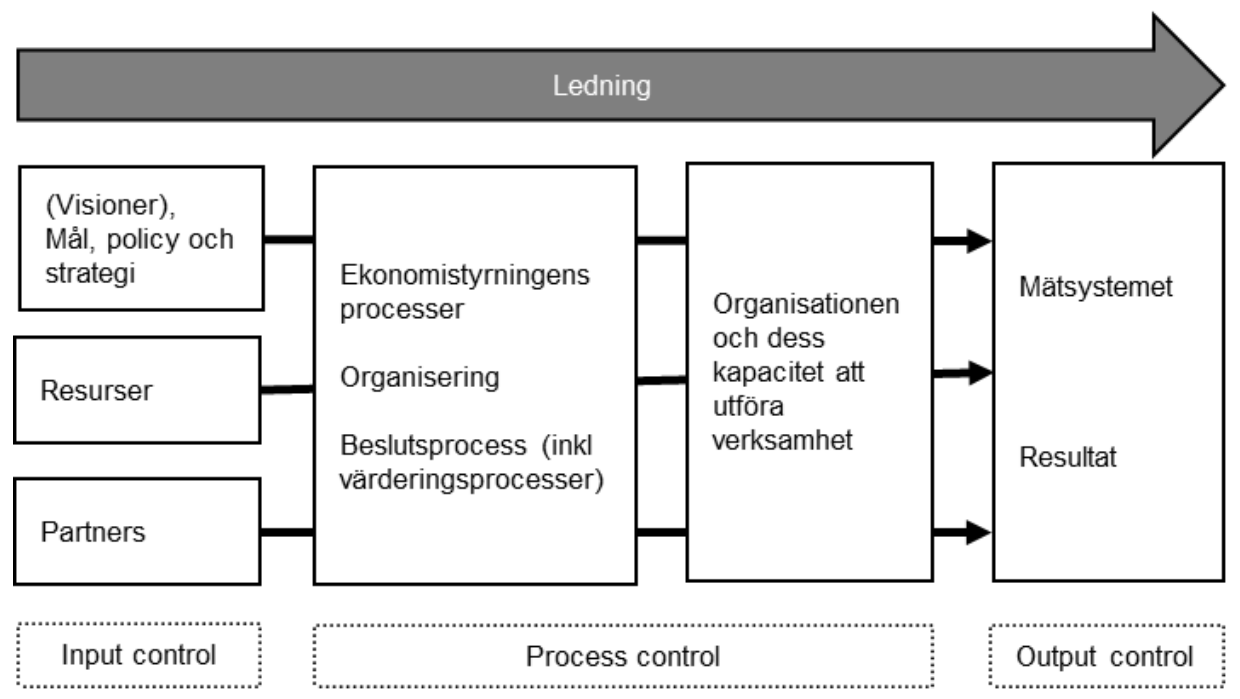

Figur 9. En tentativ förklaringsmodell med ett strategiskt styrningsperspektiv på organisationens villkor för att kunna skapa resultat (egen och förenklad modell av den s.k. EEM-modellen (EFQM-modellen)

EEM-modellens strukturella uppbyggnad med systemiska faktorer som möjliggörare, processer och resultat antas här motsvara styrningens tre 'kontrollfaser' (Hales, 1993); En initial tillämpning av denna modell ger då en analysmodell som utgörs av dess sex olika element:

I kommande empiri planeras analys utifrån denna systembaserade modell, en s k systemisk analys. I denna analysmodell har de olika elementen i processanalysen kompletterats med ett antal "nya" specifika frågor för att ingå i en organisations totala beslutsprocess. Kompletteringarna är ett resultat av diskussioner med ledningsgruppen den första empirin (Case ROBO) där, med utgångspunkt från teori, praxis visade sig inte helt följa modellen (PDCA) då den inbördes ordningen av frågorna vid den studien av beslutsprocessen ändrades relativt modellens ordning. Styrningens hela kontroll- och beslutsprocess breddades därför vad gäller innehållet i de tre beslutsstegen med avseende på dessa 'kontrollfaser' och redovisas här som:

○ Input control. Här avhandlas också ledningens förutsättningar, tillgång till relevant information om hela organisationens övergripande mål och positionering, samarbeten, resurser av olika slag och dess olika nyttoaspekter, finansiella förutsättningar inklusive restriktioner, strategier avseende såväl organisationens tillväxtstrategi som strategier för organisationens samlade Forsknings och Utvecklingsverksamhet. Här diskuterades i 
begränsad omfattning också projektets specifika förutsättningar med möjligheter, tidigare oidentifierade problem i styrningen som riskanalys, hållbarhetskriterier samt olika scenarier för den externa kommunikationen.

- Process control. Här avhandlas vilken typ av styrning och ledning som tillämpats i de olika projektfaserna beroende på yttre respektive inre påverkansfaktorer. Här diskuterades produkteffektivisering som anledning till processeffektivsering.

○ Output control. Utöver behovet av mätbarhet i ett mätsystem avhandlas här effektiviteten i mätprocesser, definitioner och villkor för en ökad mätbarhet och effektiv resultat- och aktivitetsplanering. Här avhandlas också vilka effekter på resursbasen, företagets kapitalstruktur, som hypotetiskt kan uppstå vid olika strategival. En matris föreslogs här för att förstå de olika kriterier som påverkar planeringen av kommande åtgärder i projektet.

Sammanfattningsvis avhandlas inför kommande systemisk analys av empirin (kapitel 8) dessa delvis "nya" förklaringsmodeller; en utveckling av potentiellt olika möjliga strategier d v s olika resursbaserade strategier som kunde konstateras inledningsvis i case FORCE utifrån organisationens övergripande strategi och kompletterat med kombination med viss typ av kontroll ("tight" vs "loose") som kunde identifieras i projektet. Potentiella effekter på den i kommande projekt identifierade resursbasen $(\mathrm{RB}+/-)$ vid olika strategier utgår ifrån Hollings resiliensteori (Holling, 1986). ${ }^{61}$

\subsection{En tillämpad analysmodell}

Som utgångspunkt för en analys av empiri tillämpas som nämnts ett systemsynsätt. Logiken för analysen motsvarar en systemstruktur för ekonomistyrning (MCS) och analysen indelas grovt i förklaringsmodellens tre faser här ovan: "input control", "process control" och "output control" (Hales, 1993).

En systemisk analys beskrivs här i termer av följande analysmoment: ${ }^{62}$

- Inputanalys av systemets möjliggörare ("enablers"); systemfaktorer i form av input till organisationens/ledningens system för ekonomistyrning.

- Processanalys av systemets processer ("processes"); organisationens beslutsprocesser som omfattar både strategi- och styrningsfrågor och aktiviteter som ingår i beslut och strategiska processer för resursutveckling/avveckling.

- Outputanalys av resultat ("results"); resultatfaktorer i form av output från den strategiska styrningen.

\footnotetext{
61 "A management approach based on resilience, ..., would emphasize the need to keep options open, the need to view events in a regional rather than a local context, and the need to emphasize heterogeneity. Flowing from this would be not the presumption of sufficient knowledge, but the recognition of our ignorance; not the assumption that future events are expected, but that they will be unexpected. The resilience framework can accommodate this shift of perspective, for it does not require a precise capacity to predict the future, but only a qualitative capacity to devise systems that can absorb and accommodate future events in whatever unexpected form they may take" (Holling, 1973 s. 21)

${ }^{62}$ Var och en av dessa moment omfattar en eller flera variabler som i den fortsatta analysen utgör i sig oberoende respektive beroende variabler beroende på vilka samband som analyseras. Dessa beskrivs närmare $i$ analyskapitlet (Kapitel 5)
} 
Den "nya" systemiska analysmodellen har utformats utifrån behovet av att kunna analysera ekonomistyrning innehåll och tillämpning. Analysmodellen avhandlar primärt studier av resursbaserade villkor för organisationens organisering, dess strategibeslut och ekonomistyrningsmodellens villkor för mätsystem, PMS (ex ante, ex post). Övriga aspekter på innehåll som kommunikation och redovisning avhandlas implicit. När det gäller organisationens organisering för ansvar ("accountability" respektive "responsibility"), så avgränsas denna diskussion till den som förs i strategilitteraturen om ledningens förutsättningar att påverka (DeWitt \& Meyer, 2010).

Då beslutsprocessen $\mathrm{d} v \mathrm{~s}$ avseende ledningens process för att välja strategi är central för styrningen, analyseras denna explicit och speciellt avseende den dynamik som kan observeras över tid. Vidare studeras bara tillämpningar av processer för värdering som potentiellt kan underlätta beslut (ex ante) direkt inför, respektive mätning (ex post) direkt efter, ett företags strategiimplementering (jfr "single loop learning"), d v s ingen analys görs av hur styrningen explicit påverkas av inlärningseffekter utifrån tillämpningen av mätsystemet $\mathrm{i}$ beslutsprocessen. Studien $i$ denna fas avhandlar inte några kognitiva aspekter på kommunikation i styrsystemen. 


\section{Kapitel 6 Fallstudien FORCE Perioden 2006 - 2008}

\subsection{Case FORCE ${ }^{63}$}

För att studera vilka överväganden, vilka kriterier och vilka övriga styrsystem och instrument som beslutsfattare för ett specifikt projekt och inom ett nytt affärsområde använder med delvis andra förutsättningar jämfört med tidigare "cases", så har en empirisk studie genomförts vid en ny affärsenhet, BU 3 och ett "hög-risk"-projekt; projektet Case FORCE.

Som ett led i de empiriska studierna inom `målföretaget` ${ }^{64}$ om hur resursbaserade strategier kan förväntas påverka organisationens ekonomiska styrning och explicit dess kapitalstrukturer vid större investeringar, beslutades vid ett möte med organisationens globala forskningsenhet (BU FoU/CR) under den första empiri perioden att en empirisk studie skulle genomföras under 2007. Man föreslog att studien vid lämplig tidpunkt skulle genomföras i en stor, ny global affärsenhet inom ett nytt affärsområde.

Den aktuella affärsenheten (BU 3) omfattar flexibla system för överföring av energi i stora kraftnät. Enheten marknadsför lösningar som möjliggör för energianvändande system och verksamheter att med bibehållna stabilitets- och säkerhetsmarginaler kunna effektivisera dessa. Ett projekt, här benämnt "FORCE" berör primärt denna nya affärsenhet (BU 3). Affärsenheten omfattar ett helt nytt affärsområde som också (från 2006-01-01) är en egen division i koncernen. Affärsområdet sysselsatte år 2006 globalt ca 250 personer men är det mest expansiva affärsområdet inom koncernen och hade år 2019 ca 8000 medarbetare. Området är starkt FoUorienterat och sysselsätter också ett stort antal personer inom koncernens gemensamma forskningsenhet. Inom detta område utvecklas med stor global framgång, bland annat helt nya system inom miljö/energiområdet och omfattar lösningar för verksamheter som samtidigt är mycket informationsintensiva.

I överenskommelse med affärsenhetens ledning år 2006 har en studie av "FORCE" genomförts inom ramen för denna avhandling och då med avseende på om och i så fall "hur ett resursperspektiv kan tillämpas $i$ affärsenheternas strategiarbete och ekonomistyrning, primärt utifrån ett behov att utveckla ett nytt koncept för ekonomisk styrning av höginnovativa och projekt med potentiellt hög risk $s$ New Development Project, NDP.

\subsubsection{Case FORCE - Bakgrund}

Målföretaget använder globalt, som underlag för sin ekonomiska styrning, ett beslutsstödsystem som har utvecklats internt. Detta system samlar information från en mängd olika affärssystem från olika leverantörer och med olika fokus på tillämpningsområde. Beslutsstödsystemet kompletteras med information av såväl monetär som annan styrinformation. ${ }^{65}$ Detta beslutsstödsystem används även på BU-nivå mer eller mindre frekvent. Inom FoU är systemet implementerat för att primärt styra koncernens globala program inom affärsområde FoU/CR. Systemet integrerar och konsoliderar global forskningsinformation både processuellt

\footnotetext{
${ }^{63}$ Bilagor finns i originalrapporten och biläggs därför inte i avhandlingen

${ }^{64}$ Se bil 1; 2006-08-14

${ }^{65}$ Systemet beskrivs också av Simons i dennes kursbok (Simons, 2007).
} 
och funktionellt, d v s "horisontellt" respektive "vertikalt" enligt företagets processmodell. (Figur 12)

Inför genomförande av studien formulerades först en problemställning om en "ny" strategisk ekonomistyrning:

"Studien avser at ta reda på om man, utifrån ett resursperspektiv, kan identifiera värderingar $i$ systemet som idag inte används vid utvärdering av ett konceptuellt intressant produktutvecklingsprojekt. Det namngivna projektet "FORCE" föreslås bli en "case story" som kan användas som exempel på organisationens strategiska ekonomistyrning"

\section{Projektledare för "FORCE"}

Då projektet förväntas omfatta en `ny kontext' beskrivs ett nuläge avseende vilka modeller, vilken information och vilka kriterier som används i samband med organisationens ekonomistyrning i projektets olika faser. En något utvidgad kontext föreslogs också omfatta några strategiskt utvalda kunder och leverantörer d v s ett affärsutvecklings-/affärsstrategisperspektiv läggs också på styrningsfrågorna. Initialt framställdes att empirin har en tydlig fokus på energieffektivitet och samtidigt ett långsiktigt finansiell/lönsamhetsfokus.

I projektplanen specificerar projektledaren mål och en intern arbetsgång för detta projekt och som involverar denna forskningsstudie (hämtat från projektplan):

Step 1 - Find a system to value:

"Our aim is to mirror a project/concept as a "shared work". We aim to create something that can emerge as a shift of the present paradigm. This NDP is a suitable project since it has passed some critical phases (that can be evaluated) and is now ready to be implemented. It is a concept on the "technological front edge". Tender and field demo is conducted.

The challenge: Find 5-9 "soft" arguments (values) and communicate them. The customer dialogue is central in this process. The financial solution is crucial".

Step 2 - Communicate:

"Find and communicate strategic values for our company. After deciding upon customer values - find image arguments that shows that we are in "leading" position, that should be included in the assessment. Find further argument that will shorten lead time, especially important for far East markets.

\section{Financing:}

"This project can be showed to demonstrate technical benefits (environmental), financial benefits AND social benefits! This threefold dimension of "sustainable technology" shall be viewed primarily from a "financial" $(i$ e return on assets/resources) point of view! Energy as a main resource and making resource efficiency and sustainable growth with this concept should be of certain "financial" interest - especially from environmentally interested communities and parties"

(PL $B U$ 3) 


\subsubsection{Case FORCE - Genomförande ${ }^{66}$}

En helt ny produkt, FORCE, har utvecklats i samarbete mellan intern forskning (BU FoU/CR) samt en affärsutvecklingsenhet inom BU 3 och två leverantörer. Den testas f n som en "pilot" hos en kund i södra Sverige. Ett andra pilotprojekt planeras för utvärdering i Storbritannien (GB). Produkten FORCE betraktas som ett helt nytt koncept och har ur ett vidare resursperspektiv bedömts innefatta ett flertal av de områden där företaget önskar vara världsledande och i och med detta uppnå ett uttalat långsiktigt mål eller en vision inom ‘hållbara' tillväxtsegment.

Studiens föregicks av två förberedande möten, dels med ledningspersoner inom BU FoU/CR och organisationens miljöstab (Corporate Sustainability, CS) (bilaga 1) dels med ledningen av BU 3 (bilaga 2 a,b). ${ }^{67}$

Som ett test inför genomförande av detta "business case" prövades den modell för processanalys som tillämpats vid Case ROBO En intervjuomgång genomfördes med dessa ledningspersoner inom respektive BU. Processen innebar ett antal frågor till ledningen, ställda i en viss ordning, här enligt Simons modell och PDCA-modellen (Figur 6 och 7). Svaren förväntades tydliggöra företagsledningens tillgång till information, dess kunskaper om organisationens resurser (inom BU 1 och BU FoU/CR) och andra förutsättningar som potentiellt påverkat projektledningens beslutsprocess och implicit därmed organisationens/ projektets ekonomiska styrning.

Vidare diskuterades vid dessa intervjusvar hur tidsperspektivet relativt koncernens övergripande mål, val av strategi och resurspositionering $\mathrm{d} v \mathrm{~s}$ expansion versus konsolidering (Figurerna 16 och 17) påverkar affärsledningens (vid BU 3) strategiska val och hur styrningen av enskilda projekt, inom det utvalda affärsområdet, påverkas av det strategival som ledningen gjort.

Efter beslutet om att starta studien av projektet FORCE genomfördes tre möten med personer kopplade till affärsutvecklingen av projektet; projektledare för projektet inom BU 3, controllern för BU 3 samt med ansvarig för produktutvecklingen, projektledare inom BU FoU/CR.

Vid det första mötet gjordes en situationsbeskrivning av utvecklingsprojektet FORCE och vid det senare mötet uppdaterades projektets status då också kunden i GB tagit beslut om en pilotinstallation. Vid detta möte formulerades också denna forskningsstudie utifrån vad projektledaren förväntade sig för svar på ett antal specifika frågor.

Huvuddragen i denna fallstudie innebar, som nämnts inledningsvis ett önskemål från projektledaren för FORCE, ett arbete efter en "trestegsmodell". Steg 1 innebär att identifiera och värdera projektets strategiska resurser och förmågor. Steg 2 innebär att kommunicera projektet internt. Genom att fokusera projektets finansiering avsågs att utveckla argument för att effektivisera hela processen, $d v$ s såväl inputvariabler som de huvudsakliga processerna ${ }^{68}$ samt outputvariabler.

\footnotetext{
${ }^{66}$ P.g.a. förseningar i projektet kunde alltså inte Steg 2 (kommunikation) och Steg 3 (finansiering) göras i sin helhet då utvärdering av pilotprojektet inte gjorts per september 2010).

${ }^{67}$ För att få en uppfattning om ledningens förväntningar på detta speciella forskningsprojekt (Case FORCE) genomfördes en första serie intervjuer med lednings-/ styrgruppen inom BU 3.

68 I denna empiri berörs själva 'förädlingsprocessen' endast implicit genom mätning av förändring av förädlingsvärde mm
} 


\subsubsection{Case FORCE - Fokuserade strategi och styrningsvariabler}

Affärsutvecklingsansvarig vid BU 3 formulerar inför upplägget ett konkret problem som uppstått vid strategiutvecklingen runt utvecklingsprojektet FORCE:

"Vid värderingen av utvecklingsprojektet (FORCE) var det svårt att i ett tidigt stadium kvantifiera och presentera de värden som man fär ut som slutlig effekt $i$ form av bland annat

- den potentielle kundens bild av företaget,

- myndigheternas/högskolornas/universitetens bild av företaget,

- rekryteringsmöjligheterna till företaget,

- de värden som konkurrenter/investerare ska analysera samt

- de värden som är relevanta för att beräkna organisationens tillväxt och lönsamhet.

(Affärsutvecklingsansvarig BU3)

"Det är önskvärt att projektet undersöker om man kan identifiera dessa "värderingar" för företaget, "värderingar" som inte idag (2006) används vid (ut)värdering av ett utvecklingsprojekt. Det namngivna utvecklingsprojektet (FORCE) föreslås bli en "case story" för detta syfte".

(Projektledare FORCE)

Den studie, ett "business case" som här genomförts omfattar alltså ett större utvecklingsprojekt, hög-riskprojektet FORCE. Projektet är i början av en etableringsfas och där fn ett "pilotprojekt" är under uppstartande. Utvecklingsprojektet initierades tillsammans med en leverantör redan år 2002-2003 och hade (2006) passerat ett antal (fyra av sju) "gates" i en projektmodell som tillämpas i företaget, den s.k. "Stage-Gate-modellen" (Figur 11). Motsvarande inom BU 3 är gate 1; d v s överlämning har just skett från organisationens forskningsenhet (BU FoU/CR) till produktutvecklingsgrupp vid affärsenheten (BU 3).

Följande variabler studerades inom ramen för case FORCE

Systemiska faktorer (Inputvariabler)

(A) Måldimension (ur ett ledningsperspektiv)

De systemiska faktorerna som studerats är länkade till ledarskapets förutsättningar, mål och strategi för projektet "FORCE" samt kriterier för strategisk ekonomistyrning. Redovisas under avsnittet Intervju med ledningen.

(B) Resurser/Mätbarhet (Frågan: Vad?)

De resurser (egna och partners) som kan identifieras som strategiska för projektets konkurrensfördel och dess mätbarhet (B). Redovisas under Intervjuer med ledningen samt med projektledare och controllers.

Integrerade processer (Processvariabler)

(C) Organisering/Strategi (Frågorna: Vem, vilka, för vem och varför?) Den ena typen av integrerade processer (för strategi/styrning) som studerats är den organisation och organisering (för åtagande/ansvar, legitimitet) som omfattar hela BU 3 samt avgränsat till projektet "FORCE” beträffande relationen BU 3 och BU FoU/CR. Redovisas under Intervjuer med projektledare och controllers. 


\section{(D) Beslut/Värdeskapande (Frågorna: Hur och med Vem?)}

Den andra typen av integrerade processer som studerats är beslutsprocesserna. Här redovisas endast ledningens förväntningar på en strategisk styrning samt potentiella 'problem' vid värdering, implementering och tillämpning.

De frågor (Varför? För Vem? etc) som studeras inom ramen för integrerade processen är ex ante förutsättningar (Se kriterier; Peteraf, 1993). Vidare beskrivs här de kriterier som de intervjuade ansett viktigast för projektet vid analys av beslutsprocessens olika delar. Redovisas under intervjuer med projektledare och controllers.

Styrningens output (Outputvariabler) ${ }^{69}$

(E) Mätning, effekter (Frågan: Vilka konsekvenser?)

(R 1) Resultatplanering (Frågan: Hur blev det?) Styrningens "output". Frågor ställdes bland annat om vilka instrument som används vid mätningen och uppföljning; kalkylering, budget, andra mätsystem och tekniker. Redovisas under intervjuer med projektledare och controllers.

\subsubsection{Case FORCE - Informationsinsamling och tidplan.}

Denna fallstudie genomfördes som en kvalitativ studie i strukturerad form med intervjuer. Sex personer ur BU 3's ledningsgrupp, två projektledare för projektet (varav en från BU 3 och en från BU FoU/CR) samt två affärscontrollers (varav en person från BU 3 och en person från BU FoU/CR) intervjuades under två dagar. Intervjuerna med ledningspersoner genomfördes individuellt under en timme med var och en. Övriga intervjuer genomfördes vid två tillfällen där respektive projektledning och en controller närvarade. Inför den första intervjuomgången genomfördes försöksintervjun för att kontrollera och bedöma relevansen i frågeställningar och möjliga svarsalternativ utifrån huvudfrågeställningen.

Sammanlagd intervjutid (Fas 1) var 18 timmar. Intervjuerna genomfördes efter ett i förhand utarbetat frågeformulär i syfte att frågorna skulle uppfattas lika av respondenterna. Övriga intervjuer har genomfördes i dialog efter en i förväg fastställd agenda. Svaren redovisas som kommentarer som analyseras i kapitel 5.0.

Tidplanen omfattade två perioder:

\begin{tabular}{|c|c|c|}
\hline \multirow{3}{*}{$\begin{array}{l}\text { Period } 170 \\
\text { Period } 2\end{array}$} & Fas 1-3 & $1 / 8 \quad 2006$ to m \\
\hline & Fas 4:1 & 2007 t o m \\
\hline & Fas $4: 2-5$ & $15 / 32008$ to m \\
\hline
\end{tabular}

\footnotetext{
${ }^{69}$ Mätning respektive Resultat vid implementering av en viss strategi kan som helhet först redovisas i samband med del 2 av FORCE-rapporten. Intervjuerna i del 1 svarar här bara på vad respondenterna förväntar sig i dessa två avseenden.

${ }^{70}$ I slutet av den första forskningsperioden (2005 - 2007) genomfördes som ett led i forskarutbildningen ett antal teorikurser vid LiU och studien planerades att starta 2008 för att sedan slutföras i Fas 2 och 3 under en mellanperiod (2009 - 2014). Projektet försenades ytterligare, G4/G7 förväntades nu kunna passeras tidigast hösten 2010.
} 
Under perioden 1/5 t o m 15/8 2007 genomfördes initiala möten vid fyra tillfällen med PL samt controllers. De första intervjuerna med BU 3 (Fas 1) ledningsgrupp genomfördes redan den 14/8 2006. Tiden mellan period 1 och 2 är ca 6 månader och projektet beräknas ha passerat GATE 4 innan resultat från pilotprojektet i GB skulle kunna utvärderas.

Efter intervjuerna med ledningen för BU 3 (sex personer) genomfördes intervjuerna med de personer som varit direkt involverade $i$ styrningsprocessen i samband med projektet i dess olika faser (två personer inom BU FoU/CR samt två personer inom BU 3). Resultatet från de första intervjuerna med BU 3 ledningsgrupp (Fas 1-3) sammanställdes och redovisats vid möte med PL samt BU FoU/CR den 26/3 2007.

De åtta personer (6 BU 3, 2 BU FOU/CR) som intervjuats (i Fas 1) var:

Senior vice president BU $3(\mathrm{CS}) *$ )

Ny VD, Senior vice president BU 3 (PE) (fr o m 2008-06-01)

Vice president, director BU FoU/CR ( $\mathrm{f}$ ny fr o $\mathrm{m}$ 2007-12-01) *)

Manager Business Development BU $3(\mathrm{PH}) *$ )

Manager Research and Development BU 3 (PL) *)

Project manager Technique BU 3 (JS)

Marketing manager BU 3 (TS)

Manager Power and Automation BU FoU/CR (MC) *)

(Ny tillträdande Managing Director, BU FoU/CR (PD) (OP)

Planerade men ej genomförda intervjuer (Fas 1)

Potentiell kund (GB)

\subsection{Sammanfattning av intervjuresultat från ledningsgruppen inom BU 3 redovisade enligt analysmodellens element.}

\section{Måldimension}

Om måldimensionen; ekonomi och värdering av resultat. Övergripande mål för affärsområdet för BU 3 är finansiell avkastning. Måldimensionen i denna empiri har dock primärt diskuterats $\mathrm{i}$ andra termer i samband med att styrgruppen för denna studie valde ut detta ytterligare projekt med hög risk, att analyseras specifikt. Det innebar att en fokus, utöver finansiella aspekter, lades "ex ante" vid konceptets/produktens energi- och miljöaspekter; d v s affärsriskaspekter som potentiellt påverkar organisationens konkurrensfördel då energi- och miljöstyrning med informationsteknologi ansågs vara två av organisationens kärnkompetenser och energi är organisationens primära resursslag och potentiellt utgjorde en affärs-och lönsamhetsrisk på olika sikt då projektets applikation handlade om potentiellt mycket omfattande investeringar i infrastruktur i energiintensiv industri.

I denna empiri, "Case FORCE”, är måldimensionen i operationella termer klart uttryckt som "lönsamhet" i termer av långsiktig avkastning. I empirin noteras speciellt att likviditetsaspekter, "cashflow", inte omnämns för projektet.

Avkastning i denna empiri är starkt kopplat till målet resurseffektivitet (se nedan) men inte primärt finansiell effektivitet utan snarare energieffektivitet, dock att detta inte är explicit 
uttalat. Ledningens måldimension bygger på att projektet är designat för att uppnå en unik och uthållig konkurrensfördel för projektet, målet är en förväntat hög avkastning över "normalt" som ett resultat av en strategi där ledningen fokuserar organisationens resurser och kompetens.

Svaren visade också att ledningen har förväntningar på att projektet "FORCE" ska bidra till att stärka bilden av målföretaget som ett företag

- som har lätt att fatta beslut och

- som arbetar för att uppnå en uthållig ("sustained") eller hållbar ("sustainable") konkurrensfördel.

Projektet har som nämnts ovan från början medvetet designats för att ge företaget en uttalad

- unik konkurrensfördel vilket av respondenterna här implicit tolkas som en 'hållbar' eller 'uthållig' verksamhet.

\section{Strategiska resurser}

Studien avhandlar här begreppet "resursbaserat perspektiv" och om andra begrepp samt om hur företaget identifierar sina strategiska resurser. För att få en uppfattning om hur ledningen inom affärsområdet (för BU 3) definierade begrepp samt vilka andra kopplingar man gör inför att potentiellt kunna "anamma" ett resursbaserat perspektiv intervjuades utvalda personer enskilt beträffande deras uppfattning om sex olika begrepp. Här redogörs dels för affärsledningens syn (VD BU 3) och för en sammanställning från övriga intervjuer:

Resultat från intervju med VD om begrepp (ny VD för BU 3)

- VD:s första kommentar var beträffande "resursperspektivet" att det verkade väl "introvert". Beträffande utveckling av BU's strategisk förmåga kommenterade VD att det man beslutat utveckla som strategisk kompetens för BU 3 är "en (här specificerad) unik teknologikompetens".

- Beträffande strategisk ekonomistyrning framhöll VD behovet av långsiktighet men att det inte fanns utrymme för de personer som har marknadskontakten att göra någon form av långsiktig analys. Man har gjort försök med olika former av marknadsplanering. Nu testas en ny form (av strategisk analys).

- Beträffande "unik" konkurrensfördel (uthållig konkurrensfördel) kommenterade VD om fördelen med konkurrensen med "likartade" produkter" men med delvis olika teknologi (jämfört med att vara ensam med sitt erbjudande att lösa ett problem för kunden) var positivt då det öppnade upp marknader. VD exemplifierade detta med en produkt som höll måttet i tio år där företaget var ensam med sin teknologi i jämförelse med andra lösningar som tillfredsställde samma kundbehov.

- Beträffande hållbart (se frågeformulär) beskrev VD att detta begrepp var organisationens (BU's) verkliga nisch d v s med existerande system/arkitektur kan företaget hjälpa världen med ett komplett, effektivt och stabilt system (exemplifierat med behovet vid Fort Knox i TEXAS). Det gäller speciellt vid växande stadsregioner där produktionen inte kan ligga i stadskärnan. I stället ersätts denna produktion med hjälp av två anläggningar (VD jämför med Internet) där man helt ändrar förhållandena i distributionen. Anläggningar "seriekopplas" för att få fram mer effektivitet (dubbla volymen) $\mathrm{i}$ befintligt system (i st. för att bygga ut nya system). 


\section{Resultat från enskilda intervjuer om begrepp med sex personer inom BU 3`s ledningsgrupp,}

inklusive t.f. $V D$

Beträffande strategi för RESURSTILLVÄXT (utifrån att resursbegreppet diskuterats i samband med tillväxt) gör respondenterna en koppling av detta begrepp

- till samhällsnyttan

- till INDIVIDEN och organisationen (och dess kompetensutveckling)

- till att användas som argument i Marknadsutvecklingen

Beträffande uthållig konkurrensfördel med betoning på uthållighet (och implicit som konkurrensfördel) gör respondenterna följande koppling

- till Produkt-effektivitet

- till Mervärdet

- till Resursslöseri

- till livscykelanalys (LCA/LCP)

- till att "köra i Mål" (projektet)

- till integrerad produktutveckling (PUTV)

Beträffande hållbarhet d v s i betydelsen "hållbar utveckling" gör respondenterna följande koppling

- till Resurs-effektivitet

- till Samhället

- till Miljön

- till "internt" organisationens överlevnad

- till avdelningens (BU 3’s) framgång

- till produkten/tekniken (stillestånd)

- till "kunden", ska ge input

- till Visionen

- till "Gör vi tillräckligt?"

\subsubsection{Resultat och kommentarer från samtliga intervjuer med ledningsgruppen.}

Ledningen har förväntningar på en ny affärsmodell utifrån ett resursperspektiv. En modell för detta projekt bör baseras på följande målkriterier för ekonomistyrning och därmed klassificera olika strategiska resursslag 1) respektive specifik strategisk förmåga hos organisationen. 


\begin{tabular}{|l|l|l|}
\hline Målkriterier för strategisk ekonomistyrning & Strategisk resurs & Strategisk förmåga \\
\hline $\begin{array}{l}\text { Optimering av befintlig struktur/ optimering } \\
\text { av energins verkningsgrad }\end{array}$ & Energi & Matematisk \\
\hline $\begin{array}{l}\text { Lagring vid överproduktion } \\
\text { Add On/Added Valule }\end{array}$ & Energi & Kapacitet \\
\hline Ökad processeffektivitet /tex för stålindustrin) & Pengar & Mervärde \\
\hline Automation av distributionsnätet & Inbygg teknologi & Systemförmåga \\
\hline Fler tillämpningsområden & Applikations-teknologi & Marknadskompetens \\
\hline Unik kompetens & Inbyggd information & ? \\
\hline
\end{tabular}

Figur 10. Ledningens målkriterier samt identifierade strategiska resurser och förmågor (författarens sammanfattning och översättning)

Den nya övergripande strategin innebar att förändra attityderna genom strategiska projektmål som dessa; lyfta fram dem och anpassa strategin med olika och nya referenser.

\section{Kommentar om målkriterier:}

Dessa kriterier analyserades och diskuterades övergripande i anslutning till vad som kunde avses med "resursbaserad" strategi versus en "marknadsbaserad" strategi och hur företaget kunde förväntas generera avkastning och fä en unik konkurrensfördel. Detta har inte kunnat visas i siffror ännu men däremot har det hittills handlat om 'uppfattning' utifrån erfarenhet och kunskap. Vad som är uthålligt och framförallt 'hållbart' ("sustainable") varierar mellan de intervjuade (se ovan) samt i vilket sammanhang detta mål kan tillämpas. En av ledningens förväntningar på denna studie är att den ska finna de värden som tydligt sätt manifesterar "hållbart" (implicit 'uthålligt'), kunna underlätta att ta rätt strategiska beslut och sedan kommunicera dem. Detta borde enligt respondenterna kunna mätas, men någon egentlig mätning som relaterar till detta mål finns inte enligt respondenterna.

\section{Kommentarer om kunskap; vad?}

Behovet av tydlighet och operationalisering av kunskap/begrepp var stor hos ledningspersonerna; likaså mer kunskap om vad som egentligen "triggar" (d v s varför?) i ett projekt respektive vilken egentlig kunskap som avgör hur man ska organisera sig, utifrån den strategi som kommer att tillämpas. Om det är den absolut grundläggande kunskapen, kunskapen om "kärnresursen" eller om det är förmågan att medvetandegöra och utveckla den, som är viktigast för att utveckla organisationen för mer "hållbarhet" är oklart för respondenterna. Vad i beslutsprocessen som är mätbart och vad (resursernas karaktäristika, kapacitet hos systemets förmåga eller hur resultatet påverkas i olika avseenden resultat eller effekten) som ska mätas är också oklart! 


\section{Kommentar om strategiska resurser och förmåga; vad och varför?}

Ledningsgruppen diskuterades vad strategiska resurser och strategisk förmåga innebar för målet "uthållig konkurrensfördel". Några kriterier (om resurser och organisationens förmåga) kunde respondenternas spåra i beskrivning av nuläget i projekt "FORCE".

Den lösning som "FORCE" representerar är helt framtagen utifrån att de resurser som avses är mycket värdefulla för kunden (= energi). En tillfällig förlust av denna energi får konsekvenser och stora värden går förlorade. Den slutliga lösningen som projektet representerar är en totallösning i detta initiala skede och den har inte någon egentlig motsvarighet ( $\mathrm{d}$ v s den är, om inte helt okänd för potentiella kunder/leverantörer $\mathrm{m}$ fl., så är den ändå mycket unik i energisammanhang (= m a o är det också ett "högriskprojekt")

Implicit i kunskapen om energi som strategisk resurs ligger att den är i sitt ursprung, i en viss form, både sällsynt och värdefull. Dess strategiska egenskap måste bedömas ur ett mer helhetligt sammanhang. När energi "kapslats in" har den i sin ursprungliga form (som lägesenergi) bland annat en begränsad flyttbarhet (jfr VRIO-kriterier). För att förflyttas måste den omvandlas till en ny form; denna omvandling och hur den görs, avgör hur strategisk denna resurs kan betraktas. Det innebär att kriterier för omvandling d v s systemets karaktär och kapacitet är avgörande (jfr "dynamic capability").

\section{Kommentarer om mätning; kvalitet eller kvantitet?}

Mätning i projektet av de resurser och förmågor, tillgång och karaktäristika och de processer som ger projektet dess unika konkurrensfördel, förväntas dock bygga på någon form av kvalitetsbestämning. En faktor som föreslås mätas är den glädje (!) som de inblandade har i projektet. Detta skulle spegla drivkraften eller beslutsförmågan i projektet och därmed kanske kunna mätas. Om glädje kunde kategoriseras som en resurs, som en förmåga eller som en egenskap/karaktäristik/tillstånd (i ett system) i något avseende måste diskuteras vidare.

\subsubsection{Sammanfattning av ledningens uppfattning om begrepp och av ledningens syn på systemiska faktorer}

Resultatet visade att det i vissa avseenden, exempelvis vilket värde för kunden som projektet kunde bidra med, visade stor samstämmighet, medan det $\mathrm{i}$ frågorna som handlar om vilken typ av nytta och hur projektet bidrog till en "hållbar utveckling" visade olikheter i dessa begrepps egentliga tillämpning. Begreppen kopplades till produkten och till teknikens tillförlitlighet, till organisationens vision, till samhället, miljöförstöring och till organisationens framgång mm. Begreppet "hållbar utveckling" kopplade fyra av sex respondenter ändå direkt till resurseffektivitet på olika sätt (se ovan). Begreppet "uthållighet" kopplades till "intern effektivitet" på olika sätt medan begreppet "resurstillväxt" kopplades till samhällsnyttan (eller till nyttan för individen) men en av respondenterna koppling det till marknadsutvecklingen.

Nyttobegreppet kopplades ändå starkt till värdet, med en svag koppling till pengar/finansiella mått. Begreppet var starkt riskrelaterat och kopplades till olika försäkringslösningar. Osäkerhet bedömdes finnas överlag; om tekniskt utfall, om utfall av prissättningen och osäkerheten varierar beroende på tidshorisont. Riskbegreppet och behovet av en riskdefinition relaterades bara till produktens tekniska egenskaper. 
Begreppet "sustainability" (hållbar) eller "sustained" (uthållig) visade en stark koppling till såväl publik som företags överlevnad (implicit via uthållig konkurrensfördel). Produktens livscykel går också att manifestera med begrepp som innebär 'hållbar' eller 'uthållig'. Värdet av att använda befintlig struktur i organisationen är till exempel bättre för resurseffektiviteten (d v s bättre att utveckla den egna potentialen innan man investerar i ny struktur).

En åsikt som framkom samtalen om styrningen av detta projekt (FORCE) är den möjliga RESURSEFFEKTIVISERINGEN, $\mathrm{d} v \mathrm{~s}$ genom optimering med nya metoder och processer vid ökande investeringar så ökar resurseffektiviteten. Ännu var dock inte verkningsgraden (VG) i denna lösning beräknad. VG kan komma att slå olika i olika miljöer.

En åsikt för "hållbart” är att det kan innebära en helt ny kunskap om värdet av samhällsnyttan, ett argument för hela energimarknaden. I den omvärld där denna produkt finns styrs marknaden i stor utsträckning av regelverket; Om trycket på samhällsnytta ökar genom ny kunskap så anses argument som innebär ökad resurseffektivitet, få gehör. Idag kopplas inte NYTTA och VÄRDE samman i argumentationen till kunden. Om detta (resurseffektivitet eller processeffektivitet) kan speglas på andra nivåer i till exempel företags värde eller som unik samhällsnytta (lägre skatt etc.) mm så anses det kunna bli ett argument.

\subsubsection{Kompletterande intervjuer med projektledare $(\mathrm{PL})$ och business controller $(\mathrm{BC}) .{ }^{71}$}

Resultat från de kompletterande intervjuerna (Fas 4) med projektledare samt controllers den 22/5 2007 (PL BU FoU/CR + BC BU 3) samt vid "Kunskapsmöte" den 3/7 2007 (PL BU 3 + $\mathrm{PL}$ BU FoU/CR + BC BU FoU/CR) ${ }^{72}$

Måldimension (A) (Se inledning; endast ledningsperspektiv varför det ej diskuterats vid dessa intervjuer)

Strategier och resurser $(\mathbf{B})$ och deras mätbarhet. Resultatet från dessa intervjuer redogör primärt för de nuvarande kriterierna för ekonomistyrningen vid BU 3 av projekt utifrån olika strategival. Redan vid analys vid Gate 2 görs (hos BU FoU/CR) en lönsamhetsbedömning. I tidig fas används balanserat styrkort (BSC) i flera dimensioner. I styrkortet bedöms (ex ante):

- Marknaden (avsättnings-) för den tekniska lösningen (relativt högre vikt)

- Strategisk kongruens i projektet (relativt högre vikt)

- Patent och "intellectual properties" (dock bara risk för eget intrång, ej som strategisk möjlighet)

- Behov av/möjlighet till leveranskapacitet

- Behov av/möjlighet till insourcing/outsourcing (av verksamhet)

- Eventuella resultat som "spin-offs"

Kommentarer om Resurser och förmåga.

Den enda "RESURS" som explicit identifieras i styrkortssammanhang är (andras) patenträttigheter; kan alltså vara leverantörs rättighet. En genomgång av svaren pekar dock på ett stort antal potentiella resurser av olika slag. För att identifiera dessa inför olika beslut behövs dock någon form av kategorisering eller klassificering.

\footnotetext{
${ }^{71}$ Se Agenda samt Protokoll 14/8 2007

${ }^{72}$ Se bilaga 11
} 
Intervjusvaren pekar på möjligheten att också identifiera några viktiga förmågor som finns inbyggt i såväl detta specifika projekt som i organisationens organisation.

Begreppet FÖRMÅGA anses i sin helhet kopplat till människan, som individ eller som en del av organisationen. En drivkraft bakom utveckling av förmågan förklaras med att projektet upplevs som 'KUL' d v s 'GLÄDJE' ('Spirit") och detta stimulerar förmågan att ta beslut. Denna 'glädje' upplevs kunna mätas.

Graden av förmåga uttrycks i termer av i vilken utsträckning man kan TA BESLUT; något som bygger på erfarenhet och kunskap om målet (d v s ofta MÅLET för KUNDEN) när det gäller projekt som detta. Företaget speglar totalt en kultur med hög förmåga att ta beslut; baserat på insikten om MÅL samt erfarenhet från området (information som en resurs (!) i sammanhanget.

\section{Organisering (C) samt Beslutsprocesser (D)}

\section{Kommentar om organisering; hur?}

Frågorna om organisationen besvarades vid ett flertal olika intervjutillfällen. Vid förarbetet presenterades organisationens projektorganisation och processmodell (Figur 12) Processmodellen är ett uttryck för organisationens strävan att finna en modell för att (i ett visst läge) 'konsolidera' verksamheten i och för utformning av organisationens affärssystem och en anpassning till befintlig beslutsstruktur enligt BU-modell. ${ }^{73}$ Idag har processmodellen främst ett värde i beskrivningen av organisationens värdekedja. Organisationens modell för organisering i mer strategiska projekt illustreras med den s.k. "GATE-modellen" (Figur 11) där ett antal olika strategier för att positionera resurserna kartläggs inför beslut. Två typiska strategier vid projekt är alternativen att 'insourca' vid expansion eller 'outsourca' vid konsolidering. Förvärv av potentiell alternativ leverantör diskuterades som en option.

\section{Kommentar om beslutsprocesserna (ex ante):}

Den strategiska styrningen måste ta fasta på de olika skeenden som ingår i en beslutsprocess; tidigare personliga upplevelser (ex ante) $i$ kombination med rationell och strukturerad information i vissa delar av beslutsprocessen.

\subsection{Analyssteg 1 - Partiell analys av måldimensioner mm}

Denna första delstudie (steg 1) handlar primärt om ledningens perspektiv och i ledningens förväntningar på att projektet FORCE ska bidra till organisationens vision och strategi för "hållbar utveckling" och tillväxt. Vid kompletterande intervjuer tydliggjordes de olika delarna av den struktur (A - E) som används vid analys d v s den föreslagna analysmodellen. En sammanfattande bedömning så här långt är att det råder en samsyn mellan de intervjuade, oaktat man i vissa avseenden gör olika tolkningar; olikheterna gäller snarast tolkningen av olika begrepp som har med just "hållbar" eller "uthållig" att göra.

Här nedan analyseras, i enlighet med analysmodellen (A - E/R 1), om företaget kan anses tillämpa ett resursperspektiv $\mathrm{i}$ nuläget och hur ett framtidsbeslut kan påverkas med ett resursbaserat synsätt i strategiarbetet. Redan här nämndes i empirin i någon mån ledningens

\footnotetext{
${ }^{73}$ Motsvarande arbete pågick hos exempelvis systemleverantören SAP de första åren av 2000-talet. Detta ansågs påverka även målföretagets processmodell då SAP R 3 implementerades i hela organisationen.
} 
förväntningar ${ }^{74}$ på organisationens "nya" strategiska styrning och förväntade implikationer på företagets resultat- och kapitalstruktur. De sex element som analysmodellen också redogör för (A-E) ansågs av projektledare och controllers som de viktigaste att fokusera vid analys av projektets ekonomistyrning.

Denna analys har ur forskningssynpunkt haft ett dubbelt syfte. Den syftar dels till att ge ett eller flera exempel på strategier där resursbegreppet och andra begrepp från resursbaserade teorier är tillämpbara vid 'ny' styrning, såväl vid planering som vid implementering av en strategi, dels till att förstå effekter på företagets kapitalstrukturer. Studien analyserar därför strategiska utmaningar respektive potentiella möjligheter vid den ekonomiska styrningen, ex ante/(ex post) i samband med detta komplexa produkt/affärsutvecklingsprojekt. Tanken med analysen är att undersöka hur information används vid den ekonomiska styrningen, vilken information som kan förtydligas och eventuellt kan operationaliseras för att underlätta beslut, kommunikation och uppföljning av målen och de valda strategierna.

Implicit syftar analysen också till att försöka få svar på om och hur organisationens olika strategiska resurser och förmågor kan identifieras i praktiken, hur de organiseras, processas och framförallt om och i så fall hur resultat och effekter kan mätas/värderas - och om detta stämmer med kriterierna enligt teorin. Analysen av respektive element gjordes i två steg: Först analyserades organisationens, det av ledningen beskrivna nuläge $\mathrm{m} \mathrm{h}$ a teorin, $\mathrm{d} v \mathrm{~s}$ utifrån modeller och skolbildning samt $\mathrm{i}$ ett nästa steg hur respondenterna såg på framtiden när det gäller deras respektive förväntningar på ett tidigare uttalat behov av "ny" modell för strategisk styrning. (Figur 8) Primärt syfte med detta andra steg var att få en viss inlärningseffekt och samtidigt få insikt om de strategiska utmaningar som möter ledningen inför en utveckling av en modell för mer 'hållbar' styrning. Ledningens förväntningar diskuteras i kapital 8.0, inför kommande forskning som underlag till de möjligheter som ett resursbaserat synsätt kan bidra till.

En möjlighet med detta "business case" var också att, tillsammans med organisationens företrädare, kunna utvärdera en eller flera tänkbara "resursbaserade" operationella modeller i ett strategiskt och långsiktigt projekt. En modell för beräkning av `tillväxt` användes därför för att beräkna projektets "resurseffektivitet" samt för att också beräkna projektets förväntade respektive uppnådda förädlingsvärde (Johnsson, 2006), dess avkastning (Peteraf, 1993) samt dess förväntade implikation på affärsenhetens 'resursbas'. Den modell som tillämpades för dessa beräkningar är en "lönsamhetsmodell" baserad på DuPont modellen. ${ }^{75}$ Två andra modeller avsåg att belysa hur resurser i företaget kan identifieras, klassificeras och hur organisationens resursposition kunde bestämmas i ett längre eller kortare tidsperspektiv och relativt konkurrenter.

\footnotetext{
${ }^{74}$ I kapitel 8 och 9 återkommer dessa frågeställningar och analyser till slutsatser utifrån aktuell teoribildning (TGF, RBV etc.). En vidare analys av ledningens förväntningar och implikationer på framtida ekonomisk styrning diskuteras i kapitel 8.0.

${ }^{75}$ DuPontmodellen är en erkänd och generellt tillämpad modell för extern rapportering av lönsamhet. Den tillämpas i målföretaget sedan millennieskiftet. Modellen är en avkastningsmodell där tillgångarnas omsättningshastighet, inflation mm ställs mot företagets förädlingsvärde alternativt ingående kostnaden för omsatta varor och tjänster.
} 


\subsubsection{Inför avhandlingens analys.}

Koncernen som helhet har som nämnts under åren 2003 - 2010 genomfört mycket omfattande och successiva strategiförändringar som primärt haft effekt på organisationens övergripande HR-strategier. Perioden inleddes med en stark konsolidering men f n (2019) är koncernen i en expansiv fas med olika inslag av förnyelse i olika delar av koncernen.

Vid mötet med BU FoU/CR 2006-11-28 och vid uppföljningsmöte omkring "FORCE" med BU 3 2007-03-25 fastslogs att alla frågeställningar fortfarande var aktuella och att detta "projekt" fortfarande var lämpligt att studera utifrån organisationens olika mål. Vid det interna mötet som genomfördes 2007-08-14 i form av ett "Kunskapsmöte" indikerades dock försening av projektet. Vid möte med BU FoU/CR 2008-04-09 bekräftades att projektet hade försenats ca 12 månader p. g. a. teknologiskifte. Pilotinstallation beräknades nu bli tidigast år 2010 och först då kunde en representant för kunden intervjuas. På mötet indikeras att förseningen är ett problem som måste analyseras. Vidare hade BU 3 fått ett nytt ledarskap. I de första intervjuerna med ledningsgruppen diskuterades primärt strategier och begrepp som förekommer i detta teoriområde men i huvudsak på projektnivå. "Resursbaserad strategiteori" (RBV) gjordes inte generellt explicit som en trend eller som paradigm inför just denna empiri och teorin blev därför inte heller kommunicerad i samband med den empirin för att inte påverka intervjupersonernas val av svarsalternativ vid strukturerade frågeställningar. Detta är en möjlig orsak till de relativt få utförliga intervjusvar om den ekonomiska styrningen som nu kan analyseras relativt kriterierna för resursbaserade strategier. ${ }^{76}$ I synnerhet framstod ändå ett resursbaserat synsätt tydligt vid diskussioner om nya HR-strategier som genomförts under perioden med stark konsolidering parallellt med den intensifierade energiforskning och teknologiutvecklingen som genomförts vid organisationens FoU. Speciellt visade denna analys vad företaget identifierar som strategiska resurser.

Här nedan redogörs för analysen utifrån `ett resursperspektiv på den företagsekonomiska utvecklingen' har uttolkats och synbarligen tillämpats i denna empiri. Denna empiri exemplifierar dock endast två polära strategier utifrån teorin; med processeffektivisering ("efficiency") i samband med företagets konsolidering respektive produktförnyelse inom BU 3's FoU-verksamhet i samband med expansion. Empirin visar också en potentiell implikation på ekonomistyrningens olika element: såsom organisering när det gäller vilken typ av "system" eller "karta" som används som underlag vid beslut och beträffande beslutsprocessen när det gäller vilken typ av information och vilken kunskap som fodras samt beträffande mätningen vilka modeller som används vid olika typer av värderingar.

\subsubsection{Ledningsförutsättningar (A)}

Ledningens förutsättningar är relaterade till ledningens tillgång till information, erfarenhet och kännedom (kunskap) om de olika förutsättningarna och målen för de olika projekten. En av förutsättningarna är full kännedom om koncernledningens beslut att prioritera projektet FORCE.

\footnotetext{
${ }^{76}$ Av annan empiri (Newbert, 2008) kan utläsas att denna teoribildning (RBV) ändå påverkat ledningar i samband med strategiskt beslutsfattande och att detta kan antas och här bedömas som s k "tysk kunskap" (Polyani, 1962) inför en möjlig fortsatt analys av steg 2 av denna empiri.
} 
Denna empiri visar en måldimension för detta projekt (FORCE) som är tydlig. BU 3’s ledning beskriver målet i tydliga termer av "ett unikt strategiskt projekt" där kunskapen om resursen (energi) och dess egenskaper kan utvecklas till att uppfylla organisationens mål om resurseffektivitet (speciellt hos kunden i form av energieffektivitet och finansiell effektivitet). Implicit framgår att produkten i FORCE också har en 'produktionsdesign' som är unik i sitt upplägg för BU 3 - större andel produceras 'inhouse'- och som kan bidra till projektets långsiktighet och möjlighet för BU 3 att påverka. Samtidigt värderas också speciellt om drivkraften bakom projektet upplevs som GLÄDJE ("spirit") av de personer som är involverade.

Hur implementering av organisationens affärsstrategier påverkas d v s vilken dialog som förs på olika nivåer om vilken 'glädje’ projektet FORCE innehåller är oklart; likaså vad som faktiskt ligger i begreppet för att projektet ska upplevas 'glädjefyllt'. Allt från teknisk fulländning till vilken samhällsnytta projektet har, kan speglas i begreppet. En fokus som detta projekt utgått ifrån är en måldimension som "hållbar" eller "uthållig" teknologi ("sustainable technology"). Med detta målbegrepp avses att påverka människors (kunder, leverantörer/partners och "interners") uppfattning om hela FÖRETAGET. Det är rimligen detta mål, och hur det tolkas och infrias, som ger legitimitet till projekt av detta slag.

"...uthållighet som begrepp används inte $i$ affärsverksamheten, här talar vi istället om modularisering ("building blocks") genom att byta ut delar, skifta leverantörer. FÖRETAGET ligger högt i förädlingskedjan och åtagande i detta projekt är inte integrerat med andra direkt. FORCE säljs som en "stand-alone"-lösning. Det värde som poängteras är snarare "energieffektivitet" (jfr resurseffektivitet") och det är vi som definierar denna. Nyttan är svår att identifiera för kunderna. Företaget har kunskapen om ny teknolog, samtidigt arbetar vi med RISK. Vi säljer också en "försäkring" $i$ energiöverföring (kanske detta kan liknas vid att sälja uthållighet?) Våra kunder köper mer på känsla än på ekonomiska argument (känsla av säkerhet). Vi jagar hela tiden trender (tillsammans med BU FoU/CR) tittar vi på energilösningar där det är viktigt att skapa effektiva system (system för överföring). Vi tittar också på vad man talar om inom företaget (kan vara andra saker än behovet av ny teknik) saker som kan ha en uthållighetskaraktär! (?). Organisationens profil är viktigt. Det kan inte direkt översättas i effektivitetstermer. Det är viktigt med känslan för att det är rätt kund/partner $d v s$ hos vilken går vi hem?"

\section{VD för BU $3(\mathrm{CS})$}

\section{Ledningsförutsättningar enligt resursbaserad teori.}

Ledningsperspektivet och ledningens tillgång till/beroende av och tolkning av information om hela organisationens verklighet och dess mål och uppgift är centralt för tillväxt enligt TGF (Penrose). Kopplingen mellan ledning/entreprenörskap och ekonomisk styrning är ett villkor/och en möjlighet/ enligt TGF;

"Penroses' theory requires an intimate connection between management and entrepreneurship. But managers are directly responsible for the allocation of resources, and resource allocation is the central issue in economics." (Best and Garnsey, 1999)

“... the growing firm; its managers are motivated to solve emerging problems and do so by forming new combinations (of resources and capabilities)"

(Loasby, B.J. in Dictionary of Brittish Economists, 2004) 
".. the managerial capacity to respond rapidly to opportunities by rearranging resources"

(Best and Garnsey, 1999)

"In Penrose approach managers are prime actors, whose 'preferences', however, are shaped by the internal dynamics of firms, their perception of the external (an internal) 'reality', and their own motivation..." (Pitelis, 2005)

Fokus för ledarskapet (-s beslut) är enligt RBV som nämnts för att uppnå målet "uthållig" konkurrensfördel

- att skydda organisationens identifierade "egna" strategiska resurser från extern kopiering

- att "nischa" verksamheten till resursområden med mest gynnsamma förutsättningar för att utveckla de "egna" koncepten

Ledning och ledningens kapacitet att ta beslut handlar om förmåga på individnivå. ${ }^{77}$

Ytterligare kriterier beträffande organisationens måldimension och strategier är enligt RBV (Peteraf, 1993), d v s för att konkurrensfördelen ska vara uthållig ("sustained") och att företaget kan uppvisa och mäta en avkastning utöver det normala, måste/kan

- ex ante, företaget inte ha någon konkurrens (= inte ha information om en eventuell befintlig konkurrens),

- ex ante företaget uppleva en begränsad (extern) tillgång på identifierade strategiska resurser,

- företaget bestå av en 'uppsättning' ('bundle of') identifierbara 'heterogena' resurser

- ex post, organisationens strategiska resurser/förmågor inte kan kopieras ("inimitability") samt

- ex post, organisationens strategiska resurser/förmågor inte ersättas.

Peteraf (1993) beskriver hur resultatvariabeln 'avkastning' ("rents" och "quasi-rents") generas utifrån olika prioriteringar i strategin; 'monopoly rents' beskrivs utifrån begränsat marknads/utbudsperspektiv (högre pris) medan `ricardian rents` beskrivs utifrån resursbaserad strategi och genom att företag har begränsad tillgång till vissa resurser eller det är begränsade möjligheter att expandera resurserna (implicit en begränsad möjlighet för konkurrenter att imitera dem) så att resurserna värderas och därmed prissätts högre relativt organisationens marginalkostnader för att expandera eller utveckla dem. I det resursbaserade perspektivet på strategi handlar det således om att ledningen, om man har ett resursbaserat perspektiv,

\footnotetext{
77 Med referens till idrotten kan frågeställningarna om ledningens förutsättningar för att kunna tillämpa en "resursbaserad" strategi /med dessa villkor för information $\mathrm{mm} /$ verifiera att ju bättre kunskap/information om identifierade "unika", potentiellt strategiska resurser, mål och trender och egna organisatoriska förutsättningar och legitimitet och "individens egen" erfarenhet, baserade på tidigare beslut med positivt utfall, desto lättare för ledningen att fatta nya, snabba och långsiktigt riktiga och "uthålliga" beslut.
} 
optimerar ett projekts avkastning enligt de senare förutsättningarna för att kunna upprätthålla en konkurrensfördel (per definition) inom sin bransch.

\subsubsection{Strategiska resurser (B)}

I empirin identifierar respondenterna resurser (egna och partners) som strategiska och värdefulla om de i sin form kan kopplas till en någorlunda skönjbar användning. Den strategiska 'resurs' som explicit identifieras i nuvarande styrkortssammanhang är (någon annans) patenträttigheter men primärt i syfte att undvika intrång snarare än att använda för att skapa möjlighet att utveckla vidare. En patenträttighet kan alltså vara potentiell partners/leverantörs rättighet snarare än resurs för projektet. I denna empiri visade det sig stället för att vara en strategisk resurs för projektet innebar detta en begränsning.

En genomgång av svaren i empiri pekar ändå på ett stort antal potentiella resurser, av olika slag och med olika egenskaper, som kan värderas olika i olika situationer. Respondenterna nämner energi, kunskap om energi, pengar och inbyggd teknologi. Intervjuerna pekar också på möjligheten att identifiera några viktiga förmågor som finns inbyggt i såväl detta specifika projekts organisering som i hela organisationen.

Den enda RESURS som explicit kan identifieras i anslutning till denna diskussion om förmåga är den INFORMATION som individen har eller skaffar/tar till sig inför ett beslut. En utveckling och värdering av denna resurs (eller andra resurser som kan identifieras som inbyggda hos människan och därmed $\mathrm{i}$ organisationen) anses fordra någon form av definition och kategorisering för att kunna i någon mån tydliggöras eller operationaliseras och därmed mätas. Trots att projektet betraktas som "höginnovativt" så nämns inte begrepp som innovationsförmåga explicit.

\section{Resurser enligt resursbaserad teori.}

I kapitel 1 och i teorikapitlet beskrivs vad ett resursbaserat synsätt innebär och implicit hur det kan tolkas inför studier som denna. Resurser enligt TGF (Penrose) värderas inte en resurs i dess egenskap av direkta insats i produktion utan istället i form av dess karaktäristika och egenskap som den har eller genererar i olika kombinationer med andra resursers egenskaper:

"...resources are not defined as inputs in production functions; instead ...the services yielded by resources, are a function of the way in which they are used...in combination with different types or amounts of other resources... directed towards productive opportunities, which are not themselves objective but images" (Penrose 1959, with reference to Kenneth Boulding)

Enligt RBV (Barney) är de resurser som leder till 'uthållig konkurrensfördel' förenade med villkoren eller kriterierna; värdefulla, sällsynta, oimiterbara, ej ersättningsbara och dessutom med en begränsad möjlighet att förflytta eller sälja på en marknad (= en viss intern bundenhet). De är snarast kluster ("bundles") av resurser som ger organisationens (heterogena) unikitet d v $s$ det är företagens grad av olikhet vid jämförelser mellan deras 'resursbaser' som ger dess unika konkurrensfördel (Barney, 1990). I en beslutssituation i styrningen i en värdeskapande organisation är tolkningen av kriterier för vad som är 'värde', centralt. Enligt RBV kan 'värde' 
definieras i termer av 'finansiellt värde' respektive 'effektivitet'. Efterföljande forskning har utvecklat denna tolkning i olika kontexter (Se Priem \& Butler, 2001 och Peteraf, 2003 m fl)

"... a valuable resources"..."must enable a firm to do things and behave in ways that lead to high sales, low costs, high margins, or in other ways add financial value to the firm" (Barney, 1986).

"...resources are valuable when they enable the firm to conceive of or implement strategies that improve its efficiency and effectiveness" (Barney, 1991).

\subsubsection{Organisering (C)}

Organisering för värdeskapande; här beskriver respondenterna i empirin hur roller, ansvar ser ut. Det redovisas i en beskrivning av organisationen (Se Figur 11, Gate-modellen och Figur 12, organisationens processbeskrivning). Frågeställningar och potentiella problem vid organisering anges som viktiga att diskutera, speciellt frågeställning om det åtagande som BU FoU/CR har gentemot affärsenheterna.

Globalt är organisationens utveckling väl dokumenterad. I litteraturen redogör bland andra Simons (Simons, 2000) för hur såväl organisering som system för styrning utvecklats historiskt i detta företag globalt och fram till 2006. Vid den omfattande 'omdaning' som genomfördes av koncernen under 2006 och 2007 organiserades koncernen i divisioner. Den matris med BU (Business Units) respektive BAU (Business Area Units) som företaget haft efter bildandet av koncernen, har delvis behållits men i stor utsträckning förenklats genom den 'centralisering' som skedde i samband med den omfattande konsolideringen av koncernen som inleddes redan 2003. Landansvaret blev också starkare än tidigare men på en övergripande nivå. När denna studie analyserades (2009) betraktades organisationen av affärsverksamheten närmast som en svag matrisorganisation. Trots omfattande renodling av koncernens affärssystem så har även det interna beslutsstödsystemet fortfarande en dominerande ställning i samband med styrning, vid organisering och konsolidering av affärsverksamheterna.

När denna avhandling presenteras (2021) har företaget, i samband med en påbörjad konsolidering genom avyttring, samtidigt genomgått en omfattande transformering mot en allt starkare fokus på tre globala verksamhetsområden där hela värdekedjan inkluderande FOU genomförs inom affärsområdet.

Organisationens operativa organisation var fortfarande 2009 starkt profilerad med affärsområden (BA). Ansvar för FoU inriktning har sedan åren (2006-2009) förskjutits till en högsta global BA-nivå. Företaget är samtidigt en starkt projektstyrd organisation vilket innebär att befogenheter är starkt decentraliserade. Tydligast ses detta inom koncernens FoU. Utvecklingsprojekten är i stor utsträckning kundstyrda/"orderstyrda" (f n ca $85 \%$, 2006), vilket innebär att affärsstrategiska beslut i stor utsträckning styr hur organiseringen sker. Detta påverkar relationen mellan koncernens FoU-enheter (BU FoU/CR) och affärsenheterna och hur resurser ska positioneras. Det är oklart hur ansvarsfördelningen avseende affärsenheternas finansiella resursbas (balansräkningens aktiveringar) är fördelad.

Koncernstrategiskt omfattade (2006) organisationens FoU nio stora globala utvecklingsstrategier. Koordination av utvecklingsprojekten sker i praktiken i en skärningspunkt mellan utformning/implementering av resursstyrd strategi ("vertikal/top-down - bottom-up") och produktionsstyrd strategi ("horisontell") (Figur 5). 
FoU-verksamheten organiseras utifrån ett stort antal kriterier och beroende på hur projekt prioriteras utifrån två infallsvinklar; teknologisk utveckling (koncernperspektivet) versus affärsutveckling (BU-perspektivet). Olika beslutskriterier/och tolkningar/ gäller därför på olika nivåer. Organiseringen av projektstyrningen $(\mathrm{d} v \mathrm{~s}$ vid styrning på BU-nivå av flera projekt samtidigt) sker med hjälp av den s k GATE-modellen, där varje Gate representerar en "tidpunkt" där ett antal kriterier ska vara uppfyllda. Vid respektive Gate finns ett antal frågor som utreds och beslutas (Figur 11).

Gate-modellen är utvecklad av koncernens FoU-enhet och är implementerad i affärsenheterna under 2006, med blandat mottagande. I modellen (Figur 11) representerar den nedre delen teknologiutveckling hos BU FoU/CR (TUTV) och den övre delen produktutveckling (PUTV) vid affärsenheterna. Det är inte alltid samma personer som medverkar vid de olika "gaterna" i respektive projekt. Varje gate har en "gate-assessor" hemmahörande i respektive organisation.

\begin{tabular}{|c|c|c|c|c|c|c|c|c|c|}
\hline & & & 1 & 2 & 3 & 4 & 5 & 6 & 7 \\
\hline 1 & 2 & 3 & 4 & 5 & 6 & 7 & & & \\
\hline
\end{tabular}

Figur 11 Gatemodellen. Processen för PUTV (övre) och TUTV (nedre)

Koncernstrategi för FoU programmen förankras först i BU FoU/CR (TUTV). G1,2 och 3 sker innan BU FoU/CR möter affärsstrategi från affärsverksamheterna i "skärningspunkten" (TUTV) G5. BU FoU/CR har en person (gate-assessor) i G5 som har det "tudelade" ansvaret (styrning/ekonomi). Det är inte samma person som finns i (PUTV) G5. Vid G 5 tas beslut främst utifrån ekonomiska kriterier och andra kriterier för styrkorten ${ }^{78}$.

Gate-modellen speglar i viss mån hur företaget ser sin organisation "processuellt" och relaterat delvis till hur organisationens "värdekedja" visualiseras (Se Figur 12). Omfattande processutveckling och spegling av organisationens värdeskapande processer genomfördes under åren 2001-2003. Nedanstående figur är en bearbetad/förenklad visualisering av organisationens processmodell vid denna tid. Modellen har två dimensioner; organisationens egna värdeskapande processer (horisontellt) samt "upstream/downstream" relativt leverantörer och kunder (vertikalt). ${ }^{79}$ Beroendeförhållandet mellan TUTV/PUTV och organisationens leverantörer varierar från projekt till projekt och mellan de olika affärsenheternas inriktning; om de betraktar sig som produktionsenheter eller systemintegratörer samt utifrån inställning till leverantörsberoende. "Outsourcing"-strategier förekommer i såväl TUTV som PUTV och beslutas i olika stadier av utvecklingen.

\footnotetext{
${ }^{78}$ Se bil 14: Balanserade Styrkorten; protokoll från möte 2007.

${ }^{79}$ Det vertikala ínformationsflödet exemplifierar samtidigt hur förädlingsvärdet påverkas interaktivt mellan olika processer i värdekedjan där produkt och teknologiutveckling berörs i alla värdesteg.
} 


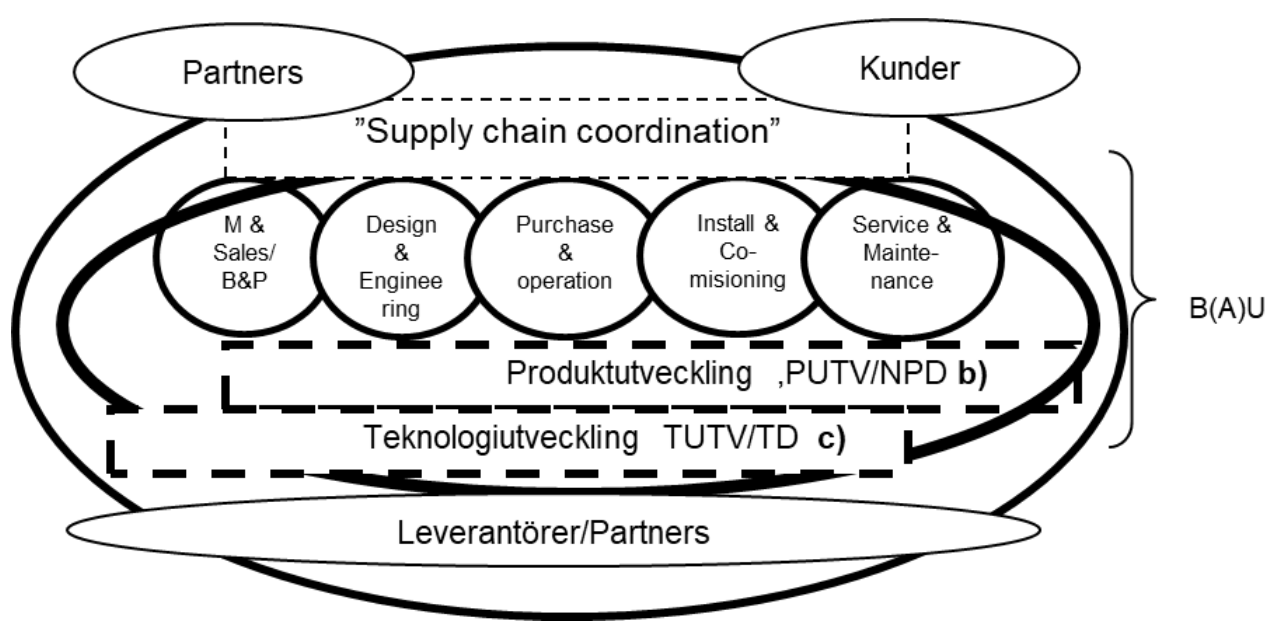

Figur 12. Organisationens organisering utifrån organisationens processmodell, här bearbetad/förenklad (jfr Porters "Value Chain") b) PUTV omfattar primärt produktutveckling eller produktförnyelse c) TUTV omfattar både 'spaning' och laborativ teknologiutveckling.

Empiri från de tre affärsutvecklingsprojekten i BU 1 och $\mathrm{BU} 3$ indikerade en pågående förändring av strategier vs ekonomistyrning inom den mer långsiktigt inriktade verksamheten. Hur organiseringen (2007) förväntades ske påverkades främst av synen på utvecklingen av projekt inom området energieffektivitet. Mål och kriterier för såväl finansiella som ekologiska och mänskliga resurser betonades starkt; även inom ramen för organisationens koncernstrategi. I empirin FORCE redovisas att utveckling sker på affärsstrategisk nivă ${ }^{80}$

Inom ramen för organisationens strategiska arkitektur har FoU/CR också en explicit uppgift, ett åtagande att utveckla och försörja affärsenheterna med "kärnkompetens". Explicita mål (\%uellt av tillgänglig arbetstid) finns för detta åtagande.

Den förseningen som uppstod ${ }^{81}$ indikerade några potentiella problem som har med organiseringen av utvecklingskompetens att göra. Orsaken till förseningen är att ett teknologiskifte blev nödvändigt när den leverantör som medverkat också var tilltänkt som leverantör för installation etc. "backade" ur. Skälet till detta har angivits. Exakt vilka avtal, vilka kontakter som har förevarit denna utveckling har inte studerats i denna avhandling.

Ett potentiellt problem (vid nuvarande organisering av TUTV) som framkom vid intervjuerna och som påverkar framtida system för ekonomistyrning är att det generellt är svårt att ta fram nya "produkter" med teknologi som inte finns hos företagen (inom koncernen). Projekteringen vid FoU/CR är styrande för bolagen (se ovan), men det är en komplicerad process. Affärskoncepten finns hos affärsenheterna. En orsak till problem att organisera TUTV kan vara att FoU/CR är alltför mycket bundna till de befintliga affärskoncepten fortfarande. Kan en "ny"

\footnotetext{
${ }^{80}$ Se bil 16: Intervju med VD; nytt ledarskap för BU 3.

${ }^{81}$ Teknikutvecklingen i detta projekt (BC 3) FORCE genomfördes primärt hos en leverantör. Riskbedömning av projektet gjordes på olika risknivåer, utöver teknisk risk både affärsrisk och finansiell risk. Projektet försenades p.g.a. teknologibrister men också utifrån hur leverantörssamarbetet fungerat.
} 
ekonomisk styrning påverka innovationsprocessen? Kan en ny modell för organisering klargöra förväntningar, ersättningssystem och rollfördelning? Dessa frågeställningar har ställt ledningen inför nya strategiperspektiv.

Ett annat potentiellt problem är att affärsenheterna, i detta fall BU 3, inte alltid är så intresserade av organisering av uppföljningen (enligt Gate-modellen). En orsak till detta kan vara att när det, är hög efterfrågan kan omvänt, affärsenheterna vara mindre intresserade av vad BU FoU/CR gör vad gäller produkteffektivisering eller nyskapande och innovativa produkter. Snarare vill man lyfta fram "utvecklingskompetensen" som BU FoU/CRs viktigaste roll. Detta kan vara ett tecken på ett mer resursbaserat perspektiv på utveckling $\mathrm{d} v \mathrm{~s}$ här ökning av kunskapen/teknologin om t. ex lagrad energi. Alternativt är det ett tecken på att det är marknadens behov som i realiteten "styr" forskningen vid BU FoU/CR.

En slutsats här vikten av att tydligt belysa företagets åtagandekultur, ett behov som uttalats initialt vid diskussionerna om en ny modell för strategiska ekonomistyrning. (Se Figur 8) I såväl horisontellt som vertikalt, inklusive partners, samarbete beskrivs ledningens behov av både 'internt' och 'externt' fokus för att åstadkomma bra, hållbara beslut. För det horisontella värdeskapandet påverkas potentiellt de initiala processerna med ett ökat fokus på FoU/innovation vid en ökad integration. I den vertikala beskrivningen, där processmodellen indikerar en materiell försörjning (supply management), påverkas ett intensifierat partnerskap på en 'utvecklingsmarknad' som en effekt av ökad extern integration. Effekten av s k kollaborativ innovation, vid såväl expansion som konsolidering, bidrar potentiellt till ett förstärkt innovationskapital. En organisatorisk effekt är en direkt påverkan på 'gate-modellen' om dessa integrations aspekter beaktas.

\section{Organisering enligt resursbaserad teori.}

Ett resursbaserat perspektiv enligt TGF (Penrose, 1959) och RBT (Barney och Clark, 2007) uttrycker endast implicit organisationen som ett system med en uppsättning resurser ("bundle of resources") respektive att företaget är organiserat ${ }^{82}$ för att kunna exploatera sina resurser. I ett ledningsperspektiv (enligt RBV) förväntas ledningen vid såväl expansion som vid konsolidering att organisera verksamheten för att framförallt (internt)

- skapa och utveckla former för bundenhet/isoleringsmekanismer för organisationens unika, strategiska resurser (kontrakt, utbildningssystem mm)

- organisatoriskt förmå organisationen att leverera kärnkompetens

Vidare bör verksamheten organiseras utifrån en mängd olika kriterier, exempelvis utifrån vilka kombinationer av resurser man använder eller vilka villkor som gäller för en potentiell (utvecklings-) /anskaffningsmarknad (ex ante) (Peteraf). Dessa många "interna" kriterier för

\footnotetext{
${ }^{82}$ En systemisk ansats vid studien av ett företag eller annan organisation, en affärsenhet eller ett projekt, eller vid studier av relationer mellan individen (Senge, 2006), implicerar att en organisering kan diskuteras utifrån aspekter på strategisk positionering av resurser och förmågor utifrån behov att antingen expandera eller konsolidera $\mathrm{i}$ olika faser (Holling $\mathrm{m} \mathrm{fl}$ ), eller enligt styrningsteorin vid planering av ekonomiskt ansvar för olika åtaganden ("accountability") respektive befogenheter ("responsibility") (Simons, 1999). Systemteoretiskt övervägs i vilken utsträckning systemet (och organisationen) sluter sig respektive öppnar sig vid olika mer eller mindre rationellt utformade strategier och vad det medför (Scott, 2006).
} 
organiseringen antyder en 'intern bundenhet' och en fokus på intern utveckling av kärnkompetens d v s en specialisering (som alternativ till inköp av specialistkompetens), en samtidig utveckling av former för 'intern' kommunikation och samtidigt en (leverantörs-) partnerfokus vid organiseringen.

\subsubsection{Beslutsprocesser (D)}

\section{Projektledarnas och controllers syn: Beslutsprocesser}

Här beskrivs särskilt beslutsprocessen och frågeställningar vid olika "gates" och hur beslut (ex ante) påverkas utifrån organisationens olika måldimensioner; "sustainable technology" "resurseffektivitet", "hållbar tillväxt" eller uthållig konkurrensfördel (sustainable competitive advantage). Frågeställningar vid olika "gates" (ex ante, ex post) diskuteras samt eventuella implikationer på en "ny" strategisk styrning. Studien redogör för ett antal potentiella problem i beslutsprocessen som respondenterna hittills indikerat, bland annat utifrån leverantörsval och skifte av teknologi.

Företaget har (i BU 3) en kultur som vill framhålla ledningens förmåga att effektivt ta beslut. Denna förmåga är då starkt människorelaterad. Ledningen efterlyser förslag som kan minska ledtiderna vid beslutsfattande vilket innebär att man fortfarande ser beslutsprocessen som ineffektiv. Att vara effektiv är att ta rätt beslut i betydelsen av ("lean") d v s i rätt tid och att besluten samtidigt är värdeskapande. I projektet FORCE har, utöver de problem som indikerats i gateprocessen (se ovan: Organisering) och i den externa relationen med leverantören, inget framkommit som beskriver själva beslutsprocessen eller ledningens förmåga att fatta beslut.

Från de tidigare studierna finns erfarenhet inom BU 1 av beslutsprocessen. I Case ROBO studerades explicit organisationens beslutsprocess; dels utifrån ett koncernstrategiskt perspektiv och som ett tankeexperiment. Vid detta experiment tillämpades Simons integrerade modell för strategi och styrning (Figur 6). Modellen diskuterades inför utvärderingen i ett antal studier; bland annat vid de tre delstudierna som genomförts vid BU 1.

En applicering här av denna modell (från Case ROBO) bekräftade att det implicit finns två dimensioner i modellen vid studier av utvecklingsprojekt:

- En strategidimension d v s strategiarbetet, utan någon finansiell bedömning men med frågeställningarna VAD? (business strategy/"top down") utifrån ett visst koncernperspektiv som resulterade $\mathrm{i}$ att viss forskningsstrategi skulle implementeras/göras operationell globalt inom BU, dock inte sagt exakt hur och när.

- En organisatoriskt funktionell ekonomistyrning med 'traditionella' styrmetoder, både ex ante (förkalkyler samt BSC) och ex post (efterkalkyl och annan anpassad uppföljning). Ingen direkt överensstämmelse konstaterades dock ex ante/ex post, men den kan givetvis finnas där.

Tre ytterligare iakttagelser gjordes i samband med de initiala fallstudierna och som bekräftas $i$ detta Case FORCE;

a) vid analys med den processanalys som gjordes utifrån denna modell (redovisade i ett "workingpaper"83) ändrades i D 2, i skärningspunkten mellan strategi och styrning,

${ }^{83}$ Boström, P S : A Critical Assessment in Process Analysis (working paper) 2005/2013/2021 
projektets status utifrån att man besvarade frågan För VEM? Det som observerats $i$ Case FORCE var: Vem som är den verkliga projektägaren när projektet är etablerat är avgörande redan $i$ innovationsfasen $i$ ett hög-riskprojekt. En tidig involvering av projektägare är strategiskt avgörande,

b) i den andra fallstudien vid BU 1 (Se Case CATHEDRAL) och intervjuer med de sex projekt- resp. gruppledare samt en programansvarig redovisade i ett "workingpaper" 84 konstaterades att mycket olika tolkningar/kriterier prioriterades, på olika organisatoriska nivåer i samband med beslut om go/no go, vid utvecklingsprojekt i relativt långt framskriden fas (Gate 4). Dessa prioriteringar följde ett visst mönster utifrån vad intervjupersonen hade för position i organisationen. Det som observerats $i$ Case FORCE var: Vem som gör tolkningen av och kommunicerar centrala begrepp som "projektets legitimitet" $\mathrm{mm}$ är avgörande för implementering och att strategisk kongruens uppnås i den ekonomiska styrningen,

c) i den första intervjun med styrgruppen från FoU/CR vid BU 1 (ledningspersoner från respektive enhet/ BU) efterlystes en modell för att dels kunna använda som tumregel vid beslut om strategiska projekt; dels kritiskt analysera (självutvärdera) strategiska utvecklingsprojekt, speciellt vid 'FFE' och utveckling av 'block-busters". Man efterlyste också bättre möjligheter att bedöma ledares såväl marknadskunskap som teknisk kompetens. Det som observerats $i$ Case FORCE var: För att även projekt BU 3 FORCE ska bli ett "case story" är en enkel beskrivning av ledningskrav, i form av en "tumregler", som kan kommunicera för alla typer av strategiska projekt och speciellt för "högriskprojekt" för att åstadkomma en legitimitet på lång sikt.

Överställt för beslutsprocessen i ekonomistyrningen är organisationens måldimension, ledarnas visioner och långsiktiga utvecklingsstrategi för att nå dessa. I alla dessa avseenden är dialogen i en 'skärningspunkt' strategi/styrning viktig för att nå den konsensus som är nödvändig. För styrningen innebär 'dialogen' dock oftast en mer ifrågasättande process; och i praktiken när strategifrågorna (dvs. VAD? och HUR?) redan "gått ett antal varv" i beslutsprocessen. I empirin från FoU/CR har detta framförallt speglats vid utvecklingsprojekt av karaktär FFE ${ }^{85}$ eller 'block-busters' ${ }^{86}$ (Se Case ROBO) och är strategiskt avgörande i projekt som projekt FORCE.

Med utgångspunkt ifrån ett resursbaserat synsätt har organisationens styrning beskrivits i termer av en "kontinuerlig besluts- och förädlingsprocess". I denna empiri poängteras vikten av att välja att fokusera strategiska resurser, ta beslut om vilka som är viktigast att utveckla, utveckla förmåga att utnyttja och konsolidera dem till "unique and core products" samt att utveckla förmågan att generera avkastning (rent) genom resurseffektivitet, i "value- och supply chains" (input/output/input) jämte förmågan att känna igen, besluta om vilka och också ta tillvara dessa genererade resurser för att "bättra på" organisationens "strategiska resursbas".

Centrala frågor för dessa beslut är därför de specifika styrningsfrågorna och de kriterier som gäller för styrningen; d v s för VEM? (d v s vem legitimerar utvecklingen, vem har behovet?) och Vilket Resultat kan förväntas och Varför? (d v s vilka effekter får det? eller vad legitimerar utvecklingen?)

\footnotetext{
${ }^{84}$ Boström, P S: Legitimacy as analyzing concept (working paper) 2005/2014/2021

${ }^{85} \mathrm{FFE}=$ Fuzzy Front End (kan jämställas med den första fasen i innovativ verksamhet/TUTV)

86 "Block busters" = större resurskrävande projekt
} 


\section{Beslutsprocesser enligt resursbaserad teori}

Beslutsprocesserna berörs inte explicit i resursbaserad teori. Om den integrerade modellen för strategi/styrning (Simons, 1995) eller delar av den, kan betraktas som en "beslutsmodell" så kan också ett antal relevanta frågor ställas i respektive del i modellen, som kriterier för beslutsfattande. Ett i någon mån vidgat perspektiv på resursbaserad strategi implicerar svaren på frågor som Vad? Hur? och med Vilka?. En utveckling av denna modell (potentiellt med PDCA-modellen) bör kunna implicera även andra frågor som en utveckling av teorin.

En utveckling av Simons modell (Figur 6) för integrerad strategi och styrning, med ett resursperspektiv, tar hänsyn till Margret Peterafs uppdelning av ex ante villkor respektive ex post-villkor och detta påverkar hur beslutsprocessen beskrivs. Det innebär för ett projekt att en integrerad, effektiv ekonomistyrning (management control), utöver dessa två faser av styrningen (ex ante/ex post) också omfattar en mellanliggande fas där själva förädlingen $d v s$ organiseringen och värdeskapande beslutsprocesser och andra processer, sker. Där sker den löpande styrningen (interactive control) med ett antal beslutsprocesser och aktiviteter under produktens hela livscykel, även i dess tidiga utvecklingsprocess, vid exempelvis FoU.

De tre faser som en integrerad beslutsmodell för styrning kan beskrivas med är då 1) ex ante, "input control", 2) "process control" samt 3) ex post, "output control". Med ett resursbaserat synsätt är denna andra fas, "process control", internt orienterad och handlar primärt om organiseringen. Det handlar om hur resurserna organiseras och vilken typ av styrning som tillämpas; en styrning av mer instrumentell, mekanistisk karaktär eller en mer organiskt utvecklad styrning. Denna process avser primärt att mätas i en kvalitativ dimension. Av det följer att även "input control" och "output control" i första hand har en kvalitativ dimension.

En integrerad modell kan, om resursbaserat strategiarbete ses som en 'vertikal' beslutsprocess (här som en "top down drop"-process från koncernstrategin) konceptualiseras ekonomisk styrning som en "horisontell beslutsprocess", ex ante respektive ex post. Om strategiprocessen däremot beskrivs horisontellt så beskrivs ekonomisk styrning som en vertikal process.

Detta innebär (i båda fallen) att dessa två processer möts i en skärningspunkt i denna integrerade beslutsprocess där själva "värdeskapandet" beslutas fortlöpande utifrån ett antal process- eller produktrelaterade frågeställningar. I denna skärningspunkt uppstår (teoretiskt) och genomförs beslut som medför att mål och medel ställs mot varandra, mål som framförallt berör organiseringen (för genomförande, ansvar, legitimitet $\mathrm{mm}$ ). Styrningens villkor och prioriteringar vid organisering bygger på olika typer ifrågasättande av mätning/värderingar av mål etc. vilket innebär att det inom "process control" genereras beslut baserade på såväl omgivande, externa faktorer som på interna möjliggörare ("enablers") från "input control". Implicit i den 'integrerade ' modellen görs ett antagande att dessa mål-eller medelskonflikter utlöser strategier som påverkar resursbasens position genom ett antal olika möjliga strategival. 


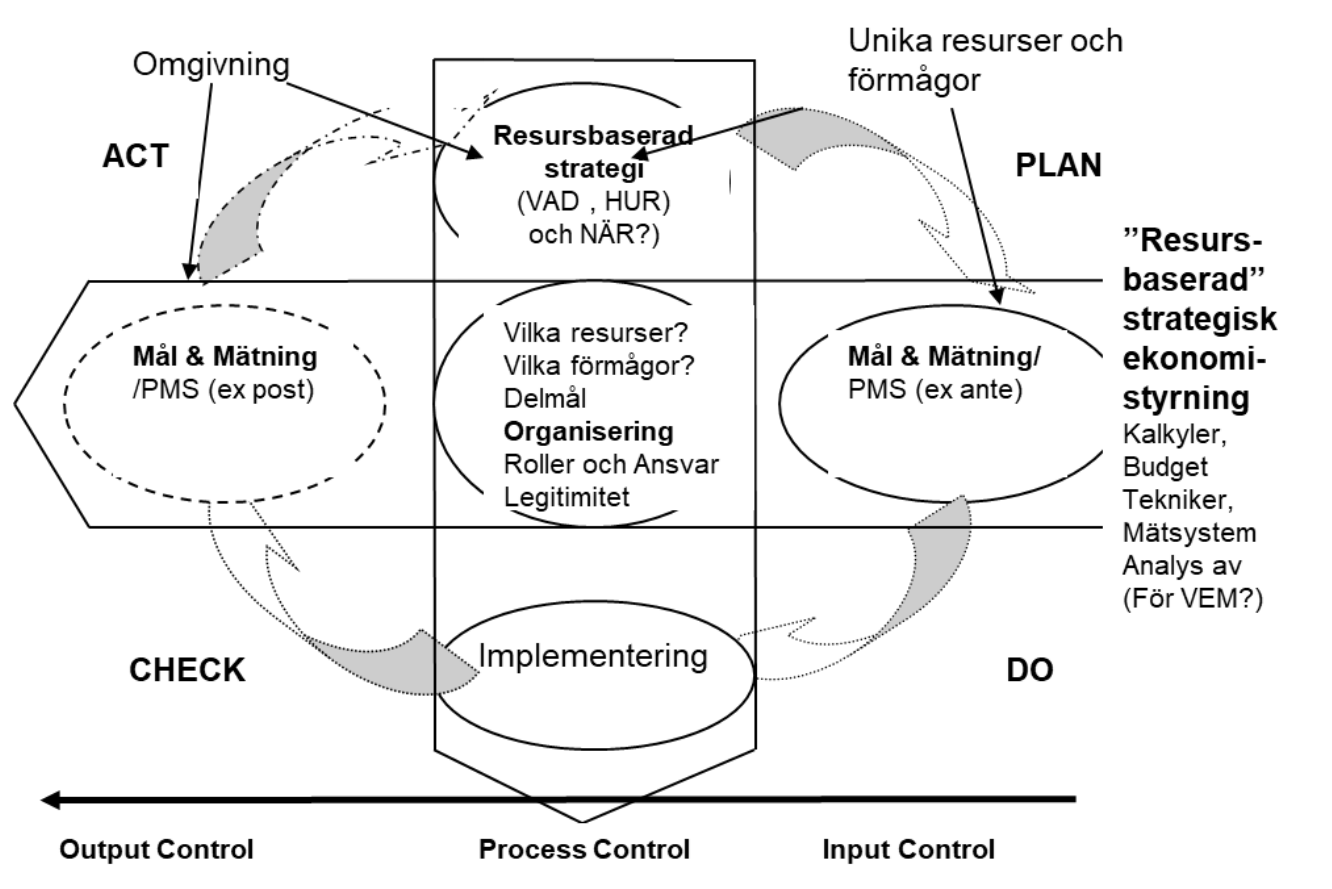

Figur 13. En integrerad beslutsmodell för resursbaserad strategi och styrning. Styrningen har delats upp i två delar; a) ex ante och b) ex post. Denna modell har efter genomförd analys av Case FORCE utvecklats utifrån "Hierarchy of Business strategy (Simons, 1995) samt PDCA modellen (Deming, 1990-1993)

Denna "process" illustrerar beskrivningen av "skärningspunkten" för strategi/styrning, och den kan bidra till förståelsen av vilka frågor som är aktuella i båda "diskurserna"; de som är gemensamma respektive de som är specifika strategifrågor (här vertikalt illustrerade) eller styrningsfrågor (här horisontellt illustrerade). Resultatet av denna studie" innebär också att dessa två "nya" dimensioner, d v s dels uppdelningen ex ante/ex post dels beskrivningen av "input/process/output" och dels återkopplingen i processen, också bidrar till att modellen kan användas som en modell för integrerad strategi/styrning på olika nivåer i en organisation och bidra till att särskilja och förstå olika typer av strategiska styrning och olika utföranden av resursbaserade strategier vid olika typer av projekt.

\subsubsection{Mätning (E)}

\section{Projektledarnas och controllers syn: Mätningen}

Målet lönsamhet beskrivs hur det uttolkas idag och hur detta mäts idag. I detta projekt ska begreppet "sustainable technology" särskilt relateras till detta projekts olika processer, deras "tekniska/ekologiska" måldimension d v s "energieffektivitet" men även begreppet "finansiell effektivitet". 
Den mätning som avhandlas i denna empiri avser mätprocesser och procedurer i de kontrollsystem som gäller dels systemets/organisationens interna effekter och resultat d v s från organisationens resurser (per definition) och kompetensområden, dels mätning av projektets funktion vid applicering mm. Vid olika former av samarbeten, s k "business combinations" eller vid helt extern mätning görs denna med metoder/procedurer som särskilt utformas för detta syfte, en s. k. "effektutvärdering”. I detta Case FORCE görs detta av 'extern' teknisk kompetens och avser primärt energioptimering.

Den interna mätningen i målföretaget beskrivs av företagens controllers i generella termer. Prognoser, budgets, kalkyler 'mäts' idag inom ekonomiområdet med något som kan hypotetiska kan beskrivas som ett "volymvärde" d v s endast i två dimensioner; volym (kvantitet) och pris (i viss valuta). Försök har redovisats av en av organisationens controller att kommunicera en modell där hänsyn även tas till projektets funktion, prioritet och risknivå.

I målföretaget sker mätning av verksamheten på traditionellt sätt. Kalkyler, budgets och nyckeltal (ex ante) och resultat (ex post) definieras (vid olika gates) där det finns möjlighet att identifiera dessa olika variabler; kvantitet och/eller pris respektive värdeskalor. Finansiella nyckeltal är överordnade, $\mathrm{d} v \mathrm{~s}$ på projektnivå primärt endast tillämpade som ‘målvärde' (ex ante) vid investeringar. I den mån dessa nyckeltal emanerar ur resultatredovisningen ställs de i relation till organisationens finansiella flöde, primärt på koncernnivå (jfr Dupont-modellen). Exempel är mätning av lönsamhets/avkastnings som uttrycks i $\%$ av organisationens tillgångar/eget kapital endast på högre nivåer. Konsolidering sker av såväl resultatmått som finansiella mått. ROCE är målföretagets residualmått på avkastning.

Andra metoder används i målföretaget för olika syften. Exempel på metoder är som har eller fortfarande används är EVA, eValue, BSC, LCA, LCC, K/I. ${ }^{87}$ I Case FORCE görs mätning vid ett flertal "gate" såväl inom TUTV som PUTV. Måldimensionen och därmed målformuleringen inför mätningen är viktig. Samtliga nuvärdeberäkningar (NPV etc.) görs på valt målperspektiv (ex ante) i TUTV G5/PUTV G2. Vid TUTV G7 görs normalt (ex post) mätning och ett antal kriterier utvärderas. I denna mätning värderas framförallt nöjdhetskriterier (internt och hos kund).

Ett specifikt behov av mätning av organisationens förmåga (utifrån valt resursslag) inom FoU är "anställningsbarhet" d v s en specifik förmåga som är önskvärd (mål) i syfte att kunna utveckla en viss strategisk resurs på ett effektivt sätt d v s med rätt kvalitet (spec.effectivity) på kompetens för ett visst åtagande. Denna "anställningsbarhet" kan mätas genom att bestämma

- kompetensutvecklingsvärde/projekt (måste prioriteras) (jfr cyklisten i `cykelanalogin’)

- teknikutvecklingsvärdet/projekt (optimeras) (jfr bakhjulet i `cykelanalogin’)

\section{Mätningen enligt resursbaserade teorier.}

Resursperspektivet utifrån given teori (RBV) innebär att mätning bör ske utifrån de kriterier som teorin stipulerar för organisationens resursutnyttjande och resursutveckling; $\mathrm{d} v \mathrm{~s}$ att

\footnotetext{
87 I bilaga ges en sammanställning, baserad på erfarenhet, av tillämpbara mätmetoder/modeller $\mathrm{m}$ a $\mathrm{p}$ tillämpningsområde och komplexitet Relevanta (primärt kvantitativa) nyckeltal används i olika processer inom HR, produktion, mm. Finansiellt relaterade metoder som 'cash flow', investeringskalkyl och finansieringsanalys, används där det är tillämpligt. Generellt mäts verksamheten utifrån det behov som ledningen har av information och utifrån kriterier för beslut (ex ante/ex post).
} 
resurserna är värdefulla (valuable), har en unikitet/ är sällsynta (rareness), har imperfekt mobilitet/immobilitet (immobility), inte är kopieringsbara (imitability), de är strategiska (strategic) och att förtaget processar dem effektivt (efficiency and effectiveness) och att detta leder till uthålliga konkurrensfördelar (sustained/sustainable competitive advantage) för företaget, detta på en marknad som består av heterogena (heterogenous), mer eller mindre unika lösningar utifrån unika resurser och förmågor. Detta innebär att en mängd villkor bara utifrån resursbaserad teori påverkar mätningen!

Teorin beskriver organisationens/systemets resurser (resources) och också deras inbyggda egenskaper (characteristics/inbound capacities) samt organisationens/ systemets skicklighet/förmåga (capability). Systemets förmåga (jfr "kompetens") och dess kapacitet (jfr "verkningsgrad") innebär därmed att systemet i viss omfattning vid ett specifikt tillfälle kan utveckla resurserna och dess egenskaper. Resultat mäts i termer av produktivitet (efficiency) och effektivitet (effectiveness) och också i termer av avkastning; (ricardian rents) eller (quasirents) (Peteraf, 1993). Effekten mäts i termer av konkurrensfördelar (competitive advantage). Förändringar i resursbasen (i finansiella termer likställt med cash-flow respektive bottom line) mäts som förändring av det definierade värdet av resursen (per definition) med hänsyn till systemets optimala förmåga och bedömd risk.

Simons (2000) beskriver mätning primärt i termer av att tillämpa ett system för att mäta företagets prestationer (performance management system, PMS). För att ledningen ska kunna bedöma framtida behov och nytta av resurser i den ekonomiska styrningen för att genomföra olika strategier (investeringar/desinvesteringar) fordras kunskap om resursen tillämpningsområde, varaktighet $\mathrm{mm}$. Simons föreslår rutiner och procedurer för att högsta ledningen ska kunna planera för allokering av de tillgångar man förfogar över; såväl materiella som immateriella, finansiella och icke-finansiella.

Tillstånd och flöden anges och mäts generellt inom traditionell ekonomistyrning i finansiella mått, $\mathrm{m}$ a o som finansiella storheter, d v s i valutaenheter (Söderbaum, 1970). Flöden, d v s köpt, producerad eller såld/levererad volym är primärt kvantitativa storheter och primärt vid bidragskalkyl och när flödet ska värderas används dimensionen pris. 'Priset' är samtidigt ett värdebegrepp och kan ibland används synonymt med begrepp som kvalitet. Mätning av kvalitet i andra sammanhang, med exempelvis BSC, tillämpas utan kvantitetsbestämning och görs i form av värdeskalor. Nyckeltal som baseras endast på kvantitativa mått är framförallt "produktivitetsmått" och motsvarar mått på prestationer ("efficiency") medan nyckeltal som uttrycker ett värde (pris) framförallt är "effektivitetsmått" och motsvarar ett mått på effekter ("effectiveness"). Resultat kan uttryckas i såväl i antingen bara kvantitativa eller kvalitativa termer eller som en kombination av kvantitet (Qn) och kvalitet (Q1).

\subsubsection{Resultatuppföljning (R)}

\section{Projektledarnas och controllers syn: Resultatuppföljning}

Hur resultatuppföljning görs idag har inte helt klarlagts i denna empiri (p g a förseningen i projektet). Projekt FORCE controller medverkade vid samtliga steg (gates) och kunde redogöra för hur Resultatplanering och Resultatuppföljning i princip genomförs vid liknande projekt. Controllern redogör för en arbetsgång som både omfattar strategiska, tekniska och ekonomiska moment. Användningen av finansiella nyckeltal i projekt är begränsad. Projektledare och 
controller redogör kort för mätning av effekter (E) och resultat (R). Begrepp som `balanced scorecards' för resultatplanering och uppföljning av effektivitetsmålen för de viktigaste strategialternativen diskuteras som ett av de viktigaste 'verktygen’ i projekt.

I rapporten från Case FORCE (Del 1) redogörs också för ett första försök att tillsammans med affärsenhetens controller och projektledare, för resultatplaneringens syfte, bestämma vilka som var strategiska resurser i detta projekt. Avgörande för projektets genomförande var överordnat projektets finansiella resurser och i viss mån egna patent. Argumentationen för projektet handlade dock om den funktion som lösningen skulle ha utifrån den resurs som det handlade om (VAD?), d v s resursen energi, och hur denna resurs skulle bidra till en måluppfyllelse för såväl kund som för BU 3 (För VEM?) utifrån deras respektive argumentation (Varför?). Den strategi man valt (HUR?) för att bland annat visa "beslutsförmåga" var att tillsammans med utvald leverantör (för prototyp) göra en pilotinstallation (och också då medverka till finansiell lösning). Hur implementering och uppföljning genomförs i Case FORCE dokumenteras inte i denna avhandling.

Detta praktiska arbete i projektet FORCE I, att försöka hitta argumentationen för projektet mm visar ett behov av en 'arbetsmodell' för intern analys och kommunikation. Ledningen (controllern) genomförde redan ett antal beräkningar både hos FoU/CR och BU 3 efter en viss tänkt arbetsgång men som inte tydliggjorts vid denna empiri. En teoretisk utgångspunkt för arbete med resultatplanering vid ett resursbaserat synsätt har bland annat föreslagits av författare som Robert Grant. ${ }^{88}$

\section{Resultatplanering och resultatuppföljning enligt resursbaserade teorier.}

Förespråkare för resursbaserad teori (Grant, Pitelis, Newbert, $\mathrm{m} \mathrm{fl}$ ) med koppling till styrning beskriver inledningsvis behovet av ett helt nytt ramverk och nya, integrerade analysverktyg. Dessa bör dels omfatta specifika frågeställningar beträffande resursers beskaffenhet (Barney 1991, Grant 1991) dels frågor om ett specifikt ("single") företags resursbas d v s hur företaget uppsättning av strategiska resurser ser ut. Ramverket ska också beskriva organisationens måldimension och också kunna användas i beslutsprocessen vid planering och uppföljning och utvärdering (och återkoppling) av organisationens strategi.

Grant föreslår också att en modell ska kunna beskriva en "arbetsgång" (d v s utgöra en tentativ arbetsmodell för att kunna användas $i$ både forskning och praktik) som kan användas för att svara detaljerat på specifika frågor. Grants `arbetsmodell’ bygger på analys och dialog och utgör stommen i en femstegsmodell (Grant, 2001). Grants modell ska kunna användas som underlag vid såväl resultatplanering (ex ante) som resultatuppföljning och utvärdering (ex post). Hänsyn tas till såväl organisatoriska som tidsmässiga implikationer i modellen.

Grants modell, "a Practical Framework" (Grant, 2001) är en modell i fem steg. (Figur 14) Den startar med arbetet med att identifiera och klassificera organisationens resurser till att

\footnotetext{
${ }^{88}$ Robert Grants femstegsmodell har stora likheter med en väl etablerad modell för organisatoriskt lärande vid japanska höginnovativa företag Nonaka, I. and Takeuchi, H., (1995). Organisatoriskt lärande avhandlas inte explicit här.
} 
identifiera specifika "resursbrister"; detta för att bland annat kunna argumentera och investera i uppgradering av organisationens "resursbas". ${ }^{89}$

Denna arbetsgång redovisar ett återkommande arbete där frågorna avsåg analys (identifikation), möjlig strategi (ex ante), analys igen och sedan strategiimplementering och slutligen frågor om resultatuppföljning och efter det en möjlig återkoppling. En arbetsgång som denna ses potentiellt som en lämplig intern 'arbetsmodell' där strategiska resurser och förmågor analyseras i väl avgränsade miljöer (leverantör, intern produktion, pilotkund $\mathrm{mm}$ ) för att finna argument. Modellen bygger på dialog. Den kan företrädesvis användas tentativt och "reversibelt" för kritisk utvärdering av specifika processer.

\begin{tabular}{|c|c|c|c|c|}
\hline \multicolumn{2}{|c|}{ Analysfas } & & \multicolumn{2}{|c|}{ Genomförande } \\
\hline $\begin{array}{l}\text { Identifiera } \\
\text { och } \\
\text { klassificera } \\
\text { befintliga } \\
\text { resurser } \\
\text { och deras } \\
\text { egenskaper } \\
\\
\text { Nyckel- } \\
\text { frågor } \\
\text { - Vem? } \\
\text { - Vilka? }\end{array}$ & $\begin{array}{l}\text { Identifiera } \\
\text { olika (unika) } \\
\text { förmågor } \\
\text { och vilka } \\
\text { resurser } \\
\text { (kombina- } \\
\text { tioner) som } \\
\text { är } \\
\text { strategiska i } \\
\text { projektet } \\
\\
\text { Nyckel- } \\
\text { fråga } \\
\text { - Vad? }\end{array}$ & $\begin{array}{l}\text { Analysera } \\
\text { bidraget till } \\
\text { att nå uthållig } \\
\text { konkurrens- } \\
\text { fördel } \\
\text { resurs- } \\
\text { effektivitet } \\
\text { och potentiell } \\
\text { avkastning } \\
\text { Nyckel- } \\
\text { frågor } \\
\text { - För Vem? } \\
\text { - Varför? } \\
\text { - När? }\end{array}$ & $\begin{array}{l}\text { Formulera } \\
\text { en strategi } \\
\text { som bäst tar } \\
\text { tillvara och } \\
\text { utvecklar } \\
\text { organisa- } \\
\text { tionens } \\
\text { förmåga } \\
\text { relativt } \\
\text { externa } \\
\text { förhållanden } \\
\text { Nyckel- } \\
\text { fråga } \\
\text { - Hur? }\end{array}$ & $\begin{array}{l}\text { Identifiera } \\
\text { löpande de } \\
\text { behov som } \\
\text { måste fyllas } \\
\text { med upp- } \\
\text { gradering av } \\
\text { resursbasen } \\
\text { och investera } \\
\text { i dessa } \\
- \text { Nyckel- } \\
\text { frågor } \\
\text { - Vad och } \\
\text { (När?) }\end{array}$ \\
\hline
\end{tabular}

Figur 14. En formaliserad arbetsmodell för strategisk planering och uppföljning utifrån mätbarhetsvillkor vid investering i utvecklingsprojekt (i översättning och tolkad från Grant, 2011)

\subsection{Analyssteg 2 Teoretiska utgångspunkter; ett konstruerat exempel}

I denna delstudie Case FORCE (steg 2) diskuteras och analyseras i en löpande dialog, primärt med målföretagets ledningspersoner, hur ett resursbaserat synsätt hos ledningen $\mathrm{i}$ ett företag kan antas påverka styrningen av verksamheten och dess konsekvenser på företagets resursbas.

\footnotetext{
${ }^{89}$ Ett implicit bidrag från avhandlingens studier är att öka kunskaper och insikter om såväl resurser och dess tillämpning inklusive bristsituationer generellt och på alla nivåer och områden som är svåra att överblicka för management. Birger Wernerfelt (Wernerfelt, 1985) förespråkar bland annat en "guide" för att identifiera vissa resurser på överställd nivå.
} 
Denna dialogform är en variant av aktionsforskning där syftet är att interagera mer med studieobjektet för att studera effekter vid kunskapsintegration d v s möjliggöra ett ömsesidigt lärande. I syfte att underlätta lärande har två exempel konstruerats primärt utifrån teoribildning som ansluter till ledningspersonernas förväntningar som framkommit i Case FORCE, Steg 1.

Genom att använda såväl befintliga, kända men också "nya" modeller (Boulding, 1953; Holling, 1986) i exemplen konkretiseras vad teorin avser med att "tillämpa ett resursperspektiv i strategiarbetet", d v s några specifika förutsättningar för och konsekvenser av organisationens ekonomiska styrning. Ett syfte med att diskutera exemplen var att inför den fortsatta forskningen bidra till att utveckla eller förfina modeller som på ett systematiskt sätt kan appliceras i styrningen. Detta genom att påvisa ledningens möjligheter att aktivt påverka olika moment i den strategiska styrningen utifrån att de tillämpar ett utvecklat resursbaserat synsätt. ${ }^{90}$

Den teori som tillämpats ovan (Porter, Barney med flera) pekar på att utgångspunkten för en analys av en långsiktig ekonomisk styrning bör vara ett formulerat och kommunicerat, specifikt mål för ett företag; en hållbar/uthållig konkurrensfördel (SCA). ${ }^{91}$ Målet ska enligt teorin uppnås genom hög effektivitet och en högre avkastning jämfört med andra företag $i$ en bransch.

De villkor som idag anses gälla inom traditionell skolbildning om ekonomistyrning och som också är kända hos personerna i denna studie baseras på ‘kända’ förekommande mönster för företagande. Det utgår oftast ifrån ett marknadsperspektiv, i förekommande fall med referens till Michael Porter, som baseras på utbudsmarknadens mönster och villkor. Detta faktum medförde att dessa exempel konstruerats med ett pedagogiskt syfte.

En utgångspunkt för denna dialog är att en öppen dialog med /innovativa/ ledare i informationsrespektive energiintensiva kontexter (och i kombinationer av dessa) förutsätter att också nya mönster uppmärksammas. I den dialog som initieras här diskuteras att det under senare tid, från början av1980-talet fram till idag, särskilt har uppmärksammats andra mönster bland annat inom den $\mathrm{s} \mathrm{k}$ ekologiska ekonomin, detta $\mathrm{m}$ a $\mathrm{p}$ hur ett företags resursbas utvecklas $\mathrm{i}$ ett dynamiskt perspektiv och över tid och speciellt dess förmåga att anpassa sig i olika avseenden. Dessa mönster har stora likheter med de utvecklingsstrategier som beskrivs inom ekonomisk teori i termer av "exploration versus exploitation" (March, 1991). C.S (Buzz) Holling, ${ }^{92}$ en av grundarna till ekologisk ekonomi, beskriver stadier i en organisation, ett systems utveckling över tid utifrån hur resursbasens utvecklas. Holling's modell (Figur 15) är en utvecklad variant av James March's modell och $i$ kombination med befintliga modeller för ekonomisk styrning möjliggör den analyser av ett antal olika resursbaserade strategier där effekter på organisationens resursbas och graden av påverkan $\mathrm{d} v \mathrm{ds}$ systemets 'slutenhet/öppenhet' exemplifieras vid specifik styrning. I dialogen med deltagarna i denna studie tillämpas denna modell som potentiell "förändringsmodell", detta i syfte att i specifika kontexter, tydliggöra och

\footnotetext{
${ }^{90}$ Se även SAMP-modellen/ISO TS 55010

${ }^{91}$ SCA måste också ifrågasättas i en kritisk analys

92 C.S. "Buzz" Holling är kanske mest känd som upphovsman till teorierna kring resiliens, vilket enkelt uttryckt innebär kapaciteten att klara av förändringar och samtidigt en förmåga hos ett system att utvecklas. Teorierna om resiliens (elasticitet) innebär förmåga hos ett socialt eller ekologiskt system att klara av en chock, exempelvis i form av klimatförändring eller ekonomisk kris, och därefter förnya och återuppbygga sig själv. Hollings modell (Holling, 1973) med fyra utvecklingsfaser, här satt i en kontext där människan proaktivt påverkar utveckling, innebär ett avsteg från den terminologi som Holling tillämpar (frigörande kreativitet, reorganisering och förnyelse, exploatering och nyttjande samt bevarande kontraktion). Här tillämpas analogt begreppen kreativitet, förnyelse, exploatering samt konsolidering.
} 
identifiera olika potentiella resursbaserade strategier. Explicit ges ett konstruerat exempel två 'polära' strategibeslut i företags tidiga processer, d v s FoU och innovation som indikerats i studien. (Figur 16 a,b och 17 a,b.)

Vid ledning och styrning av beslutsprocessen vid FoU i målföretaget har denna studie urskilt två internt orienterade huvudstrategier som överensstämmer med antaganden i resursbaserad teori, RBV. RBV, med sitt ursprung i TGF. Penrose (1959) beskriver ett scenario som handlade om strategi för 'tillväxt' med konsekvenser på resursbasens utveckling, på såväl människors utveckling som på det finansiella målet för den ekonomiska styrningen. En utveckling av resursbaserad teori, om organisationens resurser och "dynamiska" förmåga ("dynamic capabilities") i samband med (omvärlds-)förändring (Schumpeter $\mathrm{m}$ fl) innebär också ett "nytt" mönster; ett scenario med kontraktion (Lindell, 1982), i dagligt tal en "negativ" tillväxt. I dialogen framkom att en övergripande strategibeskrivning därför måste omfatta såväl en beskrivning av expansionsstrategier genom beslut om utveckling, exploatering eller effektivisering av resursbasen ("exploration", "exploitation" och "effectiveness"), som kontraktion d v s effekter vid konsolideringsstrategier genom beslut om avveckling och effektivisering ("efficiency" och "termination") av resursbasen, över viss tid eller över en viss livscykel i en marknads eller produkts utveckling (Se även March, 1991). Mot bakgrund av projekt FORCE samt behovet av ny styrmodell med enklare tumregler och en potentiell arbetsmodell exemplifieras här, i tabellform, tre aspekter på resursbaserade strategier; strategiskt 'mönster', möjlig typ av styrning samt potentiella effekter på resursbasen.

I Hollings modell (Figur 15) identifieras fyra möjliga strategiska 'mönster’; två avseende 'expansion' och två mönster avseende 'kontraktion'. I 'positionskartan' nedan visas dessa två 'ytterligheter'.

\subsubsection{Positionskarta. En modell för positionering av resurser i ett dynamiskt förlopp.}

Resurser beskrivs ovan som input till processer i ett avgränsat system och i någon form av flödesbeskrivande modeller. En annan aspekt på resurser i exempelvis ett finansiellt system, inför alternativen att expandera eller konsolidera en verksamhet, är hur systemets (läs: organisationens) finansiella tillstånd, d v s dess position (Söderbaum, 1970) ser ut $i$ en specifik situation. På ett likartat sätt kan även andra resurser, utöver finansiella, åskådliggöras i någon form av positionsbestämning, i en kartbild eller motsvarande.

Nedan ett exempel på en positionskarta som utvecklats med syfte att bestämma en organisations eller organisms resursposition. Ursprunget till modellen är hämtad från litteratur och empiri som beskriver (natur-) resurser på en aggregerad nivå. Holling, prisvinnaren 2008 av Volvos miljöpris, beskriver en karta för att bestämma en organisations position utifrån hur dess resurser är relaterade till en viss situation eller intern miljö men med internt respektive externt fokus. Modellen är en beskrivning av fyra karaktäristiska situationer eller miljöer; i denna avhandling tolkade som en kreativ miljö, en förnyelsemiljö, en expanderande/exploaterande miljö respektive en konsoliderande miljö. En positionering av organisationens resurser (och förmågor) enligt denna indelning tydliggör förutsättningar inför strategiska beslut, d v s var det system man valt att studera ( $\mathrm{t}$ ex ett företag) och dess resurser, är i ett utgångsläge. Modellen beskriver samtidigt ett dynamiskt förlopp. Den indikerar hur resursbasen i kontexten påverkas (med eftersläpningseffekter) i samband med förändring av en position. Modellen avser att visa hur ett system kan återhämta sig genom en kontinuerlig förändring samt effekterna på dess 
resursbas. ${ }^{93}$ Den visar dock inte storleken eller omfattningen av resurser/förmågor eller styrkan i förloppet.

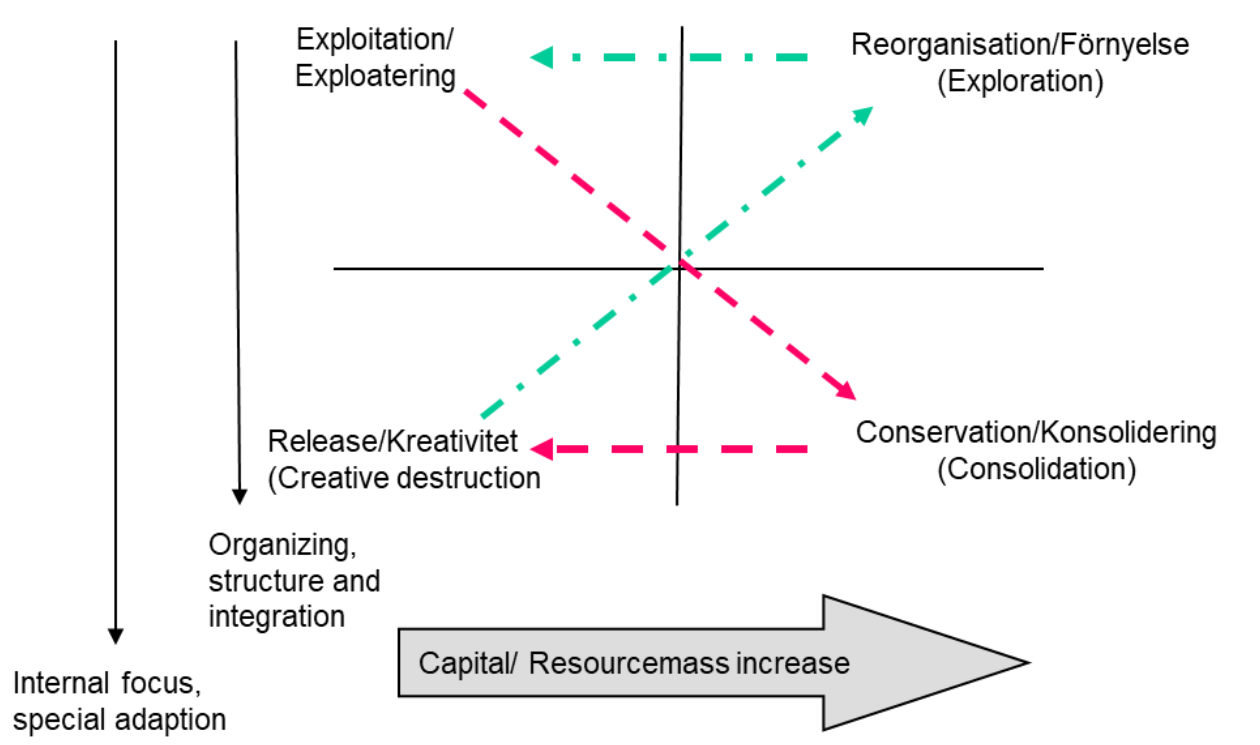

Figur 15. "Positionskartan" En modell över resurspositionering och `rött eller grönt ljus` för en uppgradering $\mathrm{i}$ miljö och social/relations kontext, organisering och initiala effekter på organisationens resursbas vid olika positionering (härledd och bearbetad från $\mathrm{G} \mathrm{S}$ (Buzz) Holling (1985).

\subsubsection{Två exempel från tillämpning i Case Force.}

En tillämpning av Hollings modell (Figur 15) bygger på hans teori om förändringsmönster i resurser i naturliga system (Holling, 1973, 1995, 2008). Modellen ger potentiellt ett underlag för att också förstå förändringar i positionering och organisering av ett företags övriga resursmassa över en längre tidsperiod, även om strategier bakom dessa `mönster’är utformade av individer.

Modellens utgångspunkter, förändringar och tänkbara styrmedel samt effekter av en resursbaserad styrning kan därför potentiellt tillämpas för att utforma en "strategimodell" för organisationer. En analys och tillämpning har diskuterats i Case FORCE men modellen måste primärt här ses som är teoretisk konstruktion inför för vidare forskning. ${ }^{94}$

\footnotetext{
${ }^{93}$ Holling (2006) beskriver exempelvis dynamiken i förändring av resursbasen vid övergång från kreativitet till förnyelse "...this is a process of slowly increasing organization...accompanied by gradual accumulation of capital." (Holling in Gunderson et al, 2010 s.95)

${ }^{94}$ Lite förenklat: Crawford Stanley Hollings modell (Holling, 1973) ger en möjlighet att i någon mån prediktera en utveckling i 'öppna system’. Holling ser verkligheten i en större systemkontext där systemet inte automatiskt
} 
Två exempel som kan härledas från empirin av FORCE vad avser valet för ledningen är att antingen uppgradera och expandera projektet ("gasa") i BU 3 eller konsolidera ("bromsa") utifrån verksamhetens och projektets finansiella restriktion. Empirin i FORCE visar att speciellt kompetensförsörjning för att utveckla "unikitet" kan lösas på många olika sätt och i olika grad förstärka projektets unikitet/organisationens kapacitet.

Det första (1) exemplet är en delvis expansiv strategi: "resursförnyelse" (jfr "exploitation" respektive "effectiveness") d v s "grönt ljus" för expansion utifrån finansiella kriterier.

\begin{tabular}{|c|c|}
\hline Expansionsstrategi & Styrningspåverkan \\
\hline $\begin{array}{l}\text { Kännetecken på } \\
\text { resursbasen }\end{array}$ & $\begin{array}{l}\text { Ok i utgångsläget, minskar initialt och ökar långsamt } \\
\text { genom denna strategiförändring }\end{array}$ \\
\hline Typ av styrning & En öppnare mer "loose" kontroll \\
\hline Beslutsprocessen & $\begin{array}{l}\text { Fokus på unik teknologi (patent etc.), resursen "känd" } \\
\text { och tillgänglig (exemplet säger inget om begränsning } \\
\text { av denna) }\end{array}$ \\
\hline Organisation & Ökad separation; delegerade befogenheter \\
\hline Mätning & $\begin{array}{l}\text { Effektivitet; "effectiveness" ökar långsamt; } \\
\text { "produktiviteten" är konstant. "Effektivitetsmålet lätt } \\
\text { att härleda/beräkna (väl definierade/ kvantifierbara } \\
\text { resurser etc.) } \\
\text { Avkastning ("rent"); avtagande p g a resursbasens } \\
\text { "eftersläpning" i början därefter ökande; riskfaktor } \\
\text { hög i alla riskfaktorer }\end{array}$ \\
\hline
\end{tabular}

Figur 16 a Case FORCE kännetecken vid applicering av expansionsstrategi

Det andra (2) exemplet är en konsoliderande strategi: "resursanpassning"(jfr "efficiency"), d v s "rött ljus" för expansion utifrån finansiella kriterier.

intar ett konstant jämviktsläge eftersom en viss utveckling påverkar utfallet och positionen. Graden av 'volatilitet' (elasticitet) påverkar säkerheten vid bedömningar. 


\begin{tabular}{|c|c|}
\hline Konsolideringsstrategi & Styrningspåverkan \\
\hline $\begin{array}{l}\text { Kännetecken på } \\
\text { resursbasen }\end{array}$ & $\begin{array}{l}\text { Värdet av RB stort i utgångsläget utifrån en tidigare } \\
\text { expansiv strategi (kvantitativt och därmed } \\
\text { opåverkbart för "nedskrivning" etc.). Strategin } \\
\text { innebär först en relativ ökning av RB ( p g a } \\
\text { eftersläpning), men syftar till en succesiv minskning } \\
\text { (inklusive nödvändig nedskrivning) av RB. }\end{array}$ \\
\hline Typ av styrning & $\begin{array}{l}\text { En ledningsstyrd, mer "tight" kontroll och } \\
\text { objektivitet belönas. }\end{array}$ \\
\hline Beslutsprocessen & $\begin{array}{l}\text { Fokus på alternativ teknologi inför nästa strategi; } \\
\text { eventuellt nya "resursslag" fordrar så objektiv och } \\
\text { riktig bedömning som möjligt (dock att } \\
\text { informationen kan vara mycket begränsad), } \\
\text { implementeringen av denna strategi kräver en stor } \\
\text { förståelse för såväl "externa" förhållanden som } \\
\text { "intern" styrning }\end{array}$ \\
\hline Organisation & Ökad "intern" bundenhet, struktur och rutiner \\
\hline Mätning & $\begin{array}{l}\text { Effektivitet; "Efficiency" ökar med en medveten } \\
\text { (objektiv?) styrning (Mätning bara på kvantitativa } \\
\text { data/ kvalitativa är inte relevant på kort sikt) }\end{array}$ \\
\hline
\end{tabular}

Figur 16 b Case FORCE kännetecken vid applicering av konsolideringsstrategi

\subsubsection{Exempel 1: Expansionsstrategiers implikation på typ av styrning och dess effekter på resursbasen}

Strategi: Expansiv. (Se Fig. 15 från "exploration" till "exploitation") En förändring som avser att (kvalitetsmässigt) delvis och på sikt expandera organisationens resursbas och som ska förbättra organisationens resursposition. Strategin innebär en "extern" fokus samt uppgradering av kvalitén (förnyelse) av en specifik resurs/-kombination/ och ledningen kan välja att också "insourca" ny specifik kompetens som kan möjliggöra utvecklingen. Utifrån kriterierna och "att förstå" enligt förklaringsmodellen (Figur 9) kan antas att styrningens olika element påverkas på följande sätt:

Tidsperspektivet vid analysen; Strategin ovan förutsätter att det är "grönt ljus" för att göra denna kvalitetsförstärkning d v s resursbasen måste i utgångsläget vara "optimal" (inga rester efter tidigare, misslyckade (?) strategier), utvecklingstiden kan komprimeras genom denna "insourcing", men om RB stiger för snabbt kan strategin behöva omprövas. Strategin är inte överdrivet konjunkturkänslig om resurser och teknologier är kända. Om resurser är "okända" är riskfaktorn hög i ett kortare perspektiv. Systemets verkningsgrad är hög vid känd teknologi. 


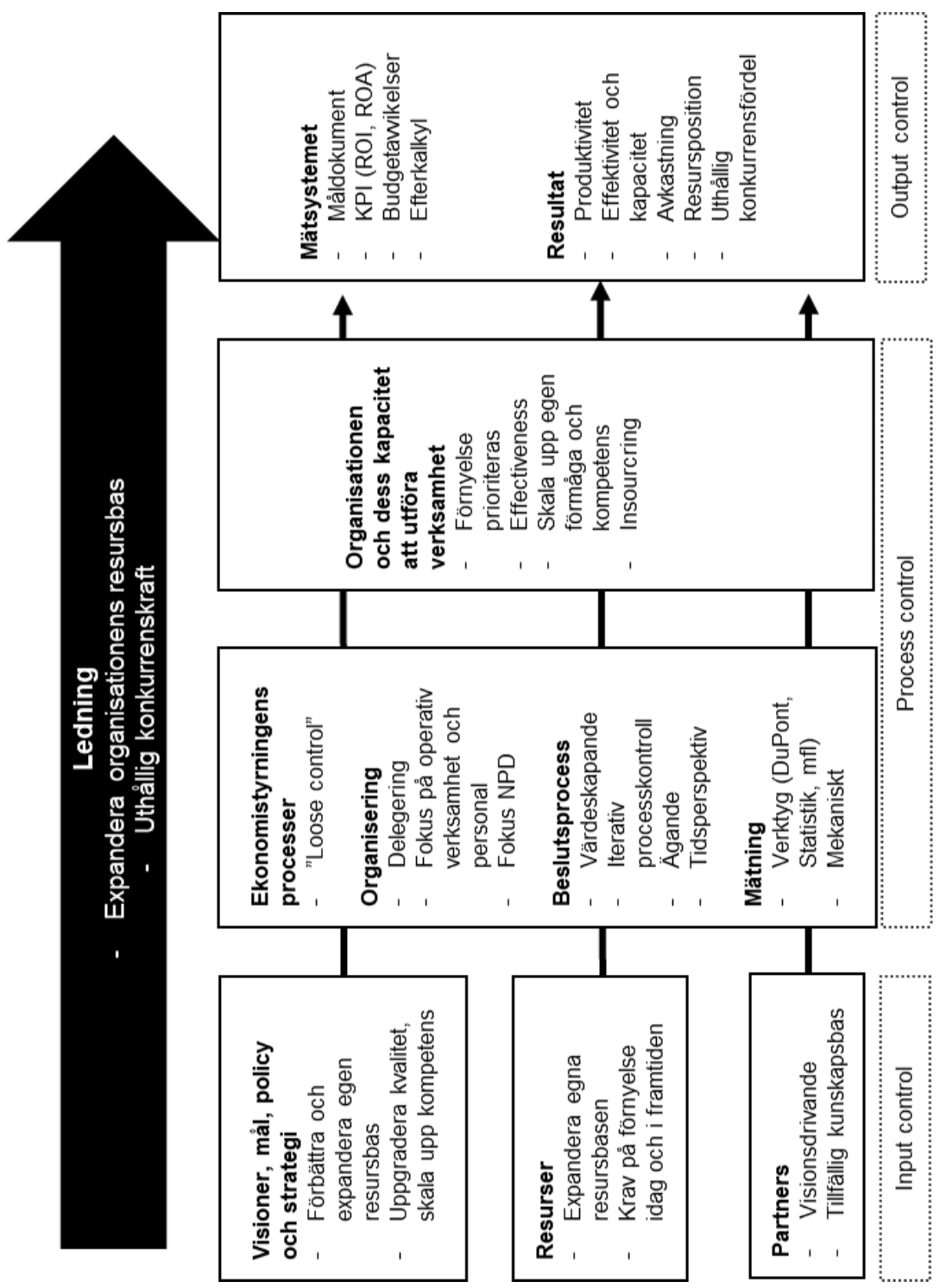


Figur 17 a. Konstruerat exempel på strategiskt styrningsperspektiv för Case FORCE vid expansionsstrategi baserat på tentativ förklaringsmodell presenterad i Figur 9. 
6.4.4 Exempel 2 Konsolideringsstrategiers implikation på typ av styrning och dess effekter på resursbasen

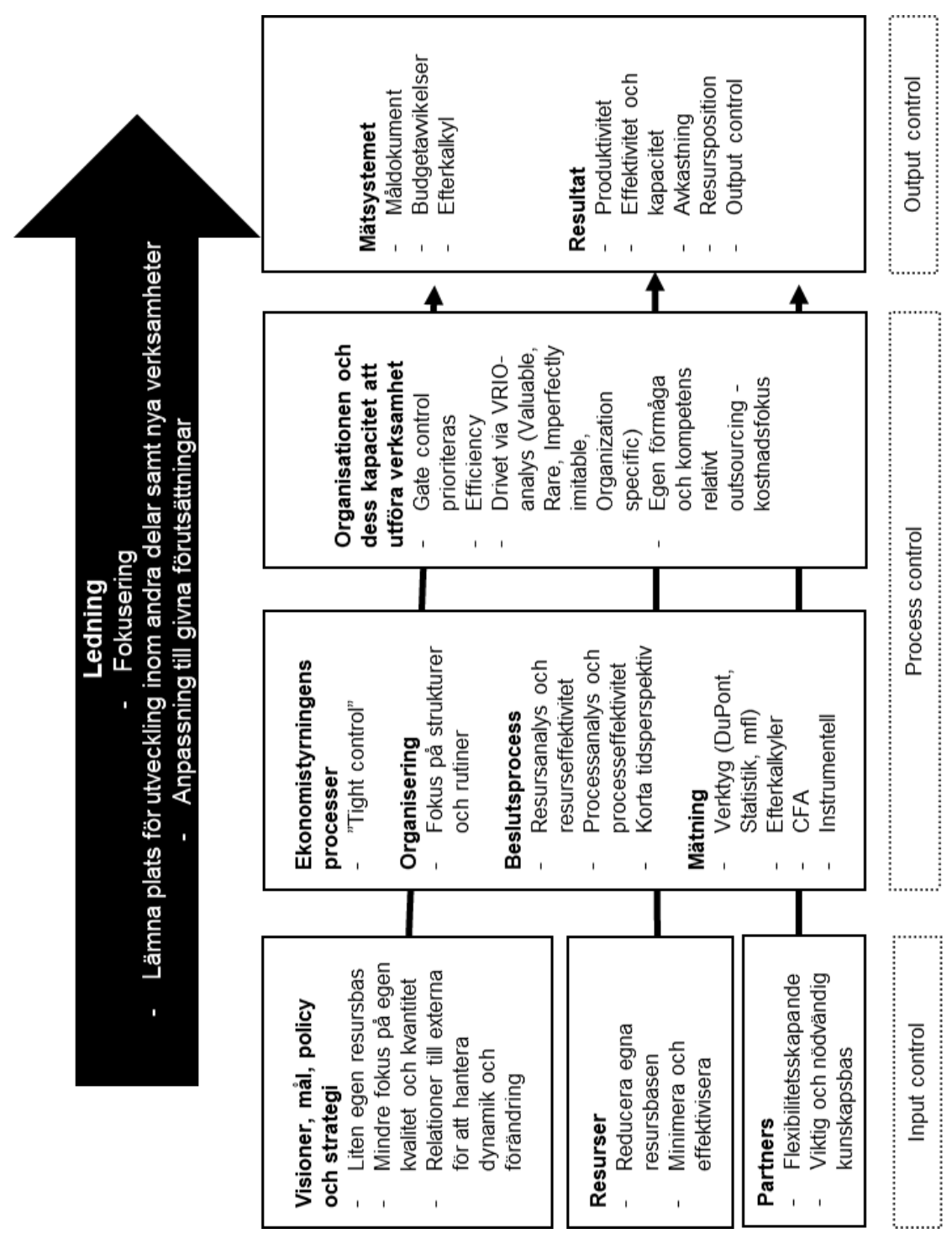


Figur 17 b. Konstruerat exempel på strategiskt styrningsperspektiv för Case FORCE vid konsolideringsstrategi baserat på tentativ förklaringsmodell presenterad i Figur 9

Strategi: Kontraktiv (Se Figur 15: från "Exploitation" till "consolidation”). En förändring som avser att lämna plats för nya verksamheter och konsolidera organisationens resurser mm. Strategin innebär en "intern" fokus och ledningen väljer att avstå från viss verksamhet (till annan) för att kunna anpassa såväl volym som kvalitet. Strategin får ses som ett steg inför en kommande "kreativ" strategi när konsolideringen är avslutad. Utifrån kriterierna (RBV) och "att förstå" enligt förklaringsmodellen (Figur 9) kan antas att styrningens olika element påverkas på följande sätt:

Tidsperspektivet vid analysen: Strategin utgår ifrån att det är "rött ljus" för uppgradering och att detta strategiskifte syftar till att minska RB (genom att avyttra verksamhet). Strategin är relativt konjunkturkänslig och ett misslyckande vid genomförande kan äventyra/försena möjligheterna att uppnå en "hållbar" konkurrensfördel. 


\section{Kapitel 7 Case INNOHUB.01 - .04 (.05) Aktionsforskning vid "öppen innovation" - i ny kontext.}

\subsection{INNOBUB}

Initiativet INNOHUB är fortsättningsvis kategoriserat som forskningsobjektet INNOHUB. Det är ett icke vinstdrivande företag som f n (2019) är fristående från ägarintresse. Grundfinansiering har gjorts i etapper med kapital från fyra intressenter. Löpande finansiering sker med egna medel genom uthyrning av lokaler och avgifter för de företag som ansluts till denna "hub", i ett ekosystem för innovationer.

INNOHUB är en s k accelerator; ett relativt nytt begrepp som etablerats i Europa. En "accelerator" är, i jämförelse med en "inkubator", en organisation som har till uppgift att hjälpa innovativa företag (SMF) med redan utvecklade innovationer, att hitta rätt partner för att snabbare få ut innovationen på marknaden (time to market). Partners kan vara utvecklingspartners i specifika utvecklingsprojekt eller konsultpartners för etablering av affärer i olika segment. En accelerator kan vara mer eller mindre knuten till en eller flera partners som har intresse av de projekt som utvecklas i SMF. I Sverige finns f n (2019) tre acceleratorer med knytning till en specifik partner. I hela Europa finns ett flertal acceleratorer men dessa är knutna till mer än ett specifikt företag (Connector i Spanien $\mathrm{m} \mathrm{fl}$ ).

INNOHUB har initierats efter studier av en global farmaceutisk industrikoncern vars regionala verksamhet i Sydsverige är experimentell forskning. INNOHUB, primärt intressentpåverkat av ett företag med global verksamhet, bedriver i stor utsträckning en tillämpad forskning, relaterat till ett antal utvalda industriella kluster. Syftet med acceleratorn INNOHUB är att invitera innovativa företag att, efter en prövoperiod (4 - 6 mån), under en tolv månaders period utveckla och etablera en innovation $i$ ett partnerskap, primärt för tillämpning vid tredje part. Perioden kan förlängas. Denna etableringsprocess kan se olika ut och slutmålet är att innovatören och den utvalda partnern tillsammans ska utveckla unika koncept med en "slutkund" d v s inom det affärsområde eller kluster där själva affären etableras och där nyttan av innovationen kan värderas. Partnerskapet, som är kontraktbaserat och omfattar tre steg, inleds med "pitchningar" och om tillämpligt med "due-dilligence" processer innan avtal sluts.

\subsubsection{Bakgrund}

Projektinitiativet INNOHUB, som i avhandlingen redovisas som ett samlat "business case" genomfördes empiriskt som fyra delstudier, som inom ramen för denna avhandling följts som följeforskning under perioden november 2018 till januari 2020, d v s 15 månader. Innan denna period var man involverad i etableringen och de tidiga faserna av initiativet från 2016.

Följeforskaren har som primär uppgift haft att bedöma initiativets legitimitet som ett "state of the Art" -projekt i ett avgränsat industrikluster samt att föreslå och pröva modeller för analys och utvärdering av delar av projektet inför aktörernas självutvärdering och beslut att investera ytterligare. Primära aktörer är, förutom anställda i projektbolaget INNOHUB, ledningen för BU FOU/CR, ett fyrtiotal anslutna aktiva "start-ups" (2019) ${ }^{95}$ samt investerare i SMF-projekt.

\footnotetext{
${ }^{95}$ Initiativet har 2021 ca 65 anslutna företag varav 20 var alumni. Ett 20-tal företag har tillkommit 2020-21 varav merparten har globala intressenter/ägare
} 
Primär investerare är målföretaget i denna avhandling. Anslutna SMF benämns i det fortsatta INNOVATÖRERNA. Externa intressenter är de fyra finansiärerna i initiativet; målföretaget, en kommun, en region och Vinnova.

Målet för denna följeforskning är att verka för utveckling av underlag för bra beslut för såväl primära aktörer som för de intressenter som finansierat initiativet INNOHUB. Följeforskningsuppdraget finansieras av initiativets fyra intressenter, alla med olika grad av involvering i ekosystemet. Ett bra beslut, implicit uttryckt i denna avhandling, måste kunna identifieras utifrån samtliga aktörers och intressenters gemensamma, övergripande mål för sitt engagemang, ett engagemang med ett "hållbart" syfte. I projektbeskrivning för INNOHUB framgår att ett syfte är att uppnå en resurstillväxt. (Projektbeskrivning 2016-09-23)

Initiativet INNOHUB initierades med en projektbeskrivning i september 2016 (Fas 1 omfattande perioden 2016-09-05 - 2019-06-30) med rubriken "Tillväxtkatalysator, öppen innovationsmiljö för Industri och SMF $i$ samverkan”. Ett år efter projektstart initierades följeforskningen av projektet i januari 2018. Den påbörjades efter en förstudie och efter finansieringsbeslut den 1 november 2018 som ett forskningsprojekt i fyra faser, varje fas med egen föreslagen forskningsagenda (feb 2018). Följeforskaren har haft en rådgivande grupp (advisory board) bestående av de fyra finansiärerna samt sedan januari 2019 tillgång till handledning samt internationell expertis bestående av experter på standardisering av ledningssystem.

Resultatet av följeforskningen avsåg att spegla hur projekt INNOHUB utvecklats och vilka mål projektet uppnått under den period som forskningens empiri omfattar d v s 2019 till och med januari 2020. Då en del av studien, modellering och förarbete genomfördes som en förstudie under 2018, redovisas i projektet även resultat från denna förstudie samt förändringar i dessa företag under 2019. Här redovisas resultat från de respektive delstudierna. (Se Figur 19)

\subsubsection{Genomförande}

Följeforskning är forskning på avancerad nivå. Följeforskning är inte en speciell forskningsmetod, inte heller en ansats, utan kan karaktäriseras som ett förhållningssätt gentemot det studerade objektet. När det gäller insamling av information är i detta fall objektet endast INNOHUB och de medverkande företagen. Följeforskaren strävar efter att ge ett evidensbaserat bidrag till forskarsamhället samt ett bidrag för praktisk förståelse och potentiellt också tillämpning. Följeforskning kan bedrivas utifrån olika forskningsansatser, med induktiva eller deduktiva förutsättningar eller kombinationer av dessa. En följeforskning kan bedrivas med olika metoder för informationsinsamling.

Följeforskningen kan i olika grad vara interaktiv, s k aktionsforskning och i vissa fall deltagarbaserad om kontexten fordrar detta för att lärande ska uppstå. Vanligt är att följeforskaren primärt har en observerande och dokumenterande roll utan djupare interaktion med objektet. Objektet också i detta avseende är INNOHUB och anslutna företag.

I detta Case INNOHUB har interaktionen i någon mån varit interventionistisk i syfte att utveckla djupare förståelse för ledning och styrning vid innovationssamarbeten (collaborative innovations). Interagerandet har endast skett mellan forskaren och objektet, inte med intressenter runt objektet, detta bland annat i syfte att inte påverka studiens resultat. 
Detta följeforskningsuppdrag innebär att utvärdera "objektet" INNOHUB och dess roll att stödja de SMF, s $k$ "post-incubators" som blir antagna till INNOHUB. Den roll som ska analyseras är rollen som accelerator för SME.

\subsubsection{Utvecklingen perioden 2016 - 2018}

INNOHUB består utöver styrgruppen av sju medarbetare, alla med specifik kompetens inom något teknik- och affärsområde. Medarbetare har rekryterats från Målföretaget, den globala industrikoncern som är en huvudintressent i forskningsprojektet. Under denna första period sökte ett stort antal SMF-företag om medlemskap i INNOHUB. Det första urvalet av företag föregicks av personliga kontakter och efterföljande antagnings- och etableringsprocess. Under denna period antogs tjugotalet företag i en första fas (ingår i Case INNOHUB .01) och något färre i en andra fas (ingår i Case INNOHUB .02). Vid utgången av 2018 var drygt fyrtio företag anslutna varav ett antal var alumni d v s hade avslutat sitt direkta medlemskap efter tolv månader vid utgången av perioden. Antalet "events" under perioden fram till och med december 2018 var ca XX st. och hade resulterat i YY antalet partnerprojekt.

Inför beslut om finansiering påbörjades följeforskningen 2018. En förstudie genomfördes som omfattade genomgång av tillgänglig information, tidigare studier mm om inkubatorverksamhet, bland annat en masteruppsats om en större tysklandsstudie om öppen innovation (Stock, 2016). Tre testintervjuer med SMF som tidigt anslutits till INNOHUB genomfördes utifrån 19 frågor (Q 1 - Q19) som bedömdes relevanta utifrån den tyska studien. Resultatet sammanfattades i dokument (2018-04-30) inför förslag till finansiering av och beslut om en utvidgad studie för perioden fram till och med juni 2020.

Följeforskaren genomförde under den första antagningsfasen (2018) under rubriken Case INNOHUB .01 sjutton djupintervjuer varav nio intervjuer kompletterade med enkäter (Bilaga 5) och värderade med attitydskalor för fem målområden som anslöt till den struktur som använts vid föregående studier. Syftet var primärt att i en tidig fas av medlemskapet undersöka innovatörernas förväntningar samt upplevda hinder för "acceleration".

Vid denna fas tillämpades systemstrukturen, med referens till EEM-modellen, i sin helhet som en test vid de tre ytterligare djupintervjuer. Syftet var att utvärdera en tillämpning av modellen för att ytterligare uppnå förståelse för vissa fenomen som observerats och för att testa en struktur för den fortsatta studien. Operationaliseringen gjordes på engelska och analogt med den tyska studien (Stock, 2016), med exakt samma frågor (Q1 - Q19), detta för att resultat skulle kunna jämföras. ${ }^{96}$ Resultatet av detta test visade att en tillämpning av hela EEM-modellen var för omfattande och komplicerad att tillämpa vid utvärdering i så tidig fas (i "förväntningsfasen”). Här påbörjades därför en utveckling av en förenklad modell för den fortsatta studien, en arbetsmodell med utgångspunkt från EEM-modellen. Avstämning med INNOHUBS styrgrupp med resultat från samtliga dessa studier gjordes den 31 mars 2019.

Vid den andra antagningsfasen och under rubriken INNOHUB .02 genomfördes en första intervju med femton nytillkommande medlemmar om deras förväntningar på medlemskapet. I

\footnotetext{
${ }^{96}$ The Case Startplatz är en fallstudie av fjorton inkubatorer i USA, Europa och Asien. Studien avsåg att finna motiv och förväntningar på innovationssamarbete mellan stora företag och "start-ups". Utifrån den omfattande och välstrukturerade redovisningen av studiens upplägg och dess resultat bedömdes den vara relevant som referensstudie i Case INNOHUB.
} 
december 2018 gjordes ett utskick med enkät samt efterföljande djupintervjuer. Enkäten utformades efter EEM-modellens struktur, men nu i en förenklad form. Enkätfrågorna utformades både som strukturerade och semistrukturerade med delvis öppna frågor som underlag för dialog. En textanalys genomfördes inför utvärdering gentemot de mål som intressenterna specificerat i projektbeskrivningen för INNOHUB (2016). Avstämning med styrgrupp samt med INNOHUB gjordes i maj 2019. (Slutrapport; del 1 2020-11-15)

\subsubsection{Utveckling under 2019}

Under perioden har INNOHUB genomfört ett stort antal "events" och "pitchningar". Dessa events har delvis lett till ett stort antal partnerprojekt och till att nya företag anslutits till INNOHUB. Under första delen av denna period tillkom ca 15 nya medlemmar varav merparten (69\%) hade utländsk ägare. Under andra hälften av året tillkom ytterligare tre medlemmar. Vid utgången av 2019 hade INNOHUB sammanlagt 60 anslutna företag, varav 20 företag blivit alumni. Cirka 90 partnerskapsprojekt har etablerats från starten av INNOHUB. Sammanlagt ca 190 event genomfördes under samma tid. INNOUHUB har etablerats i en global kontext bland annat med en etablering i Indien.

Följeforskningen har enligt en totalplanering 2019-2020 (INNOHUB, totalplanering) inriktats på genomförande av fyra olika deluppföljningar: INNOHUB .02 (fortsättning med de $15+15$ anslutna företagen), INNOHUB .03 (intervjuer med INNOHUBS medarbetare, en enkät enligt EEM-modellen samt ett 'business case' baserat på ett verkligt höginnovativt företag, INNOHUB .04 a) uppföljning utifrån målföretagets mål samt INNOHUB .04 b) uppföljning gentemot regionala aktörers och Vinnovas mål; att avrapporteras preliminärt november $2020 .^{97}$

\subsubsection{Följeforskningens genomförande}

Forskningsprojektet Case INNOUB genomfördes i fyra steg. (Figur 18) Dialoger med anslutna företag genomfördes som steg 2 respektive steg 4 . I steg 2 genomfördes två faser där sammanlagt 40 företag medverkade. I steg 4 genomfördes uppföljande intervjuer med företag från Steg 2. Under samtliga steg pågick dialog med ledning och medarbetare i företaget INNOHUB. Ett "internt" case med exempel från ett anslutet företag genomfördes anonymt med medarbetare i steg 4. Intervjuer med projektägare i målföretaget .04 a samt med initiativets intressenter, $.04 \mathrm{~b}$.

Syftet med dessa uppföljningar (INNOHUB .01,.02, .03 och .04) är att bland annat validera en föreslagen modell för intressenternas självutvärdering. Enligt projektbeskrivningen ska en modell för självutvärdering baseras på EEM-modellen. ${ }^{98}$ Valideringen avser modellens tillämpning utöver planering, beslutsfattande, styrning och utvärdering, även som en form för parternas självutvärdering av respektive investering $\mathrm{i}$ forskningsobjektet INNOHUB. Validering av modellens tillämpning som utvärderingsmodell i denna empiri syftar primärt till

\footnotetext{
${ }^{97}$ INNOHUB .04 avbröts i Januari 2020 och uppföljningen med parterna ställdes in. Två planerade aktiviteter i.04 b har därför ej genomförts. Senaste avrapportering till Vinnova för perioden januari - oktober 2019 gjordes den 30 oktober.

98 Beslutet att tillämpa EEM-modellen grundas delvis på att den tillämpats vid tidigare case. Beslutet kommunicerades initialt med Vinnova och övriga intressenter.
} 
att finna relevanta fakta för att bedöma INNOHUBS legitimitet som " the State of Art" utifrån de resultat och 'interna' effekter som uppnåtts från samarbeten under perioden.

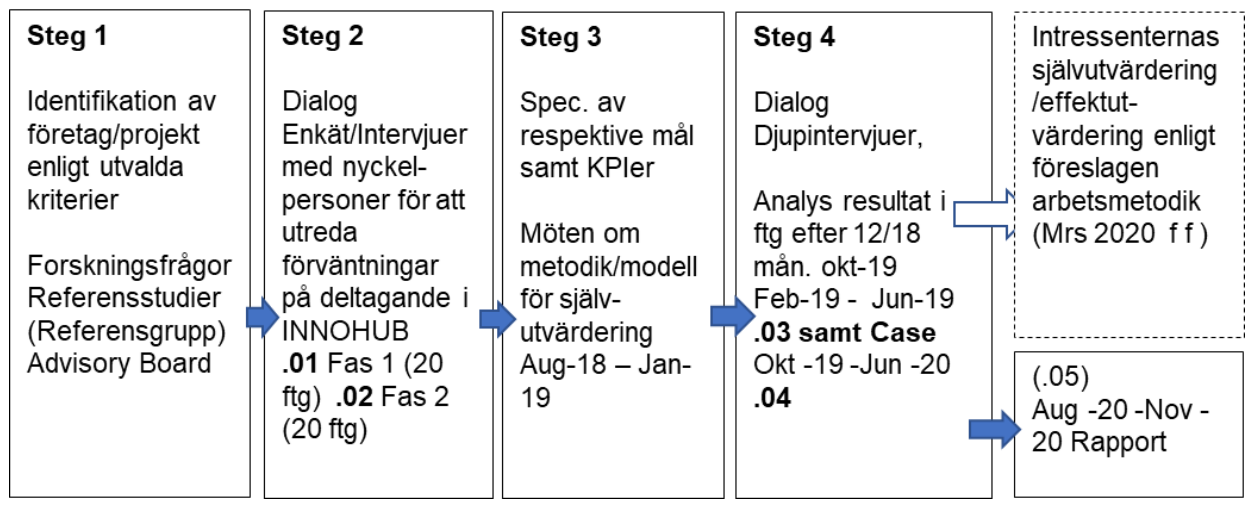

Figur 18. Arbetsgång i Case INNOHUB

Två viktiga delmål formulerades för följeforskningen; a) att utveckla de multi-/kriterier och begrepp som kännetecknar beslutsprocessen $\mathrm{i}$ form av en potentiell arbetsmodell för självutvärdering vid resursbaserad ekonomisk styrning samt b) att, i enlighet med projektspecifikation (Research Agenda, 2018-02-20) genom aktörernas tillämpning av modellen finna/utveckla en "formel" för att kunna beräkna KPIer för resurstillväxten av ett innovationskapital och kunna sätta mål, mäta resultat och effekter - detta för att underlätta för bra beslut i aktörernas olika forum.

Vid denna tidpunkt inleddes kontakt med en expertgrupp som kom att bestå av ett antal experter anslutna till ISO/TC 251 som utvecklar ledningssystem för 'asset management’. Syftet var att följa utvecklingen av internationell harmonisering avseende beslutskriterier och nyckeltal för ledning och tillgångsredovisning av kapitalintensiv verksamhet. I det att denna expertgrupp bistod med definitioner mm ses den som referensgrupp till följeforskningen.

\subsubsection{Utgångspunkt för utveckling av "arbetsmodell" och "formel"}

Utgångspunkten är den målbeskrivning som respektive "målsägare" (varje aktör samt externa intressenter) har. Något övergripande, gemensamt mål för samtliga aktörer och intressenter har inte etablerats hos målsägarna. I projektbeskrivning för INNOHUB (2016-09-23) specificeras målområden mm för respektive intressent. (Se nedan: Analys)

Uppföljning av finansiellt resultat av INNOHUBS verksamhet sker på projektnivå och görs av INNOHUBS controller. Finansiell information är konfidentiell. INNOHUBS verksamhet ska kunna bedömas utifrån den samlade nyttan av alla projekt, deras relevans, dess potentiella effekt på aktörers och intressenters (divergerande) mål, lokala projekt, regionala projekt. Projekt med bredare applikation i ekosystemet ska i kommande beslutsprocesser kunna identifieras utifrån olika kriterier och värderas av respektive projektägare/kontraktspart; antingen utifrån att en affär har genomförts eller att ett utvecklingsprojekt etablerats med en partner. Ett nytt 
"mätsystem" implicerar behovet av utveckling av ett 'innovationskapital' 99, ett värde som potentiellt kan identifieras för den samlade redovisningen av INNOHUBS uppdrag, antingen med en resultat- (förädlingsvärde, "bottom line" etc) och balansräkning eller en "cash flow" analys, inte nödvändigtvis i monetära termer (Se INNOHUB .04 a).

Den utvärdering som följeforskaren gör av INNOHUB .01 och .02 utgår dels ifrån de omdömen som innovatörerna ger utifrån sina mål och kriterier, förväntningar och eventuella förväntningsgap och om och hur dessa förväntningar infriats, $i$ undantagsfall det ekonomiska värdet som genererats i projekten. Tillämpning av den "nya" arbetsmodellen vid denna utvärdering av INNOHUB hos innovatörerna syftar till att verifiera en potentiell resurstillväxt d v s ett förväntat ökat 'innovationskapital', att upptäcka eventuella hinder för beslut och partnersamverkan samt att få ett underlag för att utveckla ett KPI som kan användas vid aktörernas och intressenternas beslutsprocesser vid kommande investeringar i detta innovationskapital.

För att följeforskningen ska ge en komplett bild i denna fas görs även en uppföljning av aktörerna d v s INNOHUBS medarbetare (INNOHUB .03/del av) samt direkta intressenter utöver innovatörerna i projekten, d v s investerare och partners (INNOHUB .03/del av). En utgångspunkt, ett antagande inför en analys är att aktörerna (.02 och .03) har samma övergripande mål för deltagande i INNOHUB och dess verksamhet.

\subsubsection{Delstudierna inom INNOHUB}

Redovisningen och analys av följeforskningen Case INNOHUB görs enligt analysmodellen (AE, R) och med frågor från den tyska studien (Se bilaga 4: Stock, 2016).

Respektive dialog inleds med en kortare beskrivning av momentet samt en målbeskrivning från en textanalys av måldokumentet. Därefter presenteras ett sammanfattat resultaten från studien, i förekommande fall med citat.

En partiell analys och en bedömning av strategiska utmaningar görs vid respektive studie. Case INNOHUB igår i den systemiska analys som görs i kapitel 8. Respondenters förväntningar och förslag till åtgärder diskuteras i kapitel 9 och 10.

De två överställda frågorna som gäller inriktningen för följeforskningen av Case INNOHUB är följande: (från projektbeskrivning 2018-02-20

- Frågeställning 1: "With reference to the "new" context for the "catalyst" INNOHUB: How will future, sustainable and "innovative" organizations be promoted to develop and grow, in order to fulfill the aims of the various stakeholders'?"

- Frågeställning 2: "With reference to the chosen and stated assumptions from $Q 1$ about new agents involved in the "new" innovation system: Which will be the optimal ways to measure benefits and sustainable values of the relations specified in this wider context?"

Dessa två frågeställningar har för att kunna operationaliseras inför denna fas av INNOHUBstudien omformulerats till två tankekonstruktioner inför analys enligt följande;

\footnotetext{
${ }^{9}$ Innovationskapital (per definition $\mathrm{f} \mathrm{n}=$ nedlagda kostnader i FoU (Chang \& Hsieh, 2011). Begreppet föreslås revideras vid fortsatt forskning.
} 
- hur organisationen, 'katalysatorn' INNOHUB möjliggör en resurstillväxt och värdetillväxt för innovativa företag och dess intressenter samt

- hur en optimalt möjlig "nytta" och hållbar resurs- och värdetillväxt kan mätas i olika kontexter från detta arbete.

Dessa två tankekonstruktioner avses endast att vara vägledande vid analys av Case INNOHUB.

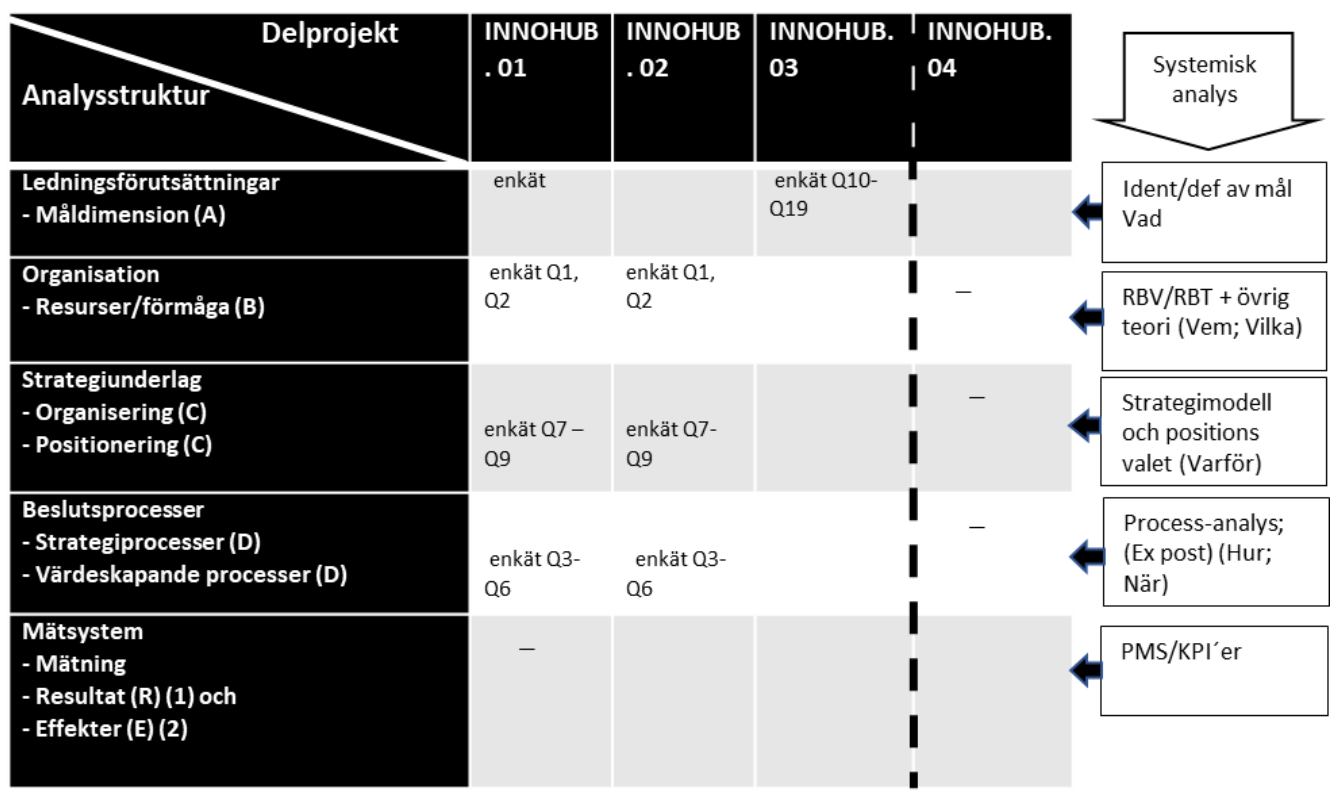

Figur 19. INNOHUB-matrisen. Matris över redovisning av empiri enligt analysmodellen. Redovisningen görs vertikalt d v s i varje delprojekt redovisas samtliga element. Analysen görs horisontellt d v s varje element i modellen analysera parallellt över samtliga delprojekt och ingår i avhandlingens systemiska analys.

\subsection{INNOHUB .01 - Initiala förväntningar}

Denna del av följeforskningen syftar till att studera faktorer som kan förklara utvecklingen av innovationskapitalet (som en del av FoU-verksamheten) i de olika anslutna företagen. Förväntningar studeras i de första 17 företagen (* Mars 2018 - ) som anslöts till INNOHUB.

Denna första del handlar om förväntningar på resurstillväxt genom projektsamarbeten och omfattar 6 månader (perioden jan - juni). Studien genomförs primärt genom att undersöka innovatörernas olika förväntningar på medlemskapet i INNOHUB. Inför Fas 2 är systematisering och beskrivning av ett "innovationssystem" viktigt för att mätning av resultat och effekter ska kunna göras. Denna första "sfär" av företag illustreras därför med ett försök att beskriva det "nya" innovationssystemet (Se bilaga 6: det "nya öppna innovationssystemet") och 
studien har ett "aktörsperspektiv". Avrapportering 31/5 samt rapport 30/6 inför fas 2. De sjutton företag som ingår i Fas 1 är alumniföretag i Fas 2.15 av dessa alumniföretag intervjuas i Fas 2.

Ett antal förväntade MÅL för medlemsföretagen (resultat och effekter) beskrevs i ursprungsdokumentet (2016-09-23). Vid en textanalys och med referens till den analysmodell som tillämpas i detta avhandlingsarbete tydliggjordes målområden, mål, medel och mätvariabler för styrningen inför kommande intervjuer. De olika målen klassificerades som input, process och output. (Hales, 1993). Dessa målvariabler utgör underlag till enkätfrågor i INNOHUB .02. För varje målvariabel specificerades ett antal medel och möjliga mätvärden, se figur 22.

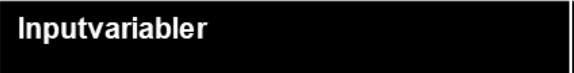

Teknologi: Ny teknik och metod

\section{$\underline{\text { Individ/Personal; Kompetens och }}$ innovationsförmåga}

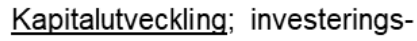
/rörelsekapital

\section{Processvariabler}

Tid och innovationssystemutveckling: process

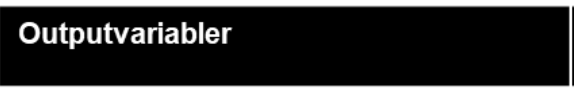

Internationaliseringsprocessutveckling: process och output

Marknadsutveckling:

\section{Mål}

Potentiellt applicerbara teknologier som input för övriga mål

Ökat innovationskapital genom intern (egenintjänad) resurstillväxt

Ökat inflöde av riskkapital till företagen för att nå övriga mål

\section{Mål}

Att växa snabbare för att nå övriga mål

\section{Mål}

Ökad internationell attraktionskraft

Koncernens framgång och attraktivitet

Figur 20. Målvariabler för INNOHUBS medlemsföretag enligt textanalys av ursprungligt projektdokument 20160923.

\subsubsection{Ledningsförutsättningar och måldimension}

I de tre företag som intervjuats som "testföretag" beskrevs detta tema mycket olika. Generellt tydliggjordes en problematik om otydlighet (initialt mycket oklart hur kommunikationen ska ske vs INNOHUBS roll snarare än vad målet bestod i) som orsak till att det uppstått ett förväntningsgap gentemot de mål (deliverables) som ändå fanns.

Frågan om innovatörernas mål i dessa tre initiala intervjuer kan sammanfattas: Bolagens förväntningar efter 18 månader fokuserade på samarbetet (primärt med Målföretaget) snarare än på förväntade leverabler (målen). 
De möjligheter man i övrigt beskriver handlar om dels kommersiellt, att sälja till gemensamma kunder med Målföretaget, och dels tekniskt, att nyttja stororganisationens tekniska kunnande. Här har inte förväntningarna (av naturliga skäl) infriats i en första fas, dock har, som exempel på INNOHUBS agerande i ett projekt, en ex-jobbare tillsatts hos Målföretaget, detta för att utveckla det tekniska samarbetet.

Som kommersiell möjlighet fanns hos hälften av företagen initialt stora förväntningar på finansiering från Målföretaget. En tydlig policy vad avser "problemägaren" och dess möjlighet till finansiering efterlystes.

Frågan om innovatörernas mål i övriga 9 företag där enkäter gjorts, har sammanfattats från frågor (Se bilaga 5). Följande målvärde redovisas för dessa; gradering $1-5 ; 1=$ inte alls, $5=\mathrm{i}$ största utsträckning.

\begin{tabular}{|c|c|c|c|c|c|c|c|c|c|c|}
\hline Målområde & 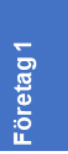 & 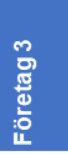 & 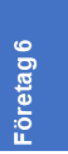 & 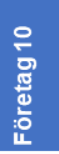 & 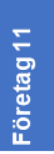 & 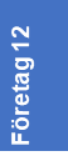 & 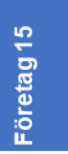 & 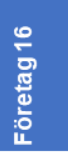 & 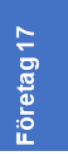 & Medel \\
\hline Snabbare tillväxt & 3 & 2 & 1 & 1 & 1 & 2 & 3 & 3 & 2 & 2,0 \\
\hline Internationell marknad & 3 & 2 & 2 & 1 & 1 & 3 & 3 & 1 & 1 & 2,0 \\
\hline $\begin{array}{l}\text { Kortare finansieringsprocess } \\
\text { (direkt projektinvestering) }\end{array}$ & 3 & 2 & 1 & 2 & 2 & 2 & 3 & 3 & 3 & 2,3 \\
\hline Kortare innovationsprocess 1 ) & 4 & 5 & 5 & 1 & 2 & 4 & 2 & 2 & 2 & 3,0 \\
\hline \multirow{2}{*}{$\begin{array}{l}\text { Lärande från andra INNOHUB } \\
\text { företag }\end{array}$} & 1 & 5 & 2 & 4 & 1 & 1 & 4 & 1 & 1 & 2,2 \\
\hline & $\sum 14$ & $\sum 16$ & $\sum 11$ & $\sum 6$ & $\sum 7$ & $\sum 12$ & $\sum 15$ & $\sum 10$ & $\sum 10$ & \\
\hline
\end{tabular}

Figur 21. INNOHUB .01 Initiala förväntningar hos 9 av de först antagna 17 företagen (enkätsvar)

Företagen i denna studie har definierats i tre kategorier; a) Innovationscenter (Företag 12) b) "start-up" med färdig affärsmodell (Företag 3, 6, 11) samt c) "full time ventures" (Företag 1, $16,10,15)$. Fyra av företagen markerar mycket stor förväntan på en snabbare innovationsprocess (Företag 1, 3, 6, 12).

Frågan om innovatörernas övriga mål och förväntningar på måldimensionen sammanfattas $\mathrm{i}$ bilaga 4 ("encl. 5", Q10 - Q 19). Dessa värden redovisas i anslutning till INNOHUB 0.3 i syfte att jämföra med den självvärdering som utförts av anställd vid INNOHUB.

\subsubsection{Organisation: Resurser och förmåga}

Av de sjutton företag som intervjuats i Fas 1 har elva respondenter $(1,3,6,7,8,9,10,11,12$, $15,17)$ utvecklat svar om INNOHUB som organisation, som potentiell resurs och dess förmåga. 
Unikt är att INNOHUB ses som en brobyggare (ny form) mellan innovatör och framförallt vissa delar av målföretaget (med för och nackdelar). Två respondenter $(7,10)$ nämner INNOHUBS förmåga att arrangera event. INNOHUB ses av en respondent (15), inte som en (fysisk) resurs, dock som en potentiell möjlighet att utveckla kontakten med Målföretaget (i och för gemensamma projekt, finansiering $\mathrm{mm}$ ). En respondent pekar på det "tysta" samarbetet där INNOHUB är en länk. Två respondenter $(6,17)$ pekar på INNOHUB som en viktig del i nätverket med andra aktörer i innovationssystemet, universitet mm. INNOHUB anses av en respondent (10) ge en kvalitetsstämpel. Frågan om INNOHUBS förmåga (svårighet?) att identifiera "problemägare" nämns av två respondenter $(8,11)$.

\subsubsection{INNOHUBS organisering och positionering}

Frågorna under denna rubrik handlar om hur INNOHUB har positionerat sig för att attrahera leverantör/innovationer/projekt av en viss typ. (Varför man samarbetar med INNOHUB och vad INNOHUB samarbetet förväntas leda till).

Positioneringen (av INNOHUB) som en "relevant" kontakt (en verklig koordinatorroll) in i Målföretaget (antingen till affärsenhet eller till CR) är genomgående nämnt av företagen (3, 6, 8. 9, 12, 17). Generellt uppfattas tillgången till kontakt med ett globalt INDUSTRIFÖRETAG (en industriell partner) som viktigt och INNOHUB är här "relevant" (2). Ett företag nämner vikten av ett lokalt samarbete bland annat vid utveckling av nya affärsmodeller. Två företag $(11,15)$ klargör syftet att lära mer om Målföretaget och framförallt de applikationer som kan bli aktuella. Ett företag (15) har uttryckt att de vill SÄLJA till Målföretaget. Tre av företagen $(3,6,7)$ har som första prioritet att INNOHUB erbjuder LAB-kapacitet. INNOHUB (enligt 6) positionerar NY teknologi och samarbete med tekniker på BU FoU/CR, nämner det goda exemplet från Norge.

Positioneringen av möjlighet till finansiering (men att Målföretaget inte äger lösningen) via Technology Venture har uppfattats positivt av (6). INNOHUB positionerar sig att inte äga eller ha kontroll utan endast vara en dörröppnare $(1)$. Två företag $(9,17)$ nämner de event som INNOHUB genomför. Fördelen med exponering i sociala media nämns (2). Endast ett företag (7) nämner förekomsten av kontorsplats ("fina kontor") som en del i positioneringen.

\subsubsection{Strategier och värdeskapande}

Här bedömer respondenten den kontext, hur och på vilken arena som samarbetet bedrivs/förväntas bedrivas samt de utvecklingsfaser och procedurer som INNOHUB medverkar i - före respektive efter beslut i projekt. Respondenternas svar speglar beslutsprocesser, som en viktig del i innovationsprocessen, i nuläge och framtid.

Av 12 företag anger 5 att de har daglig kontakt med någon i INNOHUB, 4 företag har kontakt 1 till 2 ggr/månad. Samarbetet (kontakterna) sker övervägande via mail. Ett företag (10) framhåller vikten av att kommunicera "face to face" (vilket man har genom daglig fysisk närvaro) för att löpande beslut i projekten ska fungera.

Tre företag $(2,3,6)$ har kontakt med Målföretaget (olika BU) innan första kontakt med INNOHUB. Övriga har kontaktats initialt av samma namngivna person vid INNOHUB eller möte via speed-dating (1 företag). 
I denna första fas har fokus primärt gällt rekrytering av innovatörer från INNOHUBS sida. Respondenterna speglar en process som handlar om förväntningar snarare är resultat. Två företag $(6,8)$ efterlyser ett mer agilt samarbete och ett engagemang direkt med Målföretaget (enligt företag 6 inom en viss teknologi) för att "accelerationen" ska lyckas.

INNOHUB förväntas initialt (tidigt/"ex ante"/omfattande fyra månaders processtid) göra /medverka till/ identifiera behov och en planering (inklusive LAB (6)) av respektive projekt anser tre av företagen $(6,7,11)$ och också skapa ett team från BU (6), även globalt (2). INNOHUB förväntas "conduct monitoring" (15) och ha specificerade rutiner för finansiering samt utvärdering (av referensprojekt) (8). INNOHUB förväntas inte utöva kontroll (2). INNOHUB har etablerat samarbete med CREATE för planering av övriga behov, resurser som nyttjas av två av företagen $(6,12)$.

\subsection{INNOHUB .02 - Resurs- och värdetillväxt}

Temat i denna delstudie är att studera en eventuell möjlighet att identifiera ett "innovationskapital?"(* Mars 2019 - Mars 2020) i termer av resurstillväxt och värdetillväxt i 20 företag. Denna del av följeforskningen syftar till att studera utvecklingen av en resurstillväxt (ett potentiellt innovationskapital) som ett resultat av FoU-verksamheten, i de olika affilierade företagens utvecklingsprojekt.

Efter genomgång av aktuell litteratur och resultat från Steg 1 påbörjas fas 2 med en s k självutvärdering (self evaluation). Grundtanken med självutvärdering är att följeforskaren bistår respektive innovatör i dennes egen utvärdering av sin medverkan i INNOHUB; bland annat genom intervjuer och enkäter. Självutvärderingen är frivillig och har därför inte påtvingats företagen på något sätt. Från projektbeskrivningen nedan (engelsk variant) framgår syfte, frågeställning $\mathrm{mm}$.

\subsubsection{Resurstillväxt och Värdetillväxt i denna kontext}

Initialt görs i avhandlingen en beskrivning av begreppen resurstillväxt och värdetillväxt. Med resurstillväxt avses den utveckling som sker i den organisation som studeras, $\mathrm{d}$ v s de värden som i redovisningstermer kallas "internt upparbetade" resurser/tillgångar ( d v s current or operational resources) och här synonymt med begreppet innovationskapital. Begreppet implicerar ledning av, investering i och generering av resurser genom lärande och utveckling av "know what, why, how, for whom and when". Resurstillväxten, som en del av ett företags strukturkapital, anses "stanna kvar" hos parterna i innovationssamarbetet samtidigt som den bidrar till utveckling av annat investeringskapital för infrastruktur mm. Kontrollmöjlighet och mätbarhet av resurstillväxt är generellt svag i denna kontext då dessa resurser oftast är svåra att identifiera, detta även om de aktiverats i innovatörernas ofta svårtolkade balansräkningar.

Med värdetillväxt avses den ökning av värdet på det investeringskapital som kommer andra intressenter, utöver den studerade 'organisationen', till del. Detta kapital, representerat på en marknad, kan dels genereras vid aktivering av värde från den studerade organisationens resurstillväxt (ibland i patent eller andra immateriella rättigheter), dels genereras från externt kapital för infrastruktur (i. e. "non-current resources"), supporttjänster eller (aktiveras) vid direkt förvärv. Någon form av transaktion är nödvändig för att värde ska uppstå. 


\subsubsection{Genomförande av INNOHUB .02}

Genomförande av Fas 2 sker i två steg.

- Steg 1a). Uppföljning med företag från Fas 1, "alumni”. Syfte med uppföljningen är primärt att ta reda på vad företagen själva vill fokusera vid självutvärderingen. Frågor från projektbeskrivning samt nedan för uppföljning med intervjuer:

"Important research question to follow up with alumnis".

- Are incubators (incubates) run from $R \& D$ viewpoints, meeting barriers in their ambitions to grow from strategies and goals for sustainable resource growth - and why?

- What (non-current) resources and what other infrastructure have most impact on (current) resources, capabilities and value growth /in a chosen "incubator culture" (versus in networking SME's)?

- How do leaders in various innovative and networking organizations rank the "enablers" that have impact on value growth - on various levels of the chosen context?

- How do leaders relate to the chosen (old and new) KPIs?

- Steg 1b). Genomgång av aktuell litteratur samt samtal (se nedan: Self evaluation) med de nya företagen. Syftet är att få ett underlag för att kunna svara på den överställda forskningsfrågan. En mall för självutvärdering skapas för varje företag och INNOHUB.

- Steg 2. En uppföljning med de nya företagen. ${ }^{100}$ Frågor från projektbeskrivning samt nedan för uppföljning med intervjuer:

"Questions will be further developed as KPIs for self-evaluation of the respective stakeholder and according to which type of operationalization of stakeholder relations that was suggested from Part. Suggested topics for interviews:

With reference to EEM-model starting with INNOHUB members expectations, defining new KPIs (of results and effects for members) and valuing other effect (system perspectives, contexts and follow up, consolidated valuing).

- In general: HOW can potential barriers be overcome in a strategic perspective?

- Consider WHY? What are the most urgent arguments/motives for (intentional) change?

- WICH are the "prior terms" that shall be sustained?

- WHAT are the chosen context; to accelerate, WHAT is needed, which are the enablers?

- What is the new way of organizing?

- What and how to measure? (due to the respective self-evaluation forms?

\subsubsection{Alumniuppföljning}

Följande 27 företag från FAS 1 har vid tillfället för denna delstudie (FAS 2) lämnat samarbetet med INNOHUB. Två företag från Fas 1 var vid tillfället kvar i INNOHUB: Företag 11 och 15.

${ }^{100}$ Från projektdokument .02: "This second part is mainly based on a participatory approach, a proposed self- evaluation in four well defined themes at one or two occasions with each selected member/group during the period. The respondents are newly established incubates." 
19 av de 27 företag som lämnat samarbetet och som nedan angetts med kursiv text intervjuades vid Fas 1. En uppföljning bedömdes relevant att genomföra efter 12-18 månader utifrån ovanstående frågeställningar. Dessa 19 företag, här nedan numrerade i den ordning de dokumenterats, kontaktades brevledes (se bilaga) för en andra uppföljning tillsammans med enkät. Av de 27(19) gjordes en uppföljning med $10+1$ alumniföretag markerade med fet kursivering).

De 19 företagen har $i$ det empiriska underlaget numrerats $i$ den ordning de intervjuats som företag 8 respektive 11, 2,13, 9, 7, 3, 19, 4, 5, 13, 18, 6, 7, 14, X, Y, Z, 19, 10, 6, A, 17, 8, 20, C samt $D$.

Parallellt gjordes (som referens) en djupintervju med ett framgångsrikt innovationsföretag i regionen som inte varit anslutet till INNOHUB: företaget betecknas $i$ empiriunderlaget som EP.

Dessa 11 intervjuer genomfördes som samtal, i förekommande fall med stöd av arbetsmodellen (se samtalsprotokoll) men där respondenten kunde utveckla tankegångarna fritt. För att få en jämförelse avseende förändring av förväntningsgap användes som underlag för intervjufrågor frågeställningar Q 1-Q 19 (Stock, 2016) i tillämpliga fall. Här återges ett antal kommentarer som exempel relaterat till ovanstående frågeställningar. Observera att dessa intervjuer är genomförda under 2019, men synpunkterna relaterar till perioden då respondenterna var anslutna till INNOHUB. En konkretisering och förenkling av frågorna ovan inför utformning av enkät/intervjuer där exempel på svar ges nedan:

- Med utgångspunkt från projektets/organisationens måldimension; positiva erfarenheter, risker eller andra bristande förutsättningar under tiden med INNOHUB?

Hindren har legat hos egna företaget. Ingen uttalad strategi, fel styrelse. (Företag 11)

Ett hinder var att vi inte passade in. (Eventuellt konkurrent till Målföretaget) (Företag 20)

Oklar "egen" affärsmodell. Komplicerad. (Företag 12)

Felbedömning (internt) av innovationens utvecklingstid möjlighet $m$ a $p$ alltför stor kortsiktighet. (Företag 11)

Risk att de etablerade snabbt tar över. Affärsrisk. (Har inget patent). (Företag 11)

Avsaknad av INNOHUB-strategi för "open innovation”. (Företag 12)

Osäkerhet i ledtiden, tills resultat kommer. Inköpsprocessen oklar. Finns ingen upphandlingsmodell för "innovationsupphandling”. (Företag 13)

- Med utgångspunkt från de möjligheter som INNOHUB innebär; Vilka resurser/möjligheter av mer långsiktigt slag ger resultat i samarbete med INNOHUB?

Att INNOHUB hittar rätt samarbetspartner att signa avtal med kund direkt. (Företag 11) 
Att Målföretaget har en produkt som gjort det möjligt att starta ett projekt. (Företag 9)

Att man är ett "INNOHUB-företag" som gjort ett projekt, när man kommunicerar med andra. (Företag 9)

Kompetens. (Företag 13)

- Vad har varit det viktigaste i processen för att skapa värde? (strategiskt samarbete med utvalda, andra processer, andra "möjliggörare"?)

Bra möte med det "juniora". Man har fått hjälp av INNOHUB med marknadsföringen. (Företag 12)

INNOHUBS kontaktperson bra, verkar som "coach", skulle behövas fler. (Företag 14)

- Vilka nyckeltal används?

Resultat och Balans. Utvecklingskostnader aktiverade. Osäkerhet vad EK är värt. (Företag 11)

Resultat. Kostnadsuppföljning viktigt. Externfinansiering 100\% (2019) (Företag 7)

Antalet installationer $i$ världen. (Företag 20)

Kvalitet. Ständiga förbättringar. ISO. (Referensföretaget)

\subsubsection{De nya företagen - andra antagningen}

Det övergripande syftet med deltagandet (utifrån INNOHUBS mission) är att deltagande företag ska ha goda förutsättningar för att snabbare och under vissa villkor ${ }^{101}$ få ut sitt innovationsprojekt på marknaden. "Time to market" för rätt innovation.

De erfarenheter respektive förväntningar som speglas i dessa intervjuer avser därför det direkta deltagandet d v s med ett specifikt projekt, i INNOHUB och oberoende av hur bolaget i övrigt är organiserat eller finansierat, vilka andra engagemang bolaget har, var det fysiskt är placerat etc. Här benämner vi det som ett "virtuellt, personligt" deltagande och tiden för detta deltagande är avgränsad på olika sätt som beskrivs nedan.

Denna uppföljning i Fas 2 har gjorts löpande i 15/20 "nya" företag under perioden 1/1 - 31/6 2019. ${ }^{102}$ Enkäterna har samma utformning som i Fas 1 och har här besvarats av 9 företag. Några av företagen har intervjuats vid två tillfällen för att kunna belysa såväl erfarenheter som förväntningar. Intervjuerna gjordes då företaget var aktivt, några i samband med anslutning, andra efter en period.

Djupintervjuer genomfördes med en semistrukturerad frågemall. Djupintervjuerna genomfördes med enkätfrågorna som underlag. Enkätfrågorna besvarades muntligen och

\footnotetext{
${ }^{101}$ Dessa har förändrats efter hand. I denna fas går man till marknaden (stororganisationens/målföretagets kunder) tillsammans

${ }^{102}$ De 16 företag som tillkommit efter 2019-06-31 ingår inte i denna rapport.
} 
noteringar gjordes löpande vid samtalen. Samtal genomfördes per telefon eller vid kortare möten.

I följande 11 + 1 "nya" företag har 15 intervjuer genomförts varav 10 djupintervjuer.

Företag 14, Företag 1, Företag 2, Företag 3, Företag 4, Företag 5, Företag 6, Företag 8, Företag 9, Företag 10, Företag 11 samt två specialintervjuer med företaget $E P$.

13 av de "nya" företagen har av olika skäl inte intervjuats, bland annat har man i några fall avböjt på grund av konkurrensskäl. En konkretisering och förenkling av frågorna ovan görs inför komplettering av enkäten från Fas 1:

- Med utgångspunkt från projektets/organisationens måldimension; positiva erfarenheter, risker eller andra bristande förutsättningar under tiden med INNOHUB?

Viktigt med erfarenhet hur andra har lyckats. (Företag 1)

Information om vilka certifieringar som finns. (Företag 6)

Mer marknadskunskap. (Företag 7, Företag 2)

Stororganisationens marknad viktig för att kunna arbeta mer med "inkrementell" innovation. (Företag 6)

\begin{tabular}{|c|c|c|c|c|c|c|c|c|c|c|}
\hline Målområde & 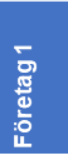 & 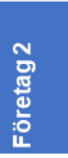 & 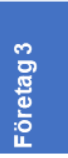 & 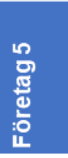 & 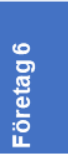 & 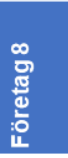 & 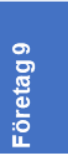 & 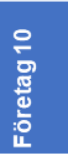 & 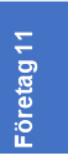 & Medel \\
\hline Snabbare tillväxt & 4 & 5 & 5 & 4 & - & - & - & - & - & 4,5 \\
\hline Internationell marknad & 4 & 4 & 4 & 2 & 5 & 4 & 3 & 5 & 2 & 3,7 \\
\hline $\begin{array}{l}\text { Kortare finansieringsprocess } \\
\text { (direkt projektinvestering) }\end{array}$ & 3 & 1 & 2 & 3 & 2 & 3 & 3 & 4 & 1 & 2,4 \\
\hline $\begin{array}{l}\text { Kortare innovationsprocess- } \\
\text { tillgång till innovationsförmåga }\end{array}$ & 1 & 4 & 2 & 3 & - & - & - & - & - & 2,0 \\
\hline $\begin{array}{l}\text { Lärande från andra INNOHUB } \\
\text { företag }\end{array}$ & 1 & 1 & 1 & 1 & 2 & 3 & 2 & 3 & 4 & 2,0 \\
\hline $\begin{array}{l}\text { Kompletterande forsknings- och } \\
\text { utvecklingspartner }\end{array}$ & - & - & - & - & - & - & 1 & 5 & 5 & 4,0 \\
\hline \multirow{2}{*}{$\begin{array}{l}\text { Kompletterande produktportfölj på } \\
\text { befintlig marknad }\end{array}$} & - & - & - & - & 3 & 4 & 5 & 2 & 5 & 4,0 \\
\hline & $\sum 13$ & $\sum 14$ & $\sum 14$ & $\sum 13$ & $\Sigma 12$ & $\sum 14$ & $\sum 14$ & $\sum 19$ & $\sum 17$ & \\
\hline
\end{tabular}

Figur 22. INNOHUB .02 Erfarenheter från samarbete hos 9 av de $15 / 20$ nya företag som intervjuats under perioden (enkätsvar). 
- Med utgångspunkt från de möjligheter som INNOHUB innebär; Vilka resurser/möjligheter av mer långsiktigt slag ger resultat i samarbete med INNOHUB? Vill inte vara beroende av ett storföretag. Finansiering behövs dock (Företag 2)

Ej för närvarande (Att Målföretaget ej är för närvarande). (Företag 1)

Målföretaget ska ej involveras nu. Ev. senare (Företag 3).

- Vad har varit viktigast i samarbetet (för at skapa värde)? (personer, processer, andra "möjliggörare)

"Matchningen är ett viktigt inslag". "Vi vill inte bli experter själva utan förlitar oss på Målföretaget. Vi är duktiga på vår teknik och samarbetet har startat bra” (Företag 5).

"Innovationskapitalet väger tungt (70\%), men även det sociala kapitalet är viktigt för oss" (Företag 5).

"Samarbetet med INNOHUB viktigt men inte avgörande, vi vill bidra till att stororganisationens egen tillverkning effektiviseras" (Företag 6).

- Med utgångspunkt från projektets/organisationens måldimension; förutsättningar för lyckade samarbeten med INNOHUB och om förutsättningar för att accelerera:

Viktigt att veta vem som har behovet $d$ v s "För Vem? (Företag 1)

Certifiering en väg. (Företag 2, Företag 6)

Ha koll på risker som tidsperspektiv (Företag 2), personalkompetens (Företag 1), modell för riskanalys (Företag 5), och relationsrisk. (Företag 6)

Att ha en tydlig och väl beskriven applikation är en förutsättning för samarbete" (Företag 5)

Viktigt att Målföretaget tydliggör sin strategi där man ser ny potential så att man kan söka efter lämpliga applikationer $i$ en tidig utvecklingsfas av helhetslösningar runt innovationen (Företag 9) 


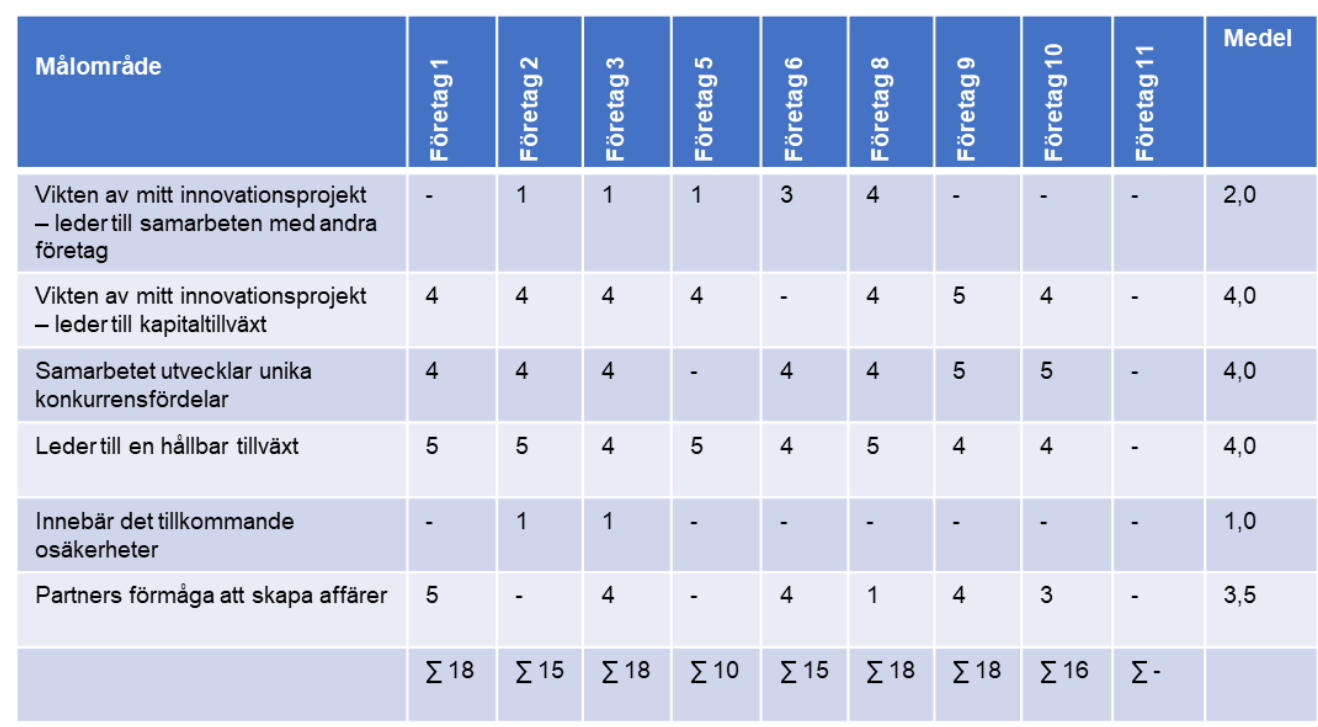

Figur 23. INNOHUB .02 förväntningar och tilltro på fortsatt samarbete hos 9 av de $15 / 20$ nya företag som intervjuats under perioden (enkätsvar).

- Med utgångspunkt från de möjligheter som INNOHUB innebär; om att finna rätt samarbetspartner(s) för att skala upp: (INNOHUBS primära roll).

"Ett absolut villkor för att skala upp en innovation är att tillsammans med partner som har nätverket, direkt förhandla len affärsmodell med den part som har behovet av lösningen" ("open book-principen” gäller). (Referensföretaget - ett etablerat utvecklingsbolag utanför INNOHUB)

"Inget behov av samarbete med övriga INNOHUB-företag" (Företag 3, Företag $5)$.

"Viktigt att snabbt få fram och kontraktera en produktägare inom Målföretaget, helst globalt; det ger innovationsprojekt inom andra enheter". (Företag 3)

- Hur mycket betyder "hållbarhetsmålen"i det fortsata arbetet?

MÁLEN 4, 8 och 9 viktigast”. (Flera Aluminföretag från omgång 1)

Viktigt med argument (Företag 1),

Viktigt med "bevis" och med miljökonsekvensanalys (Företag 2, Företag 3).

\subsubsection{Riskbedömningar}

Följande risktyper har identifierats/diskuterats vid samtalen, och en prioritering gjordes vid intervjuerna. Följande risker, figur 24, utan inbördes rangordning lyftes under intervjuerna: 


\begin{tabular}{|l|l|l|}
\hline Prio & Risk & Företag \\
\hline 1 & Risk att bli kopierad & Ftg 1, Ftg 3, Ftg 5, Ftg 8, Ftg 11 \\
\hline 1 & Risk att samarbetet inte fungerar & Ftg 6, Ftg 8, Ftg 9, Ftg 10 \\
\hline 1 & Risk med funktion i teknologi, Al, mm & Ftg 5, Ftg 9, Ftg 11 \\
\hline 2 & Brist på finansering & Ftg 8 \\
\hline 2 & Kundrisk (Affärsrisk) & Ftg 10 \\
\hline 3 & Risk med tillgång på personal och kompetens & Ftg 1 \\
\hline- & Teknisk risk avseende kvalitet & \\
\hline- & Leverantörsrisk & \\
\hline- & Annan risk & \\
\hline
\end{tabular}

Figur 24 Risker med anknytning till INNOHUB

\subsubsection{Hinder och möjligheter för uppgradering och uppskalning}

Generellt saknas insikter eller en medveten storföretagsstrategi om möjliga applikationer där tekniken är tillämplig. Av de 10 företagen är det bara 1 (2018) som utgått från en applikation för att komma vidare. Och en ny fråga aktualiseras: Med vem?

Den absolut viktigaste faktorn som framkommer vid flera intervjuer är att ha rätt partner (med rätt kompetens) i varje fas; d v s vid exploatering (uppskalning) krävs ofrånkomligt en partner med rätt nätverk och marknadskompetens.

Alla företag har valt att medverka i INNOHUB med syfte att ha ett projektsamarbete med Målföretaget, men med olika primära syften. Detta har lyckats i olika grad beroende på diverse omständigheter. Bland annat om ingen tydlig produktägare funnits vilket kan anses som dålig "timing" mm.

Några företag har endast ett "eget" syfte (4 med flera), medan andra vill uppnå ett samarbete där man kan tillföra sin kompetens. Dessa senare vill dock inte bli finansiellt beroende av Målföretaget.

Några företag framhåller behovet av tydlighet. Det gäller avseende inom vilka strategiska områden som Målföretaget vill ha samarbeten och där det dels finns utrymme för applikationstänkande, dels insikter om möjliga applikationer kopplade till agenda 2030 för en hållbar tillväxt. Intervjuerna pekar på behovet av tydlighet för att kunna nyttja de fördelar som finns för uppskalning av företagens verksamhet. Några olika förslag som framkommit från intervjupersonerna presenteras utifrån att alla vill ha ett samarbete med Målföretaget. 
Förslagen avser tydlighet och selektivitet inför beslut att fortsätta med deltagande, men också konkreta förbättringsåtgärder.

Vad kan göras bättre för att ge bättre ekonomiska (och redovisningsbara) förutsättningar för uppgradering och uppskalning?

\begin{tabular}{|c|c|c|}
\hline Område & Nyckelord & Aktivitet \\
\hline Mål & Tydlighet & $\begin{array}{l}\text { Tydliggör strategiska områden (inkl. Agneda 2030) } \\
\text { Tydliggör produktägare } \\
\text { Tydliggör vilken teknologi } \\
\text { Tydliggör vilken fas }\end{array}$ \\
\hline Mål & Selektivitet & Produktförnyelse, innovation \\
\hline Resurser & Tydlighet & $\begin{array}{l}\text { Finansiering (tydliggör strategiska områden för ev } \\
\text { förvärv) }\end{array}$ \\
\hline Organisering & Selektivitet & $\begin{array}{l}\text { Finansiering (Workshop med potentiella } \\
\text { innovationsprojekt, flera INNOHUBB-företag inkl } \\
\text { Alumniföretag) } \\
\text { Workshop med produktägare och potentiella } \\
\text { partners inom strategiska områden } \\
\text { Workshop/Webinar med nya + alumni inom resp } \\
\text { teknologiområde (genomgång av utvecklingsläget } \\
\text { för resp. teknologi) }\end{array}$ \\
\hline Mätning & Modell & $\begin{array}{l}\text { Vid varje workshop görs en genomgång enligt en } \\
\text { utvärderingsmodell }\end{array}$ \\
\hline Mätning & Mått & (KPI) sätts och beräknas för varje Innovationsprojekt \\
\hline
\end{tabular}

Figur 25. Upplevda behov för uppgradering och uppskalning

\subsection{INNOHUB .03 - INNOHUB roll som innovationsaktör}

Denna del av följeforskningen genomförs i två steg. Studien syftar till att följa hur innovationskapitalet utvecklas över tid och vilka beslut inom INNOHUB som leder till denna utveckling. I denna fas som inleds med intervjuer med ledningen i INNOHUB sätts fokus på ett innovationskapital (per definition) och följeforskningen genomförs som en observerande första del i INNOHUB under en period som sträcker sig fram till 2019-12-31 samt en uppföljande andra del under våren 2020 där de anställda i INNOHUB (teamet) medverkar i ett internt "business case" samt parallellt genomför en `egen’ enkät. ${ }^{103}$ Här redogörs i korthet för steg 1 samt en redovisning av steg 2 för att exemplifiera hur ledning och teamet ser på sitt uppdrag.

103 Under första kvartalet genomförde INNOHUB en första självutvärdering vid sidan av detta följeforskningsprojekt. Den metod som användes var NPS ("Net Promotion Score"). 47 företag/personer ingick i studien som genomfördes via teams. Genomsnittlig medverkan i INNOHUB var 2 till 8 månader. Några företag helt nya och några alumni. Av de 36 svar som gavs kan utläsas att upplevelser/förväntningar har förbättrats 


\subsubsection{Några utgångspunkter}

Forskning inom ekonomisk styrning gör idag gärna skillnad mellan domäner (eller plattformar) och de metoder som utvecklas på dessa (Lukka \& Vinnari, 2014). Den logik som understryks i den s k EEM-modellen bygger på antaganden att utveckling och potentiella strategier genereras utifrån en viss grundstruktur (en plattform eller en logik) där möjliggörare ("enablers") ses som input till en beslutsprocess. INNOHUB tillhandahåller en sådan plattform, en miljö för utveckling av ett innovationskapital.

INNOHUB som organisation bär fram ett innovationskapital, ett kapital som förutsätts utvecklas över tid i olika strategiska kontexter och i olika form. Förutsatt att detta innovationskapital kan mätas i kvalitativa och kvantitativa termer så kan processer utvärderas "ex post" och "ex ante" och med hjälp av ett antal frågeställningar (Peteraf, 1992, 1997 samt Hinings ,1997). Det gäller här explicit INNOHUBS beslutsprocess som exemplifieras i kommande "business case".

INNOHUB är i sig en organisation med ett eget innovationskapital. Ett antal personer ("teamet") med en viss "kapacitet" och med förmåga att skapa mervärde genom att dels succesivt bidra till "medlemmarnas" utveckling kvalitativt och dels, sett över en period, öka antalet innovativa medlemsföretag.

\subsubsection{Innovationsaktör och värdeskapare}

Genomförande av intervju med ledningen i INNOHUB.03

Från januari 2018 har 8 individuella möten skett med INNOHUBS ledning (VD), 2 möten med "chief operations" samt protokollförda interna arbetsmöten med övriga medarbetare vid 3 tillfällen. Utöver detta har 4 avstämningsmöten genomförts med Advisory Board, AB, under 2018. Under 2019 genomfördes 2 individuella möten med VD. Den 13/5 2019 diskuterades INNOHUBS framtid vid ett $\mathrm{s} k$ Visionsmöte med VD och tre av INNOHUBS övriga anställda.

Ett förhållande som framkom vid dessa intervjuer är att INNOHUBS innovationskapital är förbundet med dels Målföretagets (i BU CR/FOU) spjutspetsforskning, dels med innovatörernas unika innovationskoncept. Samtidigt som INNOHUB ska erbjuda "sina medlemmar" (innovatörerna) en arena för olika relaterade behov (socialt, tekniskt/miljötekniskt och ekonomiskt) så ska INNOHUBS eget innovationskapital utvecklas.

Detta medför dels ett 'internt' INNOHUB-fokus, dels ett 'externt' fokus på innovatörerna och producerande enheter inom målföretaget d v s på "faktormarknaden". En utgångspunkt, utifrån den prioritering som uttalats av INNOHUBS ledning att i första hand i INNOHUBS totala beslutsprocess "stödja" innovatörerna är att detta, genom en kontinuerlig intern anpassning till innovatörernas behov, och en samtidig också anpassning till målföretagets behov, ger en effekt på INNOHUBS "eget" innovationskapital. Denna 'split vision' ansågs innebära en speciell dynamik som potentiellt medfört ett mervärde till det samlade "innovationskapitalet".

avsevärt (alumni vs nya) på alla åtta variabler, utom på en; man efterlyser mer engagemang från Målföretaget. Studien finns att tillgå i sin helhet hos INNOHUB. 
Sammanfattningsvis har dessa möten (utom vid arbetsmöten) primärt handlat om löpande prioriteringar för följeforskningen som helhet där INNOHUB är den samlande 'resursen'. Mötesanteckningar finns att tillgå från samtliga möten. Om målet för INNOHUB kan man utläsa i planen för följeforskningen som presenterades i juni 2018. Där redovisas "utdrag" av samtal med INNOHUBS ledning dels utifrån de mål som initialt beskrevs vid AB under 2018 och dels de förväntningar och prioriteringar som utvecklats därefter.

Som utgångspunkt för övergripande prioritering och det som medförde prioritering av hur de olika delprojekten, INNOHUB .02. 03 samt .04, skulle genomföras tidsmässigt, kommunicerades och gjordes vid AB möte 15/1 2018 följande notering gjordes om huvudsakligt syfte och inriktning för INNOHUB i dess roll i ekosystemet för öppen innovation:

"Följeforskningen $i$ AstraZeneca har lyft fram "open innovation" som forskningstema. I vårt fall skulle snarare SME-värdet vara underlag för forskningstema.

\section{Ledningsgruppsmedlem INNOHUB}

Astra Zenecas Biohub har initialt varit "state of the Art" för tillämpning av innovationsprocesser i "open innovation" i Sverige. Istället för att prioritera själva innovationsprocessen som är olika i olika kontexter avseende föremålet för forskning, forskningsmetod och tidsperspektiv så prioriterar nu INNOHUB (och därmed följeforskningen) istället att fokusera på att hjälpa småföretag att kunna växa och bli framgångsrika och skapa synergier mellan Målföretaget, företagen och regionens olika innovationsaktörer.

Den vision som ledningen vid INNOHUB ger, uttolkas vid nämnda visionsmöte: Att tjäna innovationsföretagen på bästa sätt så att de kan expandera sin verksamhet. Och helst bidra till värdeskapande!

\subsubsection{Ett internt 'business case'}

Här genomförs en självutvärdering av INNOHUB där hela teamet deltar vid utvärdering av ett "case" som utvecklats utifrån verkliga förutsättningar med ett av de deltagande företagen. Detta anonymiserade "case" utvecklades av följeforskaren ,VD’n samt teknologiansvarig för det aktuella företaget vid ett antal möten under 2018.

Denna del av följeforskningen som en specifik studie syftar till att gemensamt analysera ett potentiellt innovationskapital $i$ en verklig och praktisk kontext. Kontexten handlar om ett tekniktungt (AI-teknologi) svenskt företag ${ }^{104}$ som deltar i INNOHUB "med öppen innovation", där värderingen avser själva förekomsten av "collaborative innovations".

Denna utvärdering görs i form av ett "business case" $\mathrm{d} v \mathrm{~s}$ fokus läggs på en affärsmässig dialog. Företaget i studien är en innovatör som vid tillfället har ett antal samarbetsavtal med Målföretaget. "Caset" omfattar innovation inom AI och genomförs utifrån specificerade kriterier och utifrån analysmodellens olika steg

\footnotetext{
${ }^{104}$ Företaget är anonymiserat. Det ingår i en teknikpark knuten till ett teknikuniversitet. Företaget har 15 anställda och omsätter ca $25 \mathrm{Mkr}$. Företaget är ett "typiskt" "post-inkubator"-företag. VD samt teknikchef har intervjuats för detta "case".
} 
Den 20/5 genomfördes detta "business case" med sex medarbetare vid INNOHUB. Syftet med detta från följeforskningens sida var också att, genom att testa den föreslagna arbetsmodellen (momenten A, B,C,D samt E) förstå och lära hur INNOHUB på bästa sätt kan bistå innovatören för ökat värdeskapande.

"Caset" byggde på två djupintervjuer med företaget (YYY AB) som varit anslutet till INNOHUB under 12 månader. "Caset" genomfördes genom att följeforskaren ställde 10 frågor (samma frågor som i tidigare studier (.01/.02) och delvis med hjälp av analysmodellen) och man diskuterade möjliga alternativ till svar. "Caset" och dess resultat finns att tillgå separat.

Ledningsförutsättningar, visioner, målstruktur mm:

Företaget har flera projekt med Målföretaget (5-6 st) och är representativt med ny teknologi. Helt ny teknologi har utvecklats organiskt under lång tid i företaget. Ett mål för ledningen är att potentiellt bli "uppköpt” av Målföretaget (d v s ett helt förvärv alternativt förvärv av denna, mycket expansiva del av företaget).

Resurser, partners:

Företaget har en ledande ställning inom AI, har kompetens från tekniskt universitet, arbetar som Målföretaget mot gemensam slutkund, men syfte och förväntningar på samarbete något oklart. Förväntningar måste ställas mot motprestation.

Organisering:

a) I och med samarbete måste budgetprocessen förändras.

b) Matchningen viktig utifrån aspekter på ledarskap, affärsmodeller, riskvärdering (affärsrisk), attityder, projektfinansiering snarare än det "tekniska innehållet".

Beslutsprocessen:

Frågan om behov av beslutsunderlag ej helt besvarad. Tidsperspektivet, d v s när i tid en utvärdering (och värdering) kan göras är en öppen fråga. En första utvärdering planeras efter ett halvår, men full värdering först efter 1 - 3 år efter marknadsintroduktion. Frågorna avseende andra kriterier för beslutfattande respektive återkoppling (i stage/gateprocessen) är ej besvarade.

Mätning (E):

Inget konkret förslag; generellt redogjordes för en värderingmall för ett typprojekt. (Potentiellt underlag för beräkning av innovationskapital ${ }^{105}$ )

Genomförandet av detta "Business case" har i någon mån förtydligat vilka faktorer som medarbetarna vid INNOHUB anser viktigt inför och i samarbeten. Vad gäller syftet med och möjligheten att tillämpa arbetsmodellen i ett "business case", så uppstår svårigheter vid tolkning och analys om genomgången baseras på en "diskussion" och relativt öppna frågor. Detta "Business Case" har dock bidragit till ett samtal inom INNOHUB och potentiellt också ny kunskap genom djupintervjuer med den av teamet tidigt "identifierade" innovatören.

${ }^{105}$ Definition och beräkningsmodeller för 'innovationskapital', IC, impliceras i förslag till fortsatt forskning (Kapitel 12) F n identifieras IC = "R\&D expenditures" (Ref. Chang \& Hsieh, 2011) 
Utifrån syftet att analysera och eventuellt finna kriterier för att "värdera" ett innovationskapital har studien en begränsad tillämpning. Resultat av kommentarer kan sammanfattas som att:

a) Tidsaspekten d v s hur länge projektet pågått, är en viktig faktor för att bestämma värdet samt

b) hur och i vilken miljö projektet utvecklats.

c) Viktigt är att överenskomma om gränsdragningar i projektet såsom vem som gör vad, vilka mätvärden som används mm).

d) INNOHUB inte ska bedriva egen teknikutveckling i AI.

e) För "öppen innovation" är det viktigt att förändra budgetprocessen.

f) En första utvärdering kan ske efter kort tid, men en samlad bedömning av nyttan och värdet på projektet kan ske tidigast efter det att den funnits på marknaden efter 1 till 3 år.

g) Samarbete handlar om mer än teknologin, det är viktigare med affärsmodeller, finansiering, ledarskap mm.

h) Förväntningar som INNOHUB har här måste ställas mot vilket syfte som samarbetet har som exempelvis kompetenshöjning samt

i) vid förväntningar (på XX) måste prestation och motprestation bedömas där hela projektet (alla parter) medverkar tillsammans.

\subsection{INNOHUB .04 - Resurs- och värdetillväxt.}

\subsubsection{Tillväxt för Målföretaget (.04 a)}

Denna uppföljning omfattar intervjuer med Målföretaget som projektägare samt med "Technology Venture". Intervjuer har genomförts med Målföretagets ledningscontroller vid BU FoU/CRC vid 2 tillfällen samt controller vid finansförvaltning vid två tillfällen under 2019. Enligt projektspecifikation 2016-09-25 förväntar sig Målföretaget att INNOHUBS aktiviteter genomförs för att uppnå förväntade effekter avseende: 


\begin{tabular}{|c|c|c|}
\hline Utvecklingsområde & Mål & Medel \\
\hline $\begin{array}{l}\text { Teknologi (Teknik, } \\
\text { Metod) }\end{array}$ & $\begin{array}{l}\text { Teknologi som input för att nå } \\
\text { målen }\end{array}$ & $\begin{array}{l}\text { Skapa framtida lösningar inom industriell automation, } \\
\text { robotteknik och energi tillsammans med små och } \\
\text { medelstora företag. Dynamiskt inflöde av idéer. } \\
\text { Utmana portföljen med banbrytande teknik. }\end{array}$ \\
\hline $\begin{array}{l}\text { Individ/Personal } \\
\text { (Kunskap, } \\
\text { Innovationskapital) }\end{array}$ & $\begin{array}{l}\text { Kompetens, } \\
\text { innovationsförmåga som input }\end{array}$ & $\begin{array}{l}\text { Tillgång till nystartade företag och deras innovativa } \\
\text { kultur med nya och unga påverkare. Tillgång till } \\
\text { startupföretagens kompetens och nätverk. }\end{array}$ \\
\hline Process & Att växa & $\begin{array}{l}\text { INNOHUB som "accellerator". Förbättra Målföretagets } \\
\text { arbetssätt vid innovation genom att lära av nystartade } \\
\text { företag och deras innovativa kultur med nya och unga } \\
\text { påverkare. Korta innovationscykeln, öka hastigheten } \\
\text { till marknaden och bygga konkurrenskraft för } \\
\text { Målföretaget. Öka kunskap i kritiska kompletterande } \\
\text { värdekedjor genom utnyttjande av startupföretagens } \\
\text { kompetens och nätverk. Detta åstadkoms genom } \\
\text { samarbetsprojektets tillgång } \\
\text { - till processerna, } \\
\text { - till ett kraftfullt innovationssystem samt } \\
\text { - till laboratorium. }\end{array}$ \\
\hline Riskminimering & $\begin{array}{l}\text { Minska risken vid ev. uppköp } \\
\text { och investeringar i växande } \\
\text { företag genom att tidigt etablera } \\
\text { relationer, kunskap och } \\
\text { förståelse. }\end{array}$ & INNOHUB \\
\hline Internationalisering & $\begin{array}{l}\text { Ökad internationell } \\
\text { attraktionskraft }\end{array}$ & $\begin{array}{l}\text { En dörröppnare för expansion och global marknad } \\
\text { genom t.ex. internationella samarbetspartner. } \\
\text { Attrahera internationella företag att flytta till regionen. }\end{array}$ \\
\hline Marknadsutveckling & $\begin{array}{l}\text { Målföretagets framgång och } \\
\text { attraktivitet }\end{array}$ & $\begin{array}{l}\text { Öka Målföretagets varumärke inom digitalisering och } \\
\text { Al. Bli en "thoughtman leader" på tre utvecklings- } \\
\text { marknader, nämligen industri, robotteknik och energi. }\end{array}$ \\
\hline
\end{tabular}

Figur 26. Målföretagets utvecklingsområden, mål och medel (författarens sammanställning)

Syftet med dessa intervjuer var att utifrån de mål som specificerats i ursprunglig projektspecifikation, förtydliga var huvudsaklig prioritering finns för INNOHUBS arbete utifrån Målföretaget som huvudsaklig intressent. Inom analysmodellens olika områdena rörde intervjuerna följande dimensioner:

Mål:

Målföretagets mål är avkastning (och ökade inkomster i form av cashflow) på gjorda investeringar i innovationsprojekt d v s ny teknologi. Tidsaspekten innebär att "hållbara" projekt medför ökade finansiella inkomster. Delmål som förväntas genom INNOHUBS arbete är att a) behålla marknadsandel och b) öka marknadsandel $\mathrm{d} v \mathrm{~s}$ genom att volymaspekten betonas tydligt.

\section{Resurser, Partners:}

Här nämns som "möjliggörare" de samhällssubventionerade "miljömål" som en "dragkraft" inte bara för projektutveckling utan även som finansieringskälla. 
Organisering (för värdeskapande):

Här betonas investeringen i tid, d v s att innovationsprocessen från ide' till försäljning genom samverkande innovation (stor/liten) snabbas upp ger ett (per automatik) snabbare värdeskapande. Viktigt att skilja på utvecklingsprocessen (hos innovatörer) och åtgärdsprocessen (a) med INNOHUB och (b) med produktägare hos Målföretaget.

\section{Beslutsprocessen:}

Investering i INNOHUB och samarbeten för att ta vara på INNOVATIONSKRAFTEN. Utvecklingsprocessen ska vara avklarad innan INNOHUB kommer in. Innovatören ska ha eget "cash flow". Beslut tas om vem som på (bland annat) finansiella grunder ska anslutas, d v s innovatörens position ska vara relativt stark, för att samarbetet ska bli starkt. Det finns ägarperspektiv på det samlade värdet som förväntas vara underlag för ett utvecklat innovationskapital.

\section{Mätning:}

Resultat och effekt mäts per industrisegment, men inte bara fokus på Målföretaget. Mätningen görs av antalet signerade kontrakt. Två modeller tillämpas; a) avkastningsmodell; "cash flow"/ transaktionskostnad per steg och b) värdemodellen.

Dessa möten har tillfört ytterligare utvecklingsperspektiv på de samarbeten som initieras av INNOHUB. Här läggs framförallt tonvikten på "inputvariablerna" teknologi och innovationskraft och på en "outputvariabel" som inte nämns i projektbeskrivningen, nämligen Målföretagets förväntade "cashflow". Detta senare bedöms underförstått vara ett medel för att via investering i FoU (och nya teknologier som AI) uppnå målen att behålla och öka företagets marknadsandel inom respektive industrisektor. Fokus (även vad gäller "finansiering") ska inte vara primärt på Målföretaget utan på den samlade innovationskraften. Två processvariabler, processer för att bedöma "affärsrisk" respektive processer för att uppnå högre "internationell attraktionskraft" är inte högprioriterade. (Se Kapitel 10 och 11: Diskussion och Slutsatser).

\subsubsection{Tillväxt för regionala aktörer (0.4 b)}

Denna del av följeforskningens fjärde steg, syftar primärt till att observera om något SMF företags-/projektsamarbete under projekttiden med BU FOU/CR eller annan regional partner, genom egenfinansiering eller externfinansiering, har utvecklats positivt i paritet med de förväntningar som ställts på dessa samarbeten. Ett positivt resultat bedöms påverka det regionala ekosystemet på ett positivt sätt bland annat genom att Målföretaget (här BU FOU/CR) utvecklas lokalt men också SMF och dess andra partner. Följeforskningsuppdraget är begränsat till att utforma hjälpmedel för aktörernas självutvärdering. En utvärdering av effekter bedöms kunna genomföras av aktörerna först efter en tid från att etableringar har genomförts i regionen.

Eventuella kommande effektutvärderingar, d v s konsekvenser som relaterar till regionala mål, avsågs utföras av regionens aktörer som självutvärdering parallellt med följeforskningen under den senare delen av perioden. Dessa eventuella effektutvärderingar görs av intressenterna lämpligen efter en längre tid efter avslutad medverkan i INNOHUB. Följeforskningen har föreslagit arbetsmetodik och "nya" nyckeltal för denna självvärdering och för beräkning av 
företagens s k innovationskapital (enligt "Research Plan", 2018-10-02 samt dokument, protokoll A 22, 2019-02-20).

Enligt uppdragsbeskrivningen ska alltså följeforskningen vid INNOHUB .04 primärt bidra med att utveckla nya KPIer samt en arbetsmetodik som intressenterna, vid ett senare tillfälle som de själva väljer, kan tillämpa vid en effektutvärdering (självvärdering).

Denna del av följeforskningen syftar också till att ta reda på vilka resultat (innovationer, ekonomiska) som detta initiativ, INNOHUB, i innovationssystemet har resulterat i regionalt. Intressenter i denna kunskap är (utöver regionalt BU CR/FOU) Staden, Regionen och i viss utsträckning Vinnova. Dessa tre finansiärer har bidragit till den infrastruktur som möjliggjort INNOHUBS verksamhet. Av dessa (offentliga) investeringar förutsätts en avkastning.

De KPIer som utvecklas vid följeforskningen ska möjliggöra jämförelser mellan företag i staden och i regionen (och i landet). Jämförelser och nyckeltal för dessa intressenter ska baseras på kvalitativa och kvantitativa variabler och relatera till inte bara monetära mål, utan även andra mål som kan relatera till de 17 samhällsmålen för hållbar utveckling som etablerats i Agenda 2030. En viss samordning har därför skett med övrig näringslivs - och samhällsforskning under arbetets gång, med såväl regional som global expertis.

Planeringen av följeforskningen av INNOHUB .04 (b) baseras på projektbeskrivning (2018-1002 , se nedan utdrag,) samt om möjligt genomförande en kontrafaktisk analys ${ }^{106}$ och reflektion om hur en fortsatt självutvärdering av INNOHUB kan genomföras. Dialogen med intressenterna genomfördes vid tre möten med Advisory Bord (AB) under 2018 (Protokoll A 13,15,19). Inget möte med AB under 2019. Detta steg inleddes med en dialog i tidig fas med Regionens näringslivschef samt med två experter från Regionen 2018 (protokoll A9, A22) samt 26/12 (ej protokoll). Möte 21/1 (inställt). Dialog med staden vid två tillfällen (protokoll A10, A21).

De utvecklingsområden som identifierats kopplade till INNOHUB framgår av Figur 27.

${ }^{106}$ I överenskommelse med Vinnova beslutades att, p g a att denna typ av analys primärt baseras på subjektiv värdering, denna typ av analys inte genomförs. 


\begin{tabular}{|l|l|l|}
\hline Utvecklingsområde & Mål & Medel \\
\hline $\begin{array}{l}\text { Teknologi (Teknik, } \\
\text { Metod) }\end{array}$ & $\begin{array}{l}\text { Teknologi som input för att nå } \\
\text { målen }\end{array}$ & $\begin{array}{l}\text { Skapa synergier mellan BU CR/FoU, företagen och } \\
\text { regionens olika innovationsaktörer.. }\end{array}$ \\
\hline Investeringskapital & $\begin{array}{l}\text { Ökat inflöde av riskkapital till } \\
\text { företag }\end{array}$ & $\begin{array}{l}\text { Attrahera riskkapital (Regionen). Ökat inflödet av } \\
\text { riskkapital (Vinnova). }\end{array}$ \\
\hline Internationalisering & $\begin{array}{l}\text { Ökad internationell } \\
\text { attraktionskraft }\end{array}$ & $\begin{array}{l}\text { Locka företag från regionen, rikstäckande och } \\
\text { internationellt (Regionen). }\end{array}$ \\
\hline Marknadsutveckling & $\begin{array}{l}\text { BU CR/FOUs framgång och } \\
\text { attraktivitet(output) }\end{array}$ & $\begin{array}{l}\text { Hur mycket positiva artiklar som skrivs och flöde i } \\
\text { socialt media som skrivs om INNOHUB, både } \\
\text { nationellt och internationellt. }\end{array}$ \\
\hline $\begin{array}{l}\text { Socialt } \\
\text { Skatter.(skatteintäkter } \\
\text { som output), } \\
\text { Kompetens (nytta; } \\
\text { utbildning, forskning } \\
\text { som output). }\end{array}$ & $\begin{array}{l}\text { Ökade skatteintäkter, ökad } \\
\text { kompetens (output). }\end{array}$ & $\begin{array}{l}\text { Öka skatteintäkten (Regionen), } \\
\text { Skapa nya arbetstillällen (Regionen) (Skatter) } \\
\text { Regionens tillväxt (Regionen)(Skatter), } \\
\text { Stärka regionens attraktivitet(Regionen) (Nytta, } \\
\text { Kompetens), } \\
\text { Förstärka genomförandet av strategin Affärsplan } \\
\text { (Regionen). }\end{array}$ \\
$\begin{array}{l}\text { Tillväxt i företagen (Allmänt/Vinnova) } \\
\text { Hällbarhetsaspekter }\end{array}$ \\
\hline
\end{tabular}

Figur 27. Regionala och samhälleliga utvecklingsområden, mål och medel

Ett förslag till uppföljningsmodell speciellt avpassad till INNOHUBS målstruktur presenterades vid ett tidigt dialogmöte med Regionens experter. Modellen omfattade den här s $\mathrm{k}$ arbetsmodellen; en förenklad variant av EFQM-modellen. Vid dialogmöte med Staden diskuterades den s k "simpler-modellen" (Grufman, 2001) som relevant mätmodell och som underlag för utveckling av "nytt" KPI för uppföljning av flertalet av specificerade ekonomiska mål (inklusive /potentiella/ skatteeffekter). Utifrån dessa förutsättningar utvecklades ett nytt KPI (ROICi ). Vid årsskiftet 2019/2020 redovisades tre SMF-etableringar som gjorts inom regionen genom medverkan i INNOHUB. Några effekter från dessa med påverkan på de regionala målen kunde inte utläsas varför för denna delstudie avslutades i november 2019.

\subsection{Partiell analys av INNOHUB. Fyra case. Tre roller. Två synsätt.}

Detta forskningsprojekt är relativt komplext eftersom ett antal divergerande mål/förväntade resultat har beskrivits av de olika finansierande parterna. Analysen av Case INNOHUB avser de fyra olika delstudierna: .01/.02;.03 ${ }^{107} \mathrm{samt} .04 ;(.05){ }^{108}$ där studierna exemplifierar dels ett företagsspecifikt synsätt $(01$ - .03) med utgångspunkt från en faktormarknad och behov av

107 INNOHUB .01/.02 samt .03 representerar synsätt 1 (se fig. nedan; innovation/utveckling), studier av företagsprojekt/företag anslutna till INNOHUB. Målföretaget har olika roller; här i huvudsak relaterat till synsätt $1 \mathrm{~d}$ v s medverkar i rollen som 'leverantör'

${ }^{108}$ INNOHUB .04 representerar synsätt 2 (se fig. nedan; applicering/tillämpning), utveckling av tillämplig modell för utvärdering samt KPI.

(INNOHUB .05 innefattar denna slutrapport till Vinnova omfattande samtliga studier d v s INNOHUB .01- .04.) 
utveckling av ett internt innovationskapital, dels ett mer regionalt/nationellt synsätt (.04) med utgångspunkt från behov av utveckling av applikationer för en utbudsmarknad.

Dessa två teoretiska synsätt (Se nedan Figur 28) för att förstå målet resurstillväxt från FoU och innovation framställdes som möjliga och mest relevanta utifrån respektive aktörs beskrivning av förväntade mål och med referens till de två teoribildningar som avhandlingen fokuserar;

- en innovations-/kunskapsrealerad teoribildning applicerad utifrån främst resursbaserad teori (Penrose, Wernerfelt, Barney, Teece m fl) (med utgångspunkt från INNOHUBS anslutna innovatörer) samt

- en applikations- /produktrelaterad teoribildning applicerad utifrån främst marknadsbaserad teori (Porter m fl) (med utgångspunkt från behov hos Målföretagets och regionens "kunder")

Ett tredje synsätt som diskuterades med ledningen i INNOHUB; en resurstillväxt som genereras på en kapitalmarknad d v s analyserad med finansmarknadsteori. Då detta perspektiv primärt omfattar finansiella instrument, derivat med implikation för större ägare (i detta fall Målföretaget och deras kunder) så beslutades att detta perspektiv inte prioriterades initialt.

Analysen av Case INNOHUB har som helhet utgått ifrån den analysmodell som utvecklats utifrån det första synsättet, d v s ett resursbaserat synsätt. En konsekvens av detta innebär att analysen av INNOHUB enligt ett 'utbudsmarknadssynsätt' inte kan göras enligt denna modell. I kapitel 11 diskuteras orsaker till detta och implikationerna av detta för fortsatt forskning.

Vidare intar Målföretaget ett antal olika aktörsroller i studien av INNOHUB; som utvecklingspartner till innovatörerna samt projektfinansiärerna (investerare), som kund och som applikationsansvarig. I den förstnämnda rollen, där innovationsprojekten initieras och deras form bestäms som ett led i INNOHUBS verksamhet, analyseras här de förväntningar på INNOHUB som framkommit i intervjuer med såväl innovatörer som ledning i Målföretaget. Målföretagets förväntningar analyseras endast avseende medverkan vid samarbete med innovatörer (via INNOHUB) för utveckling av ett innovationskapital $\mathrm{d} v \mathrm{~s}$ ej förvärv, finansiering av infrastruktur eller strukturkapital som sker utöver INNOHUB medverkan. De regionala aktörernas förväntningar kommenteras om tillämpligt.

INNOHUB analyseras med avseende på de olika aktörernas respektive finansiärernas målbilder. Utgångspunkt för denna analys är att denna empiri har ett primärt fokus på faktormarknaden, d v s en anskaffnings- respektive utvecklingsmarknad, en marknad som kännetecknas av “öppen innovation'. Kontexten "öppen innovation” omfattar fem kategorier av aktörer som implicit är intressenter till INNOHUB.: SMF/ innovatörer, INNOHUBS medarbetare, Målföretaget och dess kunder, investerare samt också INNOHUBS lokala, regionala och globala finansiärer.

De divergerande mål som dessa aktörer uttalar som förväntningar på INNOHUBS verksamhet behöver inte "konkurrera". Olikheterna innebär att förväntningar med det ena synsättet har en fokusering på inputvariablerna "möjliggörare" och "processer" och med det andra synsättet en fokusering på outputvariabler, d v s en förväntan på resultat i form av antingen nya produkter och tjänster eller ökade (regionala) inkomster. Dessa divergerande förväntningar innebar dock ett behov att vid följeforskningens genomförande och analys ifrågasätta om olika teoretiska strategifokus, d v s på en 'faktormarknad' alternativt en 'avsättningsmarknad', påvisar olika 
möjligheter/risker och effekter på styrningen och därmed också på förändringar av företagens kapitalstruktur och resursbas.

Redan inledningsvis utvecklades en huvudfråga inför såväl utförande som för uppföljning och analys av följeforskningen inom FoU. Kan ett och samma teoretiska synsätt tillämpas för att studera och analysera olika marknadsaspekter relativt målet "resurstillväxt"? Följande reflektion innebär en potentiell möjlighet till det men också en potentiell begränsning:

$>$ > FoU, som ett led $i$ värdeskapande verksamheter och innovation är resultat av en tidig generisk process, delvis beroende av en utvecklad "extern" infrastruktur, men också "inbäddad" $i$ en verksamhets interna processer. Den kunskapsintegration som exemplifieras i följeforskningen implicerar i huvudsak "interna" besluts- och värdeskapande processer.>>

Då de företag som initialt anslöts till INNOHUB i huvudsak var i sin tidigaste "innovationsfas" föll valet på det första perspektivet som utgångspunkt för analys. Följeforskarens bedömning var att ledningens förväntningar på INNOHUB i detta tidiga skede primärt handlade om fördelar från samarbeten runt avancerad teknologisk innovation. Förväntningar på potentiella applikationer enligt det andra perspektivet i tidigt skede kunde innebära "spekulation". Ett ytterligare skäl till valet var kravet på strikt sekretess för följeforskaren avseende bland annat tekniska landvinningar och finansiella förhållanden. Det andra perspektivet avsågs att längre fram kunna tillämpas vid intressenternas "effektutvärdering" d v s intressenternas egen självutvärdering av mer långsiktiga effekter på lokala och regionala mål. Följeforskningen (och denna analys) har följt och kommunicerat denna prioritering.

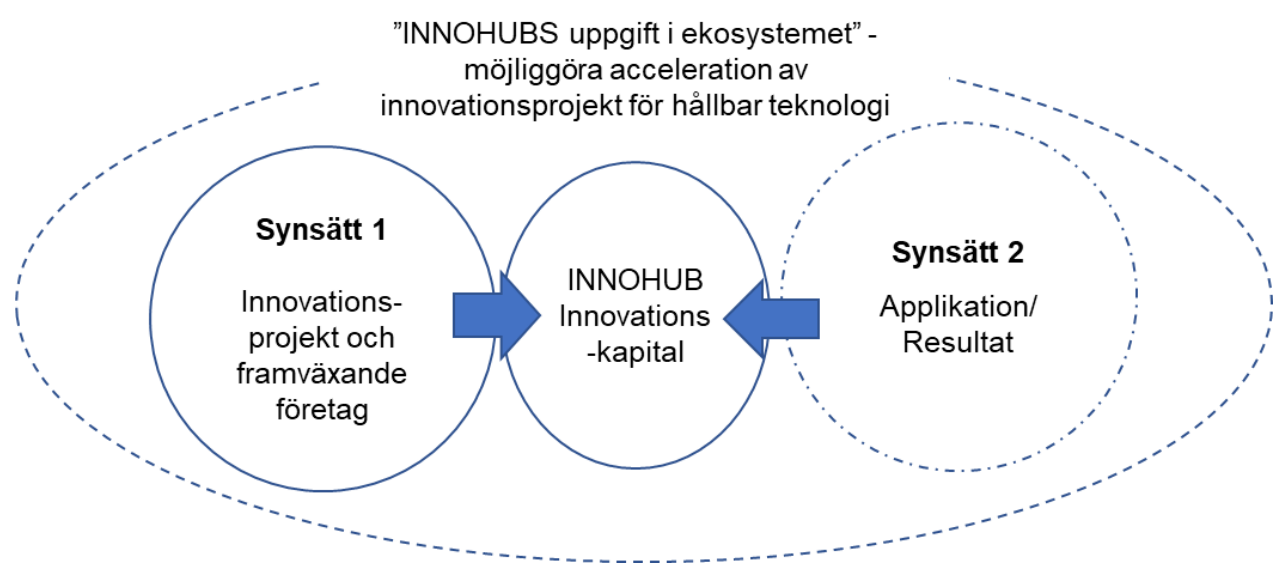

Figur 28 Två synsätt som antas påverka INNOHUBs roll i innovationsystemet

\subsubsection{Aktörernas syn på måldimensionen}

Analysmodellen definierar att måldimension kan ses som den samlade beskrivningen av mål, hinder, risker, ledningsförutsättningar; ledningens mål samt innovations- och produktionsstrategier. Nedan summeras de olika aktörernas syn på måldimensionen: 


\section{Innovatörerna.}

Målet att nå en snabb tillväxt (högsta prioritet) prioriteras genom att samarbetet innebär en kortare innovationsprocess. Det har inte infriats då hinder har funnits internt, d v s i det egna företaget, hos den egna ledningen, bland annat genom en oklar "egen" affärsmodell eller en felbedömning av innovationens utvecklingstid $\mathrm{m}$ a $\mathrm{p}$ alltför stor kortsiktighet. Bland möjligheterna att ändå uppnå målet anses samarbetet med affärsenheterna vara mycket viktigt, både vad gäller teknisk utveckling och marknadsutveckling (lika viktigt för båda typerna). Däremot är intresset att samarbeta med och lära av andra innovatörer mycket lågt. Bland de övrigt högst rankade målen är konkurrensfördel, kapitaltillväxt och två av de sjutton hållbarhetsmålen mycket viktiga. För de två innovatörer som uppnått flest strategiska kontrakt och löpande kommunikation anges två faktorer; helt ny teknologi (AI resp. Elektromagnetism) och organisk tillväxt. För ett av dessa är ett strategiskt mål att bli förvärvat av Målföretaget.

De två stora osäkerhetsfaktorerna är risken för kopiering respektive relationsrisken (att någon del av samarbetet inte fungerar).

\section{INNOHUB.}

Måldimensionen för ledningen är tudelad: Man ska ha ett 'internt' fokus $\mathrm{d} \mathrm{v} \mathrm{s}$ på Målföretagets och dess kunders behov och samtidigt ha ett 'externt' fokus på innovatörerna, d v s på faktormarknaden. En utgångspunkt för ledningen är att primärt stödja innovatörerna, d v s det görs en kontinuerlig intern anpassning till innovatörernas behov som sedan bedöms ge en effekt på INNOHUBS eget innovationskapital implicit, och i en förlängning positivt för Målföretagets innovationskapital.

\section{Målföretaget.}

Primärt mål är ökat kassaflöde (cashflow) från samarbete med ny teknologi d v s hållbara projekt snabbas upp. Delmål är att behålla och öka marknadsandel d v s här betonas volymaspekten, d v s möjligheten att skala upp, tydligt gentemot innovatören. Nya affärsmodeller (med partnerskap) provas kontinuerligt för strategisk anpassning; kontraktering av koncept (energi), finansiella partnerprogram mm. Tekniska risker (samt affärsrisker) anses reglerade gentemot partners.

\section{Regionala aktörer.}

Ett huvudmål är ökade skatteintäkter och en ökad regional kompetens. Delmål är ökade arbetstillfällen och regionens tillväxt och att stärka regionens attraktivitet.

\subsubsection{Aktörernas syn på resurser och förmågor}

Analysmodellen definierar att resurser och förmåga kan ses som det som möjliggör och skapar en grundläggande förmåga. Därmed inkluderas möjligheter; partners kompetens/(strategier) och affärsåtaganden (även internt). Nedan summeras de olika aktörernas syn på resurser och förmågor: 


\section{Innovatörerna.}

I denna kontext ser man partnerskapet (med INNOHUB) som potentiell resurs och dess förmåga att hitta rätt samarbetspartner för att 'signa' avtal med kund direkt (partnerskapet/kontrakt såldes i tre steg). Som en resurs (möjlighet) bedöms också att Målföretaget själva har en produkt som gjort det möjligt att starta ett projekt snabbare Kompetens (kunskaps-) och innovationskapital nämns som mycket viktigt. Om finansiering ska ses som en resurs fordras en större tydlighet i vilka strategiska områden som ska utvecklas, d v s innan strategin är tydlig så kan inte resursen "finansiellt kapital" identifieras! Eller m a o om strategin är tydlig så kan (potentiellt) resurser för "finansiering" identifieras.

\section{INNOHUB.}

Implicit handlar INNOHUBS resurser och förmåga om såväl tillgång till lokaler som finansiering och kunskap om respektive industriell verksamhet. (Detta nämns dock inte explicit i intervjuerna). De resurser som klargörs i empirin är partners resurser, när de kontrakterats. I empiri nämns att "case"-företaget i studien har en ledande ställning inom AI, med hög kompetens från tekniskt universitet och att företaget redan arbetar mot gemensam slutkund tillsammans med Målföretaget.

\section{Målföretaget}

Målföretaget ser i denna kontext en resurs i att INNOHUB som ska bidra till målen. Detta genom INNOHUBS tillgång till nystartade företag och deras innovativa kultur med nya och unga påverkare, $\mathrm{d}$ v s tillgång till startupföretagens kompetens och nätverk. Indirekt tillförs innovatörerna Målföretagets resurser i form av tillgång till processer, globalt nätverk, lokaler mm. Målföretagets egna resurser för samarbetsprojekt (gentemot slutkund) ligger i deras organisation för FoU och inom respektive BU.

\subsubsection{Aktörernas syn på organisering för värdeskapande}

Analysmodellen identifierar att för att resultat skall nås behöver verksamheter organiseras på olika sätt. Organisering för skapande av värdesystem och värde (Varför? Vem? Vilka?); organisatoriska förändringar (i ledning, FoU-organisation mm). Nedan summeras de olika aktörernas syn på organisering:

\section{Innovatörerna.}

Framhåller att organiseringen av den löpande verksamheten vid samtal om innovationsprojekt, finansiering mm ska vara selektivt. WS och andra "events" bör genomföras i mindre skala. Man efterlyser en gemensam arbetsform av typ stage/gate modell och en beslutsmodell där INNOHUB deltar i olika steg och i någon mån längre än idag.

\section{INNOHUB.}

I denna del av studien ses INNOHUBS organisation som ett potentiellt eget värdesystem, ett innovationskapital i en verklig och praktisk kontext. Organiseringen syftar till att medverka till ett "externt" värdeskapande för innovatörerna och Målföretaget (- $s$ kunder), dock att organisationens eget innovationskapital endast bedöms i sin egen 
kontext, d v s organiseringen och beslutsprocesserna i INNOHUB är "stand alone"processer och förutsätts vara kontextneutrala. Kontexten är en miljö där företag deltar i ett system för 'öppen innovation' och där värderingen avser själva förekomsten av fenomenet "collaborative innovations". ${ }^{109}$ Gränserna för INNOHUBS organisering med konsekvenser för medverkande företag (resursallokering, tidsperspektiv, geografiskt perspektiv, ledningsansvar) beslutas inom ramen för INNOHUBS egen organisation. Två aspekter (från enkäter med innovatörerna) med konsekvenser för INNOHUBS organisering av samarbeten är a) att budgetprocessen måste förändras b) att matchningsprinciper tydliggöras utifrån aspekter på ledarskap, affärsmodeller, riskvärdering (affärsoch relationsrisk), attityder, projektfinansiering snarare än utifrån det "tekniska innehållet".

\section{Målföretaget}

Målföretaget betonar framförallt investeringen i TID, $\mathrm{d}$ v s att innovationsprocessen från idé till försäljning genom samverkande innovation (stor/liten) snabbas upp ger ett snabbare värdeskapande. Viktigt att skilja på utvecklingsprocessen (hos innovatörer) respektive åtgärdsprocessen (a) med INNOHUB och (b) med produktägare hos Målföretaget. Vidare poängteras, $\mathrm{m}$ a $\mathrm{p}$ tidsperspektiv och innovationens "nytta" och tillämpbarhet, att en värdeskapande organisering sker både "bottom -up" och "topdown".

\section{Regionala aktörer.}

Stadens, regionens och Vinnovas engagemang i organiseringen är "indirekt", $\mathrm{d} v \mathrm{~s}$ rådgivande utifrån krav på avkastning (primärt skatteintäkter) på "indirekt" investering i INNOHUBS infrastruktur. Vinnovas krav vid organisering avser primärt återrapportering av att organisering uppfyller kraven för offentlig finansiering.

\subsubsection{Aktörernas syn på olika väsentliga processer}

Analysmodellen identifierar företagets processer för utarbetande av värdeskapande processer och för beslutsprocesserna (inklusive "omedvetna"/opåverkbara förändringar, risk), detta utifrån intressenters preferenser på tre nivåer (nuvarande och potentiella partners, anställdas, samt omgivande samhälles). Nedan summeras de olika aktörernas syn på processerna:

\footnotetext{
${ }^{109}$ Ett fenomen avseende specifikt kunskapsintegration som diskuteras i empiri med betydelse för utveckling av ett innovationskapital, konceptuellt men också med kontextuella implikationer. Ämnet, utanför denna avhandlings avgränsning, avhandlas teoretiskt inom ramen för "interfirm collaborations" (Begrgren m fl., 2011). Se förslag till fortsatt forskning kapitel 11.
} 


\section{Innovatörernas}

Innovatörernas förväntningar på beslutsprocesser, utöver organisering av den löpande verksamheten, avser kontakter med Målföretaget och vikten av att snabbt hitta rätt produktägare. Vidare efterlyses en modell för "innovationsupphandling" då inköpsprocessen är oklar och ledtiden fram till att ett första beslut kommer. För innovatören handlar det om osäkerhet vid uppskalning och vilken strategi Målföretaget därför väljer för att utveckla ett samarbete; som outsourcing eller insourcing eller i annan samarbetsform. Tidsperspektivet, d v s när i tid som värdering av innovationsprojektet ska göras, bör beslutas. Frågorna avseende andra kriterier för beslutfattande respektive återkoppling (i stage/gateprocessen) är ej besvarade.

\section{INNOHUB}

INNOHUB (-s anställda) anser att förväntningar på prestation och motprestation måste bedömas där hela projektet (alla parter) medverkar tillsammans och utifrån vilket strategiskt syfte som ett samarbete har (se exempel från "case"-studien).

\section{Målföretaget}

Målföretaget nämner, dock inte högprioriterat, strategier för riskminimering och internationalisering som de förändringsprocesser som måste tydliggöras inför strategivalet.

\section{Regionala aktörer}

De tre regionala aktörerna efterlyser också processer och strategier för att öka den internationella attraktionskraften för INNOHUB, detta också för att locka företag från såväl regionen, nationellt och internationellt, att ansluta till samarbetsprojekt.

\subsubsection{Aktörernas syn på resultat och effekter}

Analysmodellen beskriver Resultat och Effekter; informella processer (inkluderande den "osynliga" mätdimensionen)

(E), Nedan summeras de olika aktörernas syn på resultat och effekter:

\section{Innovatörerna}

Innovatörerna efterlyser större tydlighet avseende mål och strategier från Målföretaget om vilka prioriteringar som gäller och efterfrågar en arbetsform för tydligare kommunikation med workshops, seminarier $\mathrm{m} \mathrm{m}$, inom prioriterade områden. Inget konkret förslag till mall för "intern" värdering har presenterats. Generellt behov av en värderingmall för ett gemensamt typprojekt (= potentiellt underlag för beräkning av innovationskapital (förf. kommentar).

\section{Målföretaget}

Målföretaget uttrycker "cashflow" som en mer eller mindre "osynlig" mätdimension och som ett (viktigt) komplement till värdemodellen. Det är oklart hur "viktig" dimensionen är, men man uttrycker att det är en förutsättning för att uppnå målen och att kunna behålla och öka företagets marknadsandel (inom respektive industrisektor). 


\section{Regionala aktörer}

De regionala aktörerna (staden och regionen) tillämpar en modell för bestämning av måluppfyllelse i regionala program; den s k "simplermodellen", en modell med utgångspunkt i beräkning av förädlingsvärden som korrelerar med BNP. Förslag till utvärdering av regional effekt $\mathrm{m} h$ a denna metod har diskuterats initialt.

(R1 och R2)

Frågor relaterade till redovisningsperspektivet avser företags värden och värdetillväxt, företagets redovisning av goodwill samt övriga resultatfaktorer för kommunikation/redovisning: förädlingsvärden, the 'triple bottom line', resurseffektivitet, och resursavkastning/ resurstillväxt.

\section{Innovatörerna}

Denna grupp efterlyser modell för utvärdering vid workshops och ett redovisningsbart KPI för varje projekt.

\section{INNOHUB}

INNOHUB tillämpar en modell för summering av upparbetade kostnader i respektive projekt. Beräkningsmodellen är inte fullt redovisad beroende på "konfidentiell" behandling. Underlaget kan potentiellt utgöra grunden för konstruktion av innovationskapital som kan aggregeras på olika nivå och samtidigt möjliggör en separatredovisning respektive företags "resursbas".

\section{Målföretagets}

Målföretagets redovisning avseende hur utgifter och inkomster, effektivitet mm redovisas är inte kartlagd i denna studie. Förslag till "intern balansräkning" samt nyckeltal för beräkning av avkastning på innovationskapital (ROIC $i$ ) har diskuterats. Inga nyckeltal för återkoppling till mål har etablerats.

\section{Regionala aktörer.}

Kvalitativa och kvantitativa, redovisningsbara variabler som relaterar till de 17 samhällsmålen efterlyses. 
Följande kapitel, kapitel 8 - 10, omfattar Steg 3 och 4 av forskningslogiken. (Figur 2) Denna fas har en deduktiv ansats och inleds med tillämpning av analysresultat från det empiriska materialet (primärt Case FORCE redovisat i kapitel 6 och Case INNOHUB redovisat i kapitel 7) med vald systemmodell för analys; analys- och förklaringsmodellen (Figur 9).

Vid tillämpning med den tentativa förklaringsmodellen vid analys av Case FORCE identifierades två typer av övergripande strategisk utmaning, en konceptuell och en kontextuell. Konceptuellt finns behovet av en utvecklad förklaringsmodell som ger en god förståelse för strategisk ekonomisk, resursbaserad målorienterad styrning för applicering i en lärande organisation, en mer dynamisk modell men oberoende av kontext. Modellen ska kontextuellt kunna appliceras på olika 'systemnivåer' ${ }^{110} \mathrm{i}$ ett ledningssystem, d v s i grunden en enkel och generell d v s kontextneutral beslutsmodell som vid behov kan operationaliseras utifrån krav på operationell säkerhet vid potentiellt identifierad risk. ${ }^{111}$

Vid analyser av Case FORCE och Case INNOHUB redogörs nedan för de `strategiska utmaningar' som observerats. I analyserna har i första hand teorier som specificerats ovan prövats. Ett behov av en utveckling av strategiteorin utifrån resursbaserat synsätt, nu med inriktning på faktormarknaden, har tydliggjorts. Denna 'nya' teori har bland annat exemplifierats med två (2) potentiellt möjliga, två synliga helt disparata ledningsstrategier; en "gasa" och en "bromsa" - strategi. (Figurerna 16 och 17) Analysen har också exemplifierats med slutsatser avseende fokus för och typ av styrning (tight-loose control), typ av ledning (policy) samt potentiella, ackumulerade effekter på resursbasen $(\mathrm{Rb}+/-)$.

Denna avhandling diskuterar endast villkor och förutsättningar utifrån det resursbaserade synsättet, med referens till aktörerna i ekosystemet (Figur 28), som omfattar innovatörerna, INNOHUB, Målföretaget samt Investerare. Då regionala och nationella aspekter primärt berör ett 'marknadssynsätt' avhandlas förutsättningarna i dessa kontexter marginellt. ${ }^{12}$

I följande kapitel redogörs för de utmaningar som identifierats i den systemiska analysen av Case FORCE och Case INNOHUB. I kapitel 10 diskuteras vilka slutsatser som kan dras av respondenternas förväntningar på framtida 'nytt' styrsystem, förväntningar och villkor som också identifierades i förstudien samt i Case ROBO och Case CATHEDRAL.

\subsection{Longitudinell systemisk analys av FORCE och INNOHUB.}

Denna systemiska analys, gjord enligt den tentativa analys- och förklaringsmodellen, avser de två fallstudier som genomförts under de två längre perioderna; Case FORCE (4 år) och Case INNOHUB (2 år). De strategiska utmaningarna är relaterade till möjligheterna att uppnå ‘betamålet’; målet om en långsiktigt hållbar resurs- och värdetillväxt som är mätbar och därmed redovisningsbart. Ett speciellt fokus för utmaningarna är, relativt avhandlingens initialt

\footnotetext{
${ }^{110}$ Referenser till tillämpliga modeller ska göras på en beskrivningsnivå som harmoniserar med applicerade regelverk ex IFRS; Conceptual Framework, (2020); ISO HLS/Harmonized Structure (2021).

${ }^{111}$ Vid referens till tillämpliga beräkningsmodeller (exempelvis Johnsson, 2006) ska om möjligt hänsyn tas till de krav på säkerhet vid 'ny' teknologi som indikerats i Case INNOHUB .03 (Ex: vid systemering av AI-tillämpningar)

${ }^{112}$ Separat redovisning har gjort till VINNOVA enligt uppdragsbeskrivning
} 
konstaterade fenomen, att förstå förändringar i företagens balansräkningar d v s resursbasens kapitaliserade immateriella värden men även de icke-kapitaliserade immateriella resurserna $\mathrm{i}$ systemet.

\section{Ledningsförutsättningar.}

Den strategiska utmaningen inom FORCE handlar dels om att tillämpa en form eller en teori som beskriver kompletterande ledningsförutsättningar. Teorin som tillämpas vid analys stödjer företagets behov av 'unikitet', betydelsen och värdet av mer 'inhouse' produktion, nyttoaspekter samt mer av 'hållbar' teknologi. Teorin framhåller betydelsen av individens (entreprenörens) motivation som i denna empiri motsvaras av aspekten på 'glädje'. Intressant att notera den 'mekanistiska' beskrivningen i empirin relaterat till 'motivationsfaktorns' betydelse. Här kan noteras en viss skillnad mellan teori och empiri avseende vems 'nytta' som värderas och var och hur 'nytta' (och prissättning av denna) bestäms. I empiri avses primärt kundnytta (benefit/disbenefit). I RBV framhålls istället företagets prissättning som metod för att maximera avkastning för att uppnå en uthållig konkurrensfördel.

En strategisk utmaning inom FORCE är att inför beslutsprocesser upprätta en målstruktur där frågorna och villkor för Vem (intressent) respektive Varför (syfte) är tydliggjorda.

Inom INNOHUB ses öppen samverkan inom och mellan affärsenheter avseende ny teknologi (AI) och marknadskunnande som främsta möjlighet för organisk tillväxt (intern resurstillväxt) men ses samtidigt utgöra ett hot med risk för kopiering och `split vision’ $\mathrm{d} v \mathrm{~s}$ att samtidig intern och extern fokus för ledningen ställer extra krav. Ledningen framhåller den `egna resurstillväxten' (eget innovationskapital) på olika nivåer av ekosystemet för innovation, även på regional nivå.

Den strategiska utmaningen i INNOHUB är att tydliggöra vad som är organisk tillväxt d v s hur och var, d v s i vilken kontext och i vilken fas som tillväxten av innovationer ska identifieras och värderas. Ett sådant tydliggörande av kontexten i kontrakt och avtal med (nya) partnerskap kan potentiellt stimulera till "collective innovations" med större öppenhet internt i projekten.

\section{Resurser}

I FORCE handlar den strategiska utmaningen om resurser och relaterar till frågorna Vad och Vilka. I denna samlade empiri (i såväl förstudien som denna studie, FORCE) har försöken att uttolka resursbegreppet eller vad som betraktas som resurser resulterat i mer eller mindre svårighet att bestämma vad som egentligen är resurser, om annat än i mycket generella termer. Samtidigt är bilden tydlig av vilka resurser som egentligen har ett 'värde' inom ramen för de argument som används vid styrning $\mathrm{i}$ en tidig fas, $\mathrm{d} v \mathrm{~s}$ vid FoU, innovation och produktframtagning etc. Dessa argument baseras på vad som karaktäriseras som "strategiska resurser" som exempelvis energi, pengar, inbyggd respektive applicerad teknologi och därtill stödjande, relevant information.

Argumenten här eller kriterierna för vad som är värdet av strategiska resurser är direkt kopplade till 'affärsmöjligheten' i projektet FORCE; d v s information och energi för optimering av befintlig struktur (jmf optimering av energins verkningsgrad), möjlighet till 
lagring vid överproduktion, "add on/added value", möjlighet till ökad processeffektivitet (inom ex stålindustrin), möjlighet till automation av distributionssystem, möjlighet till fler tillämpningsområden och möjlighet till utveckling av unik kompetens. Samtidigt är värdet på resursen starkt kopplat till dess kunskapsinnehåll som exempel kompetens i teknologi för modularisering. Vid styrning av dessa strategiska resurser fordras att de är möjliga att beräkna, d v s att de är operationaliserade utifrån deras kvalitativa egenskaper.

Resursbaserade teorier, TGF, RBT, RBV och DCP, beskriver strategiska resurser i termer av tillgångar som $i$ kombination med andra resurser och individers/organisationers förmåga genererar värde genom att möta affärsmöjligheter, uppnå effektivitet i processer $\mathrm{mm}$. Teorierna går längre genom att utveckla kriterier för vad som ger strategiska fördelar som exempelvis projektets unikitet och begränsad mobilitet (VRIO-kriterierna). Teorin gör en kategorisering av olika resursslag som omfattar de i empirin nämnda strategiska resurserna (energi, information, kompetens, pengar $\mathrm{mm}$ ) men saknar en operationell definition!

Inom INNOHUB nämns partners och deras nätverk, kunskaps- och innovationskapital, specifik kunskap (energi, information) finansiering och den egna organisationen som resurser. Alla viktiga för attraktionskraft och framgång för såväl INNOHUB som för alla andra engagerade företag.

En strategisk utmaning är att identifiera dessa operationella strategiska resurser. Det fordras dock någon form av ytterligare definition och kontextuell kategorisering - och en ytterligare och mer distinkt bestämning av resursbegreppet för att kunna klassificera dem i respektive kategori.

En ytterligare strategisk utmaning inför såväl forskning som tillämpning är att kunna identifiera olika resursslag och därmed kunna avgöra i vilken strategikontext en viss resurs (eller resursportfölj) aktualiseras. En tydlighet i vilken strategi som gäller är ett villkor för att kunna avgöra behovet av en viss resurs, identifiera kompletterande resurser; exempel ett behov av finansiella resurser och en viss specialistkompetens. En utmaning är att utforma en 'resurshierarki' eller någon form av resurskarta som underlättar beslut.

\section{Organisering.}

De strategiska utmaningarna är flera vid organisering inom FORCE och implicerar traditionella styrningsfrågor som Varför, för Vem och Vilka organiseringen berör men samtidigt också planeringen av möjliga strategier som relaterar till frågorna Hur och med Vem. Av empirin framgår problem vid organiseringen för att utveckla 'ny' teknologi.

En strategisk utmaning för förståelse av en resursbaserad, strategisk styrning är att utifrån väldefinierade strategiska resurser och identifierad kontext utforma en modell för organisering som implicerar förändring $\mathrm{d} v \mathrm{~s}$ en dynamisk "karta" som utifrån faktormarknaden (ny kompetens, alternativa leverantörer, partners $\mathrm{mm}$ ) exemplifierar olika utvecklingsstadier. Ytterligare strategisk utmaning vid organisering är att förstå hållbarhetsaspekter som `ansvar’, 'cirkulär ekonomi', behovet av intern kommunikation och graden av öppenhet/slutenhet. Planering inför organisering omfattar strategier för såväl 'insourcing' som 'utsourcing', investering/förvärv och desinvestering/avyttring, strategier som inom koncernens 
projektportfölj kan variera mellan projekt, tidsutdräkt och risknivå. ${ }^{113}$ En strategisk utmaning inför implementering av en resursbaserad strategi inför organisering är att tydliggöra affärsenheternas ömsesidiga beroende.

En strategisk utmaning vid tillämpning av denna modell för att förklara förändringsmönster i olika resursslag (alt. resursportföljer) och i företagets resursbas är att dels beskriva den kontext (fokus: för Vem) som avses och antalet möjliga strategier. Detta är tydligt inom Case FORCE. De två exemplen med tillämpning av 'positionskartan' visar hur inte bara typ av styrning, möjliggörare eller organisatoriska effekter uppstår som resultat av strategi utan också resultat/konsekvenser på företagets resursbas, med eftersläpning. En viktig strategisk utmaning, med syfte att bedöma effekter på företagets kapitalstruktur vid de olika möjliga strategierna, är att visa/förklara dessa effekter från olika strategier på ett pedagogiskt sätt.

Strategiska utmaningar vid organisering är betydande inom en lösning som INNOHUB. Organiseringen måste ha både ett externt och ett internt perspektiv om värdetillväxt totalt sett ska uppnås. Det interna perspektivet måste också innebära olika typer av ansvar mm på olika nivåer och en organisation som positionerar resurserna/tillgångarna utifrån olika kriterier (VRIO, egenskaper, nytta, värde, legitimitet etc). Några utmaningar är att förstå hur tidsaspekten påverkar möjligheten för resurs- och värdetillväxt, möjligheter att skapa tillfälliga "buffertar" av resurser och att "matcha" rätt resurser. En strategisk utmaning för fortsatt forskning är att utveckla en modell för organisering av samarbetsformer som är kontextneutral.

\section{Beslutsprocess.}

Den strategiska utmaningen för FORCE är primärt att utforma en robust resursbaserad beslutsprocess som täcker specifikt strategifrågorna Vad, Hur och Vilka i utvecklingsprojekt men också frågor som påverkar den långsiktiga planeringen mot ett koncernstrategiskt mål i alla dess aspekter; krav på legitimitet, värdeaspekter (kvalitet versus kvantitet), påverkan på resursbasen/kapitalstrukturen och tidsaspekter. Detta samtidigt som frågor som avser både planering och TUTV och PUTV på projektnivå omfattar både Varför, för Vem, med Vem och förväntat resultat. Beslutsprocessen innebär med andra ord en integrering med organiseringsprocessen.

En strategisk utmaning är att beskriva kriterier för en robust beslutsmodell: en modell som på ett logiskt sätt vägleder beslutsfattare i olika kontexter för att reducera osäkerhet avseende strategiskt syfte vid olika konkreta alternativ, exempelvis vid 'outsourcing' respektive 'insourcing'. En mer specifik utmaning inom INNOHUB är att tydliggöra vilka som ska involveras i beslutsprocesser och när.

\section{Mätning.}

Att verklighetens mätning skiljer sig helt från mätning enligt ett resursbaserat synsätt framgår av Case FORCE. Den strategiska utmaningen är att med kunskap från ekonomistyrningsteori

\footnotetext{
${ }^{113}$ Ett teoretiskt riskbegrepp är under utredning vid Harvard. (Mikes \& Kaplan, 2021) Inom ramen för ISO 55010 och ISO 33000 pågår arbete med en definition av riskbegreppet. I Case INNOHUB har olika risknivåer relaterat till balans- respektive resultatposter analyserats.
} 
(Simons, 2000) med hänsyn till kriterier enligt resursbaserad teori (VRIO m fl) utforma ett mätsystem som kan fungera som tumregel för strategisk styrning (Figur 8) med relevanta nyckeltal. Ett mätsystem som är tillämpbart inom kontexten FoU och som omfattar innovationsoch utvecklingsprojekt bör hypotetiskt vara tillämpligt för annan kontext där strategier utgår ifrån och också påverkar hela företags resursbas d v s även de immateriella resurserna. ${ }^{114}$

En strategisk utmaning inom en organisation som INNOHUB är att utforma tydliga mätetal som kan relatera till innovatörernas och målföretagets strategiska resurs- och värdetillväxtmål och som kan kommuniceras och samtidigt utforma former för denna kommunikation. Tydligheten bör avse en mätning som relaterar till observerbara identifierade storheter som exempelvis "cash" och som samtidigt relaterar till mätning på olika systemnivåer. Ett exempel är företagens förädlingsvärde för att relatera till BNP. Ett annat exempel är tillgänglig effekt vid energilagring vid lösningar vid energiintensiv industri för att relatera till samhällets energibalans. Ett tredje exempel är den procentuella avkastningen (resurstillväxten) vid förädling av olika materias egenskaper vid olika förädlingsgrad, exempelvis vid trä- eller växtförädling och nyttan av denna.

\section{Resultatplanering/uppföljning och redovisning.}

Den strategiska utmaningen som identifierats inom Case FORCE för såväl forskning som tillämpning vid planering är att potentiellt kunna identifiera speciella resurser (och dess egenskaper, nytta och värde och eventuella 'brister' $\mathrm{mm}$ ) på avsevärt 'låga' systemnivåer (jfr Boulding) $\mathrm{d}$ v s så stringent och operationellt mätbart sätt som möjligt på 'lägsta' nivå för att kunna fastställa relevanta mätvärden relativt syfte och kontext. En mer specifik utmaning vid planering är att kunna kvantifiera 'portföljer' av resurser på ett sätt som är praktiskt användbart; exempelvis olika resursers tekniska funktion vid produktion. Tillgångar som exempelvis "patenterade system" måste identifieras som ett kombinat av resurser (Se TGF; "bundle of resources" och RBV; "portföljer av resurser"). Bakom varje resurs eller kombinat av resurser härleds resursernas inneboende (potentiella) egenskaper och de av organisationens förmågor 115 , som bedöms kunna utveckla resurserna och därmed företaget. Flertalet förmågor kan dock identifieras och planeras först efter det att resurserna i systemet varit verksamma och kan först då mätas/utvärderas inför planering. Ledarförmåga, resursförmåga och individuell förmåga ingår i resultatdimensionen (tillväxtfaktor) och den dynamik som kännetecknar dessa förmågor innebär en strategisk utmaning för ledningen vid planering.

En specifik utmaning är att vid planering göra en kompletterande beskrivning av organisationens måldimension, speciellt avseende företagets syn på vad som förädlas, önskad kapacitet för värdeskapande och hur målet antas påverka organisationens beslutsprocesser. En utmaning är behovet av en plan för hur konsolidering ska göras samt hur effektivitet mäts.

\footnotetext{
114 Beträffande Resultatplanering (ex ante) och Resultatuppföljning (ex post) $i$ teoretisk belysning, från skolbildning i ekonomistyrning ( $\mathrm{AX} \mathrm{m}$ fl, 2009) kan resultat redovisas $\boldsymbol{i}$ termer av ett värde från förädling av resurser (förädlingsvärde), avkastning på olika resursslag $i$ resursbasen samt effektivitetsmått.

${ }^{115}$ David J. Teece diskuterar skillnader mellan synliga respektive osynliga resurser och förmågor etc. (Teece, 2000). I den analys som görs här, utifrån den empiri som dokumenterats i samband med förstudien, i BC 1 (ROBO), BC 2 (CATHEDRAL) samt i detta case, BC 3 (FORCE), skiljer avhandlingen inte på olika resursslag. Mätningen kan här avse alla slags resurser (per definition).
} 
En utmaning är också att utforma en modell för att utöver att förstå också kunna vägleda; en "arbetsmodell" som kan tillämpas i dialogform; d v s beslutsfattare och aktörer ska underhand känna till och kunna tillämpas de olika stegen i modellen och de frågeställningar som tas upp i respektive steg.

En strategisk utmaning vid tillämpning av en planeringsmodell som även visas i Case FORCE är att beskriva den kontext (fokus: för Vem) som avses, men också olika möjliga strategier och dessas effekter på företagets kapitalstruktur. De två exemplen med tillämpning av 'positionskartan' visar hur inte bara typ av styrning, möjliggörare eller organisatoriska effekter uppstår som resultat av strategi utan också resultat på företagets resursbas, finansiella och ickefinansiella, dock med eftersläpning.

För organisationer där arbete bedrivs i projektform såsom i INNOHUB är en utmaning för planering av resultat är att utveckla ett redovisningsbart KPI för respektive projekt. En 'projekt' relaterad planering underlättar konstruktion av ett innovationskapital och beräkning av tillväxt av detta 'kapital'. Aggregering till olika nivåer kan underlättas genom indexering. ${ }^{116}$ En strategisk utmaning är att utforma förslag till en 'intern balansräkning' för den ekonomiska styrningen på projektnivå/affärsenhetsnivå.

En utmaning för planering är att utforma kvalitativ och kvantitativa mått för de samhällsmål som föreligger; speciellt mål 9 (Industriell förnyelse)

\subsection{Strategiska utmaningar identifierar underlag till utvecklad förklaringsmodell}

En effekt av denna systemiska analys är en nödvändighet att även inför fortsatt forskning göra en åtskillnad mellan konceptuella och kontextuella villkor. I figur 29 illustreras därför en utvecklad förklaringsmodell som, med utgångspunkt från de två identifierade överställda utmaningarna och baserat på den tentativa modellen som använts vid den systemiska analysen. Figuren visar explicit utifrån denna empiri ett behov av ett utvecklat/nytt teoretiskt ramverk och en potentiell 'ny' kontextneutral beslutsmodell för en tillämpad hållbar och uthållig, integrerad strategi/styrning.

Utöver de strategiska utmaningar för att förstå och tillämpa ett resursbaserat synsätt avseende behov av ny föreställningsram eller behovet att förstå 'balansräkningar' som identifierats i de partiella analyserna har i ovanstående systemiska analys ytterligare utmaningar identifierats varav ett antal väls ut för en fortsatt fördjupad analys. Några av utmaningarna är konceptuella och direkt beroende av att förstå ett resursbaserat synsätt vid analys av de av ledningens strategier som på något sätt påverkar eller påverkas av 'fenomenet' med immateriella resurser och förstå hur dessa immateriella resurser ska hanteras. Utmaningarna handlar primärt om att $\mathrm{i}$ en beslutsprocess (vid innovation) dels förstå det resursbaserade synsättet vid en integrerad styrning, dels förklara hur företagets styrning av resurser kan påverkas av olika resursbaserade strategier genom att tillämpa en ny beslutsmodell. ${ }^{117}$

\footnotetext{
${ }^{116}$ Inom ramen för ISO 55001 pågår en diskussion om ett utvecklingsprojekt för indexering av immateriella resurser (datakluster, energi $\mathrm{m}$ )

${ }^{117}$ I ett sökande efter generell förståelse och förklaring (se även Chenhall, 2003) har en selektering gjorts för att med fördjupad analys av såväl konceptuella faktorer som kontextneutrala faktorer tydliggöra tillämpning $\mathrm{i}$ en viss kontext. Av de tjugoåtta (28) identifierade utmaningar avser nio (9) + två (2) utmaningar för djupanalys, resterande sjutton(17) avser dels (6) sex generella faktorer eller faktorer som redogörs för under respektive avsnitt. Dessa 


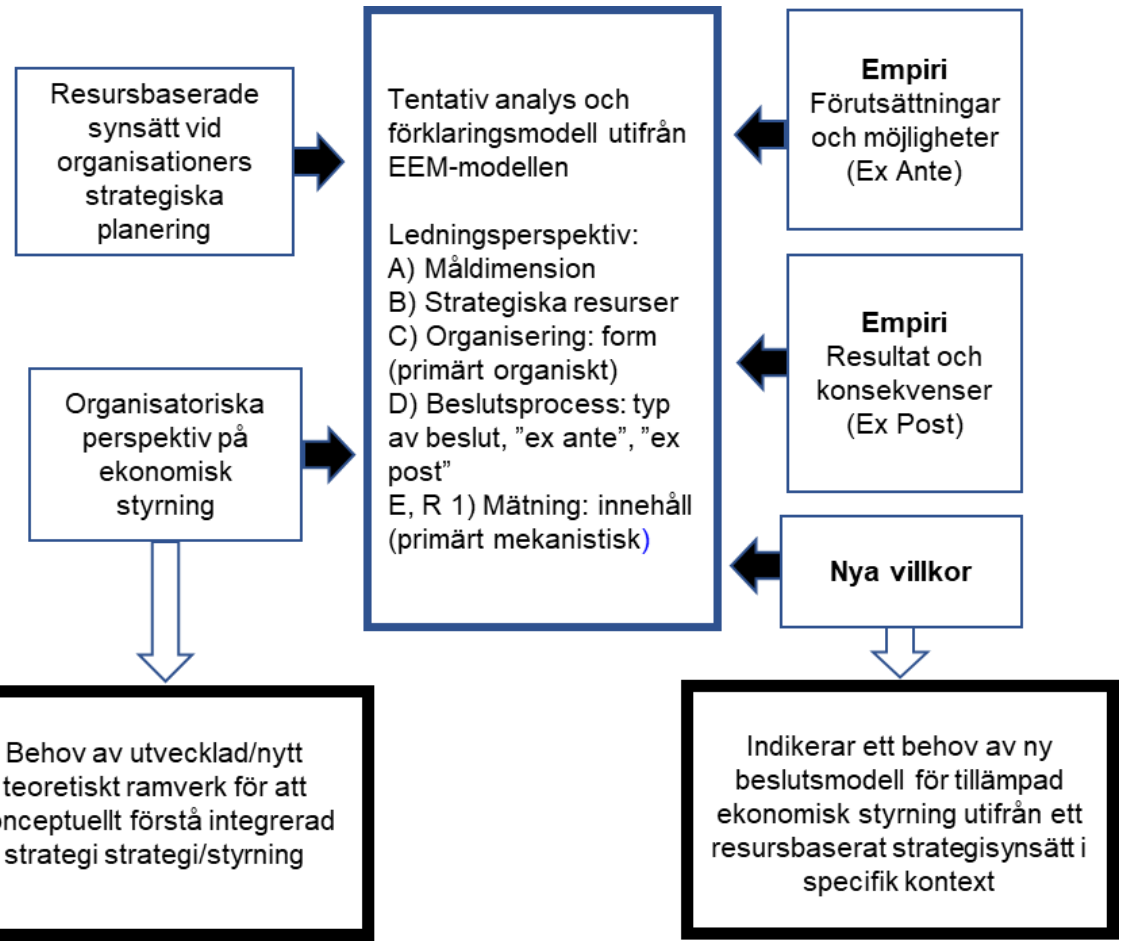

Figur 29. Två behov av modellutveckling utifrån strategiska, konceptuella respektive kontextuella utmaningar

Av tjugofem identifierade utmaningar är tre direkt relaterade till konceptuella faktorer som begreppet resurs inklusive förmåga, portföljer och innovationskapital, samt behovet av definitioner, kategorisering av resursslag mm. Fyra utmaningar är relaterade till specifika kontextuella faktorer som tidsaspekter, organisering och tillämpning av en robust beslutsmodell. Resterande utmaningar är relaterade till målstruktur, resultatplanering mätning och värdering i något avseende $\mathrm{d} v \mathrm{~s}$ både konceptuellt och kontextuellt. Samtliga dessa utmaningar indikerar behovet av fördjupad analys. ${ }^{118}$

bedöms som generella utmaningar och problematiseras därför inte här. Övriga elva (11) avser utmaningar avseende övergripande villkor för avhandlingen, villkor som diskuteras under respektive avsnitt.

${ }^{118}$ Ej med (metodologiska och övriga faktorer som diskuteras speciellt)

1 'Scope' (ny styrmodell)

2 Ny föreställningsram

3 Beskrivningsnivå, analysenhet, avgränsningar, intressenter

4 Betamålet

5 Förstå balansräkning

6 Upprätta målstruktur 
7 Organisk tillväxt

23 Portföljredovisning (tillämpning av finansiell teori)

25 Strategimodell, påverkan på RB (förslag att diskutera)

27 Intern balansräkning (förslag att diskutera)

28 Samhällsmål (förslag att diskutera) 


\section{Kapitel 9 Slutsatser från systemisk analys}

Den systemiska analysen relaterar primärt till avhandlingens inledande forskningsfråga: Vilka nya utmaningar och möjligheter skapas för företags strategiska styrning i samband med av den identifierade förändring av balansen mellan immateriella resurser och tillgångar?

För att avgränsa slutsatsen av den systemiska analysen preciseras frågeställningen ytterligare: Vid tillämpning av ett resursbaserat synsätt i en tidig fas i ett företags ekonomiska styrning, hur kan strategiska utmaningar som relaterar till ett samtidsfenomen mötas? Svaret på denna frågeställning utgår ifrån avhandlingens två initiala delfrågor:

- Vilka nya utmaningar utifrån resursbaserad analys uppstår i företags strategiska styrning som specifikt kan kopplas till ökningen av de immateriella resurs-/tillgångsslagen? (Kapitel 9.1-9-3)

- Vilka nya möjligheter och alternativa strategier skapas för företags ekonomiska styrning i samband med det observerade fenomenet? (Kapitel 9.4 - 9.5)

Detta kapitel avser att möta ovan identifierade och redovisade strategiska utmaningar. Kapitlet omfattar och begränsas primärt till de utmaningar som har stort förklaringsvärde för att förstå fenomenet med effekter på företagens kapitalstruktur och de utmaningar som ger underlag för en diskussion för att utifrån aktörernas förväntningar föreslå begrepp samt principer för en tillämpbar beslutsmodell samt förslag till nytt ramverk för ekonomisk styrning som underlag för fortsatt forskning (kapitel 10). Av de i analysen total tjugofem (25) identifierade utmaningarna görs en fördjupad analys i kapitel 9. Två identifierade utmaningar handlar om möjligheterna att inför fortsatt forskning och tillämpning förstå och tillämpa avhandlingens modeller. Detta diskuteras som svar på två ytterligare forskningsfrågor i kapitel 10.

Kapitlet redogör sedan för de tre områden för strategiska utmaningar som identifierats samt några 'nya' begrepp och modeller $\mathrm{i}$ anslutning till dessa. De nio utmaningar som från den systematiska analysen föreslås mötas genom fördjupad analys är följande:

- Tre av utmaningar som avser konceptuella faktorer: Resursbegreppet och relaterade begrepp, kategorisering mm för att förstå det resursbaserade synsättet (teori) relativt avhandlingens fenomen. (9.1) $(8,9.11)$

- Fyra av utmaningarna avser kontextuella faktorer. Processer vid beslutsfattande, organisering och effekter av olika resursbaserade strategier, inklusive tidsaspekter. Dessa faktorer har identifierats som kontextneutrala: d v s faktorer som bidrar till en generell förklaring av styrning i en viss kontext (empiri). (9.2) $(14,16,17,18)$

- Två utmaningar som avser tillämpning (praxis): Mål, resultatplanering och mätning inför strategivalet för att hantera fenomenet. $(9: 3)(21,26)$

Kapitlet avslutas (9.4 - 9.5) med en reflektion omkring den andra av de två initiala frågorna och om några ytterligare aspekter på det resursbaserat synsättet inför ledningens strategival. 
I kapitel 10 diskuteras förväntningar på en ny generell föreställningsram, målstruktur, arbetsmodell, systemperspektiv samt kontextuella begränsning inför det förslag till fortsatt forskning som redogörs för i kapitel 11.

\begin{tabular}{|c|c|c|c|}
\hline & $\begin{array}{l}\text { Kontextuella } \\
\text { utmaningar (faktorer att } \\
\text { förklara) Kapitel } 9.2\end{array}$ & $\begin{array}{l}\text { Kontextuella och } \\
\text { konceptuella utmaningar } \\
\text { Kapitel } 9.3\end{array}$ & $\begin{array}{l}\text { Konceptuella } \\
\text { utmaningar (faktorer } \\
\text { att förstå) Kapitel } 9.1\end{array}$ \\
\hline $\begin{array}{l}\text { Strategiska } \\
\text { utmaningar för } \\
\text { djupanalys. } \\
\text { Kontextneutrala }\end{array}$ & $\begin{array}{l}\text { Nr } 14 \text { Strategier } \\
\text { Nr } 16 \text { Tidsaspekter } \\
\text { Nr } 17 \text { Organisering/ } \\
\text { samarbete } \\
\text { Nr } 18 \text { Processkriterier/ } \\
\text { beslutsprocess }\end{array}$ & $\begin{array}{l}\text { Nr } 10 \text { Resurshierarki } \\
\text { Nr } 21 \text { Mål } \\
\text { Nr } 26 \text { KPI/Projekt } \\
\text { Nr } 24 \text { Arbetsmodell }\end{array}$ & $\begin{array}{l}\text { Nr } 8 \text { Definitioner, } \\
\text { identifiering } \\
\text { Nr } 9 \text { Kategorisering/ } \\
\text { hierarki } \\
\text { Nr } 11 \text { Positionering }\end{array}$ \\
\hline $\begin{array}{l}\text { Generella } \\
\text { utmaningar }\end{array}$ & $\begin{array}{l}\text { Nr } 19 \text { Vilka i processen? } \\
\text { Nr } 20 \text { Tumregler }\end{array}$ & $\begin{array}{l}\text { Nr } 15 \text { Pedagogik } \\
\text { Nr } 22 \text { Systemperspektiv }\end{array}$ & \\
\hline $\begin{array}{l}\text { Specifika } \\
\text { utmaningar } \\
\text { (separat } \\
\text { redogörelse) }\end{array}$ & $\begin{array}{l}\text { Nr } 12 \text { Hållbarhet } \\
\text { Nr } 13 \text { Beroende } \\
\text { (Organisation) }\end{array}$ & & \\
\hline
\end{tabular}

Tabell 2 Kontextuella och konceptuella utmaningar för fördjupad analys. Siffrorna 1 - 28 refererar till textanalys

\subsection{Konceptuella utmaningar}

Ett resursbaserat synsätt med huvudsaklig fokus på kunskapsintegration och innovation betonar, med utgångspunkt från avhandlingens problematisering, immateriella resurser. I "inside-out"-perspektivet (DeWitt \& Meyer, 2010) diskuterar författarna bland annat behovet av att utveckla och positionera och värdera organisationens resursbas genom att anskaffa/viderautveckla såväl fysiska (läs: synliga) resurser ("tangibles") som osynliga, immateriella tillgångar/resurser ("intangibles"). En utmaning är att kunna identifiera dessa 'osynliga' resurser genom en begreppsdefinition för de resurser som enligt denna avhandling initialt bedöms vara grunden till det fenomen och den 'obalans' som observerats i företagens kapitalstrukturer.

I företag med stor andel mjukvaruutveckling eller i utpräglade tjänsteföretag kan identifikationen och därmed också kommande värdering vara svår. I företag, som i målföretaget med en stor andel tillverkning är identifikationen lättare (Widener, 2006). Men ledningen har problem redan vid försök att redan i tidiga faser (vid FoU) identifiera dessa unika resurser (och förmågor), i synnerhet om de är inbäddade i olika system eller ingår i kombinationer av olika resursslag. Identifikationen är heller inte i och med detta kontextneutral med avseende på tydlighet, kommunicerbarhet och operationalitet (Widener, 2006).

Empirin ${ }^{119}$ indikerar att, förutsatt att man lyckats finna ett system för att värdera/bestämma dessa immateriella värdens betydelse i FoU- sammanhang, att frågeställningar runt

${ }^{119}$ Denna indikation uppstod vid ett anförande av målföretagets controller i Case ROBO. Det stöds i det arbete som pågår inom ramen för ISO 55001/550010. 
identifierbarhet, operationaliet m. m. kan lösas. Detta genom utveckling av terminologi, förtydligande av begrepp samt en beskrivning av möjliga tillämpningar av analys- och beräkningsmodeller i beslutsprocessen före, $i$ samband med och efter organisering inför själva implementeringen av resursbaserade strategier mot en utvecklingsmarknad.

Utifrån behovet av en 'teoretisk fördjupning' som bland annat speglats i Case INNOHUB av det resursbaserade synsättet, samt utifrån övrig kritik av resursbaserad teori (Akio m fl), redovisas därför här nedan några utgångspunkter, villkor för klarläggande förståelse. Detta utifrån de ledningsproblem som empirin visat och som uppkommer vid genomförande av planerade strategiförändringar (ex ante) och avseende tidsaspekten d v s när resultat ska mätas/värderas (ex post).

Man kan med en ökad tydlighet identifiera och därmed kommunicera nya resurser, nya resursslag och nya former/mönster som aktualiseras, detta för att möjliggöra för företaget att optimera nyttan av respektive resurs i en framtida konkurrenssituation och ledningen kan då bättre motivera implementering av strategiska beslut. Man kan också, utifrån ökad operationalisering av organisationens resurser/förmågor (och konkurrenssituation), potentiellt organisera verksamheten för att uppnå en bästa "konkurrensposition", en tydligare konkurrensfördel på en faktormarknad. Dessutom kan man utifrån en operationalisering mäta effektivitet och avkastning från dessa "nya" resursslag, även utifrån en breddad tillämpning i en 'ny' kontext, av resursbaserad teori.

Som en syntes av dessa utgångspunkter och som ett förslag att möta den första utmaningen, utvecklas därför här några förslag till "verktyg" som framförallt har med möjligheten att få en TYDLIGHET inför förståelse och kommunikationen av vissa resursrelaterade begrepp.

Här nedan utvecklas därför a) en definition av resursbegreppet som kan användas i en relativt bred kontext (Figur 30) och b) ett förslag till kategorisering av olika resursslag (Figur 31) i syfte att kunna klassificera olika resurser inför olika beräkningar mm. Vidare beskrivs, med hänsyn till behovet av att kunna mäta resultat och effekter c) en 'positionskarta' (Figur 15) i syfte att lättare kunna identifiera och också kommunicera ett företags konkurrensposition före respektive efter implementering.

Ett syfte med dessa förslag till utveckling av begreppen, en kategorisering och en positionering av dem är att inför eventuellt kommande forskning förhoppningsvis med detta kunna identifiera och därmed operationalisera så mycket som möjligt av tillgänglig och relevant information, detta för att också när som helst kunna applicera data $i$ någon form av modell för resultatbedömning eller resultatmätning eller en ny modell för uppställning av balansposter. Föreslagna definitioner är inte heltäckande men avser att bidra till en tydligt ökad förståelse samtidigt som de kan tillämpas som underlag för rationella prioriteringar vid komplexa beslut.

\subsubsection{Definitioner}

Hur identifieras då ett företags resurser i en ekonomisk styrning utifrån ett resursbaserat synsätt? En identifiering kräver en definition av begreppet resurs. ${ }^{120}$ Resursbaserade teorier,

\footnotetext{
${ }^{120}$ Inom ramen för IFRS Coceptual Framework (2020) är begreppet tillgång analogt med begreppet ekonomisk resurs till följd av en inträffad händelse. En ekonomisk resurs definieras som en rättighet (respektive skyldighet) $\mathrm{m}$ a o ett 'osynligt' kontrakt att nyttja något som har potential att leda till ekonomiska fördelar men inget $i$ denna 
RBV, har som ovans visats ingen definition av detta begrepp och därmed görs ingen egentlig identifikation och precisering av vad som är organisationens resurser annat än i mycket generella termer.

Enligt DeWitt and Meyer (2010) har heller inte någon enhetlig och accepterad klassificering än mindre någon enhetlig definition av resursbegreppet gjorts.

"No generally accepted classification of firm resources has yet emerged in the field of strategic management" (DeWitt \& Meyer, 2010).

För att kunna klassificera och operationalisera olika resurser $i$ en företagskontext inför avhandlingens analys av empiri har en generellt användbar definition av begreppet $\mathrm{i}$ denna kontext utvecklats. För att viss resurs ska kunna mätas görs följande förslag till definition av ordet RESURS utifrån en såväl ontologisk som epistemologisk tolkning. En resurs definieras som:

En viss mängd av något specifikt resursslag och med en viss form vid en viss tidpunkt som någon person kan omvandla till en ny form av samma resursslag (genom exempelvis ny teknik eller ny kunskap) och personen är medveten (conscious) $i$ det.

En resurs kan i denna kontext och med denna definition föreslås identifieras $\mathrm{i}$ en kvantitativ (mängd) och en kvalitativ (form) dimension (jfr ekonomistyrningens "volym/antal" och "pris"). Från avhandlingen föreslås en operationell definition utifrån ett kvantitativt respektive ett kvalitativt perspektiv enligt Figur 30.

\begin{tabular}{|l|l|l|}
\hline Resursdimension & Definition & Exemplifiering \\
\hline Kvantitativ (Qty) & $\begin{array}{l}\text { Mängddimensionen kan beskrivas i } \\
\text { termer av ANTAL, RESURSENHET och } \\
\text { RESURSSLAG }\end{array}$ & $\begin{array}{l}\text { Antal = 1000; } \\
\text { Enhet = stycken; } \\
\text { Slag = joule }\end{array}$ \\
\hline Kvalitativ (Qal) & $\begin{array}{l}\text { Formdimensionen beskrivs i termer av } \\
\text { EGENSKAP, NYTTA och VÄRDE }\end{array}$ & $\begin{array}{l}\text { Egenskap = transformerande, } \\
\text { Nytta = värmande, } \\
\text { Värde = Skala 1-5 för prestation }\end{array}$ \\
\hline
\end{tabular}

Figur 30. Operationell definition och exemplifiering av begreppet resurs

\subsubsection{Kategorisering av olika resursslag.}

I resursbaserad teori (RBV, RBT) förekommer en viss kategorisering av ekonomiska resurser. Barney $\mathrm{m}$ fl. beskriver själva etiketteringen av olika resursslag som relativt "ointressant" såväl för utveckling av förståelsen för organisationens utveckling (performance) som för den fortsatta forskningen.

"RBT is not really about resources but the attribute the resources must possess".." resources are a source of competitive advantage only if they enable the firm to implement a strategy that increase its customer to pay/or reduce its cost" (Barney and Clark, 2007)

definition klarlägger hur innehållet ska definieras. Någon operationell definition av begreppet ekonomisk resurs som möjliggör mätning förekommer heller inte i nämnda regelverk. Enligt ISO 55000 definieras värdet av en tillgång i termer av dess nytta. 
Som utgångspunkt inför kommande diskussion i kapitel 11 är det med avseende på såväl forskningsfrågan som det empiriska resultatet viktigt att skilja på resursslag och därmed att kunna kategorisera dessa. Den kategorisering Barney tillämpar skiljer på resurserna fysiskt kapital (physical capital), mänskligt kapital (human capital) och strukturkapital (structural capital) (Barney och Clark, 2007). Andra typologier inom resursbaserade teorier som har en företagsekonomisk fokus (läs: fokus på värdering av kapitalet) skiljer på finansiellt kapital, humankapital och socialt kapital, naturkapital och kulturkapital. För att i någon mån kunna bestämma kvalitet och eventuellt värdet av ett företags förädling i exempelvis ett FoU- projekt och hur detta möjliggör interna beräkningar av projektets innovationskapital, ett mycket viktigt finansiellt betingat moment vid strategivalen mellan expansion respektive konsolidering av delar av resursbasen, så görs tills vidare här en kategorisering av olika resursslag.

Denna kategorisering beskrivs utifrån att varje resursslag potentiellt också genererar någon form av avkastning (return on resources) (Johnsson, 2006). I tabellen används ordet kapital för att illustrera att ordet RESURS i ekonomisk kontext. Begreppet är utbytbart mot ordet KAPITAL och omvänt. Inför kategorisering av de olika resursslag som avhandlas här tillämpas följande begrepp:

Begreppet socialt kapital (social capital). Här innefattas mänskligt (human capital) och organisatoriskt kapital (organizational capital); d v s utöver personal (human resources) även den information och de 'mjuka' värden $\mathrm{s} \mathrm{k}$ 'intellektuellt kapital' (intellectual capital) d v s kunskap som uppstår vid integration och interaktion mellan människor och som formar organisationens kompetens och innovation (Berggren et al, 2011).

Kategorisering av olika resurser (Figur 31) m a p deras påverkan på affärsprocesser och ekonomisk styrning av projektorganisationer omfattar utöver materiella värden också applicerade teknologier och immateriella värden. Socialt kapital motsvarar i stort Barneys "human capital". Detta immateriella, sociala kapital kan sällan identifieras men kan som informationsresurser potentiellt kapitaliseras i olika former (avtal, kontrakt, rättigheter mm) och därmed identifieras och redovisas företags balansräkningar.

Begreppet finansiellt kapital (financial capital). Här innefattas det kapital som är "fritt" d v s resurser som direkt kan omvandlas till olika former av kapital med "finansiellt" värde i och för investeringar i exempelvis applicerad teknologi som stödjer en sådan omvandling. Finansiellt kapital omfattar ekonomiska resurser som primärt består av monetära tillgångar. Dessa monetära tillgångar (värdepapper, aktier, optioner mm) omfattar inte fysiska tillgångar och kan alltid värderas till nominellt värde. Finansiellt kapital ingår inte i Barneys terminologi.

Begreppet naturkapital (natural capital). Här innefattas naturtillgångar och tillgångar från växt och djurriket. Utöver vissa materiella tillgångar och energitillgångar innefattas applicerad teknologi för att processa och utveckla dessa tillgångar och immateriella värden som patent, innovationer (IP) etc. Naturkapital, genom dess ursprung från naturen motsvarar i stort Barneys "physical capital" med applikation som byggstenar i organisationens infrastrukturkapital.

I begreppet infrastrukturkapital (infrastructure capital) innefattas framförallt kapital som är bundet i olika system och som inte direkt kan omvandlas utan tjänar ett syfte att stödja organisationens resursomvandling. Större anläggningstillgångar och institutionaliserade rutiner, strukturer, stödprocesser innefattas. Begreppet motsvarar primärt fysiskt kapital och 
bara delvis av Barneys "structural capital" där tonvikten ligger på organisatoriskt strukturkapital (Barney och Clark, 2007).

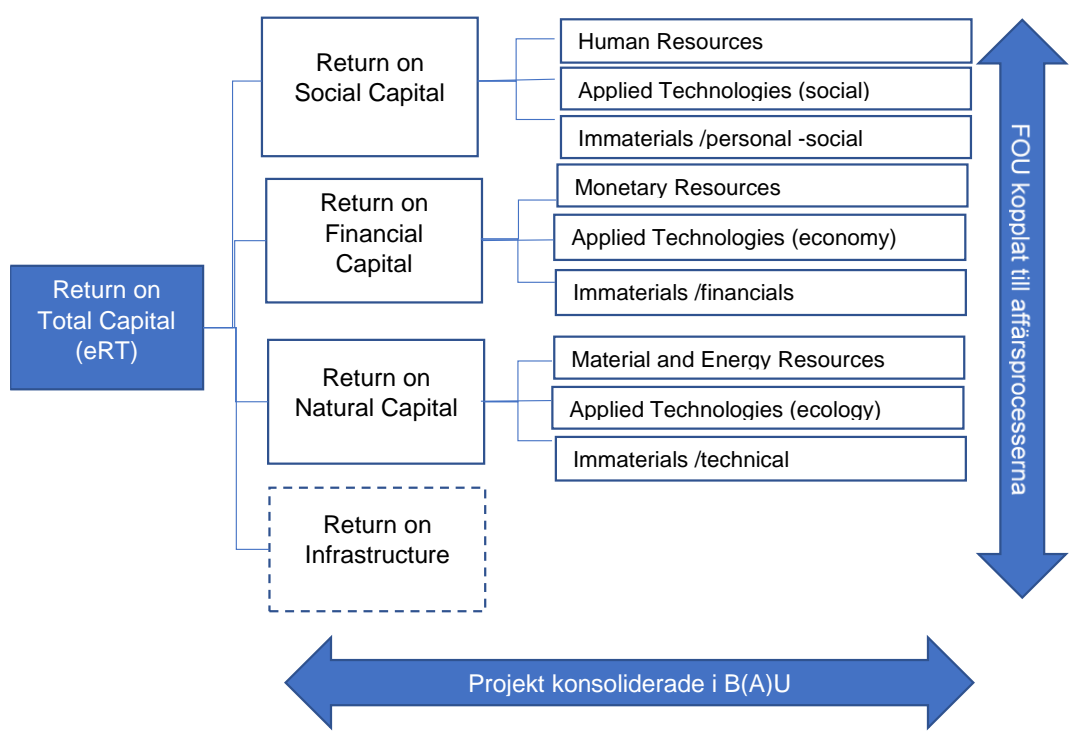

Figur 31. Kategorisering av resursslag (avhandlingens förslag, illustrerat med hur ett breddat perspektiv på resurser och dess avkastning kan bidra till en större helhetsförståelse runt företagets kapitalisering)

\subsubsection{Position och positionering.}

Organisationens strategier syftar till att uppnå ett långsiktigt mål; i detta fall både en viss prestation/produktion (flow rate) och en viss bestämd position/tillstånd/tillgång (stock level), tillsammans illustrerande en uthållig/hållbar konkurrensfördel. Begreppen position och positionering (positioning) används ofta i organisationens strategiska marknadsföring bland annat för att skapa ett unikt, icke imiterbart varumärke på en 'avsättningsmarknad'. Positionering på en 'utvecklingsmarknad' kan, jämfört med denna innebörd, anses innebära ett mål att genom en organisering av företagets resurser uppnå en unikitet i såväl organisationens förädling eller partnerrelation, som i dess resursbas. Men det kan också tillämpas för att inom ramen för en kontext att kommunicera (a flow) hur ett mål ska uppnås utifrån en väl beskriven utgångspunkt. Positionskartan har tidigare redovisats (Figur 15) utifrån de fyra grundläggande begreppen; kreativitet (creative destruction), förnyelse (exploration), exploatering (exploitation) och anpassning (consolidation).

Vad är det då som kan positioneras av organisationens interna resurser och förmågor, om företaget har ett externt fokus på en (potentiell) "anskaffningsmarknad", en faktormarknad i termer av både en insatsmarknad (ex ny kunskap) och en utvecklingsmarknad (ex ny förmåga)? 
Vad är det som kan värderas om den enskilda resursen inte är "tradeable" d v s om det inte finns en egentlig faktormarknad för resursen (eller ingen information om marknaden (Peteraf 1993))? Vad är då syftet med själva positioneringen och vilka alternativa strategier kan antas leda till denna position; d v s varför och hur sker positioneringen, vad innefattar en strategi för att ompositionera resursbasen?

För att uppnå målet hållbar ("sustainable") konkurrensfördel fordras enligt RBV specifika, unika resurser/förmågor. Ett led i styrningen är då att organisera företaget och organisationens resurser dels a) i termer av var företaget i ett nuläge befinner sig i den egna utvecklingen av sin resursmassa, dels b) i termer av att åstadkomma en konkurrensposition eller en konkurrensfördel på en anskaffningsmarknad; och som redovisas nedan (Se kapitel 9.3), denna mätt i termer av exempelvis resurseffektivitet och som avkastning på specifika, för företaget unika resurser eller kombinationer ("portföljer") av företagsunika resurser.

"In addition, the successful implementation of a strategy often requires highly firmspecific assets, as opposed to undifferentiated inputs" (Dierickx and Cool, 1989)

För att företaget ska uppnå en långsiktig, uthållig ("sustainable") position enligt kriterierna för RBV menar Dierickx med flera att organisationens /strategiska/ resurser och förmågor också måste kunna värderas i någon form av produktmarknad. De avser då i första hand inte enskilt specifika /unika/ resurser utan det som avses är en kombination av resurser ("bundle of resources") som gör dem specifika eller strategiska där de ingår någon form av produkt (product) eller tjänst (service). Detta gäller dock inte en specifik innovation som ju kan omfatta /kunskapen om/ olika kombinationer av resurser ${ }^{\mathbf{1 2 1}}$ innan de antagit viss slutlig form.

Organisationens syfte med positioneringen är dock mångfacetterat. I denna avhandlings kontext studeras hur en position kan bestämmas över tid utifrån ett utgångsläge avseende dels kvalitet vs kvantitet, dels utifrån ett internt vs externt perspektiv. Detta för att kunna diskutera vilka olika strategier och vilken organisering som kan aktualiseras för att uppfylla en viss förväntad position eller ett mätbart mål; exempelvis organisationens "added value" eller RoR TM ("return of resources").

\subsection{Kontextuella utmaningar}

De strategiska utmaningarna från analys av empirin pekar på behovet att pedagogiskt förklara det observerade fenomenet med accelererande andel immateriella tillgångar inkluderande 'osynliga, d v s icke identifierade resurser samt att förklara effekter från de olika strategier som kan tillämpas för att påverka organisationens resursbalans, explicit dess resursbas och avkastningen från denna för att implicit värdera resurstillväxtens effekter vid beräkning av innovationskapitalet, särskilt poängterat i Case INNOHUB.

Att förstå ett resursorienterat eller resursbaserat synsätt är inte bara att förstå dess koncept. Den textanalys som avsåg att identifiera utmaningar vid en potentiell tillämpning av synsättet visar behovet att förstå dess specifika kontextuella villkor. Vid tillämpning av ett potentiellt resursbaserat ledningssystem krävs en helhetsförståelse hos ledningen av den kontext som systemet avser. Och samtidigt krävs att de olika elementen i ett sådant system är kontextneutrala i och

121 Teece diskuterar också några implikationer på innovationsstrategier $\mathrm{m}$ a p bl. a produkt- och processförbättringar (Teece, 2008). 
för tillämpning i den 'nya' kontext som ledningen identifierat. Forskningsfrågan som ställs är relaterad till immateriella resursslag. ${ }^{122}$ Resurser i olika kontexter (samhälle, företag, individ) handlar om såväl immateriella som materiella och finansiella resurser. Resursorienterade synsätt påverkar utveckling där människan är intressent och även aktör inom resursområden, även utanför företagens kontroll (Penrose, 1959). En samsyn på en övergripande resursorienterad /hållbar/ måldimension för en ny kontext fordrar och ger förståelse för kontextneutrala lösningar (modeller). Detta implicerar företagsledningars behov att förstå tillämpningen av kontextneutrala modeller vid en resursorienterad policy och en resursbaserad ekonomisk styrning.

I kapitel 6.3.7 redogörs utifrån teori och empiri en modell för `integrerad’ resursbaserad strategi och styrning. Styrningen har delats upp i två delar; a) ex ante och b) ex post som implicit visar konsekvenser på företagets resursbas med tidseftersläpning implicit i modellen. Modellen beskriver utifrån positioneringsmodellen (Se Figur 15) en organisering som implicerar förändring över tid som nedan illustreras med en dynamisk "karta" över alternativ (Figur 32) på en faktormarknad.

Med avseende på tidsperspektivet och i viss mån således den finansiella aspekten (rents) på organisationens måldimension har vid analys av empiri (Case FORCE och Case INNOHUB) potentiella strategival identifierats utifrån ett resursperspektiv. Med hänvisning till begreppen "exploitaion" och "exploration" (March, 1991) illustreras fyra möjliga beslutsalternativ (Holling, 1986) d v s potentiella expansionsstrategier, i figur 32.

Att ha ett resursbaserat synsätt när företags resursrelaterade kontext och strategival diskuteras innebär i denna tolkning för det första att ett antal olika strategier kan väljas utifrån delvis olika kontexter och situationer. En resursbaserad strategi kan se ut på många olika sätt, m a o ett tillämpat resursperspektiv innebär inte en utan ett antal olika möjliga strategier beroende på om det är kvalitativa eller kvantitativa mål som ska nås och om det är resurser och förmåga (economies of scope) eller marknaden (economies of scale) som ledningen väljer att fokusera. Hur respektive strategi ska beskrivas beror också på vilken utgångspunkt som ledningen har; vilken konkurrensposition (läs: resursposition) som företaget har i utgångsläget och hur man nått denna samt vilken tillgång till information ledningen har om de olika strategialternativen. Ett breddat, resursbaserat systemsynsätt med influens från såväl naturekonomi och ekologi som teknik- och humanvetenskaper, påverkar delvis också av vilka teoretiska utgångspunkter som väljs inför fördjupad analys.

\footnotetext{
${ }^{122}$ Kontextneutrala modeller tillämpas avseende också materiella och finansiella resursslag. Ett exempel är ISOregelverkens villkor vid tillämpning där regelverken avser alla företag.
} 


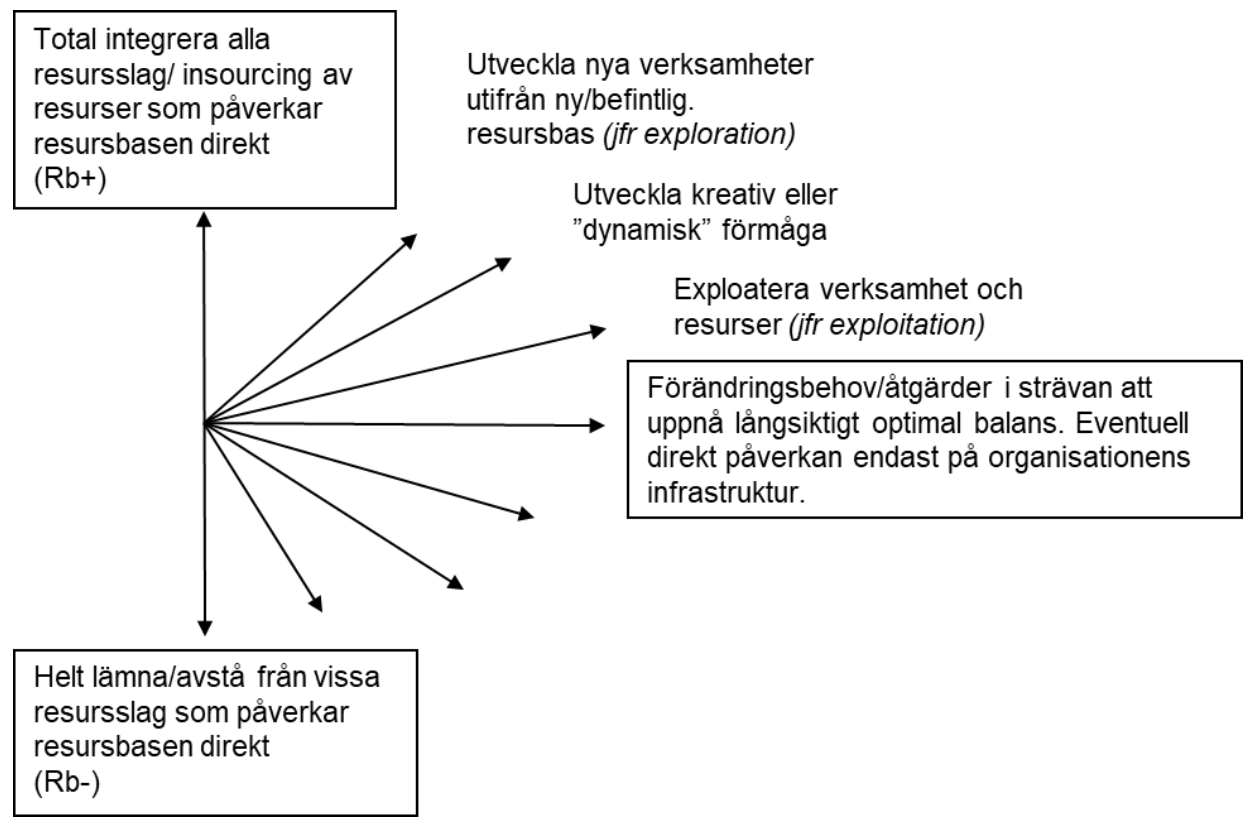

Figur 32. Potentiella beslutsalternativ för organisering av organisationens resurser för utveckling över tid av organisationens/ projektets resursbas (egen figur)

En ytterligare utmaning är att (ur legitimitets och ansvarssynpunkt) tydliggöra organisationens kontext för att dels förstå hållbarhetsaspekter, dels tydliggöra affärsenheternas och partners inbördes relation.

\subsubsection{Tidsperspektivet. Ex ante och Ex post.}

I avhandlingens initiala del diskuteras strategi och styrning utifrån ett marknadsbaserat synsätt med primär implikation för marknads- och produktionsvolym i jämförelse med ett resursbaserat synsätt med implikation för resurseffektivitet och långsiktigt optimal avkastning på företaget samlade, mer eller mindre i tid tillgängliga resursbas.

Oberoende av vilket synsätt som kännetecknar organisationen så uppstår ett behov av ledningsdynamik, med såväl "externt" som "internt" perspektiv, vid beslut om val och prioritering av strategi. Särskiljande för de två synsätten är vilket tidsperspektiv som kännetecknar det externa ledningsperspektivet; behovet ex post av utveckling av långsiktigt hållbar ny teknologi för att stärka den kvalitativa delen av resursbasen respektive behovet av kortsiktigt utvecklad, kundanpassad teknologi för att öka marknadspenetration.

Villkoren för uthållig (sustained) respektive hållbar (sustainable) position är empiriskt eller teoretiskt inte helt klargjorda utifrån olika tidsrelaterade frågeställningar och tidsperspektiv. Några ytterligare villkor, och implikationer av dessa, beskrivs av Margret Peteraf och Goncalo Pacheco-de-Almeida $\mathrm{m}$ fl. Peteraf skiljer på olika typer av vinster och hur de uppkommer respektive består, utifrån de kriterier som gäller efter det att en viss strategi har valts och 
etablerats. Med "ex post condition" menar hon att ett villkor för att företaget kan förlänga sin konkurrensfördel i ett visst tidsperspektiv, förutsatt att marknaden är heterogen till sin natur, är att konkurrensen även ex post fortsätter att vara mycket begränsad samt att tillgången på resurserna också fortsätter att vara begränsad och att detta leder till fortsatt avkastning, resurser som stannar kvar i företaget. En specifik strategi för att behålla denna konkurrensfördel är, enligt Peteraf att, ex ante, ledningen kan försvåra "rörligheten", något som samtidigt begränsar möjligheten för andra att imitera organisationens resurser (bland annat genom patent, försvåra informationen etc.

\begin{abstract}
"These two....(imperfect mobile resources and rents shared by the firm)...are key features.."

"They, in turn, make imperfect factor mobility a necessary condition for sustainable competitive advantage"..."In addition imperfect factor mobile is a particularly important component. because such resource is less likely to be imitable than other kinds".
\end{abstract}

(Peteraf, 1993 s. 184)

En invändning mot detta argument är att detta också kan medföra att resursen fortare blir obsolet eller utsätts för andra typer av konkurrerande åtgärder. (jfr ändliga resurser)

När det gäller ledningen och dess tillgång till information för att agera och positionera organisationens resurser i en viss kontext beskrivs här strategiarbetet mot bakgrund av Margret Peterafs ex ante/ex postvillkor för konkurrens (Peteraf, 1993). Ett resursbaserat synsätt omfattar implicit en ständigt pågående prövning av hur lyckad (med avseende på effektivitets mål mm) den valda strategin är. Det innebär att mer eller mindre förväntade resultat och effekter av dessa, ständigt måste korrigeras; misstag som lett till felaktigt dimensionerad eller balanserad resursbas måste rättas till, processer i systemet och strukturer i organisationen måste anpassas för att så bra som möjligt sammanfalla med kontextuella förutsättningar och villkor för hur strategierna kan genomföras. Ett resursbaserat synsätt med ett mål för värdetillväxt utesluter inte vad som händer på marknaden och aktören (ledningen/entreprenören) riktar sin fokus på att proaktivt, i stället för att agera reaktivt, ompröva och värdera sitt val av strategi utifrån en förväntad effekt på och av de resurser företaget valt att fokusera vid en affärstransaktion (Johnsson, 2006)

Pacheco-de Almeida och Zemsky (2007) diskuterar en utvecklingsstrategi, "barriers to imitation", utifrån att tiden istället komprimeras (vid implementering) och att detta påverkar avkastningen. Implicit vill de utveckla en modell för analys av dessa strategier och 'finansiella' analyser "ex ante"; d v s inför ett investeringsbeslut. De visar att komprimering av tiden inte alltid leder till bästa resultat utan att företaget kan tjäna på en alternativ och mer specifik strategi, exempelvis en strategi som innebär licensering alternativt att företaget säljer sin kunskap till andra som kan utveckla resurserna mer effektivt.

Deras bidrag är intressant ur strategisynvinkel vid en utveckling av strategier för partnerskap, vid långsiktigt syftande "joint venture" och vid mycket strategiska resurser. De visar vidare att just organisationens strategiska resurser på projekt- respektive affärsnivå bör vara föremål för studier och analyser av organisationens strategier för att utveckla en varaktig resursposition. Dierickx och Cool diskuterar också tidsperspektivet och vill poängtera att det viktigaste vid strategivalet är att optimera tiden och flödet (jfr effektivitet) och att organisationens lönsamhet 
handlar om nivån på/storleken av organisationens 'buffert' av strategiska resurser $\mathrm{d} v \mathrm{~s}$ organisationens resursbas (jfr måldimensions "avkastning") och hur den positioneras. En fortsatt studie av deras bidrag kan implicera fler specifika strategier för att å ena sidan effektivisera organisationens flöden av /vissa/ resurser, å andra sidan förändra, ompositionera, organisationens resursbas.

En ytterligare aspekt på strategivalet utifrån ett tidsperspektiv representeras av det avhandlingen vill beskriva som den egentliga grunden för det resursbaserade perspektivet, nämligen organisationens (systemets) förmåga att "resa sig" (jfr "resourdre"). Den illustreras i diskussionen om organisationens dynamik ("dynamic capabilities") genom att ledningen med sitt medvetna val och implementering av en resilient strategi (Holling, 1986), motverkar en pågående men icke önskvärd utveckling. En förklaring till organisationens hållbara konkurrensfördel är därför förmågan att genomföra långsiktiga förändringsåtgärder samt att korrigera för och lägga ut kursen för de förändringar av resursbasen som uppstår vid förändrade flöden.

Med avseende på denna förmåga och hur den tillämpas i ett tidsperspektiv, uppstår förskjutningar av lönsamhet och konkurrensfördel. Ett antal specifika strategier kan då vara nödvändiga för att optimera såväl effektivitet som lönsamhet på längre sikt.

\subsection{Mål, resultatplanering och mätning vid inför valet av strategi}

Den strategiska utmaningen avser både att för praktisk tillämpning för den ekonomiska styrningen upprätta en målstruktur och att, i syfte att inför strategival och uppföljning formulera en form för målstruktur som är kontextneutral och som samtidigt betonar ett mätbart och redovisningsbart mål för en strategi som syftar till långsiktigt hållbar resurs- och värdetillväxt. I detta perspektiv ses 'målet' konkurrensfördel i likhet med begrepp som resurseffektivitet snarast som en mer eller mindre temporär förutsättning, ett medel för att nå en hållbar tillväxt. Ett mål för denna avhandlings modeller representeras av ett $\mathrm{s}$ k 'betamål' $\mathrm{d}$ v s ett mål som uttrycker behov av ständig förändring av strategierna. Detta 'betamål' uttrycks i termer av avkastning (rent) på aktuellt förväntad resurs/resurskombination.

Resultatmätning i resursbaserad teori kan beskrivas i termer av resursutveckling och tillväxt (TGF). Hur avkastning (rent) genereras diskuteras av bland annat Edith Penrose; dock inte per definition eller i någon konkret modell som underlättar styrning generellt men med hjälp av dessa förslag till definition och kategoriseringen av resursbegreppet, och primärt genom tillämpning av en känd tillväxt-/avkastningsmodell (se sammanfattningen i kapitel 10.3) kan detta behov av mätbarhet vid olika beslut (Chenhall, 2003) uppfyllas. Detta utifrån möjligheten att värdera de olika strategivalen (för kvalitativ/kvantitativ tillväxt) utifrån olika positioner i nämnda 'positionskarta'. De tre förslag till definition, kategorisering och positioneringskarta illustrerar tillsammans förutsättningar för resultatplanering. Förslagna modeller avses att kunna valideras så långt möjligt genom dialog i kommande empirisk forskning och vid analys av denna.

I finansiella termer görs värderingen av det resultat som, med eventuella begränsningar till vissa projekt eller affärshändelse, kan avläsas och mätas i organisationens finansiella resultat (performance) och som dess bidrag till organisationens förädlingsvärde (Johnson \& Thomas, 
2007). Med ett bredare resursbaserat synsätt, omfattande inte bara finansiella resurser och på olika beskrivningsnivåer, kan värdering göras utifrån samma kriterier vid andra resursslag.

En modell som identifierats som kontextneutral vid den systemiska analysen är den beslutsmodell som representeras av PDCA-modellen som omfattar såväl upprättande målstrukturer som modeller för resultatmätning. En tillämpning med modellen inför ett strategibeslut, med villkor enligt det resursbaserade synsättet, förutsätter dock enligt teorin ledningens tillräckliga kunskap om kontextuella kriterier samt potentiella effekter vid förändring av kontext.

\subsection{En reflektion om det resursbaserade synsättet, dess utmaningar och möjligheter}

Kunskapen om de kriterier för resurser enligt teori (RBV) som redovisas av J Barney ("VRIO") är en nödvändig information, men inte tillräckligt för att bedöma om företaget kan uppnå en utsträckt (sustained) konkurrensfördel (Akio, 2005). Villkoren för när och $i$ vilken kontext som VRIO-kriterierna gäller är inte heller täckande. Dierickx et al diskuterar bland annat att imiterbarhet, d v s andra företag/systems möjlighet att imitera en resursbas eller en uppsättning resurser och förmågor, måste analyseras med avseende på utvecklingstid (time compression), sammansättningen av de resursslag man använder (mass efficiency) eller kopplingen till andra resursslag (interconnectedness), effekterna av bristande underhåll mm (asset erosion) eller bara osäkerheten om vad resurserna är; d v s hur de kan identifieras respektive kontrolleras (casual ambuigity) (Dierickx et al, 1989). Förutsättningen för att resurser (och förmåga) kan betraktas som "unika" är dock att marknaden (ex post) präglas av en hög föränderlighet (high velocity) enligt diskussionen om "dynamic capabilities" (Holling, 1973; Teece, 2008). Stora skillnader gäller också beträffande kriterierna beroende på typen av resurser; om de är mer eller mindre "tangible" etc.

Hur organisationens "capabilities" ska betraktas är beroende på hur föränderlig marknaden är (Holling, 1973). I denna avhandling diskuteras "dynamic capabilities" i ett sammanhang när det gäller organisationens och ledningens förmåga att organisera resurserna eftersom det förändrar förutsättningarna för vilken ekonomisk styrning som ska tillämpas (och hur den kan förväntas redovisa resultatet). Det innebär att vissa av de kontextuella villkor som här beskrivits bara avhandlas implicit och i detta sammanhang d v s inte avseende mätbarhet, skillnader vad avser kvalitet mm.

"...sustainability of the capabilities themselves varies with the dynamism of the market. In moderately dynamic markets, dynamic capabilities resemble the traditional conception of routines" (Teece, 2000 s. 1113)

I en marknad som präglas av snabbare förändringar och stor volatilitet är också perspektivet på dessa "dynamiska förmågor" kortare, beslut präglas av ett behov av mer information, enklare och snabbare beslutsprocesser.

“...in contrast, in high velocity markets, dynamic capabilities take on the different character. They are simple (not complicated) experiential (not analytic) and iterative (not linear) processes" (Teece, $2000 \mathrm{~s} 1113$ ) 


\section{"While dynamic capabilities in high velocity markets consists mostly of simple rules and real-time knowledge creation, they may have detailed routines to deal with aspects...” (Teece, $2000 \mathrm{s.1113})$}

En aspekt inför valet av strategi för att uppnå en hållbar respektive uthållig konkurrensfördel är då vilken typ av faktormarknad som organisationen eller det specifika projektet befinner sig $\mathrm{i}$ eller kan förväntas befinna sig i. Kravet på information från styrsystemet varierar. Hur VRIO kriterierna (Barney, 1991) ska värderas inför beslut är helt olika beroende på organisationens/projektets potentiella 'marknadssituation', men framförallt utifrån hur ledningen avgränsar de olika resursslagen $\mathrm{m}$ a $\mathrm{p}$ exempelvis unikitet, imiterbarhet, rörlighet etc. Ett felaktigt strategival utifrån en felaktig bedömning av denna senare förändringsaspekt kan innebära att expansionen går för snabbt, resursutvecklingen går för snabbt och att en strategi snabbt måste inriktas på att konsolidera verksamheten trots att VRIO-kriterierna (Barney, 1991) totalt sett talar för expansion.

En ytterligare aspekt på strategivalet utifrån detta resursbaserade synsätt är i vilken utsträckning ledningen/projektet har tillgång till /riktig/ information respektive har tillgång till "egna" resurser - och framförallt information /kunskap/ om vilka inneboende egenskaper som de har respektive som de potentiellt kan utveckla. Här poängterar David Teece (Teece, 2008) vikten av att skilja mellan olika typer av tillgångar (assets). (I denna avhandling görs dock en avgränsning beträffande individuell kompetens som resurs).

I övriga avseenden när det gäller teoribildningen runt det resursbaserade perspektivet och en utveckling av detta, görs här några ställningstaganden inför den fortsatta diskussionen om hur utmaningar respektive möjligheter kan hanteras inom ramen för detta synsätt:

○ En långsiktig, resursbaserad strategi innebär att ledningen omprövar organisationens strategi från grunden $\mathrm{d} v \mathrm{~s}$ man omprövar verksamheten utifrån tillgänglig kunskap om den /potentiella/ resursen (och dess grundläggande egenskap och påverkan i systemets processer) samt förmågan att utveckla denna (Holling, 1973; Grant, 1996; SchultzHofer, 1999).

- Ledningen utvecklar och implementerar strategier i syfte att uppnå optimal avkastning; enligt resursbaserad teori bygger denna möjlighet till avkastning på en "ricardiansk" modell (snarare än på en 'monopolmodell') dock att jämvikt på denna marknad aldrig uppehålls under någon längre tid (Holling, 1973). Trots kriteriet om immobilitet (Barney, 1991) kan resursernas inneboende egenskap förändras, exempelvis destrueras (destroyed) och kan då förflyttas, detta även implicit att dessa resurser eventuellt inte kan omsättas på en marknad. Då en faktormarknad för resurserna finns kan de utvecklas men det förutsätter att företaget har den unika förmågan att omvandla resurserna (dynamic capabilities) (Teece, 2008) när företaget har tillgång till dem.

○ För att strategivalet ska göras så rätt som möjligt eftersträvas så mycket objektivitet och så god mätbarhet av informationen som möjligt för att den ska vara så användbar /operationell/ (operational) som möjligt. Rationalitet i strategivalet kan innebära att kortsiktigt prioritera lägre resurseffektivitet om avkastningen påverkas positivt. Resurseffektivitet måste därför mätas över längre perioder och baseras på hur företaget (eller marknaden) värderar sina resurser i olika tidsperspektiv (Akio, 2005, Teece, 2008) 
○ Vid en bedömning av värdet (diskonterat eller ej) är en uppdelning i de två storheterna antal respektive pris viktiga för att kunna bedöma åtgärder som förändrar kvantitetsdimensionen respektive kvalitetsdimensionen. En kvalitetsbestämning av resurser som inte går att prissätta kan göras genom olika poängskalor (Akio, 2005). Om pris som uttrycks i valuta reduceras med valutans värde återstår en numerär som kan jämställas med poäng.

○ För att kunna kommunicera det gjorda strategivalet fordras en så objektiv kunskap som möjligt hos såväl sändare som mottagare. Kommunikationen underlättas genom att begrepp som relaterar till organisationens resurser och förmågor, system etc. är väl definierade och entydiga. Så långt som möjligt eftersträvar ledningen enkla begrepp och begrepp som betyder en och samma sak $i$ olika sammanhang (i empiri).

○ För att underlätta strategivalet, för utformning av strategierna mer i detalj, för planering och positionering och för kombinationen av resurser samt för uppföljning, är någon form av kategorisering av tillgångarna i resursbasen viktig (Se ISO 55000). I syfte att inför en kategorisering kunna identifiera även immateriella resurser/tillgångar har befintlig terminologi här kompletterats med dels en definition av begreppet RESURS samt ett försök att utifrån teori konkretisera ett antal egenskaper hos olika resurser ("tangibles" respektive "intangibles") och därmed kunna operationalisera och kategorisera resursbasen.

\subsection{Strategier för uthållig hållbar konkurrensfördel}

Avhandlingens analys pekar på strategier som hypotetiskt kan innebära en utveckling, en förändring för att uppnå en hållbar ("sustainable") konkurrensfördel, per definition, från en identifierad och kommunicerad, tidigare "sämre" konkurrensposition. Det omvända diskuteras också utifrån alternativa ledningsstrategier. Det handlar alltså om en förändring av strategi $\mathrm{d} v$ $\mathrm{s}$ från en strategi till en annan. Eftersom det finns många sätt att nå samma mål så behöver en viss vald strategi inte vara hållbar i sig om det samtidigt kombineras med en "hållbar" strategi. 123

Ett huvudkriterium enligt $R B V$ är att konkurrensfördel uppnås genom att kunna upprätthålla en avkastning "systematically above average returns" under en längre tid efter implemen-tering av strategin (Shoemaker, 1990, Peteraf, 1993). En hög avkastningsnivå handlar om såväl effektivitet i organisationens processer för förädling som hur organisationens resursbas, per

\footnotetext{
123 Inom ramen för en samhällskontext diskuteras olika grad av hållbarhet/uthållighet utifrån olika grad av resursutnyttjande och olika perspektiv på samhällsutveckling. Se diskussionen om "strong" versus "weak sustainability” utifrån en samhällskontext (Teece, 2008).

Utöver att företaget uppvisar långsiktiga, strategiskt viktiga konkurrensfördelar, ("sustainable competitive advantages") kan ett företag som är ett "sustainable" företag också karaktäriseras på andra sätt. Tre viktiga element som identifierats av T Dyllick och K Hockers (Utdrag ur Dyllick och Hockers, 2002) som illustrerar detta:

“ ...company sustainability requires a long- term business orientation..."

“...based on the three-dimensional concept a sustainable company considers not only economic but also social and environmental prerequisites and impacts of actions as well as the interdependencies between them."

Denna forskning avgränsas till att analysera potentiella effekter på organisationens långsiktiga ekonomiska styrning (per definition) och på organisationens långsiktigt inriktade FoU-verksamhet. I förlängningen av denna forskning förväntas de empiriska studierna visa effekter från dessa /resursbaserade/ affärsstrategier på andra delar av verksamheten samt hur resultat av dessa strategier i form av olika slags kapital också ska kunna mätas och värderas över tid.
} 
definition, är identifierad och organiserad. Om ledningen i ett visst läge (enligt positioneringsmodellen) $\mathrm{m}$ a p kvalitetsdimensionen (Qal) exempelvis konstaterar att avkastningsnivån bedöms bli otillräcklig (för en viss portfölj av resurser) kan detta medföra, som ett första beslut, ett val av strategi för att konsolidera resursbasen: detta genom att effektivisera resursanvändningen och $\mathrm{i}$ ett ytterlighetsfall att avyttra resurser (= påverkan endast på resursbasen).

De övergripande strategialternativ som ledningens har är således att antingen besluta om företaget som samlad organisation ska expandera, (normalisera) eller konsolidera sin verksamhet. Primärt grundas dessa beslut på finansiell information och hur organisationens finansiella resurser (och avkastning) värderas. En konsolidering $\mathrm{m}$ a $\mathrm{p}$ avyttring (desinvestering) av resurser respektive expansion $m$ a p förvärv (investering) av strategiska resurser på en "utvecklingsmarknad" berör, om ej i undantagsfall ${ }^{124}$, endast organisationens resursbas.

I ett nästa steg handlar valet om en konsolidering ska göras antingen utifrån kvantitetsdimensionen eller utifrån kvalitetsaspekterna, såväl förädlingen som avseende resursbasen. Inom ekonomistyrningskontexten bedöms bästa resultat och resursoptimering som en mest optimal relation mellan (volym), kvantitet och pris. Om prisvariabeln i denna kontext hypotetiskt ersätts med en kvalitetsvariabel så kan ett antal olika strategier beskrivas utifrån att företaget vill optimera förhållandet mellan kvantitet (Qty) och kvalitet (Qal). För volymvariabeln, där den avser uppskalning i samma resursslag, används här begreppet volym (v).

Med kvantitet (Qty) avses då den mängd av ingående "komponenter" som en resurs består av för att kunna generera eller motsvara en viss nytta. Med kvalitet (Qal) avses (per definition) värdet av den nytta som en resurs (i en viss form och med en viss egenskap) genererar eller redan har. Ett exempel på en kvantitativ ökning (Qty+) är en ökning av mängden information i en process i syfte att tillfälligt höja exempelvis inlärning och kreativitet (vilket inte med nödvändighet blir effekten). En kvantitativ minskning (Qty-) innebär analogt en minskad informationsmängd. Ett exempel på kvalitativ ökning (Qal+) är då en resurs (exempelvis i en ny form) bedöms ha en större nyttoeffekt (utan att detta behöver ha medfört en ökad kvantitet av ingående "komponenter").

Ett första val av strategi i samband med expansion kan då initialt exempelvis handla om att öka informationsmängden för att (fortfarande med ett primärt internt fokus) stimulera kreativitet och sedan successivt (med ökat externt fokus) minska informationsmängden för att öka graden av "specialisering" (jfr verkningsgrad) och genom detta åstadkomma en större relativ "nyttoeffekt" d v s ett ökat kvalitativt värde (Qal+).

En annan strategi, i syfte att expandera direkt, separera ut det som är kvalitetsdrivande, d v s öka medvetna och "kvalitetshöjande" (Qal+) processer i omvandling (jfr "effectiveness") med bibehållen eller minskad kvantitet (Qty +/-).

En position (eller oönskad utveckling) som primärt är kvantitativt driven (som exempel vid desinformation) i sin ytterlighet innebärande en potentiell destruktion av resurser kan förändras genom att minska mängden information (Qty-) d v s öka "inneslutningsgraden" i ett system. En annan strategi kan handla om att organisera resurserna i kombinationer av kvalitet (Qal+) och kvantitet Qty+), i syfte att optimera värdet av organisationens förädling och avkastning (och

${ }^{124}$ Vid förvärv där förvärvsvärdet understiger det bokförda värdet av det förvärvade uppstår resultateffekter. 
tillgångarna i resursbasen). En ytterligare strategi som primärt berör resursbasen kan innebära att helt avveckla (Rb-) eller "outsourca" viss teknologi/verksamhet för att successivt kunna ställa om till ny teknologi.

Nedanstående figur visar ett antal tänkbara strategier utifrån övergripande beslut att expandera alternativt konsolidera en verksamhet. Sammanlagt beskrivs här kortfattat nio olika strategier, fyra utifrån expansionsstrategi och fyra utifrån konsolideringsstrategi samt en strategi för att uppnå en jämn utveckling. Den sistnämnda påverkar primärt organisationens infrastruktur. Denna strategi diskuteras som en anpassning till omgivningens villkor ("adaptive change") och som en ekonomistyrning ("adaptive management") som "normaliserar" organisationens utveckling (Holling, 2000). Strategin innebär en större andel "relaterad" utveckling jämfört med övriga och fokus på processeffektivisering.

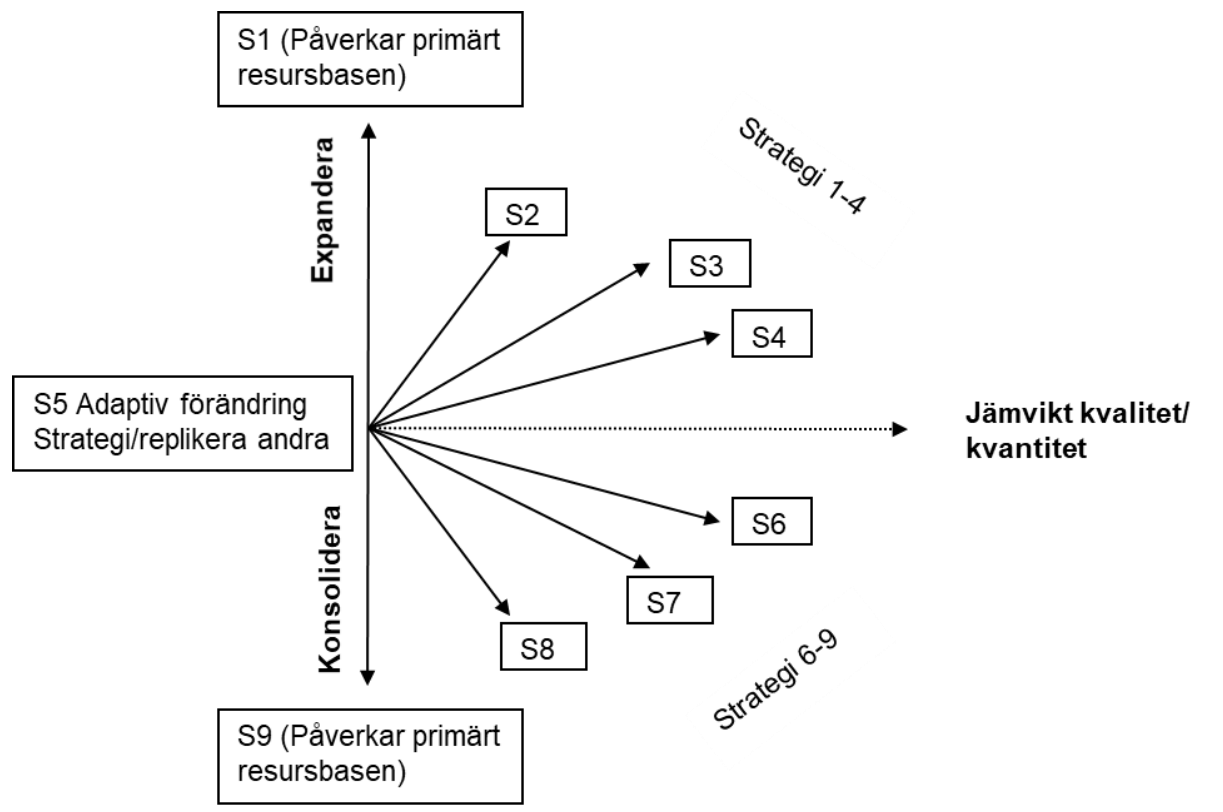

Figur 33. Strategi 1-4: Resursutveckling över tid med positiva förtecken (+) vid expansion (jfr "exploration" versus "exploitation" (March, 1991). Strategi 5-9: Resursutveckling över tid med negativa förtecken (-) (jfr "creative destruction"; frigörande) (Schumpeter, 1994, Holling, 1973) och "conservation"; konsolidering (Holling, 1973).

En utförligare beskrivning av innehållet i (och syftet med) respektive strategi diskuteras i samband med diskussionen om potentiell påverkan på ett 'ekosystem’ för en mer utvecklad resursbaserad ekonomisk styrning, i dess olika element (primärt vid organiseringen och mätprocessen) och med applikation i en 'innovationskontext'. I figur 33 nedan redovisas en principskiss över strategier vid beslut om expansion respektive vid konsolidering. Inom parentes anges begrepp som representerar de åtgärder som diskuterats i empiri, att exempelvis öka graden av specialisering, att effektivisera processerna etc. 
Efter textanalys av avhandlingens empiri kan följande exemplifiering av de olika strategierna göras (Figur 34)

\begin{tabular}{|c|c|c|c|}
\hline \multicolumn{2}{|l|}{ Strategi } & \multirow{2}{*}{$\begin{array}{l}\text { Nyckelaktivitet } \\
\text { Förvärv av ny teknologi/verksamhet } \\
\text { (påverkar primärt resursbasen) }\end{array}$} & \multirow{2}{*}{$\begin{array}{l}\text { Resulterar i } \\
\text { Ökad resursbas }(\mathrm{Rb}+)\end{array}$} \\
\hline \multirow{4}{*}{$\begin{array}{l}\text { Resurs- } \\
\text { utvecklande } \\
\text { strategier vid } \\
\text { expansion }\end{array}$} & $\begin{array}{l}\text { Strategi } 1 \\
\text { (S1) }\end{array}$ & & \\
\hline & $\begin{array}{l}\text { Strategi } 2 \\
\text { (S2) }\end{array}$ & $\begin{array}{l}\text { Helt separera kvalitet och kvantitet på input } \\
\text { och fokusera var för sig. Primärt betona } \\
\text { förbättring av kvalitet, specialisering }\end{array}$ & Fokusering på kvalitet (Qal +) \\
\hline & $\begin{array}{l}\text { Strategi } 3 \\
\text { (S3) }\end{array}$ & $\begin{array}{l}\text { Delvis integrering av kvantitet och kvalitet. } \\
\text { Processförbättra, ständig intern förändring, } \\
\text { produktivitet, processeffektivisering }\end{array}$ & Processfokusering (Qal +, Qty +) \\
\hline & $\begin{array}{l}\text { Strategi } 4 \\
\text { (S4) }\end{array}$ & $\begin{array}{l}\text { Helt integrera befintlig (hög) kvalitet och } \\
\text { kvantitet i nya produkter. Replikering av } \\
\text { kvalitet i nya tekniska lösningar, } \\
\text { produktutveckling ("Deployment") }\end{array}$ & Processutveckling (Qal x Qty) \\
\hline Adaptiv strategi & $\begin{array}{l}\text { Strategi } 5 \\
\text { (S5) }\end{array}$ & $\begin{array}{l}\text { Behålla befintlig kvalitet/kvanitet mix, } \\
\text { anpassning till omgivningens villkor dvs } \\
\text { normalisering ("Adaptive Management") }\end{array}$ & $\begin{array}{l}\text { Förbättring i takt med omgivningen } \\
\text { (Qal x Qty) }\end{array}$ \\
\hline \multirow{4}{*}{$\begin{array}{l}\text { Resurs- } \\
\text { minskande } \\
\text { strategier vid } \\
\text { konsolidering }\end{array}$} & $\begin{array}{l}\text { Strategi } 6 \\
\text { (S6) }\end{array}$ & $\begin{array}{l}\text { Med helt integrerad befintlig (låg) kvalitet och } \\
\text { kvanitet förändra antalet ( } 1 / \mathrm{n}) \text { succesivt av } \\
\text { tekniska lösningar ("Avlärning") }\end{array}$ & $\begin{array}{l}\text { Creative Destruction (jfr } \\
\text { Schumpeter) } 1 / v \text { x (Qal x Qty) }\end{array}$ \\
\hline & $\begin{array}{l}\text { Strategi } 7 \\
\text { (S7) }\end{array}$ & $\begin{array}{l}\text { Delvis separera kvalitet och kvantitet } \\
\text { ("Resource Efficiency") }\end{array}$ & $\begin{array}{l}\text { Resurseffektivisering utifrån givna } \\
\text { ramar (Qal -, Qty -) }\end{array}$ \\
\hline & $\begin{array}{l}\text { Strategi } 8 \\
\text { (S8) }\end{array}$ & $\begin{array}{l}\text { Helt separera kvalitet och kvantitet och } \\
\text { optimera/minska dem var för sig, Primärt } \\
\text { betona minskad informationsinsats (viss } \\
\text { effektivisering genom "duplicering" av } \\
\text { teknologi) }\end{array}$ & $\begin{array}{l}\text { Duplicering där möjligt, } \\
\text { Kontinuerlig effektivisering (Qal -) }\end{array}$ \\
\hline & $\begin{array}{l}\text { Strategi } 9 \\
\text { (S9) }\end{array}$ & $\begin{array}{l}\text { Avyttring av teknologi/verksamhet (påverkar } \\
\text { primärt resursbasen) }\end{array}$ & Minskad resursbas (Rb -) \\
\hline
\end{tabular}

Figur 34. Strategi 1 - 9, nyckelaktiviteter samt resultat

Dessa nio $(1+3+1+3+1)$ strategier representerar ett antal huvudstrategier som ledningen har att bedöma vid en situation då valet står mellan att expandera och/eller konsolidera olika verksamheter eller resursslag De tre expansionsstrategierna (S 2-4) respektive de tre konsolideringsstrategierna (S 6 - 8) kan, m a p hur de påverkar olika delar av den ekonomiska styrningen, ytterligare delas upp i externa("inköpta") respektive interna ("egna") resurser. Sammantaget för endast ett resursslag kan 14 strategier identifieras med avseende på hur förädlingsvärde, effektivitet och avkastning påverkas över tid. Vid kombination av flera resursslag ("portföljer") uppstår ett oändligt antal varianter av möjliga strategier. För att undvika detta görs först en bestämning av hur respektive resursslag påverkar målen för den ekonomiska styrningen; exempelvis "avkastning" eller "effektivitet" i samband med mätning.

För att kunna diskutera effekterna vad avser optimering av kvalitet versus kvantitet för ett resursslag (enligt Figur 34) illustreras detta i matris nedan (Figur 35): 


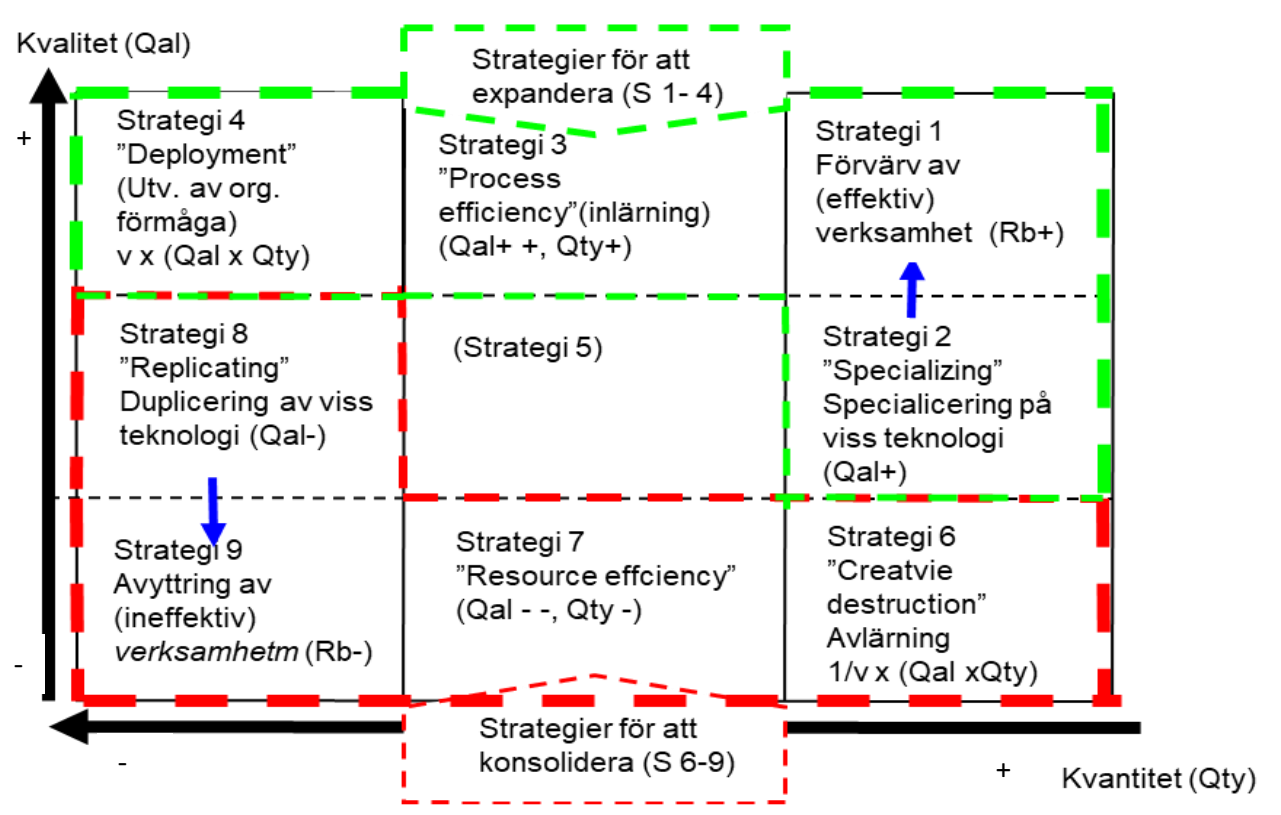

Figur 35. Strategimodellen: en strategikarta utifrån ett resursperspektiv m a p optimering av kvalitet och kvantitet vid konsolidering respektive exploatering (Matrisen är egenutvecklad)

Matrisen i figur 35 illustrerar de nio strategialternativen och deras relativa effekt på kvalitativ respektive kvantitativ förändring över tid av resursens förädlingsvärde. Strategi 1 och 9 berör endast organisationens resursbas. ${ }^{125}$

\footnotetext{
${ }^{125}$ Vid förvärv till över- respektive undervärdering inträder regelverk (IFRS, GAAP) och företagets kapitaliserade immateriella resursbas förändras. Regelverken ger också möjlighet att välja viss kapitalisering respektive nedskrivning vid övriga strategier inom ramen för resursslagets förädlingsvärde.
} 


\section{Kapitel 10 Diskussion. Ledningens Förväntningar.}

Detta kapital avser att besvara de två forskningsfrågor som relaterar till företagens förväntningar. Denna avhandling har primärt ett "internt" perspektiv på ekonomisk styrning. Den avser individer, processer, aktiviteter $\mathrm{mm}$ i de studerade organisationerna där 'interna' ägare, styrelse, ledning och övriga medarbetare är aktörer. Ägare på en `extern’ kapitalmarknad är inte studieobjekt $\mathrm{i}$ avhandlingen. Organisationen förutsätts följa de policies som avser denna kategori av 'externa' aktörer. Detta kapitel avhandlas utifrån de förväntningar som organisationer (i målföretaget) har uttryckt och dessa tolkas som en potentiell förklaring till att de möjligheter som framgått av den systemiska analysen kan infrias. ${ }^{126}$

Som ett led i de partiella analyser som genomförts av de fem empiriska studierna har företagens (läs ledningens) förväntningar på framtida system för ekonomisk styrning systematiserats. Från förstudien samt de två första case har studien konstaterat behov av 'ny' kunskap. För att få ett underlag för de förväntningar som speglas redogörs först för dessa studier och de utmaningar som identifierats.

Efter genomgång av villkor och förutsättningar för beslutsprocessen (10.2) samt förslag till nytt ramverk och ny arbetsmodell (10.3) besvaras e två forskningsfrågorna i denna deduktiva fas av avhandlingsarbetet:

Forskningsfråga 2: Vilka alternativa val gör ledningen (potentiellt utifrån redovisade förväntningar) $i$ en beslutsprocess som möjliggör långsiktigt, vs betamålet, legitima och effektiva beslut? (Kap 10.2)

Forskningsfråga 3: Hur ser den totala "förklaringsmodell" ut som, utifrån det observerade fenomenet, explicit förklarar olika 'element', delar av förklaringen (orsak, strategi, beslut, styrning och resultat) och dess konsekvenser? (Kap 10.3)

\subsection{Från induktiv förstudie och inledande fallstudier.}

Vid analyser av förstudien och med dessa första 'cases' har ett 'kunskapsgap' identifierats mellan resursbaserad strategi och ekonomistyrning, $d \mathrm{v}$ s resursbaserade teorier /RBV, RBT, TGF, DCP) förklarar inte de mönster som denna empiri avhandlar. Behovet av förståelse handlar om ett resursbaserat synsätt, hur olika resursbaserade strategier, här med fokus på faktormarknader, teoretiskt påverkar organisationens system för ekonomistyrning (Marginson, 2002). 'Gapet' är primärt relaterat till teori- och skolbildningen om ekonomisk styrning men också till specifika begrepp inom system för ekonomistyrning (MCS) som relaterar till termer och begrepp som tillämpas inom resursbaserad teori, exempelvis det företagsekonomiska begreppet 'resurs'. Ekonomistyrningsmodeller i dagens skolbildning beskriver MCS och förhållandet mellan resurser, ekonomistyrning och marknadsstrategier i en, i det närmaste

\footnotetext{
${ }^{126}$ Någon forskning om hur 'interna' ledningars ‘förväntningsvärden’ direkt påverkar ett företags "performance” kan inte dokumenteras. Däremot kan en kalkylerad förväntan (avseende påverkansfaktorer) påverka organisationens mål.
} 
statisk modell. En statisk modell, som förklarar traditionell ekonomistyrning, kan illustreras på följande sätt:

\begin{abstract}
Organisationens visioner och strategi är orienterade mot en utbudsmarknad för att där genera ett resultat (mätt i termer av ROI/ROA). Organisationen beskrivs som en kapacitet bestående av strukturer eller processer, rutiner och procedurer och anställda och som ett resultat av hur organiseringen, som en del av den samlade ekonomiska styrningen, har skett. Organiseringen är en beskrivning av arbetet med ansvarsförhållanden, delegering, centralisering mm. Resurser beskrivs implicit som förutsättningar för verksamheten.
\end{abstract}

Författarens sammanfattning från intervjuer

Förstudien indikerar att organisationens "management" i verkligheten är överordnad en formaliserad strategi- respektive styrningsprocess. Ledningen indikerar redan i förstudien ett behov av en "ny strategimodell" (en 'ny' teori) för resursbaserad ekonomisk ledning och styrning - en modell som speglar olika möjliga ledningsval och påverkan på strategier med olika tidsperspektiv, olika typ av prestationer (capex, opex), varierande resultat och effekter (performance), risker (risks); en mer dynamisk modell.

Avgörande för hur den ekonomiska styrningen utförs och vad företaget presterar är organisationens (inklusive ledningens) samlade kapacitet (jfr idrotten). Med ett resursbaserat synsätt är visioner och mål orienterade mot en faktormarknad och det resultat som förväntas efter genomförandet av strategin är primärt kvalitativt. (jfr exempel med spelarutveckling från lagidrott som fotboll). Tidsperspektivet är oftast inte uttalat.

Den strategiska utmaningen från förstudien är att argumentera för behovet av en ny styrmodell, en argumentation som möjliggör en diskussion om konceptuellt innehåll, syfte och omfattning (scope), begrepp (terms) mm i den långsiktiga och strategiska styrningen.

Vid analys av resultat av genomförd empiri Case ROBO och Case CATHEDRAL framkom också två "nya" aspekter som kommunicerades med deltagarna, nya aspekter som inte heller kunde analyseras med befintlig teori inom ekonomisk styrning eller resursbaserad strategi

- Vid en genomgång med referensgruppen av en $\mathrm{s} k$ processanalys framkom en otydlighet i hur beslutsprocessen verkligen "såg ut", i vilken ordning "frågorna" logiskt borde besvaras respektive hur det gjordes i verkligheten samt hur frågor inbördes prioriterades.

- Vid analys av beslutsprocessen visade det sig att ledningen och affärsenheternas controllers tillämpade en viss typ av styrning av respektive forskningsprojekt utifrån överställda mål, detta gällande finansiella förutsättningar och strategier för vissa utvalda projekt (de som ingick i Case ROBO).

Ett resultat av denna analys av Case ROBO och Case CATHEDRAL medförde därför en uttalad förväntan på "nya" modeller alternativt kompletteringar av befintliga modeller avseende Input (enablers) respektive Output control (results). Detta dels för att ledningen önskade en "consensus" om alla delar i styrningsprocessen, dels för att minska kunskapsgapet om villkoren för en resursbaserad ekonomisk styrning inför kommande studier. 
En strategisk utmaning från dessa två fallstudier är konceptuell; att argumentera för normativa referenser (resursbaserad teori) och ledningens förväntan på en 'ny' föreställningsram omfattande integrerad ekonomisk styrning som omfattar PDCA inklusive en beslutsprocess: input - process - output samt frågeställningar inför ledningens, inklusive ägares, strategival och dess effekter på resursbasen

Utmaningar som studien pekar på avser, utöver beskrivningsnivån för ett eventuellt ledningssystem för resursbaserad styrning, vilka övriga kontextuella avgränsningar måste göras avseende vilka intressenter respektive vilka resurskategorier som ska ingå i styrningen.

\subsection{Alternativ för ekonomisk styrning med betoning på beslutsfattande.}

Detta kapitel avser att besvara avhandlingens andra forskningsfråga: Vilka alternativa val gör ledningen (potentiellt utifrån redovisade förväntningar) $i$ en beslutsprocess som möjliggör långsiktigt, vs betamålet, legitima och effektiva beslut?

För de förväntningar som speglats i den systemiska analysen och ovan antas ledningen tidigt i beslutsprocessen (potentiellt vid övergripande koncernbeslut) och inför varje strategiskt beslut uttalar mål som tidigt kommuniceras inom hela organisationen. Med referens till en generell beslutsstruktur (Figur 5) diskuteras här, primärt utifrån förväntningar i Case INNOHUB hur d v s utifrån vilka förutsättningar som ledningen i projektinitiativet INNOHUB beslutar och agerar för att motsvara förväntningarna. Kapitlet redogör initialt för de villkor och förutsättningar för beslutsprocessen som specifikt avser objektet INNOHUB och dess kontext d v s det aktuella ekosystemet för innovation. Frågorna i beslutsprocessen handlar primärt om INNOHUBS uppgift och för vem, respektive med vem som, verksamheten fokuserar.

\subsubsection{Intressenter i beslutsprocessen}

Case INNOHUB är ett av avhandlingens fyra omfattande fallstudier, "business cases", d v s där primär diskurs handlar om /strategisk/ styrning med fokus på kunskapsintegration och innovation. I samtliga dessa "business cases" finns tydliga ägarperspektiv. Det gäller samtliga aktörer i detta "ekosystem för innovation", d v s utöver innovatörerna även 'projektägare', ledningsgrupper och styrelse i målföretaget, i det företagsspecifika initiativet INNOHUB och dess ledning, investerare i projektet och också regionala och nationella intressenter. Samtliga aktörer med 'ägarintresse' i initiativet men utifrån olika perspektiv.

Dessa olika "ägarperspektiv" medför att fokus i någon mån förskjuts från "huvudintressentens" (målföretagets) interna organisation till en större kontext; ett "ekosystem" för innovation och utveckling och med den också begreppet "ekonomisk styrning". Begreppet omfattande därmed såväl beslut utifrån samhällsaspekter som organisationens /långsiktiga/ legitimitet (läs corporate citizenship). Begreppet 'ekonomisk styrning' omfattar en styrning som således berör samtliga aktörer utifrån deras respektive perspektiv, förväntningar och målsättningar (och ägardirektiv).

Case INNOHUB är här den mest omfattande empirin och vars organisationsform här diskuteras som "state of the Art" i en öppen kontext inom detta 'nya' ekosystem. Problematiseringen och analysen avseende förväntade strategier för utvecklingen av ett 'innovationskapital' i detta större ekosystem, som en del av behovet av ökad förståelse av utveckling och tillväxt och dess 
konsekvenser, omfattar i första hand tre moment i denna explorativa forskning: a) respektive aktörs lednings- och beslutsordning vid organisering och strategival och en arbetsform för ledning och styrning utifrån ett uttalat överställt mål, b) formler för beräkning av KPIér för målformulering och löpande uppföljning av projekt samt även c) 'intern' respektive 'extern' kommunikation/redovisning. Kriterier som påverkar dessa tre moment är av både finansiell och icke-finansiell natur. Ett huvudkriterium är att organisationens ${ }^{127}$ resursbas ska kunna uttryckas i kvalitativ och kvantitativ dimension, och kunna uttryckas i termer av effekter på företagens/(intressenternas) kapitalstrukturer; därav utvecklingen av definitionen och operationalisering av begreppet resurs.

Men, som nämnts speciellt i analysen av Case FORCE och Case INNOHUB, indikerar också empirin behovet av potentiell 'ägarbestämning' som underlag för en diskussion om den referensram som efterlyses för fortsatt forskning och explicit runt ägandet vid strategisk styrning; bland annat avseende ansvar och legitimitet vid en resursbaserad styrning och dess effekter. En 'ny' referensram och därmed ett 'nytt' ramverk för integrerad strategi och styrning, i denna bredare kontext, omfattar därmed också referenser till en bredare vetenskaplig teoribildning ${ }^{128}$ och, i förekommande fall, även normerande regelverk för redovisning (GAAP, IFRS $\mathrm{m}$ fl.), ledningssystem (ISO $\mathrm{m}$ fl.), juridik; intern kontroll (COSO $\mathrm{m}$ fl.) och revision samt rättspraxis inom innovationsområdet (avtals- och patenträtt $\mathrm{mm}$ ). Detta innebär att de beslut och agerande som kan utläsas hos ledningsgruppen i INNOHUB är komplext. I avhandlingen avgränsas därför denna beslutssituation till att redogöra för ledningens "split vision" och där beslut primärt baseras på förväntningar. Detta gäller både kontextuella och konceptuella villkor.

\subsubsection{Förväntningsteori bidrar till förståelse av agerandet}

Förväntningsteori är inte utforskat i nämnvärd omfattning men i denna avhandlingsempiri är det en dimension som framträder som väsentlig i ekonomisk styrning. Tillämpad forskning och modeller om förväntningar ger förståelse i två sammanhang; a) med referens till kognitiv psykologi med tillämpning i företagsekonomisk kontext som avhandlar motivationsfaktorer på individ- och organisationsnivå "expectancy theory" (Vroom, 1964) samt b) vid kapitalmarknadsbeslut av olika karaktär (som jämviktsteorem, optimering vid alternativa räntebanor, vid kalkylränteval $\mathrm{mm}$ ).

Enligt Vroom (1964) utgår förväntningsteorin ifrån en förväntan ifrån att ansträngning (hos medarbetare) leder till prestation, att prestation leder till resultat samt att förväntan om hur resultat mäts och värderas. Denna förväntningsteori kan potentiellt ge svar på frågan om varför beslutfattare väljer att investera i framtida innovationer med okända betalningsströmmar; dvs förväntningsvärdet vid utveckling av kapital/resurser eller förväntningsvärdet som motivationsfaktor för 'intern’ legitimitet och uppkomst av tillit. Detta framträder i empirin i såväl Case FORCE som i Case INNOHUB. Nedan illustreras dessa förväntningar framförallt från intervjuer med ledningspersoner i Case FORCE.

\footnotetext{
${ }^{127}$ Här avses med `organisation’ de olika juridiska och interorganisatoriska enheter där mätning görs av förädling av resurser av innovativt slag d v s i innovations- och utvecklingsprojekt

${ }^{128}$ Avseende effekter vid mer indirekt bolagsstyrning prövas exempelvis relationen ägare/styrelse $\mathrm{m} \mathrm{h}$ a agentteori (Fama-Jensen et al, 1983)
} 
Gemensamt för förväntningar i dessa empiriska studier kan relateras till Birger Wernerfelts (Wernerfelt, 1986, 1991) och även Peter Johnsons (Johnson, 2007) forskning som handlar om bland annat optimering av förväntad avkastning från "resursportföljer" där beräkningar görs med förväntningsvärde, dock utan att förväntningsteori avhandlas.

De förväntningar som redovisas i denna avhandlings empiri från Case INNOHUB innebär som indikerats ovan explicit en förväntan på potentiell framtida nytta och värde av en innovation på en faktormarknad. På organisationsnivå illustreras detta med ett eller mindre identifierbart och kvantifierbart innehåll, redovisat som upparbetade kostnader, värde på samarbetsprojekt, kontrakt och IP och ansamlad goodwill från olika deltagande i innovationsprojekt (och andra utvecklingsprojekt), d v s redovisade värden på resurser ingående i företagets strukturkapital eller infrastruktur. Om förväntningarna på framtida värde av dessa innovationer ska kunna utgöra en hypotes om dess bidrag till ett innovationskapital och i förlängning till resultat och effekter, måste någon form av mätning kunna göras. I denna avhandling görs primärt mätning av (som exempel vid upprättande av kontrakt) ingående resurser och förmåga. Ett alternativ för fortsatt forskning är att utveckla ett förväntningsvärde för exempelvis innovationskapital och kriterier för bestämning av detta. Ett innovationskapital som, utöver partners deltagande, avser organisationens deltagande och representeras $i$ (koncernens/målföretagets/ affärsenhetens) kapitalstruktur.

Vid genomgång av systemisk analys har personerna i målföretagets ledningspositioner tidigt uttalat förväntningar avseende behovet av ny styrmodell (Figur 8) och på de olika delar av styrmodellen som redovisas i avhandlingen. Här presenteras kortfattat resultatet från de inledande och påföljande intervjuerna med ledningspersoner i målföretaget. Bara de 'fakta', respondenternas förväntningar, som påverkar denna del av avhandlingsarbetet redovisas här. Dessa förväntningar uttalades dels vid de visionsmöten som genomfördes där ledningspersoner från affärsenheter och controllers deltog, dels vid de personliga intervjuerna som genomfördes med organisationens ekonomichef, organisationens finansdirektör, organisationens informationsdirektör, organisationens personaldirektör samt med ledningen för organisationens/koncernens globala forskningscenter (FoU/CR).

\subsubsection{Ledningens förväntningar och argument för ny integrerad styrmodell.}

Bakgrunden var att målföretaget under dessa år efter millennieskiftet genomförde ett mycket omfattande omstruktureringsarbete utifrån beslutet att konsolidera den globala verksamheten. Uppskattningsvis $65 \%-70 \%$ av verksamheten avyttrades och en fokusering och konsolidering av två tidigare kärnverksamheter inleddes. Omstruktureringen ställde krav på en ny typ av system för ekonomistyrning. Ett omfattande arbete pågick för att renodla organisationens olika affärssystem. En sammanfattande slutsats från dessa möten med ledning och controllers var att företaget hade ett behov av en ny typ av styrinformation, framförallt påverkat av den allvarliga "likvida" situation som företaget hade 2005.

Ledningen efterlyste tidigt ett bredare synsätt ("utöver finansiell information") ("något i stil med T50") med nya modeller i syfte att kunna ta bättre beslut om organisationens "investeringsbas" eller "totala kapitalbas". Ett vidgat perspektiv på resurser d v s ett 'resursperspektiv' (per definition) diskuterades vid controllermöten för att få någon form av consensus om vad som avsågs med denna terminologi. Resultatet från denna genomgång av 
resursperspektivet visade som nämnts på en svårighet att bestämma vad som ska kategoriseras som organisationens resurser och hur dessa skulle identifieras och klassificeras.

Organisationens ekonomistyrning diskuterades först utifrån behovet på koncernnivå att kunna koordinera organisationens olika system för styrning för att uppnå organisationens måldimension d v s "en uthållig konkurrensfördel". ${ }^{129}$ Primärt diskuterades finansiell styrinformation men även måldimensionen och styrningsaspekterna vid miljöredovisning/ miljöstyrning samt social redovisning.

Här gjordes en analys och beräkningar för hela koncernen av bland annat förädlingsvärden, effektivitet, avkastning för olika affärsenheter, redovisade i koncernbokslutet för 2003, 2005 och 2006. Konkurrensjämförelse avseende resurseffektivitet av två resursslag genomfördes. En förväntan uttrycktes att tydligare kunna spegla koncernens konkurrensförmåga och positionering och hur den kunde följas.

För att i någon mån förtydliga detta behov utvecklades ett förslag till ramverk för en ekonomisk styrning, en modell som möjliggjorde en genomgång av ledningen förväntningar. Ramverket utvecklades utifrån den struktur som tillämpats i avhandlingens analysmodell. Det avser att kunna förklara de mest centrala ledningsaspekter som avhandlats ovan.

\subsection{Utvecklat ramverk för integrerad, dynamisk strategisk ekonomisk styrning}

Detta kapitel avser att ge ett förslag till svar på den tredje forskningsfrågan: Hur ser den totala "förklaringsmodell" ut som, utifrån det observerade fenomenet, explicit förklarar olika 'element', delar av förklaringen (symptom, orsak, strategi, beslut, styrning och resultat) och dess konsekvenser?

Det ramverk som här föreslås är ett således ett resultat av avhandlingens olika teoretiska och empiriska studier. Med utgångspunkt från EEM-modellen har denna kompletterats med den 'integrerade' beslutsmodell som redovisats i figur 13.

Detta utvecklade ramverk är en totalmodell (Figur 36) som illustrerar förhållandet mellan organisationens struktur och resultatet av styrningen. Den är primärt utformad för att ledningen på olika nivåer dels ska kunna uttolka ett sätt att förstå helheten i styrning, och dess olika delar satta i sitt sammanhang, för att därmed kunna kommunicera varje `element’ i modellen var för sig. Modellen ger i och med det också en förutsättning för en systemisk ansats för potentiellt fortsatt forskning. I detta syfte har denna nya modell, detta utvecklade ramverk för resursbaserad ledning och styrning, fått följande utseende:

${ }^{129}$ Se sammanställning från brainstorming Power Point Bild nr--)” (bilaga $1 \mathrm{c}$ ) 


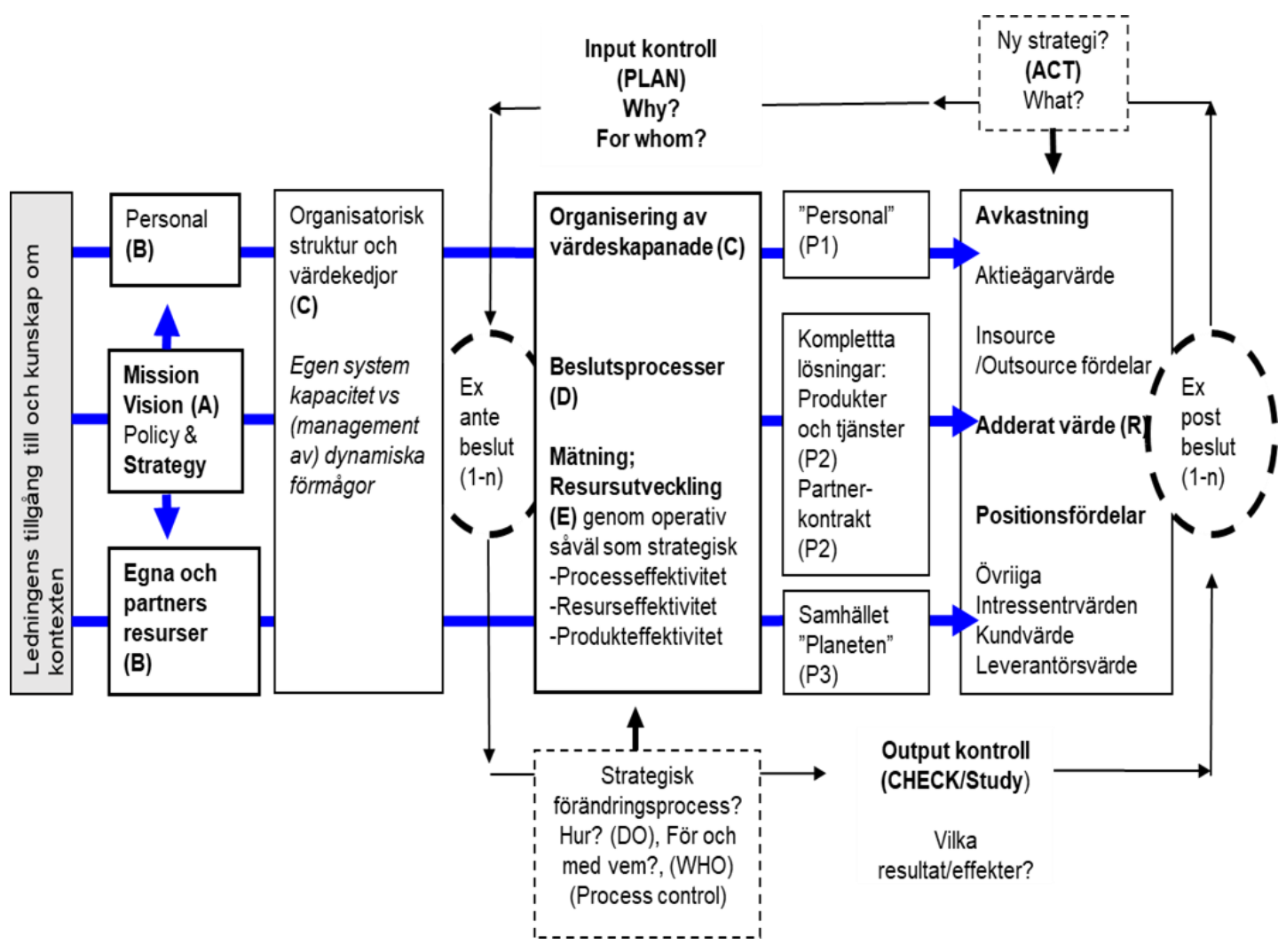

Figur 36. En ny "robust" totalmodell (baserad på EEM-modellen) och som kan ge en bild av hur ett företags resultat möjliggörs i ett system för resursbaserad ledning och ekonomisk styrning, oberoende av tidsperspektiv resursslag och andra specifika villkor $\mathrm{d} v \mathrm{~s}$ modellen är kontextneutral. Modellens motsvarighet (och argument för den) finns i kvalitetsdiskursen, den s.k. EFQM-modellen.

\subsubsection{Måldimensionen: Ledningens förväntningar vid framtida ekonomisk styrning.}

För att i den ekonomiska styrningen kunna hantera tillämpade begrepp förväntas den innehålla hur olika aktörer uppfattar ett projekt i dessa avseenden. Detta för att de ska uppfattas på likartat sätt av alla som är direkt involverade. Det förväntas rimligen i styrningen också finnas en överensstämmelse mellan målet (f n i Case FORCE sustainable technology) och de värden som ska mätas för att kunna tjäna som beslutsunderlag för kommande strategier. Det kan handla om att på något sätt också synliggöra 'magkänsla' för vad som är värdeskapande (läs: entreprenöriellt) då denna uppfattas som viktig relaterat till mer rationella beslutsunderlag. $\mathrm{Om}$ detta ska ske i form av styrkort eller på annat sätt får kommande forskning avgöra.

Som exempel på hur ett resursperspektiv hos ledningen påverkar ekonomistyrningen handlar denna diskussion om "ledningsförutsättningar" sammanfattningsvis snarast om behovet av en helt ny måldimension. Viktigast för projektet är fortfarande dess finansiella avkastning, utifrån 
att man identifierat projektet som en "sustainable technology". För affärsområdet för BU 3 handlar det om avkastning på deras kunskap inom det specifika kompetensområdet. Vad detta begrepp implicerar i form av specifika resurser eller innovationsförmåga hos organisationen är delvis oklart, primärt handlar det om organisationens förmåga att utveckla informationssystem runt denna kompetens om energi respektive teknologi. För en effektivare "resursbaserad" styrning behövs mer kunskap om dessa "nya" mål, definierade och identifierade strategiska resurser inom detta område, mer kunskap om trender, om andra organisatoriska förutsättningar och vilken "legitimitet" som varje forskningsprojekt har i olika etapper.

I intervjuerna med projektledare och controllers framgick att andra måldimensioner av resurser än den rent finansiella var viktig. Den finansiella dimensionen skulle dock vara den primära (d v s projektets ekonomiska avkastning ("rent") (i den mån det kan mätas) men dess förväntade ekonomiska bidrag till den egna affärsverksamheten (oklart om affärsenheten avsågs) är en viktig måldimension. Om detta företags förmåga att ta beslut relativt målet "sustainable technology" kan värderas i termer av bidrag (eller allra helst lönsamhet) till verksamheten, skulle detta kunna motivera en utveckling av styrning mot en "triple bottom line" (TBL).

\subsubsection{Resurser: Ledningens förväntningar vid en framtida "ny" ekonomistyrning}

Om ett resursbaserat synsätt ska kunna tillämpas förväntas en utveckling och tydligare värdering av vissa resurser som kan identifieras som inbyggda i företaget eller i olika projekt eller system. Om inte endast finansiella resurser ska värderas förväntades en tydligare kategorisering av affärsenhetens/projektets resurser och tillgångar. De förväntades vara klassificerade eller på något sätt också operationaliserade för att kunna värderas inför en tydligare ekonomistyrning.

Som exempel på hur ett resursperspektiv ansågs påverka styrningen handlade denna inledande diskussion med controllers och i Case FORCE snarast om att "kartan" måste bli tydligare. Strategiska resurser från lägsta till högsta nivå, potentiella samarbetspartners, leverantörer mm måste kunna identifieras och "kvalitetssäkras", likaså de egenskaper eller karaktäristika som utmärker dem (eller kombinationer av dem) - detta för att kunna ingå i en medveten ekonomisk styrning, måste kunna kommuniceras internt, mätas och värderas. I Case FORCE tydliggjordes detta framförallt vid bortfallet av den leverantör som medverkat vid utvecklingen av konceptet. I Case INNOHUB tydliggjordes detta vid försöken att kommunicera betydelsen av ett innovationskapital och hur detta skulle kunna beräknas och potentiellt kapitaliseras.

\subsubsection{Organiseringen: Ledningens förväntningar vid en framtida "ny" ekonomistyrning}

Projektet "FORCE" karaktäriserades som ett projekt som fyller kriterierna som strategiskt projekt ur ett resursperspektiv; $\mathrm{d}$ v s det är unikt och det är prioriterat utifrån att det förväntas innebära en unik position (p.g.a. organisationens unika kunskap inom energiområdet) och har en långsiktig och uthållig konkurrensfördel, marknaden var vid tillfället "okänd", risktagandet högt och vinstpotentialen stor. Organisationens specifika kunskap om denna resurs och dess egenskap och dess villkor på en global marknad medförde att projektet från början varit unikt. Efterföljare fanns, dock att lösningar på ett och samma problem var olika, vilket innebär att kriterierna för RBV om "unikitet" och behovet att internt behöva anpassa organiseringen för att "isolera" teknologin mm var helt uppfyllda. 
Det var svårt att av respondenternas svar utläsa förväntningar på framtida system för ekonomistyrning vad gäller organiseringen runt FORCE. Detta beror eventuellt på oklarhet om vad som egentligen orsakade försening av projektet. Oklarhet kan hypotetiskt ha funnits i projektet vad avser planeringen för fortsättningen, kriterier för hur projektet ska värderas, risker (med patent $\mathrm{mm}$ ) och eventuellt vilken roll/ansvarsfördelning som gällt (även internt hos affärsområdet för BU 3; se projektbeskrivningen).

De problem och de tänkbara strategier för att lösa detta som beskrivs var dels av "intern" natur dels relaterat till förhållandet till den potentielle leverantören och dennes resurser och förmåga. Den interna organiseringen avsåg dels förhållandet mellan affärsenheterna FoU/CR och BU 3, dels internt inom hela affärsområdet för BU 3. Den "externa" organiseringen inom ramen för den strategiska styrningen handlade om en potentiellt $n y$ global leverantör för en "joint venture".

I organiseringen mellan affärsenheterna FoU/CR och BU 3 i ett projekt som är så starkt teknologibundet (unik kunskap om energiresurser) är styrningen inriktad på vilka personer som medverkar $\mathrm{i}$ processen och att det finns en långsiktig kontinuitet och ett engagemang $\mathrm{i}$ hela "Gate"-processen som är "homogent" - i synnerhet då teknologin är ny och "okänd"/unik kunskap inte finns på "marknaden". En möjlighet att överväga (ej tydligt uttalad förväntan) är en gate-process hela vägen med om möjligt samma personer genom hela processen är ett alternativ.

Organiseringen inom affärsenheten BU 3 vid en konsolideringsstrategi innebär, om man tillämpar ett starkt resurstänkande, att inte för tidigt fördela befogenheter över organisationen även om inlärningseffekten blir mindre och ledtiden blir längre när affärsenheten växer och nya resurser tillkommer. Ansvaret inom affärsenheten förväntas inte delas vid nuvarande eller kommande organisering.

Resursperspektivet innebär en fokusering på organisering av framtida strategiska produktionsresurser på en (extern) marknad som förväntas vara heterogen, $d v$ s resurser och förmågor är svåra/omöjliga att kopiera, resurser har en begränsad rörlighet etc. I dessa projekt är förväntningarna på en långsiktig och unik konkurrensfördel stora och samtidigt är projekt som dessa ofta projekt som har en hög 'riskprofil'. Organisering av partnerskap och allianser för att utveckla utvecklings- och produktionsfördelar kräver långsiktighet $\mathrm{i}$ avtal om villkoren för intern resursutveckling och resurseffektivisering, partners olika uppgifter vid den vidare förädlingen; d v s vid kontinuerlig framtida produktion och även för "comissioning", service/garantier och underhåll $\mathrm{m}$ a o hela förädlingskedjan. Ekonomistyrningen förväntas speciellt fokusera hur detta regelsystem ser ut; vad är "ägande" till resurser/tillgångar respektive vilka resurser som "lånas". Detta måste kunna regleras tidigt vid FoU, d v s vilken potentiell förädling kan förväntas samt vem som står för vilken förädlingsinsats etc. Även andra incitament för parternas engagemang $\mathrm{i}$ hela kedjan (och under vilka villkor) måste kunna regleras i ekonomistyrningen. Tidsperspektivet och effekten av eftersläpningar ("slacks") i resursbasen vid förändrade strategier förväntas kunna analyseras inom ramen för ett system för ekonomistyrning, speciellt viktigt vid organiseringen av organisationens tidiga processer som FoU och innovation. 


\subsubsection{Beslutsprocesserna: Ledningens förväntningar vid en framtida "ny" ekonomistyrning}

I styrningen förväntades att, så tidigt som möjligt (i företag där "Gate-modellen använd redan inför Gate 1), de frågor som inte bara identifierar organisationens "strategiska" resurser utan även ställer övriga (kritiska) frågor som för ledningen kan vara mest relevanta ur "styrningsperspektiv" skall ställas. Här avsågs att svaren på frågorna Varför? För vem? När? Vilka? och Vilket Resultat? måste kunna bedömas även vid enskilda affärsutvecklingsprojekt i ett helhetssammanhang. Ledningen förväntade full access till information. Genom att tidigt definiera vad som är strategiskt viktiga resurser och förmågor, utifrån valda kriterier, i varje sammanhang och på ett operationellt sätt försöka tydliggöra och därmed kunna identifiera och värdera dem redan i strategiarbetet, så ansågs de relevanta frågorna i styrningen (ex ante) också kunna få sina svar i ett tidigt skede.

I diskussionen om "genomförandefasen" förväntades beslut om och på vilket sätt den "operationella kontrollen" skulle ske; vilken nivå som strategi skulle appliceras på (bolags-, BA-, BU- eller projektnivå) samt vilken typ av ledarskap d v s vilken typ av styrning som skulle tillämpas respektive vad ekonomistyrningen avsåg och syftade till, forskning, produktutveckling etc.

\subsubsection{Mätningen: Ledningens förväntningar vid en framtida "ny" ekonomistyrning}

Ett explicit 'mål' som diskuterats i projektet FORCE är resurseffektivitet och uttolkat i detta projekt som energieffektivitet och finansiell effektivitet och implicit (men outtalat) en resurstillväxt d V s avkastning ("rent") från respektive resursslag; här primärt från energieffektivisering vid en pilotinstallation hos kund.

Mätning ansågs mycket centralt i detta case, i detta fall vid investering i riskfylld infrastruktur och där ledningen förutsatte inte bara kunskap om vad som skulle mätas, utan att mätningen i sig är effektiv och att rätt saker mäts utifrån syftet samt att det mäts på rätt sätt, bland annat med avseende på tidsperspektiv och risknivå! Ledningen förväntade att företaget och projektledning på olika nivåer eftersträvade robusta, men också enklare regler för mätning (KPIer) där den "nya" måldimension förväntades kunna explicitgöras.

I denna avhandlings empiri avgränsas 'mätning' till "interorganisatorisk omvandling av resurser" (d v s vad som kan mätas i internredovisningen). Särskilt studeras mätningen av respektive projekts bidrag till hela organisationens ${ }^{130}$ förädlingsvärde $\mathrm{d} \mathrm{v} \mathrm{s}$ organisationens resultaträkning på en viss nivå. I Case FORCE förväntades "sustainable technology" särskilt kunna mätas, relaterat till den speciella, icke-finansiella måldimension som nämns. Det bidrag till "energieffektivitet" som produkten FORCE förväntades generera och som förväntas komma företaget till del ansågs på något sätt därför kunna mätas i en lämplig kontext. Detsamma gäller om "förmågan" ("capability") i projektet, d v s den unika kunskap som projektet förväntades generera internt. I Case INNOHUB framhåller ledningen, utöver den 'egna resurstillväxten' (INNOHUBS eget innovationskapital) att mätning fokuseras på det här genererade 'innovationskapitalet' (resurstillväxten) på olika nivåer av hela ekosystemet för innovation, även på regional nivå.

Avkastning ("rents") förväntades genereras snarast ur ett kvalitativt perspektiv på värdet och från avkastningen och uppgraderingen av projektets "unikitet" (för att efterhand skala upp

${ }^{130}$ Här avses med 'organisation’ de olika juridiska och interorganisatoriska enheter där mätning görs av förädling 190 
produktionen) och en långsiktigt kvalitativ resurspositionering, snarare än på kvantitativt volymberoende och marknadspressade marginaler.

Nedanstående sammanställning av behov av nyckeltal vid planering av resultat är gjord utifrån relevant teori samt empiri och ledningens förväntningar avseende implikationer för mätning i styrningen d v s ex ante och ex post samt med kommentarer ${ }^{131}$ och utifrån de olika strategival som redovisats ovan (figur 35) och som ger olika förväntat utfall.

Följande värden föreslås för utveckling av nyckeltal (KPI) vid mätning av resultat

- Produktivitet,

- förädlingsvärde (med referens till Johnsson and Thomas, 2007; Grufman, 2008),

- resurseffektivitet vid konsolidering vs processeffektivitet vid expansion (Figur 32),

- resurstillväxt (mätmodeller för "cash-flow"; DuPont-modllen),

- avkastning ; beräkning av "rent" (Penrose, 1059); RoR (Johnsson, 2006); TBL (Elkington, 2004); portföljavkastning (Wernerfelt, 1990); innovationskapital (Boström, 2019),

- resursposition (Holling, 2008),

- uthållig konkurrensfördel (Grufman, 2008),

- resursförmåga; (se ovan definition och operationalisering av resursbegreppet), ${ }^{132}$

- systemförmåga; (se ovan kommentar om potentiellt möjlig mätning av kapacitet)

${ }^{131}$ För att mäta /indexerad/ produktivitet så måste en kvantitetsvariabel definieras för resursen/förmågan. För att mäta effektivitet så måste både kvantitetsvariabel och kvalitetsvariabler definieras för resursen (ex ante; förväntad respektive ex post upplevd kvalitet). För att mäta avkastning så måste en resursbas (jfr kapitalbas) identifieras. För att mäta resursposition så måste någon form av tillstånd för resursen kunna beskrivas (vs tillståndet för konkurrenters resurser). Som underlag för beslutsfattande kan diskontering och nuvärdeberäkning av lämpliga variabler göras.

${ }^{132}$ Mätning av förmåga hos ett system eller ett resursslag/resursportfölj är central vid såväl utformning av mål, nyckeltal, i mätmodeller för resultatplanering och uppföljning. Mätningen av förmåga avser såväl förväntad som tillgänglig respektive utnyttjad kapacitet. Den mäts med olika begrepp beroende på typ av system (exempel servicegrad i ett distributionssystem, antal timmar i ett produktionssystem etc.) och kan avse såväl input, som process eller output i det aktuella systemet. Teoribildning kring kapacitet vid dynamiska förmågor gåt längre än vad som avhandlas här. 


\section{Kapitel 11 Slutsatser}

I detta kapitel summeras avhandlingens bidrag, begränsningar som forskningen haft samt förslag till fortsatt forskning. Bidragen i denna avhandling summeras både från ett teoretiskt och ett praktiskt perspektiv samt vilka alternativa och nya perspektiv som avhandlingen har bidragit med. Men detta avhandlingsarbete har även sina begräsningar vilket gör att det finns öppningar och behov av fortsatt forskning. Det finns även frågor som identifierats som väsentliga men som avhandlingen inte besvarat. Utöver avhandlingens bidrag i kapitel 11.1 summeras i kapitel 11.2 avhandlingens teoretiska och praktiska implikationer.

\subsection{Avhandlingens bidrag}

Avhandlingens forskningsfrågor har besvarats i kapitel 9 och diskuterats i kapitel 10. Dessa slutsatser och diskussioner har bidragit till att besvara avhandlingens syfte som är att utifrån en analys av förändringar i företags strategiska styrning när tillgångarna $\mathrm{i}$ företagets resursbas skiftas från materiella till immateriella, föreslå principer för en tillämpbar styrmodell. Dessa relaterar till avhandlingens slutsatser och modeller avseende

- nya utmaningar och möjligheter som skapas för företags strategiska styrning i samband med den identifierade förändring av balansen mellan immateriella resurser och tillgångar (11.1.2), (se 9: konceptuella (9.1) och kontextuella (9.2) utmaningar)

- alternativa val som ledningen, utifrån redovisade förväntningar $i$ en beslutsprocess, potentiellt kan göra och som möjliggör långsiktigt, vs ett ‘betamål’, legitima och effektiva beslut (11.1.3) samt (10.2)

- ett förslag till utvecklad total "förklaringsmodell" som, utifrån det observerade fenomenet, explicit föreslås förklara olika 'element' och delar av förklaringen (orsak, strategi, beslut, styrning och resultat) och dess konsekvenser (11.1.4) samt (10.3) nytt ramverk)

\subsubsection{Avhandlingens kunskapsbidrag genom applicering från angränsande kunskapsområden}

När upptakten till detta avhandlingsarbete initierades, åren efter millennieskiftet, var intresset för forskning och utbildning med tema hållbarhet mycket måttligt. Kunskapsläget måste betraktas som osäkert även om hållbarhetsteman på allvar hade gjort avtryck i företagens publika redovisningar.

När Crawford Holling 2008 fick Volvos miljöpris för sina teorier om ekosystem uppstod en ny dimension i kunskapsläget. Kunde teorier om 'marknadssystem' i förändring och teori om ekosystems anpassning och motståndskraft bidra till förklaringar till företags överlevnadsförmåga i en tid med stora volatila rörelser? Och kunde denna nya kunskap antas påverka förväntningar på nyskapande och framtida tillväxt hos företagens ledningar och ägare? Hur skulle företagens potentiella utmaningar mötas och strategier och styrning utformas utifrån dessa förväntningar?

Kunskapsläget inom ekonomistyrning har successivt breddats konceptuellt. Kunskapsläget avseende företagens strategier har i huvudsak omfattat och omfattar även idag strategier för att 
uppnå konkurrensfördelar genom positionering på en utbudsmarknad. Med ett intåg av resursbaserade förklaringar till ett företags tillväxt uppstod dock ett nytt kunskapsläge. Det kunskapsbidrag som denna avhandling vill ge handlar om en tillämpning av resursbaserad teori i ett företags innovationsarbete som, delvis stödd av naturekonomisk systemteori, kan förklara ett företags tillväxt utifrån strategier och en förväntningsbaserad och medveten styrning på en faktormarknad för resurser av olika slag.

\subsubsection{Nya utmaningar, möjligheter och begränsningar}

Det teoretiska kunskapsläget som redogjorts för i avhandlingens initiala fas har bidragit till förståelse men inte helt kunnat förklara det fenomen som observerats. En förståelse och förklaring av fenomenet har uppstått genom att implicera ett systemteoretiskt synsätt och resiliensteori. (Holling 1973) Detta har avsevärt ökat kunskap om begränsningar och möjligheter med en utvecklad teoribildning om integrerad resursbaserad strategi och styrning.

Kunskapsbidraget i avhandlingen har också en pragmatisk implikation. Komplexiteten avser såväl förväntningar på framtidens innovationer (bildandet av ett innovationskapital), ledningens 'split vision' och nya mönster avseende en 'ny' marknad. När komplexiteten ökar förändras kraven på matematisk stringens för att uppnå någon form av validitet $\mathrm{i}$ forskningsresultatet. Men det innebär också begränsningar. I denna avhandling har detta medfört att det empiriska resultatet, inklusive begrepp, modeller och mätmetoder, endast avser data som kan valideras som oberoende av kontext, $\mathrm{d} v \mathrm{~s}$ kontextneutralt. För fortsatt forskning ges bland annat som förslag att utföra validering av beräkningsmodeller för resurstillväxt, av ett innovationskapital samt av resursbasens påverkan vid olika medvetna strategival, bland annat utifrån applicering av två inriktningar av resiliensteori. ${ }^{133}$

En begränsning i detta bidrag som samtidigt ska sets som en möjlighet och som berör såväl teori som praktik, är att empiriska studier och analyser primärt utförts på organisationsnivå; enhetsnivå och i något fall projektnivå. Efter redovisning av avhandlingens slutsatser avseende utmaningar och möjligheter (kap 9) diskuteras framförallt behovet av en tydlig målstruktur (kap 10.1) för att åstadkomma en strategisk ekonomisk styrning som implicit ger effekter på företagens totala kapitalstruktur. Implikationer av en tydlig målstruktur, i empirin bland annat `hållbar teknologi`, uppstår både i form av begränsning och möjlighet då studier och analyser avseende konceptuella villkor inte utesluter implikation på andra, såväl högre som lägre nivåer, $i$ andra kontexter eller vid andra resursslag. En gränsdragning har gjorts i avhandlingen mot ett (teoretiskt) individperspektiv i avhandlingen som innebär aspekter på tillväxt/förändring på kognitiv grund. ${ }^{134}$

Avhandlingen lyfter fram ett hypotetiskt s k ‘betamål’ i syfte att också kunna operationalisera målbegrepp som avser hållbarhetsaspekter och som relaterar till samhällsmål, primärt mål 9 om industriell hållbarhet i Agenda 2030 och de 17 globala målen för hållbar utveckling. Ett `beta-

\footnotetext{
${ }^{133}$ Hollings redogörelse för två divergerande teoribildningar (se: Foundations of Eclogical Resilience/ edited by Gunderson et al. 2010, Article 2) implicerar möjligheten att i fortsatt forskning pröva dessa i ett individperspektiv vid beslutsfattande avseende resurser (per definition) och begreppets tillämpning. Se även referens; Hollnagel et al. (ed.) (2011)

${ }^{134}$ Se not 132
} 
mål kan hypotetisk medverka till infriande av förväntningar hos intressenter och aktörer i en breddad kontext; ett regionalt och framledes också globalt ekosystem för innovation.

\subsubsection{Alternativa val}

Avhandlingen redovisar nio (potentiellt fjorton) alternativa /resursbaserade/ strategier vid strategisk styrning av företag. I modellerna är strategierna avgränsade mot varandra. En teoretisk implikation är att strategierna i en praktisk kontext varvas och gränser kan upplevas otydliga vid beslutstillfället, dock att någon strategi är mer tydligt kommunicerad än andra. Modellerna beskriver också den "split vision", mellan `internt' respektive 'externt' fokus på utvecklingsmarknaden, detta som en del av den integrerade beslutsprocessen. Detta kan medföra en teoretisk implikation då ett `externt` synsätt oftast refererar till ett marknadssynsätt där volymkriterier betonas.

En applikation av den positioneringsmodell som introducerats av Holling (1986) har vid utvecklingen av teori i avhandlingen medfört synliggörande av dessa nio (fjorton) strategier. De olika strategierna presenterade i kapitel 9 ger olika fokus för styrningen; ett internt fokus vs ett externt fokus på faktormarknaden. Vidare beskriver modellen vilka organisatoriska egenskaper som ska prioriteras i systemet givet en viss möjlig ekonomisk position: kreativitet, effektivitet, produktivitet eller exploatering. Modellen är dock närmast att betrakta som en optimeringsmodell; en modell för att förklara olika optimala positioneringar (strategic fit) och förändringar av dessa över tid för en enskild resurs (eller en resursportfölj av samma slags resurser) och där resursbasen kan förväntas förändras med fördröjd effekt, efter beslut.

Det kunskapsbidrag som en applicering av denna modell medfört handlar om förståelse av hur optimeringen av en viss resursportfölj (Wernerfeldt, 1994) d v s vilka ledningsåtgärder/ aktiviteter d v s vilka beslut och åtgärder i den strategiska styrningen, som blir följden av strategiförändringen och resultatet av dessa åtgärder. Alternativen är många och en komplett genomgång innebär dels en mycket komplex kontext, och dels att dess resursbas påverkas av den ekonomiska styrningen och av organisationens potentiella förmåga att anpassa sig för att uppnå en optimal och mätbar utveckling samt att förväntade effekter på företagets kapitalstruktur sker med viss oförutsägbarhet.

En analys av strategiernas konsekvenser på ekonomistyrningen är exempelvis att perspektiven internfokus vs externfokus är avgörande för såväl hur mätningen och värderingen kan göras (kapitel 9.3) men också vilket beslut som fattas avseende valet av tidshorisont, kvalitet, typ av teknologi, samarbete med leverantör etc. Ett internt fokus exempelvis vid ledning och effektivisering av innovativa processer, innebär att förändringar av dessa variabler direkt påverkar förädlingsvärdet och den effektivitet man vill uppnå d v s antingen den interna effektiviteten/-produktiviteten eller den effektivitet som ett visst val av inköpta/"insourcade" resurser medför.

En intressant aspekt på fenomenet, som ett symptom på förändring, är utöver argument och teoretisk orsak till förändring, vilka effekter som själva skiftet av strategi innebär och vad själva skiftet egentligen syftar till i praktiken. För att i någon mån kunna belysa skiftet med avseende på olika syften med styrningen beskrivs dessa strategiska fokus i en fyrfältsmatris (Figur 37) med variablerna "form" och "mängd" och där fyra olika "syften" framgår tydligare. Här 
tydliggörs hur en strategisk "fit" genom anpassade strategier (för innovation) kan illustreras såsom i figur 37 .

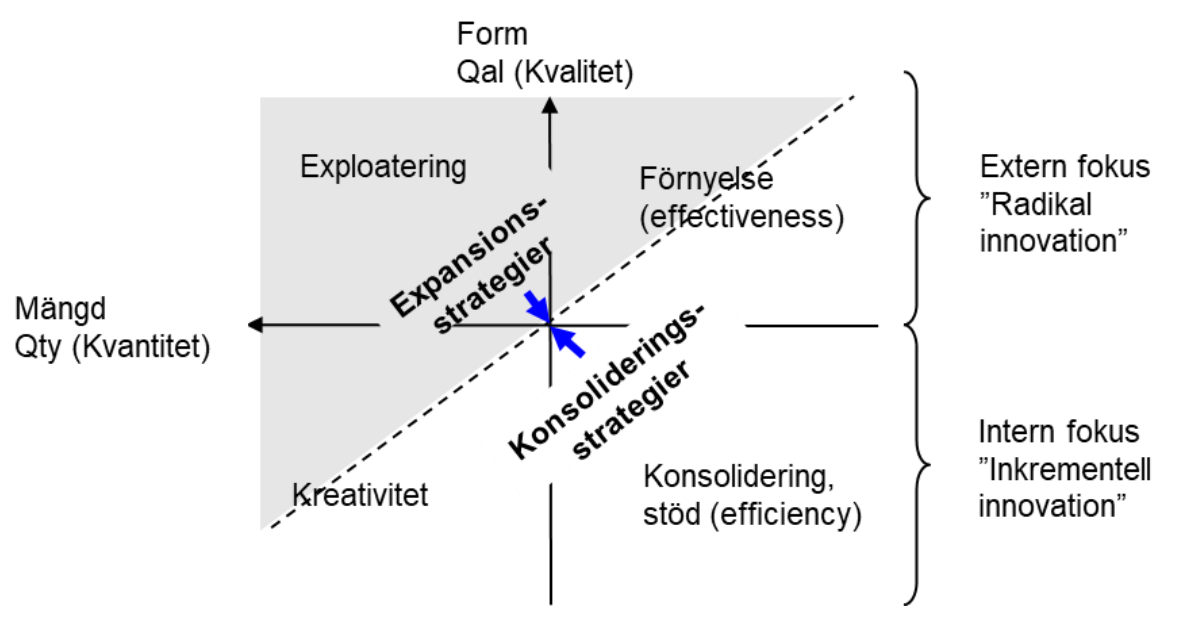

Figur 37. Skifte av strategiskt fokus. Val av fokus vid på en utvecklingsmarknad illustrerad med variablerna Mängd (Qty) och Form (Qal) De blå pilarna indikerar bästa "fit" relativt organisationens strategival och kan utöver ledningens strategival också illustrera överlevnadsstrategi samt innovationskapitalets sammansättning och betydelse.

Modellen här beskriver hur en optimering sker vid prioritering mellan variablerna form/kvantitet och mängd/kvalitet. Modellen visar att ledningen, utifrån ett behov att utveckla ett visst resursslag, kan organisera en kombination av dessa variabler (jfr pris/kvantitet) så att resursbasen (-s innovationskapital) svarar mot ett förväntat framtida innovationsbehov.

Den modell som beskriver dessa strategier med potentiella effekter på den ekonomiska styrningen är en teoretisk konstruktion av de affärsstrategiska beslut och möjliga konsekvenser av dessa som diskuterats i och delvis stöds av genomförd empiri. Långsiktiga, koncernstrategiska beslut som utformas av organisationens ägare/styrelse kan ha en, relativt affärsområden, motsatt innebörd (Fama \& Jensen, 1983) och baseras på andra villkor beträffande strategiska resurser, såväl vid beslut om konsolidering som vid beslut om expansion. Vid intervjuer med ledningsgrupper och styrgrupper i företaget på enhetsnivå efterlystes enkla tumregler för att bedöma strategiska projekt på olika nivåer. Styrningen måste därför omfatta tumregler som handlar mer än om bara finansiella nyckeltal etc. (som komplement till bland annat LCA etc). Man har efterlyst också en mer formaliserad och kritisk (frågeställande) utvärdering av efterlevnad av villkoren för den 'nya' ekonomiska styrningen i samband med strategiarbete.

En utvärdering (ex post) av den ekonomiska styrningen kan ske med s.k. kritisk processanalys. Den genomförs genom att frågorna ställs i omvänd ordning d v s i ordningen Resultat med frågorna Varför? Och Hur? och slutligen frågorna Vem? För vem? Vad? och Hur? (Se: bilaga A: Case ROBO" Critical Assessment in Process Analysis" samt bilaga B: Case CATHEDRAL "Legitimacy as Analysing Concept") 


\subsubsection{Förslaget till ny förklaringsmodell (se kapitel 10.3)}

I avhandlingen utvecklas efter analys av empiriska studier, en förklaringsmodell i linje med studiens syfte och adresserar därmed avhandlingens såväl konceptuella som kontextuella forskningsproblem avseende begrepp, kontextberoende etc.

Genom att utforma detta förslag till 'totalmodell' har syftet med avhandlingen bara delvis uppnåtts. Modellen har utvecklats utifrån analyser av empiri med stöd av etablerad styrningsteori (Simons, 2000; Deming, 1993). Applicering av dessa styrningsteorier, inom ramen för resursbaserad teori, har i avhandlingen gjorts på den $\mathrm{s} \mathrm{k}$ EEM-modellen. EEMmodellen, utvecklad för att utvärdera kvalitetsstyrning, har utvärderats utifrån ett systemperspektiv (Dahlgaard-Park, 2008). En tillämpning av modellen implicerar de sex element som genomgående använts vid analys av avhandlingens empiri. Denna tillämpning är ett kunskapsbidrag med såväl teoretisk som praktisk implikation. Modellen i sig ger dock inget kunskapsbidrag avseende direkt förklaring till uppkomsten av det observerade fenomenet. Men modellen ger ett kunskapsbidrag avseende principer för teoretisk analys av fenomenet då den implicerar principer för besluts- respektive värdeskapande processer. För att modellen ska kunna appliceras praktisk tillämpning har en arbetsmodell utvecklats som kan tillämpas som struktur för den i tidig empiri eftersökta ‘tumregeln’ för ekonomisk styrning.

\subsection{Teoretiska implikationer}

En teoretisk implikation och en viss begränsning i avhandlingen som nämnts ovan är att förklaringar söks på organisationsnivå och beslut på andra nivåer som beskrivs av Kenneth Boulding (Boulding, 1953, 1956) endast berörs implicit. Behovet av en förväntningsteori och förklaringar på individnivå innebär en såväl teoretisk som praktisk utmaning för fortsatt forskning. ${ }^{135}$

Inför fortsatta studier av hur resursbaserade teorier kan förväntas påverka ekonomisk styrning och därmed företags kapitalstruktur görs här, utifrån de tre frågeställningar som berörts i denna avhandling, en fördjupad analys av tillämpad teoribildning, primärt resursbaserade teorier. Vidare diskuteras av vad övriga tillämpade teorier har tillfört avhandlingen inom ramen för den kontextuella avgränsning som gjorts. Utöver detta diskuteras de avgränsningar som gjorts avseende möjligheten att med kompletterande teoribildning och fortsatt forskning avhandla en ytterligare förståelse för orsaker till uppkomst av fenomen, d v s varför fenomen uppstår, hur strategier uppstår och hur strategier påverkar en samhällskontext.

De resursbaserade teorier som avhandlingen tagit sin utgångspunkt i är primärt tre; TGF (Penrose, 1959), RBV (Wernerfeldt, 1984) samt RBT (Barney, 1994). Med referenser till dessa har uttolkningar av dessa tillämpats bland annat av Peteraf, (1993) och Pitelis (2005) samt Akio (2005). Implicit i samband med extern påverkan på organisationens kontext och dess implikation på styrning har också den s k resursberoende teorin, RDT (Pfeffer and Salancik ,

135 Beteendeforskarna, psykologerna Walter Mischel och Yuichi Shoda (1995), visar i sin forskning att motivationsfaktorer varierar med situation, person, mognad mm. Deras forskning kan visa motivationsfaktorer som förklarar varför vissa organisationer bygger upp "förväntningsvärden" som potentiellt kan förklara observerade förändringar i företagens kapitalstruktur. 
1978) avhandlats. Dessa mer grundläggande teoribildningar samt dessa uttolkningar har bidragit med förståelse och kritisk analys av ett grundläggande resursbaserat synsätt.

Då dessa teorier inte anses förklara (värde-) förändringar i och av resursen i sig avhandlas en teori om vad som genererar värde d v s den service som resursen bidrar till. Två författare utvecklade ett perspektiv för att förklara denna dynamik, DCP (Teece and Pisano, 1994). Denna teori, insatt i ett perspektiv där värdeförändringar och ekonomisk utveckling skapas genom entreprenörer (-s förmåga) och deras innovationer (Schumpeter, 1994), diskuteras i avhandlingen. Detta har tillfört avhandlingen en dimension som förklarar den speciella kontext som avhandlas; beslutsprocesserna vid innovation. En teoretisk implikation uppstår genom avgränsning till organiseringen i tidig fas; $\mathrm{d} v \mathrm{~s}$ tidsperspektivet innebär att forskningen är framtidsorienterad. Avsaknad av förväntningsteori och tidsperspektiv innebär viss osäkerhet vid tolkning av empiriska resultat.

Avhandlingen fokuserar implikation (från resursbaserad teori) på ekonomisk styrning. Här avhandlas ekonomistyrningsteori som en andra teoretisk utgångspunkt. Efter den analys av styrningsteorier, för att förklara strategiska förändringar av såväl kvantitativt som kvalitativt slag, som genomförts av Dahlgaard-Park (2008) valdes för avhandlingen de modeller och förklaringar som utvecklats av Simons (1995, 2000). Simons modeller utgår ifrån ett systemperspektiv och har därmed haft avgörande påverkan på avhandlingens slutsatser.

Sammantaget konstateras dock att dessa mer grundläggande teorier och (kritiska) uttolkningar inte förklarar eller skapar förståelse av avhandlingens specifika fenomen eller av alla de mönster som observerats i empiri och hur detta kan kopplas till ekonomisk styrning. Att detta fenomen med observerad förändring av företagens resursbas måste tolkas som ett symptom på att ett `nytt` mönster uppstått, i en viss kontext eller från ett specifikt agerande i samband med ekonomisk styrning, tydliggjordes vid de empiriska studier som genomförts. Detta 'nya' mönster är, oberoende om det tolkas utifrån 'externa' villkor ${ }^{136}$, en effekt av en medveten ekonomisk styrning (jfr definition av begreppet resurs).

Avhandlingen fokuserade ett resursbaserat systemsynsätt och en beskrivning av vad som kan uttolkas som en breddning vid tillämpning av resursbaserad teori. Breddningen medförde att teori från tillämpningar av resursperspektiv på andra utöver ekonomiska (finansiella) resurser, aktualiserades. En teoribildning som kunde förklara 'nya' mönster och tidsperspektiv var den s k resiliensteorin (Holling, 1973). Resiliensteori baseras på systemteori och kan förklara förändringar i och av mer eller mindre öppna system. Den har primärt tillämpats på ekologiska system. ${ }^{137}$ En potentiell teoretisk implikation är att graden av öppenhet/slutenhet varierar vid analys av ekologiska vs ekonomiska system. ${ }^{138}$

Primärt diskuteras kontext och systemsynsätt utifrån tre källor; C.S. Holling (1973); Peter Senge (2006) samt Peter Johnsson (2007). Referens görs primärt till den uttolkning som gjorts av empirin i denna avhandling.

\footnotetext{
${ }^{136}$ Med externa villkor avses här både teoretiska implikationer som exempelvis resursberoende (RBT) men också förändrade regelsystem för redovisning och rapportering (IAS, FASB)

${ }^{137}$ Se not 132

${ }^{138}$ Ludwig von Bertalanffy (1968) hävdade att biologiska system inom ramen för ekologi måste betraktas som öppna system.
} 
Fenomenet om förändringar i företagens kapitalstruktur har i denna kontext uttolkats som en fråga om hur positionering av företagets resurser sker $\mathrm{d} v \mathrm{~s}$ hur företaget resursbas löpande organiseras. För att möta behovet av en icke-linjär, dynamisk modell för att potentiellt dels kunna förklara fenomenet med 'obalans' i resursbasen i relationen materiella och immateriella resurser, dels förstå effekter av styrningen som exempelvis kontraktion av resursbasen, har i denna avhandling exemplifieras med den fyrfältsmatris som utvecklats av C.S. Holling. Detta som en del av den diskurs som handlar om resiliens vs stabilitet och som redogörs av författaren i dennes rapport. (Holling, 1973)

Även om resilienstänkande anses ha påverkat och utvecklat kunskapen om komplexa system så har den endast i begränsad omfattning avhandlats inom den företagsekonomiska diskursen. Då denna avhandling i teoretisk mening ansluter till ett resilient tänkande avseende förändringen av företagets immateriella resurser dras också en slutsats om företagsekonomiska systems uthållighet och möjliga överlevnad genom ett `hållbart’ ledarskap.

Empirin här utgår ifrån att materiella resurser inte förändras av egen kraft. Immateriella resurser och den förmåga som implicit ingår i organisationen förändrar, enligt avhandlingens slutsats, dess resursbas d v s även materiella resurser. I teori om komplexa naturliga system på antingen makronivå eller mikronivå förutsätt en kontinuerlig inbördes förändrad relation i resursbasen, en viss instabilitet av dess ingående 'element', bidra till systemets 'tillväxt' (positivt eller negativt) och kan potentiellt förklara uppkomsten av ackumulerade värden. Detta kan potentiellt förklara och bidra till ny teoretisk kunskap om det observerade fenomenet.

Denna kunskapsgenerering, som potentiellt medverkar till utveckling av organisationens förmåga, kan i denna avhandlings kontext potentiellt förklara en förändrad relationen mellan materiella och immateriella resurser och därmed som en logisk följd förklara resursbasens utveckling. Den kontext och tidsperiod som avhandlingens empiri omfattar har en karaktär av stora omvärldsförändringar och därmed potentiellt ett behov vid en medveten styrning som innefattar skapande av 'reserver' för att motstå dessa. En teoretisk implikation är att genom applikation av resiliensteori i en företagsekonomisk kontext genomföra analys. ${ }^{139}$ Resiliensteori innehåller dock ett stort mått av oförutsägbarhet avseende applicerbarhet i specifika kontexter, något som kan motverkas med ytterligare empirisk forskning.

Med avseende på en organisations resursbas och fördelningen materiella och immateriella resurser påverkas också möjligheterna att, genom ytterligare studier, förutse implikationer på systemet och dess utveckling och därmed också förstå utformningen av de strategier som väljs. Ett systems `management' som har förmåga att bredda sitt systemsynsätt, har potentiellt goda förutsättningar att välja strategi för att motstå långsiktigt negativa effekter.

Avhandlingen handlar på enhetsnivå om ledningens strategibeslut som en del av styrningens beslutsprocess där frågorna också handlar om för vem och med vem, snarare än vad. Implicit har intressentteori diskuterats som generell förutsättning för att förstå ett breddat systemperspektiv. Här begränsas avhandlingen till ett väl definierat ekosystem där systemets 'externa' intressenter och legitimitetsaspekter på systemet endast avhandlas inom ramen för potentiell partnersamverkan. En teoretisk implikation som uppstår vid analys av

\footnotetext{
${ }^{139}$ Holling gör en distinktion mellan teknisk och ekologisk resiliens (Holling, 1996). Teknisk resiliens (resilience engineering) beskriver Holling som instrumentella och matematiska system med stor förutsägbarhet och beräkningsbarhet.
} 
partnersamverkan är behovet av en utvecklad riskteori, för eventuellt kunna förklara uppkomsten och digniteten av det observerade fenomenet.

I de beslutsprocesser som avhandlats empiriskt diskuterade att ledningens förväntningar i det 'nya' ekosystemet är avgörande för den ekonomiska styrningen. En anledning kan vara att samtliga anställda målföretaget har genomgått utbildning i modern systemteori. ${ }^{140}$ Modern systemteori (Senge, 2006) omfattar teori om konsekvenser av olika strategier för s k lärande organisationer.

Teorin beskriver bland annat balansförhållanden mellan internt respektive externt fokus och de 'problem' som uppkommer vid förväntningar på systemet vid beslutsfattande utifrån dessa två fokus och detta beroende på vilket tidsperspektiv som gäller. I likhet med ekologisk resiliensteori antas systemet utveckla en "egen förmåga" att anpassa sig d v s strategier och styrning måste utgå ifrån de villkor (och implicit systemets outtalade syfte, legitimitet och mål) som gäller en viss kontext.

Någon förväntningsteori som utgår ifrån 'kollektiva' förväntningar insatt i en företagsekonomisk kontext har inte återfunnits i samtida forskning. Ekonomistyrningsteori omfattar begrepp som 'beleif systems', 'visions and system boundaries' etc. (Simons, 1995) men dessa begrepp förklarar inte hur en organisations ledarskaps samlade förväntningar leder till beslut med framtida osäkra resultat och effekter. En teoretisk implikation är behovet av en 'ny' förväntningsteori för att förklara det observerade fenomenet $i$ en specifik kontext kvarstår. Därav avgränsningen till en generell kontext vid hantering av utmaningar i denna avhandling.

En ytterligare teoretisk implikation handlar om begreppet konkurrens. I såväl resursbaserad teori som marknadsbaserad teoribildning definieras organisationens mål som ‘uthållig konkurrensfördel'. En teoretisk utmaning är att tillämpa ett konkurrensbegrepp som implicerar de variabler som ledningen identifieras; såväl finansiella som icke-finansiella mål och mål som kan relatera till organisationens krav på legitimitet i den kontext som avses.

De modeller som, utifrån ett teoretiskt perspektiv, nämns i avhandlingen baseras på resursbaserat synsätt och avhandlar enskilda projekt. 'Nya' företagsekonomiska begrepp som baseras på förädlingsvärde, 'resource margin' och modeller som beräknar värdeförändringar på resursportföljer kan, med hjälp av finansteoretiska modeller (CAPM), potentiellt tillföra företagsekonomi ett delvis nytt betraktelsesätt.

En teoretisk implikation för tillämpning av dessa modeller i avhandlingen är att applicera dem i den, i avhandlingen föreslagna föreställningsramen. En potentiell applikation av modellerna i ramverket får praktiska implikationer i den arbetsmodell som föreslås i avhandlingen.

\subsection{Praktiska implikationer}

Genom de olika case, där intervjuer i avhandlingen genomförts med personer i varierande roller, befattningar och miljöer, visas att ur ett 'internt' ekonomistyrningsperspektiv kan motivationsfaktorer och motivationsforskning potentiellt underlätta förståelsen för hur förväntningsvärden $i$ en organisation/projekt utvecklas $i$ linje med organisationens mål

\footnotetext{
${ }^{140}$ Systemteori utgör också grunden till systemanalys i dess tillämpning inom systemvetenskap och datavetenskap. Systemteori förklarar här snarast det som Holling $\mathrm{m}$ flera avser med tekniska, instrumentella och matematiska (slutna) system. Författarna Dennis m fl (2006) avhandlar systemanalys i denna kontext.
} 
(förutsatt att dessa är tydliga och kommunicerbara). Detta har nämnts som en teoretisk implikation men är samtidigt också praktisk. Här har avhandlingen därför utformat en $\mathrm{s} \mathrm{k}$ arbetsmodell som kan tillämpas av ledningspersoner där individuella tolkningar och prioriteringar är möjliga.

Det resursbaserade synsättet har inom akademi avhandlats som en filosofisk diskurs och mer eller mindre därigenom avfärdats som förklaring till ekonomisk realitet. I denna avhandling lyfts detta synsätt fram som ett alternativ till ett mer marknadsbaserat synsätt och som en företagsekonomisk realitet som i högsta grad realiseras i debatten om hållbar tillväxt och företagens villkor för att uppnå hållbarhetsmål. Den arbetsmodell som utformats med avhandlingens analysmodell som grund kan inte tillämpas där ledningen vid analys tillämpar ett synsätt som prioriterar volymaspekter före kvalitativa aspekter $i$ ett initialt verksamhetsaskede.

I en verklighet med ansträngande volatil utveckling i flera avseenden möter företag, stora som små, tidigt i beslutsprocesser, en verklighet där utvecklingen avgörs dels av tillgång till vissa resursslag som energi och information men framförallt kunskap och förmåga till innovation och samtidigt förmåga till anpassning till omvärldsförändringar. Men också oförtutsägnbarhet. Men med dessa förutsättningar på en faktormarknad för resurser följer också behov att under perioder "spara i ladorna" för att inför mer expansiva perioder kunna genomföra nödvändiga investeringar i såväl strukturkapital som infrastruktur. Den samlade bilden av dessa behov kan karaktäriseras som ett behov av ett väl avpassat innovationskapital; ett kapital som representeras av mer eller mindre identifierade och därmed mer eller mindre andel kapitaliserade immateriella resurser. Vilken dignitet detta innovationskapital har är beroende på den kontext som ledningen omfattar, omfattning av bedömt innovationsbehov, prioritering avseende exempelvis radikal vs inkrementell innovation, förväntningar avseende tillgång till resurser mm.

Det fenomen med en eskalerande andel immateriella resurser och betydelsen av dessa värden är denna avhandlings största utmaning att försöka förklara och därigenom förstå för att sedan kunna tillämpa denna kunskap praktiskt. Ett antal olika perspektiv kan antas vid studier av detta. Immateriella resurser och kapitaliserade immateriella tillgångar ger betydande bidrag till företags resurstillväxt och innovationskapital och därigenom till samhällets utveckling. Men många oklarheter och otydligheter gör att kommunicerbarheten är låg, något som påverkar såväl tillit till marknadens aktörer och kunskap om vad som legitimerar agerande. En implikation av avhandlingen för praktisk tillämpning är att betoningen på tydlighet innebär att gränserna för det som betraktas, och som kan betraktas 'internt' legitimt inklusive i partnerskap och andra samarbeten, kan klargöras.

Ett specifikt område handlar om växande värden av företags deltagande i framtida och innovativa projekt, värden som kommuniceras som immateriella värden och som företagens goodwill. Ett annat 'immateriellt’ område är det växande kunskapskapital, informationsbärare som bland annat är förutsättning för hög innovationsnivå, framsynthet och risktagande. Ett tredje område de energiresurser som implicit påverkar all utveckling, ett område där problematiken snarast handlar om att praktiskt besluta om dispositiva villkor. Samtliga tre är områden där också möjligheterna för kontroll och påverkan är svag på grund den karaktär som dessa resurser utgör med otydlighet utöver nyttjanderätt också omfattar kvalitets- och nyttoaspekter och vilka övriga värden, utöver de finansiella som de representerar. 
Immateriella resurser karaktäriseras i praktiken som svåra att identifiera och kontrollera. Så länge kravet på identifikation inom ramen för en viss kontext inte skärps så kvarstår detta. En slutsats är att om dessa immateriella resurser vs materiella resurser har stor påverkan på kontexten så försvåras den strategiska ekonomiska styrningen. Detta oberoende av om strategierna avser expansion eller konsolidering och om utvecklingsmarknaden förändras snabbt. Denna osäkerhetsaspekt (= risk?) medför ett behov av nya former för att omsätta kunskap till innovation i en lärande organisation.

En praktisk implikation av avhandlingens slutsatser avser risk- respektive osäkerhetsaspekter. En breddad forskning pågår om hur dessa begrepp generellt ska tillämpas praktiskt; bland annat i ett separat ISO-regelverk för applikation i såväl små som stora organisationer. Behovet av en klar distinktion mellan risk, osäkerhet vs den praktiskt tillämpade modellen (SWOT) har inom ramen för standardisering bedömts stort. Det pågår ett omfattande globalt arbete med harmonisering av normgivande och tydliggörande av begrepp och kriterier för 'governance' med hållbara förtecken. Regelsystemen för redovisning såväl som ISO-regelverken har, med delvis olika 'målgrupper', som ambition att primärt formalisera ledningssystem för de ekonomiska system som ska möjliggöra kloka beslut.

Som en praktisk implikation av avhandlingens slutsatser är också ett behov att bedöma risk i en breddad kontext d v s såväl relationsrisker som tekniska och affärsrelaterade risker; risker som inte endast är möjliga att kalkylera $\mathrm{i}$ finansiella termer utan även avseende andra hållbarhetsaspekter (exempelvis risk för plötslig kompetensflykt, energibortfall, miljöbrott, obstruktion, korruption etc). Denna förslagsvis breddade förståelse har framförallt empiriskt framförts av de storleksmässigt mindre, aktörerna i Case INNOHUB.

Den största utmaningen som förespeglas i denna avhandling är att medverka till denna utveckling dels genom att lyssna till de personer som är delaktiga, dels luta mot den forskning som kan bidra med möjlig kunskap.

Många av de praktiska synpunkter som personerna i denna empiri har förmedlat sedan studierna inleddes 2005 har redan genomförts. Målföretaget har organiserats så som indikerats tidigt. Företaget har transformerats genom bland annat en mycket omfattande avyttring och ett antal viktiga förvärv. Inom målföretagets forskningsverksamhet har ett större initiativ genomförts genom att initiera kollaborativ innovation med innovatörer globalt.

Kvarstår dock och har möjligen accentuerats, de otydligheter och behov avseende utvecklingen av immateriella resurser och de möjligheter och den påverkan som en framtidsinriktad ledning måste kunna hantera. Behovet av ett ledningssystem som är 'hållbart' i alla avseenden måste antas vara generellt. Det bidrag som denna avhandling kan ge är förhoppningsvis ett bidrag till en diskussion utifrån ett resursbaserat synsätt och med tillämpning av modeller som baseras på ett breddat systemsynsätt och som ger kunskap om ett flertal alternativa beslutsvägar för att uppnå en i första hand kvalitativ resurstillväxt, ett väl avgränsat innovationskapital och därmed en långsiktig hållbar värdetillväxt för ägare.

En praktisk implikation från genomgången empiri är som nämnts ovan utvecklingen av en arbetsmodell. I avhandlingens redovisning ovan har olika villkor beskrivits avseende utveckling av en robust och kontextneutral beslutsmodell, inkluderande företagets organisering och strategival. Utifrån detta 'betamål' som ett hypotetiskt överställt (och operationaliserbart) mål för samtliga intressenter i det ekosystem för innovation och utveckling som avhandlas, 
föreslås en möjlig arbetsordning; en s k arbetsmodell baserad på föreslaget ramverk för genomförande av strategiskt hållbar ekonomisk styrning.

Denna "nya" arbetsmodell (Figur 38) är en teoretisk konstruktion, ett resultat av att EEM/EEQM-modellen använts dels vid konstruktion av avhandlingens analysmodell (Figur 9) och dels vid utvecklingen av det föreslagna ramverket för integrerad ekonomisk styrning. (Figur 36). Arbetsmodellen omfattar, utöver ramverkets grundelement (A och B) de tre "nya" modellerna utvecklade utifrån analys av genomförd empiri. Dessa tre "nya" modeller benämns för positioneringsmodell, strategimodell och mätmodell, kontextuellt inordnade i analysmodellens och ramverkets struktur i en följd som underlättar tillämpning vid genomförande av strategier. Modellen avser att underlätta dialog samtidigt som det underlättar en analys (ex post) i omvänd ordning. Arbetsmodellen utgår ifrån att långsiktiga beslut om expansion eller konsolidering utifrån organisationens nuvarande position tas innan genomförande strategier beslutas.

I ledningens strategiska arbete, med referens till speciellt Case Force och behovet av mycket långsiktigt perspektiv på en utvecklingsmarknad, är ledningens förmåga att utforma och tillämpa positionskartan avgörande för att den blir ett effektivt verktyg. Valet mellan exploatering respektive konsolidering är svårt. I ledningens förmåga, och förväntningar, måste impliceras de insikter och den förståelse som är unikt för den kontext som beslutet gäller.

De tre modellerna stödjer potentiellt förklaringar av hur olika planerade strategier påverkar de olika elementen av styrningen. Följande samband mellan modellerna kan illustreras, se figur 38:

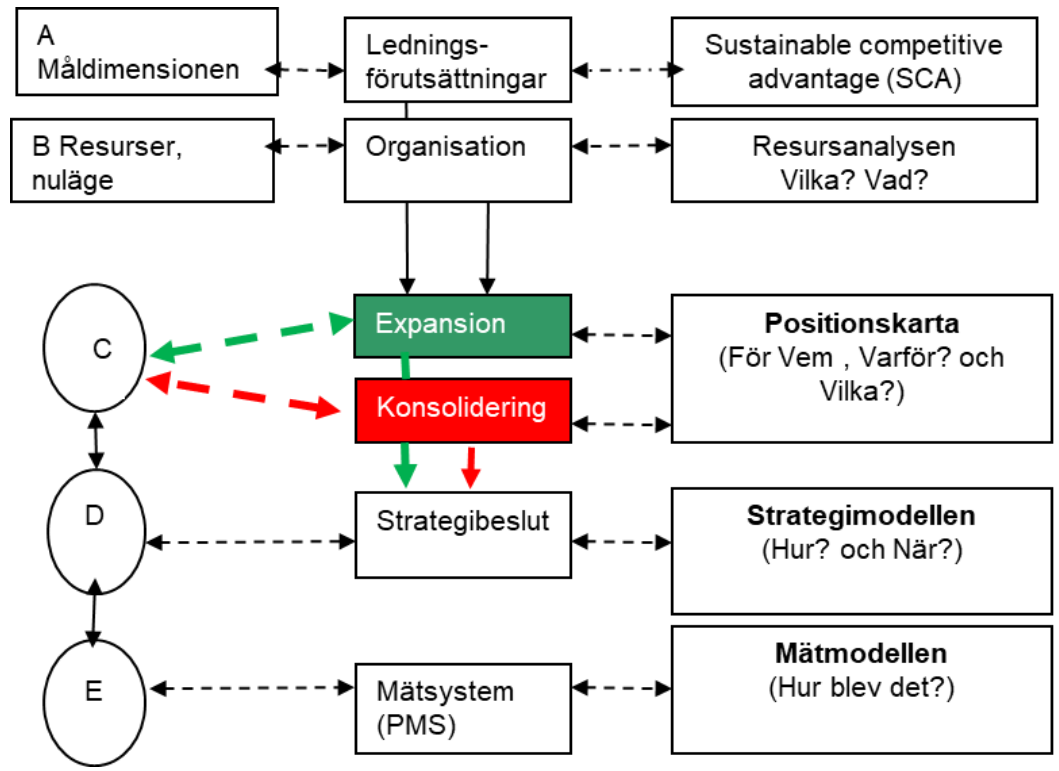

\section{Målstruktur \\ RBV - kriterier för resurser samt definition och identifikation}

Figur 15

Figur 33-35

RBV- kriterier samt nya KPI

Figur 38. En "ny" arbetsmodell. Samband mellan strategivariabler och element i ekonomisk styrning $(\mathrm{C}=$ Organiseringen/positionering, $\mathrm{D}=$ Beslutsprocessen /strategival och $\mathrm{E}=$ Mätprocessen) och relaterat till de tre förklaringsmodellerna som utvecklats i avhandlingens analys av empiri 
Figuren illustrerar och hänvisar till de modeller som var och en förklarar en del av en integrerad strategi-/ekonomistyrning, från målformuleringen till resultatuppföljningen. Modellerna omfattar målbeskrivningen (här som SCA), en modell för genomförande av en resursanalys, en modell (matris) som beskriver kontexten där organisationens strategiska (även potentiella) resurser positioneras, en modell (matris) som beskriver olika strategival och slutligen en modell som beskriver två mätvariabler. Beslut om expansion eller konsolidering (C) är ett överordnat koncernbeslut vid tillämpning av arbetsmodellen och som avser att vägleda ledningens organisering (D) vid vidare strategival.

Respektive modell och relaterad figur beskriver samband som emanerat ur den teoribildning som använts vid analyser av föregående empiri. Analysen av de empiriska studierna och villkoren för organisering, beslut och mätning visade att RBV-kriterier kunde prövas i respektive modell. Exempelvis kunde en avkastningsmodell (enligt DuPont) som valdes som mätvariabel i ett mätsystem (PMS) prövas utifrån kriterier "kapitaleffektivitet" eller "resurseffektivitet" och "return on resources" eller "above normal rent". Valet av mätvariabel, här exemplifierat med "avkastning", påverkar E: mätprocessen och hur den utformas. Några ytterligare resultat och effektvariabler undersöks inte då de är helt kontextrelaterade. Inför fortsatt forskning har ytterligare mätvariabler och nyckeltal att utformats, såväl finansiella (monetära) som icke-finansiella (numerära). De mätmetoder som föreslås ansluter helt till befintliga modeller; bland annat optimering enligt modellen för värdeförändring vid kapitalförvaltning; den s k CAPM-modellen.

\subsection{Förslag till fortsatt forskning}

I sökande efter generellt tillämpningsbara d v s kontextneutrala modeller för att förklara dessa 'nya' mönster och villkor för företags strategiska styrning har ett stort antal utmaningar identifierats inom ramen för de kontextuella systemavgränsningar som gjorts i avhandlingen.

Vissa konceptuella utmaningar uppstod som en direkt effekt av en potentiell tillämpning av detta resursbaserade synsätt. Andra identifierade utmaningar var mer generella vid strategisk styrning. Några av utmaningarna relaterade till och pekade på behovet av fortsatt forskning; bland annat beroende på avsaknad av relevant teori för att förklara nya mönster mm.

Utifrån de modeller och villkor som föreslagits i denna avhandling gäller som generellt förslag till fortsatt forskning att utifrån lämplig hypotesgenerering testa dels om krav på kontextneutralitet uppfylls, dels om de konceptuellt är tillräckliga för att uppfylla kraven att förklara, förstå och tillämpa.

Då kontext handlar om utmaningar och förväntningar i en 'ny' tid föreslås fortsatt forskning omfatta ett längre tidsperspektiv samt omfatta en vidare kontext avseende såväl industrisegment som resursområde.

En specifik och intressant fråga för fortsatt forskning runt det fenomen som identifierats i denna avhandling är exempelvis huruvida företagens samlade förväntningar på koncernnivå påverkar ställningstagande och agerande vad gäller innovationskapitalet (som immateriell resurs) och dess betydelse som företagets bidrag till mål 9 (hållbar industri).

Behovet av fortsatt forskning inom detta forskningsområde, implicit avseende effekter av kunskapsintegration och innovation, måste bedömas som stort bland annat $\mathrm{m}$ a $\mathrm{p}$ 
frågeställningar om hur rådande långtgående obalanser i såväl natur- som finansiella system ska kunna balanseras, obalanser där `rätt' hanteringen av de olika resursslagen är avgörande för systemens överlevnad.

En bedömning är att fortsatt forskning här är både kontextuell och konceptuell. Kontextuellt innebär en utveckling av ett systemsynsätt både en avsmalning med fokusering på 'partikelnivå’ och en breddning med fokusering på de delar av samhälle och 'univers' där företagsamheten berörs och berörs av. En utvärdering av resursbaserade modeller i dessa kontexter bör kunna leda till en ökad grad av generalisering och tillämpning.

Konceptuellt berörs områden som kunskapsintegration och människan förståelse av både epistemologi och ontologi, båda omsatta i praktiska frågeställningar. Behovet av en `grounded theory' för tillämpning vid utveckling av ledningssystem för resurser (RBL) har diskuterats som argument för fortsatt forskning. Forskning inom området kunskapsintegration och innovation pågår. Avhandlingen här pekar på ett behov av ytterligare forskning omkring innovationskapital och lärande; begrepp som `dynamiskt innovationskapital’ (DINNCAP) kan potentiellt förklara företags möjligheter att klara omställningar.

Genom att, med stöd av systemteori och teorier om resilienta system och dessas kännetecken, söka förklaring till det observerade fenomenet i avhandlingen, har en större förståelse uppnåtts. De två system resiliensforskningen representerar, ekologisk resiliens vs teknisk resiliens, har olika utgångspunkter avseende människans möjligheter att påverka systemet och dess 'performance'.

För fortsatt forskning är det angeläget, förutsatt att resursbaserade teorier och resiliensteori anses kunna förklara en strategisk och hållbar styrning, att pröva strategier, såväl empiriskt i organisationer med stort innovationskapital, som med anomalier från exempelvis idrott eller annan skapande och utvecklande verksamhet och över längre tid föränderliga miljöer.

Ett forskningsfält som föreslås som ett resultat av denna avhandling är forskningslogik och kritisk forskning. 
Referenser

Akio, T., (2005)

Amit, R.\& Shoemaker, P.J.H., (1993) Strategic Assets and Organizational Rent

Andrew, K. (1971)

Andersén, J., (2005)

Andersen. T.M., (2015)

Ansoff, H.I., (1965)

Anthony, R.N., (1965)

Anthony, R \& Govindarajan, V., (2007)

Anthony, R.N., Govindarajan, V.,

Hartman, F.G.H., Kraus, K., Nilsson, G Management Control Systems/European Edition (2014)

Argyris, C., Putnam, R., McLain Smith, D., (1990)

Argyres, C., (1996)
Strategic Management Journal 14, 1, 33-46

The concept of Corporate Strategies

Doe Jones, Homewood, In

Strategiska resurser och långvarig lönsamhet. En resursbaserad modell för varaktiga konkurrensfördelar i små tillverkningsföretag Doktorsavhandling (No 11), Mälardalens Högskola

The Welfare State and Economic Performance Bilaga 4 till Långtidsutredningen 2015; SOU 2015:53

The Firm of the future.

Harvard Business review, September 1965

Planning and Control Systems; framework for analysis

Harvard University Press, Boston Graduate School

Management Control System (12 th ed.)

McGraw-Hill, Boston Massachusetts
Action Science

Oxford, San Francisco

Capabilities, technologies diversification and divisionalization

Strategic Management Journal 17,5, 395-410

Den nya ekonomistyrningen

Liber

Barriers to new competition, Harvard University Press, Cambridge

Antecedants to management accounting change: a structural equation approach

Accounting, Organization and Society, 28, 675-698 
Barnat, R., (2007)

Barnes, M.C. et al (1970)

Barney, J., (1991)

Barney, J.B., (1994)

Barney, J. B. and Zajac, E.J., (1996)
The Evaluation And Control Of Organizational Strategy. Kapitel i boken: Strategic Management: Formulation and Implementation. Hämtad 2007.01 http://www.introductiontomanagement.24xls.com/en $\underline{237}$

Company Organization. Theory and Practice George Allen and Unwin Ltd, London

Firm Resources and sustained competitive advantage Journal of Management, 17, 99-120

The Resource-Based Theory of the Firm Organization Science, 7,5,469

Competitive Organizational Behavior;

Toward an Organizationally-Based Theory of competitve advantage

Strategic Management Journal, 15,5-9,

Barney, J.B. \& Ouchi, W., (eds.) (1986) Organizational Economics: Toward a new paradigm for studying and understanding organizations Josossey-Bass, San Francisco, CA

Barney, J.B. and Clark, D.N., (2007) Resource -Based Theory. Creating and Sustaining Competitive Advantage

Oxford University Press, GB

Baumol, W.J., (1967)

Business behavior, value and growth

Harcourt, Brace \& World, Inc. New York

Berggren, C., , Bergek, A.,

Bengtsson, L., Hobday, M.

and Soderlund, J. (2011) (ed.)

Knowledge Integration and Innovation

OUP, Oxford

Berry, A. J., Broadbent, J., Otley, D. T. (2005)

Management control: Theories, issues and performance (2nd ed.).

Basingstoke, UK: Palgrave Macmillan.

Berry, A.J., Coad, A.F., Harris, E.P., Otley, D.T., Stringer, C., (2009)
Emerging themes in management control: a review of recent literature.

British Accounting Review 41, 2-20. 
Bertalanffy, Ludwig von, (1968)

Bisbe, J. \& Otley, D.,(2004)

Bolumole, Y., Frankell, A., \&

Näslund, R., (2007)

Boström, P.S., (2005; 2014; 2021)

Boström, P.S., (2005; 2018; 2021))

Boström, P.S., (2008)

Boström, P.S., (2009)

Boström, P.S., (2015)

Boström, P.S., (2017)

Boström, P.S., (2017)

Boström, P.S., (2018)
General system theory: foundations, development, applications. New York: Braziller

The effects of interactive use of management control systems on product innovation

Accounting, Organization \& Society, 29,709-737

Developing a theoretical framework for logistics outsourcing

Transportation Journal (våren 2007)

Legitimacy as analyzing concept - framing R\&D and sustainable company governance (CATHEDRAL)

(working paper) Linköping University

Critical assessment with process analysis (ROBO) (working paper) Linköping University

The resource-based perspective; A framework for analysing and explaining strategy and control based on the "European Excellence Model"

Conference paper, Qmod, Helsingborg 2008

Exploring Sustainable Competitive Advantage; Modelling Structural Linkages between Resource Based Theory, Dynamic Capabilities and Sustainable Competitive Advantage - a perspective of European Excellence Model

Conference paper, Qmod, Verona 2009

MODE ZERO: Outlining a Model for Integrated Studies and Strategic Research for "Organizational Development and Growth", from the viewpoint of innovative research in $\mathrm{R} \& \mathrm{D}$, in a "sustainable" systemic context, based on the ND-model.

Working paper, Linköping University

"Boken om Resurstillväxt"

Open access: DIVA/Mälardalen University

Exploring a roadmap to Sustainable Competitive Advantage

Conference paper, EBES in Germany, 2017

Exploring a roadmap to Sustainable Growth Conference paper, EBES in Bali, 2018 
Boström, P.S., (2019)

Boulding, K.E., (1956)

Boulding, K.E., (1953)

Brown, R.H., (1978)

Brunsson, N., (1985)

Burell, G. \& Morgan, G.H., (1985)

Burns, J. , (1999)

Burns, J. and Scapens, R.W. , (2000)

Büyüközkan, G.. and

Feyzioglu, O., (2002)

Carlsson, L., (2001)

Caroll, Archie B., (1979)

Chang, W. and Hsieh,J., (2011)
Dynamic Innovation Capital (DINNCAP). To evaluate change of innovation capital in open innovation

Conference paper, EBES in GB, 2019

General Systems Theory - the skeleton of Science

Management Science 2,3, s 197- 209

Towards a General Theory of Growth

Canadian Journal of Economics and political science, 19 Aug, 1953, 326-340

Bureaucracy as praxis; toward a political phenomenology of formal organizations

Administartive Science Quaterly, 23, 365-382

The irrational Organization

Wiley, $N$ Y

Sociological Paradigm and Organizational Analysis Aldershot; Gower

The dynamics of accounting change: inter-play between new practices, routines, institutions, power and politics

Accounting, Auditing \& accountability Journal, 13, 5, 566-596

Conceptualizing managment accounting change: an institutional framework

Management Accounting Research 11, 3-25

A fuzzy-logic-based decision-making approach for new product development

International journal of production economics; 16

Framväxten av intern redovisning i Sverige

Doktorsavhandling, Uppsala Universitet no 86

A three-dimensional Conceptual Model of corporate performance

The Academy of Management review, 4,4,497-505

Intellectual Capital and Value Creation- Is Innovation Capital a Missing Link?

International Journal of Business and Management Vol.6.2 
Chau, V.S and Witcher, B.J., (2007) Dynamic capabilities for strategic team performance management: the case of Nissan

Team Performance Management, Vol 14,3,4 pp 179191, Emerald

Chenhall, R., (2003)

Management control systems design within its organizational context findings from contingencybased research and direction for the future

Accounting, Organizations and Society, 28,127-168

Chenhall,R. and Langfield-Smith, K., The role of Gainsharing and Performance Measure (1986)

Child , J.\& Kieser, A.,(1981)

as part of Strategic Change (working paper)

Development of organizations over time

In Handbook of Organizational Design; ed. Nyström.

P.C., Starbuck, W.H.

New York, Oxford University Press,

Coase, R., (1988)

The Nature of the Firm; Origin meaning and influences

Journal of Law, Economics and Organization 3, 47

Collis, D.J., (1994)

Research Note: How valuable are organizational capabilities?

Strategic Management Journal, 15,143-152

Combs, J.G. and Ketchen, D.J.,(1999) Explaining interfirm cooperation and performance: toward a reconciliation of predictions from resourcebased view and organizational economics

Strategic Management Journal, 20, 867-888

Conner, K. R. \& Prahalad, C.K., (1996) A Resource-based Theory of the Firm; Knowledge versus Opportunism

Organizational Science, 7,5, 477-501

Cyert, R and March, J., (1958)

Cyert, R. and March, J., (1963)

The role of expectations in business decision making Administrative Science Quarterly3, 307-34

A Behavioural Theory of the Firm

Prentice-Hall, Englewood Cliffs, N Y

Czarniawska, B. and Wolff, R. (2007) How we decide and how we act - on the assumptions of Viking Organization Theory

in: Organization Industrial Development, $N Y$,: de Gruyter, 139-150 (ed. by $R$ Wolff) 
Dahlgaard-Park, S. M., (2008)

Daly, H. E., \& Townsend, K.N., (1993) VALUING THE EARTH: Economics, Ecology,

Davila, T., (2000)

Dechow, N. \& Mouritsen, J., (2005)

Deming, W. Edwards (1986).

Deming, W. Edwards (2009)

Dennis, A., Wixom, B.H. and Roth, R.M., (2006)

Denzin, N.K., (1978)

Dierickx, I. and Cool, K., (1989)

Da Giau, et al, (2020).

Dowling, J \& Pfeffer, J., (1975)

Drucker, P. F., (2003)

Eisenhart, K. M. \& Martin, J.A., (2000) Dynamic Capabilities: What are they?

Eisenhardt, K.M., (1989) Ethics)

Strategic Management Journal, 21, 1105-1121

Reviewing The European Excellence Model from a Management Control View

The TQM Journal

An empirical study on the drivers of management control systems' design in new product development Accounting, Organization \& Society, 25, 383 - 409

Enterprise resource planning systems, management control and the quest for integration.

Accounting Organizations and Society 10/2005

Out of the crisis.

Cambridge University, MA USA

Taking the first step with PDCA.

(Retrieved 17 March 2011)

(The "Deming -cycle" after S. Mizuno of the

Tokyo Institute of Technology in 1959)

System Analysis Design

Wiley

Triangulation

In The Blackwell Encyclopedia of Sociology

Asset Stock Accumulation and the Sustainability of Competitive Advantage

Management Science, 32.10, 1231-1241

Sustainable development and dynamic capabilities in the fashion industry: A multi-case study in: Corporate Social Responsibility and EnvironmentalManagement Volume 28, Issue 4 July/August 2021

Organizational legitimacy

Pacific sociological review, IP 122-126

"Management Challenges for the 21 st Century"

Agency Theory: An Assessment and Review Academy of Management Review, 14, 57-74. 
Eklund, C., (2005)

Eliasson, G., (1985)

Eliasson, G., (2000)

Elkington, J., (2004)

Fama, E.F. and Jensen, M. C., (1983)

Foss, N. (ed.) (1997)

Freeman, RE., (1984)

Freeman, RE et al. (2010)

Frooman, J., (1999)

Galunic, D.C. \& Rodan, S., (1998)

Garnsey. E., (1993)

Gerdin, U. och Greve, J., (2004)

Giddens, A., (1984)
Vår ekonomi

Tidens Förlag

The Firm and Financial Markets

IUI, Stockholm

Making Intangibles Visible: The Value, the Efficiency and the Economic Consequences of Knowledge in: Buigttes-Jacquenip-Marchipont, 2000, Competitiveness and the Value of Intangible Assets Edvard Elgar, 2000, Cheltenham, UK

Enter the Triple Bottom Line (Electronic subscription, Sustain Ability Conference)

Separation of ownership and control

Journal of Law and Economics, XXVI

"Resources, Firms and Strategies" Oxford University press www.theantidote.co.uk/read/articles/rbvstrategy.html

Strategic Management. A Stakeholder Approach Marshfield MA: Pitman, Boston

Stakeholder Theory. The state of Art Camebridge University Press, Camebridge, UK

Stakeholder influence Strategies The Academy of Management review, 24, 191-205

Resource combination in the Firm: knowledge structures and the potential for Schumpeterian innovation

Strategic Management Journal 19, 1193-1201

Exploring a critical system perspective Innovation in Social Science Research, vol 6 no 2 1993: 229-256

Forms of contingency fit in management accounting research; a critical review

Accounting Organizations and Society, 29, 303-326

The Constitution of Society

Cambridge, Polity Press 
Govindarajan,V. and Fisher J., (1990) Strategy, control systems, and resource sharing; effects on business unit performance

Academy of Management Journal, 33,2, 259-285

Grant, R. M., (1991)

The Resource Based Theory of Competitive Advantage: Implications for Strategy Formulation, California Management Review, 33, pp. 114-135

Grant, R. M., (1996)

Toward a knowledge-based theory of the Firm Strategic Management Journal 17,109-122

Greiner, L., (1972)

Evolution and revolution as Organizations grow Harward Business Review, Jul-Aug, 37-46

Grufman, A., (2001)

Simpler Management.

Ekerlids förlag.

Gunderson, L.H., Allen, C.R and Holling, C.S., (ed) (2010)

Foundations of Ecological Resilience Island Press, Washington (Conn), USA

Habermas, J., (1984)

Den rationella övertygelsen (en antologi) Akademilitteratur

Hales, C., (1993)

Managing through organizations Routledge, London

Hall, R., (1992)

The Strategic Analysis of Intangible Resources Strategic Management Journal, 13,2,135-144

Hall. R., (1993)

A Framework Linking Intangible Resources and Capabilities to Sustainable Competitive Advantage Strategic Management Journal, 14,8,607-618

Hand, J. and Lev, B., (2003)

Intangible assets. Values, measures and risks. Oxford University Press

Hannan, T. M. and Freeman, J., (1984) Structural inertia and Organizational Change American Sociological Review, 49, 2, 149-164

Henri, J-F., (2006)

Management control systems and strategy: A resource-based perspective Accounting, Organizations and Society 31, 529-558

Hempel, C.G., (1952)

The function of general laws in history. Journal of Philosophy 39 (2):35-48 
Hirschman, A. O., (1970)

Hinings, C.R., (1997)

Hitt, A., (2007)

Holling, C.S., (1973)

Holling, C. S., (1986)

Holling, C.S., (1996)

Holmström, M., (1995)

Exit, voice and loyalty: Responses to decline in firms, organization and states.

Harward University press, Boston.

Reflections on processual research

Scandinavian Journal of Management, 13. 493-503,

The Management of Strategy

South-Western Cengage Learning

Resilience and Stability of Ecological Systems, Annual Review of Ecology and Systematics, Volume 4, pp. 1-23. 1973 by Annual Reviews Inc.

The resilience of Terrestial Ecosystems; Local surprice and global change

in Sustainable Development of the Biosphere ed. Clark, W.C and Munn, R.E., IIASA, Laxenberg

Engineering resilience vs. ecological resilience.

In Engineering within ecological constraints, 31-43, ed. P.C. Schultze, National Academy Press, Washington

Styrning i storföretag. En studie av styrningens utformning i tre svenska koncerner.

Doktorsavhandling (no 29,Linköpings Universitet

Hollnagel, E., Woods, D.D.

and Leveson, N., (ed.) (2006)

Resilience engineering - concepts and precepts Ashgate Publishing Limited, Surrey, England

Hollnagel, E., Partes, J. ,Woods, D.D and

Wreathall,J., (ed.) (2011),

IP Close Up (2019)

Ireland, R.D. and Hoskinsson, R.and Jetter, A.J.M. , (2003)

Jeurissen, R., (2004)
Resilience engineering in Practice,

Ashgate Publishing Limited, Surrey, England

Intangible asset; Finacial reporting impact (2019)

https://ipcloseup.com/2019/06/04/21-trillion-in-u-s-

intangible-asset-value-is-84-of-sp-500-value-ip-rights-

and-reputation-included/ Hämtad 20201115

Educating the guess: Strategies, Concepts and Tools for the Fuzzy Front End of product Development RWTH Aachen University, Technology and innovation management, Aachen, Germany

Institutional Conditions of Corporate citizenship

Journal of Business Ethics, 53, 87-96 
Johansson, U. \& Holland, J., (2003)

Johansson, U, Mårtensson, M. och Skoog, M., (2001)

Johnsson, P., (2007)

Johnson, P and Thomas, H., (2007)
Value relevant information on corporate intangibles Journal of intellectual capital, vol. 4, no 4

Mobilizing change through the management control of intangibles;

Accounting, Organizations and Society, 26, 715-733

Astute competition. The economics of strategic Diversity

EBSCO Publishing/Elsevier

Resource Margin Accounting. An alucidation and preliminary empirical testing. V1 45,3, 420-433

Management Decision, Emerald Group

Kaplan, R. S., Mikes, A. Simons, R., Tufano, P. and Hofmann, M (Jr.) (2009) "Managing Risk in the New World."

Harvard Business Review 87, no. 10 (October 2009): 68-75. .

v. Kersbergen, K \& Warden, V., (2001)Government as bridge between ....and stakeholder theory European Journal of Politics, 43. 143-171

Katz, D and Kahn, R. L.,(1966)

Kiel, L. D., (1994)

Kogut,B. \& Zander, U., (1992)
The social psychology of Organizations NY, Wiley

Chaos Theory and disaster response management: lesions for managing periods of extreme (conference paper) University of Texas

Knowledge of the Firm, combinative capabilities, and the replication of Technology

Organization Science, 3,383-397

Kowalkowski, Kindström och Witell, (2011)

Internalisation or externalisation? Examining organisational arrangements for industrial services Linköping University post print

Krishnan,V. and Ulrich, K.T., (2001) Product Development Decisions: A review of the Literature

Management Science 47, 1, 1-21

Kuhn, T. S., (1970)

The Structure of Scientific Revolution (2 ed.)

University of Chicago Press, Chicago 
Lakemond, N. och Tell, F., ed. (2016) Öppen Innovation- i teori och praktik.

Studentlitteratur, Lund

Langfield-Smidt, K., (1997)

Lindell, P., (1992)

Linnskog, L., (2007)

Lindwall, J., (2001)

Lindwall, J. och Nilsson, F., (2008)

Locket, A., (2005)

Lose,T. \& Tengeh, R.K.; (2015)

Lukka, K. and Vinnari, E., (2014)

Lukka, K. and Vinnari, E., (2017)

Macintosh, N.B., (1994)
Management Control Systems and Strategy: A critical review

Accounting, Organization \& Society, 22, 2,207-232

Strategisk styrning och förändring. En begreppsutredning baserad på en studie av Swedish Match 1960-1987.

Doktorsavhandling (No 22),Linköpings Universitet

Technological Change in an International Industrial System

Doktorsavhandling (No 47), Mälardalen University

Verksamhetsstyrning; från traditionell ekonomistyrning till modern verksamhetsstyrning Studentlitteratur

Underlättar affärssystemet en strategisk styrning?

" (Detta kompletteras f $\mathbf{n}$ )

Edith Penrose's Legacy to the Resource-Based View Managerial and Decision Economics 26, 83-98

The sustainability and challenges of Business Incubators in the Western Cape Province, South Africa

Sustainability, 7,14344; doi:10.3390/su71014344

(open access)

Domain theory and method theory in management accounting research

Accounting, Auditing \& Accountability Journal, 27,8

Combining actor-network theory with interventionistic research: present state and future potential

Accounting, Auditing \& Accountability Journal, 30,3

Management and Acciunting and Control Systems

An organizational and behavioural Approach

Wiley, England

Mahoney, J. T. \& Pandian, J. R., (1992) The resource based view in conversation of Strategic Management

Strategic Management Journal, 13 
Malmi, T.; Brown, D.A., (2008)

Mansfield, E., (1969)

March, J.G., (1991)

March, J.G., (1994)

Marginsson, D.W., (2002)

Marton, J., Lundqvist, P. och

Petterson, A.K., (2018)

McKelvey, (1973)

McKenna, J.P., (1970)
Management control systems as a package: Opportunities, challenges and research directions. Manag. Account. Res. 2008, 19, 287-300, doi:10 .

The economics of technological change

Longmans

Exploration and exploitation in Organizational Learning

Organization Science, 2, 1,71-87

A primer in decision making

Free Press, New York

Management Control Systems and their effects on strategy formation at middle management levels: evidence from a UK organization

Strategic Management Journal, 23,1019-1031

IFRS i teori och praktik

Sanoma Utbildning, Stockholm

Mineral resource estimates and public policy in US mineral Reserve

Washington DC

Aggregate Economic Analysis

Holt, Reinhart and Winston, Toronto

Merchant, K.A., \&Van der Stede, W.A., Management Control Systems; Performance

(2003)

Measurement, Evaluation and Incentives

Pearson Education Ltd, Essex, England

Merchant, K.A., \&Van der Stede, W.A., Management Control Systems;

(2007)

Performance Measurement, Evaluation and Incentive Prentice Hall Financial Times

Merchant, K.A., \& Simons, R.,(1986) Research and Control in complex organizations: An overview

Journal of Accounting Literature, 5,183-203

Mischel, W., \& Shoda, Y., (1995)

A cognitive-affective system theory of personality: Reconceptualizing situations, dispositions, dynamics, and invariance in personality structure. Psychological Review, 102(2), 246-268

Miles, R.E. and Snow, C.C., (2005) Collaborative entrepreneurship; how communities of networked firms use continuous innovation to create economic wealth

Stanford, Calif. : Stanford Business Books 
Miller, P. and Leary, T., (1987)

Miller, P. and Napier, C., (1993)

Mintzberg, H., (1978)

Mintzberg, H., \&

Van der Heyden, L., (1999)

Moldaschl, M.and Fisher,D., (2004)

Mouritzen. J., Larsen, H. T., Bukh, P.N.D., (2001)

Moustakas, C., (1990)

Nelson, R. and Winters, S., (1982)

Newbert, S. L. , (2007),

Newbert, S. L. \& Tornikoski, E.T., (2007)

Newbert, S. L., (2008)

Nilsson, F., (1997)
Accounting and the construction of the governable person

Accounting, Organizations and Society, 12.3.235-256

Genealogies of Calculations

Accounting, Organizations and Society, 18,631-647

Patterns in Strategy Formation

Management Science 24, 934-948

Drawing How Companies Really Work. Harvard Business Review. Sep/Oct99

Beyond resource based view

Management review, vol. 12, issue 3,

Intellectual capital and the capable firm:: narrating, visualizing and numbering for manageing knowledge Accounting and Organizing Society 26, 735-762

Heuristic Research; design, Methodology, and Applications

SAGE Publications, Newbury Park, Calif

An Evolutionary Theory of EconomicChange

Harward University Press, Cambridge, Ma

"Empirical Research on the Resource Based Theory of the Firm; An assessment and suggestions for future research," "Empirical research on the resource-based view of the firm:

Strategic Management Journal, 28(2), 2007121-146

"Exploring the determinants of organizational emergence: "A legitimacy perspective," Journal of Business Venturing, 22(2,

"Value, rareness, competitive advantage, and performance: A conceptual-level empirical investigation of the resource-based view of the firm," Strategic Management Journal, 29(7)

Strategi och ekonomisk styrning: en studie av hur ekonomiska styrsystem utformas och används efter företagsförvärv Avhandling, Linköpings universitet 
Nilsson, F., (2002)

Nilson, F. och Olve, N-G.(red.) 2013) Controllerhandboken

Nilsson, F \& Rapp, B., (2005)

Nonaka, I., (1994)

Nonaka, I. and Takeuchi, H., (1995)

Normann, B., (2001)

Nyström, H., (1974)

Olson, O., (1983)

Olve m fl (2003)

Otely, D., (1999)

Otley, D., Broadbent, J. \& Berry, A., (1995)

Ouchi, W.G., (1979)

Ouchi, W.G., (1980)

Oxelheim,. L., \& Wihlborg, C., (2005)
Strategy and management control systems, a study of design and use of management control systems following take-over

Accounting and Finance, 42, 41-71

\section{Liber}

Understanding competitive advantage: the importance of strategic congruence and integrated control, Berlin ; London : Springer, 2005

A dynamic theory of Knowledge creation Organization Science, 5,1,14-37

The knowledge-creating company; how Japanese companies create the dynamics of innovation New York : Oxford University Press

När kartan förändrar landskapet Liber ekonomi

Företagskreativitet och innovationer Norstedts, Stockholm

Ansvar och ändamål. Doxa. Lund)

Making scorecards actionable : balancing strategy and control Chichester : Wiley, Cop.

Performance Management: A framework for management control systems research.

Management Accounting Research, 10, 363-382

Research in Management Control: An overview of its Development

British Journal of Management, 6,31-44

A conceptual framework for the design of organizational control mechanisms. Management Science,25,833-848

Markets, Bureaucracies, and Clans Administrative Science Quarterly, 25,1,129-141

Corporate Performance and the Exposure to Macroeconomic Fluctuations 


\section{Norstedts Akademiska förlag}

Pacheco-de-Almeida, G. \& Zemsky, P., The Timing of Resource Development and (2007) Sustainable Competitive Advantage Management Science, 53,4,651-666

Peirce, Charles S., (1990)

Penrose, E., (1952)

Penrose, E., (1959)

Peters, T. \& Waterman, X. (1984)

Peteraf, A. M., (1993)

Pettigrew, A. M., (1997)

Pettigrew, A. M., (1992)

Pitelis, C., (2005)

Pfeffer, J., (1982).

Pfeffer, J and Salancik, G.R., (1978)

Poole, M.S. and Van de Ven, A.H., (2004)

Polanyi, M. , (1962)
Pragmatism och kosmologi

Bokförlaget Daidalos, Göteborg

Biological analogies in the theory of the Firm American Economic Review 4 804,19

The Theory of the Growth of the Firm White Plains, NY: M.E Sharpe

John Wiley, New York, 1959

In Search of Excellence: Lessons from America's Best-Run Companies.

New York: Harper \& Row, Publishers. pp. xx,xxi$x x i i, x x v$

The cornerstone of competitive advantage: A Resource-Based View

Strategic Management Journal, 14,3,179-191

What is a processual analysis?

Scandinavian Journal of Management, 13, 337-348,

The character and significance of strategy process research.

Strategic Management Journal 13, 5-16

Edith Penrose, organisational economics and business strategy: an assessment and extension

John Wiley \& Sons, Ltd

Organizations and organization theory

Pitman, Marshfield. Mass.

The External Control of Organizations; A Resource Dependence Perspective

Harper \& Row, NY

Handbook of organizational change and innovation New York : Oxford University Press

Personal Knowledge towards a post-critical philosophy

Routledge Kegan Paul Ltd 
Popper, K. (1959)

Porter, M.E. (1979)

Porter, M. E., (1985)

Porter, M.E., (1990)

Porter, M.E., (1991)
The logic of Scientific Discovery

Springer, Huthinsson \& Co (Hutch)

"How fompetitive forces
strategy",

Business Review, March/April 1979.

Competitive Advantage; creating and sustaining superior performance

Free Press, New York

The corporate advantage of nations

Free Press, New York

Porter on Competition and Strategy

Boston, Mass

Powell,W.W. and DiMaggio, P.J. (ed.) The new institutionalism in Organizational Analysis. (1991)

Chicago.

Prahalad, C. K., \& Hamel, G., (1994) Strategy as a field of study; Why search for a new paradigm?

Strategic Management Journal 15,5-16

Prahalad, C. K., \& Hamel, G., (1990) The Core Competence of the Corporation, Harvard Business Review, 82, 79-91

Preston, A.M., Cooper, D.J. and

Coombs, R.W., (1992)

Fabricating Budgets; a study of the production of managing budgeting in national health service

Prencipe, A., Davies, D., and

Hobday, M., (ed.) (2003)

"The Business of Systems Integration"

Oxford University Press

Priem, R.L. \& Butler, J.E., (2001) Tautology in the Resource-Based View and the Implications of Externally Determined Resource Value: Further Comments

The Academy of Management Review, 26,1,57-66

Priem, R.L. \& Butler, J.E., (2001) Is the resource based "view" a useful perspective for strategic management research?

The Academy of Management Review, 26,1,22-40

Resnik, D. B., (1998)

The Ethics of Science: An Introduction

Routledge, $N Y$ 
Remneland Wikhamn, B., (2020)

Richardsson, G.B., (1972)

Richardsson, G.B., (2002)
Företagsinitierade innovationshubbar i Sverige: 18 exempel samt ett designramverk Vinnova

The Organization of Industry

Economic Journal, 82,883-896

Mrs Penrose and Neoclassical Theory; in Pitelis 2002, 37-44

Robins, J. and Wiersema, M. F., (1995) A Resource-Based Approach to Multibusiness Firms: Empirical Analysis of Portfolio Interrelationships and Corporate Financial Performance Strategic Management Journal, 16

Rumelt, R.P, Schendel,D, Teece, D.J. Strategic Management and Economics (1991) Strategic Management Journal, 12,5-29

Rothbauer, P.M., (2008)

Triangulation.

In:Given, L., Ed., The SAGE Encyclopedia of Qualitative Research Methods, Sage Publications, Calif

Sandkull, B., (2006)

En vetenskapsteoretisk orientering för metodreflektioner vid företagsstudier Studentlitteratur

Scapens, R.W., (1994)

Never mind the gap: towards an institutional perspective on management accounting practice

Management Accounting Research, 5, 301-321

Schein, E., (1971)

Organisationspsykologi

Wahlström och Widstrand (Prentice Hall, 1965)

Schultz, W. C \& Hofer, C.W.,(1999) Creating value with entrepreneurial leadership and skill-based strategies

New York : Elsevier,

Scheerens, J., (1990).

School Effectiveness and the Development of Process Indicators of School Functioning.

School Effectiveness and School Improvement, 1, 6180 .

Schumpeter, J., (1994)

Om skapande förstörelse och entreprenörskap (i urval av R Swedberg)

City University Press, Ratio klassiker, Stockholm 
Schumpeter, J., (1934)

Schön, D. A.,(1983)

Scott, W.R., (1998)

Senge, P., (1990, 2006)

Shoemaker, P.J., (1990)

Silverman, B.S., (1999)

Simon, H. A.,(1982).

Simons, R., (1994)

Simons, R., (1995)

Simons, R., (1995)

Simons, R., (2000)
The Theory of Economic Development. An inquiry into profits, capital, credit, interest, and the business cycle

Översatt från tyska av Redvers Opie. Harvard University Press, Cambridge MASS

The reflective Practioner; how professionals Think in Action

Basic Books, Inc., Publishers, N Y

Organizations: Rational, Natural and Open systems

Englewood Cliffs, NJ: Prentice Hall

"The fifth discipline" The art and practice of learning organizations.

New York: Doubleday currency.

Strategy, complexity and economic rent

Management Science 36, 1178 - 1192

Technological resources and the direction of corporate diversification; Toward an integration of resource based view and transaction cost economics

Management Science 45,1109-1124

"Models of bounded rationality" Volume 2:

Behavioural Economics and Business Organizations" The MIT Press, Cambridge, Massachusetts, London

How New Top Managers Use Control Systems as Levers of Strategic Renewal

Strategic management Journal, 15, 3, 169-189

The role of management control systems in creating competitive advantage: new perspectives

Accounting, Organization \& Society, 15, 27-143

Levers of control : How managers use innovative control systems to drive strategic renewal

Howard Business School Press, Boston, Mass

Performance measurement \& Control Systems for implementing Strategy: Text and Cases

Pearson, New Jersey

Sirmond, G., Hitt, M.A. \& Ireland, R.D., Managing firm resources in dynamic environment (2007)

Academy of Management review, 32,1,273-29 
Stock, I., (2016)

Sraffa, P., (1960)

Stacey, R., (1993)

Sundström, A., (2015)

Sztompka, P., (1991)

Söderbaum, P., (1975)

Taleb, N.N., (2008)

Teece, D.J and Pisano, G., (1994)
Getting engaged with incubators- The case of Startplatz (Masteruppsats)

Dept. of Business Studies, Uppsala Universitet

Production of Commodities by Means of Commodities: Prelude to a Critique of Economic Theory.

On the principals of political economy and taxation, Vol 1, Cambridge University Press

Strategy as order Emergies from Chaos

Long Range Planning, 26,1,23-29

Old Swedish business in new international clothes Doktorsavhandling 186, Mälardalen University Press

Society in action: The theory of social becoming University of Chicago Press, Chicago, IL

Positionsanalys vid beslutsfattande och planering Scandinavian University Books

The Black Swan

Penquin Books, GB

The Dynamic Capabilities of Firms; an introduction. Industrial and Corporate Change, 3.3, 537 - 556

Teece, D.J. and Pisano, G. and Shuen, A., (1997)

Dynamic capabilities and Strategic Management Scandinavian Management Journal, 18, 509-533

Teece, D.J., (2007)

Explicating dynamic capabilities: The nature and microfoundations of (sustainable) enterprise performance

Strategic Management Journal, 28 (13), 1319-1350

Teece, D.J., (2009)

Dynamic capabilities and strategic management; organizing for innovation and growth Oxford University Press, Oxford

Thompson, D.J., (1967)

Organizations in action

McGraw Hill

Thompson, D.J., (1971)

Hur organisationer fungerar

Prisma 
Thompson, S. \& Wright, M., (2005)

Edith Penrose's Contribution to Economics and Strategy: An Overview

Managerial and Decision Economics 26, 57 - 66

Tushman, M.L. and Anderson, P.C., $\quad$ Managing Strategic Innovation And Change:

In: Collection of readings Oxford University Press

Törnblom, K. M., (ed.) (2004)

Proceedings GRASP 2004

Conference paper, GRASP conference

Upton, W.S., (2003)

Challenges for the new economy for business and financial reporting

In Hand \& Lev (ed.): Intangible assets: Values, measures and risk, 487-510

Oxford University press, Oxford

Varnes, C.J., \& Mikkola, J.H., (2005) Development

Creativity and Innovation management, 14,4,384-392

Van de Ven, A.H., (1986)

Central problems in the management of innovations

Management Science, 32,5,590-607

Van de Ven, A.H., (1992)

Suggestions for studying strategy process: a research note.

Strategic Management Journal 13, 169-188

Van De Ven, A. H. och Poole, M. S., Explaining development and change in (1995)

organizations"

Academy of Management Review 20, 510-540

Van der Meer - Koistra \& Scapens, R., The Governance of Lateral Relations between and (2004)

within organizations $w w w$.researchgate.net

von Bertalanffy, L., (1968)

General Systems Theory

New York. Braziller.

von Krogh, G., Nonaka, I. \&.

Knowledge creation : a source of value / edited by

Nishiguchi, T., (2000)

Basingstoke : Macmillan ; New York : St. Martin's

von Wright, Georg H., (1988)

Vetenskapen och förnuftet

Månpocket, Stockholm

Watts, R.L, \& Zimmerman, J.L., (1978) Towards a Positive Theory of the determination of Accounting Standards

Graduate School of Management, University of

Rochester

Watts, R.L, \& Zimmerman, J.L., (2006) Positive Accounting Theory. 


\section{Prentice-Hall Inc.}

Waddock, S., (2004)

Weber, M., (1978)

Weik, K.E., (1974)

Wernerfeldt, B., (1984)

West-Churchman, C., (1975)

Whetten, D.A., (1989)

Whitley, R., (1999)

Widener, S.K., (2006)

Wiener, N., (1948)

Wigblad, R., (1997)

Williamsson, O.E., (1975)

Williamsson, O.E., (1979)
Creating Corporate Accountability: Foundational Principles to Make Corporate Citizenship real Journal of Business Etichs 00, 1-15

Economy and Society: outline of interpretive sociology (vol 2)

Ed. Guenther Roth and Claus Wittich

University of California Press,, Berkley, LA, Calif

Amendments of Organizational Theorizing

The Academy of Management Journal, 17,3,487-502

RBV. A Resource Based View of the Firm

Strategic Management Journal, 5: 171-180

Systemanalys

Raben \& Sjögren

What Constitutes a Theoretical Contribution? Academy of Management Review, vol. 14, no. 4, pp. 490-495.

Firms, institutions and Management Control; the comparative analysis of coordination and control systems

Accounting, Organization and Society, 24,507-524

Associations between strategic resource importance and performance measure use: The impact on firm performance

Management Accounting Research, 17,433-457

Cybernetics or Control and Communication in the Animal and the Machine,

Hermann \& Cie Editeurs, Paris, The Technology Press, Cambridge, Mass., John Wiley \& Sons Inc., New York,

Karta över vetenskapliga samband

Studentlitteratur

The Economics of Organisation: The transaction cost approach

Working paper no 96, Philadelfia

Transaction cost economics; the Governance of Contractual Relations

Journal of Law and Economics, 22,233-261 
Witcher,B.J. and Chau,V.S., (2007)

Vroom, V. H., (1964)

Yin, R.K., (1994)

Zajac, E., (1995)

Zeidler, K., (2018)
Balanced Scorecard and Hoshin Kanri;Dynamic capabilities for managing strategic fit

Management Decision, 45, 518-538

Work and motivation.

New York: Wiley

Case Study Research: Design and Methods

(Second Edition) Sage Publications

SMJ 1994 Best Paper Prize to Birger Wernerfelt, Strategic Management Journal, 1

Det Svenska undret

Pagina Group, Stockholm

Internetkällor (utan författare)

Tillväxtverkets hemsida (uppdaterad 2019-09-26)

https://tillvaxtverket.se/om-tillvaxtverket/uppdrag/hallbar-tillvaxt.html

hämtad 2019-09-29

Intangible asset; Financial reporting impact (2019)

https://ipcloseup.com/2019/06/04/21-trillion-in-u-s-intangible-asset-value-is-84-of-sp-500-value-iprights-and-reputation-included/ Hämtad 20201115

Intangible Asset Market Value Study (uppdaterad 2020-09-22)

http://www. oceantomo.com/intangible-asset-market-value-study

hämtad 2020-09-29 


\section{Bilagor}

Här redovisas dels separat de två inledande fallstudierna (Bilaga A, B). Vidare ges några avidentifierade exempel från delar av studien med ett urval av protokoll (Bilagorna 2 till 6) samtal mm två av författarens egna sammanställningar av bakgrundsinformation (Bilagorna 7 och 8).

Fallstudier:

$\begin{array}{ll}\text { Case ROBO } & \text { (Bilaga A) } \\ \text { Case CATHEDRAL } & \text { (Bilaga B) }\end{array}$

Case CATHEDRAL (Bilaga B)

Från förstudier samt Case ROBO och Case CATHEDRAL:

Bilaga 1(a) (PP) 2003 Möte BU FoU/CR (T E)

Bilaga 1(b) (PP) 2003 Möte lednings-/ referensgrupp kontakt med ansvarig för extern forskning samt CS (G W, ansvarig för miljöstaben) (s 93 not 65)

Bilaga 1(c) Exempel på brainstorming med lednings-/ referensgrupp (2003)

Från Case FORCE:

Bilaga 2 a Styrgruppsmöte 2 2005-02-11(Exempel: planering BC 3) Beslut om Forskningsprojektet

Bilaga 2 b Intervju 2008-06-13 (Intervjuexempel) från möte med ansvarig för BU 3 (P E) och om Projektet FORCE (s 93 not 66)

Bilaga 3 Frågeformulär, ledningsgrupp BU 3 (engelsk) (2006-06-19) (s.93 not 66, s.95 not 69)

Från Case INNOHUB

Bilaga 4: Exempel på enkätfrågor (with reference to Stock, 2016)

Bilaga 5: Exempel på enkätfrågor .01, .02

Bilaga 6: Det "nya" öppna innovationssystemet; inkubatorns plats i organisering av systemet

Författarens sammanställningar, underlag:

Bilaga 7: Jämförelse mellan ett resursorienterat synsätt och ett marknadsorienterat synsätt (PP not 22; PP från WS not 46)

Bilaga 8: Utvecklingen 1970 - 2020 (2030); potentiell extern påverkan på interna beslut 



\section{Brainstormning BU FoU/CR 14 november 2003}

\section{Forskningsprojektet RESURSTILLVÄXT - ekonomistyrning för hållbar tillväxt}

-vid tillämpad forskning i XXX $A B$

Vision, kunskap, handling och resultat

\section{Vad har vi gjort tidigare?}

Några slutsatser från seminariet:

- ekonomistyrning är en fråga om mätproblem; värderingen ligger i betraktarens öga och i dennes roll

- det finns behov av "ny" styrningsinformation för "prime movers" som XXX 
Bilaga1a

\section{Syfte med dagens möte}

-Att få input till fyra forskningsfrågor

-Att få uppslag till "ny" modell för XXX

Bakgrund och fortsättning

- Varför denna forskning inom XXX

- "Abstract", om lagbundenhet och nytt fokus

- Behov av tumregler

- Koppling forskning vs XXX

- Ambitionsnivåerna; resursslag, vad \& för vem?

Inför "eget" projektet:

- Genomgång av Ditt "problem"

- Fromulera fyra forskningsfrågor 

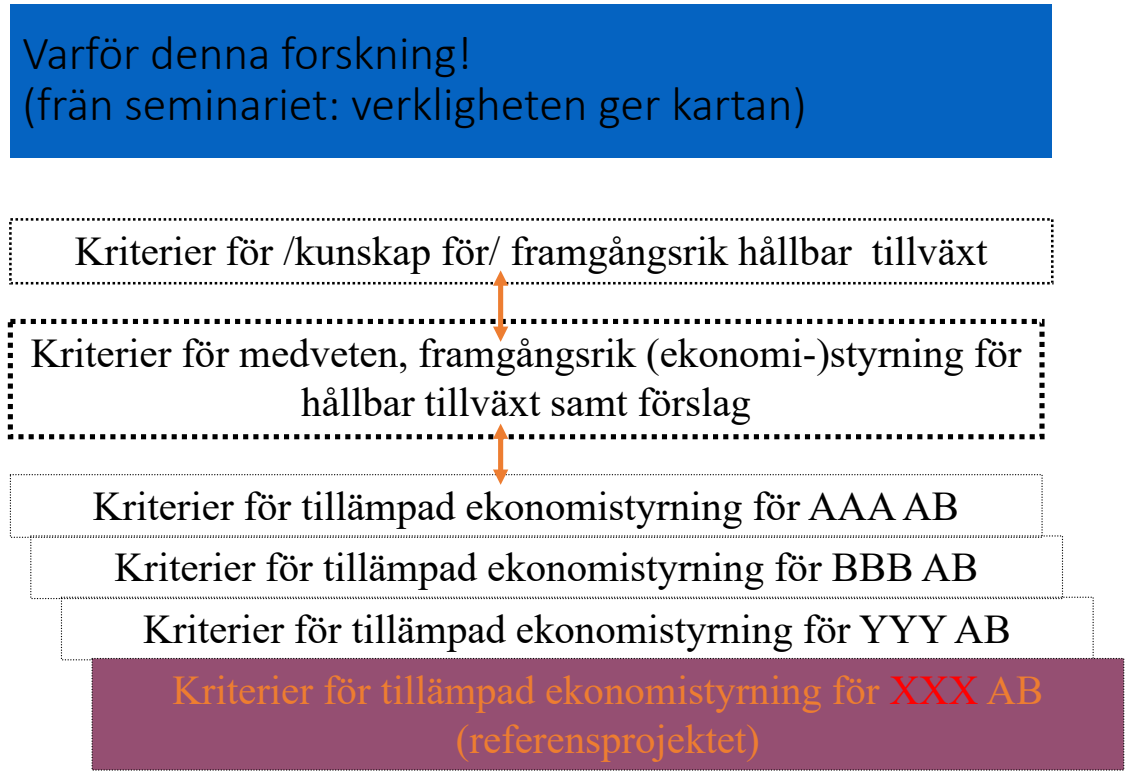

"Abstract"

Viktigt för forskningen: ${ }_{11}$

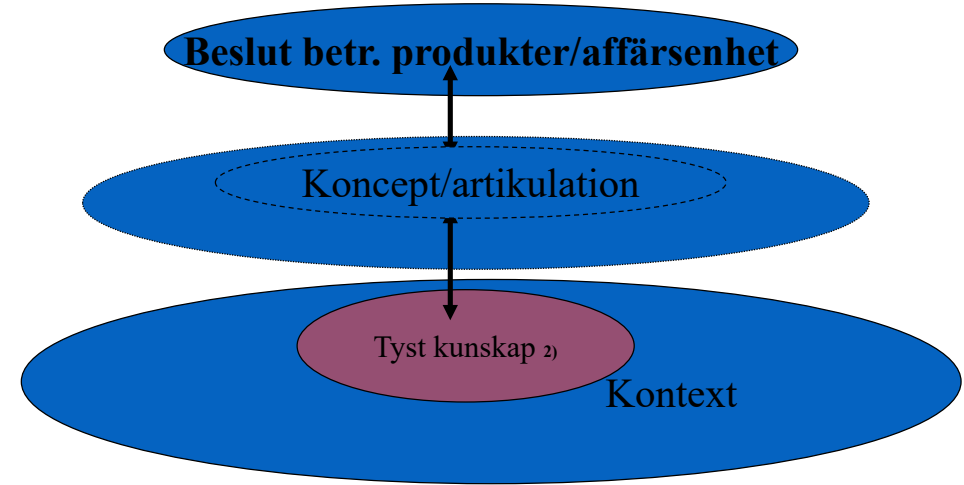

1) Von Krogh /Nonaka: Om utveckling av innovation och kompetens

2) Polyani: Om tyst kunskap och "lagbundenhet" 
Bilaga1a

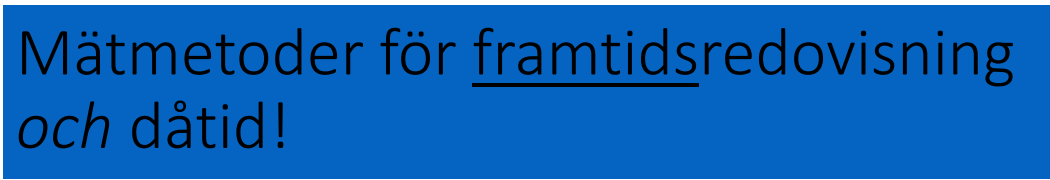

\begin{tabular}{l|l|l|l} 
& \multicolumn{2}{c}{ Traditionella } & "Ny" modell \\
Kriterier: & & & \\
Socialt & & $\mathrm{x}$ & \\
Mål dimension & & & \\
Tillämpning & & & \\
Validitet & & & \\
Reliabilitet & &
\end{tabular}

"Eget projekt"

Vilket är Ditt/Dina största styrnings-/mätproblem och vilka resursslag är viktigast?

I vems intresse - för vem är det viktigt?

Vad vill Du åstadkomma?

Kriterier? 


\section{Avstämningsmöte i XXX \\ "Kunskapsmöte" med ledningsgrupp \\ 4 december 2003}

Forskningsprojektet

RESURSTILLVÄXT - ekonomistyrning för hållbar utveckling och tillväxt

- vid tillämpad forskning i XXX AB

Vision, kunskap, handling och resultat

\section{Vad och hur hållbar utveckling och tillväxt?}

\section{Det finns en enighet...om målet!}

Resurstillvåxt.

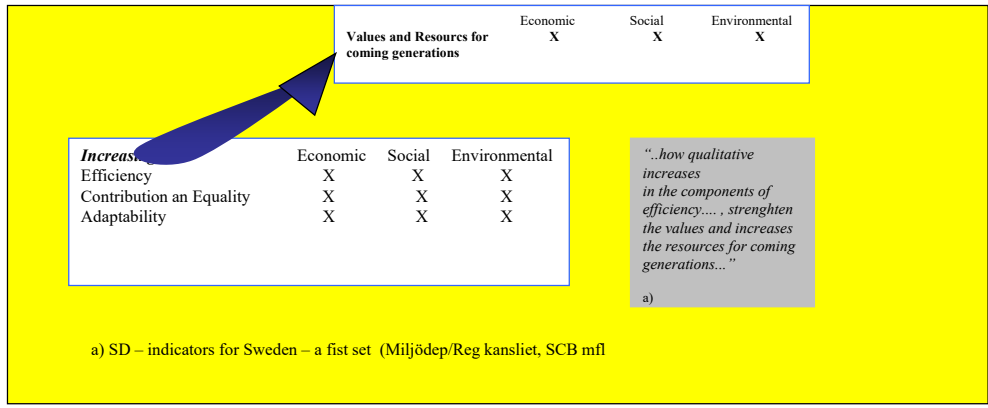

"Growth has no limits in term of population or resource use beyond which lies ecological disaster. Different limits hold for the use of energy, materials, water and land. Many of theese will manifest themselves in the form of rising costs and diminishing returns, rather than any form of loss of the reource base. The accumulation of knowledge and the development of technology can enhance the capacity of the resource base" (Brundtland: Our common future) 


\section{Tendenser i dagens}

\section{företagsekonomiska forskning...}

- En deltagande, utvecklande forskning

- Forskaren ser ett problem/potential (bransch, företag, teoribildning $\mathrm{mm}$ )

- Forskaren ser en uppgift och utkast till tänkbara lösningsförslag

- Forskaren testar empiriskt (ofta longitudinellt)

- Forskaren stöder med teori (för vetenskaplig validitet och reliabilitet, kvantitativt/kvalitativt)

- Dokumentation i avhandling (rewiews)

Fokus

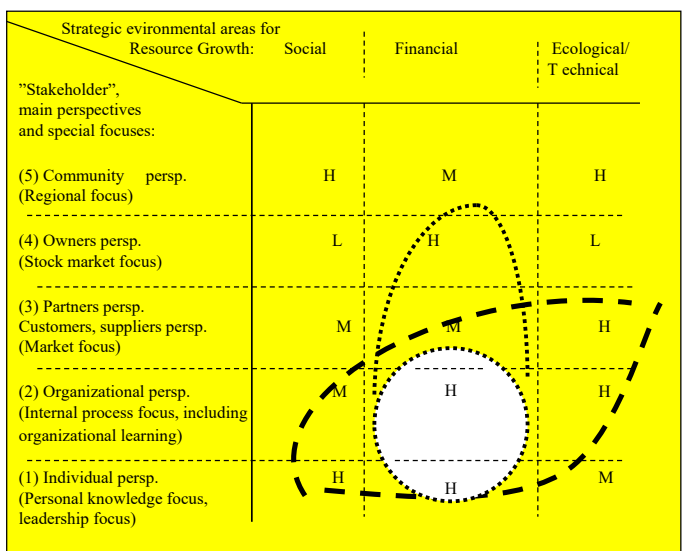




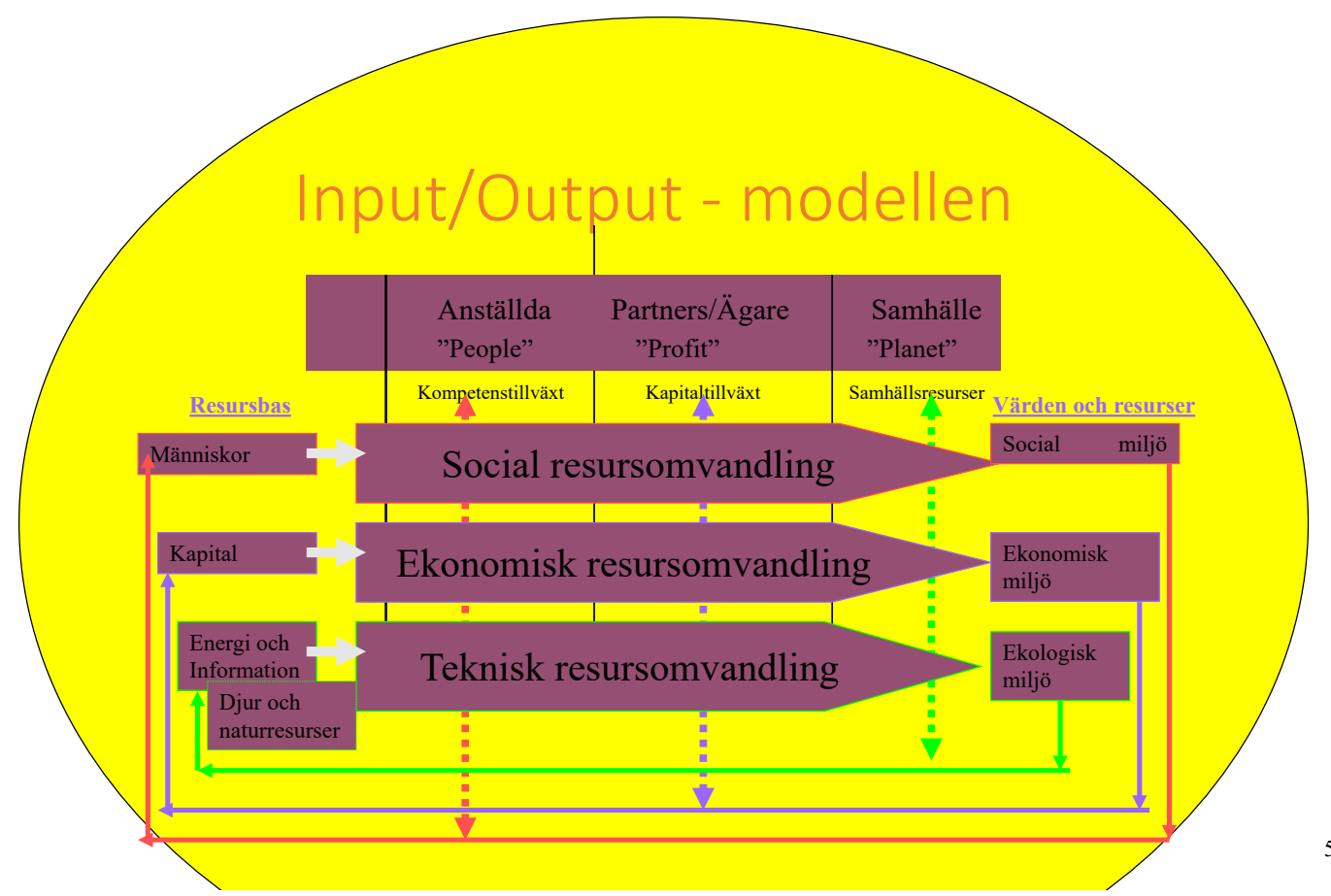

RESURSKARTAN

(för analys av samtliga resursslag inom XXX)

\begin{tabular}{|c|c|c|c|}
\hline Resurser & $\begin{array}{l}\text { Anställda } \\
\text { "People" }\end{array}$ & $\begin{array}{l}\text { Partners/Ägare } \\
\text { "Profit", }\end{array}$ & $\begin{array}{l}\text { Samhälle } \\
\text { "Planet" }\end{array}$ \\
\hline & Kompetenstillväxt & Kapitaltillväxt & Tillväxt samhällsresurser \\
\hline Sociala resurser & & & Ex Arbetsmarknad \\
\hline $\begin{array}{l}\text { Ekonomiska } \\
\text { resurser }\end{array}$ & & Ex Eget kapital + AK & \\
\hline $\begin{array}{l}\text { Tekniska miljö- } \\
\text { resurser }\end{array}$ & Ex Teknikkompetens & Ex Energikontrakt & Ex (Infrastruktur, ut) \\
\hline Övriga resurser & & & \\
\hline
\end{tabular}




\section{Hållbar tillväxt}

...finns ingen modell för ekonomistyrning som klarar detta - ännu!

Nuvarande system kan till exempel inte...

- mäta kvalitet vs pris/inflation

- mäta värdet av kunskap/kompetens

- mäta effekten av energi- och informationsresurser i företaget

- värdera tillväxten av en resursbas

\section{Ett mer precist syfte}

För forskningen

-Att få input till fyra viktiga forskningsfrågor

- Att testa en arbetsmodell och en tillväxtformel

För XXX

- Att utröna om XXX har ett behov och om möjligt ge några förslag till lösning 


\section{4 forskarfrågor}

Fråga 1: "Hållbar tillväxt" - är det/kan det vara/ ett uttalat mål för ekonomistyrning för den del av XXX som Du representerar? I så fall varför? Och för vem?

Fråga 2: Hur viktigt är det med ett övergripande mätetal för hela XXX, för framtidsredovisning (kalkyl, budget mm) resp. för dåtidsredovisning(efterkalkyl, intern värdering)?

Fråga 3: Kan XXX ansluta sig till terminologin "tillväxt av resurser"?

Fråga 4: Vilken kunskap behöver Du och Dina medarbetare för att uppnå en framgångsrik och hållbar utveckling?

\section{PROBLEMET}

Hur vet jag att det jag väljer idag - leder till hållbar tillväxt?

Finns det någon tumregel, någon hemlig formel eller speciell kunskap som jag måste ha? 


\section{Vad har vi gjort?}

En seminarium och brainstorming övningar med tio deltagande företag bland andra $X_{X X}$

1) En separat brainstormingövning med BU FoU/CRC och BU ROP

\section{Några generella slutsatser från "resursdialogen" (so far)}

Ekonomistyrning är en fråga om mätproblem; värderingen ligger i betraktarens öga och i dennes roll

Det finns behov av "ny" styrningsinformation för företag som XXX

Nya kriterier prioriteras 


\section{En fråga för XXX}

Finns det behov av ny

framtidsredovisning; finansiell resp.

"icke finansiell" och kopplat till

ekonomisystemet (XXX: xxxx)?

Nuläge:

Likviditet ( $\triangle$ av verkligt kapitalflöde)

Behov av generell modell och styrbegrepp

Metod som fokuserar framtida (och dåtida)/redovisning av/ produktivitet och lönsamhet och konkurrenskraft

Behov av tumregler...

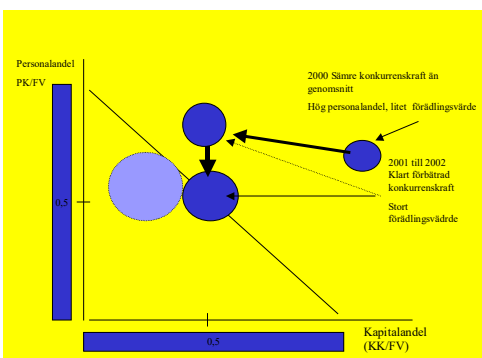

$\underset{\text { Fig } 8}{\text { Vattenfal }}$

\section{RESURSeffektivitet (Peff, Keff och Reff)}

\begin{tabular}{|c|c|c|c|c|c|c|c|}
\hline \multirow[t]{2}{*}{$\begin{array}{l}\text { År/ } \\
\text { period }\end{array}$} & $\begin{array}{l}2002 \\
\text { (6 mån) }\end{array}$ & $\begin{array}{l}2002 \\
\text { (3 mån) }\end{array}$ & $\begin{array}{l}2001 \\
\text { (12 mån) }\end{array}$ & $\begin{array}{l}2001 \\
\text { (6 mån) }\end{array}$ & $\begin{array}{l}2001 \\
\text { ( } 3 \text { mån) }\end{array}$ & $\begin{array}{l}2000 \\
\text { (12 mån) }\end{array}$ & $\begin{array}{l}2001 \\
\text { KONKURR } \\
\text { ENT(12mán }\end{array}$ \\
\hline & 0,45 & 0,37 & 0,56 & 0,48 & 0,32 & 0,57 & 0,31 \\
\hline Keff & 0,55 & 0,40 & 0,67 & 0,68 & 0,60 & 1,02 & 0,91 \\
\hline Reff & $\left.1,00_{1}\right)$ & 0,77 & 1,23 & 1,16 & 0,92 & 1,59 & 1,22 \\
\hline
\end{tabular}

1) Prediktion för 20021,10 
Bilaga1b

\section{Idag är formeln...}

...bidragsanalysen och investeringskalkylen är bra tumregler - men leder dom rätt?

...ABC, BSC, EVITA, LCC, GAP?

\section{Behov av modell för framtids- och dåtidsredovisning?}

\begin{tabular}{|c|c|c|c|}
\hline & Traditionel & & "Ny" modell \\
\hline Nivåer: & TB (Invest) & Evita ABC BSC LCA & EVA Simpler RT RT $+(\mathbf{R T}++)$ \\
\hline$X X X A B$ & & & \\
\hline BAU/avdelning & & & \\
\hline PRODUKT/ & & $\mathrm{y}$ & \\
\hline Projekt & & $\lambda$ & \\
\hline INDIVID & & & \\
\hline Kriterier: & & & \\
\hline Kommunikation & & & \\
\hline Styrning & & & \\
\hline Validitet & & & \\
\hline Reliabilitet & & & \\
\hline
\end{tabular}




\section{Ambitionsnivå}

Utveckling av ekonomistyrning för hållbar tillväxt
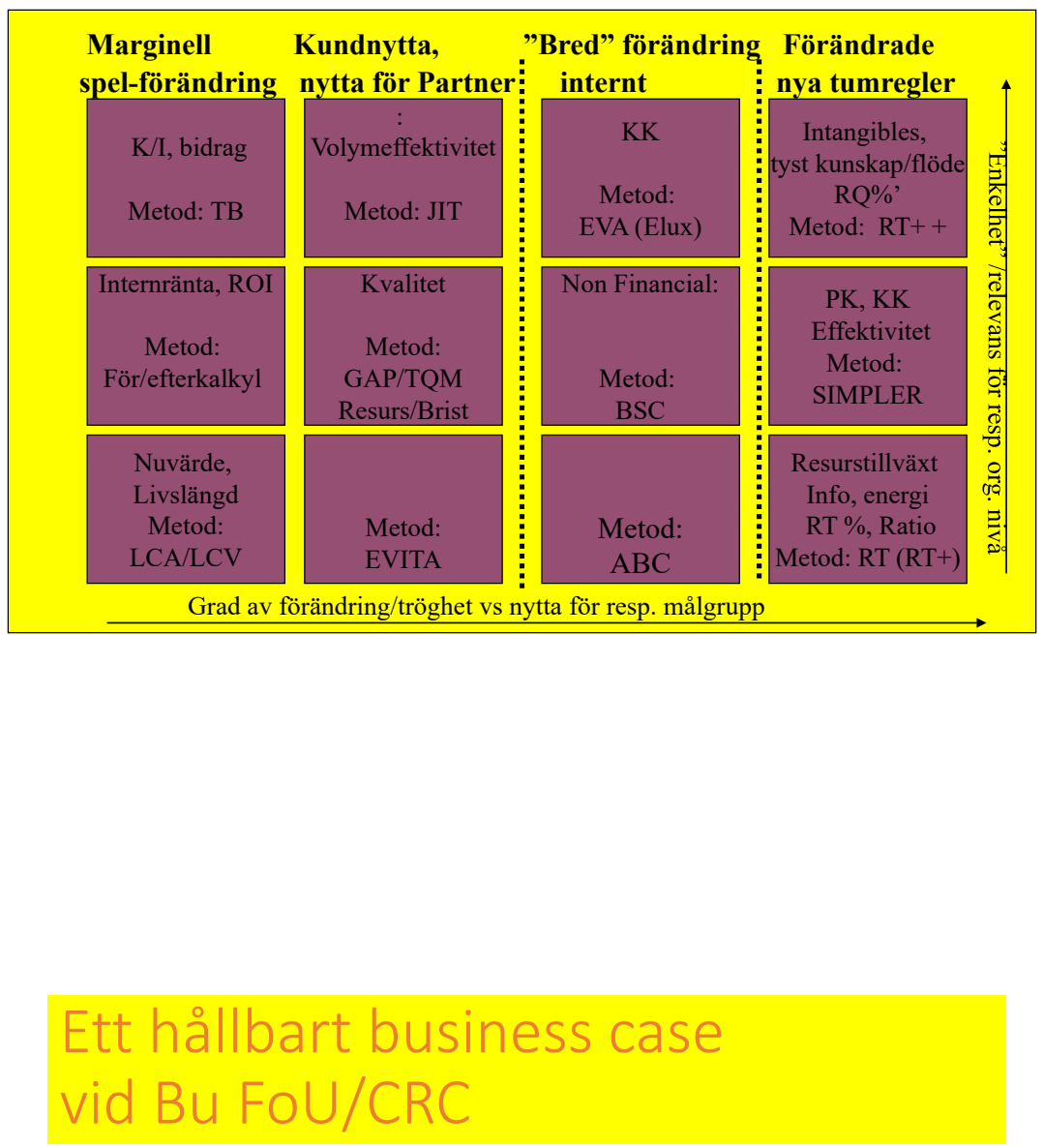

\section{Project Status reported week 211999}

Project within the phases Dp2-Dp5

\begin{tabular}{|c|c|c|c|c|c|}
\hline Project & Project Manager & Time & Cost & Quality & Functionality \\
\hline REO 517 & Sten Cognell & & & & \\
\hline RXHL 411 & Mats A Jönsson & & & & \\
\hline PST, New Parameter Setting Tool & Johan Odin & & & & \\
\hline REC 580 Rel.1.5 & Stefan Nygren & & & & \\
\hline & & & & & \\
\hline & & & & & \\
\hline \multicolumn{6}{|c|}{ Project within the phases Dp0-Dp2 } \\
\hline Project & Project Manager & Time & Cost & Quality & Functionality \\
\hline ASAP & Sven-Olof Lindström & & & & \\
\hline RExAll *2.2 & Sten Cognell & & & & \\
\hline \begin{tabular}{|l|} 
Wilma-2 \\
\end{tabular} & \begin{tabular}{|l|} 
Jonas Karlsson \\
\end{tabular} & & & & \\
\hline \begin{tabular}{|l|} 
REC 580 Rel.1.6 \\
\end{tabular} & Stefan Nygren & & & & \\
\hline SA Rel.2.0 HV Prod. & Jan Eliasson & & & & \\
\hline
\end{tabular}




\section{Kriterier \\ (slutsatser från kunskapsmötet)}

\section{Övergripande}

Ska

- dokumenterat ge en hållbar utveckling (så som XXX bestämmer sig för) (intern kalkyl/styrning)

- både visa kortsiktigt och långsiktigt rätt effekter/högsta sannolikhet för hållbar utveckling (intern/extern redovisning)

\section{Viktigt}

Priseffekter, konkurrenseffekter mm ska vara helt klara

Viktigt med tidsaspekten! (Se Ulfs kommentar från Steg 2)

\section{Kommunicerbarhet}

Ska

-vara en brygga mellan intern och extern kommunikation

-kunna utvecklas för/tillämpas i hela XXX AB

-vara pedagogiskt - framförallt internt - medarbetarens vardag

-vara anpassat till GRI-rapportering

-kunna anpassas till befintliga modeller

-följa/användas i samband med olika (ny) strategi, nya bolag mm

-vara anpassat till resp. målgrupp och dess primära intresse

-avpassas löpande till XXX's strategier för SD (hållbar utveckling) 


\section{Kriterier \\ (slutsatser från kunskapsmötet)}

\section{Mätbarhet}

Ska...

•vara lämpligt för såväl styrning (kalkyl) som redovisning (resultat)

-ersätta nuvarande produktivitetsmått/kvalitet i st. för kvantitet

-visa effektivitet på olika slags kapital(internt)och totalt företaget (externt)

•kunna användas som "Incentives" på alla nivåer (ersätta dagens mått)

•visa hur var och en bidrar till företagets förädling/utveckling -baseras på avkastning (på kapital) som huvudmått

-mäta objektiva värden

•kunna användas på produktnivå, BAU och på företaget totalt •ge mått på värdering av olika delar utifrån köp/säljperspektiv

\section{Några mätkriterier för ett hållbart "business case"}

Mätning av kundens värdering:

Förstå vad kunden vill ha alt kundens behov och nära kontakt med slutanvändaren är viktig för att göra rätt produkt

\section{Mätning av resurseffektiviteten:}

Hur vi ska mäta effektivitet från en utvecklingsorganisation så att det verkligen hjälper till att styra verksamheten. Hur vi överhuvudtaget ska jobba med tjänstemannaeffektivitet. Antal anställda per fakturerad MUSD verkar förlegat som nyckeltal!

\section{Värdering av resursbasen:}

Kompetenta resurser ska vara ledande inom de viktiga områdena'

Värderingen av produkten:

Hur vi ska mäta produktens/projektets värde på ett vettigt sätt. - helheten viktig

Värdering av åttagarkulturen:

En utvecklingsorganisation som håller vad dom lovar, produkt enligt spec, rätt tid, rätt produktkostnad 
Bilaga1b

\section{Förädlingsvärdet över tid}

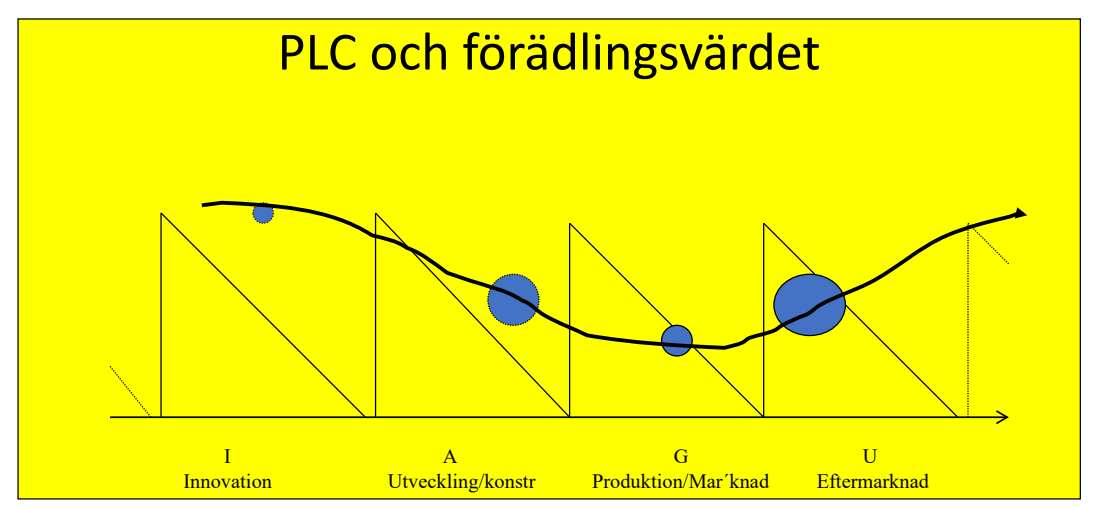




\section{Forskningsprojekt Ekonomistyrning Hållbar Tillväxt \\ PM Brainstormning 14/11 2003 \\ PSB \\ Sidan 1}

Anteckningar från möte 14/11

Medverkande:

M A

Bo-G A

$\mathrm{M} \mathrm{K}$

$\mathrm{H} \mathrm{C}$

T L

C-Y G

Staffan Boström

Följande anteckningar gjordes löpande under mötet (redovisas utan inbördes rangordning, tolkning etc.)

Viktigaste mätetalet: Hur snabbt och vilken kvalitet

Hur bra produkten accepteras av kunderna

Svårt att mäta hur man tagit beslutet:

Ny organisation/kundkopplingen måste in i "loopen"

Motsats: Fel specifikation kan göra att det bli fördyrat - den egna totalkompetensen kan vara för hög;

Viktigt att se hela kedjan; med effektivitet i hela organisationen och i alla processer/ inte bara per projekt

Vi har för mycket resurser totalt för att hitta exakt rätt kompetens; förutsägbarheten inför ett beslut blir därför svårt. Dessutom påverkar kompetensen för underhållsarbetet (ofta samma lika eller mer kvalificerade kompetenser som i utvecklingsarbetet)

VIKTIGT: Mäta OUTPUT från utvecklingsorganisationen; användaren måste vara med VIKTIGASTE INPUT/ Kostnad och TID 1)

1) Tid från idé till färdigt på marknaden; påverkas av arbetssättet

a. man kan ha teknik på hyllan

b. man har rätt kunskap/kompetens

Mjukvaruutvecklingen; Försening kan bero på att rätt resurser inte finns; fordrar därför ännu hårdare fokus på PROJEKTEN i verksamhetsstyrningen! Om detta sker ökar förståelsen för resursbilden också om man håller TIDEN. Samtidigt indikeras om man gör rätt grejor!

Högre kvalitet i beslutunderlaget - Vad är det?

1) Vi måste veta mer om mänskliga behov - förståelse för mänsklighet och marknad

2) Svårt att bedöma tid i annat avseende - i vilket perspektiv arbetar man / balansen mellan det som bolaget måste sälja inom närmaste tiden versus vad som ska utvecklas för marknaden i längre perspektiv?!

DETTA FORDRAR framförallt en strategiskt syn på utveckling av kompetens: marknaden är en förståelse för människor - det räcker inte med att prata med kunden. En sådan strategi 


\section{Bilaga1c}

Forskningsprojekt Ekonomistyrning Hållbar Tillväxt

PM Brainstormning 14/11 2003

PSB

Sidan 2

måste bygga på att vi vet att det är i linje med företagets affärsstrategi och en förståelse för FÖRETAGET. Den enskilda forskaren styr inte men måste ha denna kännedom.

Programmet: Affärsområdet har den övergripande strategin 3 - 5 år. detta måste kommuniceras bättre till forskaren.

En bra produkt ger PENGAR till företaget.

Återigen: VAD ÄR VÄRDET PÅ DET MAN FÅR UT? de gamla mätetalen för produktivitet mm funkar inte.

Idag: Debiteringsgrad/kostnad per projekt

Omsättning på nya produkter (ny? 3 år?)/ och omsättning på "nya" releaser.

Uppföljning av en "investering" - inte så vanligt men vi räknar "payback" 3 år.

På lång sikt ser vi utvecklingsavdelningen som en resurs. När jag använder den gör jag en "investering"

Man vet dock inte vad som hänt/vad som bidragit till värdet av den nya produkten

"Man BERÄKNAR så att det känns rätt i maggropen; man anpassar ..”.valet är ju svårt - om volymen minskar så har man ju gjort fel val - kanske upptäcks det för sent...- svårt men viktigt att se tillbaka; se utfallet utifrån det val man gjort. Viktigt att få med alla variabler som gjorde att man gjorde valet. För att se förädlingen - det är viktigt att se hela kedjan.

Utgångspunkt: Vi har rätt beslut - vad ligger till grund för detta ---det gick fel --- förbättra! Ju större vetskap om vad som påverkar beslutet - desto lättare att förbättra.

\section{INDIVIDFAKTORN}

Individen tar större ansvar automatiskt. Har man rätt kund gör man rätt PRIO.

VIKTIGT: Inte kundspecifik utveckling men...viktigt att ha en verklig och utpekad kund/individ/team som är med.

Kunden behov då; generell applikation;

Krav; ej alltid köptvång. Kunden kan ändå vara representativ för en viktig marknad. Kunden är inte säljavdelning etc. utan den verkliga användaren. Tiden blir då helig och man producerar rätt. Detta kan mätas!

Det gäller att skapa ett konkret fokus. den typiska användaren - han/hon kan bidra med sitt arbetssätt. Varje utvecklingsingenjör kan lära sig allt detta och hur hantera det.

Kanske skiljer vi på IT-projekt; IT-struktur för industriell verksamhet. Men riktiga teknikprojekt måste finnas!

Två viktiga perspektiv:

Intäkter - Kostnader och Kort och Lång sikt 


\section{Forskningsprojekt Ekonomistyrning Hållbar Tillväxt}

PM Brainstormning 14/11 2003

PSB

Sidan 3

Andra resursslag: I FOU arbetar vi bara med kompetens. Nya mätetal kan visa viss kompetensnivå. Kanske kan kompetensprofilerna användas?

Vad använder man KOMPETENS till? Använder man det på ett visst sätt - så leder det till OUTPUT.

REKRYTERING/Avveckling är båda intressanta alternativ. Vägen fram är viktig - minst lika viktig som målet!

Modellen - TID, KOSTNAD, KVALITET, FUNKTION - ökad medvetenhet ökar insikten hos personalen att man inte klarar projekten i tid:

(Referens till projektvärderingen enligt Madeleines mall)

VIKTIGT: genom att "köra" ett projekt har vi ju också utvecklat resurserna. Inlärningen viktig i varje projekt. Hur många projekt kan man...?

\section{HUR SKA VI DÅ MÄTA OSS SJÄLVA?}

TIDEN? - hur lång tid det tar?

Standard/hur många patent, belöningar, vetenskapliga artiklar ?

Skulle vara positivt med att se hur jag medverkat i... teknikutveckling och kompetensutveckling. 

Bilaga 2 a (FORCE)

Styrgruppsmöte 2 (Business Case)

Forskningsprojektet "Return of Resources" (Resurstillväxt)

2005-02-11

Medverkande:

$\begin{array}{ll}\text { M M } & \text { CRC } \\ \text { S L } & \text { CRC } \\ \text { SF } & \text { ROP } \\ \text { HC } & \text { ROP } \\ \text { B G A } & \text { ROP } \\ \text { Staffan Boström } & \text { ORU }\end{array}$

1 Syftet med mötet; att redovisa nuläget i forskningen, problemställningar mm samt att få styrgruppens förlag till hur gå vidare med utveckling av XXX's frågeställningar; framförallt hur effektivitetsmätning (av ledningens marknadskompetens samt produktutvecklingens specifika kompetens) ska ske. (Övriga frågor från det förra mötet 2004-02-03, besvaras skriftligen i bifogad PM, mötesprotokollet bifogas)

2 Att etablera utseendet på styrguppen, eventuell referensgrupp (ROP) samt att föreslå vad som ska tas upp på nästa BG-möte. (J G. samt ev. andra från XXX's ledningsgrupp)

3 Jag redovisade dels hur jag försökt snäva av ("koka ner") en forskningsfråga inför en förestående artikel. Frågeställningen handlar om själva beslutsprocessen och det nödvändiga att ställa ett antal (idag implicit uttryckta) frågor för att förstå dynamiken i processen. Det handlar i detta steg om ROP's beslut i de tre BC's, både PC och övriga i ledningen för Produktutveckling. Kan man dra slutsatser av detta för andra beslutsområden?

4 Jag redovisade hur framförallt effektivitetsberäkningarna gjort i respektive $\mathrm{BC}$ (För BC 1 och 3, För BC 2 (Wireless $\mathrm{I} / \mathrm{O}$ ) är inte någon kalkyl gjord ännu $\mathrm{p} g$ a läget för projektet. Jag redovisade dessutom hur varje projekt bidrar till $\mathrm{B}(\mathrm{A}) \mathrm{U}(\mathrm{ROP})$, och till hur man kan göra samma beräkningar på alla nivåer (med exempel från XXX Ltd)

5 Sammanfattningsvis rekommenderar styrgruppen att:

- vidare uppföljning närmaste månad(er) med samtliga tre projekt för att testa beräkningarna. Jag fortsätter arbetet med resp. PC.

- eventuellt finna något ytterligare projekt (mekanik eller software?) som redan är genomfört, detta för att testa vad hänt mot de förväntningar man haft från start. Ett mekanikprojekt är lättare; ett software är mer utmaning. Något WebWare- projekt kan vara svårt att hitta.

6 Ett antal (nya) frågeställningar väcktes också:

- Mätning/värdering av olika avvägningar av marknadsföringsåtgärder är viktiga.

- Viktigt att kunna mäta med olika organisatoriska avgränsningar. Exempelvis vill man mäta effektivitet i produktutvecklingsorganisationen (avgränsat bl a mot Marknad \& Sälj) 
- Ett projekt består ju ofta av ett antal mycket små förändringsprojekt. Hur ska dessa värderas/mätas i förhållande till helheten i ett större projekt?

- Tiden mellan ett projekts tillblivelse och att det realiseras (ledtiden) måste betraktas på något speciellt sätt i samband med mätning (förkalkyl - efterkalkyl).

Kan man mäta momentant förväntat/utfall ofta och med viss periodicitet?

- Hur tar vi hänsyn till tidsaxeln generellt vid effektivitetsmätning; speciellt viktigt vid denna typ av verksamhet? (teknologiutveckling/produktutveckling)

Dessa frågor måste kunna besvaras inför nästa möte. Frågorna från föregående möte (se bifogat protokoll)

7 Mina reflektioner

a) Tills vidare sätter jag fokus på effektivitetsmätningen. Vi bör enas om ett sätt att definiera effektivitet. Som jag ser det kan E mätas som antingen en kvot mellan den förädling som sker och kostnaden för den insats av kapital (KK) som fordras och /eller andra resurser ex personalkostnad (PK) som behövs - eller omvänt en kvot mellan kostnaden och förädlingen (FV). Jag rekommenderar den senare d v s Förädlingskostnad/Förädlingsvärde. Ju lägre kvot dess bättre effektivitet.

b) Beslutsmodellen d v s vad man ska mäta är uppenbarligen "kärnan" i detta, framförallt med tanke på den tid som mätningen avser och det objekt (organisation, projekt $\mathrm{mm}$ ) som mätningen avser. Kanske det är av värde att förtydliga beslutsmodellen i relation till Gatemodellen?

c) RISK. Vi har inte berört risk så mycket. Kanske ska det tas upp ännu mer i förkalkylen? Och hur följer vi upp RISK-utfallet?

d) SvK kalkylen används och är mycket tillämplig vid produktionsstyrningen. Kan vi utveckla hur en uppföljning ska ske på projektnivå? En mall - eller finns det redan?

e) Bidragskalkylen är ju inte speciellt tillämplig. då den främst används vid ledig kapacitet. Men kan vi kanske ändå göra en enkel mall som klart beräknar förädlingsvärdet (e g TB $1+$ (VC ) direkt personalkostnad)

f) Samtliga antaganden måste skrivas ner både de som rör förkalkylen och det som rör efterkalkylen. Det gäller både kapital och kompetens (och andra resurser)

g) Så småningom bör vi titta på just "avkastningsbegreppet" och koppla det till effektivitetsmätningen. Först då får vi ju ett mått på den verkliga effektiviteten

h) Kanske en referensgrupp bör finnas från ROP som består av Produktansvariga? Jag talar med GO. 
Intervju 20080613 Möte med ansvarig för BU 3 (P E) och Projekt FORCE

Detta möte är en uppföljning av tidigare intervjuer med BU 3 hela ledningsgrupp. Denna första individuella intervju varade en timme.

Anledningen till intervjun är att P E är ny chef och har efterträtt C S som chef för BU 3. P E har tidigare haft motsvarande arbete inom XXXX.

Tanken med intervjun var att i princip ställa samma frågor (se frågeformulär) som vid de tidigare intervjuerna. Då P E inte är informerad om min forskning/projektet och dess bakgrund samt att vi inte tidigare träffat varandra så höll jag agendan ”öppen”. Följande punkter "mailades" dagen före (till sekreteraren T L):

$>$ Hej,

Jag har inte formulerat några direkta frågor men de är främst tre saker som känns aktuella $i$ samband med min forskning *) just nu:

1) XXX / P Es syn på strategisk styrning och vilken typ av beslutsunderlag som känns viktigast för lite mer långsiktiga projekt. Vad är resurser och vilka resurser är strategiska?

2) Behovet av uppföljning av projekt; och andra beslutsprocesser som är lite mer strategiska/gärna med koppling till CRC och vad han förväntar sig för resultat av de lite mer strategiska projekten (typ "FORCE")

*) Forskningen innebär att jag tittar på hur styrningen av en verksamhet påverkas om man har ett resursfokus snarare än marknadsfokus (d v s man utgår "strikt" ifrån ens egna eller leverantörernas/partners strategiska resurser snarare än att marknaden styr ens beslut och handlande. Ett exempel är när man kan "skymta" en ny marknad ( $\mathrm{t}$ ex framtida energimarknad) men det finns mycket lite information att hämta utanför "huset".

Intervju:

1 Jag presenterade kort bakgrunden till denna forskning och varför vi valt projektet "FORCE" (utifrån XXX's behov att finna en ny styrmodell/ett styrmått). Vidare presenterade jag det "resursbaserade" perspektivet och kopplingen till ekonomistyrning.

P Es första kommentar var beträffande "resursperspektivet" att det verkade väl "introvert". (Efter en viss "övertalning" fäller han kommentaren "jag kan köpa det synsättet...")

2 Betr. utveckling av strategisk förmåga: $\mathrm{P}$ E kommenterade att det man beslutat utveckla som strategisk kompetens för BU 3 är "XXXXXXXXXXXXX"

3 Betr. förseningen av " konceptet FORCE " berodde främst på att std-komponenterna inte höll måttet. (En tidigare nämnd anledning var att leverantören inte kunde svara upp mot XXX’s krav på serielevereanser (utan valde att utveckla nya applikationer).

4 Beträffande "unika" konkurrensfördel (uthållig konkurrensfördel) kommenterade P E om fördelen med konkurrensen med "likartade" produkter" men med delvis olika teknologi 


\section{Bilaga $2 b$}

Case FORCE (Intervjuexempel)

Intervju 20080613 Möte med ansvarig för BU 3 (P E) och Projekt FORCE

(jämfört med att vara ensam med sitt erbjudande att lösa ett problem för kunden) var positivt då det öppnade upp marknader. P E exemplifierade detta med XXX's"stressometer" som höll måttet i 10 år XXX var ensam med sin teknologi ("rullen") i jämförelse med andra pneumatiska lösningar. (jfr heterogenitet/diffrentiering av erbjudandet)

5 Hållbarhet (se frågeformulär)

P E beskriver "hållbarhet" som XXX's (BU 3s) verkliga nisch d v s med existerande energisystem/arkitektur kan XXX hjälpa världen med ett komplett, effektivt och stabilt energisystem (exemplifierat med behovet vid Fort Knox i TEXAS). Det gäller speciellt vid växande stadsregioner där energiproduktionen inte kan ligga i stadskärnan. I stället ersätts energin utifrån med hjälp av två anläggningar (jfr Internet) där man helt ändrar förhållandena i kraftnäten. Anläggningar "seriekopplas" för att få fram mer energi (dubbla energivolymen) på befintligt nät (i st för att bygga ut nya nät).

\section{Strategisk Styrning}

P E framhåller behovet av långsiktighet men att det inte finns utrymme för de som har marknadskontakten att göra någon form av långsiktig analys. Man har gjort försök med olika marknadsplanering. Nu testas en ny form... (hur? min kommentar)

\section{Politiska beslut \\ $\mathrm{P}$ E framhåller att politiska beslut betyder mycket i valet av energiproduktion och att de är många gånger är avgörande även för hur energiöverföringen sker. "XXXX" kan utformas olika ut vid olika typer av produktion; jfr vindkraftverk och biogasproduktion (valet av energikälla är såldes central i många delar av BU 3s verksamhet)}

Däremot har detta ingen direkt effekt på totalleveransen av andra komponenter

8 Kompetenskravet vid olika produktionslösningar

Det har en direkt påverkan på BU 3 i hur nätet utformas då detta kräver specifik kompetens. Vid Off shore-produktion arbetar man specifikt med underleverantörer med denna kompetens. (Ex Akers, Götaverken $\mathrm{m} \mathrm{fl}$ ).

\section{SLUTSATS}

Fråga 1 (enligt agendan) kan anses delvis(implicit) besvarad; den viktigaste resursen är den som kan generera kraft; den viktigaste förmågan är "XXXXXX- kompetens" samt förmågan att utveckla "unika" lösningar på ett definierat problem (som kunde lösas på olika sätt). I detta fall var lösningen baserad på helt olika resurser; i det ena fallet var det "elektronik" som används vi avkänning; i andra fallet "luft" som användes som "avkännare" av spänning (exemplet "stressometer")

Vilka resurser som är mest "strategiska" framgår implicit; allt bygger på hur kraftelektroniken utvecklas runt energi (som strategisk resurs dock inte unik för XXX) men däremot var det strategiskt viktigt hur XXX’s lösningar ser ut och NÄR och i vilka applikationer de olika teknologierna tillämpades (transistor vs tyristorteknologi ex).

Som beslutsunderlag handlar det om information om "std-komponenter", om leverantörerna (-s förmåga och intresse) 
Case FORCE (Intervjuexempel) 3

Intervju 20080613 Möte med ansvarig för BU 3 (P E) och Projekt FORCE

Beträffandefrågan om "strategisk styrning" (per definition) så fungerar det inte idag $\mathrm{p} \mathrm{g} \mathrm{a} \mathrm{att}$ man har fullt upp. MEN. Det är viktigt (hur koppling till CRC är framgick inte/ min komm.)

Fråga 2 (enligt agendan) om behovet av uppföljning (ex ante) av projekt och samarbetet med CRC hanns inte med direkt. Jag berörde kort "dissonansen" i gatemodellen mellan för CRC och BU 3. (Vi ska återkomma till detta). "Problemet" med bristande uppföljning kan delvis exemplifieras med behovet av mer "framåtriktade" (långsiktiga" bedömningar; $\mathrm{d}$ v s det som man idag inte hade möjlighet att göra. (Vi ska återkomma även till denna fråga)

2008-06-23

./: frågeformulär (RESURSDIALOGEN) 

Step 1 Questions pilot case in XXX BU 3, BC FORCE)

Step 2 Interview questionaire NPD (analysis)

The research question for this analysis is:

"How and why should the "TBL-concept" of sustainability (SD) (with focus on RM, Resource Efficiency/RoR) be designed and implemented in NPD-projects and related decision processes in XXX/GS/F?"

Why?

The overall problem for this research is an assumed need of an extended view, and an operationalization, of 'sustainability' in thinking, decisions and actions in R\&D /and marketing/, and especially in NPD, in order to improve a longterm organizational performance. This in turn is assumed to emerge as a need of better information for management accounting. An extended, formalized information, beside intuition, is hereby assumed to potentially offer better strategy decisions. An answere to part of this problem is assumed to be visualized through this empiri, conducted with interviews and tests according to a certain research design. (see: Methodology)

Research design Step 1 and 2 (of a pilot study)

Part One: Questionnaires and interviews before start of the NPD project. The purpose with this part of the questionaire shall describe present opinions about SD and decicion making. The questions shall be reviewed during all phases of the NPD (G0 till G5)

This part is conducted through analysing "experienced" problems (about difficulties with interpreting SD in decision making; which benefit are expected from decisions; the total time for decision making; how projects are valuated in various stages etc) and what is most problematic with setting and ataining the goal "sustainable development" (uncertainty?, risk?, interpretation?, resource dependency, quality vs quantity, the need of management, etc).

The result shall describe questions/presumtions for possibly needed (?) HYPOTHESIS for continued analysis/research. (This will be presented in the PhDoc report)

Part Two: After implementing the project

The purpose with this part of the questionaire is to see if the problems can be solved with the suggested "work model" (including the hypothesis, definitions and a certain formula). This should prove the need of hyphothesis through applying some of the analysing concepts (process analysis critically posing the questions for What, Why, For Whom and How?) for analysing the decision situations and for follow up of the result /and to see how these instruments have functioned/. The answeres shall hopefully verify/indicate if hypothesis are needed or not.

The qusetions BEFORE (presumptions) and AFTER (verification) shall be coordinated. They aim to answere:

- Uncertainty of what shall be meant by "sustainable" (means and measure)

- Opinions about RISKS in the projects

- Uncertainty (?) in the present way of measuring BEFORE and AFTER

- The question of the "clarity" in various words (such as RESOURCES, SERVICE, FUTURE, HISTORY, CONSTRUKTIVE vs DESTRUCTIVE etc) and who gains from this clarity in defitrnions etc 


\section{Bilaga 3}

BC FORCE

Sidan 2

2006-06-19

Step 1 Questions pilot case in XXX BU 3, BC FORCE)

Step 2 Interview questionaire NPD (analysis)

- About the differences betwenn golas for regenreation, effectiveness and efficiency when it comes to tools for and the whole working area- what is valid for this specific project?

Proposed questions for the interviews: (in local language)

1 Vad förknippar Du med följande begrepp: (ge en kortfattad beskrivning)

Hållbar utveckling (Sustainability)

Uthållighet (Sustainable)

Resurstillväxt (Resource Growth)

Resurseffektivitet (Resource efficiency)

Nytta (Benefit)

Värde (Value)

Konstruktiv (Constructive, regenerative)

Destruktiv (Destructive; degenereative)

Tid (Time)

2 Hur vill Du beskriva ett HÅLLBART MÅL? / (a sustainable goal) Svara utifrån frågorna För VEM? (For whom?)

VARFÖR? (Why?)

VAD? (What?)

HUR? (How?)

NÄR? (When?)

3 Hur vill Du beskriva vad som kännetecknar RISK i Ditt arbete? (två till tre ord)

4 Hur vill Du beskriva OSÄKERHET (uncertainty) i en situation där Du ska ta beslut? (två till tre meningar)

5 Vad skulle Du vilja göra för att eventuellt minska (reduce) RISK eller OSÄKERHET i Ditt arbete? (två till tre meningar)

6 Vad skulle Du vilja göra för att öka "nyttan" i/av Ditt arbete? (increase the benefit) (två till tre meningar) 
Step 1 Questions pilot case in XXX BU 3, BC FORCE)

Step 2 Interview questionaire NPD (analysis)

7 Öppna frågor/spontana synpunkter: (Open views) 

INNOHUB Interview guideline for Part 1, Stage 1 (with reference to Stock, 2016)

Overall description (Q1 - Q2) How to describe the present system/context with reference to "enablers; resources, innovation capacities, aims?

Q1 How does the collaboration with INNOHUB look like?

Q2 What makes it special?

Background (Q3 - Q 6) How to describe the dynamics with reference. to contextual preferences, processes/procedures for communication

Q3 Who initiated the cooperation with INNOHUB?

Q4 How long last the cooperation already?

Q5 How often do you communicate with INNOHUB employees?

Q6 Which communication channel do you use?

Reasons for collaboration (Q 7 - Q 9) Why attend in this network/system? (cognitive approach)?

Q7 What does INNOHUB offer your cooperation?

Q8 Why do you collaborate with INNOHUB?

Q9 What do you expect from collaborating with INNOHUB?

Benefit the company can add (Q10 - Q11) What are the benefits with the present system?

Q10 Which benefits does INNOIHUB have from collaborating with you?

Q11 What does your company offer precisely?

Expectations (Q12 - Q17) Expectations. Strengths' and weakness with the system

Q12 Would you consider the collaboration with INNOHUB as successful? (Rank 1 - 10)

Q13 Are initial expectations met? (Rank 1 - 10)

Q14 Did your expectations change over time? (Rank 1 - 10)

Q15 If so, how?

Q16 What were the biggest obstacles?

Q17 What worked better than expected?

Follow up (Q18 - Q 19) Value of the collaboration for the company

Q18 As how important do you consider the collaboration with INNOHUB for your company (Rank 1 - 10)

Q19 Would you recommend other companies to get engaged with INNOHUB in a similar way (Rank 1 - 10) 

Bilaga 5 Exempel

INNOHUB

Expected results and effects, KPI's (guidelines for quests about deliverables)

A Please consider in what extent the following five deliverables has emerged during your "membership" in INNOHUB (1= not at all, 5 = to a highest extent)

- a faster growth rate (compared to expected growth under other, more common conditions)

1

- an opening to an international market

1 5

- an increased funding possibility (direct investment in business or IP)

1

- a shortened innovation process (compared to expected)

1

- learning and experience from other INNOHUB "member companies"

1

B Pease also consider where on this line your company shall be placed: (mark with a cross)

An Innovative center

(innovation focus)
A "start -up" business

(a ready business model)
An "up and running" business

(full time ventures) 

Bilaga 5 Det "nya" öppna innovationssystemet; inkubatorns plats i organisering av innovationssystemet

(Se powerpoint)

\section{TRADITIONELL MODELL}

Innovationshub Mottagare

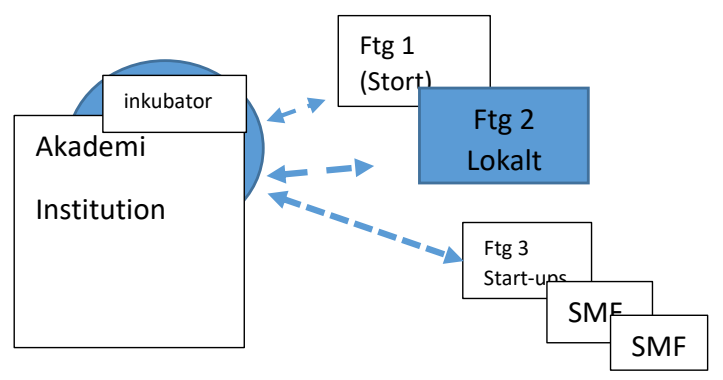

NY MODELL. Företagsinitierad modell för öppen innovation (Aktörsorienterad)

\section{Etableringsaktör}

som teknologins bidrag till organisationens lönsamhet och effektivitet

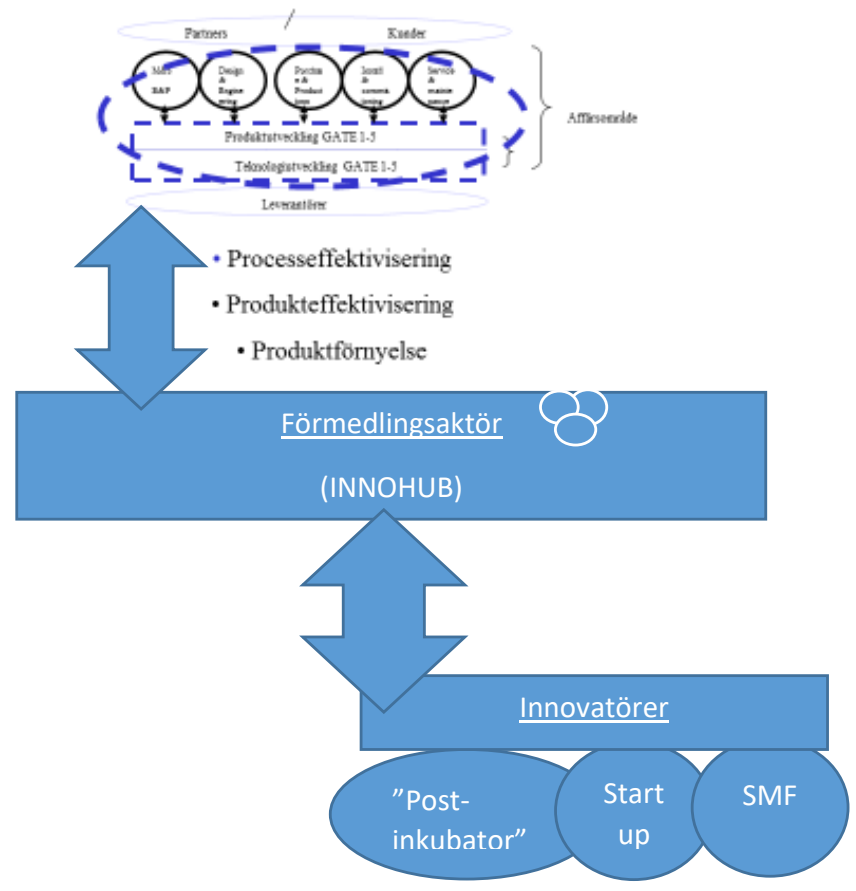





\section{Bilaga 7}

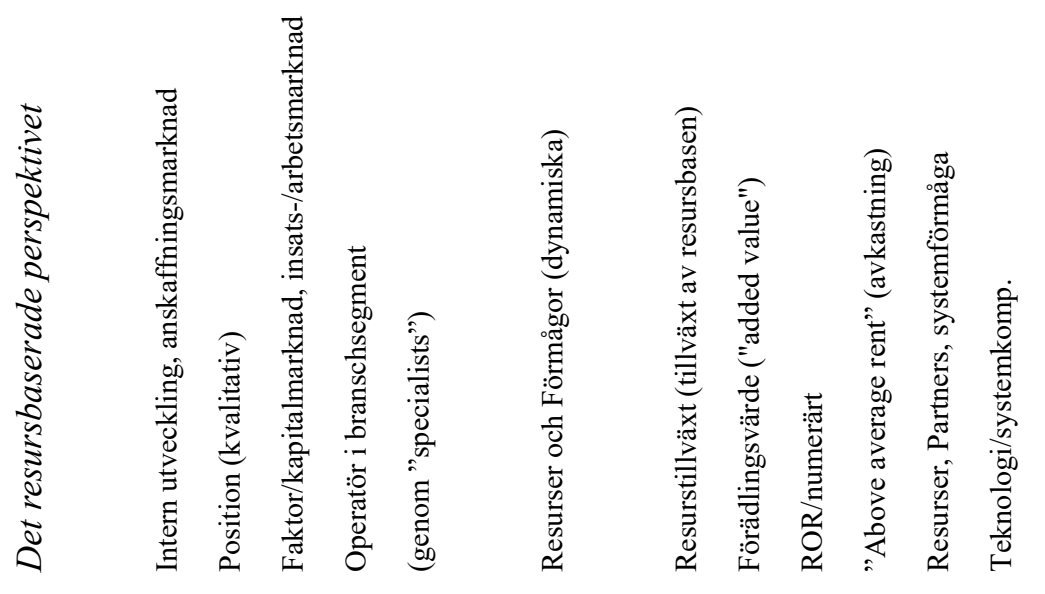

$\frac{2}{\frac{1}{2}}$

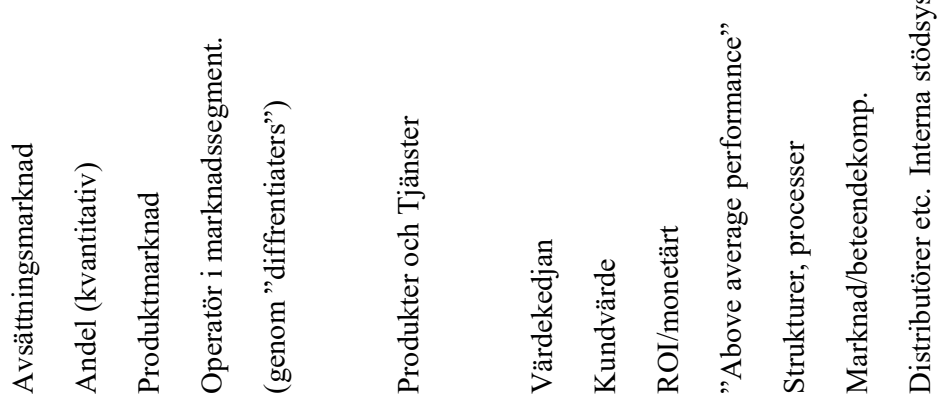





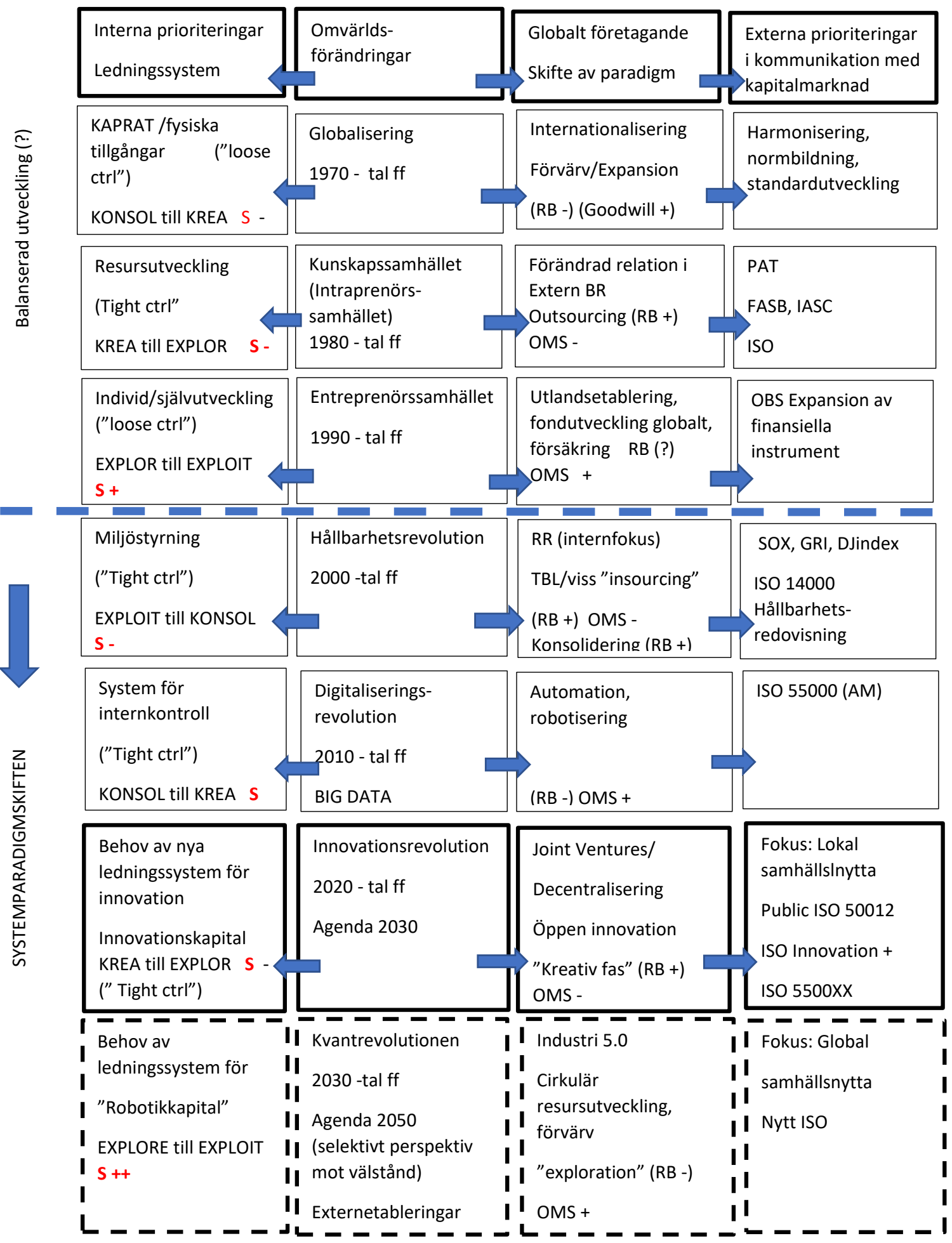

Bilaga 8. Ett försök till illustration av hur omvärldsförändringar hypotetiskt kan antas påverka interna och externa prioriteringar perioden 2020 - 2040/2050. (egen sammanställning) 



\title{
Critical assessment in $R \& D$ management with processual analysis
}

\author{
Per Staffan Boström \\ $\mathrm{Ph} \mathrm{D}$ student \\ Linköping University
}

\section{INTRODUCTION}

Decisions in $R \& D$ management are, not unlike in other management research, strategy decisions i e how contexts, projects, products, resources or concepts shall be analyzed and managed to benefit or fulfill organizational ends.

Questions frequently discussed now are "how"; i e to what extent strategy decisions in organizational contexts are based on intuition (Moustakas, 1990 and Schön, 1995), on tacit knowledge (Polanyi, 1962) or visualized knowledge of various kind (Eliasson, 2000), on history (Pettigrew, 1992), on intellectual capital in narrative or accountable form (Mouritzen, Larsen, Bukh, 2001). Strategy is also developed in stakeholders and environmental perspectives (Jetter, 2003) and as social constructs (Sztompka, 1991). From this literature we know that strategy decisions are not fully rational. Earlier views concerning the meaning of the concept "maximizing of output", are today rather connected to satisfying the benefit of the outcome (Cyert \& March, 1958, 1963). Limits for strategy decisons are the individuals bounded rationality (Simon, 1982); in some discurse superseded by "action rationality" (Brunsson, 1985).

Implications of integrated decision processes is that decisions do not lead to steady state but rather to continuous change (Greiner, 1972). Management and social behaviour changes over time (Sztompka, 1991). Time is considered in the aspect of transparancy and in the patterns of change (Van de Ven and Poole, 1995, Hinings, 1997). Various change modes are affecting how decisons are measured or valuated (Van de Ven, 1992).

Organizational limits as of power over resources (Burns, 1999) or more or less organizational inertia (Hannan and Freeman, 1984), are among other organizational structures also found in institutionalized management routines which unables or delays management change and thereby hinders the emergence of information needed for making strategic decisons. (Burns and Scapens, 2000). Large organizations, in contrast to small entrepreneurial firms, also suffer in reliance of management information in decision making due to the separation of ownership and the controlling function (Fama and Jensen, 1983). Responsibility, generated from management (Olson, 1983) is considered in relation to the legitimacy discussed in organizational decision making, also in extended contexts (Pfeffer, 1982).

My practical experience from the car industry, empirical evidence discussed in this paper from automation industry and earlier empirical evidence (Burns, 1999) shows that above mentioned aspects are found in strategy development processes and procedures of R\&D. Studies of fundamental decisions of business processes concerning product development in 
single firms shows that product development can either start intentionally or by default (Krishnan and Ulrich, 2001). It can be a complex process and include hundreds of decisions, but it can also, to a large extent, be usefully supported by knowledge and tools. The empiri also shows that extended /pre/understanding of processes, criteria and facts are desired from the decision maker, all in order to be even more effective in manageing $R \& D$. There is a continuous need for clarity and definitions in the decision process in order to choose satsifying ways and means to meet competition. As consequence of this, in this article an assessment method is recommended in $R \& D$ processes in order to increase the process knowledge and the necessary management information before decision making.

\section{Theory}

As described above the institutionalized management routines are seen as hinders for developing new decision information. Management practice shapes the management system and routinizing management activities makes the changing of the system slow and not responding to changes in requirements from users of the management information. From the empirical research of Burns and Scapens (2000) the conclusion must be drawn that organizational stability shall be seen in the light of how people's routines and activities shape a structure. A structure where certain habits and criteria are taken for granted and often though not explicit but described as tacit knowledge (Polanyi, 1962) Organizational stability can also be seen as a growing need of predictability in organizational context, in a fast changing environment. False or not - people's feelings of predictability, as expressed by some responents in the empiri, seem to be higher in a stable organization. Since management practice is a part of organizing facts, this would also emerge as stabilizing the organization.

Conclusions drawn by Burns et al is that a balance between stability and change is in the interest of the organization (Burns and Scapens, 2000). Especially in R\&D and somewhat paradoxically to research creativity where strategy decisions are made on often unpredictable future events and change, stability could be seen as an important premise. Evaluation forms, criteria and facts and figures are then necessary to be in some way routinized in R\&D. The analysis and its content in connection with the use of management information are then expected to be taken for granted.

The implications of a critical assessment in analysing decision processes shall be thoroughly considered. In two special issues about strategy process research in two journals (SMJ, 1992, 13 and SJM, 1997, 13, 4) Andrew M. Pettigrew at Warwick Business School offers a view of nature of strategy process in research of social sciences and as understood in organizational context. He offers a theory of method for conducting processual reserach by reaffirnming guiding assumptions and goals as well as a dual model with a deductive approach - in combination with an open ended analysis process of a more inductive kind. Pettigrew shows, by menthioning case studies and with reference to Piotr Stztomka (1991), that by implicitly questioning of the what, why and how - and also when - firms are moving towards " $n$ " form of characteristic.

These questions can be raised and used in a wider, more holistic analysis. This can, through combining the process analysis and mapping of trends, provide new learning and knowledge 
of organizational transformations. The method and its appliance is further developed in various organizational contexts and settings in the second paper. The process view, where the word process as such is defined according to Van de Ven (1992), can be used in a number of settings; in choice processes and implementation processes - and on various levels of an organization. One key question is for example how to create a dominant design for the industry and a sepecific firm? This question imply for sure the R\&D strategy.

The offered process analysis is organized around five internally consistent guiding assumptions. But even if outer context is mentioned, such as economic and competitive environments, it still seems that the analysis, in its role in explanation for the context and actions (agency), has a primary internalistic focal point. The stakeholder perspective when posing the questions is not explicitly made in these contexts and diffferent settings - neither in the inner nor the outer contexts

\section{Methodology}

A number of models, methods and variables are available in literature for analysing the $R \& D$ procedures and decisions (Bûyûközkan and Feyzioglu, 2002, Krishnan and Ulrich, 2001). Referring to the papers on strategy process research and the nature and conduct of processual analysis by Andrew M. Pettigrew (Pettigrew, 1992, 1997) and the reflections on processual analysis by C.R Hinings (Hinings, 1997), this paper contributes to future process analysis research by suggesting a Process Analysis in R\&D procedures. Due to the lack of explicit knowledge in the suggested method this paper discuss the need of extended processual analysis. Hinings as well as Pettigrew have pointed out certain areas for future desirous research. Pettigrew points at the managerial elite in various settings as an important research field.

Observations in practice points to the lack of knowledge in decision management and how management can be in favour of a more critical analysis; including understanding of both intraorganizational and interorganizational processes and dialogues. The lack of knowledge about R\&D processes as core and innovative processes in most business management - and the implications of management on strategy decisions of R\& D on company performance makes an extendended and critical assessment in $R \& D$ process analysis of certain interest for our search.

This article starts from the position that organizational change as well as management decisions shall be viewed as processes, rather than starting with a more "static" approach (Burns and Scapens, 2000). Accountable and management information in a certain design of a process analysis related to $R \& D$ procedures, assumes to increases the knowledge of the processes. The understanding of process analysis and the outcome of it enables a dialogue and assumes to increases the knowledge of the criteria and of the analysis as well. Decribed through these questions the analysis has an implicit intraorganizational focus.

This paper suggests that a critical process analysis is based on the questions "How?", "What?", (Pettigrew, 1992, 1997, Drucker, 2003), “Why?", “When?” (Pettigrew, 1992, 1997) and, due to the above menthioned knowledge gap, this article explore the possibility to extend the critical assessment with an additional question. This is a contribution in that it provides guidance for the new design of increased knowledge and accountable information method applicable to measuring and evaluating the outcome of the processes. 
The paper first discusses some general problems and hinders experienced from various practical organizational contexts during a longitudinal study in a global company. It also discusses some empirical findings; from intentional decision making in strategic R\&D. It thereby focuses on the problems arisen from institutionalized management practices. Reflections on these actions and management activities are made by the author, who is a "reflective" practioner (Schon, 1983), together with the product and portfolio managers involved in the empirical unit of analysis (Argyris, 1990), i e two product development cases. Secondly it discusses the relationship between organizational and environmental stability. Change's impact on management practice and usage are discussed according to findings in R\&D empiri and theory by Burns \& Scapens (Burns and Scapens, 2000). As a conlusion it finally discusses an extended critical mode when thinking and acting, using processual analysis, all in order to find the answeres to the explorative research question concerning possible new assessment questions.

\section{EMPIRI}

This longitudinal, empirical study started in 2001 and it is organized in a number of phases, from brain stormning and bench mark seminars to case studies in technology and product development. This broad empiri discuss such topics as decision processes, resource management (RMS) and management control (MCS).

In large organizations individuals on all levels seem to easily adopt procedures for collecting information and facts, for management and calculating figures and for measuring and evaluating needed input and expected outcomes in organizational contexts. Often in spite of their simplicity some of the used decision models, especially calculation models, are though not relevant for the specific decision situation but still used as instruments - and as arguments when other decision criterias are missing.

In order to view the complexity of strategy decisions and to learn about it's implications on strategy development, one limited empiri was first conducted in the R\&D organisation of the global company, during two decision instances. At this point and as a part of this larger empiri, two case studies have been performed in a global $R \& D$ organization of a company which has been involved from the beginning. The author followed ongoing product development in this company during twelve months, through the development procedures; including the technology search and implementation activities of the two very specific products. In each case the empiri was carried out through interviews with technicians, product and portfolio managers and R\&D managers in connection to decision making situations. The interviews were rather informal and the respondents gave spontanous answeres and reflections to their observations of what had happened during these situations. Documentation, memos and protocolls from all meetings and interviews with the respondents were continuously updated by the author and were immediately reviewed and accepted by the respondents.

In this empiri - in technology research (TR) as well as in new product development (NPD) the R\&D procedures include five project stages called "gates". At each "gate" the project is measured and valuated in accordance with certain critera. Certain management tools are used 
Business Case 1 ROBO (BC 1) (two case studies)

A Process Analysis, a Critical View

PSB

2005-10-12( rev 2018; 2021)

whereby calculable and expected monetary contribution, calculated as a percentage rate of the sales turnover, often sets the premises.

\section{Case One: the Wireless Tool}

Part of case description:

>>...is a concept based on a very advanced, not orderbound technology research. The application in thought was not known until the solution was technically almost ready. The product carries imbedded technology to a large extent. It is a qualifying product and so far two main concepts are known with some thought features for the user - but also for productions cost reduction i e for a high product efficiency.

This research was totally driven by new technology. Technology and product research has had several global high tech suppliers involved and has been in use for ten years. The cost amount is huge and has been split between several stakeholders.

Decison 1: (D1) The five gates (1-5) in TR passed with stipulated evaluations. The project has entered the first gate of NPD. The result of the first evaluation, when the steering committee considered internal criteria and calculable facts, resulted in a decision to stop further resource supply for the project. The calculated economic loss from this desinvestment decision represented a huge amount.

Decison 2: Reconsidering this project and especially after a visit to one of the earlier expected users, a visit proposed by one of the menber of the organization, a large factory that had just been incorporated in a global corporation, some new facts were laid on the table. This factory had at an early stage been involved in the project, about five years ago, but was forced to leave because there was no understanding for the new tehnique as qualifying in any respect. The technique had now been calculated and evaluated in quite another application. It thereby got approval from factory management.

A great interest for a new application at this factory alone could grant a certain production volume although not financially sufficient to decide on continued research. The question for WHOM? was raised i e "Is there any other stake holder that could gain from the concept or from the product in some form?" After some further investigation of factory processes at some other sites, the decision to conitnue the NPD was made. At this stage of decision making it was also considered that some new and edge critera had to be visualized. Calculation should be conducted with new figures about events and predictions; one example was: What does knowledge (technical, market and educational) mean in the value for the customers organization- as well as för the research unit and production business units in the own enterprice?. And for the whole global company as well? 
Business Case 1 ROBO (BC 1) (two case studies)

A Process Analysis, a Critical View

PSB

2005-10-12( rev 2018; 2021)

Respondents coments: (Product Manager and Technicians)

(D1) This project is technically high tech and very interesting but so far we feel that we cannot find any customer benefit that we think can motivate the price increase. This solution also complicates other parts of the product which may hinder the launch of it. Further research may also be in conflict with other projects due to limited resources. We have to calculate with a negative contribution and we therfore recommend that we end this project.

(D2) The respond we received from the factory we visited was interesting. They are really in the "front line". This "new" application is an essential and obviously a critical part of their production. We felt that we through our technical knowledge really could contribute to their sucess and long term tasks. When calculating our mutual financial benefits, on the todays quantities alone, the mere cost was minor and the contribution was positive. We will now look into our present production processes in this new defined segment and calculate on a larger scale with these new facts and figures.

Comments from the PPM (Product Portfolio Manager):

It is obvious that these new findings, new facts and figures have changed our decision. Decisions are more or less made intuitively but also in a large extent depending on the experience from economic variables and criteria. Our research organization could be in need of more management and accountable information. Todays' management systems does not consider knowledge or information on how to measure quality variables. TIME is a variable that is so difficult to consider - a project can be very "long term" and very difficult to calculate - even in small scale projects.

\section{Reflections on the Case One: the Wireless Tool}

It seems that everything is managed from an everybodies image of a so called economic truth or conformity to some organizational "laws", most often not as explicit but as tacit knowledge. These management activities are in some respect institutionalized. In this case the stakeholder perspective is not explicit. The problem obviously occurred when new decision criteria appeared; for example the new request from a user of an application. Or when the new stakeholder appears on the scene. These situations call for new decisions, often with strategic and long term impact. Working with product development in general, this is obviously an open ending situation. A variety of solutions to this problem are therefore continuously invented, all of them to an unavoidably extended resource use and bad efficiency. Due to that, this problem calls for a solution as beyond instituionalized management procedures if the organization is to continue it's efficiency.

One "sub problem" is, as mentioned above, that some of the used decision models, especially calculation models, in spite of their simplicity, are not relevant to their specific decision making instance. In many of the strategic and long term R\&D decisions where circumstances or presumptions are more or less fuzzy, the decision situation is very complex. Uncertainty of the outcome of an investment or resource input may depend on totally unpredictable events and unknown, but sometimes implicit, evaluation criteria. Facts are less calculable due to lack of information. This problem should call upon a high dergree of flexibility and a dynamic and widenig approach in managing the processes, in development procedures and in activities. 
Obviously this seems to be in conflict with an instituionalized and conformed decision structure.

Through this case study, as part of the longitudinal empirical study in the global R\&D organization, this paper explores some failed strategic decisions but also how they were corrected into a quite another path, creating new knowledge and development, through pushing "new" questions. The questions were seemingly also posed rather explicit and in a specific order.

In order to find what can be considered as the "best pratice" in strategic decisions one further case study was to be conducted. In comparison to the above case the paper explores a similar case that instead shows that product management seems to have pushed the right questions from the beginning. Seemingly also in the correct order.

\section{Case Two: the Interactive Learning Toolbox}

Part of case description:

>> ..a concept based on orderbound research. A self learning system that enables the user in an application to increase the effectivness in a very complicated production process. The product is classified as a diffrentiater i e it may contribute to the better use of the core product and in a variety of applications. It also includes a tool for analysing the production processes.

The research has been driven by a need from the user in a certain industry to really make use of all technical features in the main application. It has been developed through continuos dialogue with the user and on facts and figures of the hand of the user; of production volume, risk levels etc. Taken for granted the implicit question for WHOM? is natural for the researcher. The research is carried out by one person and to a limited cost. The calculation is based both on what the user thinks about the value of this "learning" and also on the expected wider use of more "core" product (which obviously means an expected increase of sales volume).

Decison 1 (D1) The five gates in TP were passed with stipulated evaluations. Due to the continuos dialogue with the user and continuous calculations at the site, the progress for identification of new applications, still on a small scale, was continued. The first edition was launched (Gate 3) and thereby tested and evaluated by the user. The benefit was measured in calculable terms. The next launch (second edition) was planned in a larger scale and based on calculated benefits at the users site; efficiency, productivity, knowledge increase, long term effects on quality etc. Estimations and calculations of sales contribution as well "inhouse" knowledge contribution grounded for the deciscion to launch the second edition. 
Business Case 1 ROBO (BC 1) (two case studies)

A Process Analysis, a Critical View

PSB

2005-10-12( rev 2018; 2021)

This project, when I was involved, was already in progress with a dialogue between the researcher and the user at one site. At this stage the cost of the investment is very limited because the user pays for a training licence which includes the researcher as well. The decision I made is of course in some way made by intuition. But I very well know the calculus models both on our hand but also, due to our process analysis, on the user's side. I would say that "the calculus makes it possible to make a decision but intuition shapes the decision."

\section{Comments from the R\&D Manager:}

The decision is made on the basis of economic experience and technical knowledge. What we need is more knowledge about the user and the economic and calculable criteria on users' hands. Experience of economic calculus at our hand implicitly tells us that expected calculable outcome is not reliable today. In that respect the models we use are not totally relevant for the decison situations. The $R \& D$ could need complementary management information of some kind for the model to be relevant. Time is rapidly changing the premises for decision. A better analysis of changing premises is needed.

\section{ANALYSIS AND CONCLUSIONS}

As illustrated by the first decision situation; are there any theoretical implications from the empirical findings of this paper that can affect the answeres to the two problems described in the reflections of the Case One above?

The author's reflection on the both above cases, and the finding that has to be thoroughly discussed, is that they illustrate that the main and core question is "For whom?" - a question that should be raised before searching for or before creating new accountable information. That means: Who is the most important stakeholder for this project? Who is most anxious that the analysis is to be conducted and communicated throughout the R\&D organization? Who gains most from the decision? The answeres from these questions will certainly fill the knowledge gap in the processual analysis as suggested above.

Another implication is that when these posed questions "for Whom?" are answered they can be followed by the other questions in a specific order; preferebly first "the What?" since it in practice, especially in strategic R\&D, is more often explored then "the Why?" -Then it should at last be followed by the strategy question "the How?" since strategy seems to change more often than "the What?" - or that it will be obsolete more often as Peter Drucker so eloquently describes it (Drucker, 2003)

For the second (sub-) problem the main question is what shall be measured and how? The underlying question is though still by whom i e for Whom? is the measurement important. Who is the owner of the question? In order to find calculable facts and figures for measuring, the same questions are posed and put in the right order. This makes the process analysis similar to the analysis used above.

The main problems focused upon in the empirical cases reported from R\&D and management practice, have also been discussed by Burns (Burns 2000) and Burns et al (Burns \& Scapens 2001). They made the conclusion that management change can be conceptualized as change 
in organizational rules and routines. Management has the potential to be institutionalized and thereby contribute to the ability of, and be a carrier of, organizational know-how. Management change can also be seen and analysed as a process rather than an outcome. But it is also an important insight that stability and change are not mutually exclusive processes, they occur simultaneuosly. Stability, in the face of change, can be an instrumental feature for understanding management activity of individuals and groups in the organization. Management routines and actions, including critically analysing activities such as questioning in process analysis, can be seen as instituions, stabilized or rather stabilizing the outcomes and/or, in the light of dynamic actions, be seen as ongoing and shaping continuos change.

The further implications of this empiri are of methodological nature. The findings from the two cases above show that cases like these, though from two different contexts, with different meaning and different decision criteria, can be in use of this critical assessment of the analysis. This is also relevant in a teleological perspective when organizational ends as for example the development or survival of the firm is known; or when means as competition, resource deployment or resource efficiency etc are more or less explicitly stated. There are also methodological limits. In a special issue (SJM 1997, 13.4) C.R. Hinings at University of Alberta offers a wide range of research implications from processual analysis. At least two points should be considered in this context; the need for codification of approaches in case studies and the role of time in empiri.

This paper starts with a theoretical positioning of the author. The research question, empiri and cases are then studied from a practioners observations from practice. This frame of reference, mainly from automotive and automation industry, is therefore also affecting how this research is conducted and how it shall or can be validated. Earlier observations in this research, especially from the start in 2001, is made in accordance with what Donald Shön (Shön, 1983) expresses as "reflections in action" and a strive to involve respondents in as large extent as possible. This action oriented research is most relevant as 'action science' (Argyris, Putnan and McLain Smith, 1990), and a research mode experienced from/in scandinavian industry, from corporate marketing and financial controlling on corporate level. Further codification of this empiri is not possible due to the very limitation of this study. Validity in this empiri could only gain from the controlling principle stated by Michael Polanyi; the speaker judges that his words express the reality he seeks to express!

The role of time in this empiri should be regarded in the mode of change. This empiri shows only two decision situations, though fundamentally changing the decision, which occured during twelwe months. The life-cycle of this product, in case one, can be expected to be ten times this and the reliance of these decisions has to be regarded in the light of this fact. Seen more in the teleological perspective the decision has to be validated within the frames of temporary fulfilment of organizational goals as they are described by company managers.

\section{POLICY IMPLICATIONS}

Organizations, and premises for decisions in $R \& D$, changes continously. There is no final steady state in product development but rather cumulative equilibria that can be calculated for and accounted for. This calls upon the necessity of having relevant and updated information to 


\section{Bilaga $A$}

Business Case 1 ROBO (BC 1) (two case studies)

A Process Analysis, a Critical View

PSB

2005-10-12( rev 2018; 2021)

make as satisfying decisions as possible. It also calls upon a dynamic approach in analysing the information.

Though, for the main problem, the implications of deciding how to look upon stability versus change has first to be thoroughly discussed. If a dynamic and flexible management system is preferred, then a dynamic analysis model or method is recommended to be preferred. If on the other hand stable, institutionalized management routines, which above was thought of as the main problem, are preferred, then a more routinizing analysis method is recommended. Time has to be considered as influencing the mode of this continous change.

At the same time there is a need for stability in an organization. Peoples needs of routines and habits in organizations as well as in the management practice are seen as something that is stabilizing the organization. This duality in premises for research and development and the problem this duality causes in decison situations can be solved by continuosly using critical assessment in extended process analysis, in line with guidance suggested by Pettigrew (Pettigrew, 1997). A systemized critical assessment in process analysis suggested by Hinings (Hinings, 1997) of R\&D and a continuos use and thereby institutionalizing the questioning by posing the questions of What?, Why?, How? and as proposed here, for Whom?, seems in light of that, "the what" for the author as a reflecting practioner, has emerged in this empiri, to give the answeres that could gain strategy decisions and contribute to more effective management of R\&D! 
Business Case 1 ROBO (BC 1) (two case studies)

A Process Analysis, a Critical View

PSB

2005-10-12( rev 2018; 2021)

Argyris, C., Putnam, R.,

McLain Smith, D., (1985)

\section{REFERENCES}

Brunsson, N., (1985)

Büyüközkan, G.. and

Feyzioglu, O., (2002)

Action Science

Jossey-Bass Publisher, Oxford, San Fransico

The irrational Organization

Wiley, $N Y$

A fuzzy-logic-based decision-making approach for new product development

International journal of production economics; 16

Burns, J., (1999)

The dynamics of management change: inter-play between new practices, routines, institutions, power and politics

Accounting, Auditing \& accountability Journal, 13, 5, 566-596

Burns, J. and Scapens, R.W., (2000) Conceptualizing management change: an institutional framework

Management Management Research 11, 3-25

Cyert, R and March, J, (1958)

The role of expectations in business desicion making Administrative Science Quarterly3, 307-34

Cyert, R. and March, J., (1963)

A Behavioural Theory of the Firm

Prentice-Hall, englewood Cliffs, N Y

Czarniawska, B. and

Wolff, R., (1986)

How we decide and how we act - on the assumptions of Viking Organization Theory

in: Organization Industrial development, $N Y$,: de

Gruyter, 139-150 (ed. by R Wolff)

Drucker, P. F.,(2003)

Eliasson, G., (2000)

"Management Challenges for the 21 st Century"

Making Intangibles Visible: The Value, the Efficiency and the Economic Consequences of Knowledge

in: Buigttes-Jacquenip-Marchipont, 2000, Competitiveness and the Value of Intangible Assets

Edvard Elgar, 2000, Cheltenham, UK

Fama, E.F. and Jensen, M.C., (1983) Separation of ownership and control

Journal of Law and Economics, XXV1 


\section{Bilaga $A$}

Business Case 1 ROBO (BC 1) (two case studies)

A Process Analysis, a Critical View

PSB

2005-10-12( rev 2018; 2021)

Giddens, A.,, (1984)

The Constitution of Society

Cambridge, Polity Press

Greiner, L.,(1972)

Evolution and revolution as Organizations grow Harward Business Review, Jul-Aug, 37-46

Hannan, T. M. and Freeman, J.,(1984) Structural inertia and Organizational Change American Sociological Review, 49, 2, 149-164

Hinings, C.R., (1997)

Reflections on processual research Scandinavian Journal of Management 13.493-503,

Jetter, A.J.M., (2003)

Educating the guess: Strategies, Concepts and Tools for the Fuzzy Front End of product Development RWTH Aachen University, Technologie and innovationsmanagement, Aachen, GERmany

Krishnan,V. and Ulrich, K.T., (2001) Product Development Decisions: A review of the Literature

Management Science 47, 1, 1-21

Mouritzen. J., Larsen, H. T., Bukh, P.N.D., (2001)

Intellectual capita and the capable firm:: narrating, visualizing and numbering for management knowledge

Management and Organizing Society 26, 735-762

Moustakas, C. (1990)

Heuristic Research; design, Methodology, and Applications

SAGE Publications, Newbury Park, Calif

Olson, O., (1983)

Ansvar och ändamål.

Doxa. Lund

Pettigrew, A. M., (1997)

What is a processual analysis?

Scandinavian Journal of Management 13, 337-348,

Pettigrew, A. M., (1992)

The character and significance of strategy process research.

Strategic Management Journal 13, 5-16

Pfeffer, J., (1975).

Organizations and organization theory

Pitman, Marshfield. Mass.

Polanyi, M., (1962)

Personal Knowledge towards a post-critical philosophy

Routledge Kegan Paul Ltd 
Business Case 1 ROBO (BC 1) (two case studies)

A Process Analysis, a Critical View

PSB

2005-10-12( rev 2018; 2021)

Simon, H. A., (1982).

"Models of bounded rationality" Volume 2:

Behavorial Economics and Business Organizations"

The MIT Press, Cambridge, Massachusetts, London

Schön, D. A., (1983)

The reflective Practioner; how professionals Think in Action

Basic Books, Inc., Publishers, N Y

Sztompka, P., (1991)

Society in action: The theory of social becoming

University of Chicago Press, Chicago, IL

Van de Ven, A.H., (1992)

Suggestions for studying strategy process: a research note.

Strategic Management Journal 13, 169-188

Van De Ven, A. H. and

Poole, M. S., (1995)

"Explaining development and change in organizations"

Academy of Management Review 20, 510-540 



\title{
Legitimacy as analyzing concept - framing R\&D and sustainable company governance
}

\author{
Per Staffan Boström \\ Linköping University
}

\section{INTRODUCTION}

Legitimacy, in individual as well as corporate organizational behavior and in light of citizens universal rights, are now topics on several agendas when responsibility is discussed, so also in 'sustainability' agendas. Sustainability assumes strategy decisions and approved 'citizen' behavior. How sustainability goals and ends shall be reached or fulfilled is a question discussed on many levels of science, society and in corporations, in different contexts and in back- or forecasting terms. Resource dependency, resource use and creation in strategy decisions and actions assumes responsibility. Sustainable company performance foresees responsible governance but also stakeholders' acceptance in terms of legitimacy in every, of a broad variety of contexts.

Responsibility, power and legitimacy as analytical concepts are still mainly visualized in nonbusiness, political organizations and in terms of categorical behaviors. They are seen as results of political governance when evaluating, for example, social programs *) and especially in programs where resource allocation sets the premises for the outcome and legitimacy. Links between power and responsibility are analyzed in several political contexts where legitimacy though sets a wider frame than responsibility - often seen as taken for granted by citizens in modern democracies.

The roots and meaning of 'legitimacy' can be found in legislation i e legitimate behavior meaning obeying the law. In early organizational theory, in the beginning of the past century, it was posed by the sociologist Max Weber (in Gerth et al, XXXX) in the school of bureaucracy expressing the 'rational-legal' organization where 'legal authority' describes the role of authority in performing organizational tasks; then by its followers in the Frankfurter School (Habermas, 1975), still meaning obeying organizational laws, institutional rules and practice in hierarchies but questioning its conditions and grounded state. Legitimacy and the ontological grounds for it, could be transformed to a higher level, thereby reduced in its value on the original or former level in the hierarchy. . In modern organizational research and especially in modern institutional theory, legitimacy is discussed as a main driver for organizational isomorphism in a changing environment, thereby emerging organizational stability and inertia (DiMaggio and Powell, 1983).

Legitimacy and its genealogy though originally derives from Rosseau and, seemingly somewhat contrasting to the above meaning, as a result of a free will agreement between individuals, in this school seen as derived from the diverse of given interests, different type of information, the given extent of the playroom - and the processes that creates institutions and thereof legitimate decisions.

My practical experience is that all these characteristics can be found in corporate strategy 


\section{Bilaga $B$}

Bilaga B: Business Case 2 CATHEDRAL (BC 2) A case study

2005 (rev. 2014;2021)

PSB

and especially in the continuous technology research and product development; i e in corporate $\mathrm{R} \& \mathrm{D}$ strategies when trying to valuate organizational decision processes, in governance, on performance and/or the outcome of them. My experience is limited to automation, energy power distribution and automotive industries and of the supply and retail of resources, products and services. Studies of 'action rationality' and stakeholder dialogues as well, included in my analysis of strategy decision processes (my paper in process) of $\mathrm{R} \& \mathrm{D}$, indicates that 'legitimacy' can be used as an analyzing concept when studying development processes and their outcome, on various levels of these corporations.

When discussing the sustainability in decision making processes and management accounting contexts in $\mathrm{R} \& \mathrm{D}$, a diverse of contextual questions are raised with reference to organizational theory. One main question is how to measure /intentional and legitimate/ organizational change in terms of resource transformation, value creation, competition etc. It seems that there is a gap of knowledge in modern theories that can explain how legitimate behavior shall be measured over longer period of time, or rather; what and who gives legitimacy to organizational governance in various, often dynamic contexts.

A sub-problem is that due to this gap of knowledge in how, implying also by whom, performance shall be measured, accounting management and sustainable strategy decision making and acting is not reaching its possible potential. This lack of knowledge also has certain impact on the emergence of management accounting information.

\section{Theory}

In present theoretical context, now viewing organizations as 'open systems' and their need of 'feed-back' (Katz \& Kahn, 1975), legitimacy is now discussed as clearly distinguished from responsibility; i e an extension of the organizational context (Pfeffer, 1975). Its links to the development processes and strategies (Van de Ven et al, 1995) and its derivation from organizational decisions, from thinking, talk and/or actions can now be found in analyzing concepts and viewed in models like for example the Formal Model of Organizational Analysis (Czarniawska \& Wolff, 1986) and models were also the more traditional views of rationality are questioned. The meaning of rationality in decision processes is now instead discussed in terms of action rationality (Brunsson, 1985); i e how decisions are conducted. Talk, decisions and actions are, according to the above mentioned Model (Czarniawska et al, 1986) seen as part of, though forming legitimate governance and imply good 'citizen' behavior.

Resource Management, resource dependency and efficiency in resource deployment and use, is not limited to the effect of power over resources but also reflects the needs of individuals and organizations; academic, political and corporate "citizens" (Pfeffer \& Salancik, 1978) anxious to get and to give acceptance i e legitimacy. Stakeholder analysis vs "citizenship" (Moon, Crane \& Matten, 2003, van Kersbergen, XXXX, Freeman, 1990) contribute to the understanding of legitimacy in this sense.. A further understanding of responsibility and legitimacy in various affecting environments is now discussed in terms of intensity of competition, type of legal environment and risk to reputation (Van de Ven \& Jeurissen, 2005) A non-legitimate behavior is seen as a destructive mode and calculated as a loss. A loss or waste in one context may though gain another context (Waddock, 2004) or give benefit to another stakeholder in the interacting business network (Jeurissen, 2004). Some parallels can be drawn to the theory of research legitimacy in the academic community (Hessle, XXXX)

As responsibility and its link to power is generated from accountability and accounting practice (Olsson, 1983) and various accounting systems and socio-cultures, in some of which 
changes though seems to occur rather slow (Burns, 2000), legitimacy in wider contexts i e valuating organizational performance (Dowling, J \& Pfeffer, J.,1976) is formed by continuous change in needs of accountability, in and of organizational behavior and in practicing management accounting.

Referring to the paper on Institutional conditions of Corporate Citizenship (Jeurissen, 2004) this study aims to contribute to future strategic research by suggesting an explicit meaning of corporate $R \& D$ legitimacy into the "body of knowledge" in organizational theory - due to a lack of explicit knowledge in theories of legitimacy in business organizations. - and for future research on corporate development processes in 'sustainability' contexts.

Further referring to the paper of Jeurissen (Jeurissen, 2004), "citizenship" is discussed and defined in a social constructed context $\mathrm{i}$ e a social contracting in a stakeholder or networking perspective. Jeurissen also points out the necessity of 'legitimacy' to bring clarity to the concept of "citizenship". He offers a definition of "citizenship" where to be a citizen means to accept the social contract (including economic, human, natural topics and resources as well) - still as $a$ limitation in everything done. But he views the social contract as a combination of self.-interest, beneficial in the long run, and ethics.

Corporations are analogues to individuals and reflect individual citizenship, so for example social contracting for business. is seen not only as building a framework for legitimacy, as response to the need of justification, but also guiding companies into various "partnerships" and stimulating dialogues between business, social partners a o, for creating joint solutions! A certain principle, the precautionary principle, is though seen as a bearing principle for corporate "citizenship". Sustainability in this context and in concrete terms means, according to Jeurissen, a responsibility for corporations to at least maintain the output capacity of the planet at an equal level for future generations by investing in energy technology of tomorrow.

Jeurissen also states some institutional conditions of corporate "citizenship"; subsystems which are clearly interacting and influencing each other; so for example market relationships are in some way distinguished from social relationships, though interacting. A stakeholder analysis of any kind may complete this model in order to more easily understand legitimacy (my comments). Jeurissen also has a somewhat critical point of view of responsibility in that he states: "every man's work is no man's work". He also than suggests a more conclusive and solution-orientated form of arguing/bargaining among companies and stakeholders. In a somewhat more diversified description of responsiveness categories (Caroll, 1979) with reference to Terry Mac Adam, companies with an aim to lead the industry, are seen to be progressive when competing is more like fighting than bargaining. One open question is though how the corporation in question, defines itself to be leading in this respect or at least defining what a sufficient legitimacy is. An answer to this may influence the framing of sustainable corporate behavior in a certain dynamic extent.

Legitimacy, in the context of a need of justification is also discussed in the face of stakeholder legitimacy (Berry, 2003) i e stakeholder theorist argue that corporations should meet the need of stakeholders (not only stockholders) and that companies should act in interest to "any group or individual who can affect or is affected by the achievement of the organization's objectives". But such a stakeholder focus assumes legitimacy on the hand of the stakeholder; i e the stakeholder needs legitimacy and some degree of power and must be able to create a sense of urgency about their concern. Legitimacy in the sense of reaching "corporate legitimacy" for the corporation means, somewhat a contrary to this stakeholder legitimacy, 


\section{Bilaga B}

Bilaga B: Business Case 2 CATHEDRAL (BC 2) A case study

2005 (rev. 2014;2021)

PSB

that the corporation, or part of it, is in favor of being judged with a certain kind of legitimacy from their stakeholders. One example is to be regarded as a preferred partner or supplier in the marketplace.

With reference to the Formal Model of Organizational Analysis (Fig 1), legitimacy varies with the type of organization and socio-cultural system. The model consists of three spheres: one inner, one intermediate and one outer circle. The inner circle contains talk, decision making and action. The intermediate circle $\mathrm{i}$ e somewhat extended contains legitimacy. The outer describes types of organization and socio-cultural system.

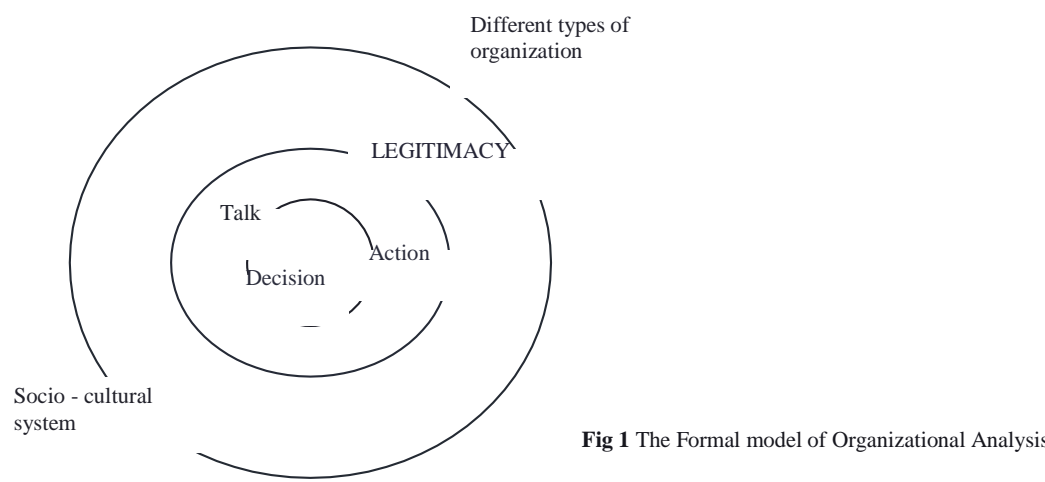

This formal model, in our study used as basic principle for analyzing legitimacy as part of a "body of knowledge" rather than as a dependent factor, is originally an attempt to offer an analyzing tool to researchers of organizations and organizational behavior. Initially it was created (Charniawska et al 1986) in an ambitious attempt to verify, through empiricism, a certain paradigm for Scandinavian management - as opposed to the traditional decision management theory.

The model consists of the three analyzing concepts; talk, decisions and actions regarded as generating legitimate organizational behavior. The model can be viewed and used in a variety of shapes depending on socio culture and level of the studied organization. In its context of resource management, it is mainly used to describe intraorganizational dependencies and certain internal foci. Using these three concepts the model can preferably be applied in a deductive research i e to verify the impact /on behavior/ of talk, decisions and/or actions in organizational government.

In this research the main aim is to establish a critical mode of research. We instead suggest a inductive research, using legitimacy as the analyzing concept.; $\mathrm{i}$ e we want to notice differences in managers opinions about organizational legitimacy and to primarily establish the interorganizational frames for legitimate behavior, If there is a need to find and explain the factors influencing the corporate behavior or to value organizational outcome, this model will be of great help in that the former concepts can be verified as main influencing factors as they are observed. Using this model in this inductive, empirical research may reach a better understanding of the kind of legitimacy and other presumptions and criteria needed to decide and/or act, i e for management to govern and influence behavior. In order to understand, by using this analytic model, we aim to observe and characterize the different types of legitimacy as well as other, criteria of more structural kind, through an empirical study. 
The empiricism is primarily expected to give answers to one or more specific questions from processual analysis and from differences in various situational (dynamic) standpoint. Posing the questions: For whom is legitimacy important? Why is legitimacy important? What is the content of legitimacy? How is legitimacy reached? When is legitimacy important? the answers from the respondents will be categorized due to level and type of organization/management.

In order to get a common language in this empiricism for understanding the limits and strives in organizational governance, actions and behavior, we will introduce a simple model visualizing the dynamics in company performance vs resource efficiency (fig 2 ).*)

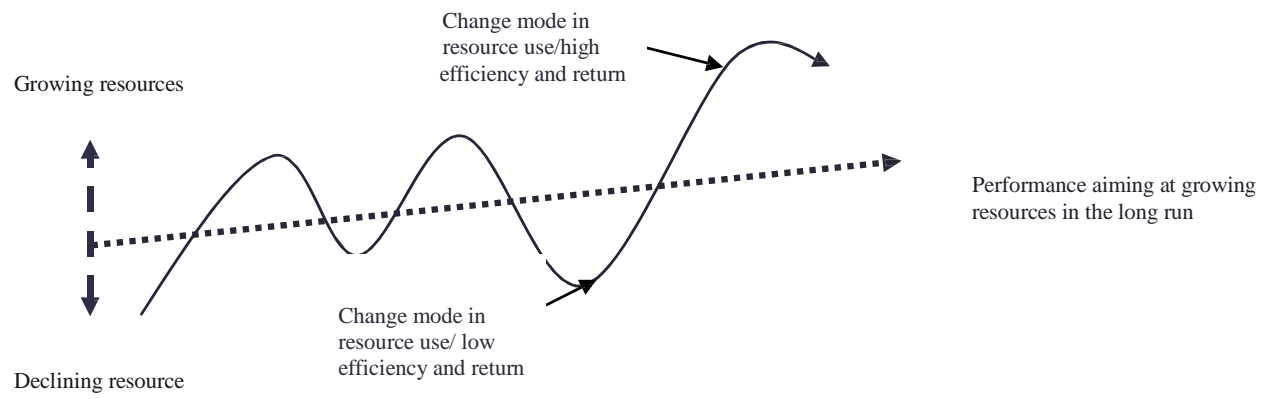

Fig 2: Gains and losses in company performance over time as result of organizational governance and behavior

*) In the above model we have as mentioned above, not taken into consideration the time lag between resource growth/decline and company performance (Holing, XXXX). The model will further down though be used to explore how legitimacy may change over time and depending on the actual mode of change.

\section{Methodology}

A number of ways to analyze R\&D is available in literature (Bûyûközkan and Feyzioglu, 2002, Krishnan and Ulrich, 2001). In this study though a limited process analysis (my paper in progress) and a limited stakeholder analysis will be used along with 'legitimacy' as an analyzing concept.

This stated need of clarity is due to a lack of explicit knowledge of using legitimacy as analyzing concept in the existing literature - with one exception from the Formal Model described below - about corporate governance and performance. My observations in business processes in practice, especially that of resource dependencies in developing processes, also points at this lack of visualized knowledge when trying to evaluate their governance and outcome. Therefor I have chosen to use interviews where the respondents who, besides their spontaneous thoughts, answer to a number of processual questions about legitimacy. - The respondents are acting as a kind of "stakeholders" - though they are the "owners" of their actual processes or situations.

Using this method the study will show that decisions in R\&D also, besides valuing the organizational performance and outcome, can favor an understanding in valuing the resource dependency and deployment in organizational development processes through this explicit made meaning of corporate legitimacy. It will thereby contribute to future research. on accountability and management accounting. 


\section{Bilaga B}

Bilaga B: Business Case 2 CATHEDRAL (BC 2) A case study

2005 (rev. 2014;2021)

PSB

One most interesting research question, with reference to the processual analysis and the valuating problem, is; where do legitimacy stem from i e ; for whom or to whom are processes and activities related; who has the interest of giving legitimacy and who has the benefit of using it? Who is the legitimate "e/valuer"? These "who"-questions have to be answered before it can be judged how legitimacy can be visualized /and communicated/ in framing a certain 'citizen' behavior! And how this it developed over time, as well. The critical assessment in posing these variety of questions, in a certain order, expects to show that the type of organization within a corporation, the size, organizational level, number of employees and the type of management can reflect different views of it and this may then also have certain effects on the organizational behavior, the governance and the expected performance.

Using a processual approach also includes a critical view of organizational behavior i e searching for differences instead of looking for similarities. The paper assumes an ongoing stakeholder dialogue, though in a limited extent, with holders of different stakes, in different organizational setting etc. to get explicitly to the meaning of legitimacy in and for $R \& D$. Critical assessment therefore posing the questions to every respondent of for whom, what it means in his/her certain context, why it is established, how it is affected and how it can be evaluated in his/her present situation.

The studies start from the position that organizations are seen as changing or ongoing developing processes - rather than starting with a more static approach (Burns \& Scapens, 2000) Time is regarded in the mode of change (Van De Ven, 1992) but is also thought to imply effects on decisions and activities. The strategy decision processes both have long foresight (15 - 30 years especially in technology research) and shorter product developing process cycles (1 - 3 tree years for continuous changes). This variance in time mode has different effects on $R \& D$ processes and is also considered in the model of resource dependency and thereof efficiency (Fig. 2)

This paper sets out to explore how 'legitimacy' can be used as an analytical concept in empiricism; how the concept is developed, traditionally more or less tacit understood and considered, in various limited R\&D programs and projects; in various parts of the corporation and in different kinds, types and sizes of the organizations within the corporation. The purpose of this paper is twofold; First, to contribute to the academic discourse and to the understanding of how organizational legitimacy can be viewed in framing corporate governance and performance in a long term and dynamic context. The paper aims to point to the potential links between theories of legitimacy formed in developing processes - through talk, decisions and actions (Czarniawska et al) - to resource dependency theories (Pfeffer\& Salancik, 1970 and Dowling \& Pfeffer, 1976) and to the theory of resource based view of the organization (RBV) (Wernerfeldt, 1986); second to contribute to accounting practice in management accounting - here by using a processual analysis in corporate $R \& D$ decision processes - to show how organizational legitimacy in corporate governance and performance, in a certain kind of organization, can be visualized as a potentially mean for measuring or valuing /limits for/ organizational behavior and its outcome, and thereby possibly be accounted for in a 'sustainable' context.

The paper is divided into three parts; first there is a introduction and a discussion of some general problems related to theories and earlier empiricism in terms of legitimacy and "citizenship", also linked to a Formal Model of Organizational Analysis (Czarniawska et al). Reflections from observations in practice, due to this model and with some references to 
papers on "corporate citizenship", are made by the author who is a "reflective practioner" (Schon, 1983). A certain model ') of resource management, resource efficiency and development will interactively be discussed with respondents in empiricism (Argyris, 1990) as part of the methodology. This model can explore why some processual question will be posed to managers about 'legitimacy'. This simple model is discussed in order to give an understanding of the "dynamic approach" in this study with certain reference to theories of change (Greiner, 1972, Van de Ven, 1992), notwithstanding to theories of time affecting resource dependency (Holling, 1986). The model aims to explore the impact of changes in governance over time on performance and resource efficiency and what can be regarded as a relevant mode of change in the empirical studies. Second, the empirical findings; from the interviews with people in the various organizations are then reviewed in short related to a processual analysis and followed by analysis and conclusions about the findings. The paper thereby reflects of the links between legitimacy and the type of organization; how differences in type, size and level, found in our empiricism, may affect processes and activities - and thereby may hypothetically establish the character of and frames for behavior of the company. Constructive versus destructive modes as well as limits for legitimacy briefly discussed with reference to the model in fig 2. Finally and as suggested policy implications from this empiricism it discusses a way to make legitimacy, which goes beyond legislation, responsibility and power, explicit: in sustainability terms. Links to future research of the resource-based view (RBV) of the corporation is suggested. Some further implications on the research agendas of corporate social responsibility and "citizenship" are also discussed due to some structural findings in empiricism. Implications on research and practice on resource management and management accounting is also considered.

This longitudinal, empirical study started in 2001 and it is organized in a number of phases; from brainstorming and benchmark seminars to case studies in technology and product development. At this point and as a part of the larger empiricism, six deep interviews have been made exclusively to discuss legitimacy in $R \& D$ and company performance. The respondents are people in various organizational situations; the organization is complex and the corporation is globally matrix organized. Responsibilities are bound to regional areas, technical areas, product areas, functional departments and business units as well. All respondents are managers; in non-profit R\&D as well as in profit centers. Monetary resources are centrally allocated to nine non-profit global programs. These R\&D programs /and their stuff/ are supported with competence resources from various global organizations within the corporation.

The interviews were held rather informal; the respondents were asked to tell what they thought about legitimacy in their certain context or decision situation. The answers of the processual questions as well as the spontaneous reflections were documented in writings. Documentation, memos and protocols were continuously updated by the author and were also reviewed by the respondents.

\section{EMPIRI}

The empirical findings through these six interviews showed that every respondent without hesitation could reflect on legitimacy in relation to his present position or actual decision situation. As will be discussed below the respondents' position in the organization reflects how the question was dealt with. Enclosed you will find a chart over the R\&D organization and location of the respondents (Encl 1) Each respondent and his/her main standpoint is 


\section{Bilaga $B$}

Bilaga B: Business Case 2 CATHEDRAL (BC 2) A case study

2005 (rev. 2014;2021)

PSB

reviewed with reference to this 'location chart'. A summary of respondents' common views are then expressed without attention to this 'respondents' location. The detailed interviews and the answers are available in Swedish.

The respondents' answers are presented in the following order:

1) General reflections about the legitimacy in his/her present research situation

2) For whom is legitimacy important; who legitimates the process etc.?

3) Why is legitimacy important of his/her research?

4) What is the content/value of legitimacy in his/her research?

5) How is legitimacy reached in his/her research?

6) When is legitimacy considered in his/her research?

Respondent 1 The Global program manager (for 1 of totally 9 corporate Programs) He represents a `non-profit', centrally financed Program The various Programs buy competence from local/regional/global "excellence centers". One Program covers for example software development for one certain industry or a range of industries.

Legitimacy for him means having done the SWOT. i e that the program as a whole that he is responsible for is successful and that SWOT gives what the customer needs. Foresight and university contacts is very important for the legitimacy of this program.

No economic discussions are held in the programs. Legitimacy is primarily a matter of technique $\mathrm{i}$ e the right technology for the future. (see also Respondent 6 )

Due to lack of time the processual questions where not posed in this interview.

\section{Respondent 2 The Local teamleader/specialist}

He represents a cost unit including long term technology development. This team leader is at the same time a project manager of some large global projects.

Legitimacy for him means according to the processual questions:

For whom is legitimacy important?

Why is legitimacy important?

What is the content of legitimacy?

How is legitimacy reached?

When is legitimacy important?
For the whole research team i e on group/teamlevel $--$

Not to deliver to market B, customer (personal) need (GAP) in core technology vs systematic "road-maps", competence, normative processes

Push vs Pull toward customers, ecology vs Market potential

Finding right (new) technology, methods

Respondent 3 The Local teamleader/specialist, cost unit, short term technology. The team leader can also be project manager of large global projects.

Legitimacy for him means:

There are two kind of legitimacy depending on for whom it is important within the corporation.

- a) for the R\&D organization (primary priority)

- b) for $R \& D$ as such in the corporation

For whom is legitimacy important? Why is legitimacy important? a) BU's in corporation b) Shareholders and students

a) --- b) investment, competence building 
What is the content of legitimacy?

How is legitimacy reached?

When is legitimacy important? a) critical mass, competence b) coop. with BU's

a) deliver result, joint with BU's b) responsiveness

a) "choosing" supplier b) investment decisions

\section{Respondent 4 The Product Line Manager,}

$\mathrm{He}$ is responsible for several research teams. He is the manager of a business unit (BU) of two kinds; formal and by commercialized products. It varies with kind of industry; Legitimacy through developing Quality gives a resource value growth of the company,

For whom is legitimacy important? In competition (Lex China) but also when giving priority to strategic programs. It differs between product areas, $\mathrm{P}$ vs $\mathrm{A}$; where $\mathrm{P}$ is stable but $\mathrm{A}$ changes more often ( $20 \%$ is very important to have legitimacy)

Why is legitimacy important? To document history, to orient fast rather than plan for future.

What is the content of legitimacy? Business strategy but also "benefit of the doubts"

How is legitimacy reached? Managements actions and trust in "track record"

When is legitimacy important? New business but also "internally" in programs

Respondent 5 The Product Line Manager, He is responsible for several research teams. $\mathrm{He}$ also is the manager of a BU.

Legitimacy for him means competence and building relations that gives understanding and TRUST (confidence). The RESULT is confirming the legitimacy i e competence is the product (giving trust) and the RESULT is the output.

For whom is legitimacy important? For Business Units and Partners (Companies within the group)

Why is legitimacy important? To be competitive (R\&D or Corporate?)

What is the content of legitimacy? It is based on TRUST (confidence) and CORE (on high level)

How is legitimacy reached? Building RELATIONS first, then delivering RESULTS

When is legitimacy important? When BA's do not have the competence (high level in interesting areas)

Respondent 6 The $\mathbf{R} \& \mathbf{D}$ Manager. He is responsible for the R\&D organization located in Sweden.

Legitimacy for him means at least legitimacy in strives for the corporation on two levels of priority: priority one: free individuals and fulfilling their "needs" in communitarian context; priority two: the company level i e for economic reasons and company progress

Legitimacy is shaped on both long term (less detailed) and short term ("test why you run"); the business strategy is how to formulate the "offer",

World class gives legitimacy and means: having the right product - right time, certain precaution. At least $20 \%$ very "elastic" projects due to fast changing in customer needs Vision maps ("the Cathedral building") is both as motivational and a strategic instrument, and have to be done before the "road maps"

For whom is legitimacy important? For individuals in a global context

Why is legitimacy important? To get "visibility" in projects and also describe the culture of the company

What is the content of legitimacy? "Profitable technology when the world is mature"

How is legitimacy reached? Two ways; mainly vision maps with trend search

When is legitimacy important? When the World is ready! 


\section{Bilaga $B$}

Bilaga B: Business Case 2 CATHEDRAL (BC 2) A case study

2005 (rev. 2014;2021)

PSB

\section{ANALYSIS AND CONCLUSIONS}

This study also confirms that:

- Legitimacy is something more...

- What you say, or rather what you think, and do i e the managers do, gives legitimacy to research.

- Different kinds of culture and the type of organization effects legitimacy (how it should be interpreted).

The study further shows;

- first and second degree of legitimacy (at least two mental levels of understanding),

- legitimacy before vs after delivery differs,

- the economic calculus means rather little (due to uncertainty?) though financial result is the main aim and which gives legitimacy to $R \& D$, and

- "sustainability" is not spontaneously linked to the word legitimacy.

.and a further interpretations

- the first degree of legitimacy means that;

1. projects can be decided if there is "trust" (= legitimacy?),

2. "financial" reality is rather a condition than a goal, and

3. different views is mentioned in time and "feelings" in "push" versus "pull" projects when they are evaluated.

Resource dependency and efficiency versus legitimacy is regarded in terms of finance and competence:

- For "push" - technological ideas and the "net-present- values".

- For "pull" - to put the right questions about business, underlying trends, personal interests, standard-forming processes, technical raising and technological decisions.

The social formation of this empiricism is, from a global point of view a most important, corporate $\mathrm{R} \& \mathrm{D}$ organization, but operating within the sphere of the corporation i e with other partners in technology and product development units. This means that other business units, $\mathrm{i}$ e companies within the corporation acting in processes (Marketing \& Sales etc) with foci in business with "end customers" are not represented in this study. The respective respondents from the business units within R\&D may well though represent them because of their daily contacts with other global business units. Some of the respondents are also part time employed in such companies, as managers of such business units.

The results from this empirical study also shows very clearly that:

- there are differences in priorities re: legitimacy between different kinds of organizations a) business (profit-) units vs program (non-profit-) units b) type of industry belonging and c) type of product. and d) the mode of change,

- there are differences in opinions (and priorities) due to the level/number of employees in the organization; the "higher" level the more open mind to community and thereby also the citizen and stakeholder perspectives, in ecology and in future for the earth i e for the company to be legitimate in a global context; on the "middle level" there is for 
example a minor belief that the corporation though has the position to have direct and high impact on politics,

- there seems to be differences due to socio-culture in how legitimacy is reached, for whom it is of major concern, what it really is, why legitimate is important and when it is important, and

- there are major but general differences in how R\&D is grounded and shall be e/valuated; that business strategy is important to follow, and some different priorities how resource and value growth is reached or limited in company performance.

Since one of the major assumptions in this analytical concept is that managements decisions and actions, i e how management behave, is of major concern for getting legitimacy, it is obvious that a shared a common view of legitimacy is important to get a smooth (efficient) and competition wise positive performance through the governance throughout the company. Nothing in this study implies that there exist disparate, destructive forces, in the different viewpoints. This empiricism instead tells us, through games like "cathedral building", that a continuous /resource/ dialogue in the organization contributes to such a progress and common views of performance and good citizenship..

When discussing our "dynamic" model of resource growth or decline; Fig 3, this showed to have impact on how sustainability, as a main aim for R\&D, can be viewed and understood.. Legitimacy framing R\&D decisions and actions was understood to have an impact on company governance. and performance. This model of "constructive" versus "destructive" modes in development also showed to increase the knowledge and insights of gains and losses in some sense.

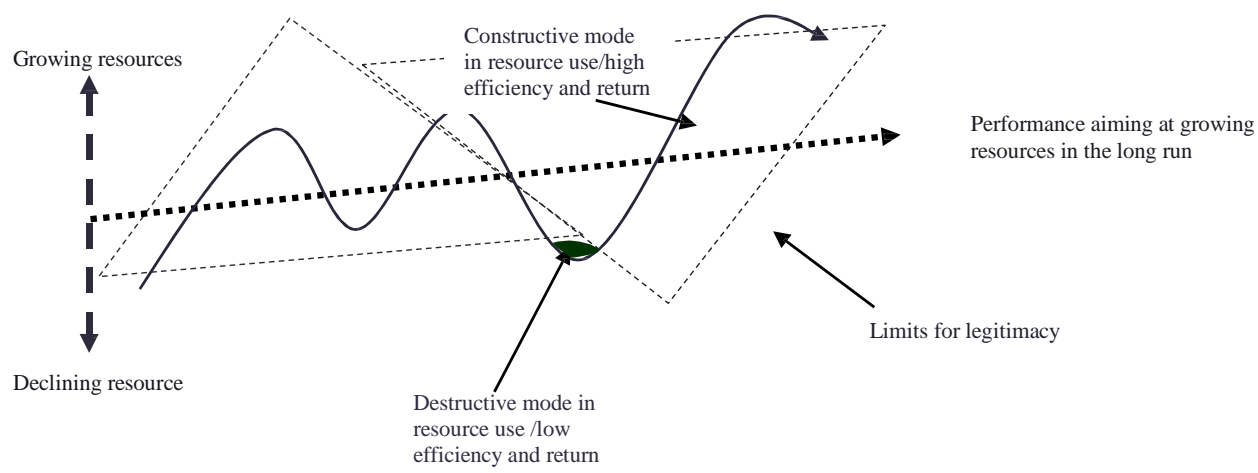

Fig 3. Constructive vs destructive modes in company performance over time as result of organizational governance and behavior and limits for legitimate behavior. 


\section{Bilaga B}

Bilaga B: Business Case 2 CATHEDRAL (BC 2) A case study

2005 (rev. 2014;2021)

PSB

\section{POLICY IMPLICATIONS}

Talk, decision and action are used as processual viewpoints in this analytical approach. Responsibility as "taken for granted" in sustainability is a base for the "citizenship contract"; also establishing the most limited frames for company governance and behavior. This empiricism though show that legitimacy is discussed in a more extended context (than responsibility) - and framing R\&D and corporate governance with individual and socio-cultural criteria. Limits and criteria for this "citizenship contract" is changing over time and due to organizational individuals belonging, type of product etc.

If it is relevant to value this empiricism not only as "talk" but as if managers really think and act according to it, it seems that company performance is affected, due to differences in individuals/managers priorities, in certain ways depending who is acting or who will have most impact on performance. It also seems that the "limits" for the contract may be questioned as a combination of self-interest (as distinctive from thinking and acting in terms of societal responsibility) and ethics, and that this effect company performance in the long run. An extended critical approach in further, extended collaborative research seems relevant if the value of resource efficiency, especially in knowledge creation in extended sustainability dialogues within the organization shall be reached.

A desirous further study including strategic discussions and a shared and multiple view of resource dependency in terms of finance, competence, natural resources. is therefore motivated to be able to explore the meaning of legitimacy vs "citizenship". Legitimacy in this study is also discussed when determining the level of mental expressions for business strategy. This do indicate that in order to give a contribution to the strategic framework and the body of knowledge for future research of "citizenship" and legitimacy, it is necessary to discuss legitimacy on various levels and various perspectives of the context; for future strategic research and for practice in $\mathrm{R} \& \mathrm{D}$ as well.

This empiricism also points out that other implications on research and theories of citizenship may occur; for example the organization may not only be viewed as administers of "citizen rights" since peoples acts and behaviors, their knowledge creation, and other important resource creation as well, is assumed to have certain effect of company and corporate performance - and of management accounting and accounting systems as well! 


\section{References}

Argyris, C., Putnam, R.,

McLain Smith, D., (1990)

Brunsson, N., (1985)

Brunsson, N., (1986)

Berry, Gregory R., (2003)

Burns, J., (1999)

Burns, J. and Scapens, R.W., (2000)

Caroll, Archie B., (1979)

DiMaggio, P.J and Powell, W.W., (1983)

Dowling, J \& Pfeffer, J., (1975)

Flyvbjerg, B.,(2001)

\section{Action Science \\ Oxford, San Fransico}

The irrational Organization

Wiley, NY

Legitimacy and Politics

Organizing against multinational corporate power in Cancer Alley

Organization and Environment, 16, 1, 3-33

The dynamics of accounting change: inter-play between new practices, routines, institutions, power and politics

Accounting, Auditing \& accountability Journal, 13, $5,566-596$

Conceptualizing management accounting change: an institutional framework

Management Accounting Research 11, 3-25

A three-dimensional Conceptual Model of corporate performance

The Academy of Management review, 4,4,497-505

Czarniawska, B. and Wolff, R., (1986) How we decide and how we act - on the assumptions of Viking Organization Theory

in: Organization Industrial Development, $N Y$,: de Gruyter, 139-150 (ed. by $R$ Wolff)

The iron cage revisited: Institutional isomorphism and collective rationality in organizational fields American sociological review, 48, 147 - 160

Organizational legitimacy

Pacific sociological review, IP 122-126

Making Social Science Matter: Why Social Inquiry

Fails and How It Can Succeed Again.

Cambridge University Press.

Gerth, H. and Wrigth Mills, C. (1953) Character and Social Structure: The Psychology of Social Institutions

New York: Harcourt, Brace \& World. 


\section{Bilaga B}

Bilaga B: Business Case 2 CATHEDRAL (BC 2) A case study

2005 (rev. 2014;2021)

PSB

Greiner, L., (1972)

Evolution and revolution as Organizations grow Harward Business Review, Jul-Aug, 37-46

Habermas, J., (1984)

Holling, S., (1986)

Freeman, J., (1999)

Jeurissen, R., (2004)

van Kersbergen, K., (XXXX)

Moon, J., Crane, A., \& Matten, D., (2004)

Olson, O., (1983)

Pfeffer, J., (1982).

Pfeffer, J \& Salancik, G.R., (1978)

Schön, D. A.,(1983)

Van de Ven, A.H.,(1992)

van de Ven, B. \& Jeurissen, R (2005)

Waddock, S., (2004)
Den rationella övertygelsen ( en antologi) Akademilitteratur

The resilience of Terrestial Ecosystems; Local surprise and global change

in Sustainable Development of the Biosphere ed.

Clark, W.C and Munn, R.E., IIASA, Laxenberg

Stakeholder influence Strategies

The Academy of Management review, 24, 191-205

Institutional Conditions of Corporate citizenship

Journal of Business Ethics, 53, 87-96

Government as bridge between ... and stakeholder theory

European Journal of Politics, 43. 143-171

Can Corporations be citizens?

Business Ethics Quarterly

Ansvar och ändamål.

Doxa. Lund)

Organizations and organization theory

Pitman, Marshfield. Mass.

The External Control of Organizations; A Resource Dependence Perspective

Harper \& Row, $N Y$

The reflective Practitioner; how professionals Think in Action

Basic Books, Inc., Publishers, N Y

Suggestions for studying strategy process: a research note.

Strategic Management Journal 13, 169-188

Competing responsibility

Business Ethics Quarterly, 15, 299-317

Creating Corporate Accountability: Foundational Principles to Make Corporate Citizenship real Journal of Business Ethics 00, 1-15 
Bilaga B: Business Case 2 CATHEDRAL (BC 2) A case study

Enclosure 1 Chart of respondents positioned in the matrix organization

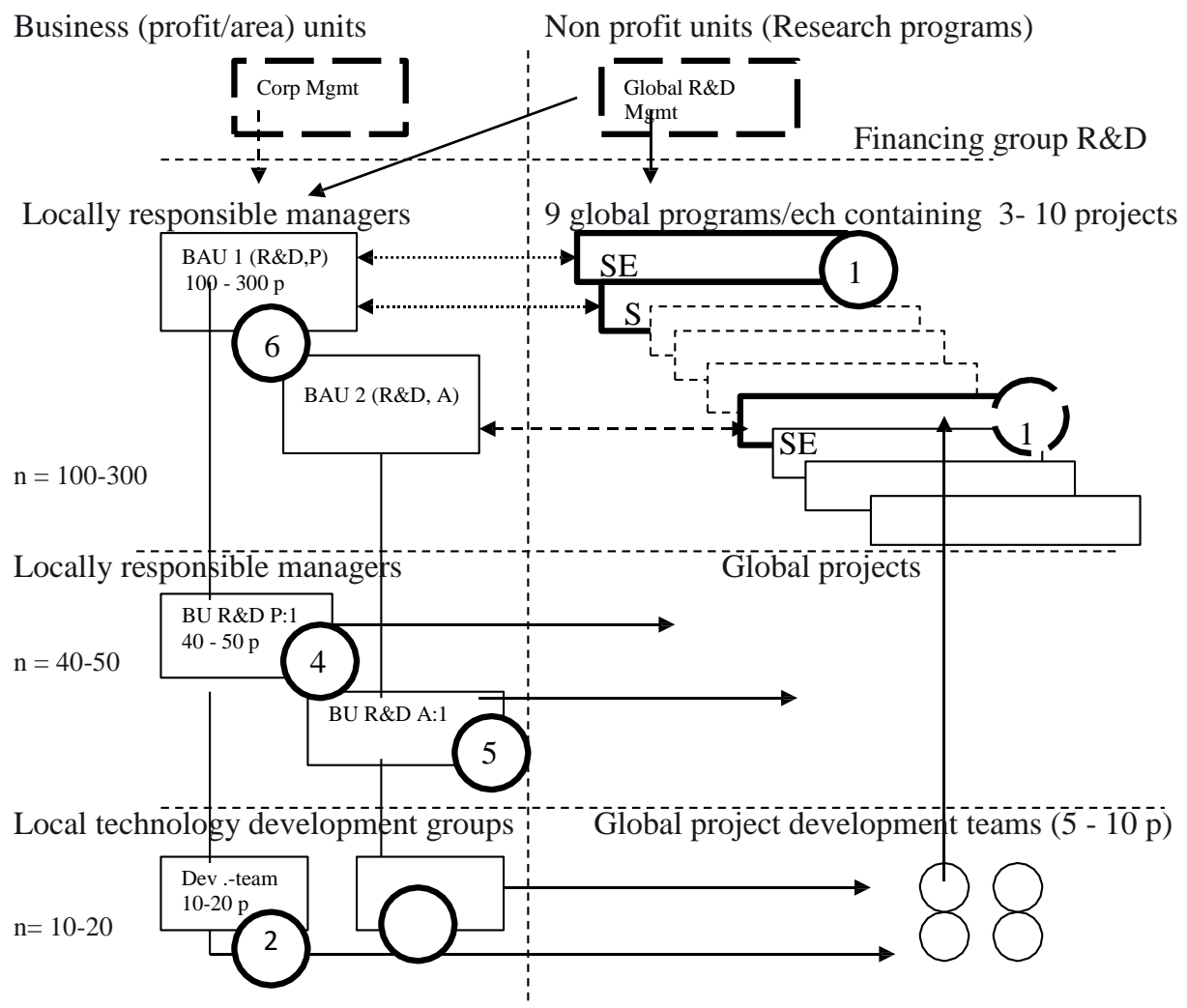





\section{FACULTY OF SCIENCE AND ENGINEERING}

Linköping Studies in Science and Technology, Dissertation No. 2189, 2021

Department of Management and Engineering

Linköping University

SE-581 83 Linköping, Sweden

www.liu.se

Resurstillväxt via innovationskapital är en fråga som är central i de organisationer som studeras i denna avhandling. Avhandlingen bidrar till att förstå och förklara de val en företagsledning kan göra när företagens resurser kontinuerligt skiftas från materiella till immateriella. Teoretiskt innebär detta utmaningar där resursbaserade teorier och strategisk ekonomistyrning traditionellt inte behandlat området men där avhandlingen tar sitt avstamp.

För att belysa effekterna av olika resursbaserade strategier baseras avhandlingen på ett flertal fallstudier. De immateriella resurser som studeras i avhandlingen kan sammanfattas som ett företags "potentiella innovationskapital" vilket är ett nytt begrepp som vuxit fram under arbetet med analysen av avhandlingens olika fall. De nyttor och värden som byggs upp med dessa immateriella resurser handlar om framtida förväntningar.

För att underlätta en strategisk och hållbar styrning är en slutsats i avhandlingen att det är väsentligt att företags "potentiella innovationskapital" identifieras och beaktas som en del av det redovisade innovationskapitalet. För att företagsledningar ska kunna identifiera ett "potentiellt innovationskapital" innehåller avhandlingen bland annat en ny definition av begreppet resurs. Om en innovativ ledning kan identifiera resursbaserade framgångskriterier och samtidigt de risker dessa kan medföra, tydliggörs utmaningarna inför valet av strategi. Strategierna handlar om att balansera företagets resursbas genom olika val. I avhandlingen identifieras genom analys av avhandlingens fall nio potentiella resursbaserade strategier.

Baserat på avhandlingens empiriska studier utvecklas de resursbaserade teorierna och teorierna om strategisk ekonomistyrning till en totalmodell för ekonomisk styrning mot målet resurstillväxt. Hur ledningen hanterar förväntningar på innovationskapitalets tillväxt konstateras i avhandlingen vara den aspekt som slutligen avgör företagets värdetillväxt i en konkurrenskontext som präglas av dynamik och stor volatilitet.

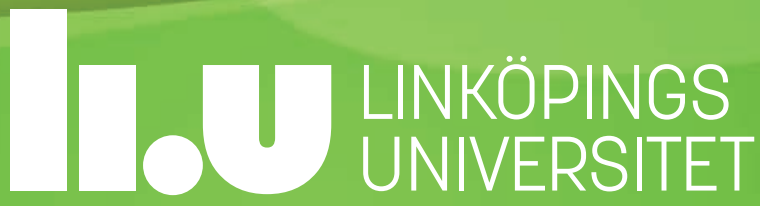

